\title{
Ultimate Heat Sink Thermal Performance and Water Utilization: Measurements on Cooling and Spray Ponds
}

Prepared by G. F. Athey, R. K. Hadlock, O. B. Abbey

Pacific Northwest Laboratory

Operated by

Battelle Memorial Institute

Prepared for

U.S. Nuclear Regulatory

Commission 


\section{NOTICE}

This report was prepared as an account of work sponsored by an agency of the United States Government. Neither the United States Government nor any agency thereof, or any of their employees, makes any warranty, expressed or implied, or assumes any legal liability or responsibility for any third party's use, or the results of such use, of any information, apparatus product or process disclosed in this report, or represents that its use by such third party would not infringe privately owned rights.

\section{Available from}

GPO Sales Program

Division of Technical Information and Document Control

U. S. Nuclear Regulatory Commission Washington, D. C. 20555

Printed copy price: $\$ 7.00$

and

National Technical Information Service Springfield, Virginia 2216] 
NUREG/CR-2514

PNL-4159

$\mathrm{RB}$

\section{Ultimate Heat Sink Thermal Performance and Water Utilization: Measurements on Cooling and Spray Ponds}

Manuscript Completed: January 1982

Date Published: February 1982

Prepared by

G. F. Athey, R. K. Hadlock, O. B. Abbey

Pacific Northwest Laboratory

Richland, WA 99352

Prepared for

Division of Health, Siting and Waste Management

Office of Nuclear Regulatory Research

U.S. Nuclear Regulatory Commission

Washington, D.C. 20555

NRC FIN B2081 


\section{Avaiłability of Reference Materials Cited in NRC Publications}

Most documents cited in NRC publications will be available from one of the following sources:

1. The NRC Public Document Room, 1717 H Street, N.W. Washington, DC 20555

2. The NRC/GPO Sales Program, U.S. Nuclear Regulatory Commission, Washington, DC 20555

3. The National Technical Information Service, Springfield, VA 22161

Although the listing that follows represents the majority of documents cited in NRC publications, it is not intended to be exhaustive.

Referenced documents available for inspection and copying for a fee from the NRC Public Document Room include NRC correspondence and internal NRC memoranda; NRC Office of Inspection and Enforcement bulletins, circulars, information notices, inspection and investigation notices; Licensee Event Reports; vendor reports and correspondence; Commission papers; and applicant and licensee documents and correspondence.

The following documents in the NUREG series are available for purchase from the NRC/GPO Sales Program: formal NRC staff and contractor reports, NRC-sponsored conference proceedings, and NRC booklets and brochures. Also available are Regulatory Guides, NRC regulations in the Code of Federal Regulations, and Nuclear Regulatory Commission /ssuances.

Documents available from the National Technical Information Service include NUREG series reports and technical reports prepared by other federal agencies and reports prepared by the Atomic Energy Commission, forerunner agency to the Nuclear Regulatory Commission.

Documents available from public and special technical libraries include all open literature items, such as books, journal and periodical articles, and transactions. Federa/ Register notices, federal and state legislation, and congressional reports can usually be obtained from these libraries.

Documents such as theses, dissertations, foreign reports and translations, and non-NRC conference proceedings are available for purchase from the organization sponsoring the publication cited.

Single copies of NRC draft reports are available free upon written request to the Division of Technical Information and Document Control, U.S. Nuclear Regulatory Commission, Washington, DC 20555.

Copies of industry codes and standards used in a substantive manner in the NRC regulatory process are maintained at the NRC Library, 7920 Norfolk Avenue, Bethesda, Maryland, and are available there for reference use by the public. Codes and standards are usually copyrighted and may be purchased from the originating organization or, if they are American National Standards, from the American National Standards Institute, 1430 Broadway, New York, NY 10018. 


\section{ACKNOWLEDGMENTS}

The enthusiastic support and assistance of EG\&G Idaho, Inc. personnel in the Raft River work is gratefully recognized. Special thanks are due to Gary Cooper, Dennis Goldman, Bob Hope, Jay Kunze, Gary Millar, Lowell Miller, Jim Neitzel, Ken Peterson, and Sue Spencer.

The work at East Mesa, California, has been facilitated by Tony Adduci at the U.S. Department of Energy, San Francisco Operations Office, and Bob Sones, Jack Mooney, Dale Barnhill, Kinney Stickler and Vern Corea of WESTEC Services, Inc. Their genuine supportive efforts are greatly appreciated.

The 1981 NRC East Mesa work was conducted simultaneously with efforts by other researchers:

Eric Adams and Carl Helfrick of MIT, Jim Nystrom of Alden Laboratories, Ben Sill and colleagues from Clemson University, Mayank Chatree of the University of Miami, John Guagliardo and colleagues from Computer Genetics

Corporation.

Massachusetts Institute of Technology, in a contract with the Electric Power Research Institute, provided subcontractual support to Battelle, Alden, Clemson, Miami, and Computer Genetics to experimentally address several aspects of evaporation from the cooling pond. Results of specialized efforts will be published elsewhere. We are grateful for the information exchange which proceeded between Battelle and the other organizations before, during, and after onsite experiments.

Contributors from Battelle, Pacific Northwest Laboratories included Jerry Allwine, Tom Bander, Don Glover, Bob Kerns, Bill Sandusky, Roger Schreck, Stan Ulanski and Jim Wetzel. Many other members of the Atmospheric Sciences Department have provided useful ideas and criticism; responsibility for the content of this report, however, is solely that of the authors.

The NRC Technical contract monitor for this program of measurements is $\mathrm{Dr}$. Robert F. Abbey, Jr. It is with pleasure that we indicate his wisdom and enthusiasm as contributions throughout the duration of the measurement program. 


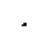




\section{ABSTRACT}

A data acquisition research program, entitled "Ultimate Heat Sink Performance Field Experiments," has been brought to completion. The primary objective is to obtain the requisite data to characterize thermal performance and water utilization for cooling ponds and spray ponds at elevated temperature. Such data are useful for modeling purposes, but the work reported here does not contain modeling efforts within its scope.

The water bodies which have been studied are indicative of nuclear reactor ultimate heat sinks, components of emergency core cooling systems. The data reflect thermal performance and water utilization for meteorological and solar influences which are representative of worst-case combinations of conditions.

Constructed water retention ponds, provided with absolute seals against seepage, have been chosen as facilities for the measurement programs; the first pond was located at Raft River, Idaho, and the second at East Mesa, California. The data illustrate and describe, for both cooling ponds and spray ponds, thermal performance and water utilization as the ponds cool from an initially elevated temperature. To obtain the initial elevated temperature, it has been convenient to conduct the measurements at geothermal sites having large supplies and delivery rates of hot geotherma? fluid.

The data are described and discussed in the text, and presented in the form of data volumes as appendices. 


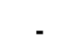




\section{SUMMARY}

The Atmospheric Sciences Department of Battelle, Pacific Northwest Laboratories, has brought to completion a data acquisition program for the U.S. Nuclear Regulatory Comission entitled, "Ultimate Heat Sink Performance Field Experiments." The primary objective was to obtain the requisite data, useful for modeling needs, to characterize thermal performance and water utilization for cooling ponds and spray ponds at elevated temperature. The work reported here does not contain modeling efforts within its scope.

The water bodies which have been studied are indicative of nuclear reactor ultimate heat sinks, components of emergency core cooling systems. The data reflect thermal performance and water utilization for meteorological and solar influences which are representative of worst-case combinations of conditions. In these ways, the project is responsive to U.S. Nuclear Regulatory Commission Regulatory Guide 1.27 "Ultimate Heat Sink for Nuclear Power Plants."

Constructed water retention ponds, provided with absolute seals against seepage, were chosen as facilities for the measurement programs. The data quantify thermal performance and water utilization as the ponds cool from an initially elevated temperature. Measurements were conducted at geothermal sites where large supplies and delivery rates of hot geothermal fluid were used to obtain initial elevated pond temperatures.

The high-quality data are described and discussed in the text and presented in the form of data volumes as appendices. The format is of convenience for calculational purposes; the data are also available in raw forms including recording to digital magnetic tape. Procedures in the field, laboratory, and computer are responsive to NRC Order No. 60-80-195, "RSP Policy and Standard Practice for Reporting Uncertainties in Reactor-Safety-Research Results." 

CONTENTS

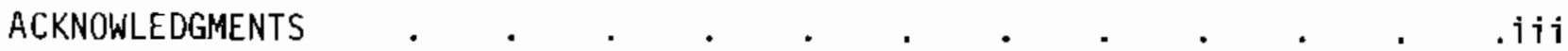
ABSTRACT . . . . . . . . . . . . . . . . . . SUMMARY . . . . . . . . . . . . . . . . . . . . . . . . . . . . . . . . . . INTRODUCTION CONCLUSIONS AND RECOMMENDATIONS . . . . . . . . . . . . 3 SITE AND FACILITY DESCRIPTION . . . . . . . . . . . . . 5 INSTRUMENTATION AND QUALITY ASSURANCE $. \quad . \quad . \quad . \quad . \quad . \quad . \quad .13$

INSTRUMENTATION

QUALITY ASSURANCE . . . . . . . . . . . . . . . . . 20

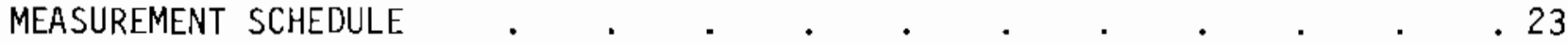

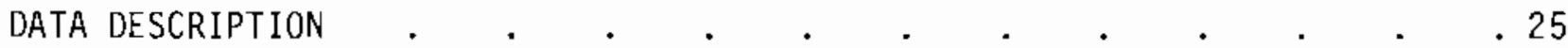

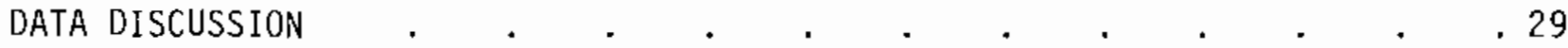

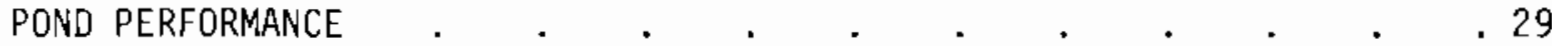

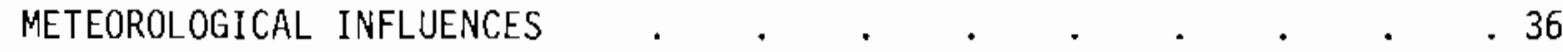
Atmospheric Pressure . . . . . . . . . . . . . . 37 Air Temperature . . . . . . . . . . . . . . 37 Humidity . . . . . . . . . . . . . . . . . . 37 Radiation. . . . . . . . . . . . . . . . . . . . 42 Meteorological Events . . . . . . . . . . . . . . . . . . . 46

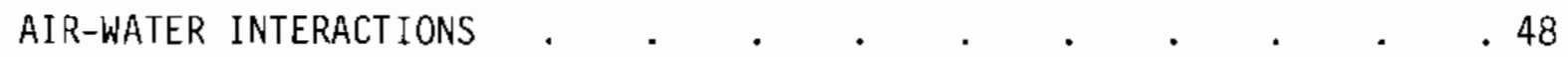
Heat and Moisture Plume . . . . . . . . . . . . . . 48 Spray Effects . . . . . . . . . . . . . . 53

Energy Exchange . . . . . . . . . . . 55 REFERENCES

APPENOIX A - RAFT RIVER I (1977) OATA VOLUME . . . . . . . . . A-1 APPENDIX B - RAFT RIVER 2 (1978) DATA VOLUME . . . . . . . . . . B-1 APPENDIX C - EAST MESA 1 (1979) DATA VOLUME . . . . . . . . . . C-1 APPENDIX D - EAST MESA 2 (1981) OATA VOLUME . . . . . . . . . . . D-1 


\section{FIGURES}

1. Photograph of East Mesa Cooling/Spray Pond with Water Retention

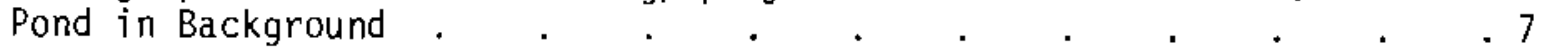

2. Diagram of the East Mesa Spray Pond Showing Approximate

Major Dimensions and Pipe Locations

3. Water Surface Area and Volume of Water Plus Mud as a

Function of Apparent Water Depth for East Mesa Pond . . . . . 10

4. Photograph of a Hook Gauge in Place on a Plexiglass

Stilling Well . . . . . . . . . . . . . . . . . . . . . . .

5. Photograph of East Mesa Pond Showing Location and

Instrumentation of a Berm Tower

6. Diagram Showing Location of the 5 Thermistors Used

During East Mesa 2 to Measure Stilling Well and

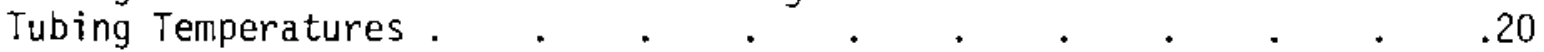

7. Two Possible Hydraulic Systems to Measure Pond Surface

Elevation . . . . . . . . . . . . . . . . . . . .

8. Temperatures of Stilling We11, Tubing and Pond on June 22-25,

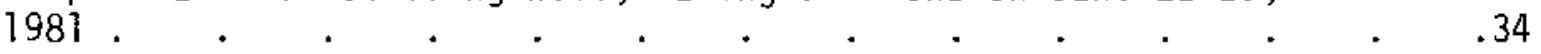

9. Pond Depth and Depth Change Per Hour for June 16, 1981 . . . . . . 35

10. Pond and Atmospheric Conditions for EM2 - Experiment 3 . . . . . 36

11. Air Temperature and Pond Bulk Temperature for East Mesa

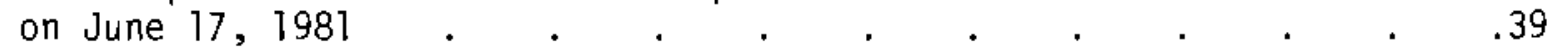

12. Air Temperature and Pond Bulk Temperatures at Raft River on
October 5, 1978 . $. \quad . \quad . \quad . \quad . \quad . \quad . \quad . \quad .40$

13. Specific Humidity of Air at Remote Tower and Saturation Specific Humidity for Air at Pond Temperature on June 17,1981

14. Specific Humidity of Air at Remote Tower and Saturation Specific Humidity for Air at Pond Temperature on october 5, 1978

15. Radiation Budget for RR2 - Hot I on July $30-31,1978$. . . . . . . 43

16. Radiation Budget for East Mesa 2 on June $23-25,1987$. . . . . . . . 44 
17. Radiative Solar Flux Components, Direct vs. Diffuse for

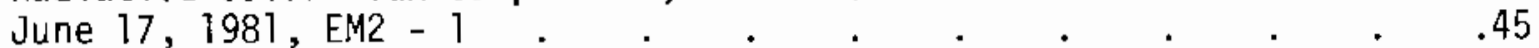

18. A Comparison of Bulk Pond Temperature Changes at East Mesa With and Without Sprays . . . . . . . . . . . . . . ${ }_{4} .47$

19. A Comparison of Wetbulb and Drybulb Data Over and Near the

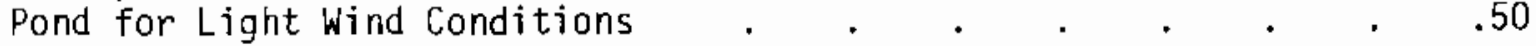

20. Spectral Amplitudes for Time-Serjes Temperature Data (nearpond tower) $. \quad . \quad . \quad . \quad . \quad . \quad . \quad . \quad . \quad . \quad . \quad .51$

21. Spectral Amplitudes for Time-Serjes Temperature Data (raft tower) . . . . . . . . . . . . . . . . . . . .

22. Under-Liner Soi? Temperatures for EM2 Experiment $3 \quad$ • $\quad . \quad$. $\quad .57$ 
1. Physical Description of Sealed Cooling Pond at Raft River, Idaho

2. Physical Description of Sealed Spray/Cooling Pond At East Mesa, California.

3. Concentrations of Dissolved Minerals and Trace Elements in the Geothermal Fluid at Raft River and East Mesa . . . 12

4. Instrumentation Common to Raft River and East Mesa . . . 14

5. Instrumentation Added for East Mesa 1 . . . . . . 18

6. Instrumentation Added for East Mesa 2 . . . . . . . 19

7. Listing of Sensor/System Performance Checks . . . . . 21

8. Measurement Schedule at Raft River and East Mesa . . . . 23

9. Key to Data Volume for Raft River and East Mesa 1--Appendices

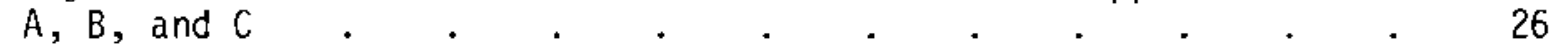

10. Key to Data Volume for East Mesa 2--Appendix D . . . . 27

11. Summary of the Seventeen Pond Cooling Experiments. . . . 30

12. Initial Pond Depth and Depth Change Over the Experimental Periods of East Mesa 2 .

13. Atmospheric Pressures During East Mesa 2, 1981 . . . . 38

14. Air Temperatures and Specific Humidities Upwind Vs. Downwind of the Pond.

15. Temperature and Relative Humidity Vs. Pond Influences . . . 55

16. Energy Budgets for Raft River 2 Experiments . . . . . 59

17. Energy Budgets for East Mesa 1 Experiments . . . . . 60

18. Energy Budgets for East Mesa 2 Experiments . . . . . . 6 ? 


\section{INTRODUCTION}

The objective of the reported research was to produce a data base usable in assessing models applicable to cooling ponds and spray ponds proposed for use as ultimate heat sinks in nuclear power plant emergency core cooling systems. The need derived from concern that certain elements of thermal performance and water utilization are not adequately predictable and that further information was required for proper design of performance tests to meet U.S. Nuclear Regulatory Commission criteria. Regulatory Guide 1.27 exhibits the criteria relevant to the data acqusition program.

The Guide discusses worst-case combinations of controlling parameters for thermal performance and water utilization. Considerations are based on timescales of one day, five days, and thirty days and their combination. The measurement programs were designed to enable quantitative assessment of all heat and moisture transfer over time periods sufficient in duration to allow extrapolation, based firmly in the data and physical principle, to the time scales associated with the criteria.

Ultimate heat sinks in active emergency core cooling systems are not available for study and therefore analogs are indicated for actual measurement programs. Initially, several different kinds of facilities were considered as candidates for data acquisition efforts. A general description of historical work and various facilities has been reported by Drake, 1975. A further report has been issued by Battelle (Hadlock, 1976) which exhibits a search for proper measurement sites and the results of a preliminary proof experiment on a small-load Battelle spray pond. Some of the candidate sites were hot ponds at Yellowstone National Park, Savannah River Laboratory, Idaho National Engineering Laboratory, and various industrial and utility facilities. As stated in another reporting of the program activity (Hadlock and Abbey, 1978), the decision for usable measurement sites was made in favor of geothermal facilities. Institutional difficulties and the need for an adequately surveyable thermally hot pond eliminated the other possible facilities.

The data resulting from this measurement effort were obtained at two geothermal sites--Raft River in Southern Idaho and East Mesa in Southern California near the border with Mexico. Ponds were constructed at the sites, suitable for intensive and comprehensive data collection programs. Measurements on sealed ponds were conducted at Raft River during July and October 1978 and at East Mesa during September and October 1979 and June and July 1981. Surmmer and fall observations enabled examination with various conditions imposed on the ponds. The data are site-specific but of generic applicability because of the variety of meteorological influences encountered.

Presented in this report are data volumes which exhibit the thermal performance and water utilization of cooling ponds at Raft River and East Mesa and of a spray system fitted to the East Mesa pond. The high quality data are described and discussed and are usable for performance modeling purposes. 



\section{CONCLUSIONS AND RECOMMENDATIONS}

An array of high-quaiity data representative of the thermal performance and water utilization of cooling ponds and spray ponds has been obtained and documented. The ponds considered were geothermal fluid retention basins constructed to serve as analogs of ultimate heat sinks as components of reactor emergency core cooling systems. The data are of sufficient quality, quantity and applicability for use in modeling of ultimate heat sink performance.

Measurements show that a cooling pond, approaching one acre in surface area and at an elevated temperature, is capable of losing tens of megawatts of heat to its surroundings. The primary heat transfer process is evaporation, with lesser contributions by sensible and radiative transfer. At pond temperatures in excess of $235^{\circ} \mathrm{C}$, pond performance is not significantly influenced by combinations of meteorological influences. Below $35^{\circ} \mathrm{C}$, pond response to ambient conditions, e.g. solar loading or high winds, becomes more apparent. Cooling performance of the system can be substantially enhanced through activation of a spray system.

Success in obtaining the requisite pond performance and meteorological data is highly involved with the choice of surveyable sites. Also, measurements must be performed on sealed ponds isolated from sources and sinks of water. The Raft River site and especially the East Mesa site, provided facilities to make the required measurements under a variety of conditions. The data presented are useful as examples of near worst-case conditions for pond performance and water utilization.

Because of the limited opportunities for measurements with sprays using very hot water $\left(>50^{\circ} \mathrm{C}\right)$, it is believed that further spray studies would be useful. It is expected that the data could be obtained at East Mesa if the geothermal wells are reactivated. In addition or as an alternative, the data could be obtained at an actual reactor in the situation of planned shutdown when resident core heat would be handled through the ultimate heat sink incorporating spray devices. 



\title{
SITE AND FACILITY DESCRIPTION
}

Geothermal testing sites generaliy have requisite amounts and necessary flow rates of thermally hot water for the rapid filling of cooling and spray ponds. The Raft River Geothermal Field Operations Facility, a U.S. Department of Energy (Idaho National Engineering Laboratory) facility near Malta, Idaho, was chosen as the site for measurements reported previously (Hadlock and Abbey, 1978). Data were obtained for a retention pond which was not sealed against seepage into the soil below during two experiments. Therefore, it has not been possible to describe, with precision, water utilization in the form of evaporation from that pond. However, the thermal performance of the unsealed pond is properly indicated by the data reported in Appendix A.

A new, sealed pond was constructed at the Raft River site in early sumrner, 1978. Pond construction was accomplished by EG\&G Idaho, Inc., site manager for DOE, and Palco Linings, Inc., of Indio, California. Description of this pond and related information are contained in Table 1 . The essentially square pond was constructed by excavation and the placing of the displaced soil in berms to form the pond periphery. The berms extended less than two meters above grade and one half meter or less above nominal pond surface when the pond was filled to an approximate depth of 1.7 meters. Berm slope, interior to the pond, reduced the pond volume from that of a rectangular solid to the resulting volume shown in Table ?. There were no obstacles to wind flow over the pond, with the exception of the elevated berms. Surrounding terrain was essentially flat with mountain ridges at distances of $10 \mathrm{kilometers}$ or more. Vegetation consisted of short grasses and sagebrush with heights ranging to about one meter.

\author{
TABLE 1. Physical Description of Sealed Cooling Pond \\ at Raft River, Idaho \\ $\begin{aligned} \text { Water Surface Area: } & \text { Nominal } 2840 \mathrm{~m}^{2} \\ \text { Water Volume: } & \text { Nominal } 3864 \mathrm{~m}^{3}\end{aligned}$ \\ Depth (at pond center): Nominal $1.7 \mathrm{~m}$ \\ Altitude (mean sea level): $\quad 1480 \mathrm{~m}$
}

The nearly square pond was lined with a layered plastic sandwich containing a nylon scrim for resistance to tearing stress. The filling (and drain) pipe which entered the pond, near pond center from below, was sealed to the liner. It was not considered necessary to cover the liner with a protective layer of soil. The filiing pipe terminated in a "T" structure which enabled introduction of water, for most of a filling episode, below the rising water surface in the pond. This enabled a maximum conservation of heat during pond filling and a maximum possible pond temperature at the beginning of a measurement episode. 
Experiments RR2 Cool I and RR2 Hot I (terminology identifying data experiments listed in the Appendices) were completed without problems. However, soon after the beginning of RR2 Hot II it was determined that a liner rupture had occurred during pond filling. RR2 Hot II was terminated, the pond was drained, and the liner was discovered to have torn along a seam over a di'stance of approximately four meters. The leak was detectable in the pond surface elevation data, vertical temperature gradient in the soil below the 1 iner, and from casual observation, i.e., visible seepage through the lower part of the berm. The torn liner was repaired and the pond was refilled for RR2 Hot III. This experiment and RR2 Hot IV proceeded with no difficulty; the leak had been successfully repaired as evidenced by the visua? observations, the water surface elevation, and the under-liner temperature data. Shortly before the planned initiation of RR Hot $V$, the pipe "T" failed and the liner ruptured along the entirety of a pond radius. The uncontrolied boiling and flashing water entering the pond at a rate of about 800 gallons per minute caused major erosion of the underlying soil and the liner was forced to the pond surface. The event terminated activity at Raft River for 1978 .

It was intended to repair the pond, repair the pond liner, redesign the pipe "T," and insta1i a spray system to make the Raft River pond suitable for spray thermal performance and water utilization measurements. However, it was not possible to make satisfactory arrangements with EG\&G, Idaho, for this kind of facility at Raft River.

Various kinds of information led to consideraton of the National Geothermal Test Facility (DOE - San Francisco Operations) at East Mesa, near El Centro, California, as the proper spray pond site for further measurements. WESTEC Services, Inc., site manager for DOE, contracted to prepare a sealed pond incorporating a spray system for the 1979 measurement program. The work was completed in late summer of 1979 with measurements initiated in mid-September. The nominal description of this pond and related information is contained in Table 2. The nearly square pond was fitted with a plastic 1 iner provided and installed by Palco Linings, Inc. prior to installation of the spray system. Between these operations a one-foot layer of soil was distributed and compacted over the liner. A drain pipe, coming from under the liner, was located at pond center, terminating slightly above the surface of the soil layer in an antiswirl structure. The pond is filled through a pipe perforated along its top surface and located near pond bottom. Below-surface filling accomplishes maximum possible pond temperature at the beginning of a measurement episode. No evidence, either visual or quantitative, indicates any leak during the duration of measurements at East Mesa during 1979 and 1981. The experiments were conducted with no discernable difficulty with the exception that filling rates available from the geothermal wells were not sufficient to raise initial temperatures to desired values.

The sealed East Mesa pond has essentially the appearance of the Raft River sealed pond. It is slightly larger, of similar depth and has similar berm configuration (Figure 1). One difference is with the layer of soil over 
TABLE 2. Physical Description of Sealed Spray/Cooling Pond at East Mesa, California

Water Surface Area:

Water Volume:

Depth (at pond center):

Altitude (mean sea level):

Number of Spray Nozzles:

Spray System Pump Capacity:
Nominal $3259 \mathrm{~m}^{2}$

Nominal $4884 \mathrm{~m}^{3}$

Nominal $1.5 \mathrm{~m}+0.3 \mathrm{~m}$ mud

$11 \mathrm{~m}$

64

Nominal 3280 gallons

per minute $\left(0.207 \mathrm{~m}^{3} \mathrm{~s}^{-1}\right)$

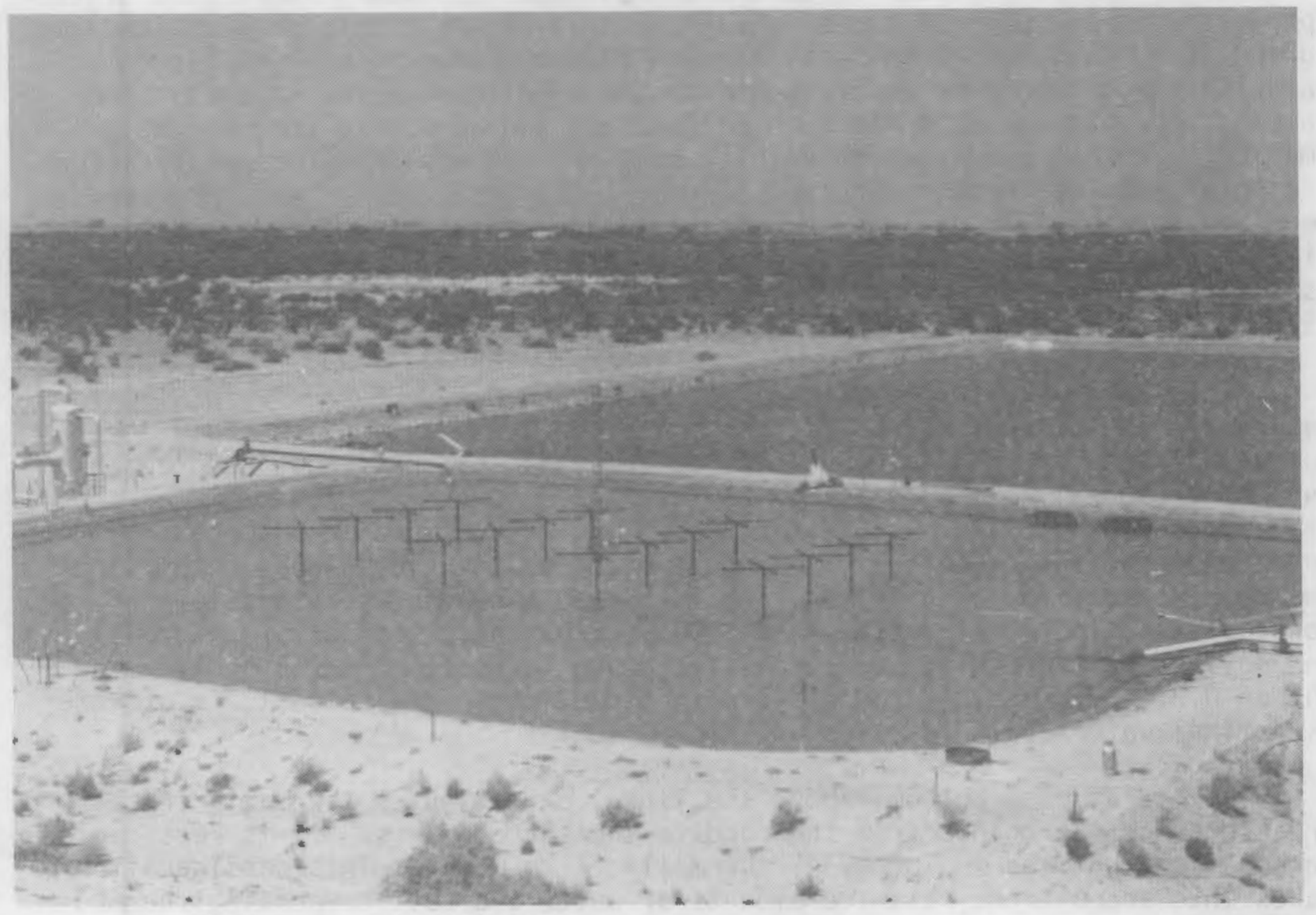

FIGURE 1. A Photograph of East Mesa Cooling/Spray Pond with Water Retention Pond in Background. View is looking WSW. 
the liner at East Mesa; this provides liner protection and is not at variance with experiment objectives. Another is that the East Mesa pond is located adjacent to a larger pond near equilibrium temperature, i.e., responding only to meteorological and solar influences. The presence of this second pond was taken into account by instrumenting the study pond around its periphery--the data show what the study pond actually experiences in meteorological influences. A major difference is that the East Mesa pond is equipped with a spray system. The surrounding terrain is quite flat and mesquite grows to heights of two meters--but not above berm top elevation.

Spray nozzles were purchased from Spray Engineering Company, Burlington, Massachusetts and Nashua, New Hampshire, (ramp-bottom nozzle \#1751) and 64 of these were installed by WESTEC on piping, designed by WESTEC, and responsive to Sprayco published specifications (Spray Engineering Co., 1977). Nozzles were located at five-foot elevation above nominal water surface and arranged in a rectangular array of sixteen clusters of four nozzles each. The layout of the spray nozzles and pond features is exhibited in Figure 2. Water was withdrawn during spray measurement episodes through the pond drain pipe by a largecapacity irrigation pump and returned to the pond through the nozzles. The pumping capacity was determined to be constant and at a rate very slightly smaller than that required for a full spray pattern per Sprayco specifications. The spray rate was measured by WESTEC (May 1981) to be $97 \%$ of the Spraycorequired rate of 3392 gallons per minute. Observation of the spray pattern dimensions, by visual comparison with known spray piping dimensions, indicates essential correspondence with the described pattern (Spray Engineering Co., 1977).

A comprehensive survey of the East Mesa pond was conducted by WESTEC following the 1981 experiments. The data obtained are adequate to enable a careful calculation of pond water volume for the range of applicable pond depths. In the horizontal, the pond was determined to be square to within $3 \%$ for shore dimensions of approximately 202 feet $(61.5 \mathrm{~m})$. Elevations were obtained at 41 locations over the essentially flat bottom and on the side slopes comprising the remainder of the pond bottom. An idealized (square) representation of the pond is exhibited in Figure 2. The survey was accomplished after pond draining and drying. A representative pond water depth was determined to be $1.5 \mathrm{~m}$ on top of $0.3 \mathrm{~m}$ of mud; this contrasts with a previously indicated $1.7 \mathrm{~m}$ of water as nominal water depth (Hadlock and Abbey, 1981).

The mud at pond bottom, above the liner, participates thermally in the process of heat exchange from the pond to the surroundings. It is reasonable to consider that the mud behaves, thermally, like water. This consideration takes into account the relative amounts of water and soil comprising the mud and the thermal capacities of each. The data indicate that lag times associated with mud cooling, due to different transfer coefficients, can be considered as a second order effect in calculations of total pond thermal performance. For the East Mesa pond, pond water depths are taken to be actual water depths plus $0.3 \mathrm{~m}$ in calculations of pond water volume. For the Raft River pond, with no mud above the liner, no such consideration is required. 


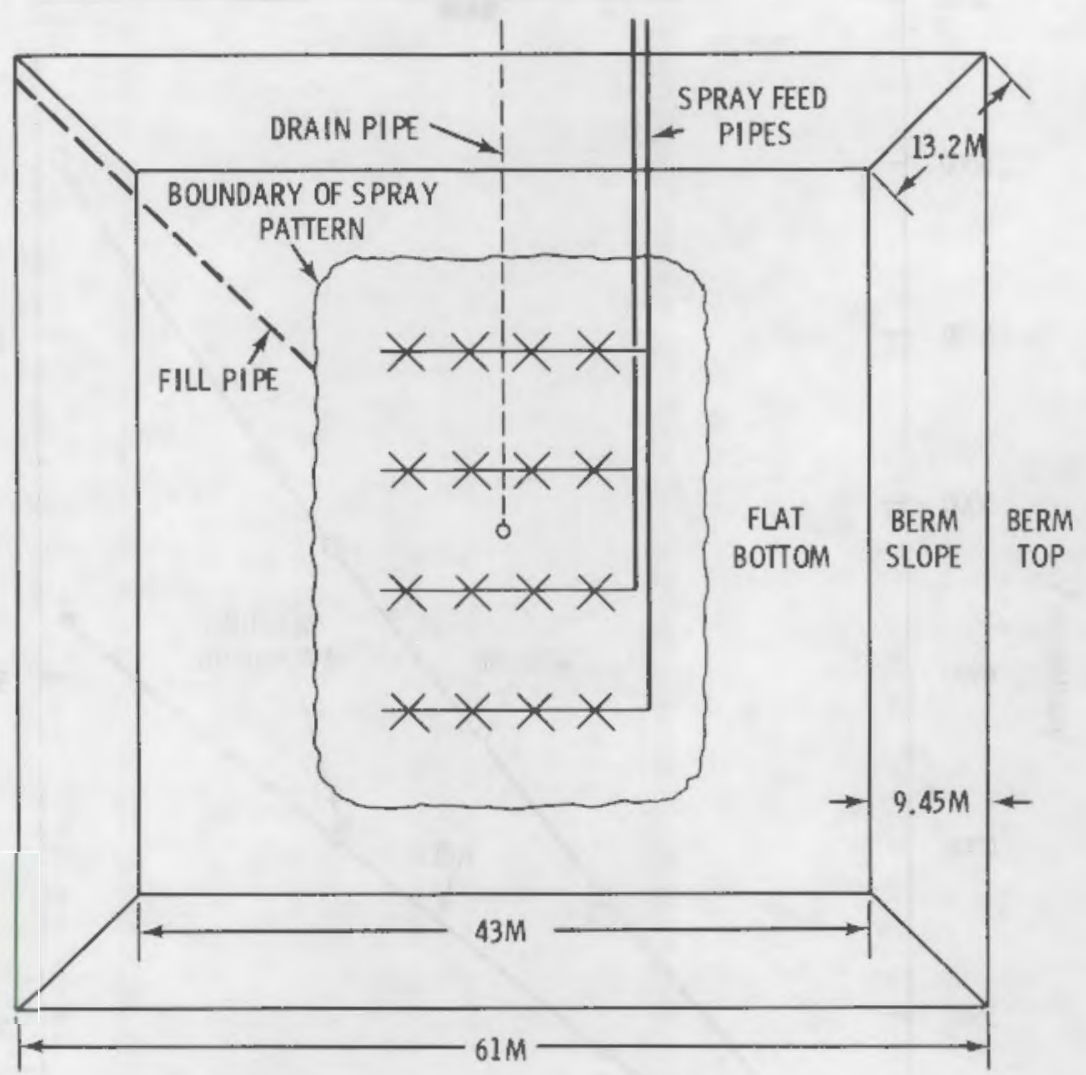

FIGURE 2. Diagram of the East Mesa Spray Pond Showing Approximate Major Dimensions and Pipe Locations. The wavy line delineates the pond surface directly distorted by spray water.

Figure 3 exhibits a staging curve by incorporating the survey data and the following assumptions:

- the pond dimensions, varying very slightly from those of a regular geometric figure, have been averaged to produce, for calculation, a regular geometric figure.

- The pond has the idealized shape of an inverted truncated pyramid.

- Water depth is shown as the apparent (actual) water depth. The contribution of the mud over the liner, however, has been included in the calculations of volume.

The information in the figure is representative and useful for consideration of all experiments performed at East Mesa. For precision calculations of water utilization, the apparent depth plus 0.3 m must be corrected for the changing water temperatures of the pond, stilling wells and connecting tubing. 


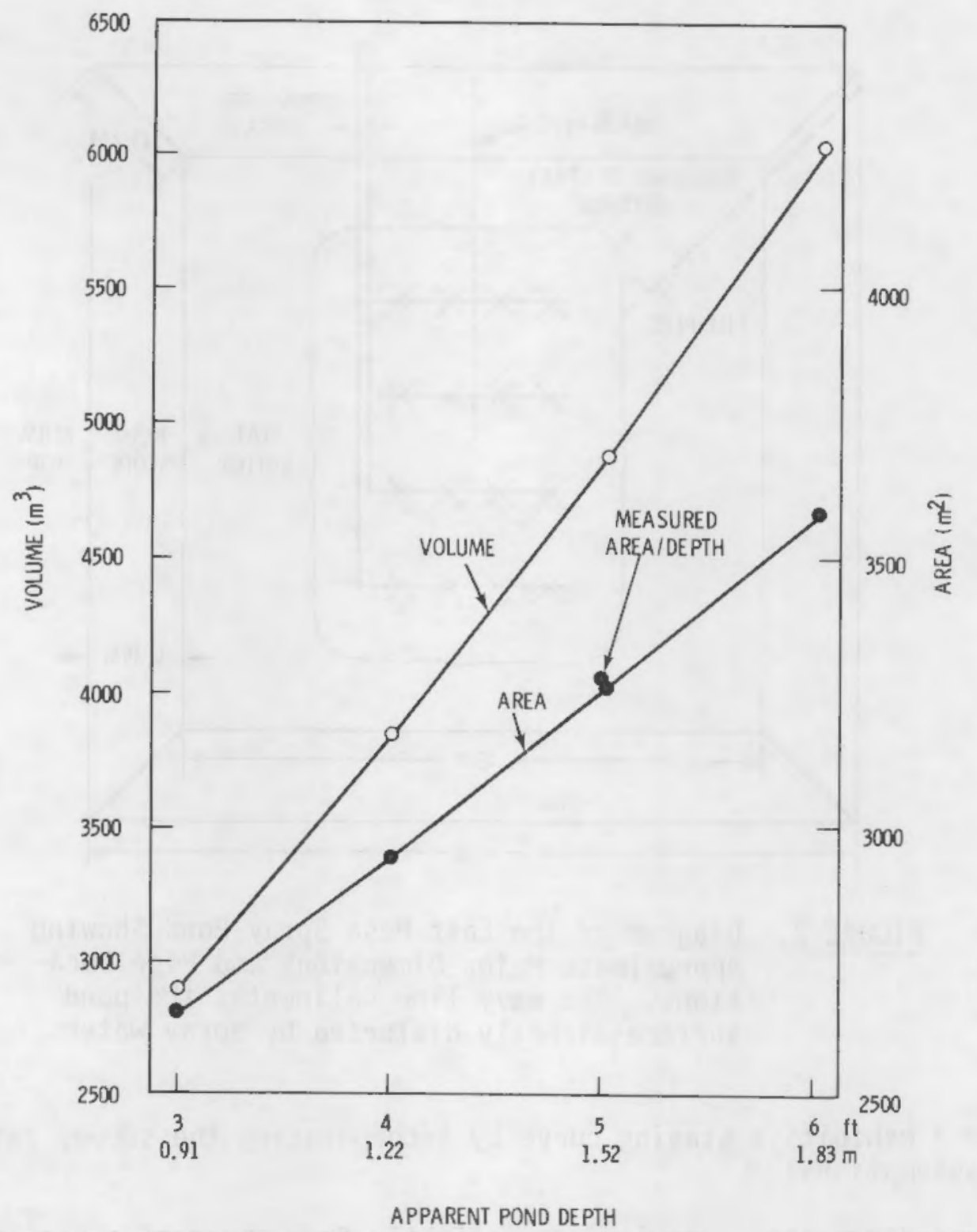

FIGURE 3. Water Surface Area and Volume of Water Plus Mud as a Function of Apparent Water Depth for East Mesa Pond. The apparent depth is that which would be obtained through use of a dipstick in the pond, with no corrections for temperature effects.

The figure indicates pond volume and water surface area as a function of apparent depth (the depth of water that would be obtained by reading a calibrated stick placed vertically in the water with the bottom of the stick touching the mud on the flat horizontal pond floor). However, the volume has been calculated taking into account the equivalent $0.3 \mathrm{~m}$ of water $(0.3 \mathrm{~m}$ of mud). The volume and area are slightly nonlinear functions of depth because of the solid geometry involved. Also indicated on the figure is a confirmation of the representativeness of the data; an actual measurement of the surface area, 
for a known depth is shown. The actual value corresponds with the curve (idealized) value to within $0.5 \%$.

The curves in the figure were constructed from equations prepared from the survey data. Volume of water and mud and surface area of water may be calculated for any required value of apparent water depth from the following expressions where $h$ is the apparent water depth in meters:

$$
\begin{aligned}
& \text { Volume }\left(\text { meters }{ }^{3}\right)=601.07+2098.52 h+423.77 h^{2}+28.53 h^{3} \\
& \text { Area }\left(\text { meters }{ }^{2}\right)=1848.14+795.375 h+85.575 h^{2} .
\end{aligned}
$$

\section{In summary:}

- the data of Table 1 are representative of the Raft River sealed pond and no more complete data are available because the pond was destroyed prior to intended survey procedures.

- The data of Table 2 are representative of the East Mesa sealed pond. Mud over the liner must be taken into account in consideration of pond thermal performance. It is reasonable to consider that $0.3 \mathrm{~m}$ of mud behaves thermally as $0.3 \mathrm{~m}$ of water.

- Apparent pond depth is the depth of water that would be determined by reading a calibrated stick placed in the water, bottom on the mud. Figure 3 has this measure as its abcissa.

- Figure 3 exhibits the calculated pond volume (including $0.3 \mathrm{~m}$ mud) and water surface area as a function of apparent depth.

- For precision calculations relating to water utilization in particular, apparent depth data must be corrected for changing water temperatures. For example, the pond volume shrinks in result of decreasing temperature in addition to any change of volume due to evaporation. Further discussion of such temperature effects on pond volume is contained elsewhere in this report.

The geothermal fluid at both sites contains dissolved minerals and trace elements. It has been determined, by reference to tables in the CRC Handbook of Chemistry and Physics (Chemical Rubber Pub1. Co., 1955) that the presence of these dissolved substances does not change thermodynamic properties of the fluid in any important way (less than $0.2 \%$ ) from those of distilled or tap water. This conclusion has been verified by the WESTEC East Mesa onsite chemistry laboratory through reference to and consideration of relevant available literature (International Critical Tables, 1928). The properties considered include specific gravity, surface tension, specific heat, heat of evaporation, vapor pressure, and themal conductivity. Table 3 lists some of the more 
TABLE 3. Concentrations of Dissolved Minerals and Trace Elements in the Geothermal Fluid at Raft River and East Mesa

\begin{tabular}{|c|c|c|}
\hline Constituent & $\frac{\text { Raft River }}{\text { (ppm) }}$ & $\frac{\text { East Mesa }}{(\mathrm{ppm})}$ \\
\hline $\mathrm{Cl}^{-}$ & 750 & 1400 \\
\hline $\mathrm{CO}_{3}{ }^{--}$ & (a) & 150 \\
\hline $\mathrm{HCO}_{3}^{-}$ & 50 & 600 \\
\hline $\mathrm{Ca}^{++}$ & 50 & 2 \\
\hline $\mathrm{Na}^{+}$ & 450 & 1200 \\
\hline $\mathrm{SO}_{4}{ }^{--}$ & 60 & (a) \\
\hline
\end{tabular}

(a) unknown, not available

concentrated and relevant chemical concentrations of the Raft River and the East Mesa geothermal fluid. During the time required to conduct an experiment series, these concentrations increased slightly due to a small concentrated residue remaining in the pond at completion of pond draining for each experiment. No oils or other evaporation- suppressing chemicals were in contact with pond water at any time at either site. 


\section{INSTRUMENTATION AND QUALITY ASSURANCE}

The objective of the work at Raft River and East Mesa was to acquire highquality data usable for the assessment of models predicting the thermal performance and water utilization of ultimate heat sinks. The accomplishment of this required the continuous monitoring of pond temperature and water surface elevation as well as the meteorological conditions influencing these quantities. Characteristic procedure has been to monitor the appropriate physical quantities as the pond cooled from an initial elevated temperature. To assure the quality and reliability of the obtained data, a series of before-and-after calibrations of sensors and systems have been performed; where applicable, reference standards were employed.

\section{INSTRUMENTATION}

Table 4 lists measurement instruments deployed at both the Raft River and the East Mesa ponds. Substantial description has been reported previously (Hadlock and Abbey, 1981). As many as 12 pond thermistors have been put into place for any given experiment. The harsh environment caused a reduction to as few as 9 operational for water temperature measurements at some times. These failures, not affecting the representativeness of the data, were due to extreme water turbulence in pond filling, and pressure and temperature impacts on the tiny bead sensor mountings. Under-liner thermistors have survived more than a year at East Mesa with no indication of degradation of signals representative of under-liner soil temperatures.

The pond surface elevation was determined with respect to an arbitrary reference level, by manual reading of water levels in stilling wells using hook gauges (Figure 4). The wells were located on the outside slope of a berm and connected to the pond water by approximately $35 \mathrm{~m}$ of flexible plastic tubing; the internal diameter of the tubing ranges from 1 to $2 \mathrm{~cm}$. There were several advantages to this method. First, it was not necessary to risk personnel contacting the hot water, and therefore, readings could be obtained without the pressures of urgency and difficulty. Second, the long connecting tubes effectively smoothed fluctuations due to wave action at the pond surface; the tubes terminated at pond bottom along a line bisecting the pond area. Finally, three such systems were used, with tubes terminating on a line usually parallel to the wind direction so that pond tilt by persistent wind was taken into account. Pond tilt is not trivial; for persistent wind of 2-3 $\mathrm{m} \mathrm{s}^{-1}$, surface elevation may differ by centimeters from edge to opposite edge of the pond.

Total downward solar radiation (direct and diffuse) was measured with an Eppley precision pyranometer located within $10 \mathrm{~m}$ of pond edge. Net radiation, for all wavelengths, was measured over the pond surface with a dual hemisphere Fritschen-type radiometer. It has not been necessary to clean the protective domes of these sensors beyond normal maintenance procedures. The net radiometer over the pond surface does collect a film of deposited salts but essentially equally for upper and lower surfaces. Thus, the differentially measured 
TABLE 4. Instrumentation Common to Raft River and East Mesa

Item

Pond Thermistors

(Yellow Springs

Instruments 44006)

Under-Liner Thermistors

(YSI 44006)

Hook Gauges/Stilling Wells

(Science Associates)

Pyranometers

(Eppley)

Net Radiometers

(Fritschen type)

Aspirated wet and Dry

Thermistors

(YSI 44006)

3-Component Wind Speed

(Direction) Sensors

(R.M. Young, Gill)

Monostatic Acoustic Sounder (Radian)

Rain Gauges

(Various manufacturers)

Barometer

Whole-Sky Camera

Logging/Recording System

(Metrodata/Digidata/

Kennedy)

\section{Comments}

9 to 12 thermistors in water at 3

levels (bottom, mid and near sfc.) and at 3 to 4 locations

5 in vertical line over $50 \mathrm{~cm}$, top thermistor in contact with liner

3 along pond centerline

On roof of mobile laboratory, adjacent to pond

Over pond surface, between pond corner and pond center (1 $\mathrm{m}$ height), or on boom from raft

7 or $8 ; 2$ on reference tower $(1.5 \mathrm{~m}$ and $10 \mathrm{~m}), 2$ on raft $(1.5 \mathrm{~m}$ and $3 \mathrm{~m})$, 3 or 4 pond edges $(1.5 \mathrm{~m})$

6 or $7 ; 2$ on reference tower $\{1.5 \mathrm{~m}$ and $10 \mathrm{~m}), 1$ on $\operatorname{raft}(1.5 \mathrm{~m}), 3$ or 4 pond edges $(1.5 \mathrm{~m})$

50 meters from pond, stability indication to $600 \mathrm{~m}$ above ground

4 wedges at pond corners, 2 tipping buckets, other large gauges

High-resolution digital display in mobile laboratory or microbarograph

Recording of cloud cover

All electrical signals continuously digitized and tape recorded at 2 or 5 -second intervals 


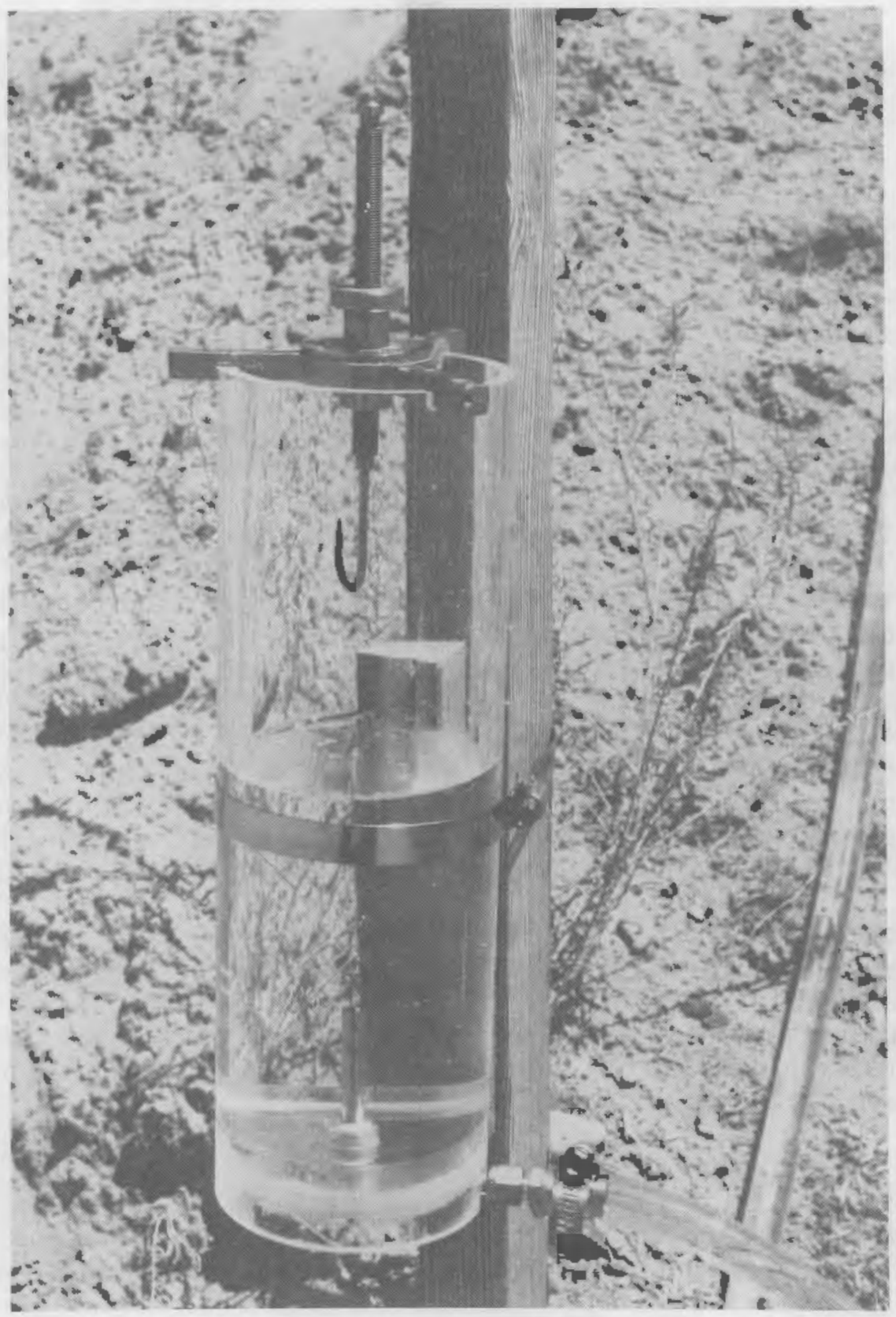

FIGURE 4. Photograph of a Hook Gauge in Place on a Plexiglass Stilling well. The plastic tubing to the right runs over the berm and into the cooling pond.

radiation is not significantly perturbed. This is verified by no apparent change in performance before and after cleaning.

Air temperatures and humidities were measured by use of aspirated bead thermistors (dry and wet-wicked). The nested aspirator tubes functioned as solar radiation shields and were constructed in-house. The remote reference 
tower was located approximately $100 \mathrm{~m}$ from the pond to provide an undisturbed data base for comparison purposes. Wind speed, and thereby wind direction, was measured at the reference tower with 3 orthogonal propellers at each height. These temperature and wind sensors were also located on short towers around the pond periphery (Figure 5) and on a towable raft located near pond center; this raft is described in detail in Hadlock and Abbey, 1978.

A monostatic acoustic sounder enabled the acquisition of qualitative information concerning thermal structure on a vertical scale of hundreds of meters above the ground surface. The information was collected as a facsimile record with the intensity of display related to the strength of signal returned from air exhibiting thermal turbulence and for transition from one turbulence intensity to another, i.e., layering. This system was used at the sites considering that ponds at elevated temperature may be influenced by convection suppression on a scale somewhat larger than characteristic pond dimensions.

Precipitation of any form would affect the information contained in water utilization data in an important way. Operational and research-type rain gauges were deployed but there was a total absence of precipitation at both sites during al1 measurement activity except during Raft River 1 (1977). A digital barometer was used to obtain surface pressure at appropriate time intervals; the data are required for psychrometric conversions of dry and wet air temperatures. Cloud cover, affecting radiative exchange, was monitored with a camera equipped with a fisheye lens. The sky was photographed at 1/2hour intervals. These photographs merely back up the actual radiative data.

With the exception of pond surface elevation, acoustic, precipitation, barometric, and photographic data, all sensor signals were recorded with a data logger connected to a 7-track digital tape recorder. Complete multichannel scans, including time information and reference system voltages were acquired in a small fraction of a second and recorded at 2 or 5 -second intervals during the observation periods.

Table 5 lists instrumentation added for the East Mesa 1 (1979) experiments. Much of it was used for spray monitoring. Additionally, there was interest in definition of the quantitative thermal structure to 70 mil above and near the pond as well as in examination of temperature detail at the water-air interface.

The tethered-balloon telemetry system enabled vertical profiling to provide additional data representing the over-pond temperature and wind environment. A typical profile, to a height of $70 \mathrm{~m}$, was accomplished in 8 minutes with 12 levels recorded in this height range. Profiles were also obtained in the descent mode to complement the ascent profiles. The data obtained are reference data and do not represent the thermal plume of the pond. However, a balloon-borne package for dry and wet aspirated temperatures was located over pond center at a height of $15 \mathrm{~m}$ over the sprays through multi-tethering. The signals were returned to the data logger via a light-weight cable. These data are representative of thermal plume for very light wind conditions and a pond surface warmer than environment. 


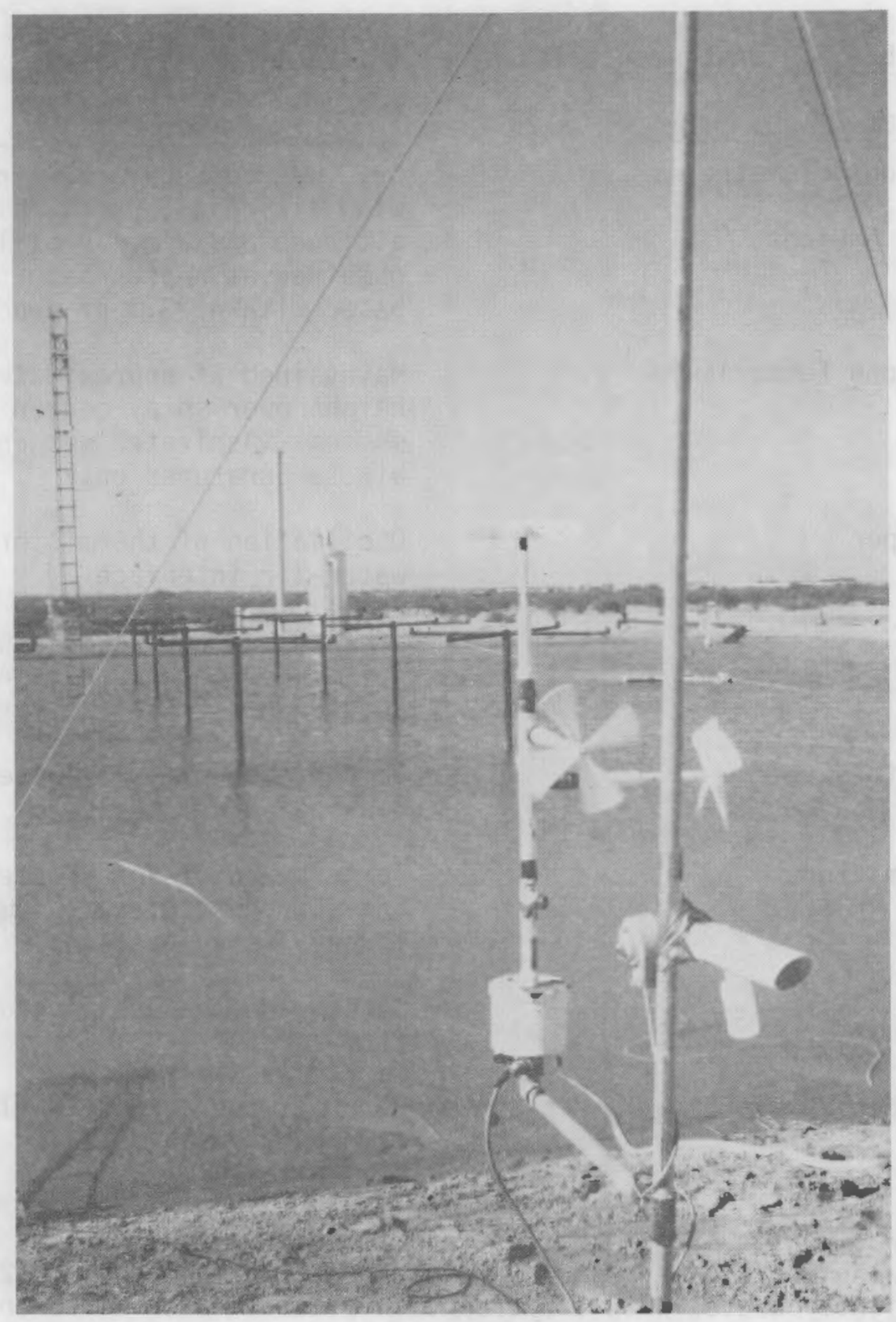

FIGURE 5. Photograph of East Mesa Pond Showing Location and Instrumentation of a Berm Tower 
TABLE 5. Instrumentation Added for East Mesa 1 (1979)

\section{Item}

Tethered Balloon Telemetry

System

(A.I.R., Inc., Ambient

Analysis)

Over-Pond Balloon Temperature

Package

(YSI/in-house)

Thermistor Dipper

(YSI/in-house)

Towable Floats

(YSI/in-house)

Nozzle Themistors

(YSI)

Collector Thermistors

(YSI)

Drift Array

Strip-Chart Recorder
Comments

Dry, wet temperature, wind speed, wind direction, pressure to altitude of $70 \mathrm{~m}$. Profiles obtained at appropriate times, based within $20 \mathrm{~m}$ of pond edge

Maintained at approximately $15 \mathrm{~m}$ height over spray center of spray system. Aspirated wet and dry air temperatures only

Oscillation of thermistor through water-air interface

Dry and wet air temperature at $0.5 \mathrm{~m}$ aboave water-air interface. Located near spray pattern

Temperature of spray water leaving spray nozzles

Temperature of spray water returning to pond surface. Towable through spray pattern

Detect and measure liquid drift from sprays

Record dipper, towable float temperatures

A device was constructed to oscillate a thermistor bead through the waterair interface with a cycle period of 5 minutes and an amplitude of $12.7 \mathrm{~cm}$. The bead was lightly coated with a hydrophobic plastic material so that, when leaving the water, the indicated temperature of the bead was not affected by evaporation of water from the bead surface.

Aspirated thermistors, for wet and dry air temperatures $0.5 \mathrm{~m}$ above the water surface were located on towable small floats, in shields specially designed to minimize passage of liquid water drops past or onto the thermistors. These sensors were positioned from shore in locations of interest near the spray pattern (pond surface disturbed by falling drops). Three of the spray nozzles were equipped with thermistors in contact with the nozzle metal and heavily insulated from the surroundings. These sensors indicate the temperature of spray water leaving the nozzles. The temperature of the spray water, as it returns to the pond, is indicated by identical thermistors, located in 
three collection funnels mounted on towable floats. The funnels were insulated on exterior surfaces and chosen of a size to assure, in the spray pattern, a a continuous flow of spray water past the thermistors located in the funnel necks. It has been possible to tow these devices in and out of the spray pattern so as to produce some description of temperature variation in the sprays. This information is not complete; data for hot $\left(>60^{\circ} \mathrm{C}\right)$ sprays is required.

For the wind speeds encountered at East Mesa, a maximum of $3.4 \mathrm{~m} \mathrm{~s}^{-1}$ (half hour average), drift was barely detectable from the spray system. An array of 30 sensitive-paper collecting stations was placed on the berms and downwind to distances of 30 meters. Additionally, 2 high-volume samplers were located on the berms up and downwind from the spray pattern. Dissolved salts in the geothermal water assist in the utilization of these sampling techniques. Drift from the sprays must, in part, evaporate prior to reaching the samplers. Drift can be of consequence in consideration of active spray water utilization.

Table 6 lists measurement instruments added to the East Mesa 2 (1981) experiment. These additional sensors were deployed to further define the energy budget of the physical system and improve the water utilization measurements.

\section{TABLE 6. Instrumentation Added for East Mesa 2 (1981)}

\section{Item}

Soil Temperature Thermistors (YSI)

Silicon-Cell Pyrometers w/Shadow Ring (Lambda)

Stilling Well and Tubing Thermistors (Figure 6) (YSI)

Barograph (Weather Measure)
Comments

Four sensors located in sandy soil $\checkmark 5$ meters away from the berm at depths of $1,3,5$ and 7 centimeters

Located next to pond net radiometer at $21 \mathrm{~m}$ above water surface. Used to define diffuse component of solar input

Five sensors spaced between a stilling well and the pond to monitor temperature. Useful in temperature corrections to pond depth

Provides continuous record of atmospheric pressure 


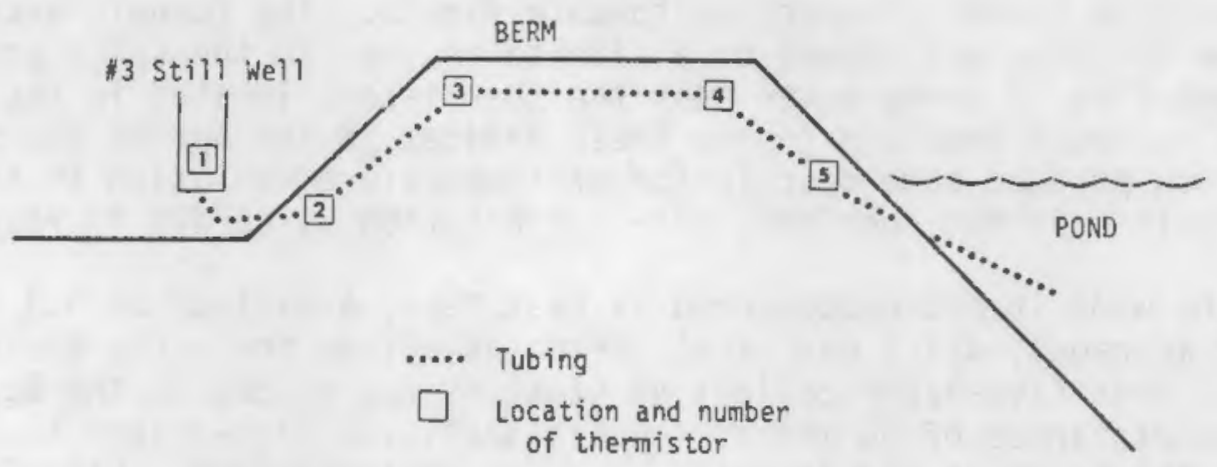

FIGURE 6. Diagram Showing Location of the 5 Thermistors Used During East Mesa 2 to Measure Stilling Well and Tubing Temperatures. Tubing was buried in the berm to a depth of 10-15 centimeters.

\section{QUALITY ASSURANCE}

It is the purpose and essence of quality assurance to define and implement adequate procedures of sensor and system calibration, of procurement and measurement operations responsive to objectives, of responsiveness to events going wrong (with corrective action), and to document all of the above. The bulk of documentation for Raft River and East Mesa data collection is contained in sets of real-time notes which exhibit a day-to-day diary of all related activity. Necessary attention is with data accuracy, resolution and representativeness. Table 7 indicates information relating to these criteria. Of prime importance is the water thermistor, hook gauge, radiometer, and electronics system accuracy and representativeness.

Thermistors in water and soil indicate the actual temperature (within $0.1^{\circ} \mathrm{C}$ ) of the medium in which they are immersed. When applying the thermistors in electronic circuitry, care was taken to assure less than $0.002^{\circ} \mathrm{C}$ selfheating by design of low voltage bridges. The excitation voltages were provided by mercury cells with extreme stability and the excitation voltages were recorded continuously along with the sensor signals.

The hook gauges are mechanical devices similar to micrometers in operation and design. The scales are engraved in metal and, after setting, it is merely a matter of reading the scales. At each time of reading, at least two stilling well level measurements were made. In this way repeatability, a portion of representativeness, was established. Additionally, representativeness was further assured, as previously described by design to eliminate effects of pond tilt due to persistent wind and also wave effects. However, spatial and temporal temperature variation in the measurement system must be considered further.

System end-to-end checks, in.the field, are the "bottom line" of a procedure to assure an accurate (not necessarily representative) data collection 


\section{TABLE 7. Listing of Sensor/System Performance Checks}

Item

Thermistors (water, soil)

Thermistors (air)

Hook Gauges

Pyranometers

Net Radiometers

Wind Sensors

Acoustic Sounder

Barometer and Barograph

Tethered-Balloon System

Digital Recording System

Strip Chart Recording System

Sensor-to-Recorder System

(includes cables)

Software for Data Averaging

Overall System Accuracy
Comments

Calibrated in controlled water bath before and after application. Accuracy $0.1^{\circ} \mathrm{C}$. Resolution $0.02^{\circ} \mathrm{C}$. Representativeness absolute.

Intercompared in controlled laboratory air before application. Accuracy $0.1^{\circ} \mathrm{C}$. Resolution $0.02^{\circ} \mathrm{C}$. Representativeness $0.5^{\circ} \mathrm{C}$ (dry), $1.0^{\circ} \mathrm{C}$ (wet).

No calibration required. Resolution 0.001 $\mathrm{cm}$. Repeatability $0.002 \mathrm{~cm}$.

Factory calibration prior to application.

Factory calibration prior to application. Intercomparison procedure after application.

Wind tunnel performance check prior to application. Bearing maintenance, new factory propellers.

No calibration required.

Before and after application check against standard mercury barometer.

Factory calibration and intercomparisons.

Application of known voltages. Accuracy and resolution 0.001 volt.

Application of known voltages.

Application of known voltages and resistances. Synchronous motor on wind sensors.

Application of dummy data to computer programs.

Same as sensor accuracy. 
system. Precision resistors were temporarily substituted for thermistors, divided mercury cells for voltage sensors, and synchronous motors for anemometer propellers. Sensor signal correction data may then be applied as and if required; the actual sensors are, generally, calibrated independently. Redundancy of sensors also assures data validity. 


\section{MEASUREMENT SCHEDULE}

The data discussed in the following sections and presented in the appendices were obtained during four separate measurement programs; two at Raft River, Idaho, and two at East Mesa, California. The names, dates, starting times and durations of individual experiments are listed in Table 8 . Also indicated is spray system usage at East Mesa.

Details for the first three programs, called Raft River 1 (RRI), Raft River 2 (RR2) and East Mesa 1 (EM1) have been discussed in earlier publications (Hadlock and Abbey, 1978 and 1981).

The East Mesa 2 (EM2) program was started on June 10, 1981. Initial intent had been to run two groups of cooling experiments--with and without sprays. Because of technical problems with the geothermal wells, the cooling pond (no sprays) experiments were conducted first using somewhat 1 imited flow rates of geothermal fluid. Pond temperatures much above $50^{\circ} \mathrm{C}$ were not attained because of reduced available flow. However, pond cooling from those levels was monitored for six cycles (I - VI). When it became clear that greater flow rates would not be obtainable, the spray portion of the program was cancelled.

TABLE 8. Measurement Schedule at Raft River and East Mesa

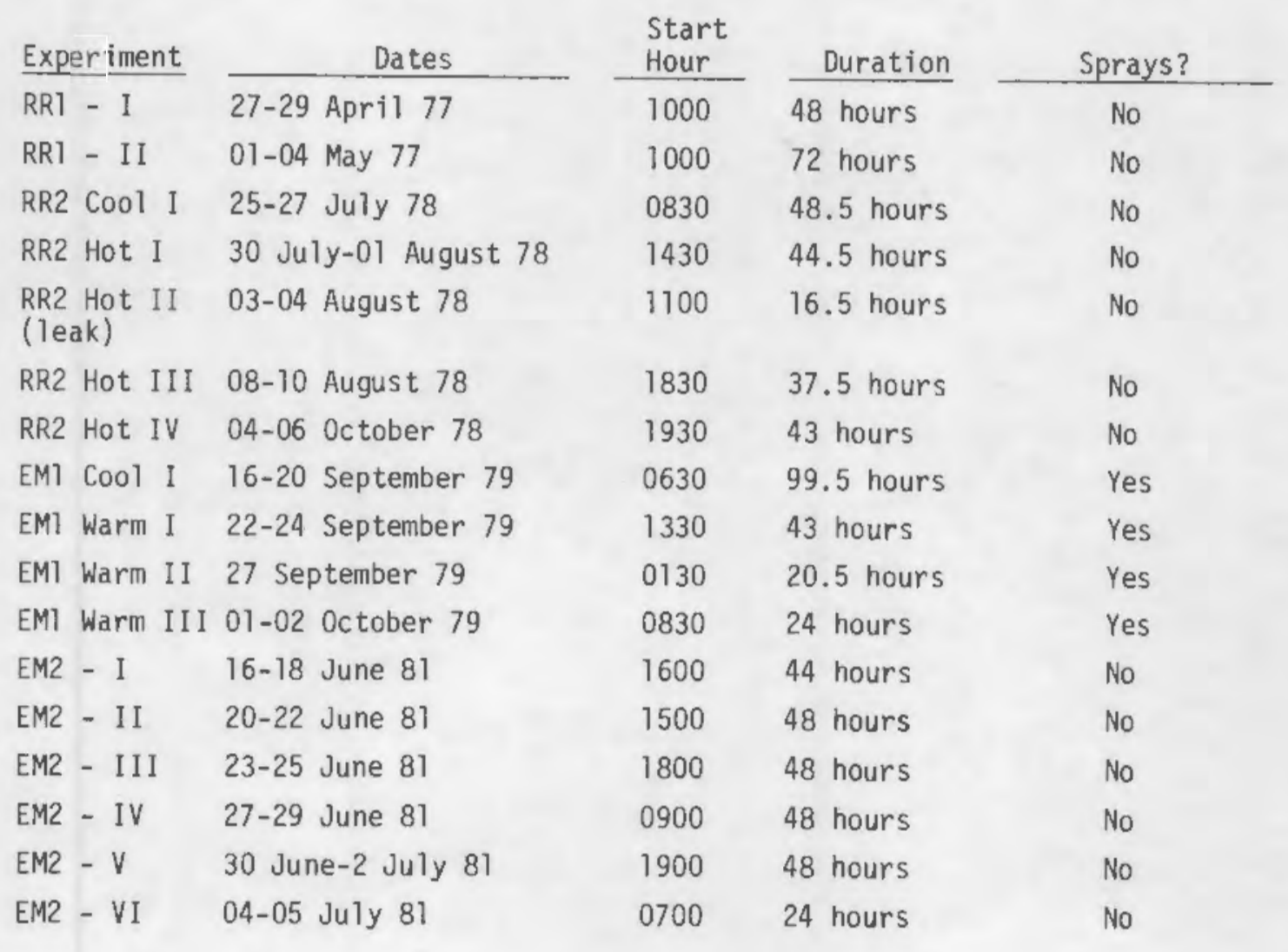




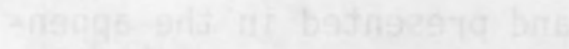

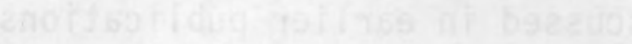

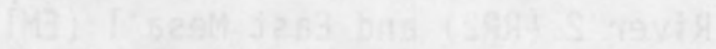
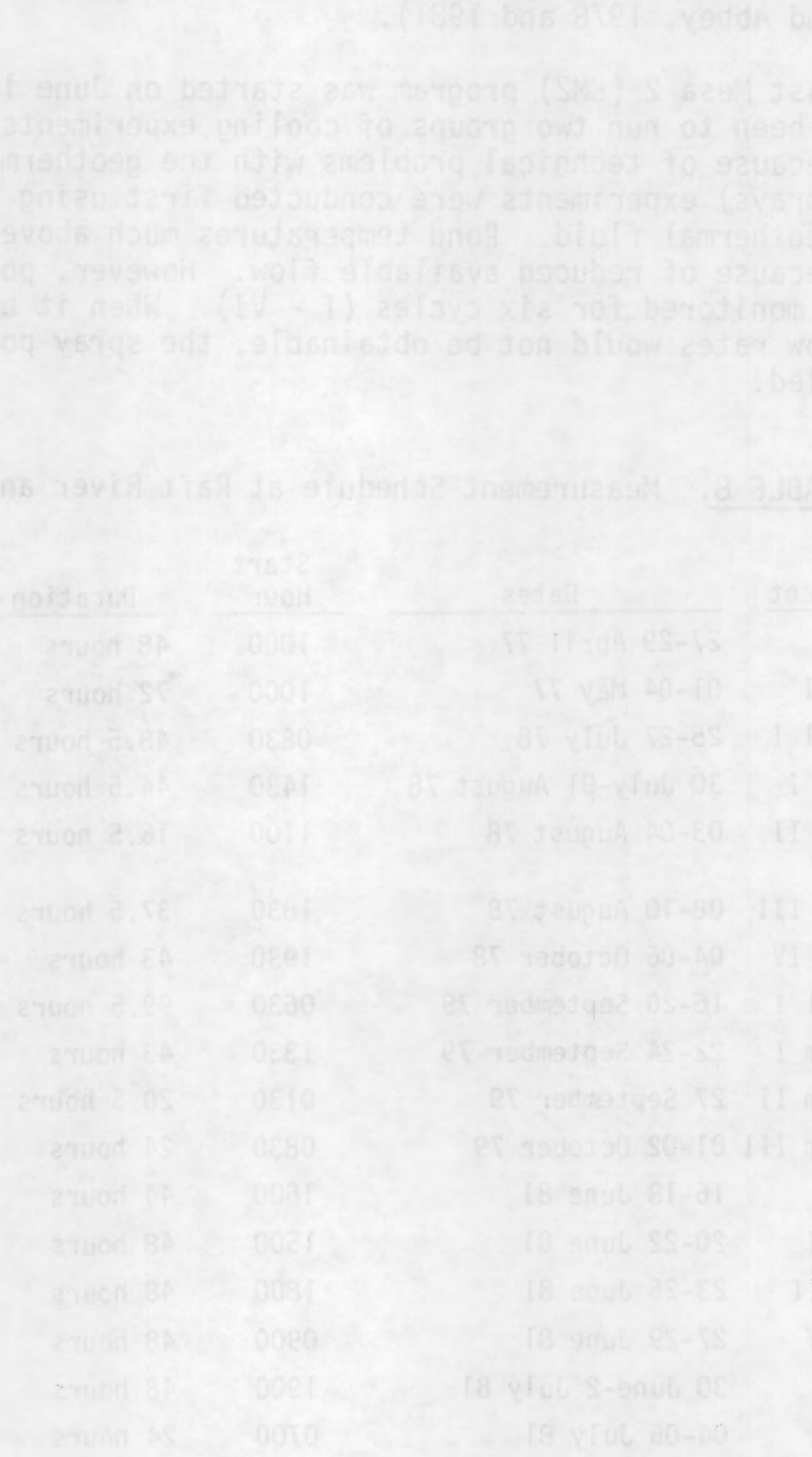


\section{DATA DESCRIPTION}

Four data volumes (Appendices A-D) present the primary information obtained in the measurement programs. The information from Raft River and East Mesa 1 has appeared in previous reports (Hadlock and Abbey, 1978 and 1981) but is included here for completeness.

In each program, additional data, e.g. atmospheric pressure, underliner temperature, soil temperature, etc., were collected and are not reported in the data volumes. However, where appropriate and useful, such information is included in the data discussion.

Table 9 shows a symbol key for the data volumes from Raft River and East Mesa 1. Most entries are half-hour averages of 1.96 second (RRI) or 5 second (RR2 and EMI) data. The averages are centered around the quarter hours and the times presented are the end of the period. The surface elevation values are averages of the instantaneous readings of several hook gauges.

Table 10 shows a symbol key for the data volume from East Mesa 2. The information is similar to that in the previous volumes with the following differences:

1. no standard deviation is given for mean pond temperature

2. a stilling well temperature is given

3. radiation values are reported as a flux $\left(\mathrm{Wm}^{-2}\right)$ and not as power (megawatts) for pond total surface

4. wind speeds are given only for the East berm tower and the remote tower

5. the temperatures at the berm towers were not averaged together to give a "periphery" value; instead only East berm temperatures are reported.

6. averages are centered around the half hours and the times presented are the center of the period. 
TABLE 9. Key to Data Volume for Raft River and East Mesa 1-Appendices A, B and C

Raft River

$\overline{\mathrm{T}}$

$S$

sfc.

Rad Down

Rad Net

W/S

Tw

Td

East Mesa

$\overline{T s}$

Rad Net
Times are Mountain Daylight Time (24 hour scale)

mean bulk pond temperature, average of $9-12$ thermistors $\left({ }^{\circ} \mathrm{C}\right)$ standard deviation of mean temperature data $\left({ }^{\circ} \mathrm{C}\right)$

pond surface elevation with arbitrary reference height, average for three gauges $(\mathrm{cm})$

total downward radiation over entire pond surface (calculated in megawatts)

net radiation over cooling pond, negative is net upward radiation (calculated in megawatts)

wind speed $\left(\mathrm{m} \mathrm{s}^{-1}\right)$; one level on raft, two on reference tower. Average of 3 (RR) and 4 (EM) berm sensors is listed for "periphery"

wet bulb air temperature $\left({ }^{\circ} \mathrm{C}\right)$, average for periphery as for $\mathrm{W} / \mathrm{S}$ dry bulb air temperature $\left({ }^{\circ} \mathrm{C}\right)$, averaging for periphery as for Tw

Times are Pacific Daylight Time (24 hour scale) Symbols are same as Raft River except:

(Col1) - mean funnel (spray collection) temperature $\left({ }^{\circ} \mathrm{C}\right.$ ) (Noz) - mean nozzle (spray production) temperature $\left({ }^{\circ} \mathrm{C}\right.$ )

(Quiet) - measured over undisturbed pond surface (megawatts) (Spray) - measured over sprays, $2 \mathrm{~m}$ above maximum spray height height (megawatts)

(Ba11) - starting with EM Warm I, over-pond $15 \mathrm{~m}$ above sprays, balloon dry and wet bulb temperatures are listed as a "top" level under "periphery" 
IABLE 10. Key to Data Volume for East Mesa 2-Appendix D

All times are Pacific Daylight Time (24 hour scale)

$\uparrow$

Sfc Elevation

Stillwell $\uparrow$

Shortwave Incoming

Net A11-Wave

Wind Speeds

Air Temperatures
Mean bulk pond temperature $\left({ }^{\circ} \mathrm{C}\right)$; an average of $9-12$ thermistors

Pond surface elevation $(\mathrm{cm})$ with arbitrary reference height; average of three hook gauges

mean water temperature $\left({ }^{\circ} \mathrm{C}\right)$ inside stilling wells at time of $\mathrm{sfc}$ elevation reading

Solar radiative flux, direct and diffuse $\left(\mathrm{W} / \mathrm{m}^{2}\right)$

Net radiative flux over pond $\left(\mathrm{W} / \mathrm{m}^{2}\right)$

Speeds $(\mathrm{m} / \mathrm{sec}$ ) at East berm tower ( 1.5 above ground level) and remote tower $(4.8 \mathrm{~m} \mathrm{agl})$

Dry and wet bulb temperatures $\left({ }^{\circ} \mathrm{C}\right)$ for:

East berm tower $(1.2 \mathrm{~m} \mathrm{agl})$

pond tower (raft) $(1.0 \mathrm{~m} \mathrm{agl})$

$(2.0 \mathrm{~m} \mathrm{agl})$

remote tower

(4.8 $\mathrm{magl})$

(9.0 m agl) 


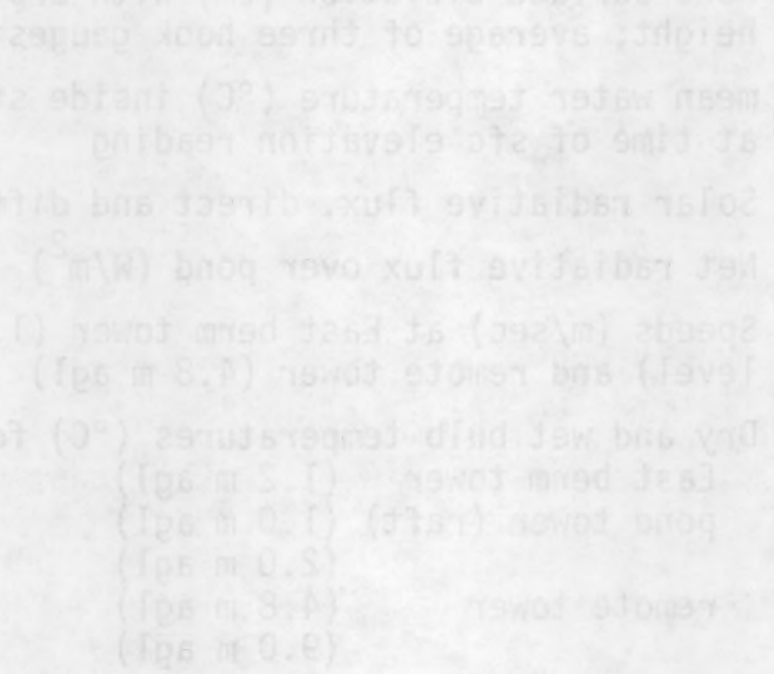

-

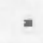




\section{DATA DISCUSSION}

The two most important indicators of pond performance are discussed first, i.e., changes in buTk pond temperature and changes in pond surface elevation. The need for correction in the elevation measurements is explained with an example. Next, the meteorological influences on the pond are summarized. Finally, three aspects of air-water interaction are discussed: temperature and moisture plume, spray effects, and energy budgets.

\section{POND PERFORMANCE}

Table 11 summarizes the 17 separate pond cooling experiments. The table contains initial and final bulk pond temperatures, decrease in surface elevation over the period (uncorrected) and air temperature range encountered. The pond temperatures help characterize each experiment. There were only two very hot $\left(>70^{\circ} \mathrm{C}\right.$ ) experiments (RR2 - Hot II and Hot IV) and the first was terminated by a leak. However, a variety of conditions were encountered during the measurement program.

The pond bulk temperature is an average of as many as 12 thermistors arranged in vertical chains. These are located near pond center (or just outside the spray pattern) and at the center of each side of the pond at about where the berm slope levels off to become the flat pond bottom. At no time at Raft River or at East Mesa has any substantial temperature stratification been observed in either the vertical or horizontal during measurement episodes except for an interface temperature departure. This is indicated by the small magnitude of the temperature standard deviation displayed in the Raft River data appendix. The data show a similar invariance for East Mesa; a standard deviation is not listed in the East Mesa appendix.

It is important to be able to assert that the ponds do not leak. There is evidence that leaks have not existed at either site except during RR Hot II:

1. Observation--with the exception mentioned, no moisture has been observed on the outside of any berm at any time. A leak of consequence, say to amount to $10 \%$ of observed water loss, would produce a depth decrease of about $0.6 \mathrm{~cm}$ in 24 hours. This translates to about $19 \mathrm{~m}^{3}$ over 24 hours-a flow through a berm that would be detected casually.

2. Procedure--WESTEC personnel have "topped off" the East Mesa pond during the summer of 1980 (no rain) at an average rate of about $0.3 \mathrm{~cm} /$ day (in amounts of about $10 \mathrm{~cm}$ at a time). This is reasonable based on expected summer evaporation only.

3. Under-Liner Temperatures--during all experiments, vertical temperature gradients in the soil below the liner are as expected depending on experiment history and instantaneous pond temperature. During RR Hot II, the gradient became essentially zero as would be expected (increased thermal conductivity, but more importantly, advection of water at bulk 
TABLE 11. Summary of the Seventeen Pond Cooling Experiments

\begin{tabular}{|c|c|c|c|c|c|c|}
\hline $\begin{array}{c}\text { Measurement } \\
\text { Program }\end{array}$ & $\begin{array}{l}\text { Expt. } \\
\text { No. }\end{array}$ & $\begin{array}{l}\text { Initial } \\
\text { Pond } \overline{\mathrm{T}} \\
\left({ }^{\circ} \mathrm{C}\right) \\
\end{array}$ & $\begin{array}{l}\text { Final } \\
\text { Pond }{ }^{\top} \\
\left({ }^{\circ} \mathrm{C}\right) \\
\end{array}$ & $\begin{array}{l}\text { Decrease in } \\
\text { sfc Elevation } \\
(\mathrm{cm}) \\
\end{array}$ & $\begin{array}{c}\text { Duration } \\
\text { (hr) }\end{array}$ & $\begin{array}{c}\text { Air Temp. } \\
\text { Range } \\
\left({ }^{\circ} \mathrm{C}\right) \\
\end{array}$ \\
\hline RRI & I & 47.4 & 27.0 & -- & 48 & $4.5-11.8$ \\
\hline RR1 & II & 50.5 & 25.5 & -- & 72 & $5.9-13.6$ \\
\hline RR2 & Cool I & 24.9 & 24.3 & 1.79 & 48.5 & $11.7-35.5$ \\
\hline RR2 & Hot I & 61.1 & 31.5 & 9.18 & 44.5 & $10.9-34.8$ \\
\hline RR2 & $\begin{array}{l}\text { Hot II } \\
\text { (leak) }\end{array}$ & 70.8 & 42.5 & $>5.80$ & 16.5 & $10.7-32.4$ \\
\hline RR2 & Hot III & 53.5 & 31.5 & $>6.63$ & 37.5 & $9.1-34.6$ \\
\hline RR2 & Hot IV & 71.8 & 31.4 & 11.46 & 43 & $0.4-24.0$ \\
\hline EM1 & Cool I & 41.9 & 24.6 & 9.97 & 99.5 & $20.5-40.7$ \\
\hline EM1 & Warm I & 51.9 & 23.4 & 10.31 & 43 & $21.5-41.7$ \\
\hline EM] & Warm II & 47.2 & 28.7 & 6.32 & 20.5 & $20.1-38.7$ \\
\hline EM1 & Warm III & 47.5 & 25.7 & 6.97 & 24 & $19.3-38.8$ \\
\hline EM2 & I & 45.8 & 33.4 & 4.14 & 44 & $19.3-45.3$ \\
\hline EM2 & I I & 45.9 & 34.5 & 4.78 & 48 & $24.0-44.3$ \\
\hline EM2 & I I I & 50.0 & 35.7 & 5.39 & 48 & $25.3-44.3$ \\
\hline EM2 & IV & 50.9 & 32.4 & 6.14 & 48 & $25.6-41.2$ \\
\hline EM2 & v & 48.0 & 34.1 & 5.42 & 48 & $22.2-40.0$ \\
\hline EM2 & VI & 45.8 & 37.5 & 3.10 & 24 & $28.7-43.7$ \\
\hline
\end{tabular}

pond temperature past all of the thermistors). The Raft River thermistor chain recovered within hours after liner repair. No such event occurred at East Mesa.

4. Low-Evaporation Measurement--during early December 1980, the East Mesa pond level was monitored with a result of no more than $1 \mathrm{~mm} / 24$ hours water loss. This puts an upper limit on a hypothetical (small) leak. More likely, there is no leak since $1 \mathrm{~mm} / 24$ hours is a reasonable (by comparison with simultaneous pan data) expectation for evaporation in winter at East Mesa.

Water surface elevation entries in the data volumes are averages for three stilling well systems. Attention to the representativeness of these data as indicative of evaporation from the pond is required. The elevation data may be affected by wind acting on the pond surface to produce a tilt. This would adversely affect the elevation data although sensors were located so as to minimize the potential effect. Elevation data are also affected by 
changing temperatures exterior to the pond, causing expansion or contraction of a portion of the measurement system and the fluid it contains. It is wise, with respect to making calculations utilizing these data, to choose a time interval with similar conditions of wind and ambient temperature at beginning and end. An appropriate interval is 24 hours. If this interval is chosen, usually the described effects on the data may safely be neglected.

However, a remaining and important effect of temperature change on the surface elevation data must be taken into account prior to using the data as indicative of evaporation. It is necessary to describe and discuss the measurement system in more detail. Figure 7 shows two representations of possible measurement systems. An "ideal" system is represented by the upper drawing and the actually deployed system by the lower drawing. Consider the ideal system, i.e., as if the tube connecting the stilling well goes through the pond berm into the pond water. Aside from the effects described previously, the gauge in the well will accurately indicate the pond surface elevation. If water leaves the pond through evaporation or other processes such as seepages, the gauge will indicate these changes. If the pond shrinks in depth by cooling, the gauge will not indicate the shrinking due to the cooling per se; it responds to weight (mass) change in the pond only. This would be a useful configuration at the pond sites. However, it has not been convenient to insert measurement system tubes through the pond liner. The risk of producing leaks would likely outweigh advantages.

The actual configuration of the measurement systems is illustrated by the lower drawing. Here, the tube comes out of the pond water, over the berm, and into the stilling well. It is important that the filled tube, essentially a static syphon, has no leaks. If a sufficient amount of air enters the tube, the measurement system will cease to function. Again, the system will indicate changes of pond level due to mass changes in the pond. But in addition the system will indicate an apparent water loss from the pond as the pond and the exposed right-hand side of the tube cools during an experiment. As the pond cools, the water volume shrinks and the elevation of the water surface decreases. This is exhibited in addition to real water loss due to evaporation. In order that hydrostatic balance remains, the left side of the system must become "longer." This happens in result of a water surface elevation decrease in the well; there is a tiny exchange of water between well and pond.

If the stilling well-pond system were isothermal during experiments, changes in pond elevation would be accurately represented by hook gauge measurements in the actual system. However, parts of the system (stilling well. and pond) change in temperature over $225^{\circ} \mathrm{C}\left(25\right.$ to $\left.50^{\circ} \mathrm{C}\right)$. The tubing temperature has a range of $230^{\circ} \mathrm{C}\left(30\right.$ to $\left.60^{\circ} \mathrm{C}\right)$. Pond temperatures generally decrease, but show afternoon heating at lower bulk temperatures $\left(<35^{\circ} \mathrm{C}\right)$. The impact of these temperature changes on determination of apparent vs. actual water volume must be given attention.

Consider changes of pond volume over two arbitrary time intervals of 1 hour and 24 hours. The following calculated values of apparent actual water loss are obtained from data of EM2, Experiment 4. Apparent value was 

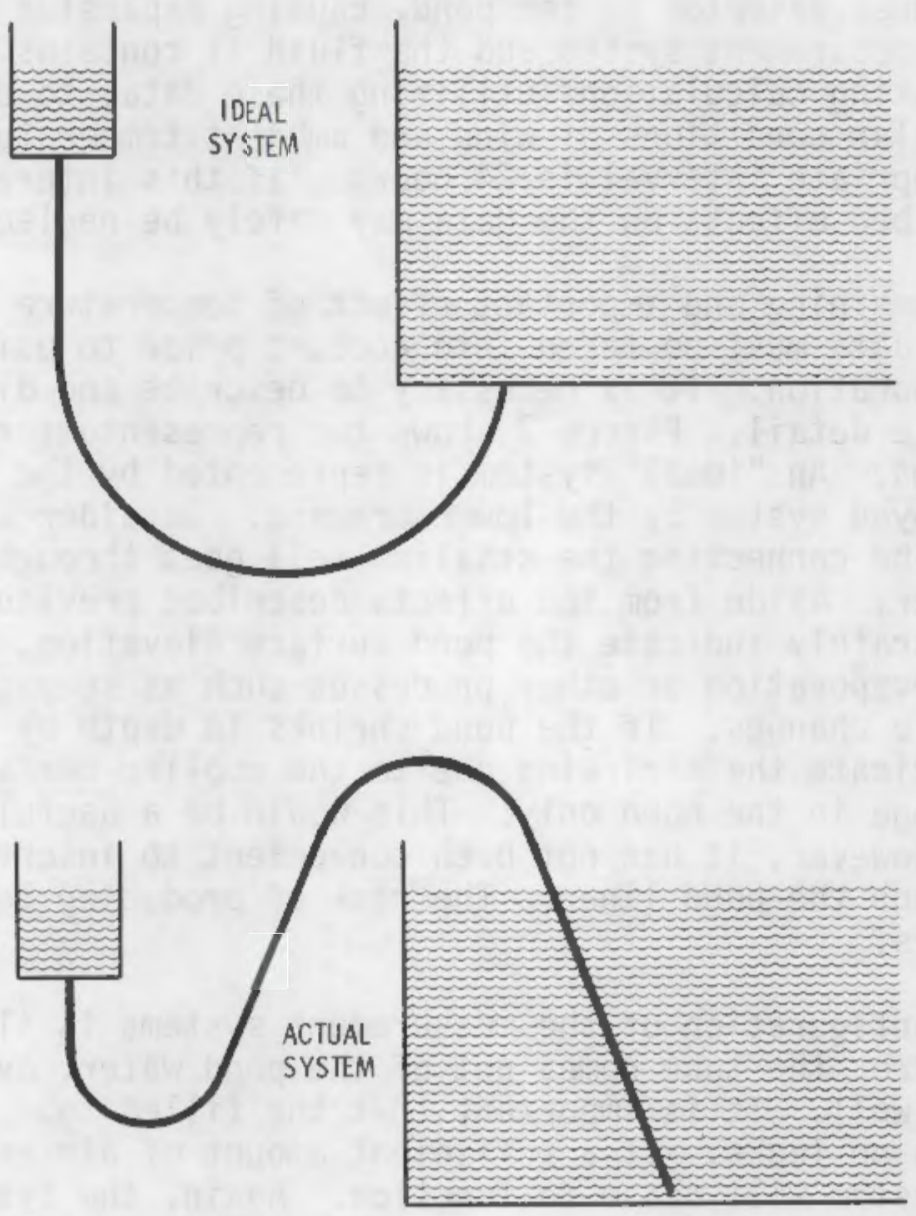

FIgURE 7. Two Possible Hydraulic Systems to Measure Pond Surface Elevation. The lower example represents that used at Raft River and East Mesa.

calculated directly from measured surface elevations using the relationship discussed earlier. Corrections to volume were made using data on water volume and density changes with temperature (Kel1, 1967).

\begin{tabular}{|c|c|c|c|c|c|c|}
\hline & \multirow{2}{*}{$\begin{array}{c}\text { Apparent } \\
\text { Volume } \\
\left(\mathrm{m}^{3}\right) \\
\end{array}$} & \multirow{2}{*}{$\begin{array}{c}\text { Actual } \\
\text { Volume } \\
\left(\mathrm{m}^{3}\right) \\
\end{array}$} & \multirow{2}{*}{$\begin{array}{l}\text { Water } \\
\text { Loss } \\
\text { Apparent } \\
\left(\mathrm{m}^{3}\right) \\
\end{array}$} & \multirow{2}{*}{$\begin{array}{l}\text { Water } \\
\text { Loss } \\
\text { Actual } \\
\left(\mathrm{m}^{3}\right) \\
\end{array}$} & \multicolumn{2}{|c|}{$\begin{array}{l}\text { Error Due to } \\
\text { Temperature } \\
\text { Change }\end{array}$} \\
\hline & & & & & $\begin{array}{c}\Delta V \\
\left(m^{3}\right) \\
\end{array}$ & $\begin{array}{c}\Delta \mathrm{h} \\
\left(\mathrm{m}^{3}\right) \\
\end{array}$ \\
\hline Initial & 4727.6 & 4727.6 & -- & -- & -- & -- \\
\hline $1 \mathrm{hr}$ & 4718.3 & 4719.8 & 9.3 & 7.8 & 1.5 & 0.08 \\
\hline $24 \mathrm{hr}$ & 4581.5 & 4608.7 & 140.0 & 118.9 & 21.1 & 0.82 \\
\hline
\end{tabular}


As indicated, significant error can be made in pond volume calculations from elevation measurements and, thus, in water utilization calculations unless corrections are made for temperature-related changes in volume.

The stilling wells undergo a much greater diurnal change in temperature than does the pond, largely due to direct solar influence. If a well water water volume of $1600 \mathrm{~cm}^{3}$ is assumed, a $0.9 \%$ increase in volume will be observed as temperature increases from 25 to $50^{\circ} \mathrm{C}$. This translates into a water level change in the stilling well of $0.0227 \mathrm{~cm}$. A similar calculation for the tubing can be done. Such thermally induced indications of pond volume changes are based on maximum temperature changes of the stilling well and tubing. Figure 6 shows the location of thermistors used to monitor the system. Figure 8 shows a representative 24 hours of system component temperatures. If water utilization is determined over a period of maximum heating or cooling, temperature corrections for stilling well and tubing are important. However, over the 1 hour period which is the standard measurement interval, changes in water volume would be slight and below the resolution of the hook gauges. Similarly, for calculations over a 24 hour period, temperatures have moved through a complete diurnal cycle and differences are again small.

Temperature corrections must be made for pond volume as determined from surface elevations for all the data. No corrections to elevations have been displayed in the data volumes. Table 12 illustrates the total error possible. It shows the apparent and correct volume changes over each of the East Mesa 2 experiments. In terms of thermal performance, an error of water utilization of $\sim 20 \mathrm{~m}^{3}$ over 2 days represents 20.5 megawatts.

Figure $g$ illustrates water utilization for the first twenty-four hour period of EM2-I. As the upper graph shows, water loss is large in the first several hours and then becomes somewhat stable. The fluctuations apparent in the loss rates are attributed to variations in wind and other meteorological influences. The curves show a slight diurnal effect, with rate of water loss increasing late in the afternoon.

It is useful to summarize the importance of the corrections required to achieve meaningful information of changing real pond volume, i.e., water loss through evaporation only.

- During the experiments, the pond cools from higher temperatures to Tower temperatures and, therefore, a portion of the measured surface elevation change is not indicative of water loss. The pond shrinks in result of the decreasing temperature of measuring system configuration results in showing the thermal portion as well as that due to evaporation. Correction to the surface elevation data is required for any time period considered for calculations.

- During the experiments, the stilling wells and connecting tubing experience temperature change. The important part of this change is the 


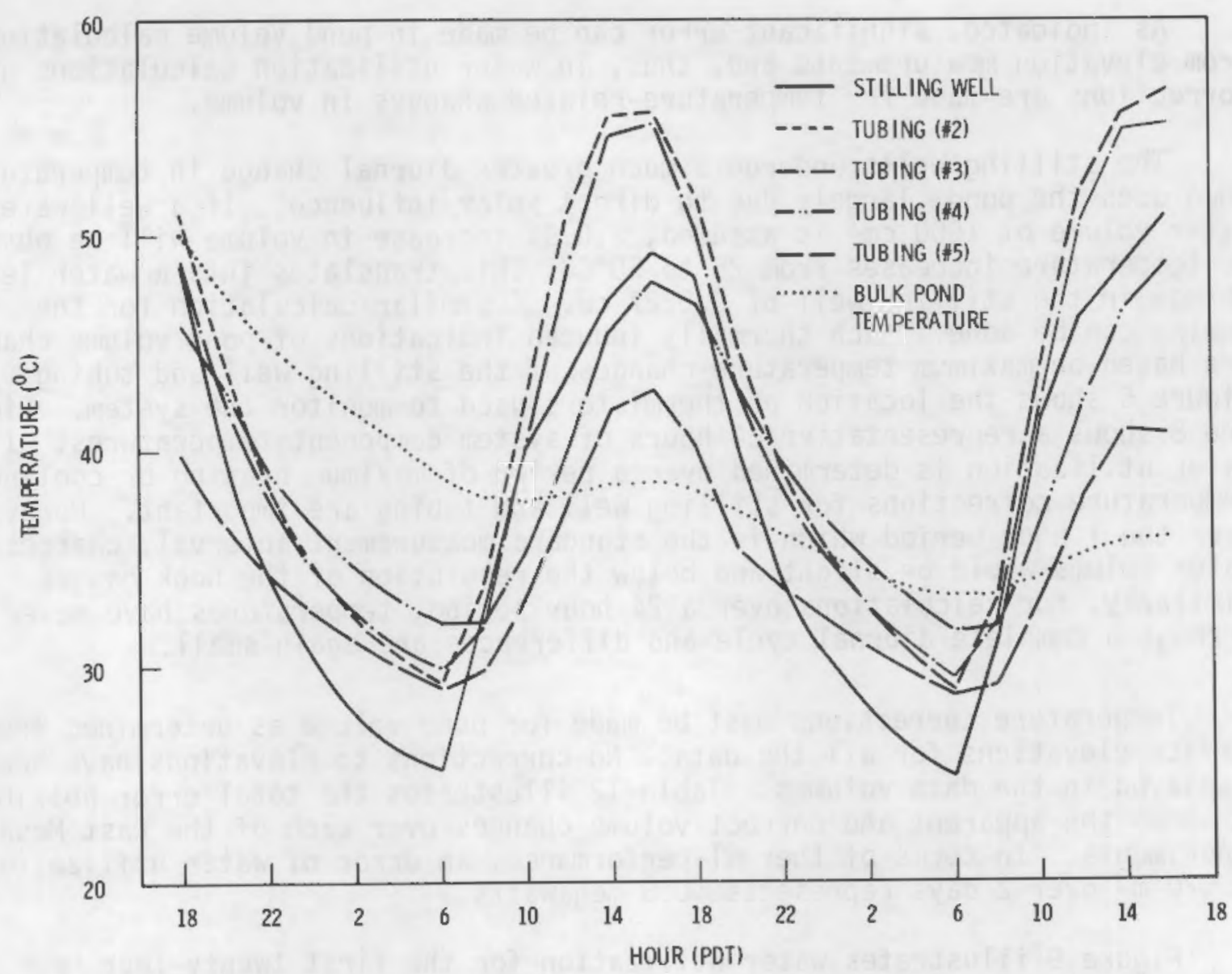

FIGURE 8. Temperatures of Stilling We11, Tubing and Pond on June 22-25, 1981 (EM2 - Experiment 3)

TABLE 12. Initial Pond Depth and Depth Change Over the Experimental Periods of East Mesa 2 (1981)

\begin{tabular}{|c|c|c|c|c|}
\hline $\begin{array}{l}\text { Expt. } \\
\text { No. }\end{array}$ & $\begin{array}{l}\text { Initial Depth } \\
\text { (m) }\end{array}$ & $\begin{array}{l}\text { Depth Change } \\
(\mathrm{cm})\end{array}$ & $\begin{array}{l}\text { Measured } \\
\text { Volume Loss } \\
\left(\mathrm{m}^{3}\right)^{-}\end{array}$ & $\begin{array}{c}\text { Corrected } \\
\text { Volume Loss } \\
\left(\mathrm{m}^{3}\right)\end{array}$ \\
\hline 1 & 1.48 & 4.141 & 145.7 & 123.9 \\
\hline 2 & 1.49 & 4.784 & 168.6 & 148.3 \\
\hline 3 & 1.48 & 5.389 & 189.2 & 162.8 \\
\hline 4 & 1.49 & 6.135 & 215.8 & 182.3 \\
\hline 5 & 1.59 & 5.424 & 197.D & 170.0 \\
\hline 6 & 1.65 & 3.099 & 115.1 & 97.8 \\
\hline
\end{tabular}




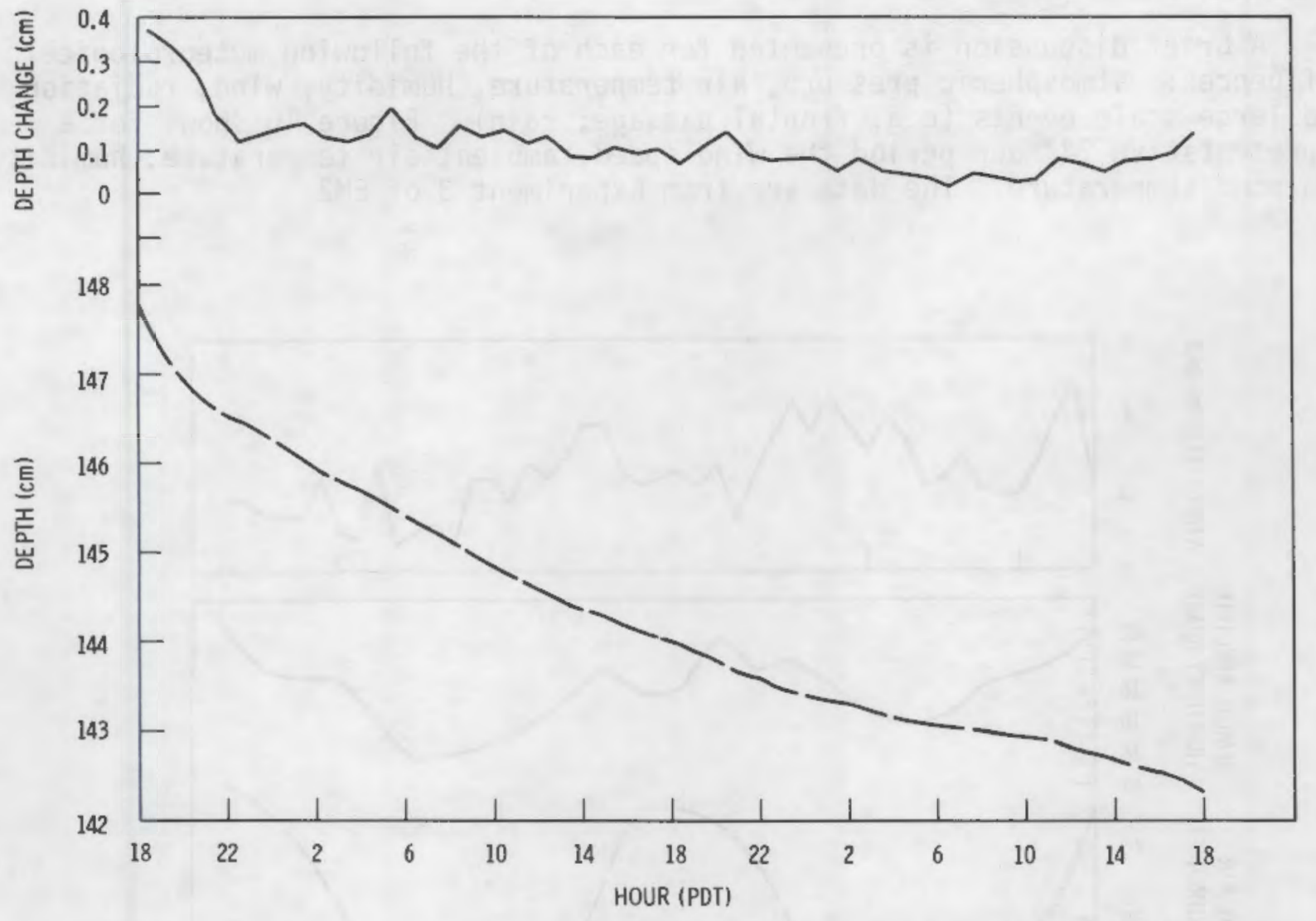

FIGURE 9. Pond Depth (apparent) and Depth Chanqe Per Hour for June 16, 1981 (EM2-1). The data have not been corrected for temperature variation.

effect of the diurnal oscillation of ambient air temperature and direct thermal loading from the sun. If calculations will involve water loss over an hour, corrections to apparent elevation change of the pond must be made, especially at times of maximum hourly temperature changes. However, if it is desired to examine evaporative water loss over a twentyfour hour period, thermal conditions of the measuring system at beginning and end are sufficiently similar that these effects may be neglected.

- Representative indication of the relative magnitudes of thermal effects on indicated pond surface elevation are given in the tables. Depending on the exact calculational or modeling purpose at hand, the data of surface elevation in the appendices must be corrected for the thermal effects. 


\section{METEOROLOGICAL INFLUENCES}

A brief discussion is presented for each of the following meteorological influences: atmospheric pressure, air temperature, humidity, wind, radiation and large-scale events (e.g. frontal passage; rain). Figure 10 shows for a representative 24 hour period the wind speed, ambient air temperature, humidity and pond temperature. The data are from Experiment 3 of EM2.
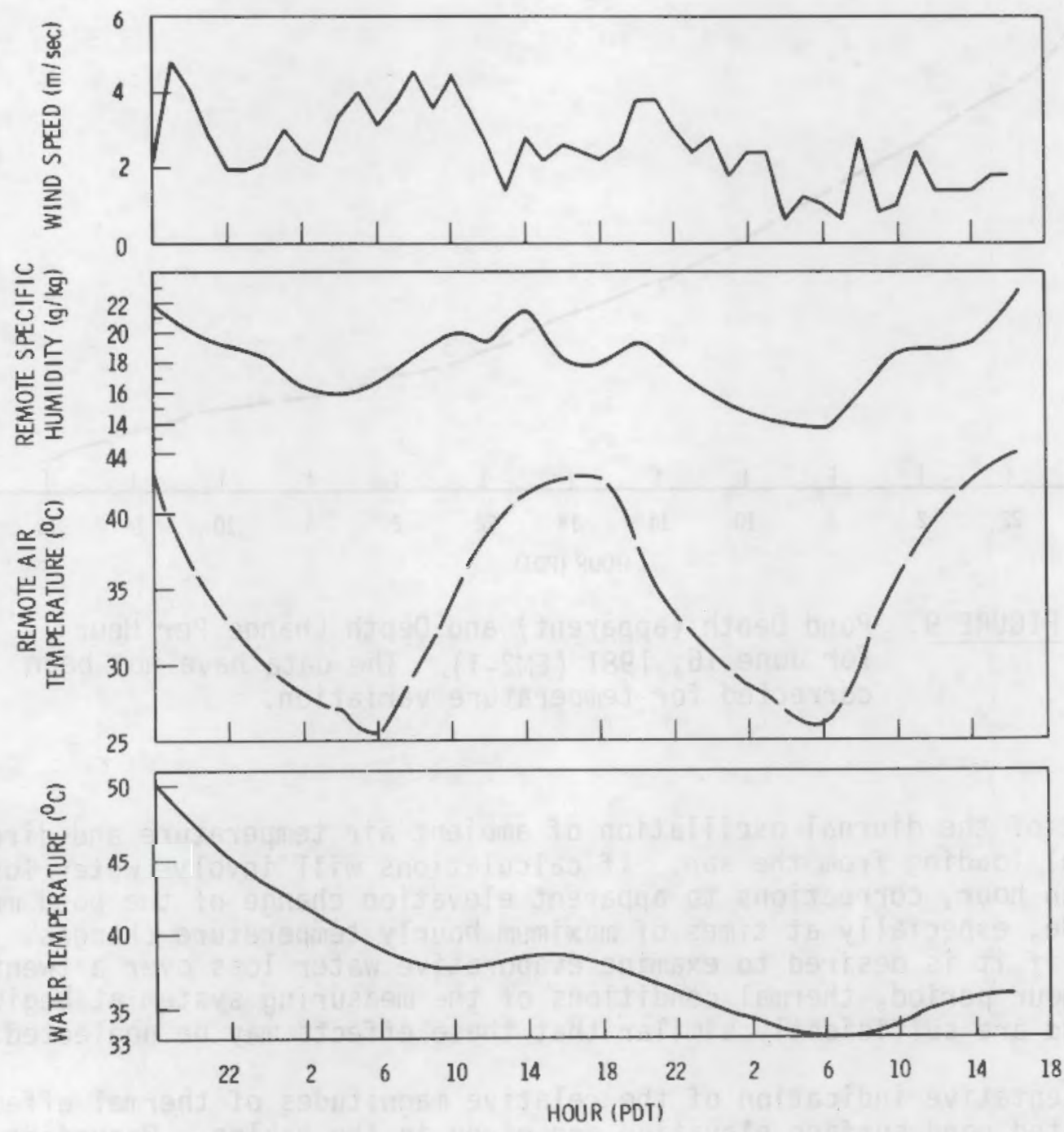

FIGURE 10. Pond and Atmospheric Conditions for EM2 - Experiment 3. Plots are Based on $1 / 2$ hour averages of 5 -second data. 


\section{Atmospheric Pressure}

Atmospheric pressure data are necessary for psychrometric calculations. However, large changes in pressure were not observed during any experiments. Pressure data showed expected daily variations and were influenced by largescale meteorological events. Hourly values of pressure are not available for the Raft River or East Mesa 1 experiments. A range of applicable pressures for each program is given below:

$$
\begin{aligned}
& \text { Raft River } 1-840-860 \mathrm{mb} \\
& \text { Raft River } 2-840-860 \mathrm{mb} \\
& \text { East Mesa } 1-1000-1020 \mathrm{mb}
\end{aligned}
$$

Table 13 gives a summary of pressures during East Mesa 2. The data were extracted from microbarograph charts for this experiment series. It is not considered that the pressure data detail is of first-order importance for calculations or modeling purposes.

\section{Air Temperature}

Dry and wet-bulb temperatures are presented in the data volumes. In all cases air temperatures are available for at least 3 locations: over pond, berm and at the remote tower. Given this information, it is possible to examine the temperature gradient above the pond as it controls sensible heat transfer. Figure 11 shows air temperature (remote) and pond bulk temperature for a 24 hour period during EM2 - I. At night, heat transfer by conduction is away from the pond. However, at mid-day, the gradient is reversed. With a warmer pond, this would be an unlikely occurrence. Figure 12 shows a similar example from RR2 - Hot IV. The pond is hotter but air temperatures are also much lower. Conduction is always away from the pond. An important aspect of cooling pond performance is the temperature difference between the pond surface and the ambient air.

Table 14 shows pond influence on air temperature. The data illustrate a 4 hour period when the wind was steady from one direction. Air temperatures downwind of the pond are greater than upwind values due to sensible heat transfer from the pond surface at temperatures exceeding $43^{\circ} \mathrm{C}$.

\section{Humidity}

Humidity is not directly expressed in the data volumes. Such information can be calculated from the wet bulb temperature and the wet bulb depression. The humidity gradient over the pond controls evaporative losses. Figures 13 and 14 show the remote specific humidity $\left(q_{a}\right)$ and the saturation specific ( $q_{s}$ ) humidity for air at the pond temperature. While it is the specific humidity 
TABLE 13. Atmospheric Pressures During East Mesa 2, 1981 (mi11ibars)

\begin{tabular}{|c|c|c|c|c|c|c|c|c|c|c|c|c|c|c|c|c|c|c|c|c|}
\hline \multirow{2}{*}{$\begin{array}{l}\text { Date } \\
\text { Time } \\
\text { (PDT)MT }\end{array}$} & \multicolumn{16}{|c|}{ June } & \multicolumn{4}{|c|}{ July } \\
\hline & $\frac{75}{-}$ & $\frac{16}{1008}$ & $\frac{17}{1004}$ & $\frac{18}{999}$ & $\frac{19}{--}$ & $\frac{20}{1002}$ & $\frac{21}{1002}$ & $\frac{22}{1002}$ & $\frac{23}{1000}$ & $\frac{24}{999}$ & $\frac{25}{1002}$ & $\frac{26}{1002}$ & $\frac{27}{1000}$ & $\frac{28}{999}$ & 29 & $\frac{30}{1002}$ & $\frac{1}{1003}$ & $\frac{2}{1004}$ & $\frac{3}{1005}$ & $\overline{4001}$ \\
\hline 2 & -- & 1008 & 1004 & 1000 & . & 1003 & 1002 & 1002 & 1000 & 1000 & 1002 & 1003 & 1001 & 999 & 1001 & 1002 & 1003 & 1004 & 1005 & 1002 \\
\hline 4 & -- & 1008 & 1003 & 1000 & -- & 1003 & 1003 & 1002 & 1000 & 1001 & 1003 & 1004 & 1002 & 999 & 1001 & 1002 & 1003 & 1004 & 1006 & 1003 \\
\hline 8 & -- & 1009 & 1004 & 1004 & -. & 1005 & 1005 & 1003 & 1003 & 1004 & 1005 & -. & 1003 & 1003 & 1003 & 1004 & 1005 & 1006 & 1007 & 1006 \\
\hline 10 & -- & 1008 & 1004 & 1003 & -- & 1004 & 1004 & 1004 & 1002 & 1004 & 1005 & -- & 1003 & 1004 & 1004 & 1004 & 1005 & 1006 & 1008 & -. \\
\hline 16 & 1009 & 1003 & 999 & 1002 & 1001 & 1000 & 1000 & 999 & 997 & 1000 & 1001 & 994 & 998 & 1001 & 1002 & 1000 & 1001 & 1002 & 1003 & -- \\
\hline 18 & 1007 & 1002 & 997 & -- & 1000 & 999 & 999 & 999 & 997 & 999 & 999 & 995 & 997 & 999 & 1001 & 1000 & 1000 & 1002 & 1002 & -- \\
\hline 20 & 1007 & 1002 & 997 & -- & 1000 & 999 & 999 & 998 & 997 & 999 & 999 & 996 & 997 & 999 & 1000 & 1000 & 1001 & 1002 & 1000 & -- \\
\hline 22 & 21008 & 1003 & 998 & -- & 1002 & 1001 & 1001 & 999 & 998 & 1001 & 1001 & 999 & 998 & 1001 & 1000 & 1002 & 1002 & 1004 & 1001 & $\ldots$ \\
\hline
\end{tabular}




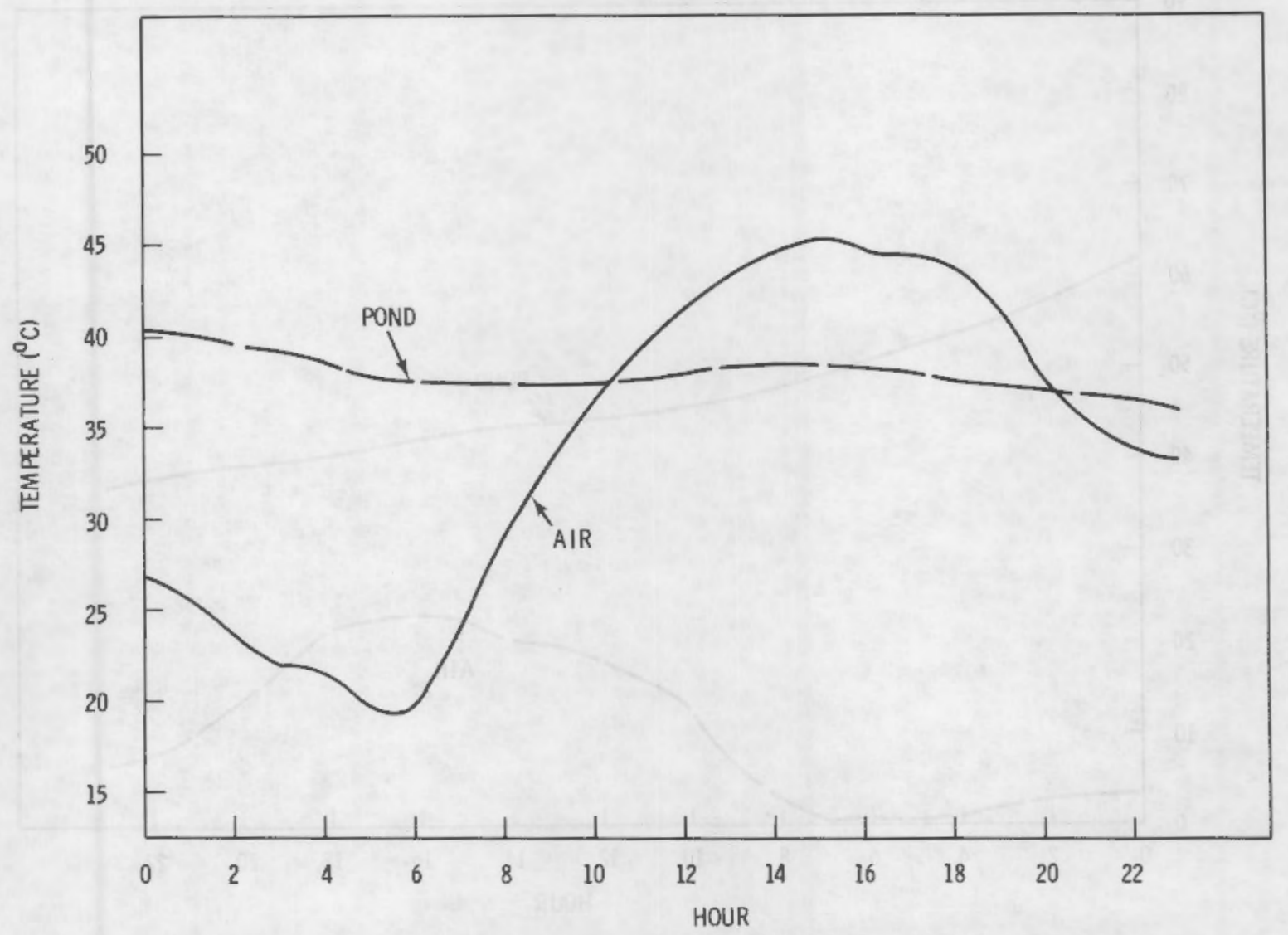

FIGURE 11. Air Temperature and Pond Bu1k Temperature for East Mesa on June 17, 1981 (EM2 - I) 


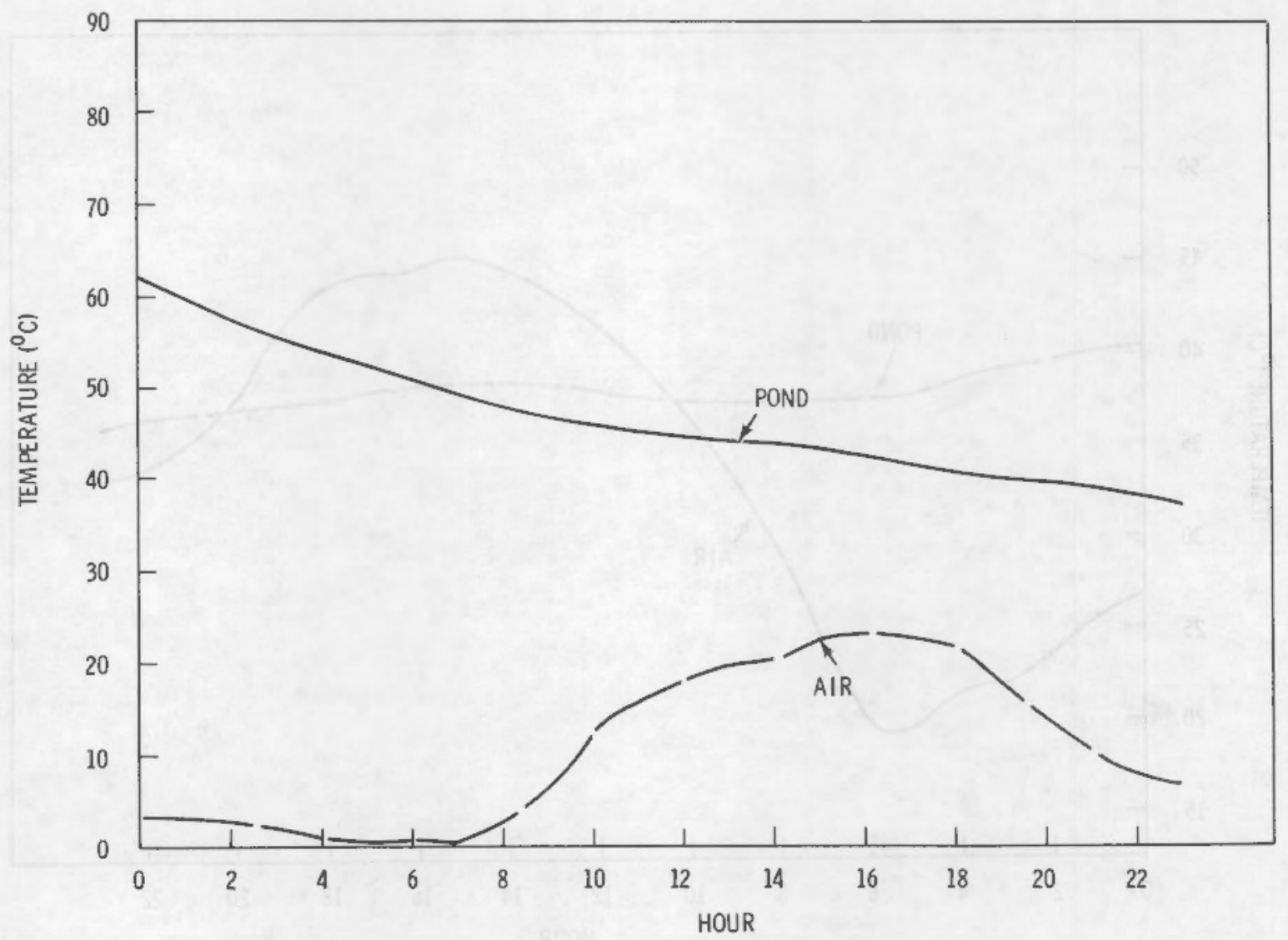

FIGURE 12. Air Temperature and Pond Bulk Temperature at Raft River on October 5, 1978 (RR2 - Hot IV) 
TABLE 14. Air Temperatures and Specific Humidities Upwind Vs. Downwind of the Pond

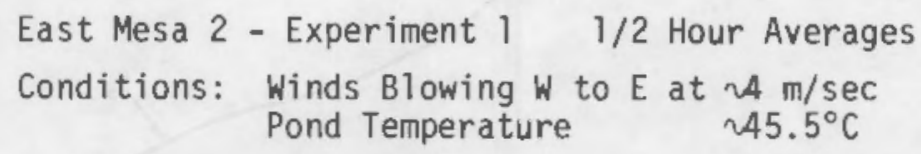

\begin{tabular}{|c|c|c|c|c|}
\hline \multirow{2}{*}{$\begin{array}{l}\text { Time } \\
\text { (PDT) }\end{array}$} & \multicolumn{2}{|c|}{$\begin{array}{l}\text { West Berm } \\
\text { (upwind) }\end{array}$} & \multicolumn{2}{|c|}{$\begin{array}{l}\text { East Berm } \\
\text { (downwind) }\end{array}$} \\
\hline & $I\left({ }^{\circ} \mathrm{C}\right)$ & $\mathrm{q}(\mathrm{g} / \mathrm{kg})$ & $\overline{\mathrm{T}}\left({ }^{\circ} \mathrm{C}\right)$ & $\mathrm{q}(\mathrm{g} / \mathrm{kg})$ \\
\hline 1600 & 39.9 & 12.2 & 41.2 & 17.3 \\
\hline 1630 & 39.6 & 12.8 & 40.8 & 18.1 \\
\hline 1700 & 39.6 & 12.6 & 40.6 & 17.8 \\
\hline 1730 & 39.3 & 12.5 & 40.3 & 17.6 \\
\hline 1800 & 39.1 & 11.9 & 40.0 & 16.8 \\
\hline 1830 & 38.5 & 12.5 & 39.4 & 17.6 \\
\hline 1900 & 37.1 & 12.5 & 37.9 & 17.2 \\
\hline 1930 & 35.3 & 11.9 & 35.9 & 16.0 \\
\hline
\end{tabular}

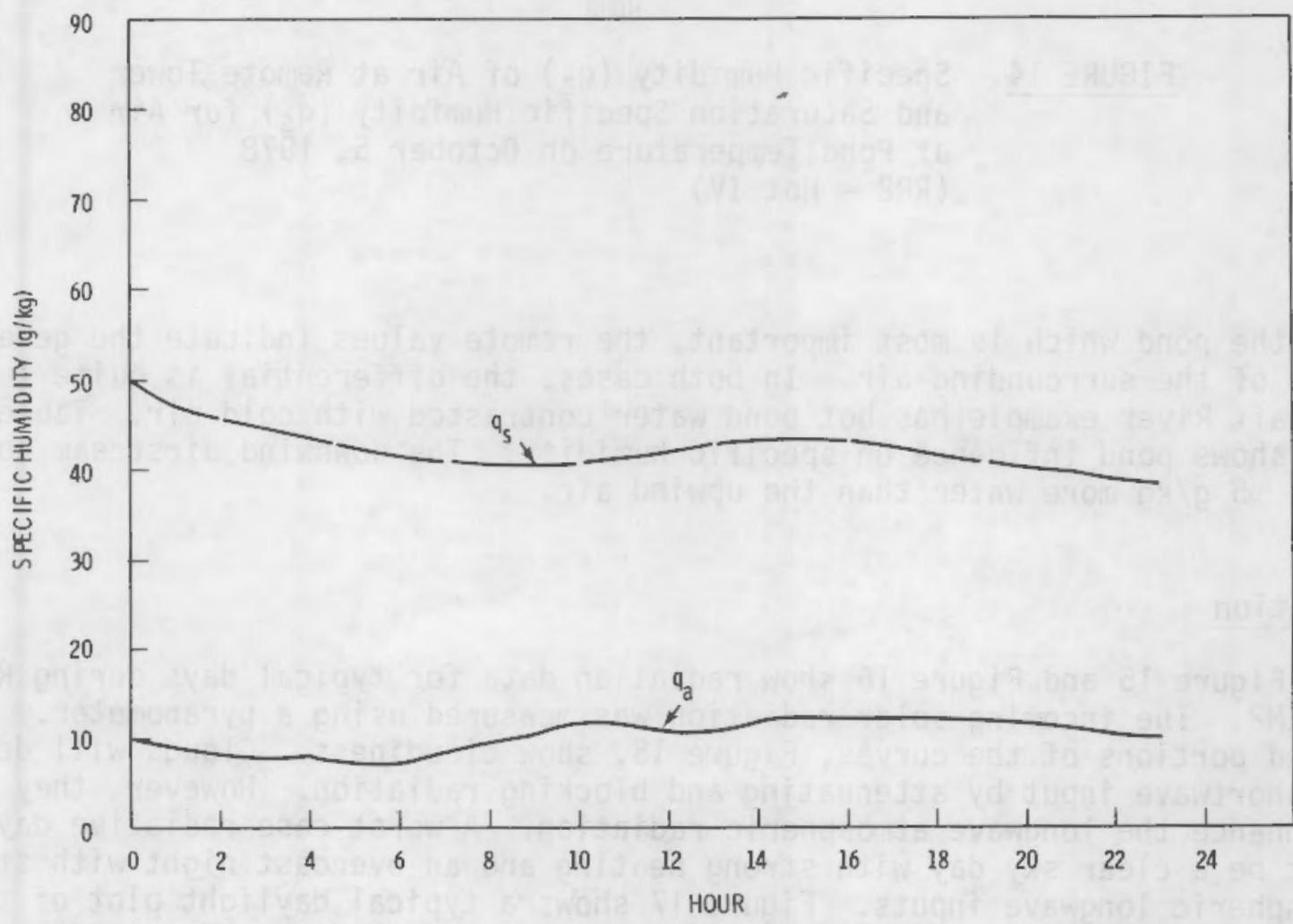

FIGURE 13. Specific Humidity $\left(q_{a}\right)$ of Air at Remote Tower and Saturation Specific Humidity $\left(q_{S}\right)$ for Air at Pond Temperature on June 17, 1981 (EM2 - 1) 


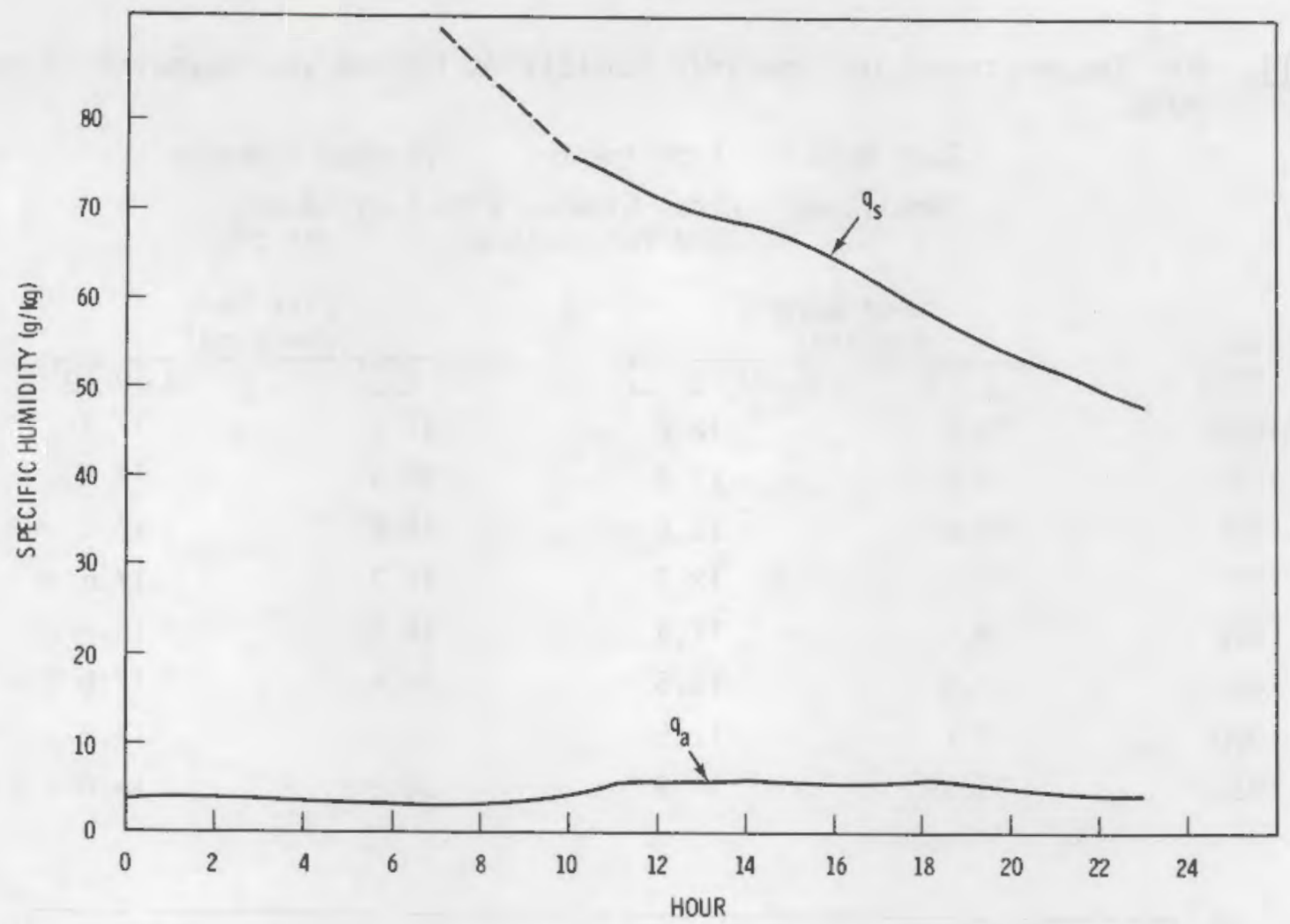

FIGURE 14. Specific Humidity $\left(\mathrm{q}_{a}\right)$ of Air at Remote Tower and Saturation Specific Humidity $\left(q_{s}\right)$ for Air at Pond Temperature on October 5, 1978 (RR2 - Hot IV)

over the pond which is most important, the remote values indicate the general state of the surrounding air. In both cases, the differential is quite large. The Raft River example has hot pond water contrasted with cold air. Table 14 also shows pond influence on specific humidity. The downwind airstream contains $\sim 5 \mathrm{~g} / \mathrm{kg}$ more water than the upwind air.

\section{Radiation}

Figure 15 and Figure 16 show radiation data for typical days during RR2 and EM2. The incoming solar radiation was measured using a pyranometer. The jagged portions of the curves, Figure 15, show cloudiness. Clouds will decrease the shortwave input by attenuating and blocking radiation. However, they tend to enhance the longwave atmospheric radiation. A worst-case radiative day might be a clear sky day with strong heating and an overcast night with strong atmospheric longwave inputs. Figure 17 shows a typical daylight plot of the makeup of solar input; direct vs. diffuse. The diffuse component is strongly controlled by cloudiness and other light scattering material in the air. 


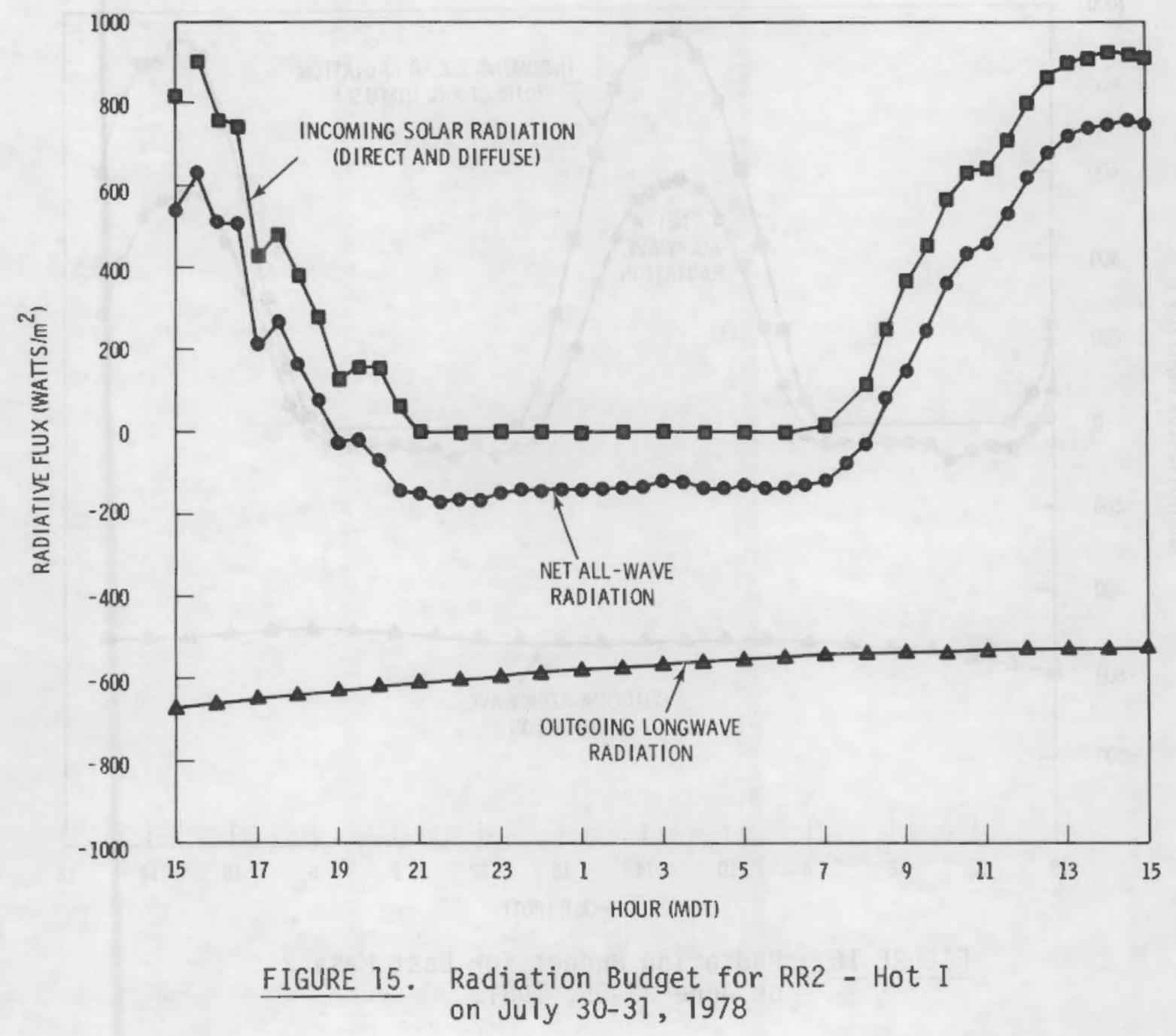




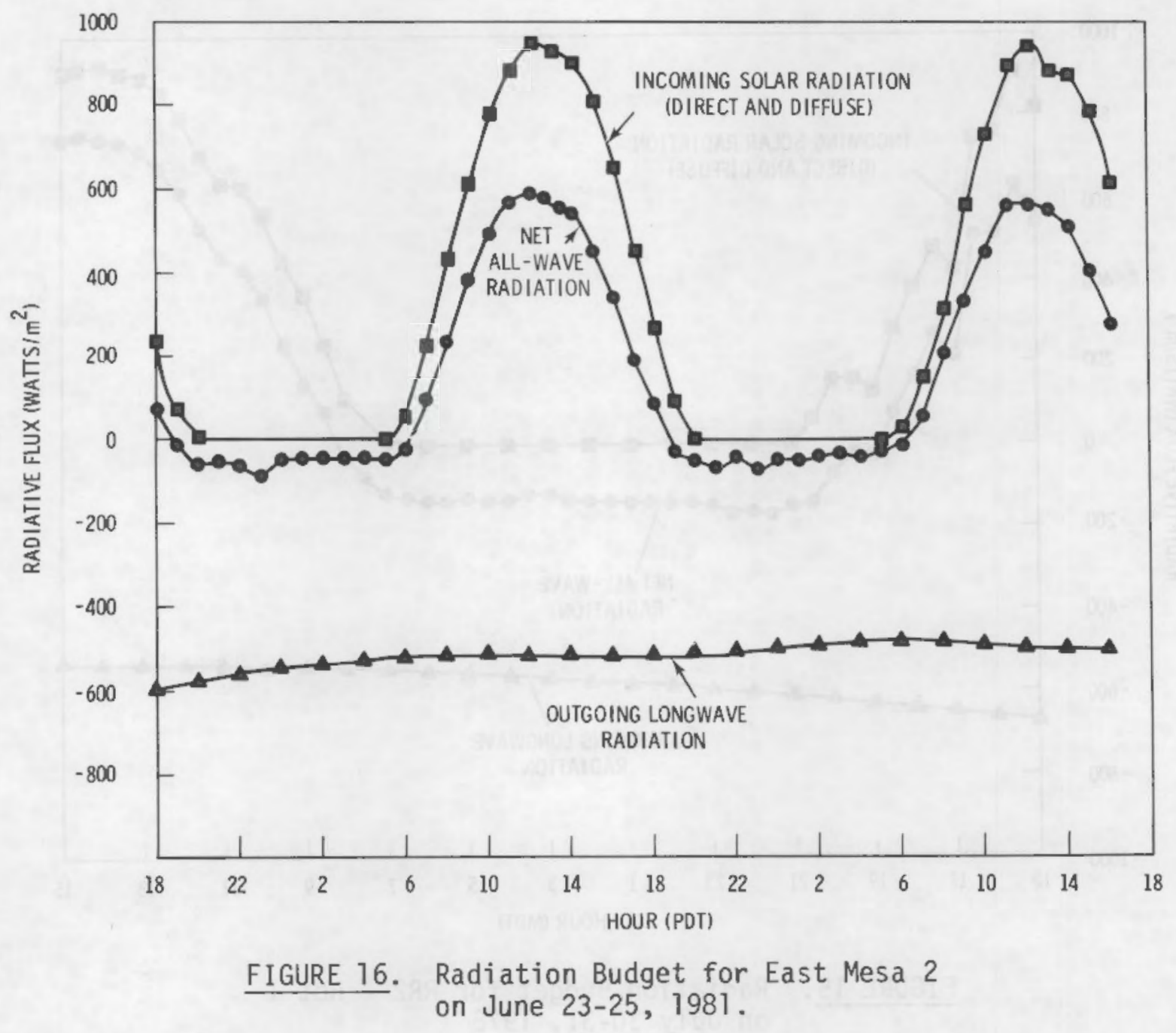




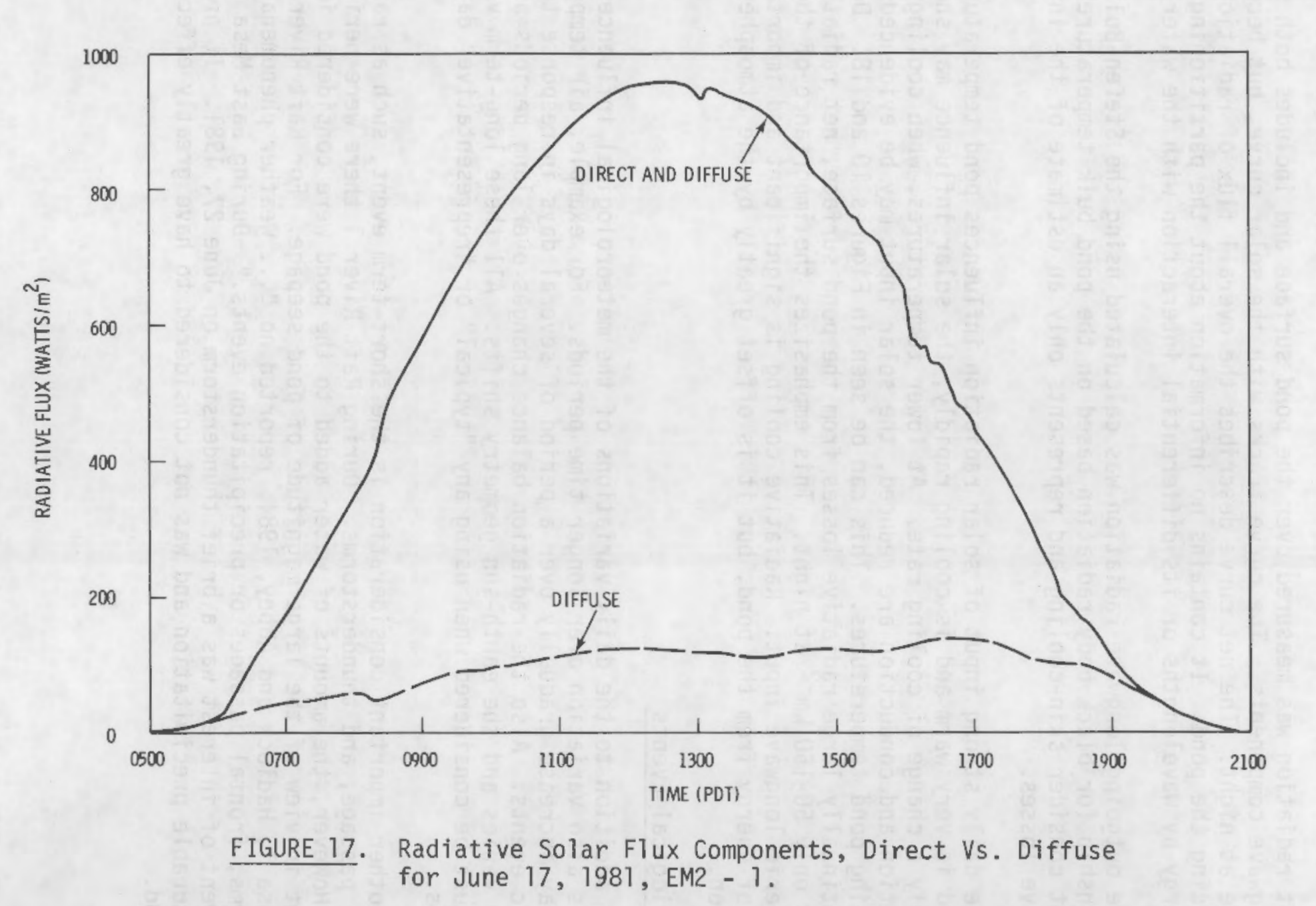


During EM2, smoke from local agricultural burning occasionally effected a decrease in total incoming solar but an increase in the diffuse component.

Net radiation was measured over the pond surface and includes both short and longwave components. The curve tracks with the solar curve, but becomes negative at night. The net curve describes the overall flux of radiation influencing the pond. It contains no information about the partitioning of the energy by wavelengths or its differential interaction with the water.

The outgoing longwave radiation was calculated using the Stefen-Boltzman relationship for black body radiation based on the pond bulk temperature. It does not consider skin-cooling and represents only an estimate of the infrared radiative losses.

The daily strong input of solar radiation influences pond temperature. If the pond is very warm and is cooling rapidly, the solar influence may show up as merely a change of cooling rate. At lower temperatures, when cooling by evaporation and conduction are reduced, the solar input may be evidenced in increasing pond temperatures. This can be seen in Figures 10 and 18 . Despite the continually large radiative losses from the pond surface, net radiation is usually only 50-150 $\mathrm{Wm}^{-2}$ at night. This emphasizes the importance of the atmospheric longwave input. Radiative cooling is significant and important to losses of energy from the pond, but it is offset greatly by the atmospheric radiation.

\section{Meteorological Events}

In addition to the daily variations of the meteorological influences, there is also variation over longer time periods. For example, air temperatures may increase gradually over a period of several days in response to synoptic events. Also the radiation balance changes over long periods as air quality varies and the earth-sun geometry shifts. All these long-term variations must be considered when using any "typical" or "representative" data in analysis.

Another important consideration is the short-term event, such as rain, frontal passage, and thunderstorms. During Raft River 1 there were periods of rain. However, the amounts of water added to the pond were considered insignificant in view of the large magnitude of pond seepage. For Raft River 2 and East Mesa 1, Hadlock and Abbey, 1981, reported no "... weather phenomena such as storms, frontal passages or precipitation events." During East Mesa 2, the only event of interest was a brief thunderstorm on June 27, 1981. It produced no measurable precipitation and was not considered to have greatly effected the pond. 


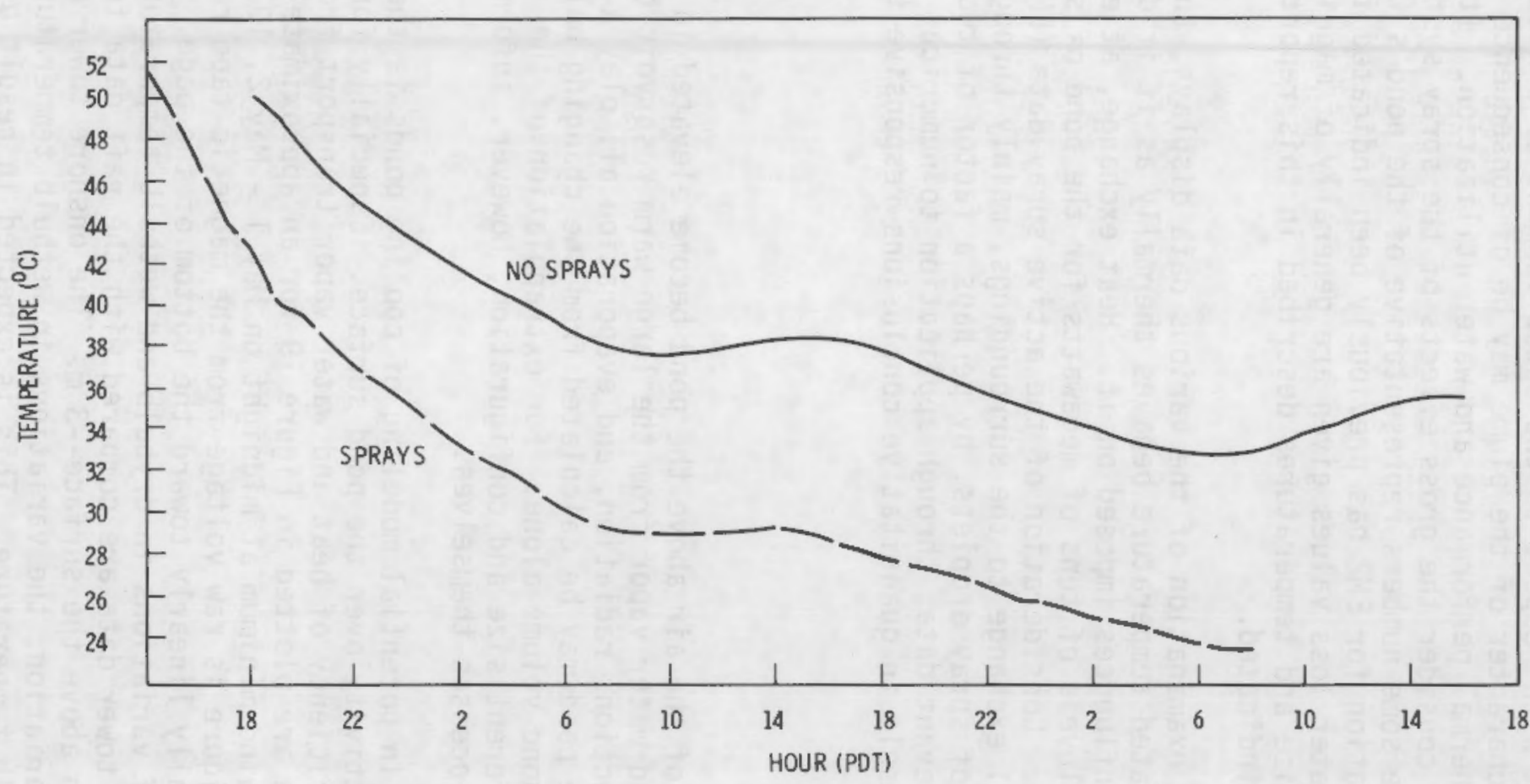

FIGURE 18. A Comparison of Bulk Pond Temperature Changes at East Mesa With and Without Sprays. Initial pond temperatures were similar, but the spray experiment started $\imath 4$ hours earlier (thus the offset curves). 


\section{AIR-WATER INTERACTIONS}

The pond interacts with the surroundings through exchange of heat and water; the exchange with the air above the pond is, aside from radiative transfer to air and space, of most interest with respect to the establishmen't of a heat and moisture plume. The physical character of the plume may be of consequence in the efficiency of the pond's thermal performance and water utilization. It is of further interest to briefly consider the gross effects of the spray system in this context and to indicate some numbers representative of the pond's thermal performance. Water utilization for EM2 has previously been indicated in Table 12 and elsewhere. The water loss values given are generally of magnitudes associated with ponds of the size and temperatures described in this report for the meteorological conditions indicated.

It is recognized, through examination of the various data displays, that the pond at substantially elevated temperature behaves thermally as if it does not "see" the meteorological influences imposed on it. Heat exchange, at elevated temperature proceeds at levels of tens of megawatts for the pond of surface area approaching one acre. Consideration of the active spray data (EMI) shows an enhancement of thermal exchange to the surroundings, mainly through increased partial evaporation of spray droplets, by perhaps a factor of two. Careful examination of the relevant data, through application to numerical models of performance, will result in quantitative conclusions responsive to user needs.

\section{Heat and Moisture Plume}

Temperature and moisture of the air above the pond become elevated in result of transport of heat and water vapor from the large warm reservoir below. Processes of conduction, convection, radiation, and evaporation all play a role. The thermal performance of the pond may be calculated from the changing bulk temperature and the changing pond volume alone. For extrapolation of the results to other ponds of different size and configuration, however, information is required to describe the processes themselves.

One item of significance in potential modeling of cooling ponds is the establishment of convective activity over the pond surface. Especially for light wind conditions, the efficiency of heat and water vapor transport from pond to air is affected. Data are plotted in Figure 19 for an approximately 150 second period during the wind minimum at midnight on May 1 - May 2, 1977 (RRI). The ordinate of the figure is raw voltage from the magnetic tape record, temperature increases essentialiy linearly toward the bottom of the page. An indication of the magnitude of variations in drybulb and wetbulb temperature is given. The onshore "East" tower data are compared with the raft data for essentially the same elevation above the surface--3 $\mathrm{m}$. The onshore tower displays data with very modest variation; the variations in wetbulb temperature are less than those for drybulb temperature. This is expected in result of the longer time-constant for the wet-wicked thermistor. On the raft, however, 
the variations on the short-term are very much larger, of the order of Celsius degrees. Again, wetbulb variations are smaller as expected considering the difference in the sensors. It is possible, however, that some of the difference might be attributable to a real difference in the structure of temperature and moisture convection from the pond surface. The character of the data displayed in the $150 \mathrm{~s}$ time-segment is representative of that for longer periods of time, up to hours in duration, for extremely light wind conditions. Examination of the longer records, and Figure 19, indicates a periodicity in the temperature data. Inspection suggests that this period is of the order of one minute.

The data (1.96 s intervals) for an approximate half-hour period were analyzed for contributions to this apparent periodicity through application of a Fast Fourier Transform (FFT) technique. This technique enables the identification of spectral amplitudes. The results are displayed in Figures 20 and 21. These results will not be overly interpreted because of the various philosophical and technical assumptions required in application to time-series data. The data were at least partially detrended prior to analysis.

The horizontal axis of the figures represents period in seconds. Spectral amplitude in millivolts, with indication of the corresponding temperature scale, is indicated in the vertical. The onshore data do not display much of interest beyond, as expected, larger amplitudes for the drybulb data throughout the spectrum. The raw data suggest a "noise" contribution of period between 6 and $8 \mathrm{~s}$, there is some evidence of this in the spectral data. These indications are interpreted as some evidence of the validity of the statistical techniques in this application. The large amplitude at the long-period end of the spectrum probably represents residual trend in the data to which the FFT is applied. Sma11 amplitude enhancement is seen at periods of 13, 17, and 85 seconds.

The raw data require that the amplitude spectra be, by comparison, more spectacular over the pond surface. Figure 21 indicates the amplitudes are larger overall and there exists a well-defined amplitude enhancement between 36 and 85 seconds. Both drybulb and wetbulb variations have a substantial contribution (periodic) at about one minute intervals.

These results may be interpreted as evidence of periodicity in the way warm, moist air leaves the pond surface under very low wind conditions. Similar analyses for the case of high wind speeds indicate no such amplitude enhancement. The spectral amplitudes are very much smaller as would be expected, and the "noise" amplitude becomes, relatively, very much larger.

It is envisioned that a layer of air near the pond surface bocomes heated through absorption of thermal radiation by enhanced water vapor content and by convection from the surface on a small space-scale (on the order of cm or $10^{\prime} \mathrm{s}$ of $\mathrm{cm}$ ). Some direct conduction of heat also occurs. After a time, conditions become critical for overturning convection on a larger space-scale (on the order of meters) and there is a rising of warm, moist air from near the pond surface and past the raft sensors at an altitude above surface of $3 \mathrm{~m}$. This condition might be quantiatively describec by a critical Rayleigh number specific to a layer of air influenced by a lower heated rigid boundary with a free boundary at the top. 


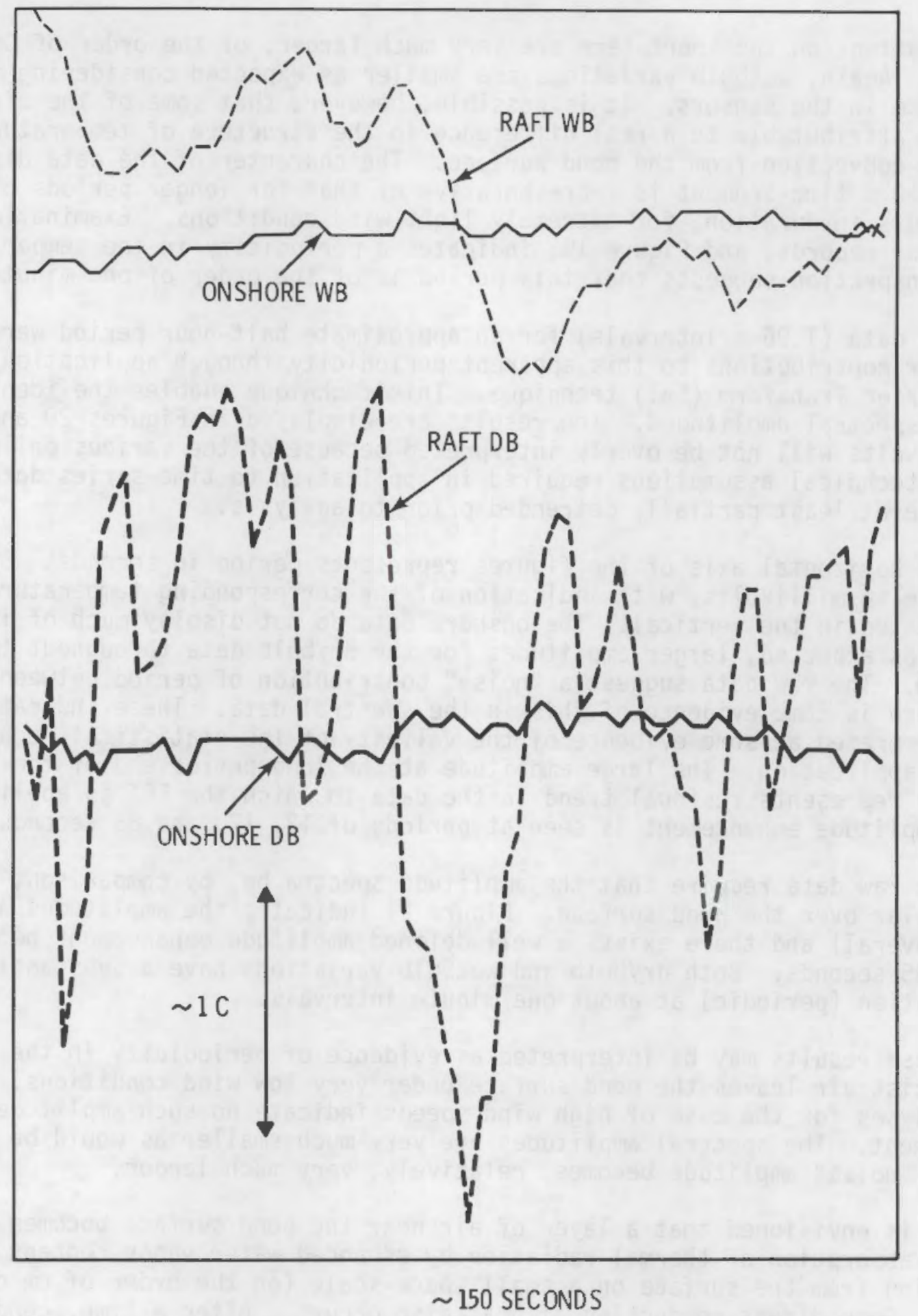

FIGURE 19. A Comparison of Wetbulb and Drybulb Data Over and Near the Pond for Light Wind Conditions. The vertical scale is indicated by the double-ended arrow at lower left. Temperature increases toward the bottom of the page. 


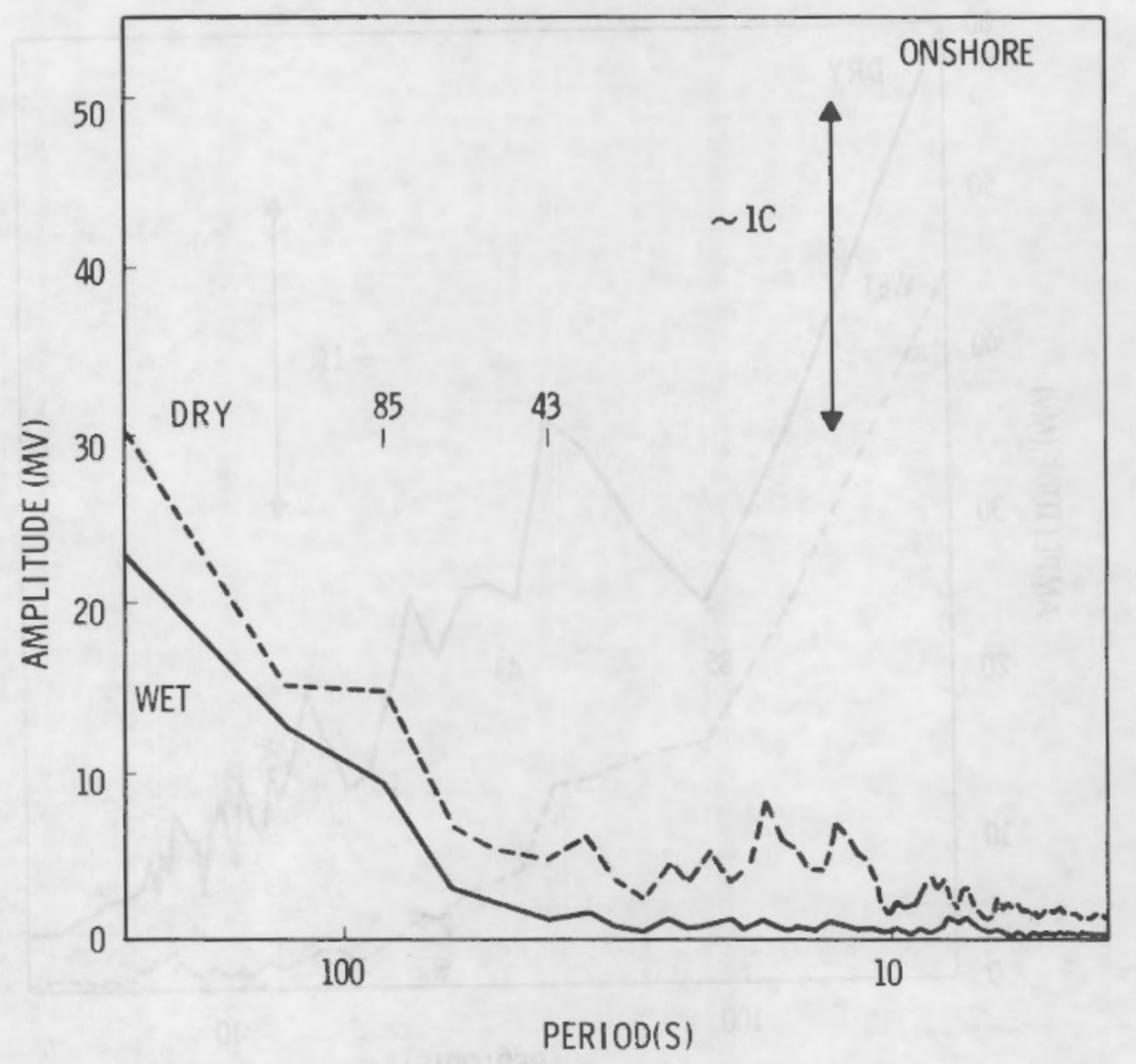

FIGURE 20. Spectral Amplitudes for Time-Series Temperature Data (near pond tower). The data of Figure 19 are representative of that used in the FFT procedure. The amplitude scale is indicated just to the right of the page center. 


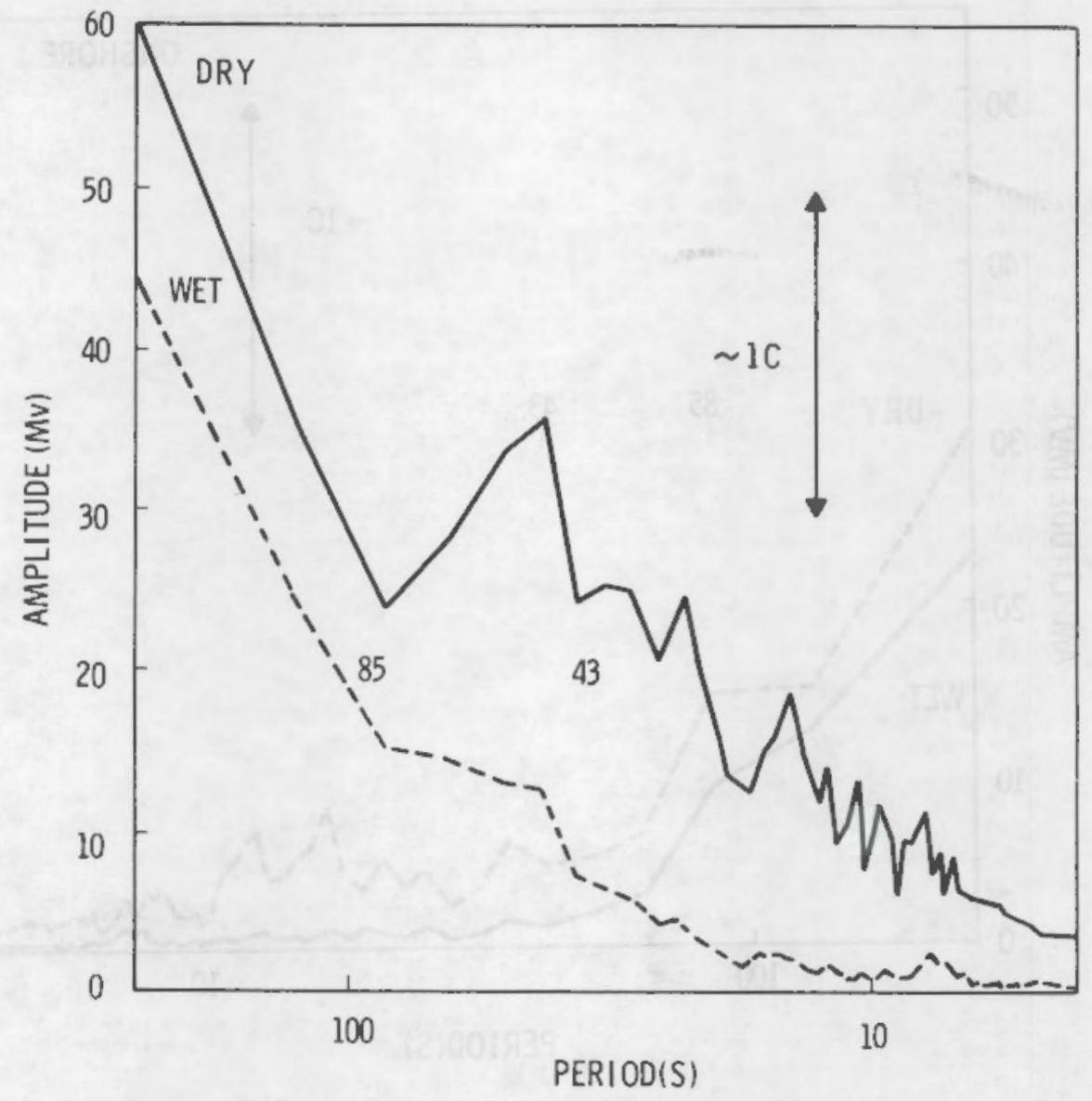

FIGURE 21. Spectral Amplitudes for Time-Series Temperature Data (raft tower). The data of Figure 19 are representative of that used in the FFT procedure. The amplitude scale is indicated just to the right of the page center. 
Once this bodily transport has occurred, conditions are ripe for the formation of another warm, moist layer near the water surface and the process repeats as long as the conditions do not change significantly. As a layer convectively rises, other air must flow in to take its place over the pond. It is believed that Figure 20 indicates this. The modest amplitude enhancement at $85 \mathrm{~s}$ period could represent the response by the ambient air near the ground.

This process is likely less efficient as a heat transfer mechanism than that which will occur when the wind is blowing. For appreciable wind, there is always a ready supply of relatively cool, dry air to transfer by evaporation and conduction. Loss of heat by the pond due to radiative exchange would probably be enhanced also. There would be less back radiation with less water vapor directly above the pond (it has been blown away).

For the case of low wind conditions, especially, it becomes useful to know what happens to the rising air after it leaves the immediate vicinity of the pond surface, say above the $3 \mathrm{~m}$ level. It has been found that the acoustic sounding data, while useful in defining stability in the surrounding atmosphere, does not indicate pond influence. First, the lowest $30 \mathrm{~m}$ of the atmosphere are not assessed because of electronic gating requirements in the system. It is anticipated that these $30 \mathrm{~m}$ are probably the most interesting with respect to convective structure. Entrainment and probably high winds above this height would soon destroy any convective plume or thermal. Second, techniques are not conveniently available to assess the air directly in the vertical above pond center.

Similar results have been obtained from application of the Fast Fourier technique to data from EM2. Time series of approximately one hour of 5 -second data were chosen for minimal wind at maximum pond temperature. In the amplitude spectra, for both dry and wet bulb temperatures over the pond at a height above surface of $3 \mathrm{~m}$, amplitude enhancement is obtained near a period of one minute. No such enhancenent was obtained for temperature data acquired simultaneously at the remote reference tower. This information is considered to be indicative of plume structure over the pond, independent of site, and by contrast with locations remote from the pond. It is also important that the spectra are similar for different frequencies of data acquisition.

Other organizations, listed in the acknowledgments of this report, participated so as to enhance aspects of understanding of the moisture from the pond. It has been indicated to Battelle by Computer Genetics Corporation, that their preliminary examination of their data may exhibit complementary detail of the physical structure of the plume and aspects of plume dynamics. Such research results will be published elsewhere and publication will indicate the cooperative arrangement among the various organizations and the Nuclear Regulatory Conmission.

\section{Spray Effects}

It has been demonstrated that activation of the East Mesa spray system substantially enhances the rate at which heat is transferred to the surroundings 
from the pond. This is illustrated, for a typical example, in the data exhibited in Figure 18. At the same time, as is indicated in the data volume for EMI, water utilization is increased substantially. A large increase in water leaving the pond through evaporation (not drift) from droplets is achieved. Recognition of a trade-off in enhanced thermal performance vs. Water utilization is important in conclusions drawn from modeling results derived from the data.

Previously (Hadlock and Abbey, 1981), consideration has been made of aspects of the effects of activating the spray system at East Mesa. Temperature and relative humidities for activated sprays are listed in Table 15. The spray field can cause mechanically/thermally induced air circulation to account for the data, for example, of 0300 EMI Warm II. There exists a substantial inversion in the ambient air and the wind speed is very low, essentially at the limit of detection. Apparently the raft dry thermistors near the sprays are experiencing air drawn in from over the desert surface. Both raft wet bulbs indicate enhanced relative humidity due to the evaporating pond and the nearby sprays. The average periphery temperature and relative humidity both are consistent with the conditions. The pond is at an elevated temperature, producing a temperature/moisture plume over its surface. The vertical or nearly vertical plume is detected by balloon sensors; the dry bulb is elevated and to an extent greater than that represented by the inversion in the ambient air. Relative humidity at the balloon does not imply a deficiency in moisture content. The air at the balloon has been heated through at least $3^{\circ} \mathrm{C}$; the wet bulb depression is correspondingly larger.

Spray nozzle temperatures are less than pond bulk temperatures because of cooling which occurs in the piping connecting the pond drain, the pump and the nozzles. The difference in temperature is very small when the bulk pond temperature is less than the ambient temperature. The difference (cooling) is only partiy apparent in the respect of $0.1^{\circ} \mathrm{C}$ accuracy in the thermistors and partially real considering that the water circulating in the piping has a residence time in the ambient air about $1 / 2$ its residence time either submerged in the pond or in pipes buried in the cool earth at 3 meter depth.

For the cases illustrated in Table 15, average spray cooling, from nozzles to collectors, ranges fram $10.3^{\circ} \mathrm{C}$ to $2.1^{\circ} \mathrm{C}$. The larger cooling as expected, is for pond water of higher temperature than that of the ambient air. However, it is interesting that, for essentially no spray volume ventilation from ambient wind, the spray cooling remains large (0300 EMI Warm II). Also, this is occurring at night with relatively high relative humidities. At elevated temperature, above say $35^{\circ} \mathrm{C}$, the pond (sprays or not) does not substantially "see" the ambient meteorology, or the solar influence. 
TABLE 15. Temperature and Relative Humidity Vs.

Pond Influences (Sprays)

Pond Warmer than Ambient (Daytime)

$15009 / 22 / 79$

EMI Warm I, W/S $(1.5 \mathrm{~m})=1.6 \mathrm{~m} \mathrm{~s}^{-1}$

Pond

Nozzle

Ref Bot

Ref Top

Periphery

Balloon

Raft Top

Raft Bot

Collector $48.9^{\circ} \mathrm{C}$

47.4

41.2

40.0

39.4

38.7

38.0

37.7

37.1
$(30 \%)$

(54)

Pond Warmer than Ambient (Nighttime) D300 $9 / 27 / 79$

EMI Wanm II, W/S $(1.5)=0.3 \mathrm{~m} \mathrm{~s}^{-1}$

Pond

Nozzle

Collector

$43.7^{\circ} \mathrm{C}$

42.2

Balloon

Ref Top

Raft Bot

Raft Top

Periphery

Ref Bot

33.6

29.3

26.7

26.1

25.8

24.8

23.5
$(57 \%)$
Pond Cooler than Ambient (Daytime) $14009 / 27 / 79$

EMI Warm II, W/S $(1.5 \mathrm{~m})=2.3 \mathrm{~m} \mathrm{~s}^{-1}$

$\begin{array}{ll}\text { Ref Bot } & 37.3^{\circ} \mathrm{C} \\ \text { Raft Top } & 36.8 \\ \text { Ref Top } & 36.3 \\ \text { Balloon } & 36.2 \\ \text { Periphery } & 35.6 \\ \text { Raft Bot } & 35.4 \\ \text { Pond } & 32.0 \\ \text { Nozzle } & 31.7 \\ \text { Collector } & 28.0\end{array}$

Pond Cooler than Ambient (Nighttime)

$20009 / 23 / 79$

EMI Warm I, W/S $(1.5 \mathrm{~m})=0.7 \mathrm{~m} \mathrm{~s}^{-1}$

$\begin{array}{ll}\text { Balloon } & 36.0^{\circ} \\ \text { Ref Top } & 34.4 \\ \text { Ref Bot } & 31.1 \\ \text { Periphery } & 28.8 \\ \text { Raft Top } & 28.2 \\ \text { Rafe Bot } & 27.3 \\ \text { Pond } & 27.2 \\ \text { Nozzle } & 26.8 \\ \text { Collector } & 24.7\end{array}$

\section{Energy Exchange}

A simplified energy budget for a pond isolated from mass sources and sinks can be described by the equation:

$$
\Delta Q_{S}=Q_{R}+Q_{H}+Q_{E}+Q_{G}
$$

where $\Delta Q_{S}=$ net change in pond energy storage (thermal performance)

$Q_{R}=$ net radiative exchange

$Q_{H}=$ net sensible heat exchange to atmosphere

$Q_{E}=$ latent heat exchange

$Q_{G}=$ heat conduction to underlying soil

For all quantities a positive value indicates an energy gain by the pond and a negative value represents an energy loss. It is recognized that any of 
the quantities with the probable exception of QE, may vary between positive and negative values.

The energy exchange of the pond with its surroundings can be described for any interval of time. However, this interval must be of sufficient duration to minimize any lag effects in the pond-atmosphere system and in the measurement system. An appropriate duration is 24 hours.

Over the selected interval, the net change in pond energy storage $\left(\triangle Q_{S}\right)$ is described by the change in bulk pond temperature. This gain or loss of energy is controlled by the four primary exchange processes listed previously. During any interval, the relative magnitude of each process may change. For example, radiative inputs are strong during the daylight hours, but become negative at night.

Heat transfer to the under-liner soil $\left(Q_{G}\right)$ depends on the soil conductivity and the temperature gradient. Figure 22 shows representative underliner soil temperatures for the 48 hours of EM2 Experiment 3 . Heat is conducted into the soil from the pond for the first 12 hours. However, the magnitude of the energy loss by the pond is small. Assuming dry sandy soil with a thermal conductivity of $0.3 \mathrm{Wm}^{-1} \mathrm{C}^{-1}$, the heat flux from pond to soil at experiment initiation is about $40 \mathrm{~W} / \mathrm{m}^{2}$. Twelve hours later, the heat transfer approaches zero as seen by the $10-\mathrm{cm}$ data; the pond, of course, has cooled significantly during this time interval. At later times, the exchange is from the soil to the pond. Over the duration of an experiment, the net time-integrated exchange becomes insignificant with respect to the other components of the balance equation.

The net radiative exchange $\left(Q_{R}\right)$ has been discussed in an earlier section. It is sufficient to summarize the major parts:

First, net radiation is strongly positive during daylight and dominates the energy budget. Second, incoming solar radiation is absorbed through the water column, not simply at the surface. Finally, at night longwave radiative losses are great but are offset strongly by longwave atmospheric inputs.

The latent heat exchange depends primarily upon the humditiy gradient above the pond. Dry air flow over the pond increases evaporation. Similarly, warmer pond water increases the saturation specific humidity at the surface and speeds evaporation. The approximate magnitude of hourly average latent heat fluxes can be calculated from pond temperature and water loss data. At the onset of an experiment, $\mathrm{Q}_{\mathrm{E}}$ values may exceed $2000 \mathrm{~W} / \mathrm{m}^{2}$. This flux rate decreases rapidly as the pond cools, with nominal values being $200-700 \mathrm{~W} / \mathrm{m}^{2}$ for a warm pond.

Sensible heat exchange $\left(Q_{H}\right)$ depends primarily upon the temperature gradient between water and air. Cold air flow over the pond surface will increase $Q_{H}$ by causing the water-air temperature profile to become more lapse. In both latent and sensible exchanges, greater wind speeds will enhance pond energy losses by advecting heat and moisture away from the interface. 


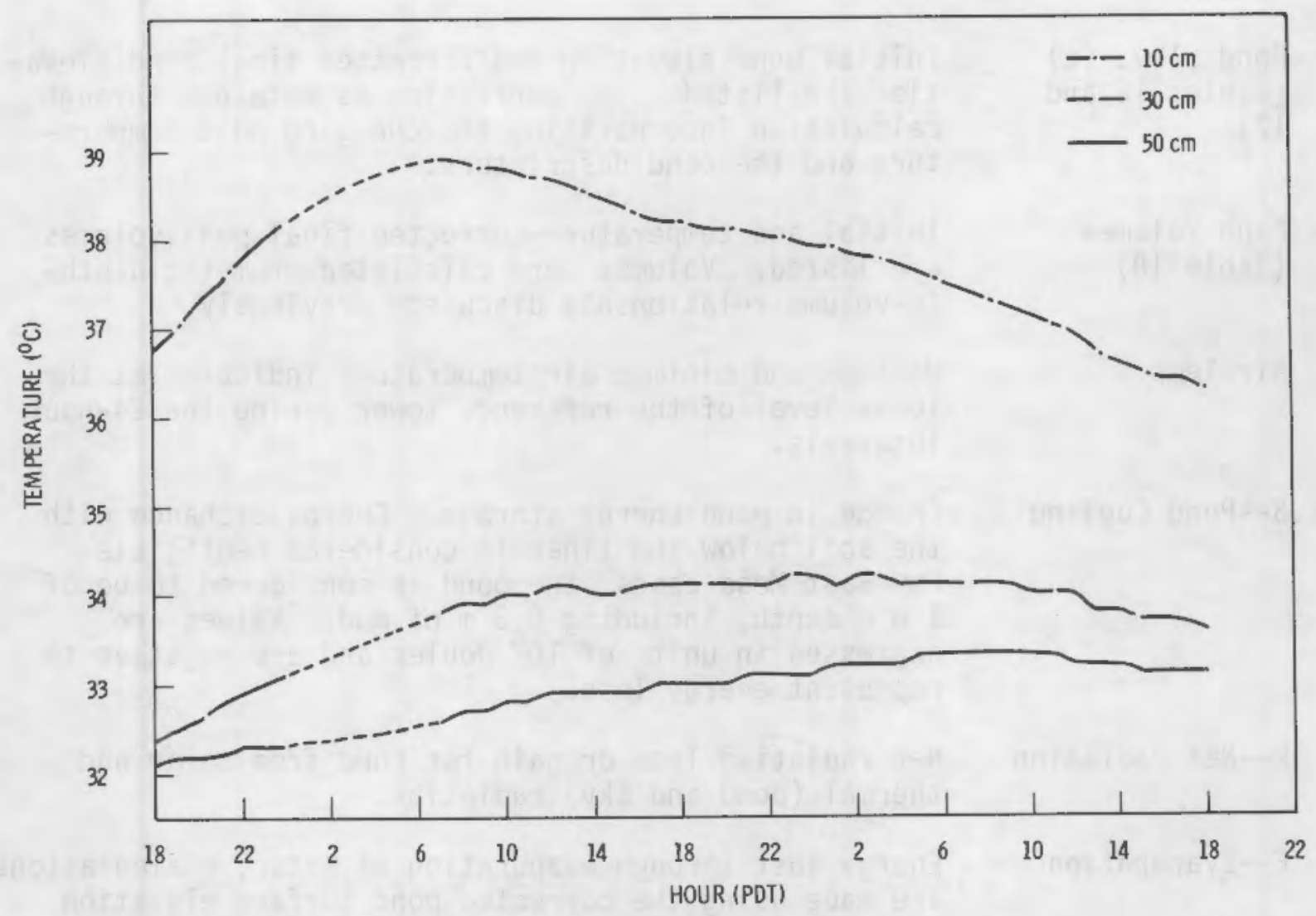

FIGURE 22. Under-Liner Soil Temperatures for EM2 Experiment 3. Dashes indicate missing but interpolated data.

Nominal calculations have been made for 24-hour intervals available from the Raft River and East Mesa 1 data contained in the appendices. The rssuits are exhibited in Tables 16,17 and 18 and are meant to be illustrative oniy. Among these examples, there exists a wide variety of pond temperatures and air temperatures relative to pond temperatures. Cooling pond examples are shown as well as spray pond examples. Each East Mesa example has similar wind and air temperature at beginning and end; the pond elevation data need only be corrected in the respect of pond cooling during experiments. The Raft River examples have some substantial wind differences from beginning to end.

The columns of data in the tables require further description:

1. Pond Temp. Initial pond temperature and final pond temperature are listed. Change in pond energy storage is calculated using these values, specific heats, and the pond descriptors previously listed.

2. Pond Elev. Initial pond elevation and final pond elevation are listed. These are uncorrected values obtained directly with the measurement systems and then averaged. 
3. Pond Elev. (c) (Tables 16 and 17)

4. Pond Volumes

(Table 18)

5. Air Temp.

6. S--Pond Cooling

7. R--Net Radiation

8. E--Evaporation

9. H--Sensible Heat Transfer
Initial pond elevation and corrected final pond elevation are listed. The correction is obtained through calculation incorporating the changing pond temperature and the pond descriptors.

Initial and temperature-corrected final pond volumes are listed. Volumes were calculated from the depthto-volume relationship discussed previously.

Maximum and minimum air temperature indicated at the lower level of the reference tower during the 24-hour intervals.

Change in pond energy storage. Energy exchange with the soil below the liner is considered negligible. For East Mesa cases, the pond is considered to be of $1.8 \mathrm{~m}$ depth, including $0,3 \mathrm{~m}$ of mud. Values are expressed in units of $10^{9}$ Joules and are negative to represent energy loss.

Net radiative loss or gain for pond from solar and thermal (pond and sky) radiation.

Energy lost through evaporation of water. Calculations are made using the corrected pond surface elevation or pond volume data. Values are expressed in units of $10^{9}$ Joules.

Energy lost in results of thermal exchange between air and water. Values are expressed in units of 109 Joules. Calculated as residual from previous budget components.

Hadlock and Abbey, 1981, present similar tables for Raft River 2 and East Mesa 1. They discuss the use of Bowen ratios for estimating sensible heat transfer. Further, they present loss-to-gain ratios as a means of describing the energy budget.

In the present evaluation, sensible heat loss $(H)$ is calculated as a residual from the other budget components. The magnitudes of $\mathrm{H}$ seem large with respect to the measured evaporation for the East Mesa experiments. Calculated sensible heat losses were about $40 \%$ of the latent heat loss. High pond temperatures causing strong temperature differentials and creating unstable atmospheric conditions may be the cause.

The effect of sprays is illustrated in Table 17. Experiments Warm I and III show the largest energy losses. Enhanced evaporation and conduction are achieved by the increased water-air content. Values for $S$ and $E$ are 40-50 percent greater than in similar experiments (EM2) without sprays. 
The three tables give good indications of the magnitude of the energy transfers under varying environmental conditions. They also illustrate the partitioning of the energy between the three dominant exchange processes: radiation, evaporation and conduction.

TABLE 16. Energy Budgets for Raft River 2 Experiments

\begin{tabular}{|c|c|c|c|c|c|c|c|c|}
\hline Experiment & $\begin{array}{l}\text { Pond } \\
\text { Temp. } \\
\left({ }^{\circ} \mathrm{C}\right)\end{array}$ & $\begin{array}{l}\text { Pond } \\
\text { Elev. } \\
\text { (cm) }\end{array}$ & $\begin{array}{c}\text { Pond } \\
\text { Elev. (c) } \\
(\mathrm{cm})\end{array}$ & $\begin{array}{l}\text { Air } \\
\text { Temp. } \\
\text { Range } \\
\left({ }^{\circ} \mathrm{C}\right)\end{array}$ & $\left.\begin{array}{c}5 \\
\left(x 10^{9} \mathrm{~J}\right.\end{array}\right)$ & $\begin{array}{c}R \\
\left(\times 10^{9} \mathrm{~J}\right) \\
\end{array}$ & $\left(x+0^{\mathrm{E}} \mathrm{J}\right)$ & $\begin{array}{c}\mathrm{H} \\
\left(\times 10^{9} \mathrm{~J}\right)\end{array}$ \\
\hline $\begin{array}{l}\text { RR2 Cool I } \\
7 / 25-7 / 26 \\
1100-1100\end{array}$ & $\begin{array}{l}25.4 \\
24.2\end{array}$ & $\begin{array}{l}7.47 \\
6.39\end{array}$ & $\begin{array}{l}7.47 \\
6.40\end{array}$ & $\begin{array}{l}35.4 \\
11.7\end{array}$ & -19.1 & 56.4 & 71.7 & -3.8 \\
\hline $\begin{array}{l}\text { RR2-Cool I } \\
7 / 26-7 / 27 \\
0800-0800\end{array}$ & $\begin{array}{l}23.8 \\
24.3\end{array}$ & $\begin{array}{l}6.55 \\
5.68\end{array}$ & $\begin{array}{l}6.55 \\
5.66\end{array}$ & $\begin{array}{l}35.6 \\
16.1\end{array}$ & +8.0 & 63.1 & -59.6 & 4.5 \\
\hline $\begin{array}{l}\text { RR2-Hot I } \\
7 / 30-7 / 31 \\
1600-1600\end{array}$ & $\begin{array}{l}58.4 \\
39.5\end{array}$ & $\begin{array}{r}10.28 \\
3.40\end{array}$ & $\begin{array}{r}10.28 \\
5.20\end{array}$ & $\begin{array}{l}33.6 \\
10.9\end{array}$ & -300.5 & 31.7 & -340.3 & 8.10 \\
\hline $\begin{array}{l}\text { RR2 Hot I } \\
7 / 31-8 / 1 \\
1000-1000\end{array}$ & $\begin{array}{l}41.3 \\
31.4\end{array}$ & $\begin{array}{l}4.80 \\
1.05\end{array}$ & $\begin{array}{l}4.80 \\
1.80\end{array}$ & $\begin{array}{l}34.8 \\
13.3\end{array}$ & -157.4 & 44.8 & -201.0 & -1.2 \\
\hline $\begin{array}{l}\text { RR2 Hot III } \\
8 / 8-8 / 9 \\
2000-2000\end{array}$ & $\begin{array}{l}50.5 \\
35.8\end{array}$ & $\begin{array}{l}5.85 \\
0.20\end{array}$ & $\begin{array}{l}5.85 \\
7.47\end{array}$ & $\begin{array}{r}34.6 \\
9.7\end{array}$ & -233.7 & 40.6 & -293.5 & 19.2 \\
\hline $\begin{array}{l}\text { RR2-Hot IV } \\
10 / 5-10.6 \\
1000-1000\end{array}$ & $\begin{array}{l}45.7 \\
31.0\end{array}$ & $\begin{array}{l}6.47 \\
2.00\end{array}$ & $\begin{array}{l}6.47 \\
3.16\end{array}$ & $\begin{array}{r}23.1 \\
1.2\end{array}$ & -233.7 & 9.3 & -221.8 & -21.2 \\
\hline
\end{tabular}


TABLE 17. Energy Budgets for East Mesa 1 Experiments

\begin{tabular}{|c|c|c|c|c|c|c|c|c|}
\hline Experiment & $\begin{array}{l}\text { Pond } \\
\text { Teemp. } \\
\left({ }^{\circ} \mathrm{C}\right)\end{array}$ & $\begin{array}{l}\text { Pond } \\
\text { Elev. } \\
\text { (cm) }\end{array}$ & $\begin{array}{c}\text { Pond } \\
\text { Elev. (c) } \\
(\mathrm{cm})\end{array}$ & $\begin{array}{l}\text { Air } \\
\text { Temp. } \\
\text { Range } \\
\left({ }^{\circ} \mathrm{C}\right)\end{array}$ & $\left.\begin{array}{r}\mathrm{S} \\
\left(x 10^{9} \mathrm{~J}\right.\end{array}\right)$ & $\begin{array}{r}R \\
\left(\times 10^{9} \mathrm{~J}\right) \\
\end{array}$ & $\begin{array}{c}E \\
(x 109 \mathrm{~J}) \\
\end{array}$ & $\stackrel{H}{(x 109 \mathrm{~J})}$ \\
\hline $\begin{array}{l}\text { EMl Cool I } \\
9 / 16-9 / 17 \\
0700-0700\end{array}$ & $\begin{array}{l}41.8 \\
35.7\end{array}$ & $\begin{array}{l}14.66 \\
11.77\end{array}$ & $\begin{array}{l}14.66 \\
12.33\end{array}$ & $\begin{array}{l}35.8 \\
20.5\end{array}$ & -229.1 & 42.0 & -177.2 & -93.9 \\
\hline $\begin{array}{l}\text { EM2 Cool I } \\
9 / 17-9 / 18 \\
0700-0700\end{array}$ & $\begin{array}{l}35.7 \\
33.1\end{array}$ & $\begin{array}{l}11.77 \\
10.21\end{array}$ & $\begin{array}{l}11.77 \\
10.43\end{array}$ & $\begin{array}{l}35.6 \\
21.5\end{array}$ & -113.2 & 46.8 & -101.9 & -58.7 \\
\hline $\begin{array}{l}\text { EM2-Cool I } \\
9 / 18-9 / 19\end{array}$ & $\begin{array}{l}33.1 \\
31.7\end{array}$ & $\begin{array}{r}10.21 \\
8.96\end{array}$ & $\begin{array}{r}10.21 \\
9.07\end{array}$ & $\begin{array}{l}39.1 \\
21.5\end{array}$ & -79.7 & 43.8 & -86.7 & -36.8 \\
\hline $\begin{array}{l}\text { EM2-Cool I } \\
\text { Sprays } \\
9 / 19-9 / 20 \\
1000-1000\end{array}$ & $\begin{array}{l}31.8 \\
24.6\end{array}$ & $\begin{array}{l}8.58 \\
4.69\end{array}$ & $\begin{array}{l}8.58 \\
5.20\end{array}$ & $\begin{array}{l}40.7 \\
20.8\end{array}$ & -294.5 & 99.5 & -257.7 & -86.9 \\
\hline $\begin{array}{l}\text { EM] -Warm I } \\
\text { Sprays } \\
9 / 22-9 / 23 \\
1400-1400\end{array}$ & $\begin{array}{l}51.3 \\
29.4\end{array}$ & $\begin{array}{r}13.76 \\
6.36\end{array}$ & $\begin{array}{r}13.76 \\
8.46\end{array}$ & $\begin{array}{l}41.3 \\
27.5\end{array}$ & -676.1 & 35.8 & -403.1 & -308.8 \\
\hline $\begin{array}{l}\text { EMI-Warm I } \\
\text { Sprays } \\
9 / 23-9 / 24 \\
0700-0700\end{array}$ & $\begin{array}{l}29.6 \\
23.4\end{array}$ & $\begin{array}{l}7.51 \\
3.89\end{array}$ & $\begin{array}{l}7.51 \\
4.30\end{array}$ & $\begin{array}{l}41.7 \\
21.5\end{array}$ & -265.4 & 44.7 & -244.1 & -66.0 \\
\hline $\begin{array}{l}\text { EMI-Warm I I I } \\
\text { Sprays } \\
10 / 1-10 / 2 \\
0830-0830\end{array}$ & $\begin{array}{l}47.5 \\
25.7\end{array}$ & $\begin{array}{r}13.89 \\
6.85\end{array}$ & $\begin{array}{r}13.89 \\
8.78\end{array}$ & 38.8 & -662.9 & 37.1 & -388.7 & -308.8 \\
\hline
\end{tabular}


TABLE 18. Energy Budgets for East Mesa 2 Experiments

\begin{tabular}{|c|c|c|c|c|c|c|c|c|}
\hline Experiment & $\begin{array}{l}\text { Pond } \\
\text { Temp. } \\
\left({ }^{\circ} \mathrm{C}\right)\end{array}$ & $\begin{array}{l}\text { Pond } \\
\text { Elev. } \\
(\mathrm{cm}) \\
\end{array}$ & $\begin{array}{c}\text { Pond } \\
\text { Volume } \\
\text { (corrected) } \\
\left(\mathrm{m}^{3}\right) \\
\end{array}$ & $\begin{array}{l}\text { Air } \\
\text { Temp. } \\
\text { Range } \\
\left({ }^{\circ} \mathrm{C}\right)\end{array}$ & $\left(\times 10^{S g} \mathrm{~J}\right)$ & $\begin{array}{c}R \\
\left(10^{9} \mathrm{~J}\right) \\
\end{array}$ & $\stackrel{E}{\left(\times 10^{9} \mathrm{~J}\right)}$ & $\begin{array}{c}H \\
\left(x 10^{9} \mathrm{~J}\right) \\
\end{array}$ \\
\hline $\begin{array}{c}1 \\
6 / 16-6 / 17 \\
1600-1600\end{array}$ & $\begin{array}{l}45.8 \\
38.3\end{array}$ & $\begin{array}{l}8.03 \\
5.38\end{array}$ & $\begin{array}{l}4727.6 \\
4648.2\end{array}$ & $\begin{array}{l}46.2 \\
19.4\end{array}$ & -252.4 & 41.8 & -190.6 & -102.2 \\
\hline $\begin{array}{c}2 \\
6 / 20-6 / 21 \\
1600-1600\end{array}$ & $\begin{array}{l}46.4 \\
38.3\end{array}$ & $\begin{array}{l}7.83 \\
5.03\end{array}$ & $\begin{array}{l}4763.0 \\
4679.5\end{array}$ & $\begin{array}{l}44.8 \\
26.6\end{array}$ & -269.3 & 41.1 & -200.4 & -110.0 \\
\hline $\begin{array}{c}3 \\
6 / 23-6 / 24 \\
1800-1800\end{array}$ & $\begin{array}{l}50.0 \\
38.0\end{array}$ & $\begin{array}{l}7.70 \\
3.98\end{array}$ & $\begin{array}{l}4727.6 \\
4620.5\end{array}$ & $\begin{array}{l}43.0 \\
25.4\end{array}$ & -377.6 & 40.0 & -257.0 & -160.6 \\
\hline $\begin{array}{c}4 \\
6 / 27-6 / 28 \\
0900-0900\end{array}$ & $\begin{array}{l}50.9 \\
36.6\end{array}$ & $\begin{array}{l}7.58 \\
3.43\end{array}$ & $\begin{array}{l}4763.0 \\
4645.0\end{array}$ & $\begin{array}{l}41.5 \\
26.2\end{array}$ & -437.5 & - & -283.2 & -- \\
\hline $\begin{array}{c}5 \\
6 / 30-7 / 1 \\
1900-1900\end{array}$ & $\begin{array}{l}48.0 \\
38.2\end{array}$ & $\begin{array}{l}7.54 \\
4.13\end{array}$ & $\begin{array}{l}5123.7 \\
5019.5\end{array}$ & $\begin{array}{l}40.2 \\
24.4\end{array}$ & -346.6 & 43.3 & -250.1 & -139.8 \\
\hline $\begin{array}{c}6 \\
7 / 4-7 / 5 \\
0700-0700\end{array}$ & $\begin{array}{l}45.8 \\
37.5\end{array}$ & $\begin{array}{l}6.08 \\
2.99\end{array}$ & $\begin{array}{l}5345.5 \\
5248.6\end{array}$ & $\begin{array}{l}44.2 \\
28.7\end{array}$ & -370.1 & 46.5 & -232.6 & -724.0 \\
\hline
\end{tabular}





\section{REFERENCES}

U.S. Nuclear Regulatory Commission, 1976. U1timate Heat Sink for Nuclear Power Plants, Regulatory Guide 1.27, Revision 2, USNRC, Washington, D.C.

Drake, R. L. 1975. A Review and Evaluation of Information on the Thermal Performance of Ultimate Heat Sinks: Spray Ponds and Cooling Ponds. BNWL-B-446, Pacjfic Northwest Laboratory, Richland, WA.

Hadlock, R. K. 1976. Thermal Performance Experiments on Ultimate Heat Sinks, Spray Ponds and Cooling Ponds. BNWL-2143, Pacific Northwest Laboratory, Richland, WA.

Hadlock, R. K. and 0. B. Abbey. 1978. Thermal Performance Measurements on Ultimate Heat Sinks-Cooling Ponds. NUREG/CR-0008, PNL-2463, Pacific Northwest Laboratory, Richland, WA.

Hadlock, R. K. and 0. B. Abbey, 1981. Thermal Performance and Water Utilization Measurements on Ultimate Heat Sinks-Cooling Ponds and Spray Ponds. NUREG/CR-1886, PNL-3689, Pacific Northwest Laboratory, Richland, WA.

Spray Engineering Company, 1977. Spray Ponds--The Answer to Thermal Pollution Problems. East Spit Brook Road, Nashua, NH.

Chemical Rubber Publishing Company, 1955. Handbook of Chemistry and Physics-37 th Edition, Cleveland, $0 H$.

McGraw-Hill Book Company, Inc. 1928. International Critical Tables, III, New, York, NY.

Kell, G. S. 1967. "Precise Representation of Volume Properties of Water at One Atmosphere," J. Chemical and Engineering Data. 12(1):66-69. 

APPENDIX A

RAFT RIVER 1 - EXPERIMENTS I AND II 
RAFT PIVER 1 (1977) - EXPERIMENT I

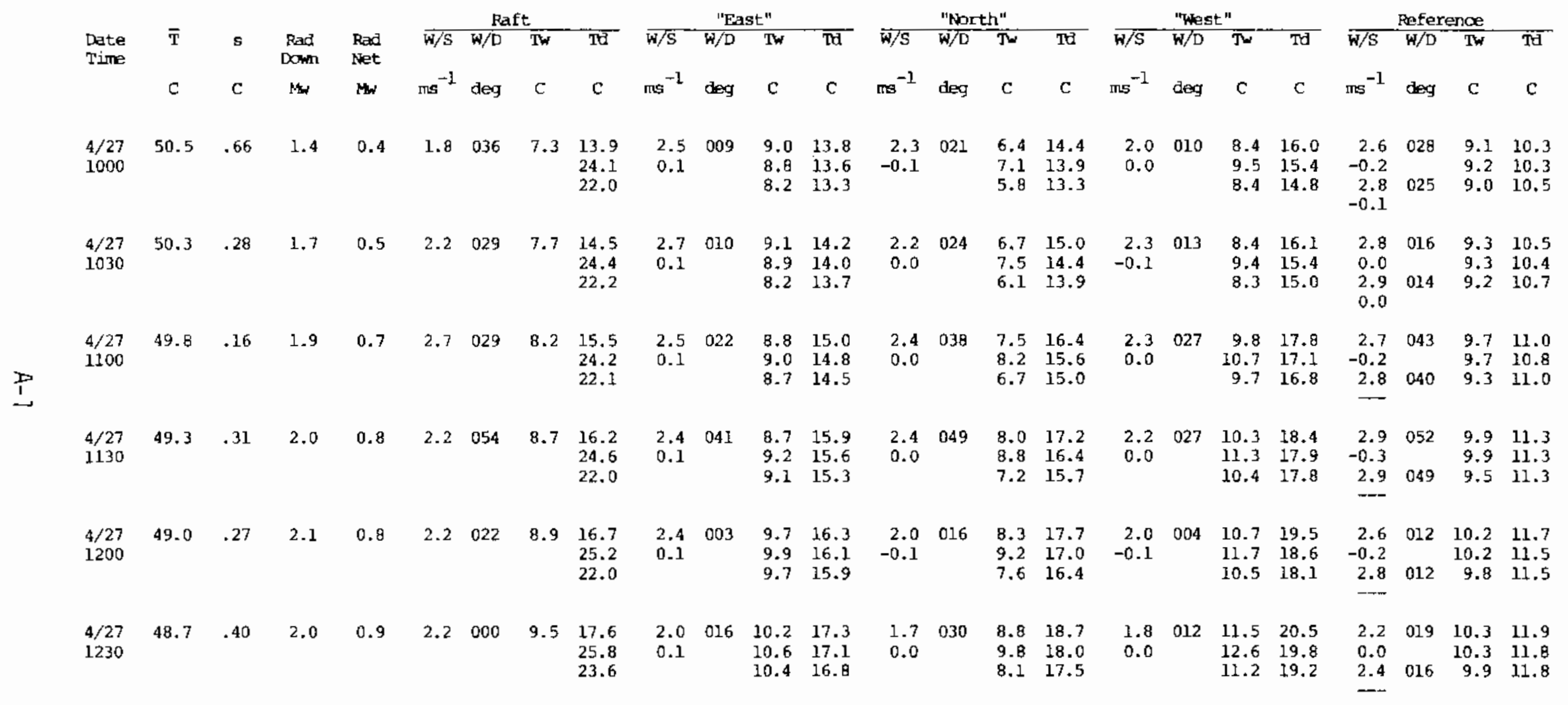




\section{RAFT RIVER $]$ (1977) - EXPERIMENT I (contd)}

\begin{tabular}{|c|c|c|c|c|c|c|c|c|c|c|c|c|c|c|c|c|c|c|c|c|c|c|c|c|}
\hline $\begin{array}{l}4 / 27 \\
1300\end{array}$ & 48.4 & .39 & 1.8 & 0.7 & 2.2 & 022 & 9.6 & $\begin{array}{l}18.1 \\
26.3 \\
25.1\end{array}$ & $\begin{array}{l}2.2 \\
0.1\end{array}$ & 028 & $\begin{array}{l}10.4 \\
10.7 \\
11.0\end{array}$ & $\begin{array}{l}18.0 \\
17.7 \\
17.4\end{array}$ & $\begin{array}{l}2.1 \\
0.0\end{array}$ & 039 & $\begin{array}{l}8.8 \\
9.8 \\
B .2\end{array}$ & $\begin{array}{l}18.9 \\
18.3 \\
17.7\end{array}$ & $\begin{array}{l}1.9 \\
0.0\end{array}$ & 024 & $\begin{array}{l}10.9 \\
12.2 \\
11.2\end{array}$ & $\begin{array}{l}20.0 \\
19.6 \\
19.4\end{array}$ & $\begin{array}{r}2.5 \\
-0.2 \\
2.6\end{array}$ & $\begin{array}{l}026 \\
026\end{array}$ & $\begin{array}{l}10.5 \\
10.5 \\
10.2\end{array}$ & $\begin{array}{l}12.2 \\
12.1 \\
12.1\end{array}$ \\
\hline $\begin{array}{l}4 / 27 \\
1330\end{array}$ & 48.2 & .19 & 1.8 & 0.8 & 1.8 & 065 & 10.0 & $\begin{array}{l}19.0 \\
27.2 \\
25.9\end{array}$ & $\begin{array}{l}2.6 \\
0.0\end{array}$ & 059 & $\begin{array}{r}9.9 \\
10.8 \\
11.5\end{array}$ & $\begin{array}{l}19.0 \\
18.7 \\
18.4\end{array}$ & $\begin{array}{l}2.6 \\
0.0\end{array}$ & 059 & $\begin{array}{r}9.6 \\
10.6 \\
8.7\end{array}$ & $\begin{array}{l}20.2 \\
19.4 \\
18.6\end{array}$ & $\begin{array}{l}2.6 \\
0.0\end{array}$ & 054 & $\begin{array}{l}12.1 \\
13.4 \\
12.1\end{array}$ & $\begin{array}{l}20.8 \\
20.8 \\
20.5\end{array}$ & $\begin{array}{r}3.2 \\
-0.3 \\
3.3\end{array}$ & $\begin{array}{l}062 \\
061\end{array}$ & $\begin{array}{l}10.8 \\
10.8 \\
10.3\end{array}$ & $\begin{array}{l}12.4 \\
12.3 \\
12.3\end{array}$ \\
\hline $\begin{array}{l}4 / 27 \\
1400\end{array}$ & 47.8 & .06 & 2.1 & 0.9 & 2.2 & 054 & 10. & $\begin{array}{l}19.8 \\
27.9 \\
26.6\end{array}$ & $\begin{array}{l}2.3 \\
0.0\end{array}$ & 040 & $\begin{array}{l}10.2 \\
11.2 \\
12.1\end{array}$ & $\begin{array}{l}19.7 \\
19.5 \\
19.2\end{array}$ & $\begin{array}{l}2.3 \\
0.0\end{array}$ & 063 & $\begin{array}{r}10.0 \\
11.1 \\
9.2\end{array}$ & $\begin{array}{l}21.0 \\
20.2 \\
19.6\end{array}$ & $\begin{array}{l}2.1 \\
0.0\end{array}$ & 050 & $\begin{array}{l}13.0 \\
14.2 \\
12.8\end{array}$ & $\begin{array}{l}22.1 \\
21.9 \\
21.5\end{array}$ & $\begin{array}{r}2.9 \\
-0.4 \\
3.1\end{array}$ & $\begin{array}{l}065 \\
065\end{array}$ & $\begin{array}{l}11.2 \\
11.1 \\
10.7\end{array}$ & $\begin{array}{l}12.7 \\
12.7 \\
12.7\end{array}$ \\
\hline $\begin{array}{l}4 / 27 \\
1430\end{array}$ & 47.6 & .06 & 1.5 & 0.7 & 1.8 & 000 & 10.7 & $\begin{array}{l}20.3 \\
27.9 \\
26.9\end{array}$ & $\begin{array}{l}1.8 \\
0.1\end{array}$ & 035 & $\begin{array}{l}11.2 \\
12.0 \\
12.7\end{array}$ & $\begin{array}{l}20.3 \\
20.1 \\
19.8\end{array}$ & $\begin{array}{l}1.7 \\
0.0\end{array}$ & 047 & $\begin{array}{r}10.2 \\
11.4 \\
9.5\end{array}$ & $\begin{array}{l}21.3 \\
20.7 \\
20.1\end{array}$ & $\begin{array}{l}1.6 \\
0.0\end{array}$ & 026 & $\begin{array}{l}13.2 \\
14.4 \\
13.0\end{array}$ & $\begin{array}{l}23.1 \\
22.5 \\
22.0\end{array}$ & $\begin{array}{r}2.1 \\
-0.2 \\
2.2\end{array}$ & $\begin{array}{l}045 \\
043\end{array}$ & $\begin{array}{l}11.3 \\
11.3 \\
10.8\end{array}$ & $\begin{array}{l}13.0 \\
12.8 \\
12.8\end{array}$ \\
\hline $\begin{array}{l}4 / 27 \\
1500\end{array}$ & 47.4 & .11 & 1.3 & 0.5 & 1.8 & 054 & 10.8 & $\begin{array}{l}20.6 \\
28.0 \\
27.0\end{array}$ & $\begin{array}{l}2.1 \\
0.1\end{array}$ & 033 & $\begin{array}{l}11.0 \\
11.9 \\
12.7\end{array}$ & $\begin{array}{l}20.6 \\
20.3 \\
20.0\end{array}$ & $\begin{array}{l}2.1 \\
0.0\end{array}$ & 046 & $\begin{array}{r}10.1 \\
11.4 \\
9.4\end{array}$ & $\begin{array}{l}21.4 \\
20.7 \\
20.2\end{array}$ & $\begin{array}{l}1.8 \\
0.0\end{array}$ & 036 & $\begin{array}{l}11.8 \\
13.1 \\
11.5\end{array}$ & $\begin{array}{l}21.3 \\
20.9 \\
20.5\end{array}$ & $\begin{array}{r}2.2 \\
-0.2 \\
2.3\end{array}$ & $\begin{array}{l}043 \\
041\end{array}$ & $\begin{array}{l}11.3 \\
11.4 \\
10.8\end{array}$ & $\begin{array}{l}13.1 \\
12.9 \\
13.0\end{array}$ \\
\hline $\begin{array}{l}4 / 27 \\
1530\end{array}$ & 46.8 & .10 & 1.2 & 0.4 & 2.7 & 000 & 10.7 & $\begin{array}{l}20.8 \\
27.8 \\
27.1\end{array}$ & $\begin{array}{l}3.0 \\
0.1\end{array}$ & 005 & $\begin{array}{l}11.9 \\
12.4 \\
12.8\end{array}$ & $\begin{array}{l}20.8 \\
20.5 \\
20.2\end{array}$ & $\begin{array}{r}2.5 \\
-0.1\end{array}$ & 018 & $\begin{array}{r}10.0 \\
11.3 \\
9.4\end{array}$ & $\begin{array}{l}21.4 \\
20.8 \\
20.3\end{array}$ & $\begin{array}{r}2.5 \\
-0.1\end{array}$ & 007 & $\begin{array}{l}11.1 \\
12.8 \\
11.2\end{array}$ & $\begin{array}{l}21.5 \\
21.0 \\
20.4\end{array}$ & $\begin{array}{r}3.1 \\
-0.1 \\
3.3\end{array}$ & $\begin{array}{l}011 \\
008\end{array}$ & $\begin{array}{l}11.3 \\
11.4 \\
10.8\end{array}$ & $\begin{array}{l}13.0 \\
12.9 \\
13.0\end{array}$ \\
\hline $\begin{array}{l}4 / 27 \\
1600\end{array}$ & 46.7 & .26 & 1.1 & 0.4 & 2.7 & 000 & 10.6 & $\begin{array}{l}20.7 \\
21.0 \\
18.8\end{array}$ & $\begin{array}{l}3.4 \\
0.1\end{array}$ & 007 & $\begin{array}{l}11.7 \\
12.2 \\
1.2 .7\end{array}$ & $\begin{array}{l}20.8 \\
20.5 \\
20.2\end{array}$ & $\begin{array}{r}2.8 \\
-0.1\end{array}$ & 018 & $\begin{array}{r}10.0 \\
11.3 \\
9.4\end{array}$ & $\begin{array}{l}21.3 \\
20.8 \\
20.1\end{array}$ & $\begin{array}{r}2.9 \\
-0.1\end{array}$ & 013 & $\begin{array}{l}11.0 \\
12.7 \\
11.1\end{array}$ & $\begin{array}{l}21.3 \\
20.9 \\
20.3\end{array}$ & $\begin{array}{l}3.2 \\
0.0 \\
3.6\end{array}$ & $\begin{array}{l}012 \\
009\end{array}$ & $\begin{array}{l}11.3 \\
11.4 \\
10.8\end{array}$ & $\begin{array}{l}13.0 \\
12.9 \\
13.0\end{array}$ \\
\hline $\begin{array}{l}4 / 27 \\
1630\end{array}$ & 46.2 & .24 & 1.0 & 0.3 & 2.7 & 018 & 10.5 & $\begin{array}{l}20.6 \\
19.4 \\
17.2\end{array}$ & $\begin{array}{l}3.2 \\
0.1\end{array}$ & 022 & $\begin{array}{l}11.4 \\
12.0 \\
12.6\end{array}$ & $\begin{array}{l}20.7 \\
20.5 \\
20.2\end{array}$ & $\begin{array}{r}2.9 \\
-0.1\end{array}$ & 0.30 & $\begin{array}{r}9.9 \\
11.1 \\
9.3\end{array}$ & $\begin{array}{l}21.1 \\
20.5 \\
20.1\end{array}$ & $\begin{array}{r}2.8 \\
-0.1\end{array}$ & 024 & $\begin{array}{l}10.9 \\
12.6 \\
11.1\end{array}$ & $\begin{array}{l}21.1 \\
20.8 \\
20.3\end{array}$ & $\begin{array}{l}3.4 \\
0.1 \\
3.7\end{array}$ & $\begin{array}{l}020 \\
015\end{array}$ & $\begin{array}{l}11.3 \\
11.3 \\
10.8\end{array}$ & $\begin{array}{l}13.0 \\
12.8 \\
13.0\end{array}$ \\
\hline
\end{tabular}


RAFT RIVER I (1977) - EXPERIMENT I (contd)

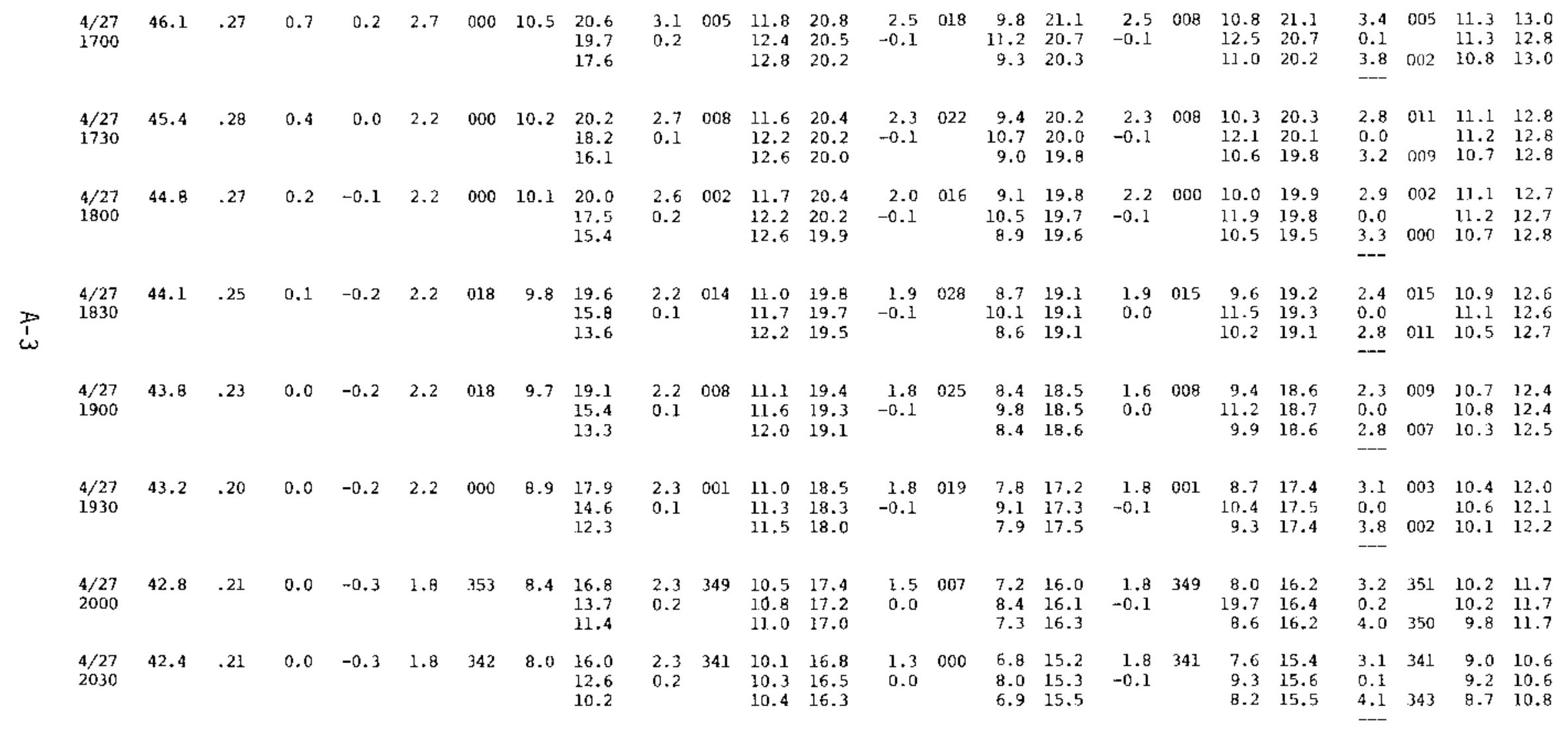


RAFT RIVER 1 (1977) - EXPERIMENT I (contd)

\begin{tabular}{|c|c|c|c|c|c|c|c|c|c|c|c|c|c|c|c|c|c|c|c|c|c|c|c|c|}
\hline $\begin{array}{l}4 / 27 \\
2100\end{array}$ & 42.0 & .20 & 0.0 & -0.2 & 1.3 & 342 & 8.0 & $\begin{array}{r}15.1 \\
10.9 \\
8.0\end{array}$ & $\begin{array}{l}0.5 \\
0.1\end{array}$ & 014 & $\begin{array}{l}9.3 \\
9.0 \\
9.6\end{array}$ & $\begin{array}{l}15.0 \\
15.0 \\
15.1\end{array}$ & $\begin{array}{l}0.7 \\
0.0\end{array}$ & 079 & $\begin{array}{l}6.6 \\
7.6 \\
6.6\end{array}$ & $\begin{array}{l}14.2 \\
1.4 .2 \\
14.4\end{array}$ & $\begin{array}{l}0.3 \\
0.1\end{array}$ & 022 & $\begin{array}{l}8.5 \\
9.6 \\
8.4\end{array}$ & $\begin{array}{l}14.8 \\
14.9 \\
14.7\end{array}$ & $\begin{array}{l}0.6 \\
0.0 \\
1.1\end{array}$ & $\begin{array}{l}027 \\
023\end{array}$ & $\begin{array}{l}9.3 \\
9.4 \\
9.0\end{array}$ & $\begin{array}{l}10.6 \\
10.6 \\
10.8\end{array}$ \\
\hline $\begin{array}{l}4 / 27 \\
2130\end{array}$ & 41.7 & .24 & 0.0 & -0.2 & 0.4 & $\mathrm{v}$ & B.I & $\begin{array}{r}14.0 \\
8.8 \\
5.5\end{array}$ & $\begin{array}{l}0.2 \\
0.0\end{array}$ & 234 & $\begin{array}{l}6.5 \\
7.4 \\
8.1\end{array}$ & $\begin{array}{l}12.8 \\
13.0 \\
13.2\end{array}$ & $\begin{array}{l}0.5 \\
0.0\end{array}$ & 094 & $\begin{array}{l}6.0 \\
7.1 \\
6.7\end{array}$ & $\begin{array}{l}12.5 \\
12.7 \\
13.3\end{array}$ & $\begin{array}{l}0.3 \\
0.1\end{array}$ & 232 & $\begin{array}{l}7.7 \\
8.9 \\
8.2\end{array}$ & $\begin{array}{l}13.2 \\
13.5 \\
13.6\end{array}$ & $\begin{array}{l}0.7 \\
0.0 \\
0.9\end{array}$ & $\begin{array}{l}170 \\
136\end{array}$ & $\begin{array}{l}8.9 \\
9.1 \\
8.7\end{array}$ & $\begin{array}{l}10.1 \\
10.2 \\
10.5\end{array}$ \\
\hline $\begin{array}{l}4 / 27 \\
2200\end{array}$ & 41.4 & .20 & 0.0 & -0.2 & 0.4 & 295 & 6.8 & $\begin{array}{r}13.3 \\
9.0 \\
-\end{array}$ & $\begin{array}{l}1.0 \\
0.0\end{array}$ & 287 & $\begin{array}{l}7.3 \\
7.8 \\
8.2\end{array}$ & $\begin{array}{l}12.9 \\
12.9 \\
13.1\end{array}$ & $\begin{array}{l}0.7 \\
0.0\end{array}$ & 308 & $\begin{array}{l}5.9 \\
7.1 \\
6.2\end{array}$ & $\begin{array}{l}12.0 \\
12.2 \\
13.2\end{array}$ & $\begin{array}{l}1.3 \\
0.0\end{array}$ & 289 & $\begin{array}{l}5.5 \\
7.0 \\
6.9\end{array}$ & $\begin{array}{l}11.1 \\
11.7 \\
12.8\end{array}$ & $\begin{array}{l}1.4 \\
0.0 \\
0.7\end{array}$ & $\begin{array}{l}276 \\
262\end{array}$ & $\begin{array}{l}8.5 \\
9.0 \\
8.7\end{array}$ & $\begin{array}{r}9.7 \\
10.2 \\
10.4\end{array}$ \\
\hline $\begin{array}{l}4 / 27 \\
2230\end{array}$ & 40.9 & .24 & 0.0 & -0.2 & 0.9 & 281 & 6.8 & $\begin{array}{r}12.8 \\
8.4 \\
---\end{array}$ & $\begin{array}{l}0.8 \\
0.0\end{array}$ & 267 & $\begin{array}{l}6.7 \\
7.3 \\
7.6\end{array}$ & $\begin{array}{l}12.5 \\
12.5 \\
12.5\end{array}$ & $\begin{array}{l}1.0 \\
0.1\end{array}$ & 255 & $\begin{array}{l}8.1 \\
8.4 \\
6.5\end{array}$ & $\begin{array}{l}13.3 \\
13.1 \\
12.9\end{array}$ & $\begin{array}{l}1.1 \\
0.0\end{array}$ & 271 & $\begin{array}{l}5.13 \\
7.1 \\
6.4\end{array}$ & $\begin{array}{l}11.6 \\
11.9 \\
12.1\end{array}$ & $\begin{array}{l}2.0 \\
0.0 \\
2.2\end{array}$ & $\begin{array}{l}255 \\
241\end{array}$ & $\begin{array}{l}8.6 \\
8.9 \\
8.6\end{array}$ & $\begin{array}{r}9.8 \\
10.0 \\
10.3\end{array}$ \\
\hline $\begin{array}{l}4 / 27 \\
2300\end{array}$ & 40.6 & .23 & 0.0 & -0.2 & 0.4 & 288 & 7.0 & $\begin{array}{r}13.2 \\
9.7 \\
6.4\end{array}$ & $\begin{array}{l}0.8 \\
0.1\end{array}$ & 311 & $\begin{array}{l}7.3 \\
7.9 \\
8.2\end{array}$ & $\begin{array}{l}13.0 \\
13.0 \\
13.1\end{array}$ & $\begin{array}{l}0.5 \\
0.1\end{array}$ & 306 & $\begin{array}{l}6.4 \\
7.2 \\
5.9\end{array}$ & $\begin{array}{l}12.5 \\
12.5 \\
12.8\end{array}$ & $\begin{array}{l}1.0 \\
0.0\end{array}$ & 303 & $\begin{array}{l}5.9 \\
7.3 \\
6.5\end{array}$ & $\begin{array}{l}12.0 \\
12.3 \\
12.5\end{array}$ & $\begin{array}{l}1.4 \\
0.0 \\
1.4\end{array}$ & $\begin{array}{l}291 \\
274\end{array}$ & $\begin{array}{l}8.7 \\
8.9 \\
8.6\end{array}$ & $\begin{array}{r}9.9 \\
10.1 \\
10.3\end{array}$ \\
\hline $\begin{array}{l}4 / 27 \\
2330\end{array}$ & 40.0 & .21 & 0.0 & -0.2 & 0.9 & 281 & 7.6 & $\begin{array}{r}14.7 \\
9.2 \\
6.1\end{array}$ & $\begin{array}{l}0.8 \\
0.1\end{array}$ & 278 & $\begin{array}{l}7.8 \\
8.5 \\
9.0\end{array}$ & $\begin{array}{l}14.4 \\
14.5 \\
14.5\end{array}$ & $\begin{array}{l}0.8 \\
0.1\end{array}$ & 265 & $\begin{array}{l}8.1 \\
8.8 \\
7.1\end{array}$ & $\begin{array}{l}14.8 \\
14.7 \\
14.7\end{array}$ & $\begin{array}{l}1.1 \\
0.0\end{array}$ & 277 & $\begin{array}{l}6.9 \\
8.3 \\
7.5\end{array}$ & $\begin{array}{l}13.5 \\
13.8 \\
14.0\end{array}$ & $\begin{array}{l}1.7 \\
0.0 \\
2.0\end{array}$ & $\begin{array}{l}269 \\
262\end{array}$ & $\begin{array}{l}9.2 \\
9.4 \\
9.0\end{array}$ & $\begin{array}{l}10.6 \\
10.7 \\
10.9\end{array}$ \\
\hline $\begin{array}{l}4 / 28 \\
0000\end{array}$ & 39.5 & .19 & 0.0 & -0.2 & 0.4 & $\mathrm{v}$ & 7.1 & $\begin{array}{r}13.3 \\
8.0 \\
--\end{array}$ & $\begin{array}{l}0.8 \\
0.1\end{array}$ & 298 & $\begin{array}{l}7.3 \\
7.9 \\
8.2\end{array}$ & $\begin{array}{l}13.1 \\
13.1 \\
13.2\end{array}$ & $\begin{array}{l}0.4 \\
0.1\end{array}$ & 280 & $\begin{array}{l}7.2 \\
8.0 \\
6.6\end{array}$ & $\begin{array}{l}13.2 \\
13.2 \\
13.3\end{array}$ & $\begin{array}{l}0.9 \\
0.0\end{array}$ & 290 & $\begin{array}{l}6.3 \\
7.6 \\
6.8\end{array}$ & $\begin{array}{l}12.3 \\
12.6 \\
12.7\end{array}$ & $\begin{array}{l}1.3 \\
0.0 \\
1.3\end{array}$ & 279 & $\begin{array}{l}8.8 \\
8.9 \\
8.6\end{array}$ & $\begin{array}{l}10.0 \\
10.1 \\
10.4\end{array}$ \\
\hline $\begin{array}{l}4 / 28 \\
0030\end{array}$ & 39.6 & .16 & 0.0 & -0.2 & 0.4 & $v$ & 7.0 & $\begin{array}{r}12.4 \\
7.5 \\
\end{array}$ & $\begin{array}{l}0.3 \\
0.1\end{array}$ & 296 & $\begin{array}{l}6.8 \\
7.5 \\
7.9\end{array}$ & $\begin{array}{l}11.9 \\
12.0 \\
12.1\end{array}$ & $\begin{array}{l}0.2 \\
0.0\end{array}$ & 332 & $\begin{array}{l}6.3 \\
7.3 \\
6.2\end{array}$ & $\begin{array}{l}11.7 \\
11.9 \\
12.1\end{array}$ & $\begin{array}{l}0.6 \\
0.0\end{array}$ & 299 & $\begin{array}{l}5.5 \\
6.8 \\
6.2\end{array}$ & $\begin{array}{l}10.7 \\
11.2 \\
11.5\end{array}$ & $\begin{array}{l}1.0 \\
0.0 \\
1.4\end{array}$ & $\begin{array}{l}225 \\
221\end{array}$ & $\begin{array}{l}8.3 \\
8.5 \\
8.2\end{array}$ & $\begin{array}{l}9.4 \\
9.5 \\
9.7\end{array}$ \\
\hline
\end{tabular}


RAFT RIVER 1 (1977) - EXPERIMENT I (contd)

\begin{tabular}{|c|c|c|c|c|c|c|c|c|c|c|c|c|c|c|c|c|c|c|c|c|c|c|c|c|}
\hline $\begin{array}{l}4 / 2 \mathrm{~B} \\
0100\end{array}$ & 39.2 & .21 & 0.0 & -0.2 & 0.4 & $\mathrm{v}$ & 6.7 & $\begin{array}{r}12.2 \\
8.2 \\
-\cdots\end{array}$ & $\begin{array}{l}0.4 \\
0.0\end{array}$ & 039 & $\begin{array}{l}6.2 \\
6.9 \\
7.5\end{array}$ & $\begin{array}{l}11.3 \\
11.5 \\
11.9\end{array}$ & $\begin{array}{l}0.5 \\
0.0\end{array}$ & 059 & $\begin{array}{l}5.5 \\
6.5 \\
5.7\end{array}$ & $\begin{array}{l}11.0 \\
11.2 \\
11.8\end{array}$ & $\begin{array}{l}0.4 \\
0.0\end{array}$ & 006 & $\begin{array}{l}6.1 \\
7.2 \\
6.7\end{array}$ & $\begin{array}{l}10.9 \\
11.4 \\
11.8\end{array}$ & $\begin{array}{l}0.5 \\
0.0 \\
0.7\end{array}$ & $\begin{array}{l}091 \\
106\end{array}$ & $\begin{array}{l}8.4 \\
B .5 \\
B .2\end{array}$ & $\begin{array}{l}9.5 \\
9.6 \\
9.7\end{array}$ \\
\hline $\begin{array}{l}4 / 28 \\
0130\end{array}$ & 38.8 & .23 & 0.0 & -0.2 & 0.9 & $\mathrm{v}$ & 6.5 & $\begin{array}{r}12.4 \\
7.5 \\
-\end{array}$ & $\begin{array}{l}0.4 \\
0.0\end{array}$ & 268 & $\begin{array}{l}6.3 \\
7.1 \\
7.6\end{array}$ & $\begin{array}{l}11.8 \\
12.0 \\
12.2\end{array}$ & $\begin{array}{l}0.3 \\
0.1\end{array}$ & 228 & $\begin{array}{l}6.7 \\
7.4 \\
6.0\end{array}$ & $\begin{array}{l}12.2 \\
12.1 \\
12.2\end{array}$ & $\begin{array}{l}0.7 \\
0.0\end{array}$ & 272 & $\begin{array}{l}6.3 \\
7.4 \\
6.6\end{array}$ & $\begin{array}{l}11.5 \\
11.7 \\
11.8\end{array}$ & $\begin{array}{l}1.0 \\
0.0 \\
1.1\end{array}$ & $\begin{array}{l}244 \\
228\end{array}$ & $\begin{array}{l}8.4 \\
8.6 \\
8.3\end{array}$ & $\begin{array}{r}9.6 \\
9.7 \\
10.0\end{array}$ \\
\hline $\begin{array}{l}4 / 28 \\
0200\end{array}$ & 38.5 & .17 & 0.0 & -0.2 & 0.4 & $\mathrm{v}$ & 6.0 & $\begin{array}{r}11.6 \\
7.0 \\
---\end{array}$ & $\begin{array}{l}0.7 \\
0.1\end{array}$ & 293 & $\begin{array}{l}6.6 \\
7.1 \\
7.4\end{array}$ & $\begin{array}{l}11.7 \\
11.7 \\
11.8\end{array}$ & $\begin{array}{l}0.3 \\
0.1\end{array}$ & 273 & $\begin{array}{l}6.0 \\
6.6 \\
5.4\end{array}$ & $\begin{array}{l}11.3 \\
11.2 \\
11.4\end{array}$ & $\begin{array}{l}0.9 \\
0.0\end{array}$ & $2 \mathrm{BB}$ & $\begin{array}{l}5.5 \\
6.6 \\
5.9\end{array}$ & $\begin{array}{l}10.7 \\
10.9 \\
11.1\end{array}$ & $\begin{array}{l}1.3 \\
0.0 \\
1.4 \\
\end{array}$ & $\begin{array}{l}272 \\
263\end{array}$ & $\begin{array}{l}8.3 \\
8.5 \\
8.3\end{array}$ & $\begin{array}{l}9.4 \\
9.6 \\
9.9\end{array}$ \\
\hline $\begin{array}{l}4 / 28 \\
0230\end{array}$ & 38.2 & .22 & 0.0 & -0.2 & 0.9 & $\mathrm{v}$ & 5.8 & $\begin{array}{r}11.1 \\
6.1 \\
---\end{array}$ & $\begin{array}{l}0.7 \\
0.0\end{array}$ & 282 & $\begin{array}{l}6.1 \\
6.6 \\
6.9\end{array}$ & $\begin{array}{l}10.8 \\
10.9 \\
11.1\end{array}$ & $\begin{array}{l}0.4 \\
0.1\end{array}$ & 269 & $\begin{array}{l}5.7 \\
6.4 \\
5.2\end{array}$ & $\begin{array}{l}10.6 \\
10.6 \\
10.9\end{array}$ & $\begin{array}{l}0.9 \\
0.0\end{array}$ & 282 & $\begin{array}{l}4.7 \\
6.0 \\
5.6\end{array}$ & $\begin{array}{r}9.5 \\
10.1 \\
10.5\end{array}$ & $\begin{array}{l}1.2 \\
0.0 \\
1.3 \\
0.0\end{array}$ & $\begin{array}{l}267 \\
254\end{array}$ & $\begin{array}{l}8.0 \\
8.3 \\
8.1\end{array}$ & $\begin{array}{l}9.1 \\
9.3 \\
9.6\end{array}$ \\
\hline $\begin{array}{l}4 / 28 \\
0300\end{array}$ & 37.9 & .22 & 0.0 & -0.2 & 0.9 & $\mathrm{v}$ & 4.9 & $\begin{array}{r}9.8 \\
5.5 \\
----\end{array}$ & $\begin{array}{l}1.0 \\
0.1\end{array}$ & 276 & $\begin{array}{l}5.4 \\
5.8 \\
6.0\end{array}$ & $\begin{array}{l}9.7 \\
9.7 \\
9.8\end{array}$ & $\begin{array}{l}0.9 \\
0.1\end{array}$ & 271 & $\begin{array}{l}5.4 \\
5.8 \\
4.6\end{array}$ & $\begin{array}{l}9.9 \\
9.7 \\
9.9\end{array}$ & $\begin{array}{l}1.1 \\
0.0\end{array}$ & 280 & $\begin{array}{l}4.4 \\
5.4 \\
4.8\end{array}$ & $\begin{array}{l}8.8 \\
9.0 \\
9.1\end{array}$ & $\begin{array}{l}2.3 \\
0.0 \\
2.5\end{array}$ & $\begin{array}{l}271 \\
264\end{array}$ & $\begin{array}{l}7.6 \\
7.9 \\
7.9\end{array}$ & $\begin{array}{l}8.6 \\
8.9 \\
9.3\end{array}$ \\
\hline $\begin{array}{l}4 / 28 \\
0330\end{array}$ & 37.4 & .22 & 0.0 & -0.2 & 0.9 & $\mathrm{v}$ & 5.2 & $\begin{array}{r}10.4 \\
5.6 \\
---\end{array}$ & $\begin{array}{l}0.8 \\
0.1\end{array}$ & 284 & $\begin{array}{l}5.7 \\
6.2 \\
6.3\end{array}$ & $\begin{array}{l}10.1 \\
10.2 \\
10.2\end{array}$ & $\begin{array}{l}0.7 \\
0.1\end{array}$ & 284 & $\begin{array}{l}5.4 \\
6.0 \\
4.9\end{array}$ & $\begin{array}{l}10.2 \\
10.2 \\
10.5\end{array}$ & $\begin{array}{l}1.0 \\
0.0\end{array}$ & 288 & $\begin{array}{l}4.6 \\
5.7 \\
5.1\end{array}$ & $\begin{array}{l}9.3 \\
9.6 \\
9.8\end{array}$ & $\begin{array}{l}1.9 \\
0.0 \\
2.1\end{array}$ & $\begin{array}{l}267 \\
254\end{array}$ & $\begin{array}{l}7.8 \\
8.0 \\
7.8\end{array}$ & $\begin{array}{l}8.7 \\
9.0 \\
9.3\end{array}$ \\
\hline $\begin{array}{l}4 / 28 \\
0400\end{array}$ & 37.2 & .22 & 0.0 & -0.2 & 0.4 & $\mathrm{v}$ & 5.4 & $\begin{array}{c}9.3 \\
--- \\
---\end{array}$ & $\begin{array}{l}0.3 \\
0.0\end{array}$ & 214 & $\begin{array}{l}4.1 \\
4.8 \\
5.3\end{array}$ & $\begin{array}{l}8.2 \\
8.4 \\
8.7\end{array}$ & $\begin{array}{l}0.4 \\
0.1\end{array}$ & 180 & $\begin{array}{l}5.5 \\
6.0 \\
4.9\end{array}$ & $\begin{array}{l}9.2 \\
9.2 \\
9.2\end{array}$ & $\begin{array}{l}0.6 \\
0.1\end{array}$ & 243 & $\begin{array}{l}4.7 \\
5.6 \\
5.1\end{array}$ & $\begin{array}{l}8.3 \\
8.7 \\
8.9\end{array}$ & $\begin{array}{l}0.9 \\
0.0 \\
0.9\end{array}$ & $\begin{array}{l}215 \\
215\end{array}$ & $\begin{array}{l}7.3 \\
7.5 \\
7.2\end{array}$ & $\begin{array}{l}8.1 \\
8.2 \\
8.4\end{array}$ \\
\hline $\begin{array}{l}4 / 28 \\
0430\end{array}$ & 36.7 & .17 & 0.0 & -0.2 & 0.9 & $\mathrm{v}$ & 5.1 & $\begin{array}{l}10.0 \\
---\end{array}$ & $\begin{array}{l}0.9 \\
0.1\end{array}$ & 296 & $\begin{array}{l}6.1 \\
6.4 \\
6.5\end{array}$ & $\begin{array}{l}10.0 \\
10.0 \\
10.1\end{array}$ & $\begin{array}{l}0.6 \\
0.1\end{array}$ & 316 & $\begin{array}{l}4.3 \\
5.3 \\
4.5\end{array}$ & $\begin{array}{l}9.0 \\
9.3 \\
9.8\end{array}$ & $\begin{array}{l}1.0 \\
0.0\end{array}$ & 297 & $\begin{array}{l}3.9 \\
5.1 \\
4.8\end{array}$ & $\begin{array}{l}8.3 \\
8.8 \\
9.4\end{array}$ & $\begin{array}{l}1.2 \\
0.0 \\
1.2\end{array}$ & $\begin{array}{l}289 \\
280\end{array}$ & $\begin{array}{l}7.4 \\
7.7 \\
7.4\end{array}$ & $\begin{array}{l}8.3 \\
8.6 \\
8.8\end{array}$ \\
\hline
\end{tabular}


RAFT RIVER 1 (1977) - EXPERIMENT I (contd)

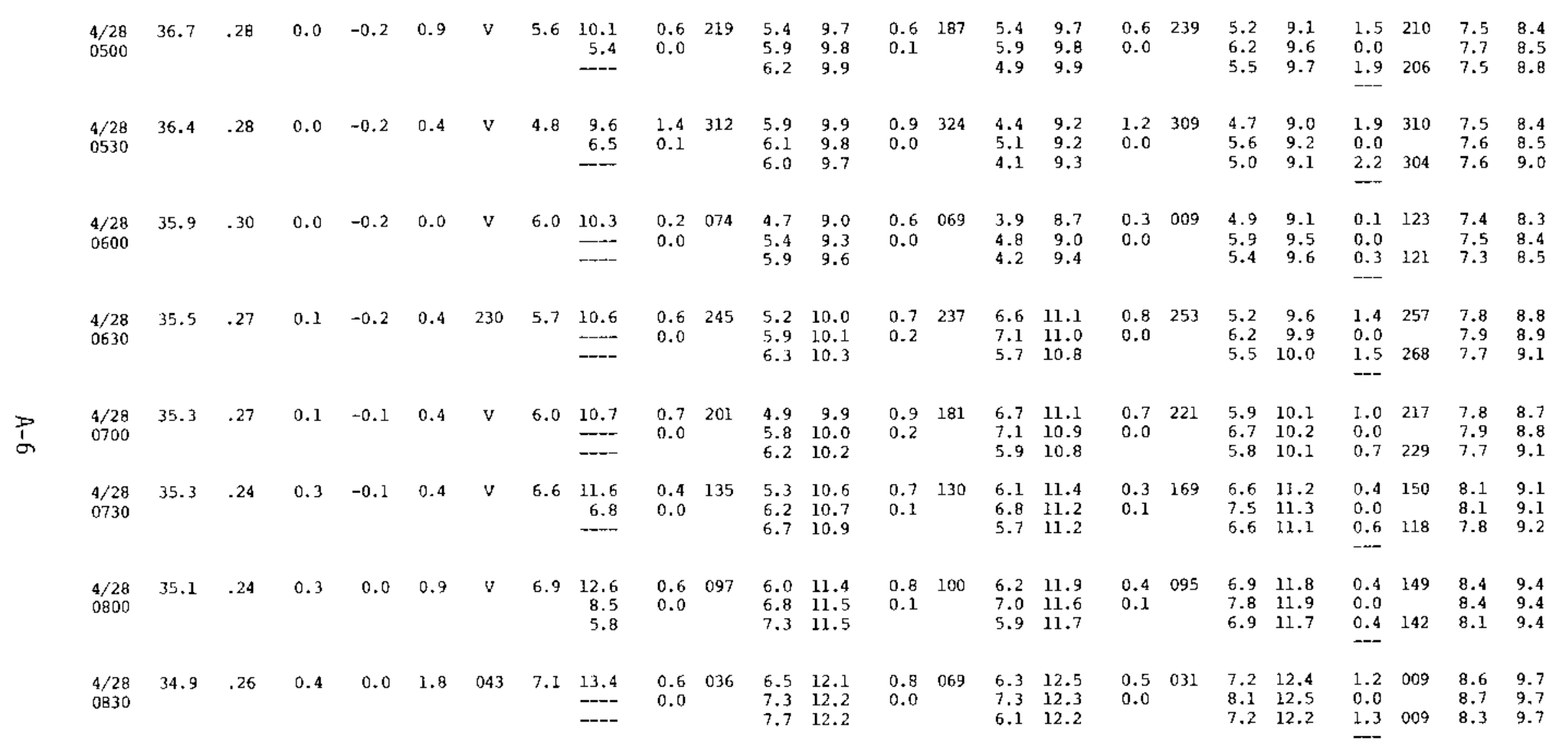


RAFT RIVER 1 (1977) - EXPERIMENT I (contd)

\begin{tabular}{|c|c|c|c|c|c|c|c|c|c|c|c|c|c|c|c|c|c|c|c|c|c|c|c|c|}
\hline $\begin{array}{l}4 / 28 \\
0900\end{array}$ & 34.6 & .24 & 0.6 & 0.1 & 1.3 & 000 & 7.2 & $\begin{array}{r}13.8 \\
10.5 \\
8.1\end{array}$ & $\begin{array}{l}2.1 \\
0.1\end{array}$ & 018 & $\begin{array}{l}7.6 \\
9.2 \\
8.4\end{array}$ & $\begin{array}{l}13.7 \\
13.6 \\
13.5\end{array}$ & $\begin{array}{l}1.9 \\
0.0\end{array}$ & 029 & $\begin{array}{l}6.6 \\
7.9 \\
6.3\end{array}$ & $\begin{array}{l}13.9 \\
13.6 \\
13.4\end{array}$ & $\begin{array}{l}1.8 \\
0.0\end{array}$ & 016 & $\begin{array}{l}7.4 \\
8.6 \\
7.5\end{array}$ & $\begin{array}{l}13.8 \\
13.7 \\
13.4\end{array}$ & $\begin{array}{l}2.2 \\
0.0 \\
2.4\end{array}$ & $\begin{array}{l}023 \\
019\end{array}$ & $\begin{array}{l}8.8 \\
8.9 \\
8.5\end{array}$ & $\begin{array}{l}10.1 \\
10.0 \\
10.1\end{array}$ \\
\hline $\begin{array}{l}4 / 28 \\
0930\end{array}$ & 34.4 & .28 & 1.2 & 0.4 & 1.3 & 079 & 8.2 & $\begin{array}{l}15.1 \\
12.9 \\
10.3\end{array}$ & $\begin{array}{l}1.7 \\
0.0\end{array}$ & 075 & $\begin{array}{l}7.7 \\
8.6 \\
9.1\end{array}$ & $\begin{array}{l}14.8 \\
14.7 \\
14.6\end{array}$ & $\begin{array}{l}1.8 \\
0.0\end{array}$ & 078 & $\begin{array}{l}7.9 \\
8.9 \\
7.4\end{array}$ & $\begin{array}{l}15.7 \\
15.3 \\
14.9\end{array}$ & $\begin{array}{l}1.6 \\
0.1\end{array}$ & 071 & $\begin{array}{r}9.2 \\
10.1 \\
8.9\end{array}$ & $\begin{array}{l}15.5 \\
15.3 \\
15.0\end{array}$ & $\begin{array}{r}2.1 \\
-0.1 \\
2.2\end{array}$ & 076 & $\begin{array}{l}9.5 \\
9.6 \\
9.1\end{array}$ & $\begin{array}{l}10.8 \\
10.7 \\
10.8\end{array}$ \\
\hline $\begin{array}{l}4 / 28 \\
1000\end{array}$ & 34.2 & .29 & 1.6 & 0.6 & 1.3 & 090 & 9.1 & $\begin{array}{l}16.8 \\
14.0 \\
11.5\end{array}$ & $\begin{array}{l}1.8 \\
0.0\end{array}$ & 089 & $\begin{array}{r}8.6 \\
9.6 \\
10.3\end{array}$ & $\begin{array}{l}16.6 \\
16.6 \\
16.3\end{array}$ & $\begin{array}{l}1.9 \\
0.0\end{array}$ & 087 & $\begin{array}{r}9.5 \\
10.1 \\
8.4\end{array}$ & $\begin{array}{l}17.8 \\
17.3 \\
16.8\end{array}$ & $\begin{array}{l}1.7 \\
0.1\end{array}$ & 083 & $\begin{array}{r}10.3 \\
11.2 \\
9.9\end{array}$ & $\begin{array}{l}17.1 \\
16.9 \\
16.7\end{array}$ & $\begin{array}{r}2.1 \\
-0.1 \\
2.3\end{array}$ & $\begin{array}{l}087 \\
085\end{array}$ & $\begin{array}{r}10.2 \\
10.2 \\
9.7\end{array}$ & $\begin{array}{l}11.6 \\
11.5 \\
11.5\end{array}$ \\
\hline $\begin{array}{l}4 / 28 \\
1030\end{array}$ & 34.0 & .29 & 1.8 & 0.8 & 1.3 & 072 & 10.0 & $\begin{array}{l}17.8 \\
14.2 \\
11.8\end{array}$ & $\begin{array}{l}1.1 \\
0.0\end{array}$ & 084 & $\begin{array}{r}9.5 \\
10.6 \\
11.2\end{array}$ & $\begin{array}{l}17.8 \\
17.7 \\
17.5\end{array}$ & $\begin{array}{l}1.4 \\
0.0\end{array}$ & 086 & $\begin{array}{r}10.6 \\
11.1 \\
9.3\end{array}$ & $\begin{array}{l}18.8 \\
18.3 \\
17.9\end{array}$ & $\begin{array}{l}1.0 \\
0.1\end{array}$ & 081 & $\begin{array}{l}10.9 \\
11.9 \\
10.7\end{array}$ & $\begin{array}{l}18.3 \\
18.0 \\
17.8\end{array}$ & $\begin{array}{r}1.4 \\
-0.1 \\
1.5\end{array}$ & $\begin{array}{l}079 \\
079\end{array}$ & $\begin{array}{l}10.6 \\
10.6 \\
10.2\end{array}$ & $\begin{array}{l}12.1 \\
12.0 \\
12.1\end{array}$ \\
\hline $\begin{array}{l}4 / 28 \\
1100\end{array}$ & 33.9 & .31 & 1.8 & 0.8 & 1.3 & 072 & 10.5 & $\begin{array}{l}19.2 \\
15.5 \\
13.4\end{array}$ & $\begin{array}{l}1.6 \\
0.0\end{array}$ & 068 & $\begin{array}{l}10.2 \\
11.4 \\
11.9\end{array}$ & $\begin{array}{l}19.1 \\
19.0 \\
18.8\end{array}$ & $\begin{array}{l}1.7 \\
0.0\end{array}$ & 077 & $\begin{array}{r}11.2 \\
11.8 \\
9.8\end{array}$ & $\begin{array}{l}20.4 \\
19.8 \\
19.4\end{array}$ & $\begin{array}{l}1.4 \\
0.1\end{array}$ & 073 & $\begin{array}{l}11.7 \\
12.7 \\
11.4\end{array}$ & $\begin{array}{l}19.7 \\
19.4 \\
19.2\end{array}$ & $\begin{array}{r}1.9 \\
-0.1 \\
1.9\end{array}$ & $\begin{array}{l}073 \\
072\end{array}$ & $\begin{array}{l}11.0 \\
11.0 \\
10.5\end{array}$ & $\begin{array}{l}12.6 \\
12.5 \\
12.5\end{array}$ \\
\hline $\begin{array}{l}4 / 28 \\
1130\end{array}$ & 34.1 & .28 & 2.0 & 0.9 & 1.8 & 086 & 11.3 & $\begin{array}{l}21.0 \\
16.7 \\
14.6\end{array}$ & $\begin{array}{r}2.3 \\
-0.1\end{array}$ & 082 & $\begin{array}{l}10.6 \\
12.0 \\
12.8\end{array}$ & $\begin{array}{l}20.9 \\
20.7 \\
20.4\end{array}$ & $\begin{array}{l}2.3 \\
0.0\end{array}$ & 082 & $\begin{array}{l}11.7 \\
12.5 \\
10.4\end{array}$ & $\begin{array}{l}22.2 \\
21.5 \\
20.9\end{array}$ & $\begin{array}{l}2.2 \\
0.1\end{array}$ & 080 & $\begin{array}{l}12.4 \\
13.6 \\
12.2\end{array}$ & $\begin{array}{l}21.2 \\
21.0 \\
20.9\end{array}$ & $\begin{array}{r}2.8 \\
-0.1 \\
2.9\end{array}$ & $\begin{array}{l}079 \\
078\end{array}$ & $\begin{array}{l}11.5 \\
11.5 \\
10.9\end{array}$ & $\begin{array}{l}13.2 \\
13.1 \\
13.1\end{array}$ \\
\hline $\begin{array}{l}4 / 28 \\
1200\end{array}$ & 34.0 & .29 & 1.5 & 0.7 & 1.3 & 083 & $1\} .2$ & $\begin{array}{l}21.3 \\
16.4 \\
14.6\end{array}$ & $\begin{array}{l}1.3 \\
0.0\end{array}$ & 072 & $\begin{array}{l}10.6 \\
12.2 \\
13.0\end{array}$ & $\begin{array}{l}21.2 \\
21.1 \\
21.0\end{array}$ & $\begin{array}{l}1.5 \\
0.0\end{array}$ & 085 & $\begin{array}{l}11.5 \\
12.5 \\
10.3\end{array}$ & $\begin{array}{l}22.2 \\
21.7 \\
21.3\end{array}$ & $\begin{array}{l}1.3 \\
0.1\end{array}$ & 078 & $\begin{array}{l}12.2 \\
13.6 \\
12.2\end{array}$ & $\begin{array}{l}21.5 \\
21.4 \\
21.3\end{array}$ & $\begin{array}{r}1.4 \\
-0.1 \\
1.5\end{array}$ & $\begin{array}{l}079 \\
081\end{array}$ & $\begin{array}{l}11.6 \\
11.6 \\
11.1\end{array}$ & $\begin{array}{l}13.4 \\
13.3 \\
13.3\end{array}$ \\
\hline $\begin{array}{l}4 / 28 \\
1230\end{array}$ & 33.7 & .28 & 1.2 & 0.5 & 1.3 & $v$ & 11.2 & $\begin{array}{l}21.6 \\
15.3 \\
13.6\end{array}$ & $\begin{array}{l}0.8 \\
0.0\end{array}$ & 141 & $\begin{array}{l}10.8 \\
12.5 \\
13.3\end{array}$ & $\begin{array}{l}21.9 \\
21.8 \\
21.6\end{array}$ & $\begin{array}{l}1.2 \\
0.1\end{array}$ & 141 & $\begin{array}{l}12.0 \\
12.8 \\
11.1\end{array}$ & $\begin{array}{l}22.4 \\
22.0 \\
21.7\end{array}$ & $\begin{array}{l}0.7 \\
0.1\end{array}$ & 176 & $\begin{array}{l}12.1 \\
13.8 \\
12.3\end{array}$ & $\begin{array}{l}22.1 \\
22.0 \\
21.7\end{array}$ & $\begin{array}{l}1.3 \\
0.0 \\
1.5\end{array}$ & $\begin{array}{l}176 \\
170\end{array}$ & $\begin{array}{l}11.5 \\
11.5 \\
11.0\end{array}$ & $\begin{array}{l}13.3 \\
13.2 \\
13.3\end{array}$ \\
\hline
\end{tabular}




\section{RAFT RIVER 1 (1977) - EXPERIMENT I (contd)}

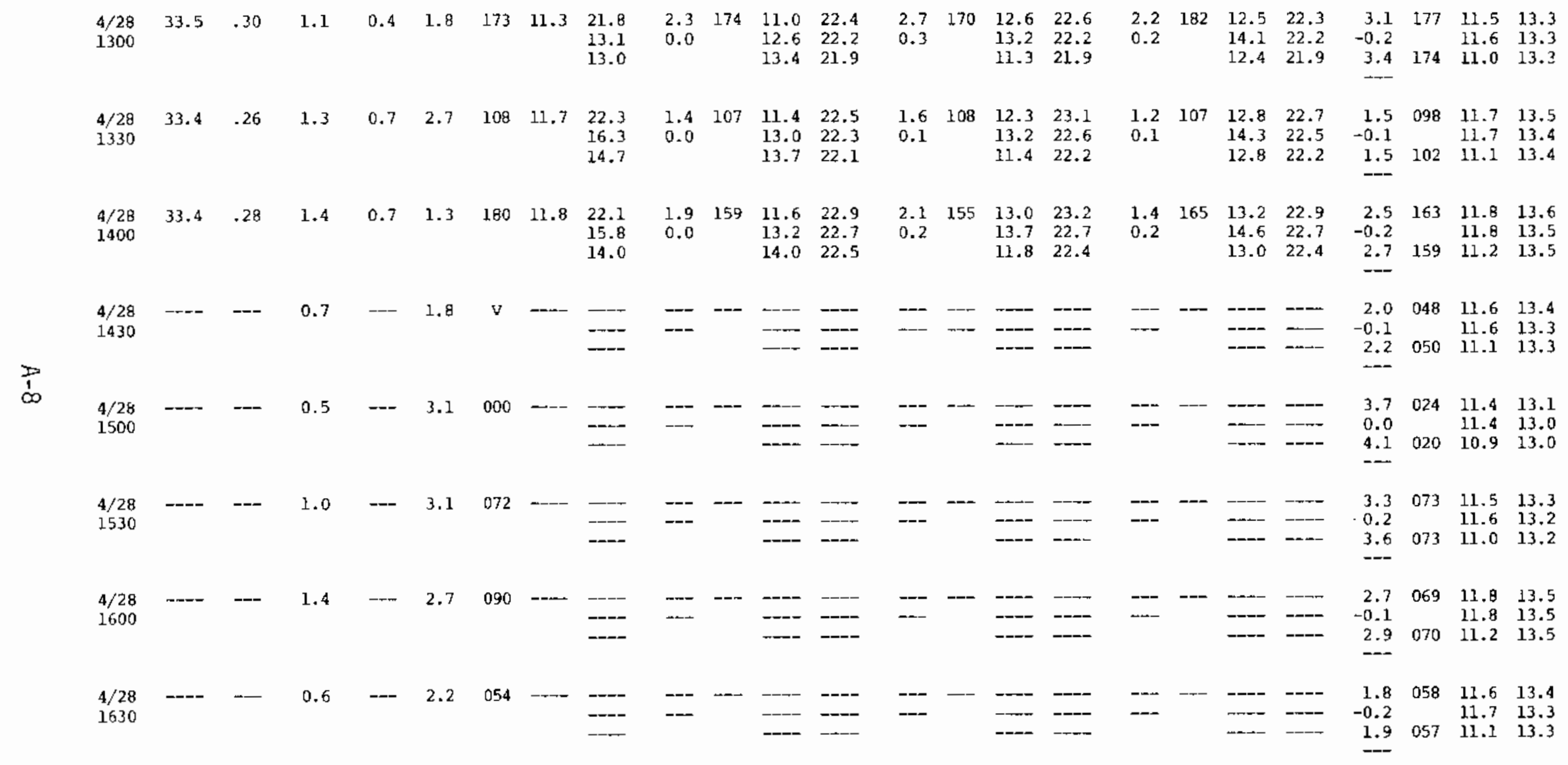




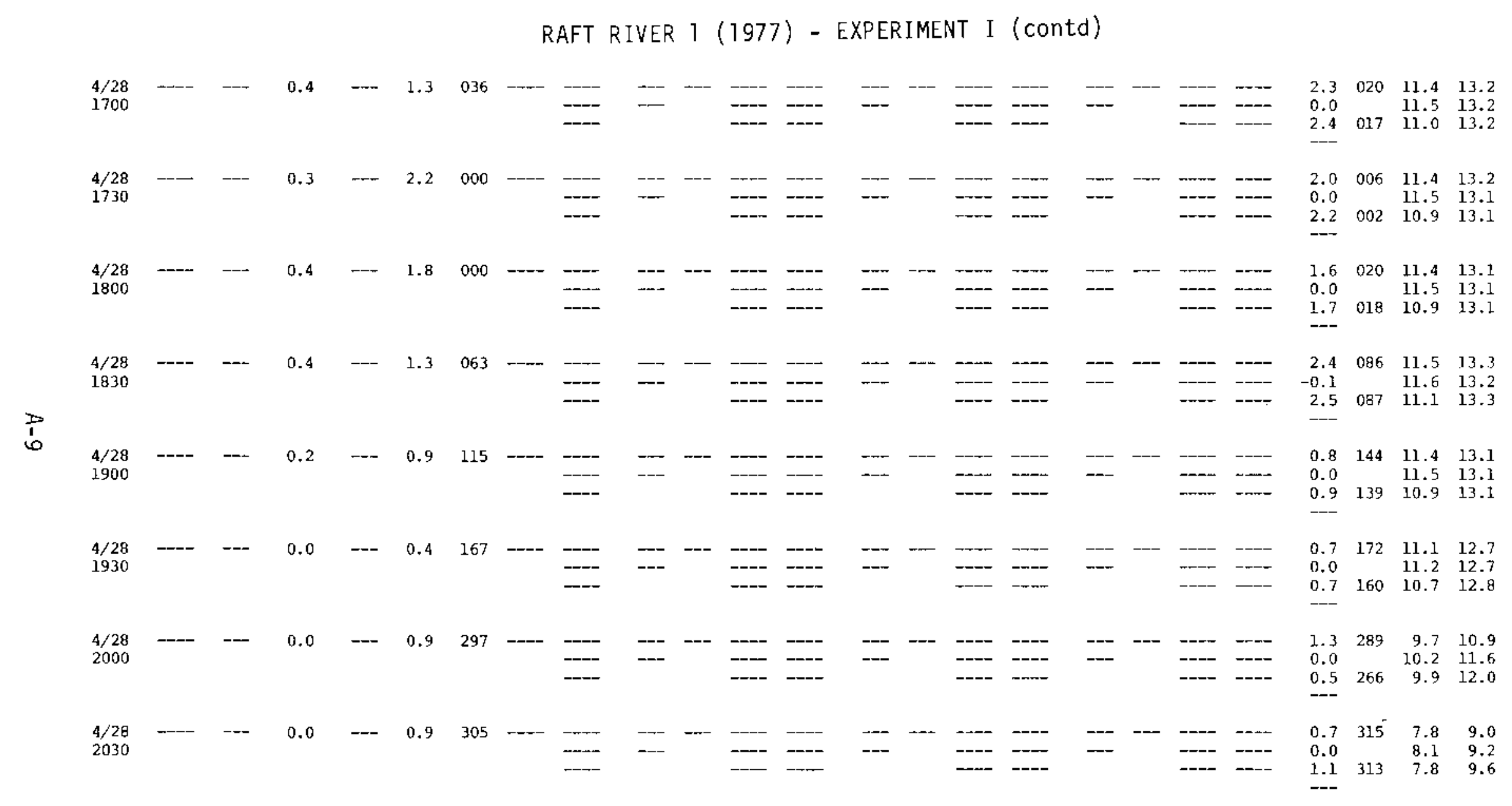


RAFT RIVER T (1977) - EXPERIMENT I (contd)

\begin{tabular}{|c|c|c|c|c|c|c|c|c|c|c|c|c|c|c|c|c|c|c|c|c|c|c|c|c|}
\hline $\begin{array}{l}4 / 28 \\
2100\end{array}$ & 30.3 & .25 & 0.0 & -0.2 & 0.4 & $\mathrm{v}$ & 6.5 & $\begin{array}{l}11.5 \\
--- \\
--\end{array}$ & $\begin{array}{l}0.6 \\
0.0\end{array}$ & 223 & $\begin{array}{l}5.9 \\
6.7 \\
7.1\end{array}$ & $\begin{array}{l}10.8 \\
10.9 \\
11.3\end{array}$ & $\begin{array}{l}0.8 \\
0.1\end{array}$ & 216 & $\begin{array}{l}7.3 \\
7.5 \\
6.2\end{array}$ & $\begin{array}{l}11.9 \\
11.6 \\
11.5\end{array}$ & $\begin{array}{l}1.0 \\
0.0\end{array}$ & 248 & $\begin{array}{l}6.5 \\
7.4 \\
6.8\end{array}$ & $\begin{array}{l}10.8 \\
11.2 \\
11 . .5\end{array}$ & $\begin{array}{l}1.3 \\
0.0 \\
1.2\end{array}$ & $\begin{array}{l}219 \\
214\end{array}$ & $\begin{array}{l}8.6 \\
8.8 \\
8.5\end{array}$ & $\begin{array}{r}9.6 \\
9.8 \\
10.1\end{array}$ \\
\hline $\begin{array}{l}4 / 28 \\
2130\end{array}$ & 30.0 & .25 & 0.0 & -0.2 & 0.9 & 290 & 5.4 & $\begin{array}{l}10.4 \\
-\end{array}$ & $\begin{array}{l}1.1 \\
0.1\end{array}$ & 297 & $\begin{array}{l}6.2 \\
6.5 \\
6.5\end{array}$ & $\begin{array}{l}10.3 \\
10.3 \\
10.5\end{array}$ & $\begin{array}{l}1.1 \\
0.0\end{array}$ & 310 & $\begin{array}{l}5.0 \\
5.7 \\
5.6\end{array}$ & $\begin{array}{r}9.9 \\
10.0 \\
11.5\end{array}$ & $\begin{array}{l}1.5 \\
0.0\end{array}$ & 300 & $\begin{array}{l}4.8 \\
5.7 \\
5.5\end{array}$ & $\begin{array}{r}9.1 \\
9.4 \\
10.1\end{array}$ & $\begin{array}{l}2.3 \\
0.0 \\
2.1\end{array}$ & 265 & $\begin{array}{l}8.1 \\
8.6 \\
8.4\end{array}$ & $\begin{array}{r}9.1 \\
9.7 \\
10.0\end{array}$ \\
\hline $\begin{array}{l}4 / 28 \\
2200\end{array}$ & 29.8 & .23 & 0.0 & -0.2 & 0.9 & 290 & 5.1 & $\begin{array}{r}9.8 \\
---\end{array}$ & $\begin{array}{l}0.7 \\
0.1\end{array}$ & 298 & $\begin{array}{l}5.5 \\
6.0 \\
6.0\end{array}$ & $\begin{array}{l}9.5 \\
9.5 \\
9.6\end{array}$ & $\begin{array}{l}0.5 \\
0.0\end{array}$ & 321 & $\begin{array}{l}4.6 \\
5.2 \\
4.7\end{array}$ & $\begin{array}{l}9.0 \\
9.0 \\
9.7\end{array}$ & $\begin{array}{l}1.2 \\
0.0\end{array}$ & 302 & $\begin{array}{l}4.3 \\
5.2 \\
5.1\end{array}$ & $\begin{array}{l}8.3 \\
8.6 \\
9.4\end{array}$ & $\begin{array}{l}1.1 \\
0.0 \\
1.0\end{array}$ & $\begin{array}{l}280 \\
273\end{array}$ & $\begin{array}{l}7.6 \\
7.9 \\
7.8\end{array}$ & $\begin{array}{l}8.5 \\
8.8 \\
9.2\end{array}$ \\
\hline $\begin{array}{l}4 / 28 \\
2230\end{array}$ & 29.5 & .23 & 0.0 & -0.2 & 0.4 & 260 & 4.8 & $\begin{array}{r}8.9 \\
--\end{array}$ & $\begin{array}{l}0.7 \\
0.0\end{array}$ & 267 & $\begin{array}{l}5.0 \\
5.3 \\
5.6\end{array}$ & $\begin{array}{l}8.6 \\
8.6 \\
9.0\end{array}$ & $\begin{array}{l}1.1 \\
0.1\end{array}$ & 257 & $\begin{array}{l}5.8 \\
5.8 \\
4.5\end{array}$ & $\begin{array}{l}9.5 \\
9.2 \\
9.1\end{array}$ & $\begin{array}{l}1.4 \\
0.0\end{array}$ & 270 & $\begin{array}{l}4.1 \\
5.0 \\
4.7\end{array}$ & $\begin{array}{l}7.8 \\
8.3 \\
8.8\end{array}$ & $\begin{array}{l}2.0 \\
0.0 \\
2.4\end{array}$ & $\begin{array}{l}256 \\
242\end{array}$ & $\begin{array}{l}7.6 \\
7.8 \\
7.7\end{array}$ & $\begin{array}{l}8.5 \\
8.6 \\
9.0\end{array}$ \\
\hline $\begin{array}{l}4 / 28 \\
2300\end{array}$ & 29.5 & .22 & 0.0 & -0.2 & 0.4 & 234 & 4.8 & $\begin{array}{r}8.6 \\
- \\
\hdashline-\end{array}$ & $\begin{array}{l}0.6 \\
0.0\end{array}$ & 199 & $\begin{array}{l}4.0 \\
4.2 \\
4.7\end{array}$ & $\begin{array}{l}6.9 \\
7.1 \\
7.7\end{array}$ & $\begin{array}{l}0.8 \\
0.1\end{array}$ & 190 & $\begin{array}{l}5.6 \\
5.8 \\
5.0\end{array}$ & $\begin{array}{l}9.1 \\
8.9 \\
8.9\end{array}$ & $\begin{array}{l}0.6 \\
0.0\end{array}$ & 229 & $\begin{array}{l}4.0 \\
4.7 \\
4.3\end{array}$ & $\begin{array}{l}7.2 \\
7.6 \\
7.8\end{array}$ & $\begin{array}{l}1.3 \\
0.0 \\
1.6\end{array}$ & $\begin{array}{l}215 \\
227\end{array}$ & $\begin{array}{l}7.3 \\
7.5 \\
7.4\end{array}$ & $\begin{array}{l}8.0 \\
8.3 \\
8.6\end{array}$ \\
\hline $\begin{array}{l}4 / 28 \\
2330\end{array}$ & 29.4 & .18 & 0.0 & -0.2 & 0.4 & 216 & 4.0 & $\begin{array}{r}6.9 \\
--- \\
-\end{array}$ & $\begin{array}{l}0.8 \\
0.0\end{array}$ & 220 & $\begin{array}{l}3.3 \\
3.4 \\
3.8\end{array}$ & $\begin{array}{l}5.7 \\
5.6 \\
6.2\end{array}$ & $\begin{array}{l}1.2 \\
0.2\end{array}$ & 213 & $\begin{array}{l}5.1 \\
4.9 \\
3.8\end{array}$ & $\begin{array}{l}7.7 \\
7.3 \\
7.3\end{array}$ & $\begin{array}{l}1.1 \\
0.0\end{array}$ & 247 & $\begin{array}{l}3.3 \\
3.9 \\
3.7\end{array}$ & $\begin{array}{l}5.8 \\
6.2 \\
6.5\end{array}$ & $\begin{array}{l}2.2 \\
0.0 \\
2.6\end{array}$ & $\begin{array}{l}214 \\
206\end{array}$ & $\begin{array}{l}7.0 \\
7.2 \\
7.0\end{array}$ & $\begin{array}{l}7.6 \\
7.9 \\
8.2\end{array}$ \\
\hline $\begin{array}{l}4 / 29 \\
0000\end{array}$ & 29.3 & .19 & 0.0 & -0.2 & 0.4 & 234 & 3.7 & $\begin{array}{r}7.3 \\
--- \\
-0\end{array}$ & $\begin{array}{l}0.7 \\
0.0\end{array}$ & 266 & $\begin{array}{l}3.7 \\
3.6 \\
3.7\end{array}$ & $\begin{array}{l}6.2 \\
5.9 \\
6.1\end{array}$ & $\begin{array}{l}1.1 \\
0.1\end{array}$ & 255 & $\begin{array}{l}4.7 \\
4.7 \\
3.6\end{array}$ & $\begin{array}{l}7.9 \\
7.6 \\
7.6\end{array}$ & $\begin{array}{l}1.4 \\
0.0\end{array}$ & 269 & $\begin{array}{l}3.1 \\
3.9 \\
3.7\end{array}$ & $\begin{array}{l}6.2 \\
6.7 \\
7.1\end{array}$ & $\begin{array}{l}2.0 \\
0.0 \\
2.4\end{array}$ & $\begin{array}{l}253 \\
239\end{array}$ & $\begin{array}{l}6.9 \\
7.0 \\
6.9\end{array}$ & $\begin{array}{l}7.6 \\
7.7 \\
8.0\end{array}$ \\
\hline $\begin{array}{l}4 / 29 \\
0030\end{array}$ & 29.1 & .19 & 0.0 & -0.2 & 0.4 & 220 & 3.6 & \begin{tabular}{r}
7.6 \\
\hdashline- \\
\end{tabular} & $\begin{array}{l}1.3 \\
0.0\end{array}$ & 194 & $\begin{array}{l}3.0 \\
3.4 \\
3.8\end{array}$ & $\begin{array}{l}6.1 \\
6.2 \\
6.7\end{array}$ & $\begin{array}{l}1.8 \\
0.2\end{array}$ & 185 & $\begin{array}{l}5.0 \\
4.9 \\
3.8\end{array}$ & $\begin{array}{l}8.1 \\
7.7 \\
7.5\end{array}$ & $\begin{array}{l}1.2 \\
0.0\end{array}$ & 202 & $\begin{array}{l}4.1 \\
4.6 \\
3.8\end{array}$ & $\begin{array}{l}7.0 \\
7.1 \\
6.9\end{array}$ & $\begin{array}{l}2.3 \\
0.0 \\
2.9\end{array}$ & $\begin{array}{l}225 \\
226\end{array}$ & $\begin{array}{l}6.9 \\
7.0 \\
6.8\end{array}$ & $\begin{array}{l}7.6 \\
7.7 \\
7.9\end{array}$ \\
\hline
\end{tabular}


RAFT RIVER 1 (1977) - EXPERIMENT I (contd)

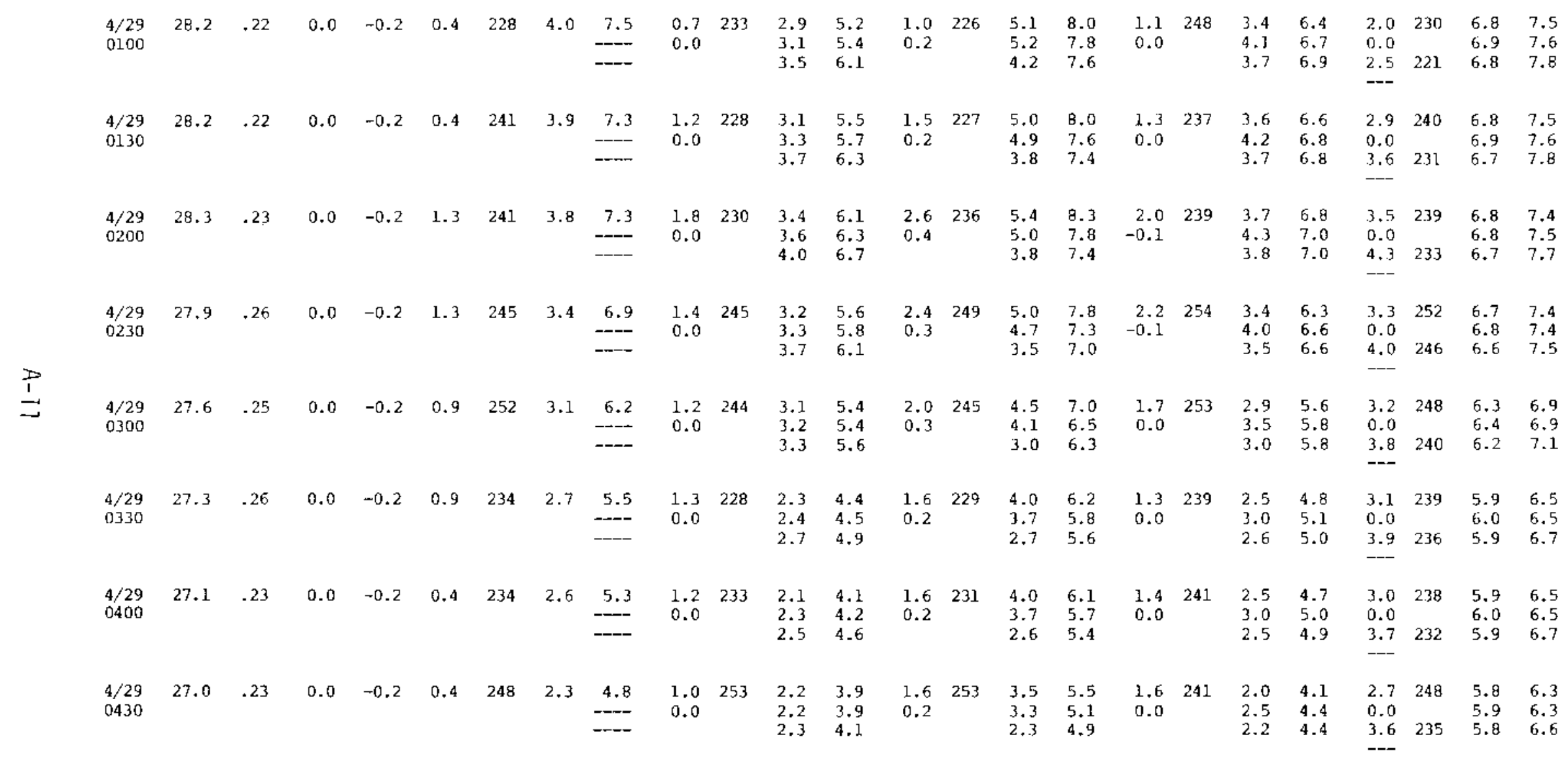




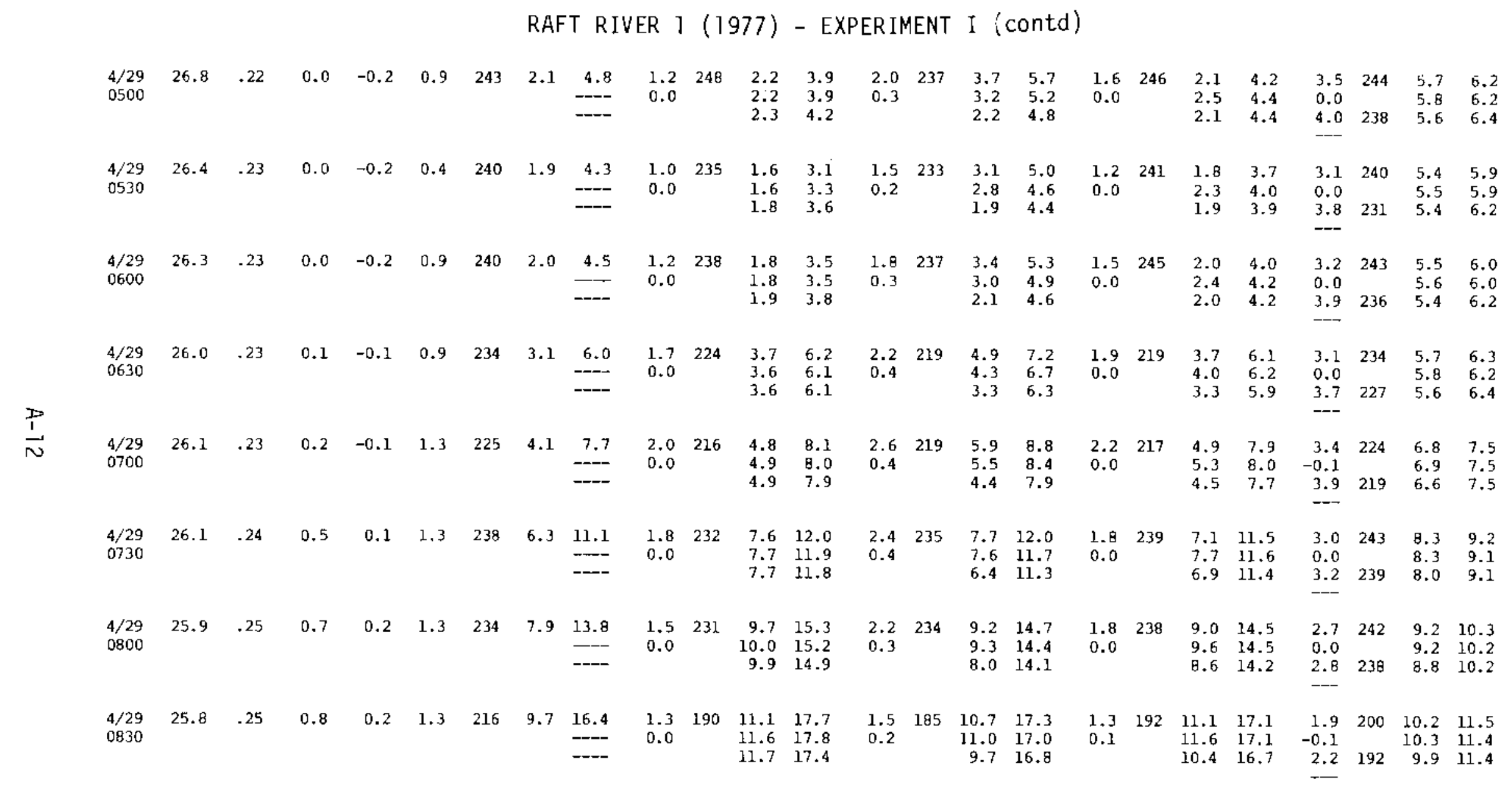


RAFT RIVER 1 (1977) - EXPERIMENT I (contd)

\begin{tabular}{|c|c|c|c|c|c|c|c|c|c|c|c|c|c|c|c|c|c|c|c|c|c|c|c|c|}
\hline $\begin{array}{l}4 / 29 \\
0900\end{array}$ & 25.6 & .29 & 1.1 & 0.4 & 3.1 & 144 & 11.6 & $\begin{array}{l}19.0 \\
-\end{array}$ & $\begin{array}{r}4.4 \\
-0.1\end{array}$ & 143 & $\begin{array}{l}12.8 \\
12.9 \\
13.4\end{array}$ & $\begin{array}{l}20.4 \\
20.0 \\
19.7\end{array}$ & $\begin{array}{l}4.0 \\
0.2\end{array}$ & 136 & $\begin{array}{l}12.2 \\
12.9 \\
11.5\end{array}$ & $\begin{array}{l}19.8 \\
19.5 \\
19.2\end{array}$ & $\begin{array}{l}3.7 \\
0.4\end{array}$ & 138 & $\begin{array}{l}13.9 \\
13.9 \\
12.6\end{array}$ & $\begin{array}{l}19.8 \\
19.6 \\
19.3\end{array}$ & $\begin{array}{r}5.2 \\
-0.3 \\
5.7\end{array}$ & $\begin{array}{l}145 \\
143\end{array}$ & $\begin{array}{l}11.3 \\
11.3 \\
10.8\end{array}$ & $\begin{array}{l}12.6 \\
12.4 \\
12.4\end{array}$ \\
\hline $\begin{array}{l}4 / 29 \\
0930\end{array}$ & 25.6 & .43 & 1.3 & 0.6 & 4.5 & 135 & 12.1 & $\frac{20.0}{--}$ & $\begin{array}{r}5.2 \\
-0.1\end{array}$ & 137 & $\begin{array}{l}13.1 \\
13.5 \\
14.1\end{array}$ & $\begin{array}{l}21.5 \\
21.0 \\
20.7\end{array}$ & $\begin{array}{l}4.8 \\
0.2\end{array}$ & 127 & $\begin{array}{l}12.7 \\
13.6 \\
12.0\end{array}$ & $\begin{array}{l}20.9 \\
20.7 \\
20.1\end{array}$ & $\begin{array}{l}4.4 \\
0.5\end{array}$ & 129 & $\begin{array}{l}14.3 \\
14.5 \\
13.1\end{array}$ & $\begin{array}{l}20.8 \\
20.6 \\
20.2\end{array}$ & $\begin{array}{r}6.4 \\
-0.4 \\
7.2 \\
\end{array}$ & $\begin{array}{l}129 \\
128\end{array}$ & $\begin{array}{l}11.5 \\
11.5 \\
11.0\end{array}$ & $\begin{array}{l}12.9 \\
12.7 \\
12.7\end{array}$ \\
\hline $\begin{array}{l}4 / 29 \\
1000\end{array}$ & 25.5 & .43 & 1.5 & 0.7 & 5.8 & 130 & 12.5 & 20.7 & $\begin{array}{r}6.4 \\
-0.1\end{array}$ & 130 & $\begin{array}{l}13.2 \\
13.9 \\
14.6\end{array}$ & $\begin{array}{l}22.0 \\
21.6 \\
21.5\end{array}$ & $\begin{array}{l}5.9 \\
0.2\end{array}$ & 120 & $\begin{array}{l}13.2 \\
14.3 \\
12.4\end{array}$ & $\begin{array}{l}21.9 \\
21.9 \\
20.9\end{array}$ & $\begin{array}{l}5.6 \\
0.6\end{array}$ & 122 & $\begin{array}{l}14.7 \\
14.8 \\
13.4\end{array}$ & $\begin{array}{l}21.4 \\
21.2 \\
20.9\end{array}$ & $\begin{array}{r}7.6 \\
-0.5 \\
8.6\end{array}$ & $\begin{array}{l}126 \\
123\end{array}$ & $\begin{array}{l}11.7 \\
11.7 \\
11.1\end{array}$ & $\begin{array}{l}13.1 \\
13.0 \\
12.9\end{array}$ \\
\hline
\end{tabular}


RAFT RIVER 1 (1977) - EXPERIMENT 2

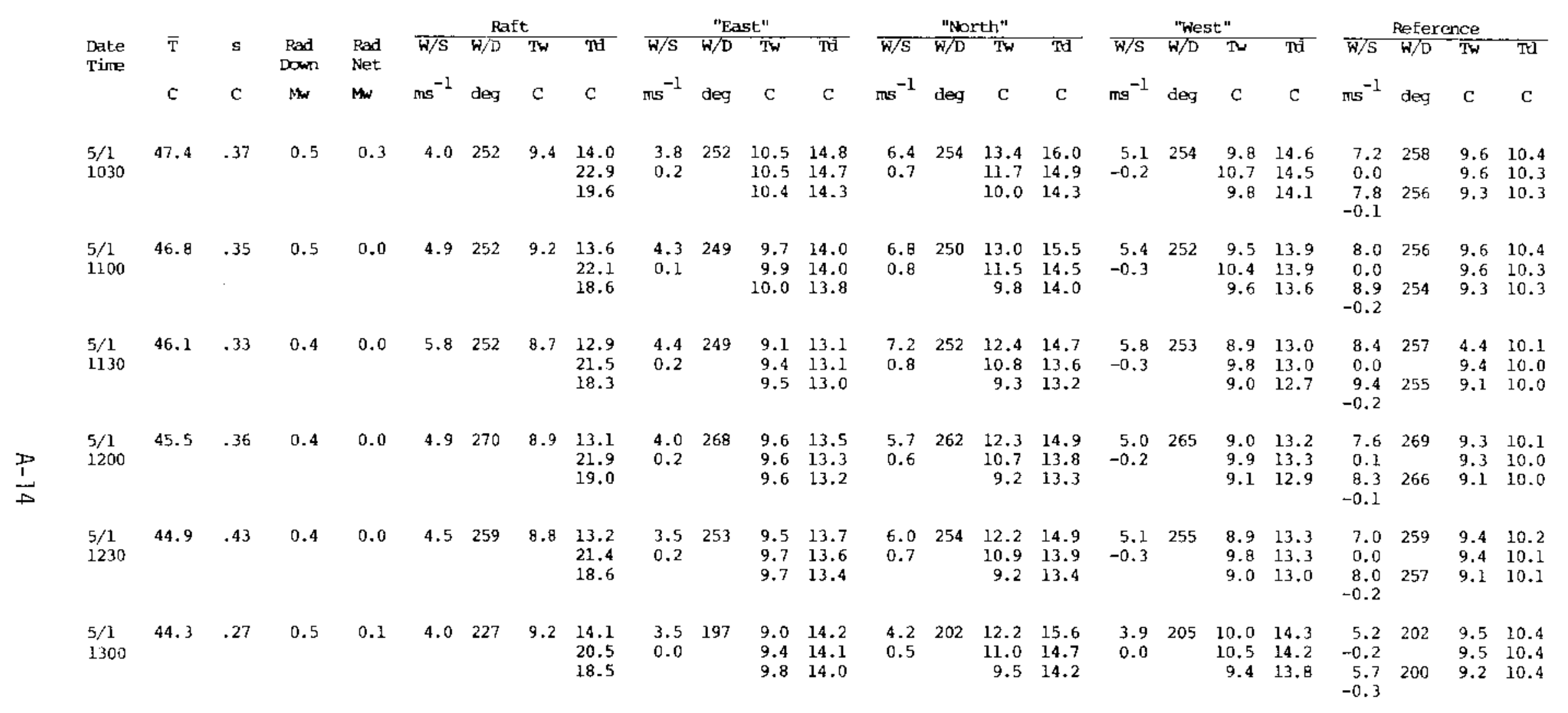


RAFT RIVER 1 (1977) - EXPERIMENT 2 (contd)

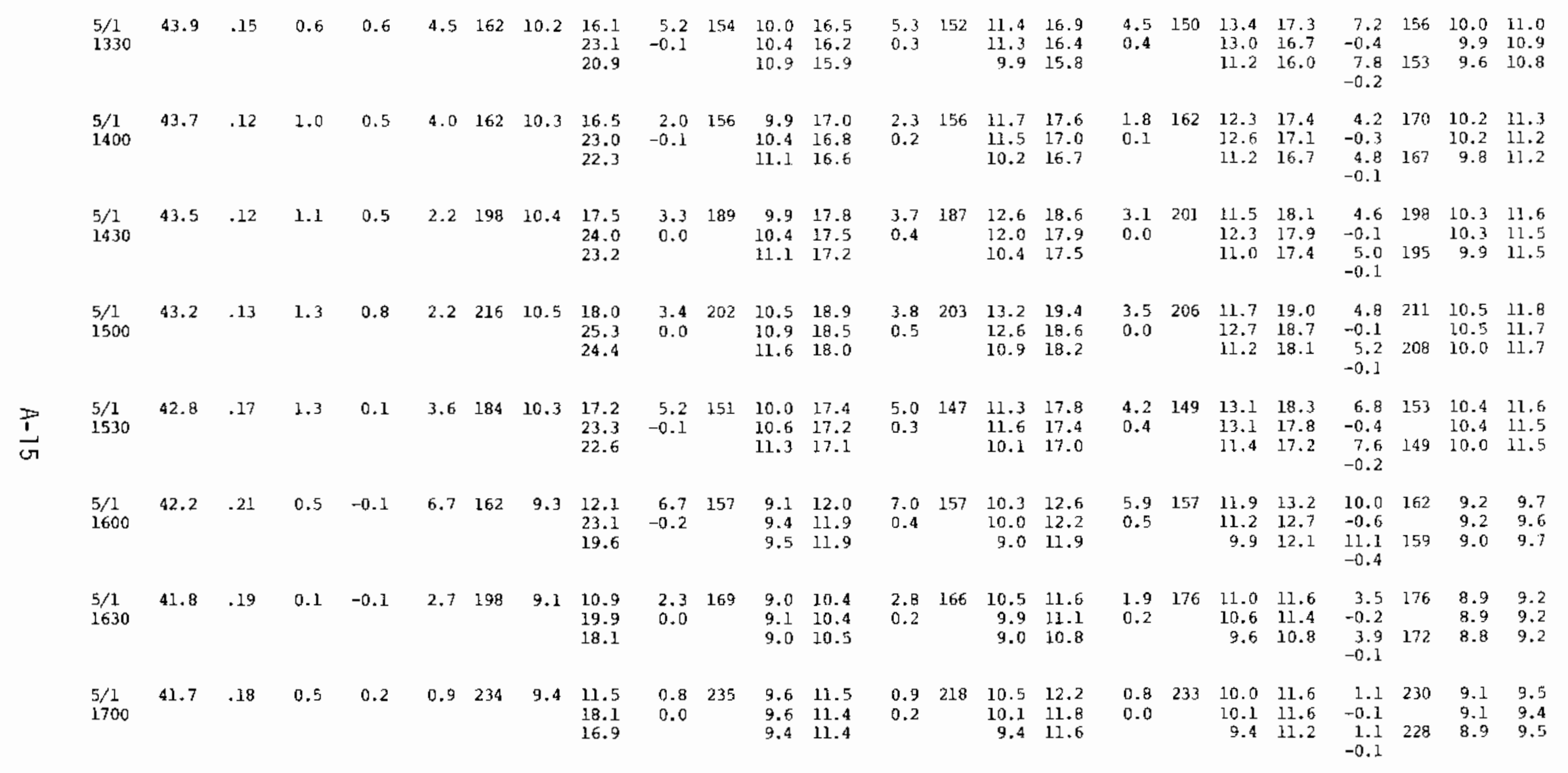


RAFT RIVER 1 (1977) - EXPERIMENT 2 (contd)

\begin{tabular}{|c|c|c|c|c|c|c|c|c|c|c|c|c|c|c|c|c|c|c|c|c|c|c|c|c|}
\hline $\begin{array}{l}5 / 1 \\
1730\end{array}$ & 41.5 & .18 & 0.4 & 0.4 & 1.3 & v & 9.8 & $\begin{array}{l}12.8 \\
20.4 \\
19.2\end{array}$ & $\begin{array}{l}1.4 \\
0.0\end{array}$ & 138 & $\begin{array}{l}9.8 \\
9.9 \\
9.9\end{array}$ & $\begin{array}{l}12.9 \\
12.8 \\
12.6\end{array}$ & $\begin{array}{l}1.6 \\
0.1\end{array}$ & 131 & $\begin{array}{r}10.1 \\
10.0 \\
9.2\end{array}$ & $\begin{array}{l}13.0 \\
12.7 \\
12.5\end{array}$ & $\begin{array}{l}1.2 \\
0.2\end{array}$ & 140 & $\begin{array}{l}11.2 \\
11.2 \\
10.4\end{array}$ & $\begin{array}{l}1.3 .3 \\
13.1 \\
12.8\end{array}$ & $\begin{array}{r}1.8 \\
-0.1 \\
2.0 \\
0.0\end{array}$ & $\begin{array}{l}154 \\
152\end{array}$ & $\begin{array}{l}9.4 \\
9.4 \\
9.2\end{array}$ & $\begin{array}{r}10.0 \\
9.9 \\
9.9\end{array}$ \\
\hline $\begin{array}{l}5 / 1 \\
1800\end{array}$ & 41.3 & .23 & 0.2 & 0.1 & 0.9 & $\mathrm{v}$ & 9.6 & $\begin{array}{l}12.9 \\
19.2 \\
18.6\end{array}$ & $\begin{array}{l}0.8 \\
0.0\end{array}$ & 223 & $\begin{array}{l}9.7 \\
9.9 \\
9.8\end{array}$ & $\begin{array}{l}13.0 \\
12.9 \\
12.8\end{array}$ & $\begin{array}{l}1.0 \\
0.2\end{array}$ & 219 & $\begin{array}{r}10.7 \\
10.4 \\
9.6\end{array}$ & $\begin{array}{l}13.5 \\
13.1 \\
12.9\end{array}$ & $\begin{array}{l}0.9 \\
0.0\end{array}$ & 233 & $\begin{array}{r}10.2 \\
10.5 \\
9.7\end{array}$ & $\begin{array}{l}12.9 \\
12.9 \\
12.5\end{array}$ & $\begin{array}{l}1.4 \\
0.0 \\
1.4 \\
0.0\end{array}$ & $\begin{array}{l}241 \\
235\end{array}$ & $\begin{array}{l}9.3 \\
9.3 \\
9.1\end{array}$ & $\begin{array}{l}9.9 \\
9.9 \\
9.9\end{array}$ \\
\hline $\begin{array}{l}5 / 1 \\
1830\end{array}$ & 41.1 & .23 & 0.1 & -0.1 & 0.4 & 234 & 10.1 & $\begin{array}{l}12.9 \\
19.3 \\
18.8\end{array}$ & $\begin{array}{l}0.6 \\
0.0\end{array}$ & 210 & $\begin{array}{r}9.7 \\
10.0 \\
10.0\end{array}$ & $\begin{array}{l}12.6 \\
12.6 \\
12.6\end{array}$ & $\begin{array}{l}0.8 \\
0.2\end{array}$ & 206 & $\begin{array}{l}11.1 \\
11.0 \\
10.2\end{array}$ & $\begin{array}{l}13.5 \\
13.2 \\
13.1\end{array}$ & $\begin{array}{l}0.8 \\
0.0\end{array}$ & 232 & $\begin{array}{r}10.1 \\
10.5 \\
9.8\end{array}$ & $\begin{array}{l}12.5 \\
12.6 \\
12.3\end{array}$ & $\begin{array}{l}0.9 \\
0.0 \\
1.1 \\
0.0\end{array}$ & $\begin{array}{l}228 \\
224\end{array}$ & $\begin{array}{l}9.3 \\
9.4 \\
9.2\end{array}$ & $\begin{array}{r}9.9 \\
9.9 \\
10.0\end{array}$ \\
\hline $\begin{array}{l}5 / 1 \\
1900\end{array}$ & 40.9 & .25 & 0.0 & -0.2 & 0.4 & 252 & 9.9 & $\begin{array}{l}13.0 \\
18.4 \\
18.1\end{array}$ & $\begin{array}{l}0.6 \\
0.1\end{array}$ & 266 & $\begin{array}{r}9.9 \\
10.1 \\
10.1\end{array}$ & $\begin{array}{l}12.8 \\
12.8 \\
12.7\end{array}$ & $\begin{array}{l}0.4 \\
0.1\end{array}$ & 261 & $\begin{array}{r}10.2 \\
10.4 \\
9.7\end{array}$ & $\begin{array}{l}12.9 \\
12.8 \\
12.8\end{array}$ & $\begin{array}{l}0.7 \\
0.0\end{array}$ & 277 & $\begin{array}{r}10.0 \\
9.9 \\
9.4\end{array}$ & $\begin{array}{l}12.0 \\
12.2 \\
12.1\end{array}$ & $\begin{array}{l}0.9 \\
0.0 \\
0.9 \\
0.0\end{array}$ & $\begin{array}{l}276 \\
271\end{array}$ & $\begin{array}{l}9.3 \\
9.4 \\
9.2\end{array}$ & $\begin{array}{r}10.0 \\
9.9 \\
10.0\end{array}$ \\
\hline $\begin{array}{l}5 / 1 \\
1930\end{array}$ & 40.6 & .33 & 0.0 & -0.2 & 4.5 & $\mathrm{v}$ & 8.6 & $\begin{array}{l}11.0 \\
20.2 \\
18.2\end{array}$ & $\begin{array}{l}2.5 \\
0.1\end{array}$ & 248 & $\begin{array}{l}8.7 \\
8.9 \\
8.8\end{array}$ & $\begin{array}{l}10.8 \\
10.9 \\
10.9\end{array}$ & $\begin{array}{l}4.1 \\
0.5\end{array}$ & 249 & $\begin{array}{r}10.1 \\
9.5 \\
8.7\end{array}$ & $\begin{array}{l}11.9 \\
11.3 \\
11.2\end{array}$ & $\begin{array}{r}3.4 \\
-0.1\end{array}$ & 253 & $\begin{array}{l}9.3 \\
9.1 \\
6.5\end{array}$ & $\begin{array}{l}10.7 \\
10.8 \\
10.5\end{array}$ & $\begin{array}{r}5.3 \\
0.0 \\
5.8 \\
-0.1\end{array}$ & $\begin{array}{l}253 \\
251\end{array}$ & $\begin{array}{l}8.8 \\
8.8 \\
8.7\end{array}$ & $\begin{array}{l}9.3 \\
9.3 \\
9.3\end{array}$ \\
\hline $\begin{array}{l}5 / 1 \\
2000\end{array}$ & 40.1 & .31 & 0.0 & -0.2 & 3.1 & 252 & 7.6 & $\begin{array}{r}8.7 \\
19.9 \\
17.8\end{array}$ & $\begin{array}{l}1.4 \\
0.1\end{array}$ & 270 & $\begin{array}{l}8.5 \\
8.3 \\
7.9\end{array}$ & $\begin{array}{l}9.0 \\
8.9 \\
8.9\end{array}$ & $\begin{array}{l}1.6 \\
0.2\end{array}$ & 257 & $\begin{array}{l}8.7 \\
8.1 \\
7.4\end{array}$ & $\begin{array}{l}9.6 \\
8.8 \\
8.7\end{array}$ & $\begin{array}{r}1.5 \\
-0.1\end{array}$ & 269 & $\begin{array}{l}7.6 \\
7.6 \\
7.1\end{array}$ & $\begin{array}{l}8.1 \\
8.2 \\
7.9\end{array}$ & $\begin{array}{l}2.3 \\
0.0 \\
2.7 \\
0.0\end{array}$ & $\begin{array}{l}270 \\
267\end{array}$ & $\begin{array}{l}8.1 \\
8.1 \\
8.0\end{array}$ & $\begin{array}{l}\text { B. } 3 \\
8.3 \\
8.3\end{array}$ \\
\hline $\begin{array}{l}5 / 1 \\
2030\end{array}$ & 39.9 & .28 & 0.0 & -0.2 & 1.3 & 000 & 8.1 & $\begin{array}{r}8.8 \\
20.7 \\
19.6\end{array}$ & $\begin{array}{l}1.4 \\
0.1\end{array}$ & 003 & $\begin{array}{l}8.8 \\
8.6 \\
8.1\end{array}$ & $\begin{array}{l}8.7 \\
9.1 \\
9.1\end{array}$ & $\begin{array}{l}1.0 \\
0.0\end{array}$ & 031 & $\begin{array}{l}7.2 \\
7.3 \\
7.2\end{array}$ & $\begin{array}{l}8.2 \\
8.1 \\
8.3\end{array}$ & $\begin{array}{l}1.1 \\
0.0\end{array}$ & 000 & $\begin{array}{l}7.6 \\
7.7 \\
7.3\end{array}$ & $\begin{array}{l}8.0 \\
8.3 \\
8.1\end{array}$ & $\begin{array}{l}1.7 \\
0.0 \\
2.2 \\
0.0\end{array}$ & $\begin{array}{l}013 \\
008\end{array}$ & $\begin{array}{l}8.0 \\
8.0 \\
7.9\end{array}$ & $\begin{array}{l}8.1 \\
8.1 \\
8.2\end{array}$ \\
\hline $\begin{array}{l}5 / 1 \\
2100\end{array}$ & 39.8 & .25 & 0.0 & -0.2 & 0.9 & 072 & 7.8 & $\begin{array}{r}8.6 \\
20.0 \\
18.6\end{array}$ & $\begin{array}{l}1.2 \\
0.0\end{array}$ & 094 & $\begin{array}{l}7.1 \\
7.3 \\
7.2\end{array}$ & $\begin{array}{l}7.3 \\
8.0 \\
8.2\end{array}$ & $\begin{array}{l}1.3 \\
0.0\end{array}$ & 094 & $\begin{array}{l}7.0 \\
7.1 \\
7.0\end{array}$ & $\begin{array}{l}7.9 \\
7.8 \\
8.1\end{array}$ & $\begin{array}{l}1.1 \\
0.1\end{array}$ & 087 & $\begin{array}{l}8.6 \\
9.3 \\
7.8\end{array}$ & $\begin{array}{l}8.8 \\
8.8 \\
8.1\end{array}$ & $\begin{array}{r}1.7 \\
-0.1 \\
2.2 \\
0.0\end{array}$ & $\begin{array}{l}093 \\
090\end{array}$ & $\begin{array}{l}7.9 \\
7.9 \\
7.8\end{array}$ & $\begin{array}{l}8.0 \\
8.0 \\
8.1\end{array}$ \\
\hline
\end{tabular}


RAFT RIVER 1 (1977) - EXPERIMENT 2 (contd)

\begin{tabular}{|c|c|c|c|c|c|c|c|c|c|c|c|c|c|c|c|c|c|c|c|c|c|c|c|c|}
\hline $\begin{array}{l}5 / 1 \\
2130\end{array}$ & 39.6 & .26 & 0.0 & -0.2 & 0.4 & $\mathrm{v}$ & 7.8 & $\begin{array}{r}8.2 \\
17.4 \\
15.5\end{array}$ & $\begin{array}{l}0.7 \\
0.0\end{array}$ & 207 & $\begin{array}{l}7.2 \\
7.3 \\
7.1\end{array}$ & $\begin{array}{l}7.8 \\
7.7 \\
7.9\end{array}$ & $\begin{array}{l}0.8 \\
0.1\end{array}$ & 194 & $\begin{array}{l}8.4 \\
8.1 \\
7.8\end{array}$ & $\begin{array}{l}9.1 \\
8.5 \\
8.7\end{array}$ & $\begin{array}{l}0.7 \\
0.0\end{array}$ & 226 & $\begin{array}{l}8.0 \\
7.8 \\
7.4\end{array}$ & $\begin{array}{l}8.1 \\
8.2 \\
7.7\end{array}$ & $\begin{array}{l}1.2 \\
0.0 \\
1.5 \\
0.0\end{array}$ & $\begin{array}{l}213 \\
198\end{array}$ & $\begin{array}{l}7.8 \\
7.8 \\
7.8\end{array}$ & $\begin{array}{l}8.0 \\
8.0 \\
8.0\end{array}$ \\
\hline $\begin{array}{l}5 / 1 \\
2200\end{array}$ & 39.4 & .26 & 0.0 & -0.2 & 0.4 & 288 & 7.5 & $\begin{array}{r}7.9 \\
18.3 \\
16.2\end{array}$ & $\begin{array}{l}1.2 \\
0.1\end{array}$ & 286 & $\begin{array}{l}8.1 \\
7.8 \\
7.3\end{array}$ & $\begin{array}{l}8.3 \\
8.2 \\
8.1\end{array}$ & $\begin{array}{l}0.8 \\
0.0\end{array}$ & 296 & $\begin{array}{l}7.6 \\
7.4 \\
7.0\end{array}$ & $\begin{array}{l}8.2 \\
7.7 \\
8.0\end{array}$ & $\begin{array}{l}1.0 \\
0.0\end{array}$ & 291 & $\begin{array}{l}6.8 \\
6.9 \\
6.6\end{array}$ & $\begin{array}{l}7.0 \\
7.1 \\
7.1\end{array}$ & $\begin{array}{l}1.9 \\
0.0 \\
2.1 \\
0.0\end{array}$ & $\begin{array}{l}282 \\
274\end{array}$ & $\begin{array}{l}7.8 \\
7.8 \\
7.8\end{array}$ & $\begin{array}{l}7.9 \\
7.9 \\
8.2\end{array}$ \\
\hline $\begin{array}{l}5 / 1 \\
2230\end{array}$ & 39.2 & .28 & 0.0 & -0.2 & 0.9 & 276 & 6.9 & $\begin{array}{r}7.2 \\
18.9 \\
16.4\end{array}$ & $\begin{array}{l}1.4 \\
0.1\end{array}$ & 287 & $\begin{array}{l}7.5 \\
7.2 \\
6.7\end{array}$ & $\begin{array}{l}7.6 \\
7.5 \\
7.5\end{array}$ & $\begin{array}{l}1.1 \\
0.1\end{array}$ & 292 & $\begin{array}{l}7.2 \\
7.0 \\
6.5\end{array}$ & $\begin{array}{l}7.9 \\
7.3 \\
7.4\end{array}$ & $\begin{array}{l}1.3 \\
0.0\end{array}$ & 289 & $\begin{array}{l}6.2 \\
6.3 \\
6.1\end{array}$ & $\begin{array}{l}6.3 \\
6.4 \\
6.5\end{array}$ & $\begin{array}{l}2.6 \\
0.0 \\
2.9 \\
0.0\end{array}$ & $\begin{array}{l}286 \\
277\end{array}$ & $\begin{array}{l}7.6 \\
7.7 \\
7.7\end{array}$ & $\begin{array}{l}7.7 \\
7.8 \\
8.2\end{array}$ \\
\hline $\begin{array}{l}5 / 1 \\
2300\end{array}$ & 39.0 & -30 & 0.0 & -0.2 & 1.3 & 306 & 6.0 & $\begin{array}{r}6.3 \\
19.9 \\
17.6\end{array}$ & $\begin{array}{l}1.8 \\
0.1\end{array}$ & 311 & $\begin{array}{l}7.5 \\
7.1 \\
6.5\end{array}$ & $\begin{array}{l}7.5 \\
7.2 \\
7.1\end{array}$ & $\begin{array}{l}1.0 \\
0.0\end{array}$ & 324 & $\begin{array}{l}5.7 \\
5.6 \\
5.4\end{array}$ & $\begin{array}{l}6.3 \\
6.0 \\
6.2\end{array}$ & $\begin{array}{l}1.3 \\
0.0\end{array}$ & 309 & $\begin{array}{l}5.4 \\
5.6 \\
5.4\end{array}$ & $\begin{array}{l}5.5 \\
5.7 \\
5.7\end{array}$ & $\begin{array}{l}1.8 \\
0.0 \\
2.0 \\
0.0\end{array}$ & $\begin{array}{l}310 \\
305\end{array}$ & $\begin{array}{l}7.2 \\
7.3 \\
7.3\end{array}$ & $\begin{array}{l}7.2 \\
7.3 \\
7.4\end{array}$ \\
\hline $\begin{array}{l}5 / 1 \\
2330\end{array}$ & 38.8 & .27 & 0.0 & -0.2 & 0.4 & v & 6.9 & $\begin{array}{r}7.2 \\
17.6 \\
15.7\end{array}$ & $\begin{array}{l}0.3 \\
0.0\end{array}$ & 134 & $\begin{array}{l}6.0 \\
6.1 \\
5.9\end{array}$ & $\begin{array}{l}6.4 \\
6.2 \\
6.5\end{array}$ & $\begin{array}{l}0.6 \\
0.1\end{array}$ & 121 & $\begin{array}{l}6.3 \\
6.3 \\
6.2\end{array}$ & $\begin{array}{l}7.1 \\
6.7 \\
7.1\end{array}$ & $\begin{array}{l}0.1 \\
0.1\end{array}$ & 183 & $\begin{array}{l}6.3 \\
6.3 \\
6.1\end{array}$ & $\begin{array}{l}6.3 \\
6.5 \\
6.3\end{array}$ & $\begin{array}{l}0.5 \\
0.0 \\
0.6 \\
0.0\end{array}$ & $\begin{array}{l}142 \\
128\end{array}$ & $\begin{array}{l}7.2 \\
7.3 \\
7.3\end{array}$ & $\begin{array}{l}7.3 \\
7.3 \\
7.4\end{array}$ \\
\hline $\begin{array}{l}5 / 2 \\
0000\end{array}$ & 38.6 & .26 & 0.0 & -0.2 & 0.0 & $\mathrm{v}$ & 7.2 & $\begin{array}{r}7.4 \\
16.6 \\
15.0\end{array}$ & $\begin{array}{l}0.2 \\
0.0\end{array}$ & 169 & $\begin{array}{l}5.6 \\
5.8 \\
5.7\end{array}$ & $\begin{array}{l}6.2 \\
6.0 \\
6.5\end{array}$ & $\begin{array}{l}0.6 \\
0.1\end{array}$ & 120 & $\begin{array}{l}5.8 \\
6.0 \\
6.1\end{array}$ & $\begin{array}{l}6.4 \\
6.2 \\
6.8\end{array}$ & $\begin{array}{l}0.4 \\
0.1\end{array}$ & 257 & $\begin{array}{l}5.6 \\
5.8 \\
5.6\end{array}$ & $\begin{array}{l}5.6 \\
6.0 \\
5.9\end{array}$ & $\begin{array}{l}0.5 \\
0.0 \\
0.7 \\
0.0\end{array}$ & $\begin{array}{l}185 \\
174\end{array}$ & $\begin{array}{l}7.0 \\
7.1 \\
7.1\end{array}$ & $\begin{array}{l}7.1 \\
7.2 \\
7.3\end{array}$ \\
\hline $\begin{array}{l}5 / 2 \\
0030\end{array}$ & 38.5 & .28 & 0.0 & -0.2 & 0.0 & $\mathrm{v}$ & 6.8 & $\begin{array}{r}6.9 \\
16.3 \\
14.5\end{array}$ & $\begin{array}{l}0.4 \\
0.0\end{array}$ & 160 & $\begin{array}{l}5.3 \\
5.4 \\
5.4\end{array}$ & $\begin{array}{l}6.0 \\
5.9 \\
6.1\end{array}$ & $\begin{array}{l}0.8 \\
0.1\end{array}$ & 138 & $\begin{array}{l}5.9 \\
5.9 \\
5.9\end{array}$ & $\begin{array}{l}6.6 \\
6.1 \\
6.6\end{array}$ & $\begin{array}{l}0.5 \\
0.1\end{array}$ & 214 & $\begin{array}{l}5.3 \\
5.6 \\
5.4\end{array}$ & $\begin{array}{l}5.3 \\
5.7 \\
5.7\end{array}$ & $\begin{array}{l}1.0 \\
0.0 \\
1.4 \\
0.0\end{array}$ & $\begin{array}{l}178 \\
179\end{array}$ & $\begin{array}{l}6.9 \\
7.0 \\
7.0\end{array}$ & $\begin{array}{l}6.9 \\
7.0 \\
7.2\end{array}$ \\
\hline $\begin{array}{l}5 / 2 \\
0100\end{array}$ & 38.4 & .26 & 0.0 & -0.2 & 0.0 & $\mathrm{v}$ & 6.7 & $\begin{array}{r}6.8 \\
16.6 \\
14.7\end{array}$ & $\begin{array}{l}0.3 \\
0.0\end{array}$ & 213 & $\begin{array}{l}5.7 \\
5.8 \\
5.7\end{array}$ & $\begin{array}{l}6.4 \\
6.3 \\
6.5\end{array}$ & $\begin{array}{l}0.5 \\
0.1\end{array}$ & 168 & $\begin{array}{l}6.7 \\
6.6 \\
6.5\end{array}$ & $\begin{array}{l}7.3 \\
6.9 \\
7.2\end{array}$ & $\begin{array}{l}0.5 \\
0.0\end{array}$ & 248 & $\begin{array}{l}5.7 \\
6.0 \\
5.7\end{array}$ & $\begin{array}{l}5.7 \\
6.0 \\
5.9\end{array}$ & $\begin{array}{l}1.0 \\
0.0 \\
1.3 \\
0.0\end{array}$ & $\begin{array}{l}199 \\
192\end{array}$ & $\begin{array}{l}7.1 \\
7.2 \\
7.2\end{array}$ & $\begin{array}{l}7.2 \\
7.2 \\
7.3\end{array}$ \\
\hline
\end{tabular}


RAFT RIVER 1 (1977) - EXPERIMENT 2 (contd)

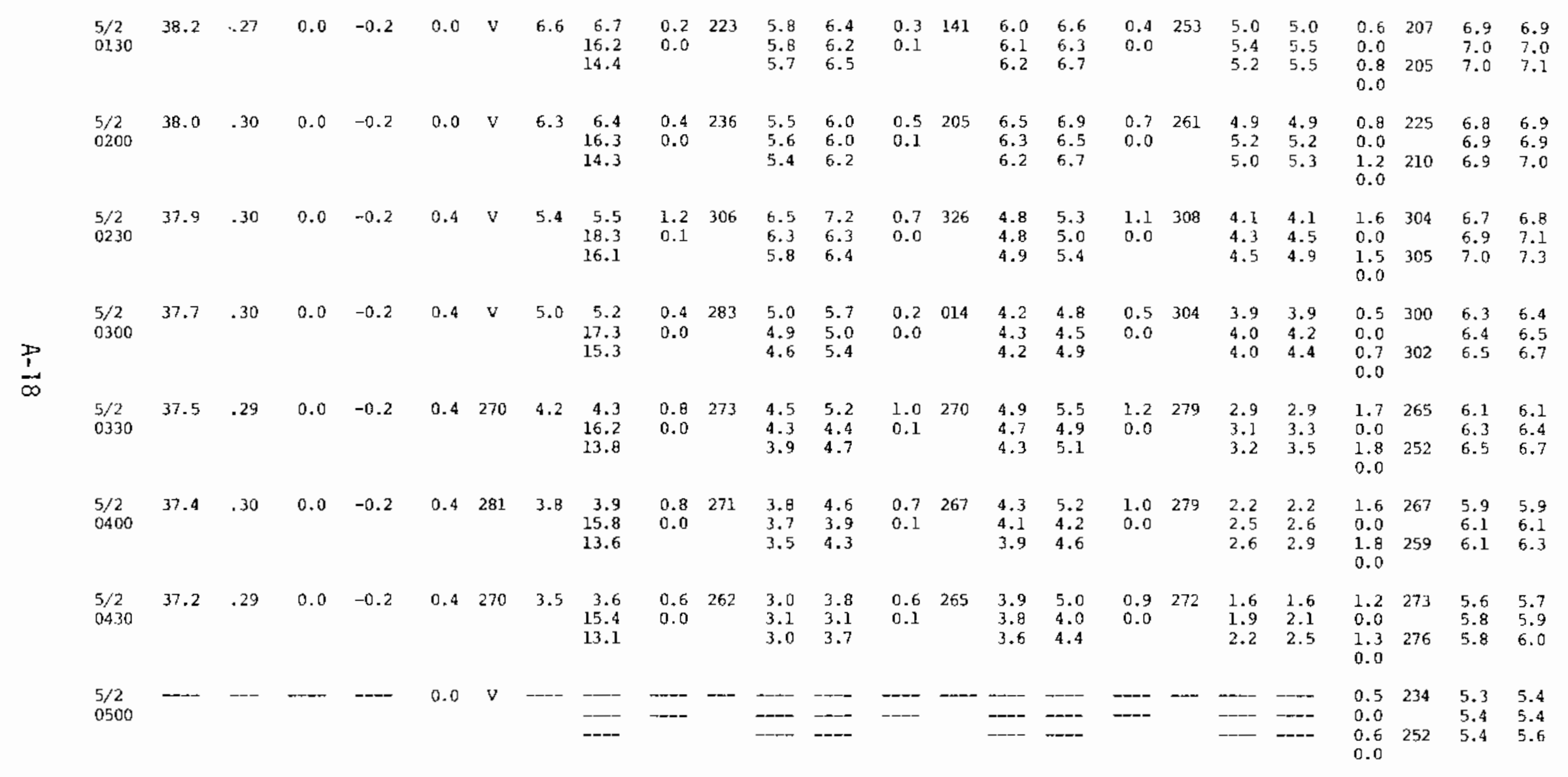




$$
\begin{aligned}
& \text { RAFT RIVER } 1 \text { (1977) - EXPERIMENT } 2 \text { (contd) }
\end{aligned}
$$

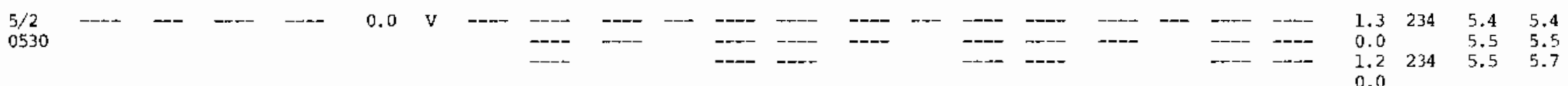

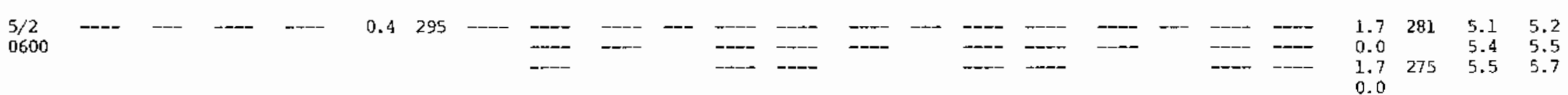

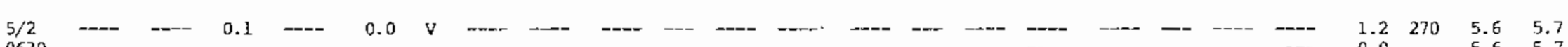

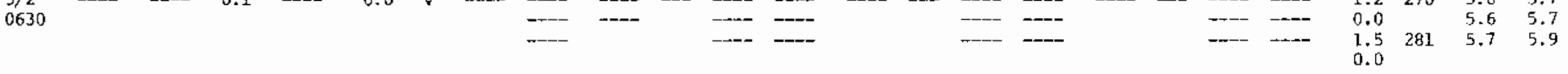

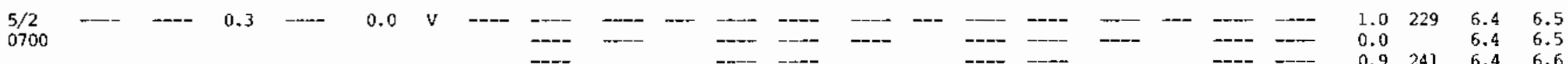

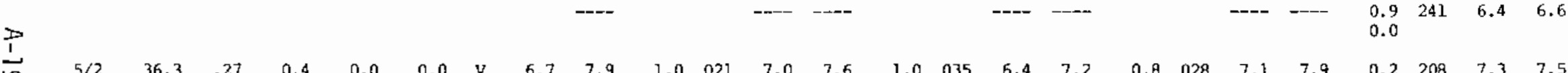

$$
\begin{aligned}
& \begin{array}{llllllllllllllllllllllllll}
5 / 2 & 36.3 & .27 & 0.4 & 0.0 & 0.0 & \mathrm{v} & 6.7 & 7.9 & 1.0 & 021 & 7.0 & 7.6 & 1.0 & 035 & 5.4 & 7.2 & 0.8 & 028 & 7.1 & 7.9 & 0.2 & 208 & 7.3 & 7.5 \\
0730 & & & & & & & & 20.8 & 0.0 & & 7.1 & 7.7 & 0.0 & & 6.5 & 7.5 & 0.0 & & 7.2 & 7.9 & 0.0 & & 7.3 & 7.4 \\
& & & & & & & & 20.3 & & & 6.7 & 7.6 & & & 6.4 & 7.5 & & & 6.7 & 7.5 & 0.1 & 217 & 7.2 & 7.5
\end{array} \\
& \begin{array}{lllllllllllllllllllllllllll}
5 / 2 & 36.3 & .25 & 0.6 & 0.1 & 0.4 & 029 & 7.1 & 8.4 & 1.3 & 021 & 7.4 & 8.1 & 1.3 & 037 & 6.9 & 7.7 & 1.2 & 018 & 7.4 & 8.4 & 1.2 & 020 & 7.6 & 7.8
\end{array}
\end{aligned}
$$

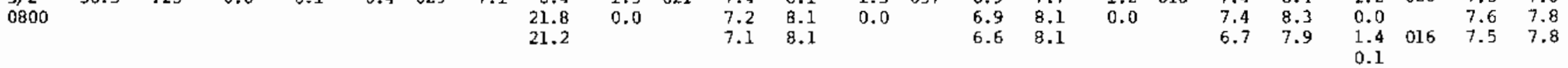

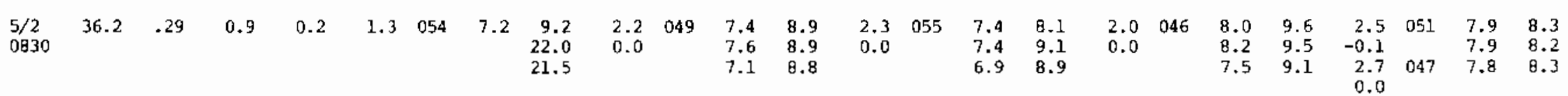

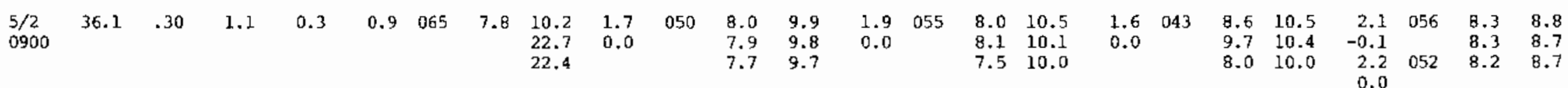


RAFT RIVER 1 (1977) - EXPERIMENT 2 (contd)

\begin{tabular}{|c|c|c|c|c|c|c|c|c|c|c|c|c|c|c|c|c|c|c|c|c|c|c|c|c|}
\hline $\begin{array}{l}5 / 2 \\
0930\end{array}$ & 36.0 & .28 & 1.3 & 0.5 & 1.3 & 036 & 8.1 & $\begin{array}{l}11.0 \\
24.2 \\
22.8\end{array}$ & $\begin{array}{l}2.0 \\
0.1\end{array}$ & 029 & $\begin{array}{l}8.5 \\
8.5 \\
8.3\end{array}$ & $\begin{array}{l}10.9 \\
10.8 \\
10.6\end{array}$ & $\begin{array}{l}2.0 \\
0.0\end{array}$ & 038 & $\begin{array}{l}8.4 \\
8.6 \\
7.8\end{array}$ & $\begin{array}{l}11.6 \\
11.1 \\
10.8\end{array}$ & $\begin{array}{l}1.8 \\
0.0\end{array}$ & 028 & $\begin{array}{l}8.9 \\
9.1 \\
8.3\end{array}$ & $\begin{array}{l}11.5 \\
11.3 \\
10.8\end{array}$ & $\begin{array}{r}2.2 \\
-0.1 \\
2.3 \\
0.0\end{array}$ & $\begin{array}{l}041 \\
038\end{array}$ & $\begin{array}{l}8.6 \\
8.6 \\
8.4\end{array}$ & $\begin{array}{l}9.1 \\
9.9 \\
9.1\end{array}$ \\
\hline $\begin{array}{l}5 / 2 \\
1000\end{array}$ & 36.0 & .27 & 1.5 & 0.6 & 1.3 & 036 & B. 5 & $\begin{array}{l}11.9 \\
24.9 \\
24.9\end{array}$ & $\begin{array}{l}2.1 \\
0.0\end{array}$ & 034 & $\begin{array}{l}8.8 \\
8.7 \\
8.7\end{array}$ & $\begin{array}{l}11.7 \\
11.6 \\
11.3\end{array}$ & $\begin{array}{l}2.1 \\
0.0\end{array}$ & 038 & $\begin{array}{l}8.9 \\
9.2 \\
8.2\end{array}$ & $\begin{array}{l}12.7 \\
12.1 \\
11.7\end{array}$ & $\begin{array}{l}2.0 \\
0.0\end{array}$ & 030 & $\begin{array}{l}9.4 \\
9.6 \\
8.8\end{array}$ & $\begin{array}{l}12.5 \\
12.2 \\
11.7\end{array}$ & $\begin{array}{r}? .5 \\
-0.1 \\
2.6 \\
0.0\end{array}$ & 043 & $\begin{array}{l}8.9 \\
8.9 \\
8.6\end{array}$ & $\begin{array}{l}9.5 \\
9.4 \\
9.4\end{array}$ \\
\hline $\begin{array}{l}5 / 2 \\
1030\end{array}$ & 36.0 & .21 & 1.7 & 0.8 & 1.8 & 036 & 8.7 & $\begin{array}{l}12.5 \\
25.3 \\
25.3\end{array}$ & $\begin{array}{l}2.0 \\
0.1\end{array}$ & 019 & $\begin{array}{l}9.0 \\
9.0 \\
9.0\end{array}$ & $\begin{array}{l}12.3 \\
12.1 \\
12.0\end{array}$ & $\begin{array}{l}2.0 \\
0.0\end{array}$ & 032 & $\begin{array}{l}9.2 \\
9.5 \\
8.4\end{array}$ & $\begin{array}{l}13.4 \\
12.8 \\
12.4\end{array}$ & $\begin{array}{l}1.9 \\
0.0\end{array}$ & 020 & $\begin{array}{r}9.7 \\
10.0 \\
9.1\end{array}$ & $\begin{array}{l}13.4 \\
13.0 \\
12.5\end{array}$ & $\begin{array}{l}2.3 \\
0.0 \\
2.4 \\
0.0\end{array}$ & $\begin{array}{l}020 \\
018\end{array}$ & $\begin{array}{l}9.1 \\
9.1 \\
8.9\end{array}$ & $\begin{array}{l}9.9 \\
9.7 \\
9.8\end{array}$ \\
\hline $\begin{array}{l}5 / 2 \\
1100\end{array}$ & 36.0 & .19 & 1.8 & 0.8 & 1.8 & 054 & 9.0 & $\begin{array}{l}13.3 \\
25.5 \\
25.4\end{array}$ & $\begin{array}{l}2.0 \\
0.0\end{array}$ & 039 & $\begin{array}{l}9.2 \\
9.3 \\
9.4\end{array}$ & $\begin{array}{l}13.2 \\
13.0 \\
12.8\end{array}$ & $\begin{array}{l}2.1 \\
0.0\end{array}$ & 051 & $\begin{array}{l}9.4 \\
9.8 \\
8.6\end{array}$ & $\begin{array}{l}14.3 \\
13.6 \\
13.2\end{array}$ & $\begin{array}{l}1.8 \\
0.0\end{array}$ & 042 & $\begin{array}{r}10.0 \\
10.4 \\
9.5\end{array}$ & $\begin{array}{l}14.1 \\
13.7 \\
13.3\end{array}$ & $\begin{array}{r}2.5 \\
-0.2 \\
2.6 \\
-0.1\end{array}$ & $\begin{array}{l}052 \\
051\end{array}$ & $\begin{array}{l}9.4 \\
9.4 \\
9.1\end{array}$ & $\begin{array}{l}10.3 \\
10.2 \\
10.2\end{array}$ \\
\hline $\begin{array}{l}5 / 2 \\
1130\end{array}$ & 35.8 & .19 & 1.0 & 0.2 & 1.3 & $v$ & 8.5 & $\begin{array}{l}12.9 \\
22.2 \\
22.2\end{array}$ & $\begin{array}{l}0.5 \\
0.0\end{array}$ & 000 & $\begin{array}{l}8.7 \\
9.0 \\
9.1\end{array}$ & $\begin{array}{l}12.9 \\
12.8 \\
12.7\end{array}$ & $\begin{array}{l}0.5 \\
0.1\end{array}$ & 057 & $\begin{array}{l}8.9 \\
9.3 \\
8.3\end{array}$ & $\begin{array}{l}13.4 \\
13.1 \\
12.9\end{array}$ & $\begin{array}{l}0.4 \\
0.0\end{array}$ & 018 & $\begin{array}{l}9.3 \\
9.9 \\
9.0\end{array}$ & $\begin{array}{l}13.3 \\
13.1 \\
12.8\end{array}$ & $\begin{array}{r}0.8 \\
-0.1 \\
0.8 \\
-0.1\end{array}$ & $\begin{array}{l}023 \\
016\end{array}$ & $\begin{array}{l}9.2 \\
9.3 \\
9.0\end{array}$ & $\begin{array}{l}10.1 \\
10.0 \\
10.1\end{array}$ \\
\hline $\begin{array}{l}5 / 2 \\
1200\end{array}$ & 35.6 & .27 & 0.3 & 0.1 & 1.8 & 288 & 8.4 & $\begin{array}{l}11.4 \\
21.9 \\
20.7\end{array}$ & $\begin{array}{l}1.7 \\
0.1\end{array}$ & 283 & $\begin{array}{l}9.1 \\
9.1 \\
8.9\end{array}$ & $\begin{array}{l}11.6 \\
11.5 \\
11.3\end{array}$ & $\begin{array}{l}1.5 \\
0.2\end{array}$ & 288 & $\begin{array}{l}9.4 \\
9.2 \\
8.3\end{array}$ & $\begin{array}{l}11.9 \\
11.5 \\
11.4\end{array}$ & $\begin{array}{r}1.8 \\
-0.1\end{array}$ & 292 & $\begin{array}{l}9.3 \\
9.4 \\
8.6\end{array}$ & $\begin{array}{l}11.4 \\
11.3 \\
11.0\end{array}$ & $\begin{array}{l}2.5 \\
0.1 \\
2.7 \\
0.0\end{array}$ & $\begin{array}{l}294 \\
203\end{array}$ & $\begin{array}{l}8.9 \\
8.9 \\
8.6\end{array}$ & $\begin{array}{l}9.4 \\
9.4 \\
9.4\end{array}$ \\
\hline $\begin{array}{l}5 / 2 \\
1230\end{array}$ & 35.5 & .36 & 0.4 & 0.3 & 1.8 & 252 & 8.4 & $\begin{array}{l}11.3 \\
21.7 \\
20.5\end{array}$ & $\begin{array}{l}1.9 \\
0.1\end{array}$ & 303 & $\begin{array}{l}9.0 \\
8.9 \\
8.8\end{array}$ & $\begin{array}{l}11.4 \\
11.3 \\
11.2\end{array}$ & $\begin{array}{l}1.3 \\
0.2\end{array}$ & 292 & $\begin{array}{l}9.5 \\
9.2 \\
8.4\end{array}$ & $\begin{array}{l}11.8 \\
11.4 \\
11.3\end{array}$ & $\begin{array}{r}1.7 \\
-0.1\end{array}$ & 296 & $\begin{array}{l}9.3 \\
9.4 \\
8.6\end{array}$ & $\begin{array}{l}11.3 \\
11.3 \\
11.0\end{array}$ & $\begin{array}{l}2.2 \\
0.0 \\
2.3 \\
0.0\end{array}$ & $\begin{array}{l}300 \\
297\end{array}$ & $\begin{array}{l}8.9 \\
8.9 \\
8.6\end{array}$ & $\begin{array}{l}9.4 \\
9.3 \\
9.4\end{array}$ \\
\hline $\begin{array}{l}5 / 2 \\
1300\end{array}$ & 35.4 & .33 & 0.7 & 0.2 & 1.3 & v & 9.0 & $\begin{array}{l}12.3 \\
21.8 \\
20.9\end{array}$ & $\begin{array}{l}1.6 \\
0.1\end{array}$ & 286 & $\begin{array}{l}9.5 \\
9.5 \\
9.5\end{array}$ & $\begin{array}{l}12.4 \\
12.3 \\
12.2\end{array}$ & $\begin{array}{l}1.2 \\
0.2\end{array}$ & 278 & $\begin{array}{l}9.9 \\
9.8 \\
8.8\end{array}$ & $\begin{array}{l}12.9 \\
12.4 \\
12.2\end{array}$ & $\begin{array}{l}1.5 \\
0.0\end{array}$ & 278 & $\begin{array}{r}10.0 \\
10.3 \\
9.4\end{array}$ & $\begin{array}{l}12.6 \\
12.5 \\
12.2\end{array}$ & $\begin{array}{l}2.3 \\
0.0 \\
2.3 \\
0.0\end{array}$ & $\begin{array}{l}282 \\
282\end{array}$ & $\begin{array}{l}9.3 \\
9.2 \\
9.0\end{array}$ & $\begin{array}{l}9.9 \\
9.8 \\
9.8\end{array}$ \\
\hline
\end{tabular}




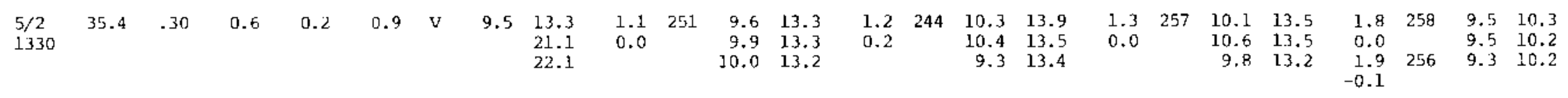

$$
\begin{aligned}
& \begin{array}{llllllllllllllllllllllllllll}
5 / 2 & 35.2 & .32 & 0.6 & 0.2 & 1.8 & 281 & 9.2 & 13.3 & 2.3 & 307 & 9.9 & 13.5 & 1.7 & 302 & 10.0 & 13.9 & 2.0 & 303 & 10.2 & 13.7 & 2.8 & 309 & 9.6 & 10.3
\end{array}
\end{aligned}
$$

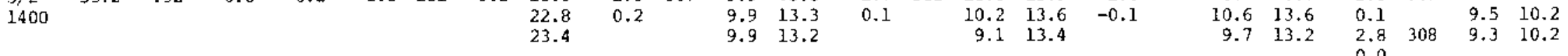

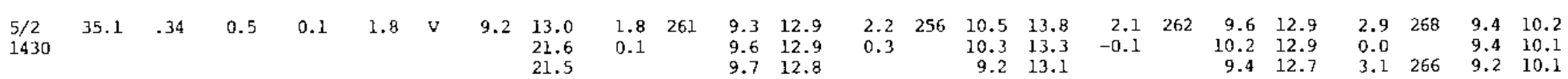

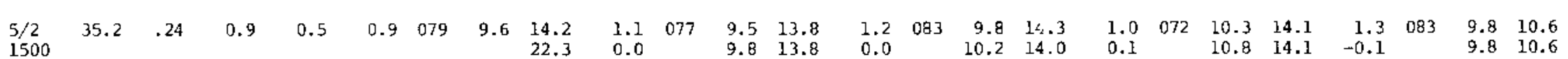

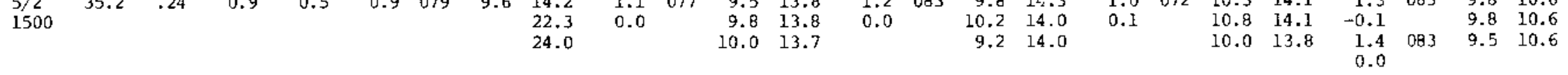

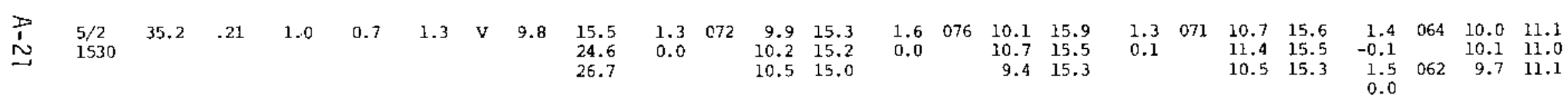

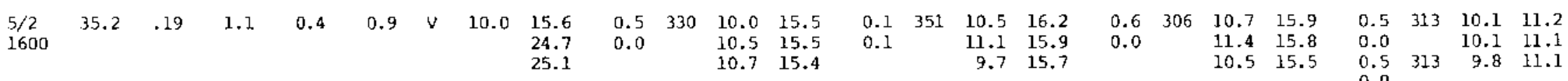

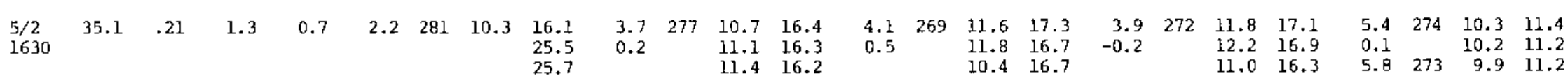

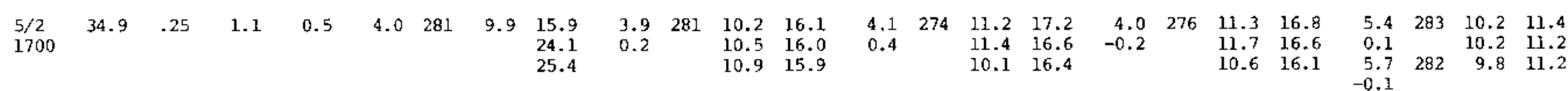




\section{RAFT RIVER 7 (1977) - EXPERIMENT 2 (contd)}

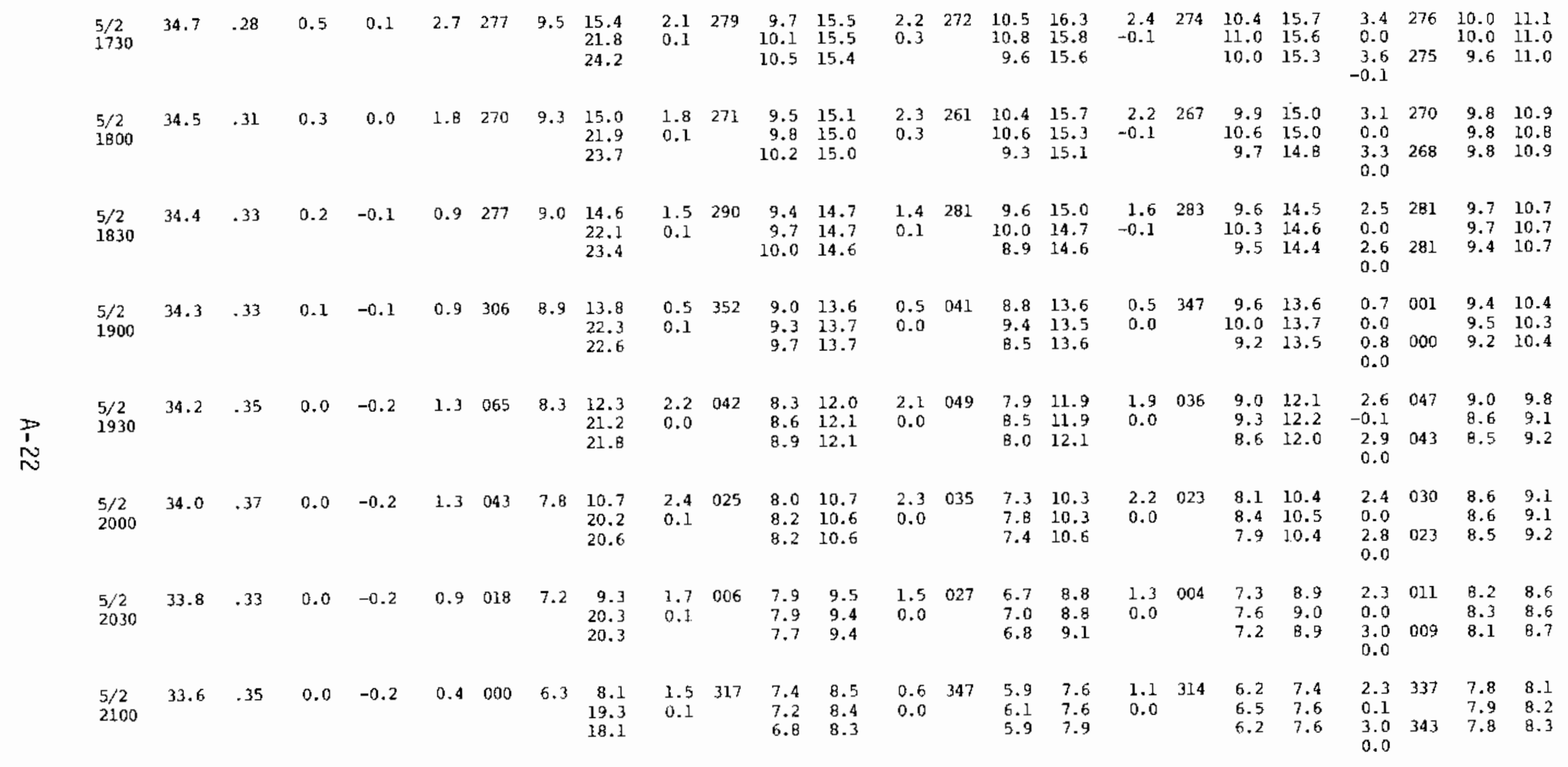


RAFT RIVER 1 (1977) - EXPERIMENT 2 (contd)

\begin{tabular}{|c|c|c|c|c|c|c|c|c|c|c|c|c|c|c|c|c|c|c|c|c|c|c|c|c|}
\hline $\begin{array}{l}5 / 2 \\
21.30\end{array}$ & 33.5 & 34 & 0.0 & -0.2 & 0.4 & 306 & 5.7 & $\begin{array}{r}6.6 \\
18.6 \\
16.8\end{array}$ & $\begin{array}{l}1.7 \\
0.2\end{array}$ & 305 & $\begin{array}{l}6.3 \\
6.2 \\
5.7\end{array}$ & $\begin{array}{l}7.0 \\
6.9 \\
6.8\end{array}$ & $\begin{array}{l}0.8 \\
0.1\end{array}$ & 315 & $\begin{array}{l}5.3 \\
5.4 \\
5.0\end{array}$ & $\begin{array}{l}6.6 \\
6.5 \\
6.7\end{array}$ & $\begin{array}{l}1.1 \\
0.0\end{array}$ & 299 & $\begin{array}{l}5.0 \\
5.3 \\
5.0\end{array}$ & $\begin{array}{l}5.9 \\
6.1 \\
6.0\end{array}$ & $\begin{array}{l}2.6 \\
0.0 \\
3.2 \\
0.0\end{array}$ & 307 & $\begin{array}{l}6.9 \\
7.1 \\
7.2\end{array}$ & $\begin{array}{l}7.1 \\
7.3 \\
7.7\end{array}$ \\
\hline $\begin{array}{l}5 / 2 \\
2200\end{array}$ & 33.4 & .36 & 0.0 & -0.2 & 0.4 & 313 & 5.3 & $\begin{array}{r}6.7 \\
18.8 \\
17.2\end{array}$ & $\begin{array}{l}1.5 \\
0.1\end{array}$ & 303 & $\begin{array}{l}6.3 \\
6.2 \\
5.8\end{array}$ & $\begin{array}{l}7.0 \\
7.0 \\
6.9\end{array}$ & $\begin{array}{l}0.8 \\
0.0\end{array}$ & 312 & $\begin{array}{l}5.3 \\
5.4 \\
5.0\end{array}$ & $\begin{array}{l}6.7 \\
6.6 \\
6.7\end{array}$ & $\begin{array}{l}1.1 \\
0.0\end{array}$ & 301 & $\begin{array}{l}5.1 \\
5.4 \\
5.2\end{array}$ & $\begin{array}{l}6.0 \\
6.2 \\
6.2\end{array}$ & $\begin{array}{l}2.6 \\
0.0 \\
3.3 \\
0.0\end{array}$ & $\begin{array}{l}304 \\
318\end{array}$ & $\begin{array}{l}7.1 \\
7.2 \\
7.3\end{array}$ & $\begin{array}{l}7.3 \\
7.4 \\
7.9\end{array}$ \\
\hline $\begin{array}{l}5 / 2 \\
2230\end{array}$ & 33.3 & .33 & 0.0 & -0.2 & 0.4 & 302 & 4.8 & $\begin{array}{r}6.1 \\
18.7 \\
16.9\end{array}$ & $\begin{array}{l}1.4 \\
0.1\end{array}$ & 297 & $\begin{array}{l}5.5 \\
5.4 \\
5.2\end{array}$ & $\begin{array}{l}6.3 \\
6.3 \\
6.3\end{array}$ & $\begin{array}{l}1.1 \\
0.0\end{array}$ & 303 & $\begin{array}{l}4.8 \\
4.8 \\
4.5\end{array}$ & $\begin{array}{l}6.0 \\
5.8 \\
6.0\end{array}$ & $\begin{array}{l}1.1 \\
0.0\end{array}$ & 297 & $\begin{array}{l}4.5 \\
4.8 \\
4.6\end{array}$ & $\begin{array}{l}5.2 \\
5.5 \\
5.5\end{array}$ & $\begin{array}{l}2.9 \\
0.0 \\
3.1 \\
0.0\end{array}$ & $\begin{array}{l}295 \\
301\end{array}$ & $\begin{array}{l}6.8 \\
7.0 \\
7.3\end{array}$ & $\begin{array}{l}7.1 \\
7.3 \\
7.9\end{array}$ \\
\hline $\begin{array}{l}5 / 2 \\
2300\end{array}$ & 33.2 & .33 & 0.0 & -0.2 & 0.4 & $28 \mathrm{~B}$ & 4.6 & $\begin{array}{r}5.8 \\
18.1 \\
16.2\end{array}$ & $\begin{array}{l}1.2 \\
0.1\end{array}$ & $2 B 0$ & $\begin{array}{l}4.9 \\
4.8 \\
4.7\end{array}$ & $\begin{array}{l}5.7 \\
5.7 \\
5.7\end{array}$ & $\begin{array}{l}1.0 \\
0.1\end{array}$ & 279 & $\begin{array}{l}5.2 \\
5.0 \\
4.5\end{array}$ & $\begin{array}{l}5.1 \\
5.9 \\
5.9\end{array}$ & $\begin{array}{l}1.2 \\
0.0\end{array}$ & 281 & $\begin{array}{l}4.3 \\
4.6 \\
4.4\end{array}$ & $\begin{array}{l}5.0 \\
5.2 \\
5.3\end{array}$ & $\begin{array}{l}2.4 \\
0.0 \\
3.0 \\
0.0\end{array}$ & $\begin{array}{l}282 \\
276\end{array}$ & $\begin{array}{l}6.5 \\
6.7 \\
6.8\end{array}$ & $\begin{array}{l}6.8 \\
6.9 \\
7.3\end{array}$ \\
\hline $\begin{array}{l}5 / 2 \\
2330\end{array}$ & 33.1 & .30 & 0.0 & -0.2 & 0.4 & 299 & 4.9 & $\begin{array}{r}6.3 \\
19.2 \\
17.3\end{array}$ & $\begin{array}{l}1.5 \\
0.0\end{array}$ & 286 & $\begin{array}{l}5.4 \\
5.2 \\
5.0\end{array}$ & $\begin{array}{l}6.2 \\
6.1 \\
6.1\end{array}$ & $\begin{array}{l}1.4 \\
0.1\end{array}$ & 289 & $\begin{array}{l}5.4 \\
5.3 \\
4.9\end{array}$ & $\begin{array}{l}6.6 \\
6.4 \\
6.4\end{array}$ & $\begin{array}{l}1.5 \\
0.0\end{array}$ & 288 & $\begin{array}{l}4.8 \\
5.1 \\
4.9\end{array}$ & $\begin{array}{l}-5.6 \\
5.8 \\
5.9\end{array}$ & $\begin{array}{l}2.7 \\
0.0 \\
3.4 \\
0.0\end{array}$ & $\begin{array}{l}2 B 5 \\
275\end{array}$ & $\begin{array}{l}6.7 \\
6.9 \\
7.0\end{array}$ & $\begin{array}{l}6.9 \\
7.1 \\
7.5\end{array}$ \\
\hline $\begin{array}{l}5 / 3 \\
0000\end{array}$ & 33.0 & .28 & 0.0 & -0.2 & 0.4 & $\mathrm{v}$ & 4.6 & $\begin{array}{r}5.6 \\
17.5 \\
15.8\end{array}$ & $\begin{array}{l}0.6 \\
0.0\end{array}$ & 199 & $\begin{array}{l}4.3 \\
4.4 \\
4.4\end{array}$ & $\begin{array}{l}5.2 \\
5.2 \\
5.3\end{array}$ & $\begin{array}{l}0.8 \\
0.2\end{array}$ & 186 & $\begin{array}{l}5.3 \\
5.1 \\
4.8\end{array}$ & $\begin{array}{l}6.1 \\
5.9 \\
5.9\end{array}$ & $\begin{array}{l}0.6 \\
0.1\end{array}$ & 215 & $\begin{array}{l}4.7 \\
4.9 \\
4.5\end{array}$ & $\begin{array}{l}5.2 \\
5.4 \\
5.2\end{array}$ & $\begin{array}{l}1.1 \\
0.0 \\
1.1 \\
0.0\end{array}$ & $\begin{array}{l}215 \\
226\end{array}$ & $\begin{array}{l}6.4 \\
6.5 \\
6.5\end{array}$ & $\begin{array}{l}6.6 \\
6.6 \\
6.8\end{array}$ \\
\hline $\begin{array}{l}5 / 3 \\
0030\end{array}$ & 32.8 & .29 & 0.0 & -0.2 & 0.0 & $\mathrm{~V}$ & 4.8 & $\begin{array}{r}5.9 \\
17.1 \\
15.7\end{array}$ & $\begin{array}{l}0.4 \\
0.0\end{array}$ & 206 & $\begin{array}{l}4.3 \\
4.4 \\
4.4\end{array}$ & $\begin{array}{l}5.2 \\
5.3 \\
5.4\end{array}$ & $\begin{array}{l}0.8 \\
0.1\end{array}$ & 172 & $\begin{array}{l}5.1 \\
5.0 \\
4.8\end{array}$ & $\begin{array}{l}6.0 \\
6.0 \\
6.0\end{array}$ & $\begin{array}{l}0.5 \\
0.0\end{array}$ & 232 & $\begin{array}{l}4.7 \\
4.8 \\
4.4\end{array}$ & $\begin{array}{l}5.3 \\
5.4 \\
5.3\end{array}$ & $\begin{array}{l}1.3 \\
0.0 \\
1.8 \\
0.0\end{array}$ & $\begin{array}{l}194 \\
182\end{array}$ & $\begin{array}{l}6.5 \\
6.6 \\
6.5\end{array}$ & $\begin{array}{l}6.7 \\
6.8 \\
7.0\end{array}$ \\
\hline $\begin{array}{l}5 / 3 \\
0100\end{array}$ & 32.7 & .31 & 0.0 & -0.2 & 0.0 & $\mathrm{v}$ & 5.1 & $\begin{array}{r}6.1 \\
17.8 \\
16.4\end{array}$ & $\begin{array}{l}0.2 \\
0.0\end{array}$ & 237 & $\begin{array}{l}4.6 \\
4.8 \\
4.7\end{array}$ & $\begin{array}{l}5.7 \\
5.6 \\
5.5\end{array}$ & $\begin{array}{l}0.4 \\
0.1\end{array}$ & 220 & $\begin{array}{l}5.0 \\
5.0 \\
4.7\end{array}$ & $\begin{array}{l}6.0 \\
5.9 \\
6.0\end{array}$ & $\begin{array}{l}0.6 \\
0.0\end{array}$ & 260 & $\begin{array}{l}4.8 \\
5.0 \\
4.7\end{array}$ & $\begin{array}{l}5.4 \\
5.6 \\
5.5\end{array}$ & $\begin{array}{l}1.0 \\
0.0 \\
1.5 \\
0.0\end{array}$ & $\begin{array}{l}225 \\
210\end{array}$ & $\begin{array}{l}6.6 \\
6.6 \\
6.6\end{array}$ & $\begin{array}{l}6.8 \\
6.8 \\
6.9\end{array}$ \\
\hline
\end{tabular}


RAFT RIVER ] (1977) - EXPERIMENT 2 (contd)

\begin{tabular}{|c|c|c|c|c|c|c|c|c|c|c|c|c|c|c|c|c|c|c|c|c|c|c|c|c|}
\hline $\begin{array}{l}5 / 3 \\
0130\end{array}$ & 32.6 & .32 & 0.0 & -0.2 & 0.0 & $\mathrm{v}$ & 5.0 & $\begin{array}{r}5.8 \\
17.2 \\
15.8\end{array}$ & $\begin{array}{l}0.4 \\
0.0\end{array}$ & 203 & $\begin{array}{l}4.4 \\
4.5 \\
4.5\end{array}$ & $\begin{array}{l}5.1 \\
5.2 \\
5.3\end{array}$ & $\begin{array}{l}0.6 \\
0.1\end{array}$ & 186 & $\begin{array}{l}5.3 \\
5.2 \\
5.0\end{array}$ & $\begin{array}{l}6.1 \\
5.9 \\
6.0\end{array}$ & $\begin{array}{l}0.5 \\
0.1\end{array}$ & 232 & $\begin{array}{l}4.8 \\
4.9 \\
4.6\end{array}$ & $\begin{array}{l}5.2 \\
5.3 \\
5.2\end{array}$ & $\begin{array}{l}1.0 \\
0.0 \\
1.0 \\
0.0\end{array}$ & 215 & $\begin{array}{l}6.5 \\
6.6 \\
6.6\end{array}$ & $\begin{array}{l}6.7 \\
6.7 \\
6.8\end{array}$ \\
\hline $\begin{array}{l}5 / 3 \\
0200\end{array}$ & 32.5 & .31 & 0.0 & -0.2 & 0.0 & $v$ & 4.8 & $\begin{array}{r}5.6 \\
17.7 \\
15.9\end{array}$ & $\begin{array}{l}0.7 \\
0.0\end{array}$ & 253 & $\begin{array}{l}4.7 \\
4.6 \\
4.7\end{array}$ & $\begin{array}{l}5.3 \\
5.4 \\
5.5\end{array}$ & $\begin{array}{l}0.7 \\
0.1\end{array}$ & 281 & $\begin{array}{l}5.2 \\
5.0 \\
4.7\end{array}$ & $\begin{array}{l}5.8 \\
5.7 \\
5.8\end{array}$ & $\begin{array}{l}0.9 \\
0.0\end{array}$ & 268 & $\begin{array}{l}4.2 \\
4.4 \\
4.3\end{array}$ & $\begin{array}{l}4.6 \\
4.9 \\
5.0\end{array}$ & $\begin{array}{l}1.5 \\
0.0 \\
1.8 \\
0.0\end{array}$ & $\begin{array}{l}254 \\
246\end{array}$ & $\begin{array}{l}6.5 \\
6.6 \\
6.6\end{array}$ & $\begin{array}{l}6.7 \\
6.8 \\
7.0\end{array}$ \\
\hline $\begin{array}{l}5 / 3 \\
0230\end{array}$ & 32.4 & .31 & 0.0 & -0.2 & 0.0 & $\mathrm{v}$ & 4.9 & $\begin{array}{r}5.8 \\
18.0 \\
16.3\end{array}$ & $\begin{array}{l}0.8 \\
0.0\end{array}$ & 232 & $\begin{array}{l}4.6 \\
4.8 \\
4.7\end{array}$ & $\begin{array}{l}5.4 \\
5.5 \\
5.6\end{array}$ & $\begin{array}{l}1.1 \\
0.2\end{array}$ & 229 & $\begin{array}{l}5.7 \\
5.4 \\
5.0\end{array}$ & $\begin{array}{l}6.3 \\
6.1 \\
6.0\end{array}$ & $\begin{array}{l}1.0 \\
0.0\end{array}$ & 254 & $\begin{array}{l}4.6 \\
4.8 \\
4.5\end{array}$ & $\begin{array}{l}5.1 \\
5.2 \\
5.2\end{array}$ & $\begin{array}{l}2.1 \\
0.0 \\
2.7 \\
0.0\end{array}$ & $\begin{array}{l}238 \\
233\end{array}$ & $\begin{array}{l}6.7 \\
6.7 \\
6.7\end{array}$ & $\begin{array}{l}6.9 \\
6.9 \\
7.0\end{array}$ \\
\hline $\begin{array}{l}5 / 3 \\
0300\end{array}$ & 32.3 & .28 & 0.0 & -0.2 & 0.0 & $v$ & 4.9 & $\begin{array}{r}5.8 \\
18.1 \\
16.3\end{array}$ & $\begin{array}{l}0.7 \\
0.0\end{array}$ & 244 & $\begin{array}{l}4.6 \\
4.8 \\
4.7\end{array}$ & $\begin{array}{l}5.3 \\
5.4 \\
5.5\end{array}$ & $\begin{array}{l}0.7 \\
0.1\end{array}$ & 229 & $\begin{array}{l}5.3 \\
5.1 \\
4.9\end{array}$ & $\begin{array}{l}6.1 \\
5.9 \\
6.0\end{array}$ & $\begin{array}{l}0.7 \\
0.0\end{array}$ & 256 & $\begin{array}{l}4.6 \\
4.7 \\
4.4\end{array}$ & $\begin{array}{l}5.0 \\
5.2 \\
5.1\end{array}$ & $\begin{array}{l}1.5 \\
0.0 \\
1.9 \\
0.0\end{array}$ & $\begin{array}{l}250 \\
249\end{array}$ & $\begin{array}{l}6.6 \\
6.7 \\
6.6\end{array}$ & $\begin{array}{l}6.8 \\
6.8 \\
7.0\end{array}$ \\
\hline $\begin{array}{l}5 / 3 \\
0330\end{array}$ & 32.2 & .31 & 0.0 & -0.2 & 0.0 & $\mathrm{v}$ & 5.1 & $\begin{array}{r}6.2 \\
17.9 \\
16.3\end{array}$ & $\begin{array}{l}0.6 \\
0.0\end{array}$ & 265 & $\begin{array}{l}5.1 \\
5.0 \\
5.0\end{array}$ & $\begin{array}{l}5.9 \\
6.0 \\
5.9\end{array}$ & $\begin{array}{l}0.8 \\
0.1\end{array}$ & 248 & $\begin{array}{l}5.6 \\
5.5 \\
5.1\end{array}$ & $\begin{array}{l}6.5 \\
5.3 \\
6.3\end{array}$ & $\begin{array}{l}0.8 \\
0.0\end{array}$ & 265 & $\begin{array}{l}4.6 \\
4.9 \\
4.7\end{array}$ & $\begin{array}{l}5.2 \\
5.5 \\
5.5\end{array}$ & $\begin{array}{l}1.5 \\
0.0 \\
1.9 \\
0.0\end{array}$ & $\begin{array}{l}258 \\
252\end{array}$ & $\begin{array}{l}6.7 \\
6.8 \\
6.7\end{array}$ & $\begin{array}{l}6.9 \\
6.9 \\
7.0\end{array}$ \\
\hline $\begin{array}{l}5 / 3 \\
0400\end{array}$ & 32.1 & .29 & 0.0 & -0.2 & 0.0 & $\mathrm{v}$ & 4.7 & $\begin{array}{r}5.7 \\
17.4 \\
16.0\end{array}$ & $\begin{array}{l}0.6 \\
0.0\end{array}$ & 275 & $\begin{array}{l}4.7 \\
4.7 \\
4.6\end{array}$ & $\begin{array}{l}5.4 \\
5.4 \\
5.5\end{array}$ & $\begin{array}{l}0.2 \\
0.1\end{array}$ & 265 & $\begin{array}{l}4.8 \\
4.8 \\
4.5\end{array}$ & $\begin{array}{l}5.7 \\
5.6 \\
5.7\end{array}$ & $\begin{array}{l}0.6 \\
0.0\end{array}$ & 276 & $\begin{array}{l}4.3 \\
4.5 \\
4.2\end{array}$ & $\begin{array}{l}4.8 \\
5.0 \\
5.0\end{array}$ & $\begin{array}{l}1.1 \\
0.0 \\
1.4 \\
0.0\end{array}$ & $\begin{array}{l}290 \\
300\end{array}$ & $\begin{array}{l}6.5 \\
6.5 \\
6.5\end{array}$ & $\begin{array}{l}6.6 \\
6.7 \\
7.0\end{array}$ \\
\hline $\begin{array}{l}5 / 3 \\
0430\end{array}$ & 32.0 & .30 & 0.0 & -0.2 & 0.0 & $v$ & 5.0 & $\begin{array}{r}6.2 \\
17.3 \\
16.0\end{array}$ & $\begin{array}{l}0.3 \\
0.0\end{array}$ & 255 & $\begin{array}{l}4.5 \\
4.6 \\
4.7\end{array}$ & $\begin{array}{l}5.4 \\
5.6 \\
5.8\end{array}$ & $\begin{array}{l}0.1 \\
0.1\end{array}$ & 172 & $\begin{array}{l}4.8 \\
5.0 \\
5.0\end{array}$ & $\begin{array}{l}5.8 \\
5.9 \\
6.3\end{array}$ & $\begin{array}{l}0.6 \\
0.0\end{array}$ & 269 & $\begin{array}{l}4.3 \\
4.7 \\
4.6\end{array}$ & $\begin{array}{l}5.0 \\
5.6 \\
5.7\end{array}$ & $\begin{array}{l}0.6 \\
0.0 \\
0.7 \\
0.0\end{array}$ & $\begin{array}{l}233 \\
224\end{array}$ & $\begin{array}{l}6.6 \\
6.7 \\
6.6\end{array}$ & $\begin{array}{l}6.8 \\
6.9 \\
7.0\end{array}$ \\
\hline $\begin{array}{l}5 / 3 \\
0500\end{array}$ & 31.8 & .33 & 0.0 & -0.2 & 0.0 & $\mathrm{v}$ & 4.4 & $\begin{array}{r}5.1 \\
16.8 \\
15.4\end{array}$ & $\begin{array}{l}0.4 \\
0.0\end{array}$ & 233 & $\begin{array}{l}3.9 \\
4.1 \\
4.0\end{array}$ & $\begin{array}{l}4.5 \\
4.6 \\
4.7\end{array}$ & $\begin{array}{l}0.5 \\
0.1\end{array}$ & 200 & $\begin{array}{l}4.8 \\
4.8 \\
4.6\end{array}$ & $\begin{array}{l}5.4 \\
5.4 \\
5.5\end{array}$ & $\begin{array}{l}0.6 \\
0.0\end{array}$ & 165 & $\begin{array}{l}3.7 \\
3.9 \\
3.8\end{array}$ & $\begin{array}{l}4.1 \\
4.4 \\
4.4\end{array}$ & $\begin{array}{l}1.1 \\
0.0 \\
1.6 \\
0.0\end{array}$ & $\begin{array}{l}224 \\
221\end{array}$ & $\begin{array}{l}6.2 \\
6.3 \\
6.3\end{array}$ & $\begin{array}{l}6.4 \\
6.4 \\
6.6\end{array}$ \\
\hline
\end{tabular}


RAFT RIVER 1 (1977) - EXPERIMENT 2 (contd)

\begin{tabular}{|c|c|c|c|c|c|c|c|c|c|c|c|c|c|c|c|c|c|c|c|c|c|c|c|c|}
\hline $\begin{array}{l}5 / 3 \\
0530\end{array}$ & 31.8 & .33 & 0.0 & -0.2 & 0.0 & $v$ & 3.9 & $\begin{array}{r}4.5 \\
17.1 \\
15.4\end{array}$ & $\begin{array}{l}0.5 \\
0.0\end{array}$ & 220 & $\begin{array}{l}3.5 \\
3.6 \\
3.5\end{array}$ & $\begin{array}{l}4.0 \\
4.1 \\
4.2\end{array}$ & $\begin{array}{l}0.7 \\
0.1\end{array}$ & 204 & $\begin{array}{l}4.5 \\
4.3 \\
4.1\end{array}$ & $\begin{array}{l}5.1 \\
4.8 \\
4.9\end{array}$ & $\begin{array}{l}0.7 \\
0.0\end{array}$ & 247 & $\begin{array}{l}3.5 \\
3.6 \\
3.5\end{array}$ & $\begin{array}{l}3.7 \\
3.9 \\
3.9\end{array}$ & $\begin{array}{l}1.3 \\
0.0 \\
1.8 \\
0.0\end{array}$ & $\begin{array}{l}213 \\
205\end{array}$ & $\begin{array}{l}6.0 \\
6.0 \\
6.1\end{array}$ & $\begin{array}{l}6.1 \\
6.1 \\
6.3\end{array}$ \\
\hline $\begin{array}{l}5 / 3 \\
0600\end{array}$ & 31.7 & .32 & 0.0 & -0.2 & 0.0 & $\mathrm{~V}$ & 4.4 & $\begin{array}{r}5.0 \\
16.4 \\
15.3\end{array}$ & $\begin{array}{l}0.3 \\
0.0\end{array}$ & 176 & $\begin{array}{l}3.7 \\
3.8 \\
3.8\end{array}$ & $\begin{array}{l}4.2 \\
4.4 \\
4.5\end{array}$ & $\begin{array}{l}0.5 \\
0.1\end{array}$ & 162 & $\begin{array}{l}4.6 \\
4.7 \\
4.6\end{array}$ & $\begin{array}{l}5.3 \\
5.2 \\
5.4\end{array}$ & $\begin{array}{l}0.3 \\
0.0\end{array}$ & 228 & $\begin{array}{l}4.0 \\
4.2 \\
3.9\end{array}$ & $\begin{array}{l}4.4 \\
4.5 \\
4.3\end{array}$ & $\begin{array}{l}1.3 \\
0.0 \\
1.5 \\
0.0\end{array}$ & $\begin{array}{l}252 \\
234\end{array}$ & $\begin{array}{l}6.1 \\
6.2 \\
6.2\end{array}$ & $\begin{array}{l}6.2 \\
6.3 \\
6.4\end{array}$ \\
\hline $\begin{array}{l}5 / 3 \\
0630\end{array}$ & 31.6 & .29 & 0.0 & -0.1 & 0.0 & $\mathrm{~V}$ & 4.8 & $\begin{array}{r}5.5 \\
17.6 \\
16.2\end{array}$ & $\begin{array}{l}0.4 \\
0.0\end{array}$ & 235 & $\begin{array}{l}4.4 \\
4.5 \\
4.4\end{array}$ & $\begin{array}{l}5.0 \\
5.1 \\
5.1\end{array}$ & $\begin{array}{l}0.6 \\
0.1\end{array}$ & 210 & $\begin{array}{l}5.1 \\
5.0 \\
4.8\end{array}$ & $\begin{array}{l}5.8 \\
5.6 \\
5.7\end{array}$ & $\begin{array}{l}0.5 \\
0.0\end{array}$ & 257 & $\begin{array}{l}4.4 \\
4.6 \\
4.3\end{array}$ & $\begin{array}{l}4.8 \\
5.0 \\
5.9\end{array}$ & $\begin{array}{l}1.2 \\
0.0 \\
1.5 \\
0.0\end{array}$ & $\begin{array}{l}238 \\
234\end{array}$ & $\begin{array}{l}6.4 \\
6.4 \\
6.4\end{array}$ & $\begin{array}{l}6.5 \\
6.6 \\
6.7\end{array}$ \\
\hline $\begin{array}{l}5 / 3 \\
0700\end{array}$ & 31.5 & .31 & 0.1 & 0.0 & 0.0 & $v$ & 5.4 & $\begin{array}{r}6.3 \\
18.1 \\
16.9\end{array}$ & $\begin{array}{l}0.4 \\
0.0\end{array}$ & 236 & $\begin{array}{l}5.1 \\
5.2 \\
5.1\end{array}$ & $\begin{array}{l}5.9 \\
5.9 \\
5.9\end{array}$ & $\begin{array}{l}0.5 \\
0.1\end{array}$ & 212 & $\begin{array}{l}5.7 \\
5.6 \\
5.3\end{array}$ & $\begin{array}{l}6.5 \\
6.4 \\
6.4\end{array}$ & $\begin{array}{l}0.6 \\
0.0\end{array}$ & 252 & $\begin{array}{l}5.3 \\
5.4 \\
5.0\end{array}$ & $\begin{array}{l}5.8 \\
5.9 \\
5.7\end{array}$ & $\begin{array}{l}0.8 \\
0.0 \\
0.9 \\
0.0\end{array}$ & $\begin{array}{l}250 \\
254\end{array}$ & $\begin{array}{l}6.7 \\
6.8 \\
6.7\end{array}$ & $\begin{array}{l}6.9 \\
6.9 \\
7.1\end{array}$ \\
\hline $\begin{array}{l}5 / 3 \\
0730\end{array}$ & 31.5 & .28 & 0.2 & 0.0 & 0.0 & $v$ & 6.9 & $\begin{array}{r}8.5 \\
19.0 \\
18.5\end{array}$ & $\begin{array}{l}0.5 \\
0.0\end{array}$ & 201 & $\begin{array}{l}6.2 \\
6.4 \\
6.5\end{array}$ & $\begin{array}{l}7.9 \\
7.9 \\
8.0\end{array}$ & $\begin{array}{l}0.8 \\
0.1\end{array}$ & 178 & $\begin{array}{l}6.8 \\
6.8 \\
6.4\end{array}$ & $\begin{array}{l}8.5 \\
8.3 \\
8.3\end{array}$ & $\begin{array}{l}0.5 \\
0.0\end{array}$ & 208 & $\begin{array}{l}7.1 \\
7.3 \\
6.7\end{array}$ & $\begin{array}{l}8.3 \\
8.4 \\
8.1\end{array}$ & $\begin{array}{l}0.8 \\
0.0 \\
0.8 \\
0.0\end{array}$ & $\begin{array}{l}245 \\
245\end{array}$ & $\begin{array}{l}7.3 \\
7.3 \\
7.2\end{array}$ & $\begin{array}{l}7.6 \\
7.6 \\
7.7\end{array}$ \\
\hline $\begin{array}{l}5 / 3 \\
0800\end{array}$ & 31.4 & .27 & 0.4 & 0.0 & 0.0 & $\mathrm{v}$ & 6.8 & $\begin{array}{r}9.8 \\
19.1 \\
18.8\end{array}$ & $\begin{array}{l}0.5 \\
0.0\end{array}$ & 291 & $\begin{array}{l}6.4 \\
6.6 \\
6.7\end{array}$ & $\begin{array}{l}8.4 \\
8.5 \\
8.5\end{array}$ & $\begin{array}{l}0.7 \\
0.1\end{array}$ & 177 & $\begin{array}{l}7.1 \\
7.2 \\
6.8\end{array}$ & $\begin{array}{l}9.1 \\
8.9 \\
8.9\end{array}$ & $\begin{array}{l}0.5 \\
0.0\end{array}$ & 219 & $\begin{array}{l}7.2 \\
7.3 \\
6.8\end{array}$ & $\begin{array}{l}8.7 \\
8.8 \\
8.5\end{array}$ & $\begin{array}{l}0.7 \\
0.0 \\
0.6 \\
0.0\end{array}$ & $\begin{array}{l}205 \\
212\end{array}$ & $\begin{array}{l}7.7 \\
7.8 \\
7.6\end{array}$ & $\begin{array}{l}8.1 \\
8.1 \\
8.1\end{array}$ \\
\hline $\begin{array}{l}5 / 3 \\
0830\end{array}$ & 31.4 & .27 & 0.6 & 0.2 & 0.0 & $v$ & 7.1 & $\begin{array}{r}9.8 \\
19.4 \\
20.8\end{array}$ & $\begin{array}{l}0.3 \\
0.0\end{array}$ & 094 & $\begin{array}{l}6.8 \\
7.0 \\
7.1\end{array}$ & $\begin{array}{l}9.4 \\
9.4 \\
9.5\end{array}$ & $\begin{array}{l}0.7 \\
0.0\end{array}$ & 097 & $\begin{array}{l}6.7 \\
7.1 \\
6.6\end{array}$ & $\begin{array}{l}9.6 \\
9.5 \\
9.6\end{array}$ & $\begin{array}{l}0.1 \\
0.1\end{array}$ & 044 & $\begin{array}{l}7.4 \\
7.7 \\
7.1\end{array}$ & $\begin{array}{l}9.6 \\
9.7 \\
9.4\end{array}$ & $\begin{array}{l}0.0 \\
0.0 \\
0.1 \\
0.0\end{array}$ & $\begin{array}{l}058 \\
025\end{array}$ & $\begin{array}{l}8.1 \\
8.1 \\
7.9\end{array}$ & $\begin{array}{l}8.7 \\
8.6 \\
8.6\end{array}$ \\
\hline $\begin{array}{l}5 / 3 \\
0900\end{array}$ & 31.4 & .26 & 0.9 & 0.3 & 0.4 & 072 & 7.6 & $\begin{array}{l}11.0 \\
21.2 \\
23.4\end{array}$ & $\begin{array}{l}1.1 \\
0.0\end{array}$ & 078 & $\begin{array}{l}7.5 \\
7.7 \\
7.9\end{array}$ & $\begin{array}{l}10.5 \\
10.5 \\
10.5\end{array}$ & $\begin{array}{l}1.3 \\
0.0\end{array}$ & 081 & $\begin{array}{l}7.6 \\
7.9 \\
7.4\end{array}$ & $\begin{array}{l}11.0 \\
10.8 \\
10.8\end{array}$ & $\begin{array}{l}1.0 \\
0.1\end{array}$ & 072 & $\begin{array}{l}8.5 \\
8.5 \\
7.9\end{array}$ & $\begin{array}{l}10.8 \\
10.8 \\
10.6\end{array}$ & $\begin{array}{r}1.3 \\
-0.1 \\
1.4 \\
0.0\end{array}$ & $\begin{array}{l}077 \\
076\end{array}$ & $\begin{array}{l}8.6 \\
8.6 \\
8.4\end{array}$ & $\begin{array}{l}9.2 \\
9.2 \\
9.2\end{array}$ \\
\hline
\end{tabular}


RAFT RIVER 1 (1977) - EXPERIMENT 2 (contd)

\begin{tabular}{|c|c|c|c|c|c|c|c|c|c|c|c|c|c|c|c|c|c|c|c|c|c|c|c|c|}
\hline $\begin{array}{l}5 / 3 \\
0930\end{array}$ & 31.5 & .22 & 1.2 & 0.5 & 0.9 & 090 & 8.3 & $\begin{array}{l}11.9 \\
22.5 \\
25.2\end{array}$ & $\begin{array}{l}1.6 \\
0.0\end{array}$ & 076 & $\begin{array}{l}8.2 \\
8.3 \\
8.4\end{array}$ & $\begin{array}{l}11.5 \\
11.4 \\
11.3\end{array}$ & $\begin{array}{l}1.8 \\
0.0\end{array}$ & 078 & $\begin{array}{l}8.6 \\
8.7 \\
8.1\end{array}$ & $\begin{array}{l}12.3 \\
11.9 \\
11.8\end{array}$ & $\begin{array}{l}1.5 \\
0.1\end{array}$ & 072 & $\begin{array}{l}9.4 \\
9.3 \\
8.6\end{array}$ & $\begin{array}{l}12.0 \\
11.9 \\
11.6\end{array}$ & $\begin{array}{r}2.0 \\
-0.1 \\
2.0 \\
-0.1\end{array}$ & $\begin{array}{l}079 \\
076\end{array}$ & $\begin{array}{l}9.0 \\
9.0 \\
8.8\end{array}$ & $\begin{array}{l}9.7 \\
9.6 \\
9.7\end{array}$ \\
\hline $\begin{array}{l}5 / 3 \\
1000\end{array}$ & 31.6 & .17 & 1.4 & 0.6 & 1.3 & 182 & 8.7 & $\begin{array}{l}13.1 \\
23.4 \\
26.4\end{array}$ & $\begin{array}{l}1.5 \\
0.0\end{array}$ & 054 & $\begin{array}{l}8.1 \\
9.0 \\
9.2\end{array}$ & $\begin{array}{l}13.0 \\
12.8 \\
12.7\end{array}$ & $\begin{array}{l}1.7 \\
0.0\end{array}$ & 058 & $\begin{array}{l}9.2 \\
9.5 \\
8.5\end{array}$ & $\begin{array}{l}13.9 \\
13.4 \\
13.1\end{array}$ & $\begin{array}{l}1.5 \\
0.1\end{array}$ & 049 & $\begin{array}{r}10.1 \\
10.0 \\
9.1\end{array}$ & $\begin{array}{l}13.5 \\
13.3 \\
12.9\end{array}$ & $\begin{array}{r}1.6 \\
-0.1 \\
1.6 \\
0.0\end{array}$ & $\begin{array}{l}057 \\
053\end{array}$ & $\begin{array}{l}9.3 \\
9.3 \\
9.1\end{array}$ & $\begin{array}{l}10.2 \\
10.1 \\
10.1\end{array}$ \\
\hline $\begin{array}{l}5 / 3 \\
1030\end{array}$ & 31.6 & .16 & 1.1 & 0.5 & 1.3 & 090 & 9.1 & $\begin{array}{l}13.9 \\
25.1 \\
26.1\end{array}$ & $\begin{array}{l}2.0 \\
0.0\end{array}$ & 075 & $\begin{array}{l}9.0 \\
9.2 \\
9.5\end{array}$ & $\begin{array}{l}13.6 \\
13.5 \\
13.3\end{array}$ & $\begin{array}{l}2.1 \\
0.0\end{array}$ & 072 & $\begin{array}{l}9.5 \\
9.7 \\
8.8\end{array}$ & $\begin{array}{l}14.5 \\
14.0 \\
13.7\end{array}$ & $\begin{array}{l}1.8 \\
0.1\end{array}$ & 065 & $\begin{array}{r}10.3 \\
10.3 \\
9.5\end{array}$ & $\begin{array}{l}14.0 \\
13.9 \\
13.6\end{array}$ & $\begin{array}{r}2.6 \\
-0.2 \\
2.7 \\
-0.1\end{array}$ & $\begin{array}{l}071 \\
070\end{array}$ & $\begin{array}{l}9.5 \\
9.6 \\
9.3\end{array}$ & $\begin{array}{l}10.5 \\
10.4 \\
10.4\end{array}$ \\
\hline $\begin{array}{l}5 / 3 \\
1100\end{array}$ & 31.5 & .17 & 0.9 & 0.4 & 1.8 & 054 & 9.6 & $\begin{array}{l}14.4 \\
25.1 \\
26.2\end{array}$ & $\begin{array}{l}2.8 \\
0.1\end{array}$ & 026 & $\begin{array}{l}9.3 \\
9.5 \\
9.8\end{array}$ & $\begin{array}{l}14.1 \\
14.0 \\
13.8\end{array}$ & $\begin{array}{r}2.8 \\
-0.1\end{array}$ & 037 & $\begin{array}{r}9.7 \\
10.0 \\
9.0\end{array}$ & $\begin{array}{l}15.0 \\
14.5 \\
14.2\end{array}$ & $\begin{array}{l}2.5 \\
0.0\end{array}$ & 029 & $\begin{array}{r}10.6 \\
10.7 \\
9.8\end{array}$ & $\begin{array}{l}15.0 \\
14.8 \\
14.3\end{array}$ & $\begin{array}{r}2.8 \\
-0.1 \\
3.0 \\
0.0\end{array}$ & $\begin{array}{l}026 \\
021\end{array}$ & $\begin{array}{l}9.6 \\
9.6 \\
9.3\end{array}$ & $\begin{array}{l}10.6 \\
10.5 \\
10.5\end{array}$ \\
\hline $\begin{array}{l}5 / 3 \\
1130\end{array}$ & 31.3 & .25 & 0.5 & 0.1 & 3.1 & 036 & 8.9 & $\begin{array}{l}13.5 \\
23.3 \\
24.4\end{array}$ & $\begin{array}{l}3.9 \\
0.2\end{array}$ & 208 & $\begin{array}{l}9.6 \\
9.4 \\
9.6\end{array}$ & $\begin{array}{l}13.5 \\
13.4 \\
13.3\end{array}$ & $\begin{array}{r}3.5 \\
-0.1\end{array}$ & 019 & $\begin{array}{l}9.0 \\
9.5 \\
8.6\end{array}$ & $\begin{array}{l}13.8 \\
13.5 \\
13.4\end{array}$ & $\begin{array}{r}3.4 \\
-0.1\end{array}$ & 011 & $\begin{array}{r}9.8 \\
10.1 \\
9.2\end{array}$ & $\begin{array}{l}13.9 \\
13.7 \\
13.3\end{array}$ & $\begin{array}{l}4.6 \\
0.0 \\
5.2 \\
0.0\end{array}$ & $\begin{array}{l}013 \\
010\end{array}$ & $\begin{array}{l}9.4 \\
9.4 \\
9.1\end{array}$ & $\begin{array}{l}10.2 \\
10.2 \\
10.2\end{array}$ \\
\hline $\begin{array}{l}5 / 3 \\
1200\end{array}$ & 31.2 & .22 & 0.6 & 0.3 & 3.1 & 036 & 9.0 & $\begin{array}{l}13.6 \\
22.0 \\
24.7\end{array}$ & $\begin{array}{l}4.1 \\
0.2\end{array}$ & 017 & $\begin{array}{l}9.2 \\
9.4 \\
9.6\end{array}$ & $\begin{array}{l}13.5 \\
13.4 \\
13.3\end{array}$ & $\begin{array}{r}3.9 \\
-0.1\end{array}$ & 026 & $\begin{array}{l}9.2 \\
9.6 \\
8.7\end{array}$ & $\begin{array}{l}14.0 \\
13.6 \\
13.4\end{array}$ & $\begin{array}{r}3.8 \\
-0.1\end{array}$ & 020 & $\begin{array}{r}10.0 \\
10.2 \\
9.3\end{array}$ & $\begin{array}{l}13.9 \\
13.7 \\
13.3\end{array}$ & $\begin{array}{r}4.4 \\
-0.1 \\
4.8 \\
0.0\end{array}$ & $\begin{array}{l}026 \\
020\end{array}$ & $\begin{array}{l}9.4 \\
9.4 \\
9.2\end{array}$ & $\begin{array}{l}10.3 \\
10.2 \\
10.2\end{array}$ \\
\hline $\begin{array}{l}5 / 3 \\
1230\end{array}$ & 31.0 & .21 & 0.7 & 0.1 & 3.6 & 043 & 8.9 & $\begin{array}{l}13.1 \\
21.0 \\
23.8\end{array}$ & $\begin{array}{l}4.4 \\
0.1\end{array}$ & 031 & $\begin{array}{l}9.0 \\
9.3 \\
9.5\end{array}$ & $\begin{array}{l}13.0 \\
13.0 \\
12.9\end{array}$ & $\begin{array}{r}4.5 \\
-0.1\end{array}$ & 037 & $\begin{array}{l}9.1 \\
9.4 \\
8.7\end{array}$ & $\begin{array}{l}13.3 \\
13.0 \\
12.9\end{array}$ & $\begin{array}{r}4.1 \\
-0.1\end{array}$ & 031 & $\begin{array}{r}9.9 \\
10.1 \\
9.3\end{array}$ & $\begin{array}{l}13.4 \\
13.3 \\
13.0\end{array}$ & $\begin{array}{r}4.9 \\
-0.7 \\
5.4 \\
0.0\end{array}$ & $\begin{array}{l}036 \\
032\end{array}$ & $\begin{array}{l}9.4 \\
9.5 \\
9.2\end{array}$ & $\begin{array}{l}10.2 \\
10.1 \\
10.2\end{array}$ \\
\hline $\begin{array}{l}5 / 3 \\
1300\end{array}$ & 30.9 & .20 & 0.3 & 0.1 & 4.5 & 036 & 8.4 & $\begin{array}{l}11.6 \\
24.4 \\
22.4\end{array}$ & $\begin{array}{l}5.3 \\
0.2\end{array}$ & 020 & $\begin{array}{l}8.6 \\
8.7 \\
8.8\end{array}$ & $\begin{array}{l}11.6 \\
11.5 \\
11.4\end{array}$ & $\begin{array}{r}4.9 \\
-0.1\end{array}$ & 026 & $\begin{array}{l}8.4 \\
8.7 \\
B .1\end{array}$ & $\begin{array}{l}11.7 \\
11.5 \\
11.5\end{array}$ & $\begin{array}{r}4.8 \\
-0.1\end{array}$ & 021 & $\begin{array}{l}9.2 \\
9.3 \\
8.7\end{array}$ & $\begin{array}{l}11.8 \\
11.7 \\
11.4\end{array}$ & $\begin{array}{r}5.7 \\
-0.1 \\
6.5 \\
0.0\end{array}$ & $\begin{array}{l}027 \\
022\end{array}$ & $\begin{array}{l}8.9 \\
9.0 \\
8.7\end{array}$ & $\begin{array}{l}9.5 \\
9.5 \\
9.5\end{array}$ \\
\hline
\end{tabular}


RAFT RIVER 1 (1977) - EXPERIMENT 2 (contd)

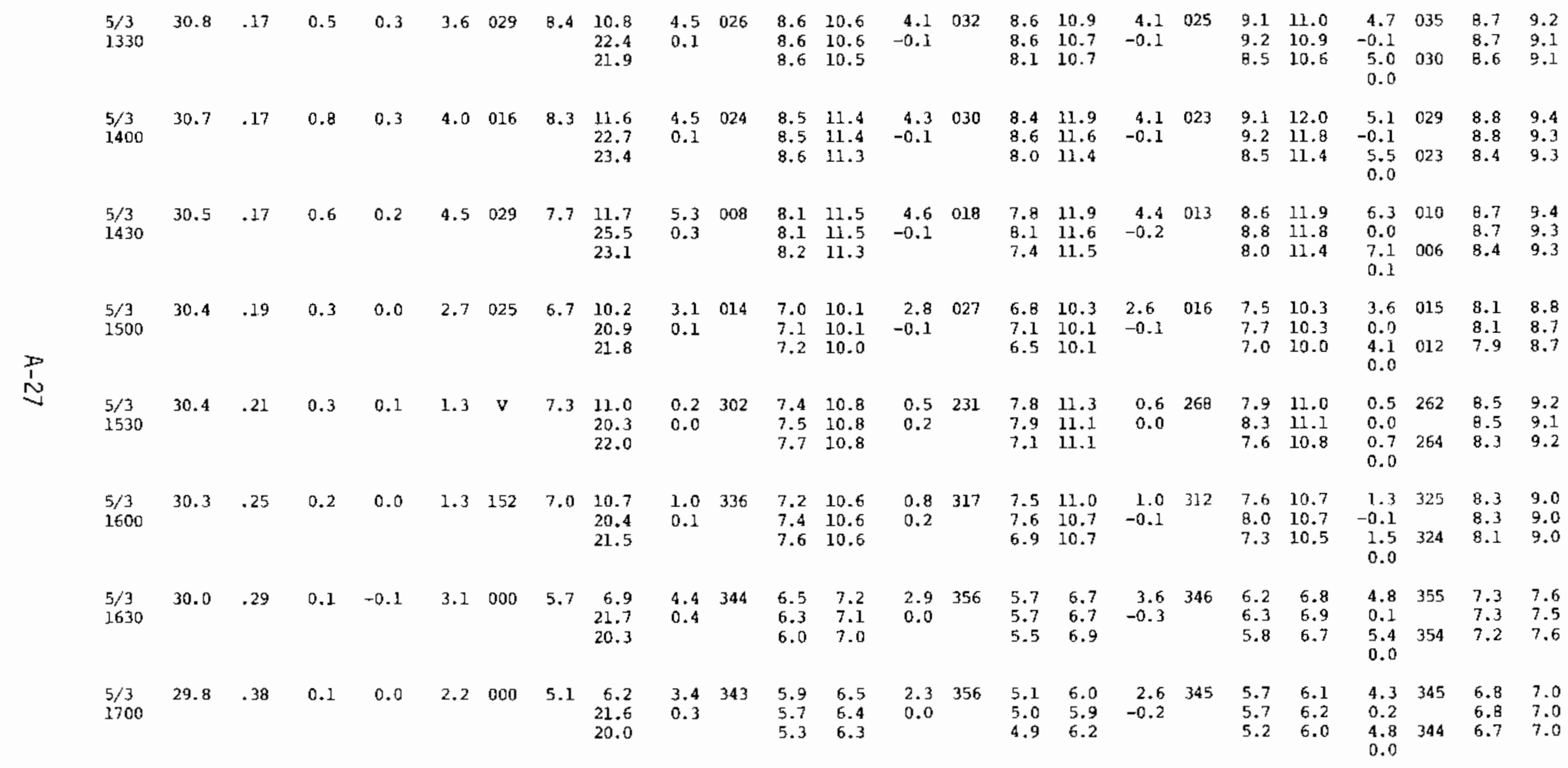


RAFT RIVER 1 (1977) - EXPERIMENT 2 (contd)

\begin{tabular}{|c|c|c|c|c|c|c|c|c|c|c|c|c|c|c|c|c|c|c|c|c|c|c|c|c|}
\hline $\begin{array}{l}5 / 3 \\
1730\end{array}$ & 29.6 & .45 & 0.2 & -0.1 & 1.3 & 324 & 4.6 & $\begin{array}{r}6.0 \\
20.6 \\
18.7\end{array}$ & $\begin{array}{l}1.6 \\
0.1\end{array}$ & 300 & $\begin{array}{l}5.1 \\
5.0 \\
4.8\end{array}$ & $\begin{array}{l}6.0 \\
5.9 \\
5.9\end{array}$ & $\begin{array}{l}1.4 \\
0.1\end{array}$ & 295 & $\begin{array}{l}4.9 \\
4.7 \\
4.4\end{array}$ & $\begin{array}{l}6.0 \\
5.8 \\
5.9\end{array}$ & $\begin{array}{r}1.6 \\
-0.1\end{array}$ & 292 & $\begin{array}{l}5.1 \\
5.1 \\
4.7\end{array}$ & $\begin{array}{l}5.7 \\
5.8 \\
5.6\end{array}$ & $\begin{array}{l}2.6 \\
0.0 \\
2.9 \\
0.0\end{array}$ & $\begin{array}{l}297 \\
296\end{array}$ & $\begin{array}{l}6.6 \\
6.6 \\
6.5\end{array}$ & $\begin{array}{l}6.8 \\
6.8 \\
6.9\end{array}$ \\
\hline $\begin{array}{l}5 / 3 \\
1800\end{array}$ & 29.5 & .38 & 0.0 & -0.1 & 2.2 & 281 & 4.3 & $\begin{array}{r}5.4 \\
21.0 \\
18.2\end{array}$ & $\begin{array}{l}2.2 \\
0.1\end{array}$ & 279 & $\begin{array}{l}4.7 \\
4.7 \\
4.4\end{array}$ & $\begin{array}{l}5.4 \\
5.4 \\
5.3\end{array}$ & $\begin{array}{l}2.5 \\
0.3\end{array}$ & 271 & $\begin{array}{l}5.1 \\
4.7 \\
4.2\end{array}$ & $\begin{array}{l}5.9 \\
5.5 \\
5.4\end{array}$ & $\begin{array}{r}2.4 \\
-0.1\end{array}$ & 274 & $\begin{array}{l}4.6 \\
4.7 \\
4.3\end{array}$ & $\begin{array}{l}5.1 \\
5.2 \\
5.0\end{array}$ & $\begin{array}{l}3.7 \\
0.0 \\
4.0 \\
0.0\end{array}$ & $\begin{array}{l}275 \\
273\end{array}$ & $\begin{array}{l}6.4 \\
6.4 \\
6.3\end{array}$ & $\begin{array}{l}6.6 \\
6.6 \\
6.6\end{array}$ \\
\hline $\begin{array}{l}5 / 3 \\
1830\end{array}$ & 29.5 & .38 & 0.0 & -0.1 & 1.3 & 245 & 4.3 & $\begin{array}{r}5.3 \\
18.8 \\
17.3\end{array}$ & $\begin{array}{l}1.6 \\
0.0\end{array}$ & 204 & $\begin{array}{l}4.4 \\
4.4 \\
4.2\end{array}$ & $\begin{array}{l}5.0 \\
5.0 \\
5.0\end{array}$ & $\begin{array}{l}2.0 \\
0.3\end{array}$ & 198 & $\begin{array}{l}5.2 \\
4.7 \\
4.3\end{array}$ & $\begin{array}{l}5.9 \\
5.5 \\
5.4\end{array}$ & $\begin{array}{l}1.7 \\
0.0\end{array}$ & 212 & $\begin{array}{l}4.7 \\
4.7 \\
4.3\end{array}$ & $\begin{array}{l}5.1 \\
5.2 \\
4.9\end{array}$ & $\begin{array}{r}3.0 \\
-0.1 \\
3.3 \\
0.0\end{array}$ & $\begin{array}{l}196 \\
195\end{array}$ & $\begin{array}{l}6.1 \\
6.1 \\
6.0\end{array}$ & $\begin{array}{l}6.2 \\
6.2 \\
6.2\end{array}$ \\
\hline $\begin{array}{l}5 / 3 \\
1900\end{array}$ & 29.3 & .41 & 0.0 & -0.1 & 1.3 & 176 & 4.2 & $\begin{array}{r}5.0 \\
20.5 \\
18.5\end{array}$ & $\begin{array}{l}1.8 \\
0.0\end{array}$ & 143 & $\begin{array}{l}4.3 \\
4.3 \\
4.2\end{array}$ & $\begin{array}{l}4.8 \\
4.8 \\
4.9\end{array}$ & $\begin{array}{l}2.1 \\
0.1\end{array}$ & 139 & $\begin{array}{l}4.5 \\
4.3 \\
4.0\end{array}$ & $\begin{array}{l}5.6 \\
5.0 \\
5.0\end{array}$ & $\begin{array}{l}1.5 \\
0.2\end{array}$ & 141 & $\begin{array}{l}5.3 \\
5.1 \\
4.5\end{array}$ & $\begin{array}{l}5.5 \\
5.4 \\
5.0\end{array}$ & $\begin{array}{r}2.5 \\
-0.1 \\
2.8 \\
-0.1\end{array}$ & $\begin{array}{l}148 \\
145\end{array}$ & $\begin{array}{l}6.2 \\
6.2 \\
6.1\end{array}$ & $\begin{array}{l}6.3 \\
6.3 \\
6.3\end{array}$ \\
\hline $\begin{array}{l}5 / 3 \\
1930\end{array}$ & 29.3 & .39 & 0.0 & -0.1 & 1.3 & 104 & 4.2 & $\begin{array}{r}5.1 \\
20.3 \\
18.9\end{array}$ & $\begin{array}{l}1.6 \\
0.0\end{array}$ & 090 & $\begin{array}{l}4.2 \\
4.2 \\
4.1\end{array}$ & $\begin{array}{l}4.8 \\
4.8 \\
4.9\end{array}$ & $\begin{array}{l}1.7 \\
0.0\end{array}$ & 085 & $\begin{array}{l}4.0 \\
4.0 \\
3.9\end{array}$ & $\begin{array}{l}4.8 \\
4.7 \\
5.0\end{array}$ & $\begin{array}{l}1.4 \\
0.1\end{array}$ & $08 \mathrm{I}$ & $\begin{array}{l}5.0 \\
4.9 \\
4.4\end{array}$ & $\begin{array}{l}5.3 \\
5.2 \\
4.9\end{array}$ & $\begin{array}{r}2.0 \\
-0.1 \\
2.5 \\
0.0\end{array}$ & $\begin{array}{l}090 \\
090\end{array}$ & $\begin{array}{l}6.2 \\
6.2 \\
6.2\end{array}$ & $\begin{array}{l}6.3 \\
6.3 \\
6.4\end{array}$ \\
\hline $\begin{array}{l}5 / 3 \\
2000\end{array}$ & 29.2 & .34 & 0.0 & -0.1 & 0.4 & $\mathrm{~V}$ & 4.2 & $\begin{array}{r}5.2 \\
18.7 \\
17.4\end{array}$ & $\begin{array}{l}0.4 \\
0.0\end{array}$ & 257 & $\begin{array}{l}4.2 \\
4.3 \\
4.2\end{array}$ & $\begin{array}{l}4.9 \\
4.9 \\
5.0\end{array}$ & $\begin{array}{l}0.5 \\
0.1\end{array}$ & 240 & $\begin{array}{l}4.5 \\
4.3 \\
4.0\end{array}$ & $\begin{array}{l}5.3 \\
5.1 \\
5.2\end{array}$ & $\begin{array}{l}0.6 \\
0.0\end{array}$ & 267 & $\begin{array}{l}4.4 \\
4.5 \\
4.2\end{array}$ & $\begin{array}{l}4.8 \\
5.0 \\
4.8\end{array}$ & $\begin{array}{l}1.0 \\
0.0 \\
1.1 \\
0.0\end{array}$ & $\begin{array}{l}259 \\
253\end{array}$ & $\begin{array}{l}6.3 \\
6.3 \\
6.2\end{array}$ & $\begin{array}{l}6.4 \\
6.4 \\
6.5\end{array}$ \\
\hline $\begin{array}{l}5 / 3 \\
2030\end{array}$ & 29.1 & .33 & 0.0 & -0.1 & 0.4 & 274 & 3.9 & $\begin{array}{r}5.1 \\
19.0 \\
17.3\end{array}$ & $\begin{array}{l}1.5 \\
0.1\end{array}$ & 281 & $\begin{array}{l}4.4 \\
4.3 \\
4.1\end{array}$ & $\begin{array}{l}5.2 \\
5.1 \\
5.1\end{array}$ & $\begin{array}{l}1.4 \\
0.2\end{array}$ & 269 & $\begin{array}{l}4.6 \\
4.3 \\
3.9\end{array}$ & $\begin{array}{l}5.5 \\
5.2 \\
5.2\end{array}$ & $\begin{array}{l}1.5 \\
0.0\end{array}$ & 275 & $\begin{array}{l}4.1 \\
4.3 \\
3.9\end{array}$ & $\begin{array}{l}4.6 \\
4.8 \\
4.7\end{array}$ & $\begin{array}{l}2.0 \\
0.0 \\
2.6 \\
0.0\end{array}$ & $\begin{array}{l}281 \\
276\end{array}$ & $\begin{array}{l}6.2 \\
6.2 \\
6.1\end{array}$ & $\begin{array}{l}5.4 \\
6.4 \\
6.5\end{array}$ \\
\hline $\begin{array}{l}5 / 3 \\
2100\end{array}$ & 28.9 & .36 & 0.0 & -0.1 & 2.2 & 288 & 3.8 & $\begin{array}{r}5.0 \\
24.6 \\
18.6\end{array}$ & $\begin{array}{l}3.8 \\
0.3\end{array}$ & 299 & $\begin{array}{l}4.4 \\
4.2 \\
4.0\end{array}$ & $\begin{array}{l}5.1 \\
5.1 \\
5.0\end{array}$ & $\begin{array}{l}3.2 \\
0.1\end{array}$ & 294 & $\begin{array}{l}4.1 \\
4.0 \\
3.7\end{array}$ & $\begin{array}{l}5.1 \\
4.9 \\
5.0\end{array}$ & $\begin{array}{r}3.0 \\
-0.2\end{array}$ & 295 & $\begin{array}{l}4.0 \\
4.2 \\
3.9\end{array}$ & $\begin{array}{l}4.6 \\
4.8 \\
4.7\end{array}$ & $\begin{array}{l}5.2 \\
0.2 \\
6.0 \\
0.0\end{array}$ & $\begin{array}{l}297 \\
297\end{array}$ & $\begin{array}{l}6.2 \\
6.2 \\
6.1\end{array}$ & $\begin{array}{l}6.4 \\
6.4 \\
6.5\end{array}$ \\
\hline
\end{tabular}


RAFT RIVER 1 (1977) - EXPERIMENT 2 (contd)

\begin{tabular}{|c|c|c|c|c|c|c|c|c|c|c|c|c|c|c|c|c|c|c|c|c|c|c|c|c|}
\hline $\begin{array}{l}5 / 3 \\
2130\end{array}$ & 28.8 & .33 & 0.0 & -0.1 & 2.7 & 306 & 3.6 & $\begin{array}{r}5.0 \\
23.8 \\
18.6\end{array}$ & $\begin{array}{l}2.9 \\
0.3\end{array}$ & 301 & $\begin{array}{l}4.3 \\
3.8 \\
3.8\end{array}$ & $\begin{array}{l}5.1 \\
5.0 \\
4.5\end{array}$ & $\begin{array}{l}2.4 \\
0.1\end{array}$ & 297 & $\begin{array}{l}3.9 \\
3.8 \\
3.5\end{array}$ & $\begin{array}{l}5.0 \\
4.9 \\
5.0\end{array}$ & $\begin{array}{r}2.4 \\
-0.1\end{array}$ & 296 & $\begin{array}{l}3.9 \\
4.1 \\
3.7\end{array}$ & $\begin{array}{l}4.5 \\
4.8 \\
4.7\end{array}$ & $\begin{array}{l}3.9 \\
0.1 \\
4.6 \\
0.0\end{array}$ & $\begin{array}{l}301 \\
301\end{array}$ & $\begin{array}{l}6.1 \\
6.1 \\
6.0\end{array}$ & $\begin{array}{l}6.3 \\
6.3 \\
6.4\end{array}$ \\
\hline $\begin{array}{l}5 / 3 \\
2200\end{array}$ & 28.7 & .35 & 0.0 & -0.1 & 1.8 & 295 & 3.6 & $\begin{array}{r}5.4 \\
20.2 \\
17.5\end{array}$ & $\begin{array}{l}1.5 \\
0.1\end{array}$ & 291 & $\begin{array}{l}4.1 \\
3.5 \\
3.7\end{array}$ & $\begin{array}{l}5.3 \\
5.6 \\
4.8\end{array}$ & $\begin{array}{l}1.2 \\
0.1\end{array}$ & 283 & $\begin{array}{l}4.1 \\
4.0 \\
3.6\end{array}$ & $\begin{array}{l}5.6 \\
5.5 \\
5.6\end{array}$ & $\begin{array}{l}1.3 \\
0.0\end{array}$ & 285 & $\begin{array}{l}3.8 \\
4.0 \\
3.6\end{array}$ & $\begin{array}{l}4.8 \\
5.0 \\
5.0\end{array}$ & $\begin{array}{l}2.3 \\
0.0 \\
2.6 \\
0.0\end{array}$ & $\begin{array}{l}284 \\
285\end{array}$ & $\begin{array}{l}6.1 \\
6.2 \\
6.1\end{array}$ & $\begin{array}{l}6.5 \\
6.5 \\
6.6\end{array}$ \\
\hline $\begin{array}{l}5 / 3 \\
2230\end{array}$ & 28.7 & .32 & 0.0 & -0.1 & 0.0 & $v$ & 4.0 & $\begin{array}{r}5.2 \\
18.8 \\
16.8\end{array}$ & $\begin{array}{l}0.4 \\
0.0\end{array}$ & 163 & $\begin{array}{l}3.7 \\
3.4 \\
4.0\end{array}$ & $\begin{array}{l}4.6 \\
5.1 \\
4.8\end{array}$ & $\begin{array}{l}0.8 \\
0.1\end{array}$ & 146 & $\begin{array}{l}4.0 \\
3.9 \\
3.7\end{array}$ & $\begin{array}{l}5.1 \\
5.0 \\
5.1\end{array}$ & $\begin{array}{l}0.4 \\
0.1\end{array}$ & 208 & $\begin{array}{l}4.1 \\
4.3 \\
3.9\end{array}$ & $\begin{array}{l}4.8 \\
5.0 \\
4.8\end{array}$ & $\begin{array}{l}0.7 \\
0.0 \\
0.8 \\
0.0\end{array}$ & $\begin{array}{l}186 \\
187\end{array}$ & $\begin{array}{l}6.0 \\
6.1 \\
6.0\end{array}$ & $\begin{array}{l}6.3 \\
6.3 \\
6.3\end{array}$ \\
\hline $\begin{array}{l}5 / 3 \\
2300\end{array}$ & 28.6 & .32 & 0.0 & -0.1 & 0.0 & $\mathrm{v}$ & 3.9 & $\begin{array}{r}5.0 \\
19.4 \\
17.7\end{array}$ & $\begin{array}{l}0.6 \\
0.0\end{array}$ & 110 & $\begin{array}{l}3.7 \\
3.0 \\
4.4\end{array}$ & $\begin{array}{l}4.4 \\
4.6 \\
5.0\end{array}$ & $\begin{array}{l}0.8 \\
0.0\end{array}$ & 107 & $\begin{array}{l}3.6 \\
3.7 \\
3.5\end{array}$ & $\begin{array}{l}4.6 \\
4.6 \\
4.9\end{array}$ & $\begin{array}{l}0.5 \\
0.1\end{array}$ & 102 & $\begin{array}{l}4.5 \\
4.6 \\
4.2\end{array}$ & $\begin{array}{l}5.0 \\
5.1 \\
4.9\end{array}$ & $\begin{array}{l}0.7 \\
0.0 \\
0.9 \\
0.0\end{array}$ & $\begin{array}{l}136 \\
131\end{array}$ & $\begin{array}{l}6.0 \\
6.0 \\
5.9\end{array}$ & $\begin{array}{l}6.2 \\
6.2 \\
6.3\end{array}$ \\
\hline $\begin{array}{l}5 / 3 \\
2330\end{array}$ & 28.5 & .34 & 0.0 & -0.2 & 0.4 & 324 & 3.6 & $\begin{array}{r}4.5 \\
19.6 \\
17.2\end{array}$ & $\begin{array}{l}0.2 \\
0.0\end{array}$ & 054 & $\begin{array}{l}3.5 \\
2.7 \\
3.6\end{array}$ & $\begin{array}{l}4.0 \\
4.1 \\
4.1\end{array}$ & $\begin{array}{l}0.4 \\
0.1\end{array}$ & 091 & $\begin{array}{l}3.3 \\
3.4 \\
3.3\end{array}$ & $\begin{array}{l}4.1 \\
4.1 \\
4.5\end{array}$ & $\begin{array}{l}0.2 \\
0.0\end{array}$ & 323 & $\begin{array}{l}3.7 \\
3.9 \\
3.5\end{array}$ & $\begin{array}{l}4.1 \\
4.3 \\
4.1\end{array}$ & $\begin{array}{l}0.3 \\
0.0 \\
0.7 \\
0.0\end{array}$ & $\begin{array}{l}100 \\
105\end{array}$ & $\begin{array}{l}5.8 \\
5.8 \\
5.8\end{array}$ & $\begin{array}{l}5.9 \\
6.0 \\
5.1\end{array}$ \\
\hline $\begin{array}{l}5 / 4 \\
0000\end{array}$ & 28.4 & .36 & 0.0 & -0.2 & 0.4 & 317 & 1.9 & $\begin{array}{r}2.8 \\
20.0 \\
17.0\end{array}$ & $\begin{array}{l}1.6 \\
0.1\end{array}$ & 321 & $\begin{array}{l}2.9 \\
2.7 \\
2.3\end{array}$ & $\begin{array}{l}3.2 \\
3.0 \\
3.1\end{array}$ & $\begin{array}{l}0.9 \\
0.0\end{array}$ & 341 & $\begin{array}{l}1.4 \\
1.5 \\
1.7\end{array}$ & $\begin{array}{l}2.1 \\
2.2 \\
2.8\end{array}$ & $\begin{array}{l}1.3 \\
0.0\end{array}$ & 319 & $\begin{array}{l}1.9 \\
2.0 \\
1.0\end{array}$ & $\begin{array}{l}2.1 \\
2.3 \\
2.4\end{array}$ & $\begin{array}{l}2.3 \\
0.0 \\
2.3 \\
0.0\end{array}$ & $\begin{array}{l}320 \\
320\end{array}$ & $\begin{array}{l}5.2 \\
5.4 \\
5.5\end{array}$ & $\begin{array}{l}5.3 \\
5.6 \\
5.9\end{array}$ \\
\hline $\begin{array}{l}5 / 4 \\
0030\end{array}$ & 28.3 & .34 & 0.0 & -0.1 & 0.0 & 270 & 1.8 & $\begin{array}{r}2.9 \\
20.4 \\
16.5\end{array}$ & $\begin{array}{l}1.2 \\
0.1\end{array}$ & 308 & $\begin{array}{l}2.6 \\
2.4 \\
2.2\end{array}$ & $\begin{array}{l}3.0 \\
3.0 \\
3.1\end{array}$ & $\begin{array}{l}0.7 \\
0.0\end{array}$ & 329 & $\begin{array}{l}1.6 \\
1.6 \\
1.6\end{array}$ & $\begin{array}{l}2.4 \\
2.4 \\
3.0\end{array}$ & $\begin{array}{l}1.0 \\
0.0\end{array}$ & 308 & $\begin{array}{l}1.7 \\
1.8 \\
1.6\end{array}$ & $\begin{array}{l}2.0 \\
2.2 \\
2.3\end{array}$ & $\begin{array}{l}1.9 \\
0.0 \\
2.1 \\
0.0\end{array}$ & $\begin{array}{l}298 \\
294\end{array}$ & $\begin{array}{l}4.9 \\
5.1 \\
5.2\end{array}$ & $\begin{array}{l}5.1 \\
5.4 \\
5.7\end{array}$ \\
\hline $\begin{array}{l}5 / 4 \\
0100\end{array}$ & 28.2 & .32 & 0.0 & -0.1 & 0.4 & 152 & 2.4 & $\begin{array}{r}3.8 \\
20.0 \\
15.8\end{array}$ & $\begin{array}{l}0.7 \\
0.0\end{array}$ & 139 & $\begin{array}{l}2.5 \\
2.5 \\
2.5\end{array}$ & $\begin{array}{l}3.5 \\
3.6 \\
3.7\end{array}$ & $\begin{array}{l}0.8 \\
0.2\end{array}$ & 226 & $\begin{array}{l}2.9 \\
2.7 \\
2.4\end{array}$ & $\begin{array}{l}4.1 \\
3.9 \\
4.0\end{array}$ & $\begin{array}{l}0.8 \\
0.0\end{array}$ & 248 & $\begin{array}{l}2.4 \\
2.6 \\
2.3\end{array}$ & $\begin{array}{l}3.1 \\
3.3 \\
3.3\end{array}$ & $\begin{array}{l}1.5 \\
0.0 \\
1.7 \\
0.0\end{array}$ & $\begin{array}{l}244 \\
242\end{array}$ & $\begin{array}{l}5.3 \\
5.4 \\
5.3\end{array}$ & $\begin{array}{l}5.6 \\
5.6 \\
5.7\end{array}$ \\
\hline
\end{tabular}




$$
\begin{aligned}
& \text { RAFT RIVER } 1 \text { (1977) - EXPERIMENT } 2 \text { (contd) }
\end{aligned}
$$

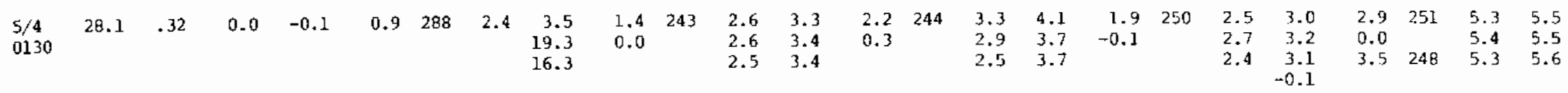

$$
\begin{aligned}
& \begin{array}{llllllllllllllllllllllllll}
5 / 4 & 28.0 & .35 & 0.0 & -0.1 & 0.9 & 284 & 2.3 & 3.4 & 1.1 & 285 & 2.7 & 3.3 & 0.8 & 273 & 2.7 & 3.5 & 1.2 & 281 & 2.3 & 2.7 & 1.6 & 292 & 5.2 & 5.4 \\
0200 & & & & & & & & 19.6 & 0.1 & & 2.7 & 3.3 & 0.1 & & 2.5 & 3.3 & 0.0 & & 2.5 & 3.0 & 0.0 & & 5.2 & 5.4 \\
& & & & & & & & 16.6 & & & 2.5 & 3.3 & & & & 2.2 & 3.4 & & & 2.2 & 2.9 & 1.7 & 286 & 5.2 & 5.5
\end{array}
\end{aligned}
$$

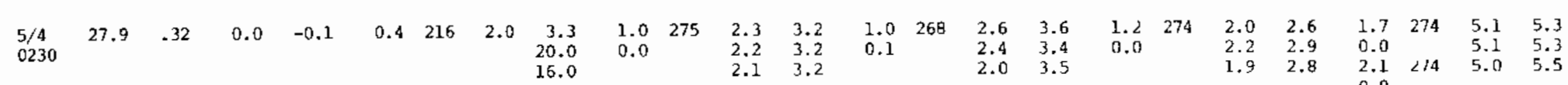

$$
\begin{aligned}
& \begin{array}{llllllllllllllllllllllllll}
5 / 4 & 27.9 & .34 & 0.0 & -0.2 & 0.0 & v & 1.6 & 2.6 & 0.3 & 206 & 1.4 & 1.9 & 0.5 & 169 & 1.9 & 2.6 & 0.4 & 248 & 1.4 & 1.8 & 1.0 & 211 & 4.8 & 5.0 \\
0300 & & & & & & & & 19.7 & 0.0 & & 1.4 & 2.0 & 0.1 & & 1.8 & 2.5 & 0.0 & & 1.6 & 2.0 & 0.0 & & 4.9 & 5.1
\end{array}
\end{aligned}
$$

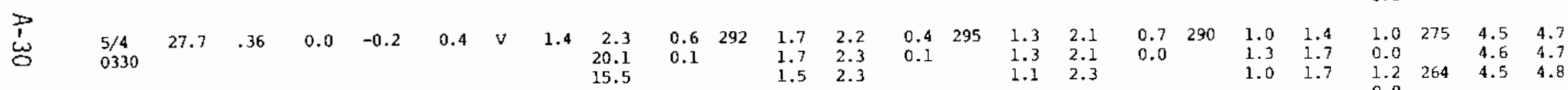

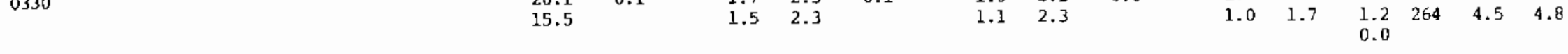

$$
\begin{aligned}
& \begin{array}{lllllllllllllllllllllllllll}
5 / 4 & 27.7 & .32 & 0.0 & -0.2 & 0.0 & v & 1.3 & 2.7 & 0.8 & 256 & 1.5 & 2.4 & 1.0 & 244 & 2.0 & 3.1 & 1.1 & 258 & 1.2 & 2.0 & 1.6 & 254 & 4.7 & 4.9 \\
0400 & & & & & & & & 20.3 & 0.0 & & 1.5 & 2.5 & 0.2 & & 1.8 & 2.9 & 0.0 & & 1.5 & 2.3 & 0.0 & & 4.8 & 5.0 \\
& & & & & & & & 15.5 & & & 1.5 & 2.6 & & & 1.4 & 3.0 & & & 1.3 & 2.3 & 2.0 & 247 & 4.7 & 5.1
\end{array}
\end{aligned}
$$

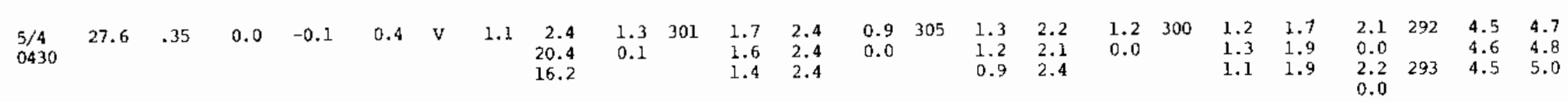

$$
\begin{aligned}
& \begin{array}{llllllllllllllllllllllllll}
5 / 4 & 27.5 & .35 & 0.0 & -0.1 & 0.4 & 324 & 1.3 & 2.9 & 0.8 & 296 & 1.7 & 2.9 & 0.3 & 276 & 1.5 & 2.8 & 0.8 & 286 & 1.3 & 2.2 & 1.0 & 287 & 4.7 & 5.0 \\
0500 & & & & & & & & 20.3 & 0.1 & & 1.7 & 2.9 & 0.1 & & 1.4 & 2.7 & 0.0 & & 1.6 & 2.5 & 0.0 & & 4.8 & 5.1 \\
& & & & & & & & 16.2 & & & 1.7 & 3.0 & & & & 1.2 & 3.0 & & & 1.2 & 2.5 & 1.1 & 288 & 4.7 & 5.2
\end{array}
\end{aligned}
$$




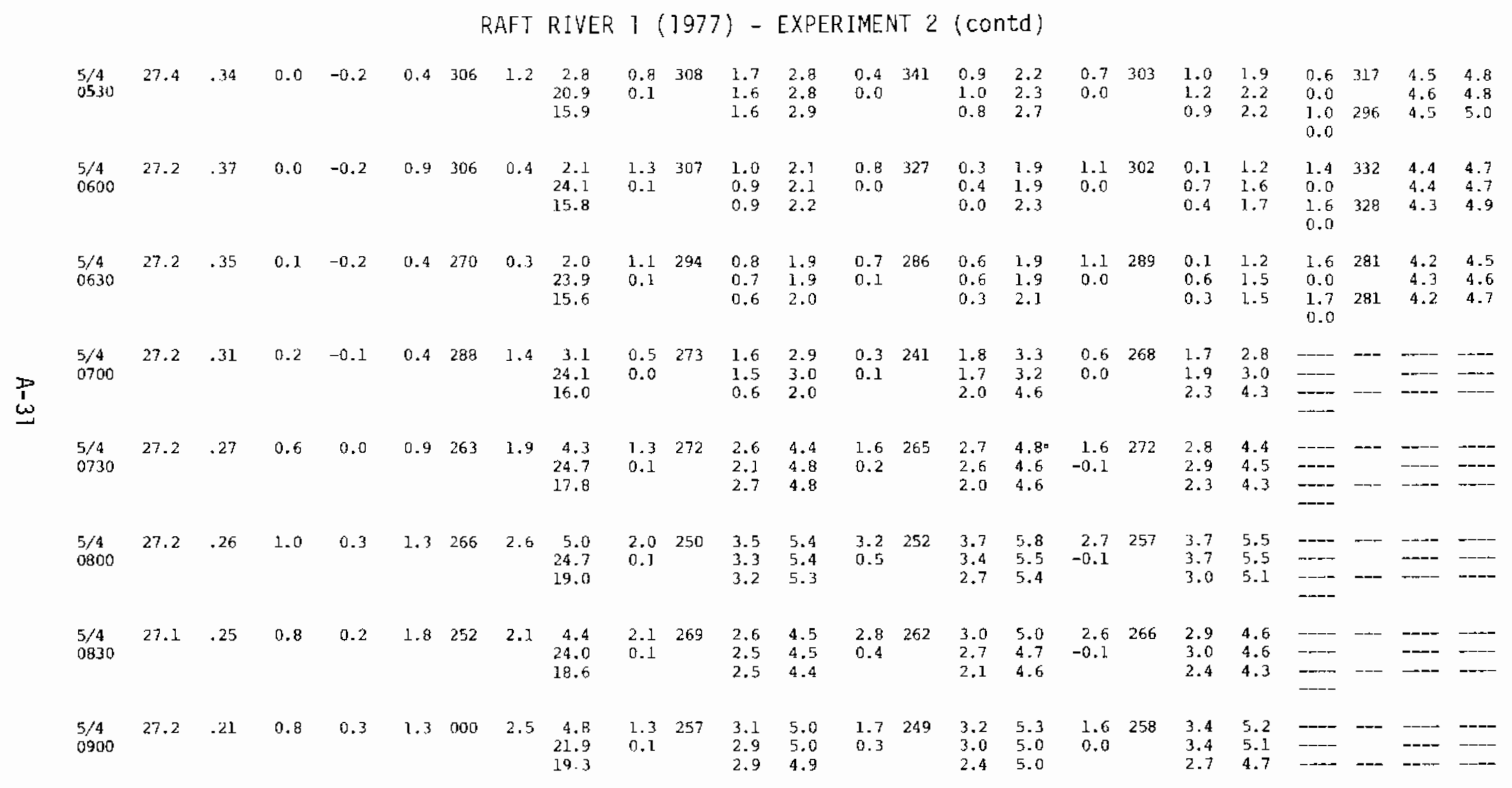


RAFT RIVER 1 (1977) - EXPERIMENT 2 (contd)

\begin{tabular}{|c|c|c|c|c|c|c|c|c|c|c|c|c|c|c|c|c|c|c|c|c|c|c|c|}
\hline $\begin{array}{l}5 / 4 \\
0930\end{array}$ & 27.0 & .23 & 1.0 & 0.1 & 1.3 & 036 & 3.1 & $\begin{array}{r}5.6 \\
22.0 \\
19.7\end{array}$ & $\begin{array}{l}1.9 \\
0.0\end{array}$ & 043 & $\begin{array}{l}2.5 \\
2.5 \\
2.5\end{array}$ & $\begin{array}{l}4.6 \\
4.6 \\
4.5\end{array}$ & $\begin{array}{l}1.9 \\
0.0\end{array}$ & 051 & $\begin{array}{l}2.5 \\
2.5 \\
2.0\end{array}$ & $\begin{array}{l}4.9 \\
4.6 \\
4.7\end{array}$ & $\begin{array}{l}1.7 \\
0.0\end{array}$ & 044 & $\begin{array}{l}3.2 \\
3.2 \\
2.5\end{array}$ & $\begin{array}{l}4.9 \\
4.8 \\
4.5\end{array}$ & $\begin{array}{l}---- \\
--- \\
---\end{array}$ & --- & $\begin{array}{l}---- \\
---- \\
---\end{array}$ \\
\hline $\begin{array}{l}5 / 4 \\
1000\end{array}$ & 27.0 & .26 & 0.5 & 0.2 & 0.9 & 000 & 2.8 & $\begin{array}{r}5.6 \\
21.7 \\
19.4\end{array}$ & $\begin{array}{l}1.3 \\
0.1\end{array}$ & 350 & $\begin{array}{l}2.3 \\
2.3 \\
2.4\end{array}$ & $\begin{array}{l}4.6 \\
4.6 \\
4.5\end{array}$ & $\begin{array}{l}0.9 \\
0.1\end{array}$ & 011 & $\begin{array}{l}2.3 \\
2.4 \\
1.9\end{array}$ & $\begin{array}{l}5.0 \\
4.7 \\
4.8\end{array}$ & $\begin{array}{l}1.1 \\
0.0\end{array}$ & 352 & $\begin{array}{l}2.8 \\
2.9 \\
2.2\end{array}$ & $\begin{array}{l}4.9 \\
4.8 \\
4.5\end{array}$ & $\begin{array}{l}---- \\
--- \\
---\end{array}$ & & $\begin{array}{l}---- \\
---- \\
---\end{array}$ \\
\hline
\end{tabular}


APPENDIX B

RAFT RIVER 2 DATA VOLUME 
RAFT RIVER 2 (1978) - COOL I

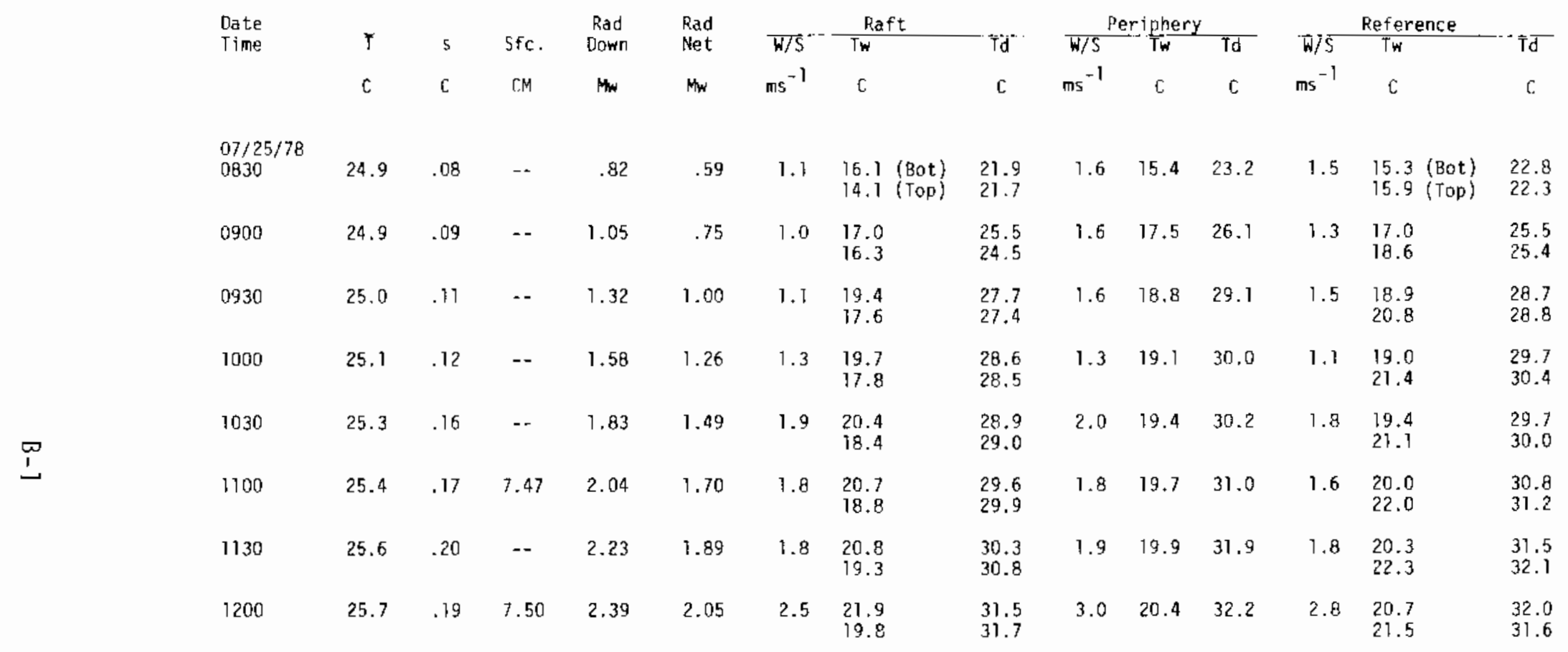


RAFT RIVER 2 (1978) - COOL I (contd)

\begin{tabular}{|c|c|c|c|c|c|c|c|c|c|c|c|c|c|c|c|}
\hline & 1230 & 25.9 & 19 & -. & 2.43 & 2.17 & 3.5 & $\begin{array}{l}20.6 \\
20.0\end{array}$ & $\begin{array}{l}33.0 \\
32.1\end{array}$ & 4.1 & 20.7 & 32.5 & 3.7 & $\begin{array}{l}21.0 \\
21.4\end{array}$ & $\begin{array}{r}32.6 \\
37.6\end{array}$ \\
\hline & 1300 & 26.0 & .20 & 7.51 & 2.51 & 2.26 & 2.1 & $\begin{array}{l}22.3 \\
20.2\end{array}$ & $\begin{array}{l}32.1 \\
32.2\end{array}$ & 2.6 & 20.9 & 32.8 & 2.0 & $\begin{array}{l}21.4 \\
22.3\end{array}$ & $\begin{array}{l}33.2 \\
32.4\end{array}$ \\
\hline & 1330 & 26.2 & .19 & -- & 2.60 & 2.34 & 1.8 & $\begin{array}{l}22.4 \\
20.2\end{array}$ & $\begin{array}{r}32.9 \\
33.0\end{array}$ & 2.2 & 21.1 & 33.7 & 1.8 & $\begin{array}{l}21.5 \\
22.3\end{array}$ & $\begin{array}{l}33.9 \\
33.0\end{array}$ \\
\hline & 1400 & 26.3 & .20 & 7.41 & 2.64 & 2.37 & 4.2 & $\begin{array}{l}22.8 \\
20.1\end{array}$ & $\begin{array}{l}33.9 \\
33.7\end{array}$ & 4.4 & 21.4 & 34.9 & 4.0 & $\begin{array}{l}21.7 \\
22.5\end{array}$ & $\begin{array}{l}35.2 \\
33.9\end{array}$ \\
\hline & 1430 & 26.5 & .21 & . & 2.67 & 2.35 & 3.2 & $\begin{array}{l}23.0 \\
20.1\end{array}$ & $\begin{array}{l}34.0 \\
33.8\end{array}$ & 3.5 & 21.3 & 35.1 & 3.2 & $\begin{array}{l}21.6 \\
22.9\end{array}$ & $\begin{array}{l}35.2 \\
34.2\end{array}$ \\
\hline & 1500 & 26.7 & .22 & 7.41 & 2.46 & 2.25 & 3.7 & $\begin{array}{l}23.3 \\
20.8\end{array}$ & $\begin{array}{l}34.1 \\
33.8\end{array}$ & 4.0 & 21.5 & 35.3 & 3.2 & $\begin{array}{l}22.1 \\
23.3\end{array}$ & $\begin{array}{l}35.2 \\
34.5\end{array}$ \\
\hline & 1530 & 26.8 & I 21 & -- & 2.42 & 2.21 & 4.3 & $\begin{array}{l}23.3 \\
20.2\end{array}$ & $\begin{array}{l}34.4 \\
34.1\end{array}$ & 4.5 & 21.4 & 35.1 & 4.1 & $\begin{array}{l}21.9 \\
22.4\end{array}$ & $\begin{array}{l}35.4 \\
34.0\end{array}$ \\
\hline N & 1600 & 26.9 & .21 & 7.23 & 2.33 & 2.06 & 5.4 & $\begin{array}{l}23.2 \\
20.7\end{array}$ & $\begin{array}{l}34.3 \\
34.0\end{array}$ & 5.9 & 21.1 & 34.8 & 5.5 & $\begin{array}{l}21.6 \\
21.8\end{array}$ & $\begin{array}{l}35.0 \\
33.5\end{array}$ \\
\hline & 1630 & 26.9 & .20 & -- & 2.20 & 1.90 & 5.3 & $\begin{array}{l}23.1 \\
20.0\end{array}$ & $\begin{array}{l}34.2 \\
33.9\end{array}$ & 5.4 & 21.3 & 34.9 & 5.0 & $\begin{array}{l}21.7 \\
22.1\end{array}$ & $\begin{array}{l}35.1 \\
33.5\end{array}$ \\
\hline & 1700 & 27.0 & .18 & - & 2.00 & 1.70 & 4.5 & $\begin{array}{l}22.7 \\
19.7\end{array}$ & $\begin{array}{l}33.7 \\
33.5\end{array}$ & 4.5 & 21.1 & 34.7 & 4.4 & $\begin{array}{l}21.4 \\
22.2\end{array}$ & $\begin{array}{l}34.7 \\
33.4\end{array}$ \\
\hline & 1730 & 27.0 & .17 & -. & 1.76 & 1.48 & 4.3 & $\begin{array}{r}22.5 \\
19.5\end{array}$ & $\begin{array}{l}33.4 \\
33.1\end{array}$ & 4.5 & 20.8 & 34.3 & 4.2 & $\begin{array}{l}21.1 \\
21.9\end{array}$ & $\begin{array}{r}34.4 \\
33.0\end{array}$ \\
\hline
\end{tabular}


RAFT RIVER 2 (1978) - COOL I (contd)

\begin{tabular}{|c|c|c|c|c|c|c|c|c|c|c|c|c|c|c|c|}
\hline & 1800 & 26.9 & .13 & -- & 1.51 & 1.22 & 4.3 & $\begin{array}{l}22.6 \\
19.6\end{array}$ & $\begin{array}{l}33.4 \\
33.2\end{array}$ & 4.3 & 20.8 & 34.2 & 4.1 & $\begin{array}{l}21.2 \\
22.0\end{array}$ & $\begin{array}{l}34.2 \\
33.1\end{array}$ \\
\hline & 1830 & 26.9 & זו. & -- & 1.25 & .95 & 4.2 & $\begin{array}{l}22.3 \\
19.4\end{array}$ & $\begin{array}{l}33.0 \\
32.9\end{array}$ & 4.5 & 20.4 & 33.0 & 4.2 & $\begin{array}{l}20.9 \\
21.6\end{array}$ & $\begin{array}{l}33.6 \\
32.6\end{array}$ \\
\hline & 1900 & 26.8 & .10 & -- & .97 & .67 & 4.2 & $\begin{array}{l}22.0 \\
19.2\end{array}$ & $\begin{array}{l}32.6 \\
32.4\end{array}$ & 4.3 & 20.2 & 33.0 & 4.0 & $\begin{array}{l}20.6 \\
21.4\end{array}$ & $\begin{array}{l}33.1 \\
32.1\end{array}$ \\
\hline & 1930 & 26.6 & .10 & -- & .71 & .40 & 4.6 & $\begin{array}{l}21.9 \\
19.0\end{array}$ & $\begin{array}{l}32.4 \\
32.2\end{array}$ & 4.8 & 19.9 & 32.4 & 4.5 & $\begin{array}{l}20.3 \\
21.0\end{array}$ & $\begin{array}{l}32.4 \\
31.7\end{array}$ \\
\hline & 2000 & 26.5 & .12 & -- & .45 & .16 & 3.8 & $\begin{array}{l}21.7 \\
18.8\end{array}$ & $\begin{array}{l}31.8 \\
31.9\end{array}$ & 4.0 & 19.4 & 31.7 & 3.8 & $\begin{array}{r}19.8 \\
20.9\end{array}$ & $\begin{array}{l}31.8 \\
31.2\end{array}$ \\
\hline & 2039 & 26.3 & .12 & -. & .21 & -.06 & 2.7 & $\begin{array}{l}21.3 \\
18.7\end{array}$ & $\begin{array}{l}21.1 \\
31.3\end{array}$ & 3.0 & 18.7 & 30.5 & 2.7 & $\begin{array}{l}19.0 \\
20.5\end{array}$ & $\begin{array}{l}30.5 \\
30.3\end{array}$ \\
\hline & 2100 & 26.2 & .11 & -- & 0 & -.11 & 1.7 & $\begin{array}{l}18.8 \\
16.8\end{array}$ & $\begin{array}{l}27.8 \\
28.3\end{array}$ & 2.3 & 16.9 & 27.6 & 1.8 & $\begin{array}{l}17.1 \\
18.8\end{array}$ & $\begin{array}{l}27.5 \\
28.0\end{array}$ \\
\hline 1 & 2130 & 26.0 & .10 & -- & 0 & -.13 & 0.7 & $\begin{array}{l}17.3 \\
15.8\end{array}$ & $\begin{array}{l}25.1 \\
26.1\end{array}$ & 1.0 & 16.0 & 25.5 & 0.9 & $\begin{array}{l}16.2 \\
17.7\end{array}$ & $\begin{array}{l}25.6 \\
26.4\end{array}$ \\
\hline & 2200 & 26.0 & .12 & -- & 0 & -.13 & 0.6 & $\begin{array}{l}16.7 \\
15.5\end{array}$ & $\begin{array}{l}23.9 \\
25.7\end{array}$ & 1.0 & 15.5 & 24.9 & 0.8 & $\begin{array}{l}16.0 \\
17.9\end{array}$ & $\begin{array}{l}25.4 \\
26.7\end{array}$ \\
\hline & 2230 & 25.9 & .10 & -- & 0 & -.14 & 0.4 & $\begin{array}{l}15.6 \\
15.3\end{array}$ & $\begin{array}{l}22.2 \\
25.3\end{array}$ & 0.4 & 15.0 & 23.9 & 0.6 & $\begin{array}{l}15.1 \\
16.3\end{array}$ & $\begin{array}{l}23.5 \\
23.0\end{array}$ \\
\hline & 2300 & 25.8 & 11 & -- & 0 & -.14 & 0.1 & $\begin{array}{l}14.6 \\
13.7\end{array}$ & $\begin{array}{l}20.8 \\
22.4\end{array}$ & 0.3 & 13.6 & 21.3 & 0.5 & $\begin{array}{l}13.5 \\
15.7\end{array}$ & $\begin{array}{l}20.9 \\
22.3\end{array}$ \\
\hline
\end{tabular}




\section{RAFT RIVER 2 (1978) - COOL I (contd)}

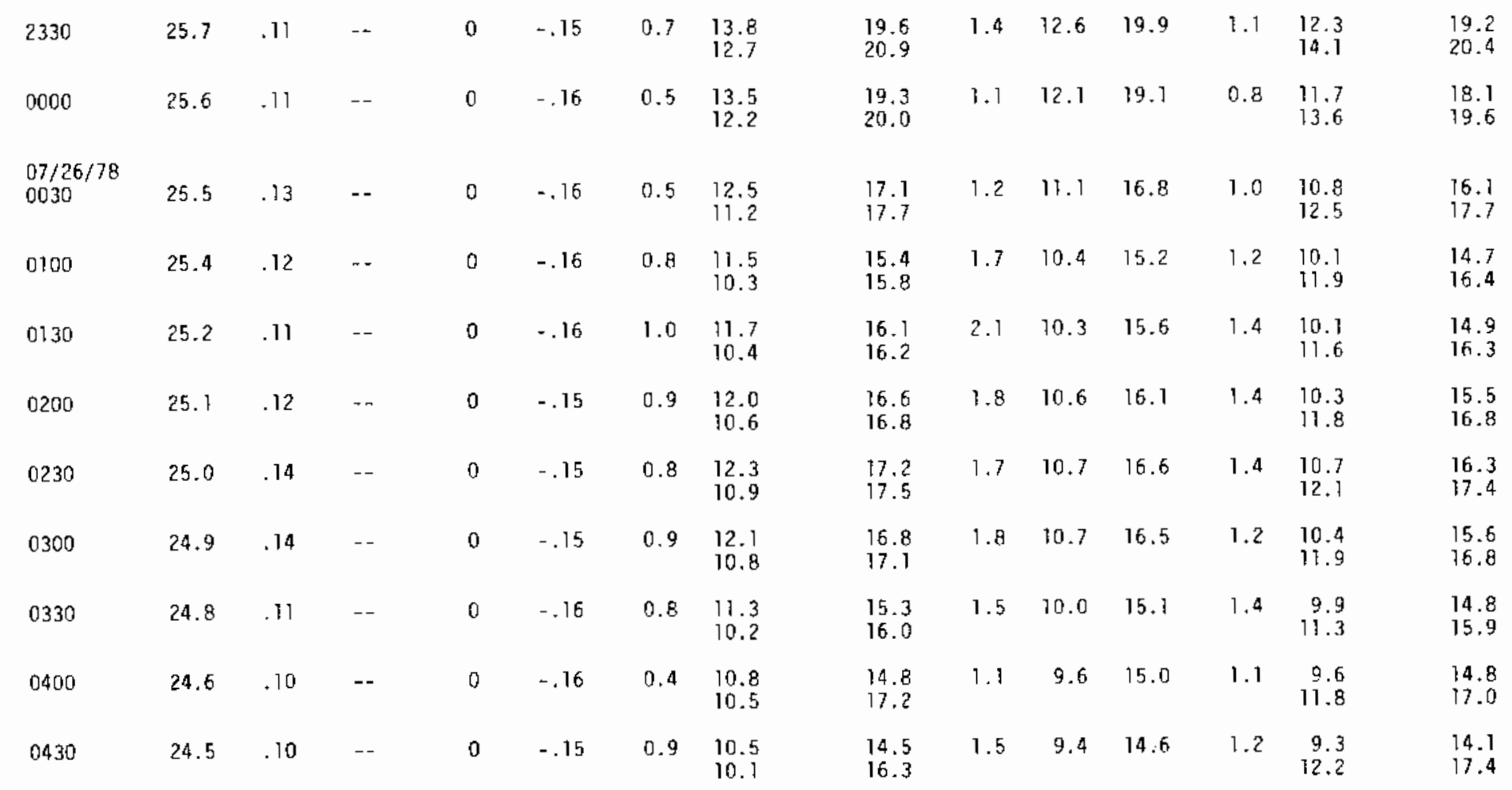


RAFT RIVER 2 (1978) - COOL I (contd)

占

\begin{tabular}{|c|c|c|c|c|c|c|c|c|c|c|c|c|c|c|}
\hline 0500 & 24.4 & 11 & 6.67 & 0 & -.16 & 0.4 & $\begin{array}{r}10.6 \\
9.6\end{array}$ & $\begin{array}{l}14.3 \\
15.0\end{array}$ & 1.1 & 9.1 & 13.8 & 1.0 & $\begin{array}{r}9.0 \\
10.8\end{array}$ & $\begin{array}{l}13.4 \\
15.0\end{array}$ \\
\hline 0530 & 24.3 & .11 & -. & 0 & -.16 & 0.7 & $\begin{array}{l}9.8 \\
8.9\end{array}$ & $\begin{array}{l}13.3 \\
14.2\end{array}$ & 1.4 & 8.6 & 13.1 & 1.3 & $\begin{array}{r}8.3 \\
10.1\end{array}$ & $\begin{array}{l}12.5 \\
14.0\end{array}$ \\
\hline 0600 & 24.2 & .13 & 6.67 & 0 & -.16 & 1.4 & $\begin{array}{l}9.8 \\
8.9\end{array}$ & $\begin{array}{l}13.3 \\
13.9\end{array}$ & 2.2 & 8.5 & 12.8 & 1.7 & $\begin{array}{r}8.4 \\
10.1\end{array}$ & $\begin{array}{l}12.3 \\
14.1\end{array}$ \\
\hline 0630 & 24.0 & .16 & - & .01 & -.16 & 1.5 & $\begin{array}{l}9.3 \\
8.4\end{array}$ & $\begin{array}{l}12.6 \\
12.8\end{array}$ & 2.3 & 8.2 & 12.1 & 1.7 & $\begin{array}{l}8.7 \\
9.3\end{array}$ & $\begin{array}{l}11.7 \\
12.7\end{array}$ \\
\hline 0700 & 23.9 & .16 & 6.61 & .06 & -.11 & 1.0 & $\begin{array}{l}9.9 \\
8.8\end{array}$ & $\begin{array}{l}13.2 \\
13.6\end{array}$ & 1.6 & 8.8 & 13.2 & 1.4 & $\begin{array}{l}8.5 \\
9.9\end{array}$ & $\begin{array}{l}12.4 \\
13.8\end{array}$ \\
\hline 0730 & 23.8 & .12 & $\ldots$ & .27 & .06 & 1.2 & $\begin{array}{l}11.7 \\
10.2\end{array}$ & $\begin{array}{l}15.4 \\
15.2\end{array}$ & 1.7 & 11.0 & 16.1 & 1.5 & $\begin{array}{l}30.5 \\
11.6\end{array}$ & $\begin{array}{l}15.3 \\
16.1\end{array}$ \\
\hline 0800 & 23.8 & 11 & 6.55 & .53 & .31 & 0.9 & $\begin{array}{l}13.3 \\
11.8\end{array}$ & $\begin{array}{l}18.0 \\
17.8\end{array}$ & 1.3 & 12.9 & 19.1 & 1.1 & $\begin{array}{l}12.7 \\
13.2\end{array}$ & $\begin{array}{l}18.8 \\
18.0\end{array}$ \\
\hline 0830 & 23.9 & .12 & -- & .80 & .56 & 0.6 & $\begin{array}{r}15.8 \\
14.1\end{array}$ & $\begin{array}{l}21.1 \\
20.9\end{array}$ & 0.9 & 15.4 & 22.7 & 1.0 & $\begin{array}{l}15.2 \\
16.4\end{array}$ & $\begin{array}{l}22.2 \\
22.0\end{array}$ \\
\hline 0900 & 23.9 & .10 & 6.46 & 8.19 & .86 & 2.1 & $\begin{array}{l}17.2 \\
15.5\end{array}$ & $\begin{array}{l}24.0 \\
23.6\end{array}$ & 2.3 & 16.6 & 24.4 & 1.8 & $\begin{array}{l}16.2 \\
16.9\end{array}$ & $\begin{array}{l}24.0 \\
23.7\end{array}$ \\
\hline 0930 & 24.0 & .11 & - & 1.33 & 1.00 & 2.4 & $\begin{array}{l}17.4 \\
15.6\end{array}$ & $\begin{array}{l}24.7 \\
24.5\end{array}$ & 2.4 & 16.7 & 24.7 & 2.3 & $\begin{array}{l}16.2 \\
17.0\end{array}$ & $\begin{array}{r}25.0 \\
24.5\end{array}$ \\
\hline 1000 & 24.0 & 11 & -- & 1.58 & 1.27 & 3.1 & $\begin{array}{l}18.3 \\
16.3\end{array}$ & $\begin{array}{l}25.7 \\
25.8\end{array}$ & 3.2 & 17.3 & 26.3 & 2.8 & $\begin{array}{l}17.0 \\
17.5\end{array}$ & $\begin{array}{l}26.7 \\
25.5\end{array}$ \\
\hline
\end{tabular}




\section{RAFT RIVER 2 (1978) - COOL I (contd)}

\begin{tabular}{|c|c|c|c|c|c|c|c|c|c|c|c|c|c|c|c|}
\hline & 1030 & 24.1 & .13 & -- & 1.82 & 1.50 & 2.7 & $\begin{array}{l}18.9 \\
16.9\end{array}$ & $\begin{array}{l}26.7 \\
26.8\end{array}$ & 2.9 & 17.7 & 27.3 & 2.3 & $\begin{array}{l}17.9 \\
18.4\end{array}$ & $\begin{array}{l}27.4 \\
26.7\end{array}$ \\
\hline & 1100 & 24.2 & .16 & 6.39 & 2.04 & 1.70 & 2.8 & $\begin{array}{l}19.6 \\
17.8\end{array}$ & $\begin{array}{l}26.9 \\
27.1\end{array}$ & 3.1 & 18.8 & 28.2 & 3.0 & $\begin{array}{l}18.9 \\
79.3\end{array}$ & $\begin{array}{l}27.7 \\
27.0\end{array}$ \\
\hline & 1130 & 24.4 & .18 & -- & 2.21 & 1.92 & 2.7 & $\begin{array}{l}20.2 \\
18.5\end{array}$ & $\begin{array}{l}28.4 \\
28.9\end{array}$ & 2.9 & 19.1 & 29.4 & 2.8 & $\begin{array}{l}19.4 \\
19.9\end{array}$ & $\begin{array}{l}29.4 \\
28.7\end{array}$ \\
\hline & 1200 & 24.5 & .18 & 6.35 & 2.30 & 2.08 & 3.6 & $\begin{array}{l}21.1 \\
19.0\end{array}$ & $\begin{array}{l}29.7 \\
29.9\end{array}$ & 3.7 & 19.5 & 30.0 & 3.2 & $\begin{array}{l}19.7 \\
20.1\end{array}$ & $\begin{array}{l}30.3 \\
29.3\end{array}$ \\
\hline & 1230 & 24.6 & .20 & -. & 2.41 & 2.20 & 3.7 & $\begin{array}{l}21.5 \\
19.4\end{array}$ & $\begin{array}{l}30.6 \\
30.7\end{array}$ & 3.8 & 20.0 & 30.8 & 3.3 & $\begin{array}{l}20.1 \\
20.4\end{array}$ & $\begin{array}{l}31.2 \\
30.1\end{array}$ \\
\hline & 1300 & 24.8 & .20 & 6.22 & 2.51 & 2.30 & 3.3 & $\begin{array}{l}21.8 \\
19.6\end{array}$ & $\begin{array}{l}31.0 \\
31.1\end{array}$ & 3.4 & 20.2 & 31.4 & 2.9 & $\begin{array}{l}20.5 \\
21.0\end{array}$ & $\begin{array}{l}32.1 \\
31.0\end{array}$ \\
\hline & 1330 & 25.1 & .16 & -. & 2.60 & 2.37 & 2.3 & $\begin{array}{l}22.0 \\
20.0\end{array}$ & $\begin{array}{l}31.8 \\
32.0\end{array}$ & 2.6 & 20.7 & 32.2 & 2.2 & $\begin{array}{l}21.0 \\
21.7\end{array}$ & $\begin{array}{l}33.0 \\
32.1\end{array}$ \\
\hline $\begin{array}{l}\infty \\
1 \\
0\end{array}$ & 1400 & 25.3 & .18 & 6.21 & 2.64 & 2.38 & 2.6 & $\begin{array}{l}22.9 \\
20.6\end{array}$ & $\begin{array}{l}33.1 \\
32.9\end{array}$ & 2.8 & 21.4 & 33.2 & 2.7 & $\begin{array}{l}21.7 \\
22.3\end{array}$ & $\begin{array}{r}33.6 \\
32.7\end{array}$ \\
\hline & 1430 & 25.6 & .20 & -- & 2.63 & 2.36 & 3.0 & $\begin{array}{l}23.5 \\
20.8\end{array}$ & $\begin{array}{l}33.8 \\
33.4\end{array}$ & 3.5 & 21,4 & 33.7 & 3.2 & $\begin{array}{l}21.6 \\
22.5\end{array}$ & $\begin{array}{r}33.8 \\
33.2\end{array}$ \\
\hline & 1500 & 25.7 & .21 & 6.19 & 2.54 & 2.30 & 2.6 & $\begin{array}{l}23.7 \\
20.8\end{array}$ & $\begin{array}{l}34.2 \\
33.9\end{array}$ & 3.2 & 21.4 & 34.7 & 2.8 & $\begin{array}{l}21.9 \\
22.9\end{array}$ & $\begin{array}{l}34.4 \\
33.8\end{array}$ \\
\hline & 1530 & 26.0 & .23 & -- & 2.39 & 2.16 & 2.6 & $\begin{array}{l}23.9 \\
21.0\end{array}$ & $\begin{array}{l}34.6 \\
34.3\end{array}$ & 3.2 & 21.8 & 34.7 & 2.6 & $\begin{array}{l}22.1 \\
23.2\end{array}$ & $\begin{array}{l}34.7 \\
34.2\end{array}$ \\
\hline
\end{tabular}


RAFT RIVER 2 (1978) - COOL I (contd)

\begin{tabular}{|c|c|c|c|c|c|c|c|c|c|c|c|c|c|c|c|}
\hline & 1600 & 26.2 & .24 & 6.17 & 2.37 & 2.10 & 2.4 & $\begin{array}{l}24.0 \\
21.0\end{array}$ & $\begin{array}{l}35.0 \\
34.6\end{array}$ & 2.8 & 22.0 & 35.3 & 2.5 & $\begin{array}{l}22.2 \\
23.3\end{array}$ & $\begin{array}{l}35.2 \\
34.6\end{array}$ \\
\hline & 1630 & 26.4 & .23 & -- & 2.18 & 1.90 & 1.7 & $\begin{array}{l}23.8 \\
20.8\end{array}$ & $\begin{array}{l}35.0 \\
34.6\end{array}$ & 2.0 & 21.9 & 35.2 & 1.7 & $\begin{array}{l}22.0 \\
23.4\end{array}$ & $\begin{array}{l}35.2 \\
35.1\end{array}$ \\
\hline & 1700 & 26.5 & .19 & -. & 1.99 & 1.71 & 2.2 & $\begin{array}{l}23.9 \\
20.8\end{array}$ & $\begin{array}{l}35.3 \\
34.9\end{array}$ & 2.4 & 21.9 & 35.4 & 2.1 & $\begin{array}{l}22.1 \\
23.3\end{array}$ & $\begin{array}{l}35.6 \\
35.2\end{array}$ \\
\hline & 1730 & 26.6 & .15 & -- & 1.78 & 1.50 & 2.2 & $\begin{array}{l}23.9 \\
20.8\end{array}$ & $\begin{array}{l}35.3 \\
35.0\end{array}$ & 2.6 & 22.0 & 35.5 & 2.3 & $\begin{array}{l}22.2 \\
23.1\end{array}$ & $\begin{array}{l}35.5 \\
35.0\end{array}$ \\
\hline & 1800 & 26.5 & .13 & -- & .91 & .72 & 2.4 & $\begin{array}{l}23.3 \\
20.4\end{array}$ & $\begin{array}{l}34.4 \\
34.1\end{array}$ & 2.9 & 21.5 & 34.5 & 2.7 & $\begin{array}{l}21.8 \\
22.6\end{array}$ & $\begin{array}{l}34.4 \\
34.1\end{array}$ \\
\hline & I830 & 26.5 & .12 & - & .87 & .67 & 2.0 & $\begin{array}{l}23.1 \\
20.1\end{array}$ & $\begin{array}{l}34.6 \\
34.4\end{array}$ & 2.2 & 21.0 & 34.6 & 2.1 & $\begin{array}{l}21.4 \\
22.4\end{array}$ & $\begin{array}{l}34.4 \\
34.1\end{array}$ \\
\hline & 1900 & 26.4 & .11 & -- & .48 & .38 & 2.9 & $\begin{array}{l}22.4 \\
19.6\end{array}$ & $\begin{array}{l}33.8 \\
33.8\end{array}$ & 3.1 & 20.4 & 34.0 & 2.4 & $\begin{array}{l}20.6 \\
21.7\end{array}$ & $\begin{array}{l}34.2 \\
33.8\end{array}$ \\
\hline 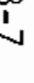 & 1930 & 26.3 & .10 & -- & .36 & .30 & 1.5 & $\begin{array}{l}22.1 \\
19.6\end{array}$ & $\begin{array}{l}32.3 \\
32.3\end{array}$ & 1.8 & 20.4 & 32.5 & 1.8 & $\begin{array}{l}20.6 \\
21.5\end{array}$ & $\begin{array}{l}32.0 \\
31.9\end{array}$ \\
\hline & 2000 & 26.3 & .11 & -- & .19 & .14 & 0.2 & $\begin{array}{l}21.5 \\
19.2\end{array}$ & $\begin{array}{l}31.0 \\
31.1\end{array}$ & 0.4 & 19.9 & 31.2 & 0.2 & $\begin{array}{l}20.0 \\
21.2\end{array}$ & $\begin{array}{l}31.1 \\
30.4\end{array}$ \\
\hline & 2030 & 26.2 & .10 & -- & .13 & .07 & 0.5 & $\begin{array}{l}21.3 \\
18.9\end{array}$ & $\begin{array}{l}31.7 \\
31.5\end{array}$ & 0.4 & 19.4 & 31.1 & 0.3 & $\begin{array}{l}19.6 \\
20.7\end{array}$ & $\begin{array}{l}31.0 \\
30.4\end{array}$ \\
\hline & 2100 & 26.2 & .10 & -- & 0 & -.04 & 0.8 & $\begin{array}{r}19.6 \\
17.9\end{array}$ & $\begin{array}{l}28.3 \\
29.6\end{array}$ & 0.8 & 18.0 & 28.8 & 0.7 & $\begin{array}{l}18.3 \\
19.9\end{array}$ & $\begin{array}{l}28.7 \\
28.9\end{array}$ \\
\hline
\end{tabular}




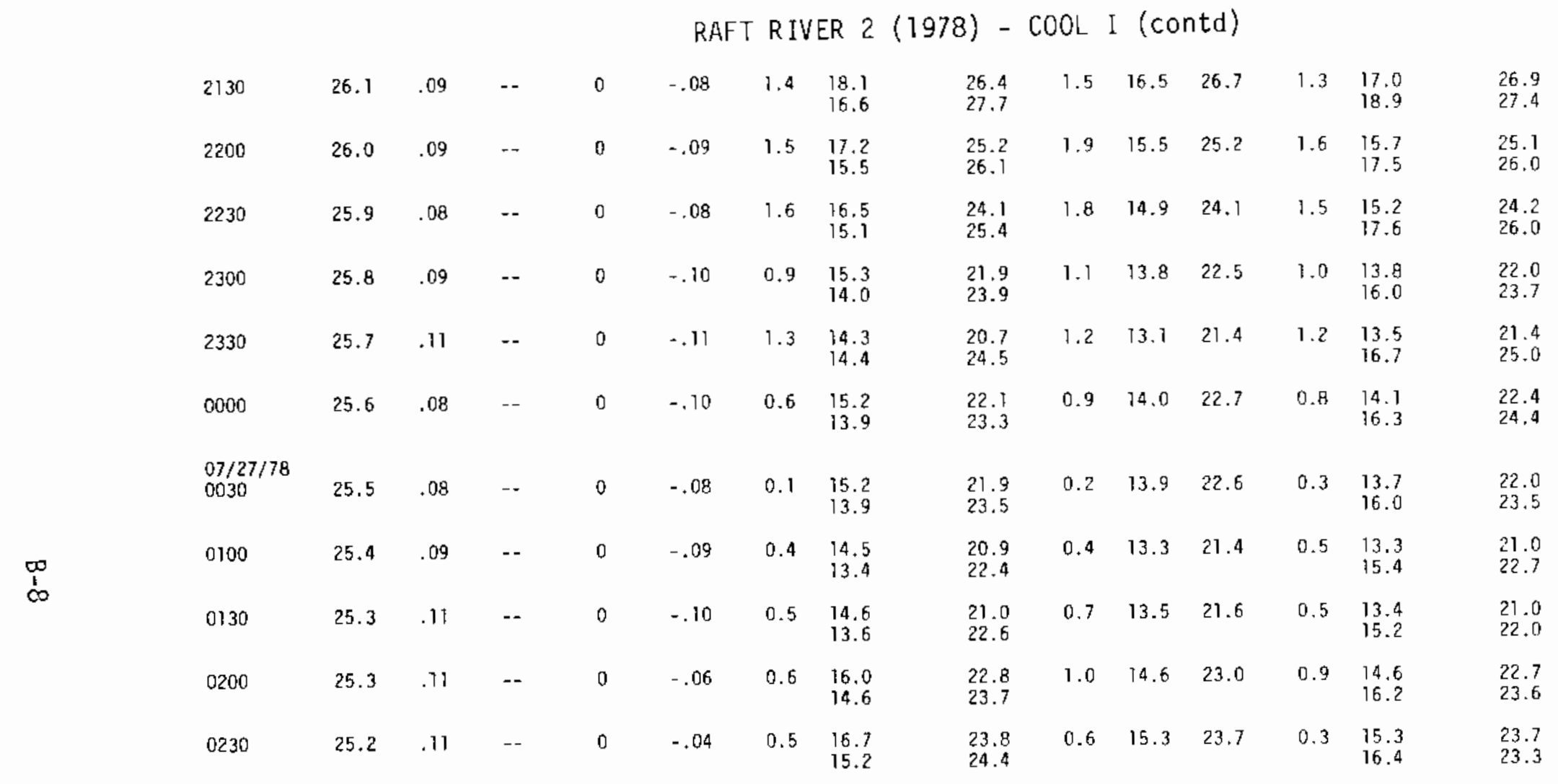




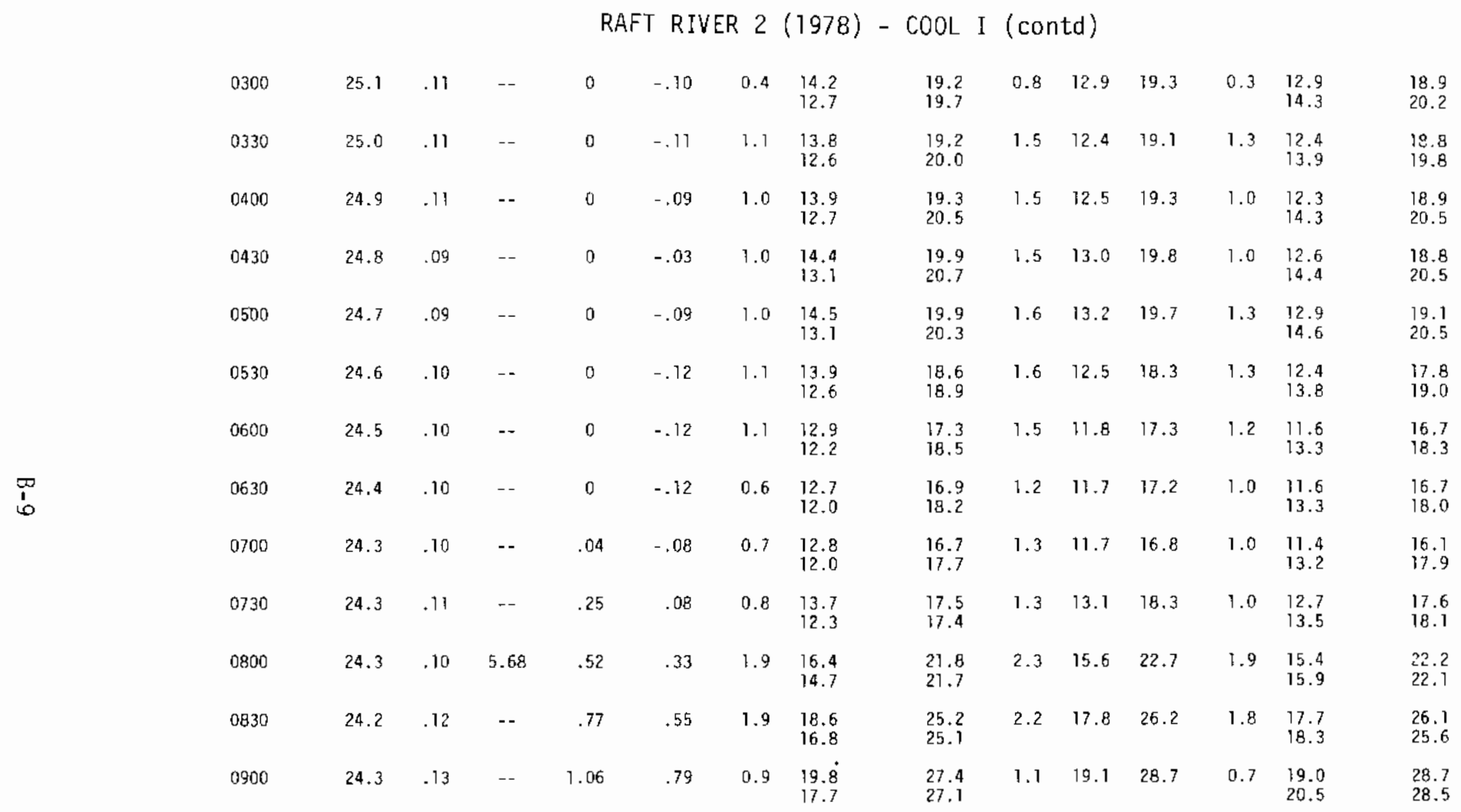


RAFT RIVER 2 (1978) - HOT I

\begin{tabular}{|c|c|c|c|c|c|c|c|c|c|c|c|c|c|c|c|}
\hline & \multirow{3}{*}{$\begin{array}{l}\text { Date } \\
\text { Time }\end{array}$} & & & & Rad & $\operatorname{Rad}$ & \multicolumn{3}{|c|}{ Raft } & \multicolumn{3}{|c|}{ Periptiery } & \multicolumn{3}{|c|}{ Reference } \\
\hline & & $\top^{\top}$ & $s$ & Sfc. & Down & Net & W/S & $T_{w}$ & $\overline{T d}$ & $W / 5$ & $f_{w}$ & Td & $\bar{W} / \bar{S}$ & $T_{W}$ & $T d$ \\
\hline & & $c$ & $c$ & CM & $M$ & Mw & $\mathrm{ms}^{-1}$ & $c$ & $c$ & $\mathrm{~ms}^{-1}$ & $c$ & C & $\mathrm{ms}^{-1}$ & c & $c$ \\
\hline & $\begin{array}{l}07 / 30 / 78 \\
1430\end{array}$ & 61.1 & .34 & -.-- & & & 1.1 & $\begin{array}{l}24.3 \text { (Bot) } \\
21.1 \text { (Top) }\end{array}$ & $\begin{array}{l}33.4 \\
32.4\end{array}$ & 1.3 & 22.1 & 32.5 & $\begin{array}{l}1.0 \\
1.4\end{array}$ & $\begin{array}{l}20.6 \text { (8ot) } \\
23.5 \text { (Top) }\end{array}$ & $\begin{array}{l}32.2 \\
31.8\end{array}$ \\
\hline & 1500 & 60.0 & .24 & ----- & 2.33 & 1.54 & 2.0 & $\begin{array}{l}24.8 \\
21.4\end{array}$ & $\begin{array}{l}34.3 \\
33.3\end{array}$ & 1.9 & 22.3 & 33.2 & $\begin{array}{l}1.6 \\
1.7\end{array}$ & $\begin{array}{l}21.4 \\
24.1\end{array}$ & $\begin{array}{l}33.1 \\
32.7\end{array}$ \\
\hline & 1530 & 59.3 & .34 & $\cdots--$ & 2.57 & 1.80 & 1.1 & $\begin{array}{l}24.8 \\
21.6\end{array}$ & $\begin{array}{l}34.7 \\
33.8\end{array}$ & 1.1 & 22.7 & 33.8 & $\begin{array}{l}0.8 \\
1.0\end{array}$ & $\begin{array}{l}21.7 \\
24.4\end{array}$ & $\begin{array}{l}33.7 \\
33.7\end{array}$ \\
\hline & 1600 & 58.4 & .30 & 10.28 & 2.16 & 1.45 & 2.2 & $\begin{array}{l}24.8 \\
21.4\end{array}$ & $\begin{array}{l}34.6 \\
33.6\end{array}$ & 2.4 & 22.1 & 33.5 & $\begin{array}{l}2.0 \\
2.2\end{array}$ & $\begin{array}{l}21.9 \\
24.4\end{array}$ & $\begin{array}{l}33.6 \\
32.7\end{array}$ \\
\hline & 1630 & 57.5 & .46 & $-\cdots$ & 2.12 & 1.44 & 1.4 & $\begin{array}{l}24.3 \\
21.1\end{array}$ & $\begin{array}{l}34.3 \\
33.4\end{array}$ & 1.6 & 21.8 & 33.3 & 1.7 & $\begin{array}{l}21.2 \\
23.8\end{array}$ & $\begin{array}{l}33.5 \\
32.5\end{array}$ \\
\hline 5 & 1700 & 56.8 & .25 & 10.25 & 1.22 & .61 & 1.6 & $\begin{array}{l}23.6 \\
20.9\end{array}$ & $\begin{array}{l}33.9 \\
33.9\end{array}$ & 1.9 & 22.3 & 33.3 & $\begin{array}{l}1.8 \\
2.2\end{array}$ & $\begin{array}{l}21.3 \\
24.0\end{array}$ & $\begin{array}{l}32.9 \\
32.4\end{array}$ \\
\hline & 1730 & 56.0 & .23 & ---- & 1.37 & .77 & 2.4 & $\begin{array}{l}24.1 \\
20.8\end{array}$ & $\begin{array}{l}34.0 \\
33.1\end{array}$ & 2.3 & 22.2 & 33.4 & 2.1 & $\begin{array}{l}21.2 \\
23.8\end{array}$ & $\begin{array}{l}32.9 \\
32.5\end{array}$ \\
\hline & 1800 & 55.3 & .24 & 9.93 & 1.08 & .47 & 1.4 & $\begin{array}{l}24.0 \\
21.1\end{array}$ & $\begin{array}{l}33.8 \\
33.0\end{array}$ & 1.3 & 22.0 & 33.2 & 1.1 & $\begin{array}{l}21.3 \\
23.9\end{array}$ & $\begin{array}{l}32.9 \\
32.5\end{array}$ \\
\hline & 1830 & 54.7 & .24 & $\cdots$ & .79 & .22 & 1.6 & $\begin{array}{l}23.9 \\
21.0\end{array}$ & $\begin{array}{l}33.5 \\
32.8\end{array}$ & 1.7 & 22.3 & 32.7 & $\begin{array}{l}1.4 \\
1.5\end{array}$ & $\begin{array}{l}21.5 \\
23.8\end{array}$ & $\begin{array}{l}32.4 \\
32.0\end{array}$ \\
\hline
\end{tabular}


RAFT RIVER 2 (1978) - HOT I (contd)

\begin{tabular}{|c|c|c|c|c|c|c|c|c|c|c|c|c|c|c|}
\hline 1900 & 53.9 & .30 & 9.52 & .36 & -.07 & 2.7 & $\begin{array}{l}22.9 \\
19.8\end{array}$ & $\begin{array}{l}32.4 \\
31.7\end{array}$ & 2.9 & 21.0 & 31.6 & $\begin{array}{l}2.4 \\
\cdots\end{array}$ & $\begin{array}{l}20.1 \\
22.7\end{array}$ & $\begin{array}{l}31.2 \\
31.0\end{array}$ \\
\hline 1930 & 53.3 & .42 & ---- & .50 & -.05 & 3.5 & $\begin{array}{l}22.9 \\
19.8\end{array}$ & $\begin{array}{l}33.1 \\
32.4\end{array}$ & 3.9 & 20.9 & 32.1 & $\begin{array}{l}3.4 \\
--\end{array}$ & $\begin{array}{l}19.9 \\
22.8\end{array}$ & $\begin{array}{l}31.8 \\
31.6\end{array}$ \\
\hline 2000 & 52.7 & .44 & 9.02 & .45 & -.19 & 4.0 & $\begin{array}{l}23.5 \\
20.1\end{array}$ & $\begin{array}{l}33.5 \\
32.7\end{array}$ & 4.7 & 20.9 & 31.9 & 4.2 & $\begin{array}{l}19.9 \\
22.8\end{array}$ & $\begin{array}{l}31.6 \\
31.4\end{array}$ \\
\hline 2030 & 52.3 & .36 & ----- & .18 & -.41 & 2.9 & $\begin{array}{l}22.7 \\
19.6\end{array}$ & $\begin{array}{l}32.0 \\
31.3\end{array}$ & 3.7 & 20.3 & 30.8 & 3.1 & $\begin{array}{l}19.3 \\
22.2\end{array}$ & $\begin{array}{l}30.4 \\
30.6\end{array}$ \\
\hline 2100 & 51.7 & .25 & 8.57 & 0 & -.42 & 1.6 & $\begin{array}{l}20.5 \\
17.7\end{array}$ & $\begin{array}{l}28.6 \\
28.0\end{array}$ & 2.3 & 18.4 & 27.7 & 1.9 & $\begin{array}{l}17.5 \\
20.5\end{array}$ & $\begin{array}{l}27.3 \\
28.2\end{array}$ \\
\hline 2130 & 51.1 & .25 & $-\ldots$ & 0 & -.49 & 0.4 & $\begin{array}{l}19.4 \\
17.8\end{array}$ & $\begin{array}{l}26.4 \\
26.0\end{array}$ & 0.6 & 16.3 & 24.7 & $\begin{array}{l}0.4 \\
0.3\end{array}$ & $\begin{array}{l}16.2 \\
18.5\end{array}$ & $\begin{array}{l}24.0 \\
25.3\end{array}$ \\
\hline 2200 & 50.6 & .63 & 8.31 & 0 & -.47 & 1.0 & $\begin{array}{l}18.7 \\
16.2\end{array}$ & $\begin{array}{l}24.3 \\
23.9\end{array}$ & 0.9 & 15.3 & 22.4 & $\begin{array}{l}0.8 \\
0.8\end{array}$ & $\begin{array}{l}15.1 \\
17.6\end{array}$ & $\begin{array}{r}22.0 \\
23.8\end{array}$ \\
\hline 2230 & 50.1 & .25 & -.-. & 0 & -.48 & 1.8 & $\begin{array}{l}18.1 \\
15.4\end{array}$ & $\begin{array}{l}23.0 \\
22.5\end{array}$ & 1.9 & 14.5 & 21.0 & $\begin{array}{l}1.9 \\
2.1\end{array}$ & $\begin{array}{l}14.4 \\
17.8\end{array}$ & $\begin{array}{l}20.7 \\
23.7\end{array}$ \\
\hline 2300 & 49.5 & .21 & 8.05 & 0 & -.42 & 1.7 & $\begin{array}{l}17.1 \\
14.6\end{array}$ & $\begin{array}{l}22.3 \\
22.0\end{array}$ & 2.0 & 13.8 & 20.5 & $\begin{array}{l}1.8 \\
2.2\end{array}$ & $\begin{array}{l}17.1 \\
17.4\end{array}$ & $\begin{array}{l}22.3 \\
23.5\end{array}$ \\
\hline 2330 & 48.9 & .23 & ----- & 0 & -.40 & 1.5 & $\begin{array}{l}16.8 \\
14.1\end{array}$ & $\begin{array}{l}21.8 \\
21.6\end{array}$ & 2.1 & 13.2 & 20.0 & $\begin{array}{l}1.5 \\
3.0\end{array}$ & $\begin{array}{l}13.2 \\
17.0\end{array}$ & $\begin{array}{r}19.9 \\
23.4\end{array}$ \\
\hline 0000 & 48.4 & .22 & $-\ldots$ & 0 & -.41 & 1.0 & 15.7 & 20.7 & 1.6 & 12.3 & 18.8 & 1.3 & 12.2 & 18.2 \\
\hline $\begin{array}{l}07 / 31 / 78 \\
0030\end{array}$ & 48.0 & .23 & ----- & 0 & -.40 & 1.2 & $\begin{array}{l}15.1 \\
12.6\end{array}$ & $\begin{array}{l}20.0 \\
19.8\end{array}$ & 1.5 & 12.2 & 18.4 & $\begin{array}{l}1.1 \\
1.9\end{array}$ & $\begin{array}{l}11.8 \\
14.6\end{array}$ & $\begin{array}{l}17.6 \\
20.2\end{array}$ \\
\hline
\end{tabular}


RAFT RIVER 2 (1978) - HOT I (contd)

\begin{tabular}{|c|c|c|c|c|c|c|c|c|c|c|c|c|c|c|c|}
\hline & 0100 & 47.5 & .22 & $\cdots$ & 0 & -.40 & 1.6 & $\begin{array}{l}14.9 \\
12.6\end{array}$ & $\begin{array}{l}18.5 \\
18.2\end{array}$ & 1.9 & 12.1 & 16.9 & $\begin{array}{l}1.6 \\
1.9\end{array}$ & $\begin{array}{l}11.8 \\
14.1\end{array}$ & $\begin{array}{l}16.2 \\
18.6\end{array}$ \\
\hline & 0130 & 47.0 & .26 & --.-- & 0 & -.40 & 1.4 & $\begin{array}{l}14.5 \\
12.3\end{array}$ & $\begin{array}{l}17.8 \\
17.3\end{array}$ & 1.8 & 12.0 & 16.2 & $\begin{array}{l}1.3 \\
1.9\end{array}$ & $\begin{array}{r}11.5 \\
13.4\end{array}$ & $\begin{array}{l}15.5 \\
17.4\end{array}$ \\
\hline & 0200 & 46.5 & .22 & ---- & 0 & -.39 & 1.3 & $\begin{array}{l}14.2 \\
11.8\end{array}$ & $\begin{array}{l}17.9 \\
17.6\end{array}$ & 1.7 & 11.3 & 16.3 & $\begin{array}{l}1.4 \\
2.2\end{array}$ & $\begin{array}{l}11.2 \\
13.3\end{array}$ & $\begin{array}{l}15.6 \\
17.7\end{array}$ \\
\hline & 0230 & 46.2 & .23 & ---- & 0 & -.38 & 1.2 & $\begin{array}{l}13.8 \\
11.4\end{array}$ & $\begin{array}{l}18.1 \\
17.8\end{array}$ & 1.6 & 10.5 & 16.3 & $\begin{array}{l}1.2 \\
2.1\end{array}$ & $\begin{array}{l}10.4 \\
13.0\end{array}$ & $\begin{array}{l}15.4 \\
17.8\end{array}$ \\
\hline & 0300 & 45.7 & .25 & $\ldots$ & 0 & -.34 & 1.7 & $\begin{array}{l}13.6 \\
11.5\end{array}$ & $\begin{array}{l}17.6 \\
17.2\end{array}$ & 2.0 & 17.2 & 16.2 & $\begin{array}{l}1.6 \\
2.3\end{array}$ & $\begin{array}{l}11.0 \\
12.8\end{array}$ & $\begin{array}{l}15.6 \\
16.9\end{array}$ \\
\hline & 0330 & 45.2 & .30 & $\ldots$ & 0 & -.35 & 1.2 & $\begin{array}{l}13.9 \\
11.9\end{array}$ & $\begin{array}{l}17.4 \\
16.7\end{array}$ & 1.6 & 11.5 & 15.8 & $\begin{array}{l}3.2 \\
1.9\end{array}$ & 11.3 & $\begin{array}{l}15.5 \\
16.6\end{array}$ \\
\hline & 0400 & 44.8 & .37 & $\ldots$ & 0 & -.38 & 0.6 & $\begin{array}{l}13.6 \\
12.0\end{array}$ & $\begin{array}{l}17.7 \\
17.4\end{array}$ & 0.9 & 11.8 & 16.5 & $\begin{array}{l}0.4 \\
1.1\end{array}$ & $\begin{array}{l}10.9 \\
12.5\end{array}$ & $\begin{array}{l}15.7 \\
16.9\end{array}$ \\
\hline & 0430 & 44.3 & .21 & $\ldots$ & 0 & -.38 & 0.1 & $\begin{array}{l}12.8 \\
11.2\end{array}$ & $\begin{array}{l}15.8 \\
15.6\end{array}$ & 0.3 & 10.6 & 14.2 & $\begin{array}{l}0.2 \\
0.0\end{array}$ & $\begin{array}{l}10.0 \\
11.4\end{array}$ & $\begin{array}{l}13.7 \\
15.1\end{array}$ \\
\hline & 0500 & 43.9 & .24 & ---- & 0 & -.36 & 1.4 & $\begin{array}{r}11.8 \\
9.9\end{array}$ & $\begin{array}{l}14.5 \\
13.8\end{array}$ & 1.7 & 9.2 & 12.7 & $\begin{array}{l}1.6 \\
2.2\end{array}$ & $\begin{array}{r}9.2 \\
10.7\end{array}$ & $\begin{array}{l}12.5 \\
14.0\end{array}$ \\
\hline & 0530 & 43.5 & .25 & ----- & 0 & -.38 & 1.0 & $\begin{array}{r}12.0 \\
9.9\end{array}$ & $\begin{array}{l}15.0 \\
14.6\end{array}$ & 1.4 & 9.0 & 13.0 & $\begin{array}{l}1.2 \\
2.0\end{array}$ & $\begin{array}{r}8.9 \\
11.3\end{array}$ & $\begin{array}{l}12.8 \\
15.4\end{array}$ \\
\hline & 0600 & 43.2 & .24 & ----- & 0 & -.38 & 1.0 & $\begin{array}{r}11.4 \\
9.5\end{array}$ & $\begin{array}{l}14.6 \\
14.4\end{array}$ & 1.2 & 8.4 & 12.8 & $\begin{array}{l}1.1 \\
1.5\end{array}$ & $\begin{array}{r}8.4 \\
10.5\end{array}$ & $\begin{array}{l}12.5 \\
14.6\end{array}$ \\
\hline & 0630 & 42.8 & .23 & --.- & 0 & -.36 & 1.5 & $\begin{array}{r}11.4 \\
9.5\end{array}$ & $\begin{array}{l}13.3 \\
12.8\end{array}$ & 2.0 & 9.4 & 11.9 & $\begin{array}{l}1.5 \\
1.1\end{array}$ & $\begin{array}{l}8.5 \\
9.9\end{array}$ & $\begin{array}{l}10.9 \\
12.6\end{array}$ \\
\hline
\end{tabular}


RAFT RIVER 2 (1978) - HOT I (contd)

\begin{tabular}{|c|c|c|c|c|c|c|c|c|c|c|c|c|c|c|c|}
\hline & 0700 & 42.5 & .23 & -.... & .02 & -.34 & 0.7 & $\begin{array}{l}11.6 \\
10.0\end{array}$ & $\begin{array}{l}13.8 \\
13.3\end{array}$ & 0.9 & 8.9 & 12.0 & $\begin{array}{l}0.8 \\
1.0\end{array}$ & $\begin{array}{r}8.7 \\
10.0\end{array}$ & $\begin{array}{l}11.5 \\
13.3\end{array}$ \\
\hline & 0730 & 42.2 & .24 & ..... & .19 & -.22 & 1.2 & $\begin{array}{l}11.6 \\
10.0\end{array}$ & $\begin{array}{l}14.3 \\
13.8\end{array}$ & 1.4 & 9.7 & 13.4 & $\begin{array}{l}1.1 \\
1.2\end{array}$ & $\begin{array}{r}9.5 \\
11.2\end{array}$ & $\begin{array}{l}12.9 \\
14.3\end{array}$ \\
\hline & 0800 & 41.9 & .24 & $\ldots$ & .33 & -.09 & 1.2 & $\begin{array}{l}12.1 \\
11.9\end{array}$ & $\begin{array}{l}16.7 \\
16.2\end{array}$ & 1.4 & 12.0 & 16.4 & $\begin{array}{l}1.2 \\
1.4\end{array}$ & $\begin{array}{l}11.7 \\
12.3\end{array}$ & $\begin{array}{l}15.8 \\
15.8\end{array}$ \\
\hline & 0830 & 41.7 & .28 & --- & .72 & .24 & 1.4 & $\begin{array}{l}15.0 \\
13.6\end{array}$ & $\begin{array}{l}19.2 \\
18.8\end{array}$ & 1.5 & 14.2 & 19.5 & \begin{tabular}{l}
1.5 \\
\hdashline$\ldots$
\end{tabular} & $\begin{array}{l}13.7 \\
14.2\end{array}$ & $\begin{array}{l}18.9 \\
18.2\end{array}$ \\
\hline & 0900 & 41.5 & .27 & 5.02 & 1.04 & .42 & 0.7 & $\begin{array}{l}17.1 \\
15.7\end{array}$ & $\begin{array}{l}23.0 \\
22.3\end{array}$ & 0.7 & 86.6 & 23.0 & $\begin{array}{l}0.7 \\
0.5\end{array}$ & $\begin{array}{l}15.8 \\
17.1\end{array}$ & $\begin{array}{l}22.3 \\
21.8\end{array}$ \\
\hline & 0930 & 41.5 & .29 & 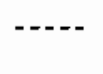 & 1.27 & .71 & 1.2 & $\begin{array}{l}17.4 \\
16.0\end{array}$ & $\begin{array}{r}24.6 \\
23.9\end{array}$ & 1.4 & 17.2 & 24.5 & $\begin{array}{l}1.1 \\
1.3\end{array}$ & $\begin{array}{l}16.4 \\
18.1\end{array}$ & $\begin{array}{l}23.8 \\
23.4\end{array}$ \\
\hline & 1000 & 41.3 & .31 & 4.80 & 1.61 & 1.04 & 2.0 & $\begin{array}{l}17.7 \\
16.2\end{array}$ & $\begin{array}{l}25.4 \\
25.0\end{array}$ & 2.5 & 17.4 & 25.7 & $\begin{array}{l}2.1 \\
2.5\end{array}$ & $\begin{array}{l}16.5 \\
18.4\end{array}$ & $\begin{array}{l}25.0 \\
24.6\end{array}$ \\
\hline & 1030 & 41.1 & .29 & -...- & 1.79 & 1.24 & 2.6 & $\begin{array}{l}18.5 \\
16.8\end{array}$ & $\begin{array}{l}25.8 \\
25.4\end{array}$ & 3.1 & 18.7 & 26.2 & $\begin{array}{l}2.7 \\
3.2\end{array}$ & $\begin{array}{l}17.4 \\
19.1\end{array}$ & $\begin{array}{l}25.5 \\
25.0\end{array}$ \\
\hline & 1100 & 40.9 & .31 & 4.59 & 1.82 & 1.30 & 3.6 & $\begin{array}{l}19.0 \\
17.6\end{array}$ & $\begin{array}{l}27.1 \\
26.9\end{array}$ & 3.7 & 18.5 & 27.2 & 3.2 & $\begin{array}{l}18.1 \\
19.8\end{array}$ & $\begin{array}{l}26.9 \\
26.0\end{array}$ \\
\hline & 1130 & 40.7 & .35 & $\cdots$ & 2.01 & 1.50 & 3.3 & $\begin{array}{l}19.2 \\
17.9\end{array}$ & $\begin{array}{l}27.6 \\
27.6\end{array}$ & 3.5 & 18.5 & 27.8 & $\begin{array}{l}3.1 \\
-.-\end{array}$ & $\begin{array}{l}18.2 \\
20.7\end{array}$ & $\begin{array}{l}27.6 \\
26.7\end{array}$ \\
\hline & 1200 & 40.5 & .39 & 4.50 & 2.28 & 1.76 & 3.5 & $\begin{array}{l}19.9 \\
18.4\end{array}$ & $\begin{array}{l}28.7 \\
28.5\end{array}$ & 3.7 & 19.0 & 28.5 & $\begin{array}{l}3.3 \\
\cdots-\end{array}$ & $\begin{array}{l}18.7 \\
20.7\end{array}$ & $\begin{array}{l}28.7 \\
27.7\end{array}$ \\
\hline & 1230 & 40.4 & .31 & -- & 2.45 & 1.93 & 3.8 & $\begin{array}{l}20.4 \\
18.9\end{array}$ & $\begin{array}{l}29.8 \\
29.4\end{array}$ & 3.8 & 19.5 & 29.4 & 3.2 & $\begin{array}{l}19.2 \\
21.2\end{array}$ & $\begin{array}{r}29.5 \\
28.4\end{array}$ \\
\hline
\end{tabular}


RAFT RIVER 2 (1978) - HOT I (contd)

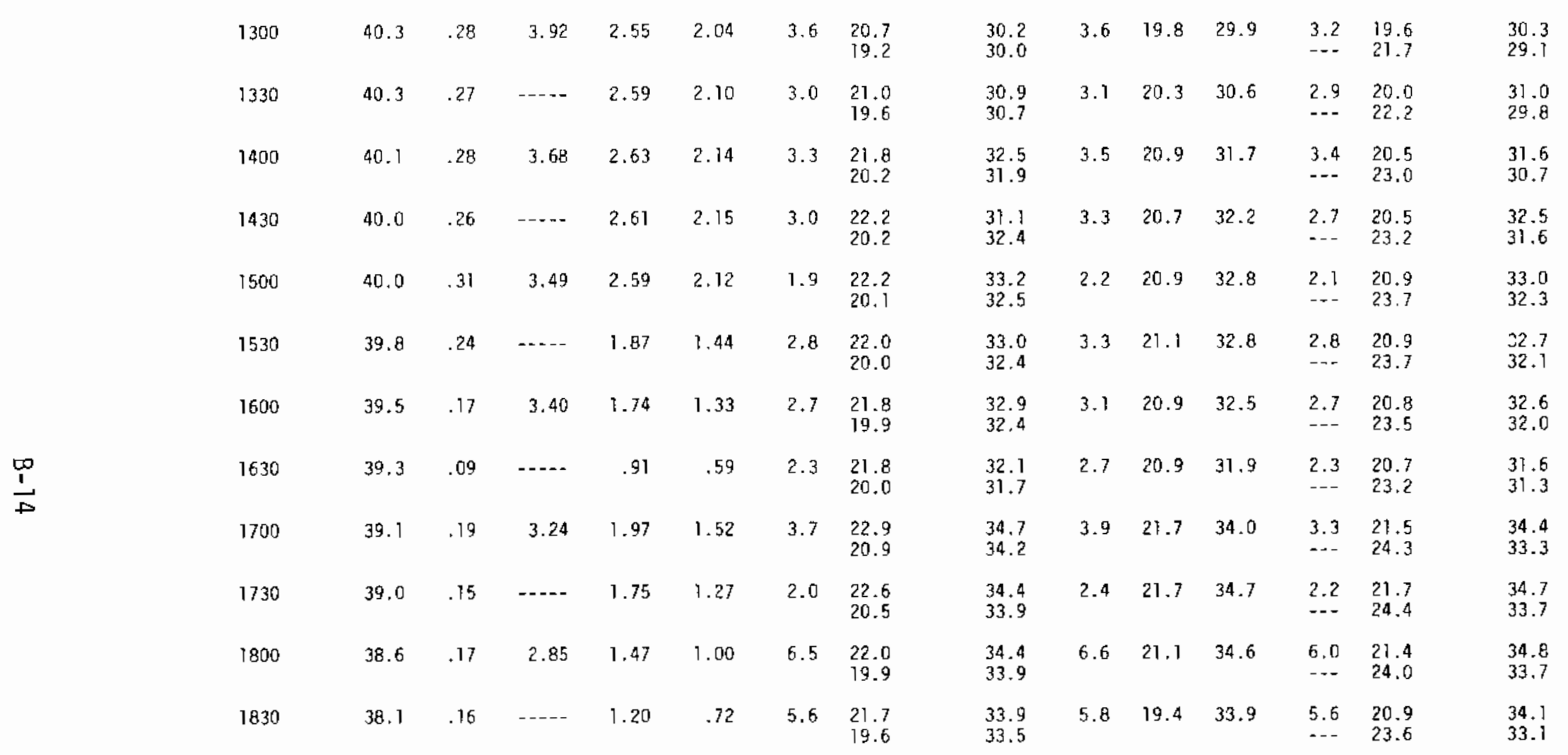


RAFT RIVER 2 (1978) - HOT I (contd)

\begin{tabular}{|c|c|c|c|c|c|c|c|c|c|c|c|c|c|c|c|}
\hline & 1900 & 37.6 & .16 & 2.61 & .91 & .44 & 5.4 & $\begin{array}{l}21.4 \\
19.4\end{array}$ & $\begin{array}{l}33.4 \\
33.0\end{array}$ & 5.7 & 20.4 & 33.2 & $\begin{array}{l}5.5 \\
---\end{array}$ & $\begin{array}{l}20.7 \\
23.3\end{array}$ & $\begin{array}{l}33.3 \\
32.6\end{array}$ \\
\hline & 1930 & 37.1 & .10 & --.-- & .62 & .18 & 5.0 & $\begin{array}{l}20.9 \\
18.9\end{array}$ & $\begin{array}{l}32.5 \\
32.7\end{array}$ & 5.6 & 19.8 & 32.1 & $\begin{array}{l}5.3 \\
-\end{array}$ & $\begin{array}{l}19.7 \\
22.6\end{array}$ & $\begin{array}{l}32.1 \\
31.7\end{array}$ \\
\hline & 2000 & 36.5 & .09 & 2.32 & .43 & .07 & 4.5 & $\begin{array}{l}20.8 \\
18.9\end{array}$ & $\begin{array}{l}31.5 \\
32.2\end{array}$ & 5.1 & 19.4 & 30.9 & $\begin{array}{l}4.9 \\
-\cdots\end{array}$ & $\begin{array}{r}19.4 \\
22.1\end{array}$ & $\begin{array}{l}30.9 \\
30.6\end{array}$ \\
\hline & 2030 & 32.3 & .09 & ..... & .10 & -.09 & 1.8 & $\begin{array}{l}19.7 \\
18.1\end{array}$ & $\begin{array}{r}29.5 \\
29.3\end{array}$ & 2.0 & 18.7 & 29.2 & $\begin{array}{l}1.9 \\
---\end{array}$ & $\begin{array}{l}18.5 \\
21.3\end{array}$ & $\begin{array}{l}29.2 \\
29.3\end{array}$ \\
\hline & 2100 & 36.0 & .12 & 2.30 & 0 & -.16 & 1.2 & $\begin{array}{l}18.6 \\
17.1\end{array}$ & $\begin{array}{l}27.0 \\
27.0\end{array}$ & 1.4 & 17.6 & 26.6 & 1.2 & $\begin{array}{l}17.3 \\
20.0\end{array}$ & $\begin{array}{l}26.2 \\
27.4\end{array}$ \\
\hline & 2130 & 35.8 & .15 & ...- & 0 & -.18 & 1.3 & $\begin{array}{l}18.5 \\
17.0\end{array}$ & $\begin{array}{l}28.0 \\
28.2\end{array}$ & 1.4 & 17.2 & 27.5 & 1.4 & $\begin{array}{l}17.2 \\
20.3\end{array}$ & $\begin{array}{r}27.5 \\
28.4\end{array}$ \\
\hline & 2200 & 35.6 & .15 & 2.21 & 0 & -.18 & 1.4 & $\begin{array}{l}17.5 \\
16.1\end{array}$ & $\begin{array}{l}26.3 \\
26.6\end{array}$ & 1.7 & 16.3 & 25.9 & $\begin{array}{l}1.5 \\
-. .\end{array}$ & $\begin{array}{l}16.5 \\
19.9\end{array}$ & $\begin{array}{l}26.2 \\
27.7\end{array}$ \\
\hline $\mathbb{1}_{1}$ & 2230 & 35.4 & .18 & -..-- & 0 & -.20 & 1.6 & $\begin{array}{l}17.1 \\
15.7\end{array}$ & $\begin{array}{l}25.7 \\
25.9\end{array}$ & 1.8 & 15.8 & 25.1 & $\begin{array}{l}1.6 \\
2.3\end{array}$ & $\begin{array}{l}16.0 \\
18.8\end{array}$ & $\begin{array}{l}25.2 \\
26.2\end{array}$ \\
\hline & 2300 & 35.2 & .13 & 2.11 & 0 & -.22 & 3.3 & $\begin{array}{l}17.3 \\
15.9\end{array}$ & $\begin{array}{l}26.6 \\
26.7\end{array}$ & 3.4 & 16.1 & 26.0 & $\begin{array}{l}3.0 \\
3.8\end{array}$ & $\begin{array}{l}16.4 \\
19.3\end{array}$ & $\begin{array}{l}25.9 \\
27.0\end{array}$ \\
\hline & 2330 & 34.9 & .12 & ---.- & 0 & -.22 & 1.3 & $\begin{array}{l}17.0 \\
15.5\end{array}$ & $\begin{array}{l}26.6 \\
26.5\end{array}$ & 1.5 & 15.8 & 25.9 & $\begin{array}{l}1.1 \\
1.8\end{array}$ & $\begin{array}{l}16.0 \\
18.9\end{array}$ & $\begin{array}{l}25.9 \\
26.8\end{array}$ \\
\hline & 0000 & 34.6 & .16 & 2.00 & 0 & -.24 & 1.3 & $\begin{array}{l}16.0 \\
14.6\end{array}$ & $\begin{array}{l}23.6 \\
23.6\end{array}$ & 1.5 & 14.9 & 23.1 & $\begin{array}{l}1.1 \\
1.8\end{array}$ & $\begin{array}{l}14.4 \\
16.9\end{array}$ & $\begin{array}{l}22.3 \\
23.2\end{array}$ \\
\hline
\end{tabular}


RAFT RIVER 2 (1978) - HOT I (contd)

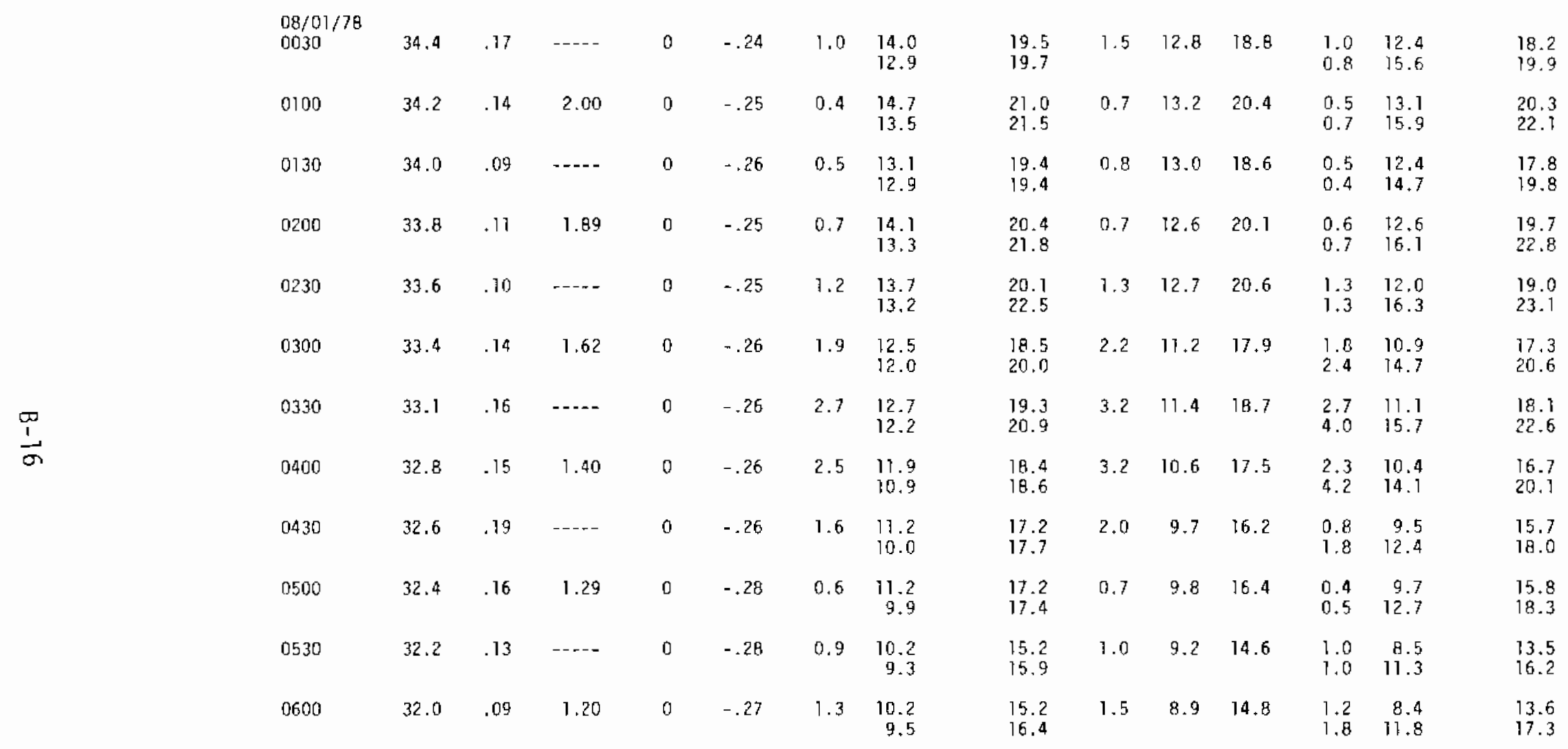


RAFT RIJER 2 (1978) - HOT I (contd)

\begin{tabular}{|c|c|c|c|c|c|c|c|c|c|c|c|c|c|c|c|}
\hline & 0630 & 31.8 & .13 & $\ldots$ & .01 & -.27 & 1.2 & $\begin{array}{l}9.7 \\
9.0\end{array}$ & $\begin{array}{l}14.7 \\
15.6\end{array}$ & 1.5 & 8.3 & 13.9 & $\begin{array}{l}1.4 \\
1.9\end{array}$ & $\begin{array}{r}8.0 \\
11.6\end{array}$ & $\begin{array}{l}13.3 \\
16.8\end{array}$ \\
\hline & 0700 & 31.6 & .11 & 1.11 & .05 & -.24 & 0.3 & $\begin{array}{l}9.9 \\
9.0\end{array}$ & $\begin{array}{l}14.6 \\
15.6\end{array}$ & 0.4 & 9.1 & 14.7 & $\begin{array}{l}0.4 \\
0.1\end{array}$ & $\begin{array}{r}8.7 \\
11.5\end{array}$ & $\begin{array}{l}14.3 \\
16.7\end{array}$ \\
\hline & 0730 & 31.4 & .09 & ----- & .26 & -.12 & 0.9 & $\begin{array}{l}11.8 \\
10.4\end{array}$ & $\begin{array}{l}17.2 \\
17.2\end{array}$ & 1.0 & 11.1 & 17.8 & $\begin{array}{l}1.0 \\
1.2\end{array}$ & $\begin{array}{l}10.4 \\
12.8\end{array}$ & $\begin{array}{l}16.6 \\
18.2\end{array}$ \\
\hline & 0800 & 31.3 & .10 & 1.19 & .53 & .78 & 0.3 & $\begin{array}{l}12.9 \\
11.6\end{array}$ & $\begin{array}{l}18.7 \\
18.4\end{array}$ & 0.3 & 12.8 & 19.1 & $\begin{array}{l}0.1 \\
0.2\end{array}$ & $\begin{array}{l}11.8 \\
13.6\end{array}$ & $\begin{array}{l}17.7 \\
18.8\end{array}$ \\
\hline & 0830 & 31.3 & .09 & ----- & .81 & .43 & 1.3 & $\begin{array}{l}14.1 \\
12.7\end{array}$ & $\begin{array}{l}22.0 \\
21.7\end{array}$ & 1.4 & 13.9 & 22.3 & 1.1 & $\begin{array}{l}13.3 \\
15.4\end{array}$ & $\begin{array}{l}22.1 \\
21.7\end{array}$ \\
\hline & 0900 & 31.2 & .15 & 1.10 & 1.06 & .66 & 1.4 & $\begin{array}{l}14.8 \\
13.5\end{array}$ & $\begin{array}{l}23.4 \\
23.0\end{array}$ & 1.5 & 14.8 & 23.6 & $\begin{array}{l}1.4 \\
\ldots .\end{array}$ & $\begin{array}{l}14.0 \\
16.5\end{array}$ & $\begin{array}{l}23.5 \\
23.1\end{array}$ \\
\hline & 0930 & 31.3 & .17 & $\cdots$ & 1.34 & .87 & 1.7 & $\begin{array}{l}15.3 \\
14.2\end{array}$ & $\begin{array}{l}24.2 \\
23.8\end{array}$ & 1.9 & 15.5 & 24.4 & $\begin{array}{l}1.4 \\
---\end{array}$ & $\begin{array}{l}15.3 \\
17.4\end{array}$ & $\begin{array}{l}24.2 \\
23.8\end{array}$ \\
\hline & 1000 & 31.4 & .28 & ----- & 1.59 & 1.14 & 2.2 & $\begin{array}{l}15.6 \\
14.4\end{array}$ & $\begin{array}{l}24.5 \\
24.5\end{array}$ & 2.5 & 15.6 & 25.0 & 2.7 & $\begin{array}{l}15.0 \\
17.5\end{array}$ & $\begin{array}{l}25.0 \\
24.3\end{array}$ \\
\hline & 1030 & 31.4 & .27 & ----- & 1.83 & 1.39 & 2.4 & $\begin{array}{l}16.3 \\
15.1\end{array}$ & $\begin{array}{r}25.3 \\
25.4\end{array}$ & 2.6 & 16.2 & 25.9 & 2.4 & $\begin{array}{l}15.7 \\
18.0\end{array}$ & $\begin{array}{l}25.9 \\
25.0\end{array}$ \\
\hline & 1100 & 31.5 & .29 & --- & 2.01 & 1.57 & 2.1 & $\begin{array}{l}16.5 \\
15.6\end{array}$ & $\begin{array}{l}25.8 \\
26.1\end{array}$ & 2.2 & 16.6 & 26.7 & $\begin{array}{l}1.9 \\
---\end{array}$ & $\begin{array}{l}16.4 \\
18.9\end{array}$ & $\begin{array}{l}26.9 \\
26.1\end{array}$ \\
\hline
\end{tabular}


RAFT RIVER 2 (1978) - HOT II (LEAK)

\begin{tabular}{|c|c|c|c|c|c|c|c|c|c|c|c|c|c|c|c|}
\hline & \multirow{3}{*}{$\begin{array}{l}\text { Date } \\
\text { Time }\end{array}$} & & & & \multirow{2}{*}{$\begin{array}{l}\text { Rad } \\
\text { Down }\end{array}$} & \multirow{2}{*}{$\begin{array}{l}\text { Rad } \\
\text { Net }\end{array}$} & \multicolumn{3}{|c|}{ Raft } & \multicolumn{3}{|c|}{ Periphery } & \multicolumn{3}{|c|}{ Reference } \\
\hline & & $\overline{\mathrm{T}}$ & 5 & $5 \mathrm{fc}$. & & & $w / S$ & $T_{w}$ & Td & $\bar{W} / \mathrm{S}$ & $T w$ & Td & $\overline{W / S}$ & $T_{W}$ & $T d$ \\
\hline & & c & c & $C M$ & Hw & Mw & $\mathrm{ms}^{-1}$ & c & c & $\mathrm{ms}^{-1}$ & c & c & $\mathrm{ms}^{-1}$ & c & c \\
\hline & $\begin{array}{l}08 / 03 / 78 \\
1100\end{array}$ & 70.8 & .12 & 5.80 & 2.00 & 1.16 & 2.6 & $\begin{array}{l}21.3 \text { (Bot) } \\
16.7 \text { (Top) }\end{array}$ & $\begin{array}{l}25.0 \\
24.1\end{array}$ & 3.0 & 18.9 & 24.7 & $\begin{array}{l}2.7 \\
3.2\end{array}$ & $\begin{array}{l}16.1 \text { (Bot) } \\
17.7 \text { (Top) }\end{array}$ & $\begin{array}{l}23.4 \\
22.8\end{array}$ \\
\hline & 1130 & 69.2 & .22 & 5.31 & 2.18 & 1.34 & 2.5 & $\begin{array}{l}21.3 \\
17.0\end{array}$ & $\begin{array}{l}26.0 \\
25.2\end{array}$ & 2.7 & 18.6 & 25.4 & $\begin{array}{l}2.5 \\
3.0\end{array}$ & $\begin{array}{l}16.5 \\
18.3\end{array}$ & $\begin{array}{l}24.6 \\
23.9\end{array}$ \\
\hline & 1200 & 67.7 & .23 & 4.84 & 2.34 & 1.50 & 2.7 & $\begin{array}{l}27.8 \\
17.8\end{array}$ & $\begin{array}{l}27.4 \\
26.8\end{array}$ & 2.7 & 18.7 & 26.4 & 2.3 & $\begin{array}{l}17.2 \\
19.3\end{array}$ & $\begin{array}{l}26.1 \\
25.4\end{array}$ \\
\hline & 1230 & 66.1 & .27 & 4.36 & 2.47 & 1.67 & 3.6 & $\begin{array}{l}21.6 \\
17.8\end{array}$ & $\begin{array}{l}28.3 \\
27.4\end{array}$ & 3.6 & 19.0 & 27.2 & 3.2 & $\begin{array}{l}17.6 \\
19.6\end{array}$ & $\begin{array}{l}27.0 \\
25.9\end{array}$ \\
\hline 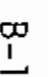 & 1300 & 64.6 & .22 & 3.85 & 2.55 & 1.78 & 3.4 & $\begin{array}{l}22.5 \\
18.7\end{array}$ & $\begin{array}{l}29.5 \\
28.7\end{array}$ & 3.6 & 19.3 & 28.2 & $\begin{array}{l}3.2 \\
-\cdots\end{array}$ & $\begin{array}{l}18.3 \\
20.4\end{array}$ & $\begin{array}{l}28.3 \\
27.0\end{array}$ \\
\hline & 1330 & 63.3 & .25 & 3.42 & 2.58 & 1.85 & 3.8 & $\begin{array}{l}22.4 \\
19.0\end{array}$ & $\begin{array}{l}30.6 \\
29.6\end{array}$ & 3.9 & 20.0 & 29.4 & $\begin{array}{l}3.4 \\
-.-\end{array}$ & $\begin{array}{l}18.8 \\
21.0\end{array}$ & $\begin{array}{l}29.4 \\
28.0\end{array}$ \\
\hline & 1400 & 61.9 & .21 & 3.09 & 2.55 & 1.88 & 3.0 & $\begin{array}{l}22.7 \\
19.3\end{array}$ & $\begin{array}{l}31.3 \\
30.2\end{array}$ & 3.2 & 20.1 & 29.9 & 2.9 & $\begin{array}{l}19.1 \\
21.6\end{array}$ & $\begin{array}{l}30.1 \\
28.9\end{array}$ \\
\hline & 3430 & 61.0 & .20 & 2.70 & 2.51 & 1.85 & 2.7 & $\begin{array}{l}22.9 \\
19.6\end{array}$ & $\begin{array}{l}32.0 \\
3 T .0\end{array}$ & 2.8 & 20.2 & 30.4 & 2.4 & $\begin{array}{l}19.2 \\
22.1\end{array}$ & $\begin{array}{l}30.5 \\
29.6\end{array}$ \\
\hline & 1500 & 60.1 & .23 & 2.36 & 2.48 & 1.82 & 3.1 & $\begin{array}{l}23.0 \\
19.5\end{array}$ & $\begin{array}{r}32.9 \\
31.7\end{array}$ & 3.2 & 20.1 & 31.4 & $\begin{array}{l}2.9 \\
3.2\end{array}$ & $\begin{array}{r}19.5 \\
22.4\end{array}$ & $\begin{array}{l}31.4 \\
30.4\end{array}$ \\
\hline
\end{tabular}


RAFT RIVER 2 (1978) - HOT II (LEAK) (contd)

\begin{tabular}{|c|c|c|c|c|c|c|c|c|c|c|c|c|c|c|c|}
\hline & 1530 & 58.8 & .18 & 2.00 & 2.39 & 1.74 & 4.0 & $\begin{array}{l}22.7 \\
19.1\end{array}$ & $\begin{array}{l}32.7 \\
31.6\end{array}$ & 4.3 & 20.5 & 31.5 & $\begin{array}{l}3.7 \\
3.9\end{array}$ & $\begin{array}{l}19.5 \\
22.3\end{array}$ & $\begin{array}{l}37.4 \\
30.3\end{array}$ \\
\hline & 1600 & 57.8 & .21 & 1.77 & 2.24 & 1.62 & 3.6 & $\begin{array}{l}22.6 \\
19.1\end{array}$ & $\begin{array}{l}32.9 \\
31.8\end{array}$ & 3.9 & 20.4 & 31.8 & $\begin{array}{l}3.4 \\
3.9\end{array}$ & $\begin{array}{r}19.5 \\
22.4\end{array}$ & $\begin{array}{l}31.5 \\
30.6\end{array}$ \\
\hline & 1630 & 56.8 & .21 & 1.34 & 2.05 & 1.48 & 4.1 & $\begin{array}{l}22.8 \\
19.4\end{array}$ & $\begin{array}{l}33.4 \\
32.3\end{array}$ & 4.3 & 20.6 & 32.2 & $\begin{array}{l}3.8 \\
3.4\end{array}$ & $\begin{array}{l}19.8 \\
22.8\end{array}$ & $\begin{array}{l}32.3 \\
31.7\end{array}$ \\
\hline & 1700 & 55.7 & .14 & 1.09 & 1.88 & 1.30 & 4.5 & $\begin{array}{l}22.5 \\
19.1\end{array}$ & $\begin{array}{l}33.4 \\
32.3\end{array}$ & 4.9 & 20.4 & 32.2 & $\begin{array}{l}4.1 \\
4.4\end{array}$ & $\begin{array}{r}19.8 \\
22.9\end{array}$ & $\begin{array}{l}32.2 \\
31.2\end{array}$ \\
\hline & 1730 & 54.8 & .16 & .69 & 1.70 & 1.10 & 4.4 & $\begin{array}{l}22.4 \\
19.0\end{array}$ & $\begin{array}{l}33.4 \\
32.3\end{array}$ & 4.5 & 20.2 & 32.3 & $\begin{array}{l}3.9 \\
\ldots\end{array}$ & $\begin{array}{l}19.6 \\
22.7\end{array}$ & $\begin{array}{l}32.4 \\
31.3\end{array}$ \\
\hline & 1800 & 53.8 & .14 & .51 & 1.46 & .85 & 3.6 & $\begin{array}{l}21.9 \\
18.7\end{array}$ & $\begin{array}{l}32.9 \\
31.9\end{array}$ & 4.0 & 20.2 & 32.0 & $\begin{array}{l}3.5 \\
4.1\end{array}$ & $\begin{array}{l}19.5 \\
22.6\end{array}$ & $\begin{array}{l}31.6 \\
30.9\end{array}$ \\
\hline & 1830 & 52.9 & .12 & $\cdots$ & 1.23 & .58 & 3.3 & $\begin{array}{l}21.7 \\
18.4\end{array}$ & $\begin{array}{l}33.4 \\
32.5\end{array}$ & 3.6 & 19.8 & 32.5 & $\begin{array}{l}3.1 \\
--.\end{array}$ & $\begin{array}{l}19.1 \\
22.5\end{array}$ & $\begin{array}{l}32.7 \\
31.3\end{array}$ \\
\hline 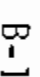 & 1900 & 52.0 & .09 & .....- & .97 & .29 & 3.9 & $\begin{array}{l}21.3 \\
17.7\end{array}$ & $\begin{array}{l}33.4 \\
32.5\end{array}$ & 4.5 & 18.9 & 32.4 & 4.2 & $\begin{array}{l}18.2 \\
22.1\end{array}$ & $\begin{array}{l}32.2 \\
31.6\end{array}$ \\
\hline & 1930 & 51.0 & .15 & ---- & .72 & -.01 & 3.9 & $\begin{array}{l}20.9 \\
17.4\end{array}$ & $\begin{array}{l}33.1 \\
32.2\end{array}$ & 4.5 & 18.4 & 31.8 & $\begin{array}{l}4.0 \\
\cdots\end{array}$ & $\begin{array}{l}17.8 \\
21.8\end{array}$ & $\begin{array}{l}31.6 \\
31.2\end{array}$ \\
\hline & 2000 & 50.1 & .15 & $\cdots$ & .47 & -.26 & 3.2 & $\begin{array}{l}21.2 \\
17.4\end{array}$ & $\begin{array}{l}32.5 \\
31.6\end{array}$ & 3.8 & 18.1 & 30.8 & $\begin{array}{l}3.4 \\
--\end{array}$ & $\begin{array}{r}17.5 \\
21.4\end{array}$ & $\begin{array}{l}30.6 \\
30.5\end{array}$ \\
\hline & 2030 & 49.4 & .26 & $\cdots$ & .19 & -.40 & 2.4 & $\begin{array}{l}20.3 \\
16.9\end{array}$ & $\begin{array}{l}30.5 \\
30.0\end{array}$ & 2.9 & 17.4 & 28.9 & 2.5 & $\begin{array}{l}16.8 \\
20.6\end{array}$ & $\begin{array}{l}28.7 \\
29.1\end{array}$ \\
\hline & 2100 & 48.8 & .28 & $\cdots$ & 0 & -.41 & 1.9 & $\begin{array}{l}16.4 \\
13.5\end{array}$ & $\begin{array}{l}24.5 \\
24.1\end{array}$ & 2.4 & 13.6 & 23.2 & $\begin{array}{l}2.0 \\
2.4\end{array}$ & $\begin{array}{l}14.4 \\
17.8\end{array}$ & $\begin{array}{l}23.7 \\
25.2\end{array}$ \\
\hline
\end{tabular}


RAFT RIVER 2 (1978) - HOT II (LEAK) (contd)

\begin{tabular}{|c|c|c|c|c|c|c|c|c|c|c|c|c|c|c|c|}
\hline & 2130 & 48.2 & .22 & ---- & 0 & -.42 & 2.3 & $\begin{array}{l}14.7 \\
12.0\end{array}$ & $\begin{array}{l}22.4 \\
22.0\end{array}$ & 2.8 & 12.0 & 21.1 & $\begin{array}{l}2.2 \\
3.5\end{array}$ & $\begin{array}{l}12.8 \\
16.4\end{array}$ & $\begin{array}{l}21.5 \\
23.5\end{array}$ \\
\hline & 2200 & 47.6 & .25 & ----- & 0 & -.41 & 1.4 & $\begin{array}{l}14.6 \\
11.9\end{array}$ & $\begin{array}{l}21.5 \\
21.3\end{array}$ & 1.7 & 11.6 & 20.1 & $\begin{array}{l}1.5 \\
2.3\end{array}$ & $\begin{array}{l}12.4 \\
16.1\end{array}$ & $\begin{array}{l}20.3 \\
22.9\end{array}$ \\
\hline & 2230 & 47.2 & .21 & $\cdots$ & 0 & -.41 & 1.2 & $\begin{array}{l}14.6 \\
12.1\end{array}$ & $\begin{array}{l}21.7 \\
21.2\end{array}$ & 1.5 & 11.6 & 19.6 & $\begin{array}{l}1.0 \\
2.0\end{array}$ & $\begin{array}{l}10.9 \\
14.9\end{array}$ & $\begin{array}{l}18.5 \\
21.4\end{array}$ \\
\hline & 2300 & 46.8 & .24 & ---- & 0 & -.40 & 1.3 & $\begin{array}{l}13.4 \\
10.9\end{array}$ & $\begin{array}{r}19.3 \\
19.1\end{array}$ & 1.7 & 10.6 & 17.9 & $\begin{array}{l}1.1 \\
1.9\end{array}$ & $\begin{array}{l}10.1 \\
13.3\end{array}$ & $\begin{array}{l}16.9 \\
19.1\end{array}$ \\
\hline & 2330 & 46.3 & .25 & ....- & 0 & -.40 & 1.3 & $\begin{array}{r}12.3 \\
9.7\end{array}$ & $\begin{array}{l}17.6 \\
17.0\end{array}$ & 1.7 & 10.0 & 16.2 & $\begin{array}{l}1.3 \\
1.2\end{array}$ & $\begin{array}{r}9.2 \\
11.6\end{array}$ & $\begin{array}{l}15.5 \\
16.6\end{array}$ \\
\hline & 0000 & 45.9 & .22 & --- & 0 & -.40 & 1.6 & $\begin{array}{r}11.0 \\
8.7\end{array}$ & $\begin{array}{l}15.7 \\
15.1\end{array}$ & 2.1 & 8.4 & 14.1 & $\begin{array}{l}1.5 \\
1.6\end{array}$ & $\begin{array}{r}8.0 \\
10.6\end{array}$ & $\begin{array}{l}13.6 \\
15.4\end{array}$ \\
\hline$p_{1}^{\infty}$ & $\begin{array}{l}08 / 04 / 78 \\
0030\end{array}$ & 45.3 & .21 & $\cdots$ & 0 & -.40 & 1.9 & $\begin{array}{r}10.5 \\
8.3\end{array}$ & $\begin{array}{l}15.4 \\
14.8\end{array}$ & 2.4 & 8.1 & 14.0 & $\begin{array}{l}1.9 \\
2.1\end{array}$ & $\begin{array}{r}7.9 \\
10.2\end{array}$ & $\begin{array}{l}13.7 \\
14.8\end{array}$ \\
\hline & 0100 & 44.6 & .30 & -..-- & 0 & -.39 & 1.7 & $\begin{array}{r}10.2 \\
7.9\end{array}$ & $\begin{array}{l}15.0 \\
14.4\end{array}$ & 2.1 & 7.4 & 13.3 & $\begin{array}{l}1.6 \\
2.7\end{array}$ & $\begin{array}{l}7.4 \\
9.7\end{array}$ & $\begin{array}{l}12.9 \\
14.3\end{array}$ \\
\hline & 0130 & 44.1 & .26 & $-\cdots$ & 0 & -.39 & 1.8 & $\begin{array}{r}10.2 \\
8.0\end{array}$ & $\begin{array}{l}15.1 \\
14.5\end{array}$ & 2.3 & 7.6 & 13.5 & $\begin{array}{l}1.6 \\
2.8\end{array}$ & $\begin{array}{l}7.5 \\
9.7\end{array}$ & $\begin{array}{l}13.2 \\
14.3\end{array}$ \\
\hline & 0200 & 43.7 & .26 & $-\cdots$ & 0 & -.38 & 1.4 & $\begin{array}{l}9.9 \\
7.7\end{array}$ & $\begin{array}{l}14.0 \\
13.8\end{array}$ & 1.6 & 7.2 & 12.5 & $\begin{array}{l}1.3 \\
1.5\end{array}$ & $\begin{array}{l}6.8 \\
9.7\end{array}$ & $\begin{array}{l}11.8 \\
14.2\end{array}$ \\
\hline & 0230 & 43.3 & .25 & $---\ldots$ & 0 & -.38 & 1.1 & $\begin{array}{l}9.8 \\
7.5\end{array}$ & $\begin{array}{l}13.8 \\
13.5\end{array}$ & 1.4 & 6.8 & 12.2 & $\begin{array}{l}1.2 \\
1.4\end{array}$ & $\begin{array}{l}6.4 \\
9.2\end{array}$ & $\begin{array}{l}11.3 \\
13.6\end{array}$ \\
\hline
\end{tabular}


RAFT RIVER 2 (1978) - HOT II (LEAK)

$\begin{array}{lllllllllllllll}0300 & 42.9 & .28 & \ldots \ldots & 0 & -.38 & 1.9 & 9.2 & 13.2 & 2.5 & 6.6 & 11.8 & 1.9 & 6.5 & 11.2 \\ & & & & & & & 7.0 & 12.8 & & & & 2.8 & 9.1 & 13.3 \\ 0330 & 42.5 & .26 & \ldots . . & 0 & -.37 & 1.4 & 8.8 & 12.7 & 1.9 & 6.3 & 11.2 & 1.5 & 6.2 & 10.7 \\ & & & & & & & 6.6 & 12.3 & & & & 2.4 & 8.1 & 12.0\end{array}$

1
1
1 
RAFT RIVER 2 (1978) - HOT III

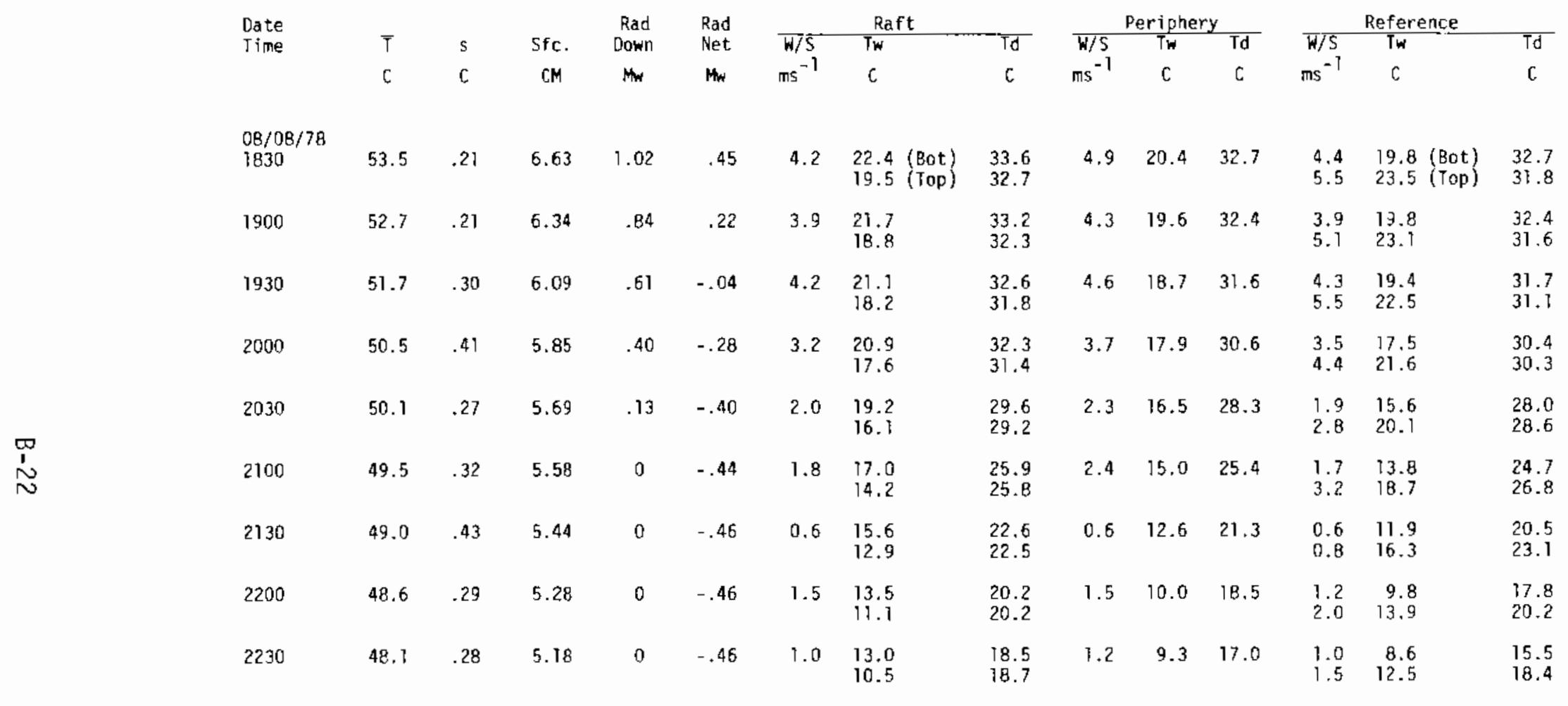


RAFT RIVER 2 (1978) - HOT III (contd)

\begin{tabular}{|c|c|c|c|c|c|c|c|c|c|c|c|c|c|c|}
\hline 2300 & 47.7 & .26 & 5.02 & 0 & -.46 & 0.9 & $\begin{array}{r}11.5 \\
9.6\end{array}$ & $\begin{array}{l}17.2 \\
17.3\end{array}$ & 1.1 & 8.1 & 15.3 & $\begin{array}{l}0.9 \\
1.5\end{array}$ & $\begin{array}{r}7.5 \\
11.8\end{array}$ & $\begin{array}{l}14.4 \\
17.6\end{array}$ \\
\hline 2330 & 47.2 & .24 & 4.90 & 0 & -.45 & 1.2 & $\begin{array}{r}11.0 \\
8.6\end{array}$ & $\begin{array}{l}15.7 \\
15.5\end{array}$ & 1.5 & 7.7 & 14.0 & $\begin{array}{l}1.0 \\
2.1\end{array}$ & $\begin{array}{r}7.0 \\
10.5\end{array}$ & $\begin{array}{l}12.7 \\
15.6\end{array}$ \\
\hline 0000 & 46.7 & .25 & 4.78 & 0 & -.45 & 1.4 & $\begin{array}{r}10.1 \\
7.8\end{array}$ & $\begin{array}{l}15.1 \\
14.5\end{array}$ & 1.9 & 7.0 & 13.3 & $\begin{array}{l}1.3 \\
2.7\end{array}$ & $\begin{array}{l}7.0 \\
9.8\end{array}$ & $\begin{array}{l}12.8 \\
14.6\end{array}$ \\
\hline $\begin{array}{l}08 / 09 / 78 \\
0030\end{array}$ & 46.3 & .24 & -...- & 0 & -.43 & 1.6 & $\begin{array}{r}10.0 \\
7.8\end{array}$ & $\begin{array}{l}14.9 \\
14.4\end{array}$ & 2.1 & 7.1 & 13.3 & $\begin{array}{l}1.5 \\
3.0\end{array}$ & $\begin{array}{l}7.1 \\
9.8\end{array}$ & $\begin{array}{l}12.7 \\
14.4\end{array}$ \\
\hline 0100 & 45.9 & .23 & 4.51 & 0 & -.43 & 1.9 & $\begin{array}{l}9.7 \\
7.6\end{array}$ & $\begin{array}{l}14.6 \\
14.0\end{array}$ & 2.3 & 7.1 & 13.1 & $\begin{array}{l}1.8 \\
3.1\end{array}$ & $\begin{array}{l}7.1 \\
9.5\end{array}$ & $\begin{array}{l}12.8 \\
13.9\end{array}$ \\
\hline 0130 & 45.3 & .28 & ---- & 0 & -.42 & 1.9 & $\begin{array}{l}9.6 \\
7.3\end{array}$ & $\begin{array}{l}14.4 \\
13.7\end{array}$ & 2.2 & 6.9 & 12.8 & $\begin{array}{l}1.8 \\
3.0\end{array}$ & $\begin{array}{l}6.8 \\
9.7\end{array}$ & $\begin{array}{l}12.5 \\
13.5\end{array}$ \\
\hline 0200 & 44.6 & .27 & 4.40 & 0 & -.42 & 1.5 & $\begin{array}{l}9.6 \\
7.3\end{array}$ & $\begin{array}{l}14.7 \\
13.6\end{array}$ & 1.9 & 6.7 & 12.5 & $\begin{array}{l}1.6 \\
2.7\end{array}$ & $\begin{array}{l}6.6 \\
9.2\end{array}$ & $\begin{array}{l}12.2 \\
13.8\end{array}$ \\
\hline 0230 & 44.2 & .21 & $\cdots-$ & 0 & -.40 & 1.7 & $\begin{array}{l}9.2 \\
7.0\end{array}$ & $\begin{array}{l}13.5 \\
13.2\end{array}$ & 1.9 & 6.2 & 11.9 & $\begin{array}{l}1.6 \\
2.6\end{array}$ & $\begin{array}{l}6.1 \\
9.2\end{array}$ & $\begin{array}{l}11.3 \\
13.7\end{array}$ \\
\hline 0300 & 43.7 & .25 & 4.08 & 0 & -.40 & 2.0 & $\begin{array}{l}8.8 \\
6.6\end{array}$ & $\begin{array}{l}13.1 \\
12.4\end{array}$ & 2.4 & 6.2 & 11.6 & $\begin{array}{l}1.9 \\
3.1\end{array}$ & $\begin{array}{l}6.0 \\
8.2\end{array}$ & $\begin{array}{l}11.1 \\
12.3\end{array}$ \\
\hline 0330 & 43.3 & .24 & $\cdots$ & 0 & -.39 & 1.8 & $\begin{array}{l}8.5 \\
6.3\end{array}$ & $\begin{array}{l}12.6 \\
12.3\end{array}$ & 2.3 & 5.8 & 11.2 & $\begin{array}{l}1.9 \\
3.4\end{array}$ & $\begin{array}{l}5.8 \\
8.6\end{array}$ & $\begin{array}{l}10.8 \\
12.9\end{array}$ \\
\hline 0400 & 42.9 & .22 & 3.81 & 0 & -.39 & 1.6 & $\begin{array}{l}8.7 \\
6.7\end{array}$ & $\begin{array}{l}13.0 \\
12.7\end{array}$ & 2.0 & 6.0 & 11.4 & $\begin{array}{l}1.6 \\
2.9\end{array}$ & $\begin{array}{l}6.0 \\
8.9\end{array}$ & $\begin{array}{l}11.1 \\
13.3\end{array}$ \\
\hline 0430 & 42.6 & .22 & $-\cdots-$ & 0 & -.39 & 1.4 & $\begin{array}{l}8.6 \\
6.4\end{array}$ & $\begin{array}{l}12.7 \\
12.1\end{array}$ & 1.9 & 5.8 & 11.1 & $\begin{array}{l}1.4 \\
2.7\end{array}$ & $\begin{array}{l}5.8 \\
8.3\end{array}$ & $\begin{array}{l}10.6 \\
12.4\end{array}$ \\
\hline
\end{tabular}




\section{RAFT RIVER 2 (1978) - HOT III (contd)}

\begin{tabular}{|c|c|c|c|c|c|c|c|c|c|c|c|c|c|c|c|}
\hline & 0500 & 42.3 & .21 & 3.64 & 0 & -.38 & 1.2 & $\begin{array}{l}9.0 \\
7.1\end{array}$ & $\begin{array}{l}13.1 \\
13.1\end{array}$ & 1.3 & 6.2 & 11.5 & $\begin{array}{l}1.1 \\
1.9\end{array}$ & $\begin{array}{l}5.9 \\
9.0\end{array}$ & $\begin{array}{l}11.0 \\
13.4\end{array}$ \\
\hline & 0530 & 41.9 & .22 & $\cdots$ & 0 & -.38 & 1.6 & $\begin{array}{l}8.7 \\
6.6\end{array}$ & $\begin{array}{l}12.8 \\
12.7\end{array}$ & 2.0 & 5.8 & 11.2 & $\begin{array}{l}1.6 \\
2.6\end{array}$ & $\begin{array}{l}5.6 \\
9.3\end{array}$ & $\begin{array}{l}10.6 \\
13.8\end{array}$ \\
\hline & 0600 & 41.6 & .24 & 3.44 & 0 & -.38 & 1.6 & $\begin{array}{l}8.3 \\
6.2\end{array}$ & $\begin{array}{l}12.2 \\
11.9\end{array}$ & 2.0 & 5.7 & 10.8 & $\begin{array}{l}1.5 \\
2.7\end{array}$ & $\begin{array}{l}5.2 \\
7.8\end{array}$ & $\begin{array}{r}9.9 \\
11.8\end{array}$ \\
\hline & 0630 & 41.2 & .26 & $-\cdots$ & 0 & -.38 & 2.0 & $\begin{array}{l}7.3 \\
5.6\end{array}$ & $\begin{array}{l}10.9 \\
10.4\end{array}$ & 2.5 & 5.2 & 9.6 & $\begin{array}{l}1.9 \\
3.4\end{array}$ & $\begin{array}{l}5.0 \\
7.0\end{array}$ & $\begin{array}{r}9.1 \\
10.5\end{array}$ \\
\hline & 0700 & 40.8 & .24 & 3.19 & .01 & -.34 & 1.8 & $\begin{array}{l}7.2 \\
5.4\end{array}$ & $\begin{array}{l}10.9 \\
10.2\end{array}$ & 2.2 & 5.0 & 9.5 & $\begin{array}{l}1.7 \\
2.9\end{array}$ & $\begin{array}{l}4.9 \\
6.8\end{array}$ & $\begin{array}{r}9.1 \\
10.2\end{array}$ \\
\hline & 0730 & 40.5 & .20 & $-\cdots$ & .20 & -.26 & 1.1 & $\begin{array}{l}8.7 \\
6.9\end{array}$ & $\begin{array}{l}12.8 \\
12.2\end{array}$ & 1.3 & 7.1 & 12.4 & $\begin{array}{l}1.0 \\
1.9\end{array}$ & $\begin{array}{l}6.5 \\
8.7\end{array}$ & $\begin{array}{l}11.6 \\
13.0\end{array}$ \\
\hline & 0800 & 40.2 & .21 & 3.01 & .46 & .02 & 1.5 & $\begin{array}{r}10.9 \\
9.1\end{array}$ & $\begin{array}{l}16.1 \\
15.4\end{array}$ & 1.5 & 9.8 & 16.4 & $\begin{array}{l}1.2 \\
1.8\end{array}$ & $\begin{array}{r}9.4 \\
11.0\end{array}$ & $\begin{array}{l}15.8 \\
15.6\end{array}$ \\
\hline & 0830 & 40.0 & .18 & $\cdots-$ & .73 & .28 & 1.6 & $\begin{array}{l}12.6 \\
11.1\end{array}$ & $\begin{array}{l}18.9 \\
18.3\end{array}$ & 1.7 & 12.0 & 19.5 & $\begin{array}{l}1.3 \\
1.9\end{array}$ & $\begin{array}{l}11.6 \\
13.2\end{array}$ & $\begin{array}{l}19.1 \\
18.3\end{array}$ \\
\hline & 0900 & 39.9 & .19 & 2.82 & .99 & .54 & 1.4 & $\begin{array}{l}14.6 \\
13.1\end{array}$ & $\begin{array}{l}22.1 \\
21.5\end{array}$ & 1.5 & 14.3 & 22.8 & $\begin{array}{l}1.4 \\
1.7\end{array}$ & $\begin{array}{l}13.6 \\
15.8\end{array}$ & $\begin{array}{l}22.2 \\
21.5\end{array}$ \\
\hline & 0930 & 39.8 & .16 & --- & 1.26 & .76 & 1.1 & $\begin{array}{l}15.6 \\
14.4\end{array}$ & $\begin{array}{l}24.6 \\
24.3\end{array}$ & 1.2 & 15.6 & 25.7 & $\begin{array}{l}1.0 \\
1.1\end{array}$ & $\begin{array}{l}15.0 \\
18.1\end{array}$ & $\begin{array}{l}25.3 \\
24.8\end{array}$ \\
\hline & 1000 & 39.7 & .20 & 2.60 & 1.50 & 1.02 & 0.7 & $\begin{array}{l}16.5 \\
15.2\end{array}$ & $\begin{array}{l}26.1 \\
25.9\end{array}$ & 0.8 & 16.5 & 27.2 & $\begin{array}{l}0.6 \\
0.7\end{array}$ & $\begin{array}{l}15.9 \\
19.4\end{array}$ & $\begin{array}{l}26.9 \\
26.5\end{array}$ \\
\hline & 1030 & 39.7 & .18 & $\cdots$ & 1.74 & 1.27 & 1.9 & $\begin{array}{l}17.3 \\
16.0\end{array}$ & $\begin{array}{l}26.8 \\
26.6\end{array}$ & 2.2 & 17.8 & 27.6 & $\begin{array}{l}2.0 \\
2.3\end{array}$ & $\begin{array}{l}16.3 \\
19.6\end{array}$ & $\begin{array}{l}26.8 \\
26.5\end{array}$ \\
\hline
\end{tabular}


RAFT RIVER 2 (1978) - HOT III (contd)

\begin{tabular}{|c|c|c|c|c|c|c|c|c|c|c|c|c|c|c|c|}
\hline & 1100 & 39.6 & .25 & 2.41 & 1.95 & 1.52 & 2.9 & $\begin{array}{r}17.9 \\
16.5\end{array}$ & $\begin{array}{l}28.5 \\
28.5\end{array}$ & 3.0 & 17.2 & 28.9 & $\begin{array}{l}2.6 \\
3.1\end{array}$ & $\begin{array}{l}16.9 \\
20.4\end{array}$ & $\begin{array}{l}28.8 \\
28.1\end{array}$ \\
\hline & 1130 & 39.4 & .26 & --.-- & 2.13 & 1.72 & 3.5 & $\begin{array}{l}18.6 \\
17.1\end{array}$ & $\begin{array}{l}29.4 \\
29.3\end{array}$ & 3.7 & 17.5 & 29.5 & $\begin{array}{l}3.2 \\
3.8\end{array}$ & $\begin{array}{l}17.4 \\
20.8\end{array}$ & $\begin{array}{l}29.5 \\
28.6\end{array}$ \\
\hline & 1200 & 39.3 & .27 & 2.13 & 2.30 & 1.86 & 3.9 & $\begin{array}{l}19.0 \\
17.6\end{array}$ & $\begin{array}{l}30.2 \\
29.9\end{array}$ & 3.9 & 18.0 & 30.0 & $\begin{array}{l}3.5 \\
4.3\end{array}$ & $\begin{array}{l}17.8 \\
21.3\end{array}$ & $\begin{array}{l}30.0 \\
29.0\end{array}$ \\
\hline & 1230 & 39.0 & .29 & $\ldots$ & 2.42 & 2.00 & 3.8 & $\begin{array}{l}19.3 \\
18.1\end{array}$ & $\begin{array}{l}30.8 \\
30.6\end{array}$ & 3.9 & 18.4 & 30.6 & $\begin{array}{l}3.6 \\
4.4\end{array}$ & $\begin{array}{l}78.4 \\
21.9\end{array}$ & $\begin{array}{l}30.8 \\
29.7\end{array}$ \\
\hline & 1300 & 38.9 & .34 & 1.85 & 2.52 & 2.10 & 3.7 & $\begin{array}{l}19.7 \\
18.4\end{array}$ & $\begin{array}{l}31.5 \\
31.2\end{array}$ & 4.1 & 18.8 & 31.3 & $\begin{array}{l}3.6 \\
4.2\end{array}$ & $\begin{array}{l}18.9 \\
22.6\end{array}$ & $\begin{array}{l}31.9 \\
30.7\end{array}$ \\
\hline & 1330 & 38.8 & .32 & - - & 2.56 & 2.15 & 3.8 & $\begin{array}{l}20.3 \\
19.1\end{array}$ & $\begin{array}{l}32.5 \\
32.1\end{array}$ & 4.2 & 19.5 & 32.2 & $\begin{array}{l}3.6 \\
4.3\end{array}$ & $\begin{array}{r}19.5 \\
23.1\end{array}$ & $\begin{array}{l}32.6 \\
31.3\end{array}$ \\
\hline & 1400 & 38.7 & .29 & 1.64 & 2.52 & 2.16 & 4.4 & $\begin{array}{l}21.1 \\
19.6\end{array}$ & $\begin{array}{l}33.8 \\
33.1\end{array}$ & 4.6 & 20.0 & 33.0 & $\begin{array}{l}4.1 \\
5.1\end{array}$ & $\begin{array}{l}19.8 \\
23.8\end{array}$ & $\begin{array}{l}33.4 \\
32.1\end{array}$ \\
\hline & 1430 & 38.4 & .27 & $\ldots$ & 2.05 & 1.74 & 4.3 & $\begin{array}{r}21.0 \\
19.4\end{array}$ & $\begin{array}{l}33.4 \\
32.8\end{array}$ & 4.7 & 19.7 & 32.7 & $\begin{array}{l}4.2 \\
5.0\end{array}$ & $\begin{array}{l}19.7 \\
23.6\end{array}$ & $\begin{array}{l}33.2 \\
32.0\end{array}$ \\
\hline & 1500 & 38.2 & .23 & 1.40 & 1.70 & 1.49 & 4.2 & $\begin{array}{r}21.0 \\
79.4\end{array}$ & $\begin{array}{l}33.5 \\
32.9\end{array}$ & 4.2 & 19.8 & 32.8 & $\begin{array}{l}3.6 \\
4.6\end{array}$ & $\begin{array}{l}19.7 \\
23.7\end{array}$ & $\begin{array}{l}33.1 \\
32.0\end{array}$ \\
\hline & 1530 & 38.1 & .32 & ...... & 2.62 & 2.35 & 4.5 & $\begin{array}{l}21.9 \\
20.2\end{array}$ & $\begin{array}{l}34.6 \\
33.9\end{array}$ & 4.7 & 20.4 & 33.6 & $\begin{array}{l}4.1 \\
5.1\end{array}$ & $\begin{array}{l}20.3 \\
24.2\end{array}$ & $\begin{array}{l}33.9 \\
32.6\end{array}$ \\
\hline & 1600 & 37.9 & .20 & 1.13 & 1.64 & 1.35 & 4.0 & $\begin{array}{l}21.2 \\
19.5\end{array}$ & $\begin{array}{l}33.8 \\
33.1\end{array}$ & 4.2 & 20.0 & 33.0 & $\begin{array}{l}3.7 \\
4.6\end{array}$ & $\begin{array}{l}20.1 \\
24.0\end{array}$ & $\begin{array}{l}33.4 \\
32.4\end{array}$ \\
\hline & 1630 & 37.7 & .22 & ---- & 1.73 & 1.48 & 3.2 & $\begin{array}{l}20.9 \\
19.2\end{array}$ & $\begin{array}{l}33.4 \\
32.9\end{array}$ & 3.5 & 19.9 & 33.0 & $\begin{array}{l}3.3 \\
4.2\end{array}$ & $\begin{array}{l}19.7 \\
23.8\end{array}$ & $\begin{array}{l}33.0 \\
32.2\end{array}$ \\
\hline
\end{tabular}


RAFT RIVER 2 (1978) - HOT III (contd)

\begin{tabular}{|c|c|c|c|c|c|c|c|c|c|c|c|c|c|c|c|}
\hline & 1700 & 37.5 & .27 & .96 & 1.72 & 1.45 & 4.5 & $\begin{array}{l}21.2 \\
19.5\end{array}$ & $\begin{array}{l}34.0 \\
33.5\end{array}$ & 4.6 & 20.3 & 34.4 & $\begin{array}{l}4.3 \\
5.5\end{array}$ & $\begin{array}{l}20.7 \\
24.4\end{array}$ & $\begin{array}{l}34.6 \\
33.3\end{array}$ \\
\hline & 1730 & 37.2 & .24 & $\ldots$ & .49 & 1.22 & 4.9 & $\begin{array}{l}21.0 \\
19.4\end{array}$ & $\begin{array}{l}33.8 \\
33.4\end{array}$ & 4.1 & 20.3 & 34.3 & $\begin{array}{l}3.9 \\
5.0\end{array}$ & $\begin{array}{l}20.7 \\
24.4\end{array}$ & $\begin{array}{l}34.5 \\
33.3\end{array}$ \\
\hline & 1800 & 37.0 & .22 & .62 & 1.26 & .96 & 3.7 & $\begin{array}{l}21.0 \\
19.3\end{array}$ & $\begin{array}{l}33.7 \\
33.3\end{array}$ & 3.9 & 20.1 & 33.9 & $\begin{array}{l}3.8 \\
4.7\end{array}$ & $\begin{array}{l}20.3 \\
24.1\end{array}$ & $\begin{array}{l}34.0 \\
32.9\end{array}$ \\
\hline & 1830 & 36.7 & .22 & $-\cdots$ & 1.03 & .69 & 4.2 & $\begin{array}{l}20.9 \\
19.3\end{array}$ & $\begin{array}{l}33.3 \\
33.0\end{array}$ & 4.6 & 19.9 & 33.3 & $\begin{array}{l}4.3 \\
5.4\end{array}$ & $\begin{array}{l}20.2 \\
23.9\end{array}$ & $\begin{array}{l}33.3 \\
22.5\end{array}$ \\
\hline & 1900 & 36.4 & .18 & .44 & .72 & .36 & 3.4 & $\begin{array}{l}20.4 \\
18.9\end{array}$ & $\begin{array}{l}32.5 \\
32.1\end{array}$ & 3.4 & 19.5 & 32.5 & $\begin{array}{l}3.2 \\
4.1\end{array}$ & $\begin{array}{r}19.9 \\
23.5\end{array}$ & $\begin{array}{l}32.6 \\
31.9\end{array}$ \\
\hline & 1930 & 36.1 & .17 & $-\cdots$ & .52 & .14 & 3.1 & $\begin{array}{l}20.2 \\
18.6\end{array}$ & $\begin{array}{l}32.1 \\
31.7\end{array}$ & 3.2 & 19.0 & 31.8 & $\begin{array}{l}3.0 \\
4.0\end{array}$ & $\begin{array}{l}19.4 \\
23.7\end{array}$ & $\begin{array}{l}31.8 \\
31.4\end{array}$ \\
\hline & 2000 & 35.8 & .17 & .20 & .35 & -.02 & 3.5 & $\begin{array}{l}20.1 \\
18.5\end{array}$ & $\begin{array}{l}31.5 \\
31.3\end{array}$ & 3.6 & 18.8 & 30.9 & $\begin{array}{l}3.4 \\
4.5\end{array}$ & $\begin{array}{l}19.2 \\
22.8\end{array}$ & $\begin{array}{l}31.0 \\
30.8\end{array}$ \\
\hline & 2030 & 35.5 & .19 & ---- & .12 & -.07 & 2.8 & $\begin{array}{l}19.4 \\
18.0\end{array}$ & $\begin{array}{l}30.0 \\
29.9\end{array}$ & 3.0 & 18.1 & 29.6 & $\begin{array}{l}2.7 \\
3.7\end{array}$ & $\begin{array}{l}18.6 \\
22.1\end{array}$ & $\begin{array}{l}29.6 \\
29.7\end{array}$ \\
\hline & 2100 & 35.3 & .18 & .05 & 0 & $-.1 \mathrm{~B}$ & 1.8 & $\begin{array}{l}17.8 \\
16.6\end{array}$ & $\begin{array}{l}27.4 \\
27.5\end{array}$ & 2.2 & 16.7 & 27.1 & $\begin{array}{l}1.9 \\
3.1\end{array}$ & $\begin{array}{l}17.0 \\
20.8\end{array}$ & $\begin{array}{l}27.2 \\
28.2\end{array}$ \\
\hline & 2130 & 35.1 & .17 & -..- & 0 & -.20 & 1.7 & $\begin{array}{l}16.5 \\
15.8\end{array}$ & $\begin{array}{l}24.7 \\
26.2\end{array}$ & 2.1 & 15.3 & 24.6 & $\begin{array}{l}1.8 \\
2.9\end{array}$ & $\begin{array}{l}15.6 \\
20.8\end{array}$ & $\begin{array}{l}25.0 \\
28.1\end{array}$ \\
\hline & 2200 & 35.0 & .18 & -..- & 0 & -.21 & 1.2 & $\begin{array}{r}15.5 \\
14.8\end{array}$ & $\begin{array}{l}22.7 \\
23.7\end{array}$ & 1.5 & 14.5 & 22.5 & $\begin{array}{l}1.1 \\
1.6\end{array}$ & $\begin{array}{l}14.2 \\
18.6\end{array}$ & $\begin{array}{l}21.9 \\
24.8\end{array}$ \\
\hline & 2230 & 34.8 & .18 & .... & 0 & -.17 & 0.5 & $\begin{array}{l}15.3 \\
14.1\end{array}$ & $\begin{array}{l}22.5 \\
22.7\end{array}$ & 0.8 & 13.8 & 21.9 & $\begin{array}{l}0.5 \\
1.3\end{array}$ & $\begin{array}{l}13.8 \\
17.4\end{array}$ & $\begin{array}{l}21.6 \\
23.4\end{array}$ \\
\hline
\end{tabular}


RAFT RIVER 2 (1978) - HOT III (contd)

\begin{tabular}{|c|c|c|c|c|c|c|c|c|c|c|c|c|c|c|c|}
\hline & 2300 & 34.6 & .18 & -...- & 0 & -.20 & 0.5 & $\begin{array}{l}15.6 \\
14.5\end{array}$ & $\begin{array}{l}23.0 \\
23.3\end{array}$ & 0.6 & 14.1 & 22.4 & $\begin{array}{l}0.3 \\
0.9\end{array}$ & $\begin{array}{l}14.1 \\
17.3\end{array}$ & $\begin{array}{r}21.9 \\
23.2\end{array}$ \\
\hline & 2330 & 34.4 & .19 & -...- & 0 & -.20 & 0.4 & $\begin{array}{l}14.2 \\
13.2\end{array}$ & $\begin{array}{l}20.1 \\
20.1\end{array}$ & 0.6 & 13.3 & 19.6 & $\begin{array}{l}0.4 \\
0.9\end{array}$ & $\begin{array}{l}12.7 \\
15.4\end{array}$ & $\begin{array}{l}18.8 \\
20.3\end{array}$ \\
\hline & 0000 & 34.3 & .16 & $\cdots$ & 0 & -.20 & 0.4 & $\begin{array}{l}13.3 \\
12.3\end{array}$ & $\begin{array}{l}18.3 \\
18.4\end{array}$ & 0.6 & 11.8 & 17.3 & $\begin{array}{l}0.4 \\
1.1\end{array}$ & $\begin{array}{l}11.7 \\
14.6\end{array}$ & $\begin{array}{l}16.9 \\
19.2\end{array}$ \\
\hline & $\begin{array}{l}08 / 10 / 78 \\
0030\end{array}$ & 34.1 & .19 & -..- & 0 & -.20 & 1.9 & $\begin{array}{l}12.9 \\
11.9\end{array}$ & $\begin{array}{l}18.5 \\
18.4\end{array}$ & 2.5 & 12.0 & 18.0 & $\begin{array}{l}2.0 \\
3.5\end{array}$ & $\begin{array}{l}11.1 \\
14.4\end{array}$ & $\begin{array}{r}17.1 \\
19.1\end{array}$ \\
\hline & 0100 & 33.8 & .19 & $-\cdots$ & 0 & -.22 & 1.2 & $\begin{array}{l}12.1 \\
11.0\end{array}$ & $\begin{array}{l}16.6 \\
16.6\end{array}$ & 1.6 & 11.0 & 15.8 & $\begin{array}{l}1.2 \\
2.2\end{array}$ & $\begin{array}{l}10.5 \\
13.1\end{array}$ & $\begin{array}{l}15.2 \\
17.3\end{array}$ \\
\hline & 0130 & 33.6 & .24 & -.... & 0 & -.22 & 0.5 & $\begin{array}{l}11.8 \\
10.8\end{array}$ & $\begin{array}{l}16.6 \\
16.1\end{array}$ & 0.9 & 9.9 & 14.9 & $\begin{array}{l}0.7 \\
1.9\end{array}$ & $\begin{array}{r}9.8 \\
12.5\end{array}$ & $\begin{array}{l}14.6 \\
16.7\end{array}$ \\
\hline & 0200 & 33.4 & .27 & ..... & 0 & -.19 & 1.3 & $\begin{array}{l}11.8 \\
10.6\end{array}$ & $\begin{array}{l}16.2 \\
16.2\end{array}$ & 2.0 & 10.6 & 15.4 & $\begin{array}{l}1.3 \\
3.0\end{array}$ & $\begin{array}{l}10.1 \\
13.1\end{array}$ & $\begin{array}{l}14.8 \\
17.5\end{array}$ \\
\hline & 0230 & 33.2 & .29 & $\ldots$ & 0 & -.14 & 0.8 & $\begin{array}{l}11.8 \\
10.8\end{array}$ & $\begin{array}{l}16.3 \\
16.4\end{array}$ & 1.1 & $10 . ?$ & 15.3 & $\begin{array}{l}0.7 \\
1.5\end{array}$ & $\begin{array}{l}10.3 \\
13.1\end{array}$ & $\begin{array}{l}15.3 \\
17.4\end{array}$ \\
\hline & 0300 & 3.3 .1 & .26 & -...- & 0 & -.11 & 1.0 & $\begin{array}{l}11.9 \\
11.3\end{array}$ & $\begin{array}{l}17.0 \\
17.6\end{array}$ & $T .1$ & 10.5 & 16.2 & $\begin{array}{l}0.9 \\
1.2\end{array}$ & $\begin{array}{l}11.0 \\
13.5\end{array}$ & $\begin{array}{l}16.4 \\
18.1\end{array}$ \\
\hline & 0330 & 33.0 & .30 & $-\cdots$ & 0 & -.12 & 0.9 & $\begin{array}{l}13.6 \\
12.7\end{array}$ & $\begin{array}{l}18.6 \\
18.8\end{array}$ & 1.0 & 12.2 & 17.7 & $\begin{array}{l}0.9 \\
1.6\end{array}$ & $\begin{array}{l}12.0 \\
14.6\end{array}$ & $\begin{array}{l}17.3 \\
19.2\end{array}$ \\
\hline & 0400 & 32.8 & .26 & .... & 0 & -.10 & 1.2 & $\begin{array}{l}13.6 \\
12.7\end{array}$ & $\begin{array}{l}19.1 \\
18.9\end{array}$ & 1.5 & 12.5 & 18.4 & $\begin{array}{l}1.0 \\
2.7\end{array}$ & $\begin{array}{l}12.3 \\
14.5\end{array}$ & $\begin{array}{l}17.9 \\
19.1\end{array}$ \\
\hline & 0430 & 32.6 & .22 & $--\cdot-$ & 0 & -.11 & 0.6 & $\begin{array}{l}13.8 \\
13.0\end{array}$ & $\begin{array}{l}19.4 \\
19.2\end{array}$ & 0.8 & 12.4 & 18.5 & $\begin{array}{l}0.5 \\
1.2\end{array}$ & $\begin{array}{l}12.2 \\
14.4\end{array}$ & $\begin{array}{l}18.2 \\
19.0\end{array}$ \\
\hline
\end{tabular}


RAFT RIVER 2 (1978) - HOT III (contd)

\begin{tabular}{|c|c|c|c|c|c|c|c|c|c|c|c|c|c|c|c|}
\hline & 0500 & 32.5 & .22 & ----- & 0 & -.09 & 0.5 & $\begin{array}{l}13.4 \\
14.2\end{array}$ & $\begin{array}{l}18.7 \\
18.7\end{array}$ & 0.6 & 12.1 & 17.9 & $\begin{array}{l}0.6 \\
1.0\end{array}$ & $\begin{array}{l}32.2 \\
14.6\end{array}$ & $\begin{array}{l}17.9 \\
19.3\end{array}$ \\
\hline & 0530 & 32.3 & .23 & -..-- & 0 & -.11 & 0.3 & $\begin{array}{l}13.6 \\
-\end{array}$ & $\begin{array}{l}19.2 \\
19.5\end{array}$ & 0.3 & 12.7 & 18.8 & $\begin{array}{l}0.2 \\
0.3\end{array}$ & $\begin{array}{l}12.5 \\
16.2\end{array}$ & $\begin{array}{l}18.5 \\
21.6\end{array}$ \\
\hline & 0600 & 32.2 & .26 & $-\cdots$ & 0 & -.16 & 0.7 & $\begin{array}{l}12.3 \\
\ldots\end{array}$ & $\begin{array}{l}18.8 \\
19.2\end{array}$ & 0.9 & 12.3 & 18.2 & $\begin{array}{l}0.6 \\
0.4\end{array}$ & $\begin{array}{l}33.7 \\
14.9\end{array}$ & $\begin{array}{l}18.1 \\
19.8\end{array}$ \\
\hline & 0630 & 32.0 & .23 & $\ldots$ & 0 & -.09 & 2.0 & $\begin{array}{l}13.9 \\
\ldots\end{array}$ & $\begin{array}{l}20.6 \\
21.5\end{array}$ & 2.3 & 12.9 & 20.2 & $\begin{array}{l}2.1 \\
2.7\end{array}$ & 13.5 & $\begin{array}{l}20.5 \\
-\end{array}$ \\
\hline & 0700 & 31.9 & .21 & $--\cdots$ & .02 & -.11 & 1.4 & $\begin{array}{l}14.3 \\
-\end{array}$ & $\begin{array}{l}20.5 \\
20.4\end{array}$ & 2.0 & 13.6 & 20.2 & $\begin{array}{l}1.5 \\
2.6\end{array}$ & $\begin{array}{l}13.3 \\
15.9\end{array}$ & $\begin{array}{l}19.8 \\
20.7\end{array}$ \\
\hline & 0730 & 31.7 & .26 & ...... & .10 & -.04 & 0.5 & 13.2 & $\begin{array}{l}18.2 \\
17.9\end{array}$ & 0.7 & 12.2 & 17.7 & $\begin{array}{l}0.5 \\
1.0\end{array}$ & $\begin{array}{l}12.0 \\
13.9\end{array}$ & $\begin{array}{l}17.4 \\
18.3\end{array}$ \\
\hline & 0800 & 31.5 & .26 & --.-- & .13 & .01 & 2.1 & 13.9 & $\begin{array}{l}19.8 \\
19.6\end{array}$ & 2.5 & 12.9 & 19.4 & $\begin{array}{l}2.0 \\
3.3\end{array}$ & $\begin{array}{l}13.0 \\
15.1\end{array}$ & $\begin{array}{l}19.1 \\
19.9\end{array}$ \\
\hline
\end{tabular}


RAFT RIVER 2 (1978) - HOT IV

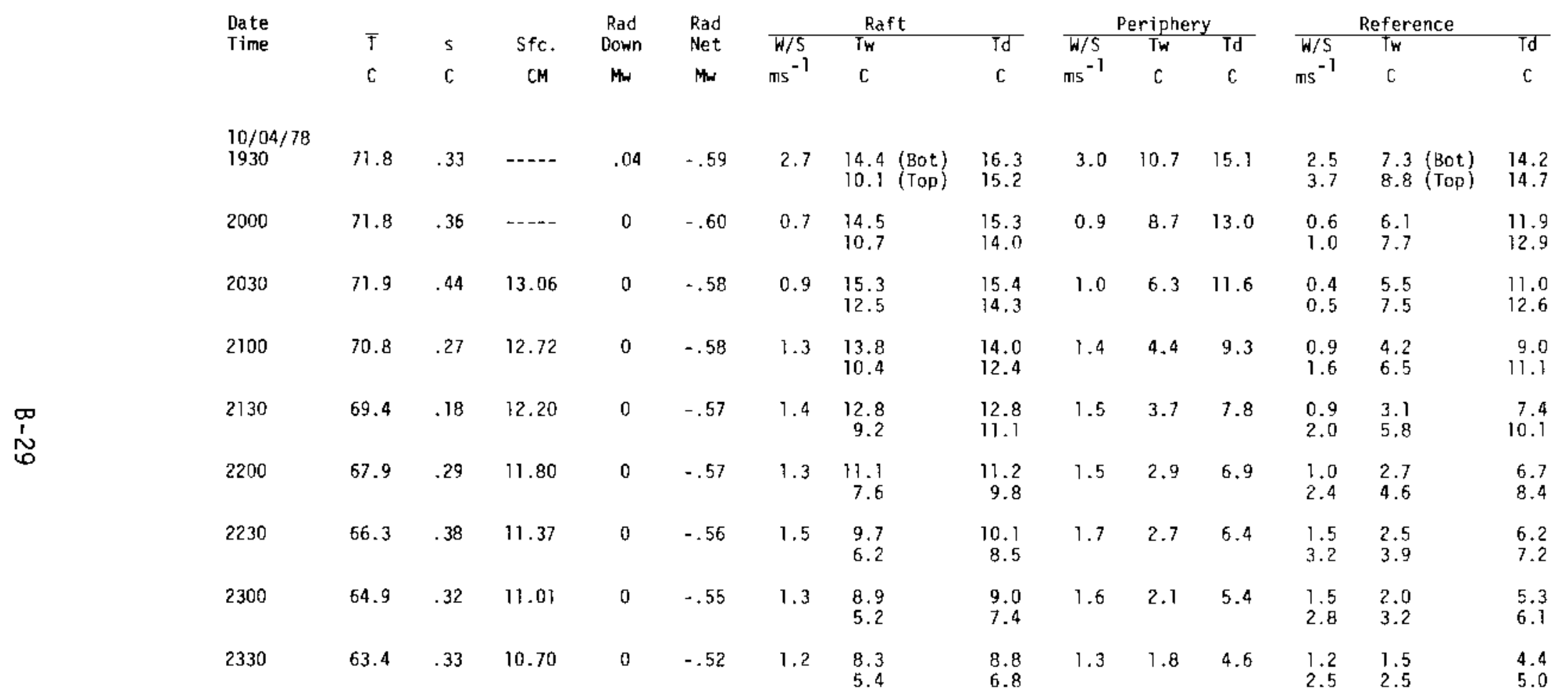


RAFT RIVER 2 (1978) - HOT IV (contd)

\begin{tabular}{|c|c|c|c|c|c|c|c|c|c|c|c|c|c|c|}
\hline 0000 & 62.1 & .29 & 10.51 & 0 & -.49 & 1.5 & $\begin{array}{l}7.7 \\
4.7\end{array}$ & $\begin{array}{l}8.2 \\
6.1\end{array}$ & 1.3 & 1.3 & 3.8 & $\begin{array}{l}0.9 \\
2.1\end{array}$ & 2.9 & $\begin{array}{l}3.5 \\
4.7\end{array}$ \\
\hline $\begin{array}{l}10 / 05 / 78 \\
0030\end{array}$ & 60.9 & .21 & 10.17 & 0 & -.47 & 1.5 & $\begin{array}{l}7.2 \\
3.5\end{array}$ & $\begin{array}{l}7.4 \\
5.2\end{array}$ & 1.8 & .4 & 3.0 & $\begin{array}{l}1.4 \\
2.9\end{array}$ & 2.8 & $\begin{array}{l}2.8 \\
4.4\end{array}$ \\
\hline 0100 & 59.8 & .34 & 9.80 & 0 & -.48 & 1.5 & $\begin{array}{l}6.5 \\
3.3\end{array}$ & $\begin{array}{l}6.9 \\
5.0\end{array}$ & 1.6 & 1.1 & 3.4 & $\begin{array}{l}1.4 \\
2.7\end{array}$ & $\begin{array}{r}.8 \\
1.9\end{array}$ & $\begin{array}{l}3.3 \\
4.1\end{array}$ \\
\hline 0130 & 58.6 & .18 & 9.57 & 0 & -.48 & 1.4 & $\begin{array}{l}6.1 \\
3.0\end{array}$ & $\begin{array}{l}6.6 \\
4.6\end{array}$ & 1.4 & .7 & 2.9 & $\begin{array}{l}1.3 \\
2.5\end{array}$ & $\begin{array}{l}.5 \\
1.5\end{array}$ & $\begin{array}{l}2.8 \\
3.6\end{array}$ \\
\hline 0200 & 57.6 & .22 & 9.34 & 0 & -.49 & 1.5 & $\begin{array}{l}6.3 \\
3.1\end{array}$ & $\begin{array}{l}6.7 \\
5.2\end{array}$ & 1.4 & .6 & 3.3 & $\begin{array}{l}1.1 \\
2.2\end{array}$ & $\begin{array}{r}.4 \\
1.6\end{array}$ & $\begin{array}{l}3.0 \\
4.1\end{array}$ \\
\hline 0230 & 56.5 & .30 & 9.06 & 0 & -.49 & 1.6 & $\begin{array}{l}5.7 \\
2.5\end{array}$ & $\begin{array}{l}5.9 \\
4.4\end{array}$ & 1.7 & .4 & 2.8 & $\begin{array}{l}1.7 \\
3.4\end{array}$ & $\begin{array}{r}.2 \\
1.4\end{array}$ & $\begin{array}{l}2.6 \\
3.5\end{array}$ \\
\hline 0300 & 55.5 & .15 & 8.83 & 0 & -.47 & 1.3 & $\begin{array}{l}5.4 \\
2.5\end{array}$ & $\begin{array}{l}5.4 \\
4.0\end{array}$ & 1.5 & .6 & 2.3 & $\begin{array}{l}1.1 \\
1.9\end{array}$ & 1.0 & $\begin{array}{l}2.1 \\
3.0\end{array}$ \\
\hline 0330 & 54.8 & .28 & 8.63 & 0 & -.45 & 1.5 & $\begin{array}{l}4.6 \\
1.5\end{array}$ & $\begin{array}{l}4.6 \\
2.8\end{array}$ & 1.4 & $\cdots$ & 1.0 & $\begin{array}{l}1.1 \\
2.1\end{array}$ &.--1 & 2.7 \\
\hline 0400 & 53.8 & .31 & 8.43 & 0 & -.45 & 1.5 & $\begin{array}{l}4.0 \\
1.1\end{array}$ & $\begin{array}{l}4.0 \\
2.7\end{array}$ & 1.6 & $-\cdot$ & .9 & $\begin{array}{l}1.4 \\
2.9\end{array}$ & $-\cdot$ & $\begin{array}{l}1.0 \\
2.0\end{array}$ \\
\hline 0430 & 53.0 & .23 & $-\cdots-$ & 0 & -.45 & 1.5 & $\begin{array}{l}4.4 \\
1.4\end{array}$ & $\begin{array}{l}4.4 \\
3.0\end{array}$ & 1.5 & -- & 1.2 & $\begin{array}{l}1.4 \\
2.5\end{array}$ & .7 & $\begin{array}{l}1.3 \\
2.5\end{array}$ \\
\hline 0500 & 52.2 & .23 & 8.04 & 0 & -.44 & 1.8 & $\begin{array}{r}3.4 \\
.5\end{array}$ & $\begin{array}{l}3.4 \\
2.0\end{array}$ & 1.8 & $\cdots$ & .4 & $\begin{array}{l}7.5 \\
2.5\end{array}$ & $\begin{array}{l}-- \\
\cdots\end{array}$ & $\begin{array}{r}.4 \\
1.3\end{array}$ \\
\hline 0530 & 51.2 & .24 & ----- & 0 & -.44 & 1.3 & $\begin{array}{r}3.4 \\
.7\end{array}$ & $\begin{array}{l}3.4 \\
2.2\end{array}$ & 1.4 & -- & .3 & $\begin{array}{l}1.2 \\
2.4\end{array}$ & $-\cdots$ & 1.6 \\
\hline
\end{tabular}


RAFT RIVER 2 (1978) - HOT IV (contd)

\begin{tabular}{|c|c|c|c|c|c|c|c|c|c|c|c|c|c|c|}
\hline 0600 & 50.5 & .24 & 7.69 & 0 & -.44 & 1.3 & $\begin{array}{r}3.5 \\
.8\end{array}$ & $\begin{array}{l}3.5 \\
2.8\end{array}$ & 1.5 & -.. & .9 & $\begin{array}{l}1.3 \\
2.3\end{array}$ & -. & $\begin{array}{r}.8 \\
2.1\end{array}$ \\
\hline 0630 & 49.9 & .19 & -..-- & 0 & -.45 & 1.1 & $\begin{array}{l}3.7 \\
1.2\end{array}$ & $\begin{array}{l}4.0 \\
3.1\end{array}$ & 1.4 & $\ldots$ & 1.0 & $\begin{array}{l}1.1 \\
2.2\end{array}$ & .5 & $\begin{array}{r}.5 \\
2.8\end{array}$ \\
\hline 0700 & 49.2 & .23 & 7.39 & 0 & -.44 & 1.5 & $\begin{array}{r}3.0 \\
.6\end{array}$ & $\begin{array}{l}3.1 \\
2.2\end{array}$ & 1.4 & --- & .4 & $\begin{array}{l}1.3 \\
2.5\end{array}$ & $\begin{array}{l}--- \\
--\end{array}$ & $\begin{array}{r}.4 \\
1.8\end{array}$ \\
\hline 0730 & $\ldots$ & $-\cdots$ & -..-- & 0 & -- &.- & $\begin{array}{l}--- \\
---\end{array}$ & --. & --- & $\ldots$ & --- & $\begin{array}{l}1.2 \\
2.0\end{array}$ & --- & -- \\
\hline 0800 & --.- & $\ldots$ & 7.01 & .05 &.-- & -- & $-\cdots$ & --- & -.. & -- & $\ldots$ & $\begin{array}{l}1.6 \\
2.9\end{array}$ & $\cdots$ & -- \\
\hline 0830 & -..- & --. & --.-- & .25 & -.29 & 1.8 & $\begin{array}{l}3.7 \\
1.9\end{array}$ & $\begin{array}{l}4.4 \\
3.8\end{array}$ & 1.7 & .8 & 3.1 & $\begin{array}{l}1.6 \\
2.5\end{array}$ & $\begin{array}{r}.4 \\
1.0\end{array}$ & $\begin{array}{l}2.8 \\
3.0\end{array}$ \\
\hline 0900 & $\ldots$ & -- & 6.78 & .53 & -.11 & 1.8 & $\begin{array}{l}5.9 \\
4.4\end{array}$ & $\begin{array}{l}7.5 \\
6.9\end{array}$ & 1.7 & 3.7 & 7.3 & $\begin{array}{l}1.7 \\
2.1\end{array}$ & $\begin{array}{l}2.8 \\
3.3\end{array}$ & $\begin{array}{l}6.3 \\
6.1\end{array}$ \\
\hline 0930 & 46.3 & .21 & -..-- & .83 & .15 & 1.8 & $\begin{array}{l}7.0 \\
5.8\end{array}$ & $\begin{array}{l}9.6 \\
9.2\end{array}$ & 1.7 & 6.4 & 9.9 & $\begin{array}{l}1.6 \\
1.9\end{array}$ & $\begin{array}{l}4.2 \\
5.0\end{array}$ & $\begin{array}{l}8.9 \\
8.6\end{array}$ \\
\hline 1000 & 45.7 & .23 & 6.47 & 1.11 & .36 & 0.5 & $\begin{array}{l}9.6 \\
9.3\end{array}$ & $\begin{array}{l}13.7 \\
13.8\end{array}$ & 0.4 & 8.3 & 14.0 & $\begin{array}{l}0.6 \\
0.6\end{array}$ & $\begin{array}{l}6.5 \\
7.9\end{array}$ & $\begin{array}{l}12.7 \\
12.8\end{array}$ \\
\hline 1030 & 45.5 & .30 & $\ldots$ & 1.37 & .52 & 0.8 & $\begin{array}{l}10.4 \\
10.8\end{array}$ & $\begin{array}{l}15.0 \\
16.6\end{array}$ & 0.9 & 9.1 & 14.9 & $\begin{array}{l}0.7 \\
0.8\end{array}$ & $\begin{array}{l}7.5 \\
8.8\end{array}$ & $\begin{array}{l}14.4 \\
14.3\end{array}$ \\
\hline 1100 & 45.1 & .41 & 6.21 & 1.58 & .71 & 1.0 & $\begin{array}{l}11.1 \\
10.7\end{array}$ & $\begin{array}{l}16.0 \\
16.1\end{array}$ & 1.0 & 10.0 & 17.0 & $\begin{array}{l}0.8 \\
1.0\end{array}$ & $\begin{array}{l}8.5 \\
9.6\end{array}$ & $\begin{array}{l}15.5 \\
15.3\end{array}$ \\
\hline 1130 & 44.9 & .43 & $+\cdots$ & 1.75 & .89 & 1.5 & $\begin{array}{l}11.5 \\
11.1\end{array}$ & $\begin{array}{l}17.0 \\
17.1\end{array}$ & 1.5 & 11.2 & 18.2 & $\begin{array}{l}1.4 \\
1.8\end{array}$ & $\begin{array}{r}9.2 \\
10.5\end{array}$ & $\begin{array}{l}16.9 \\
16.9\end{array}$ \\
\hline
\end{tabular}


RAFT RIVER 2 (1978) - HOT IV (contd)

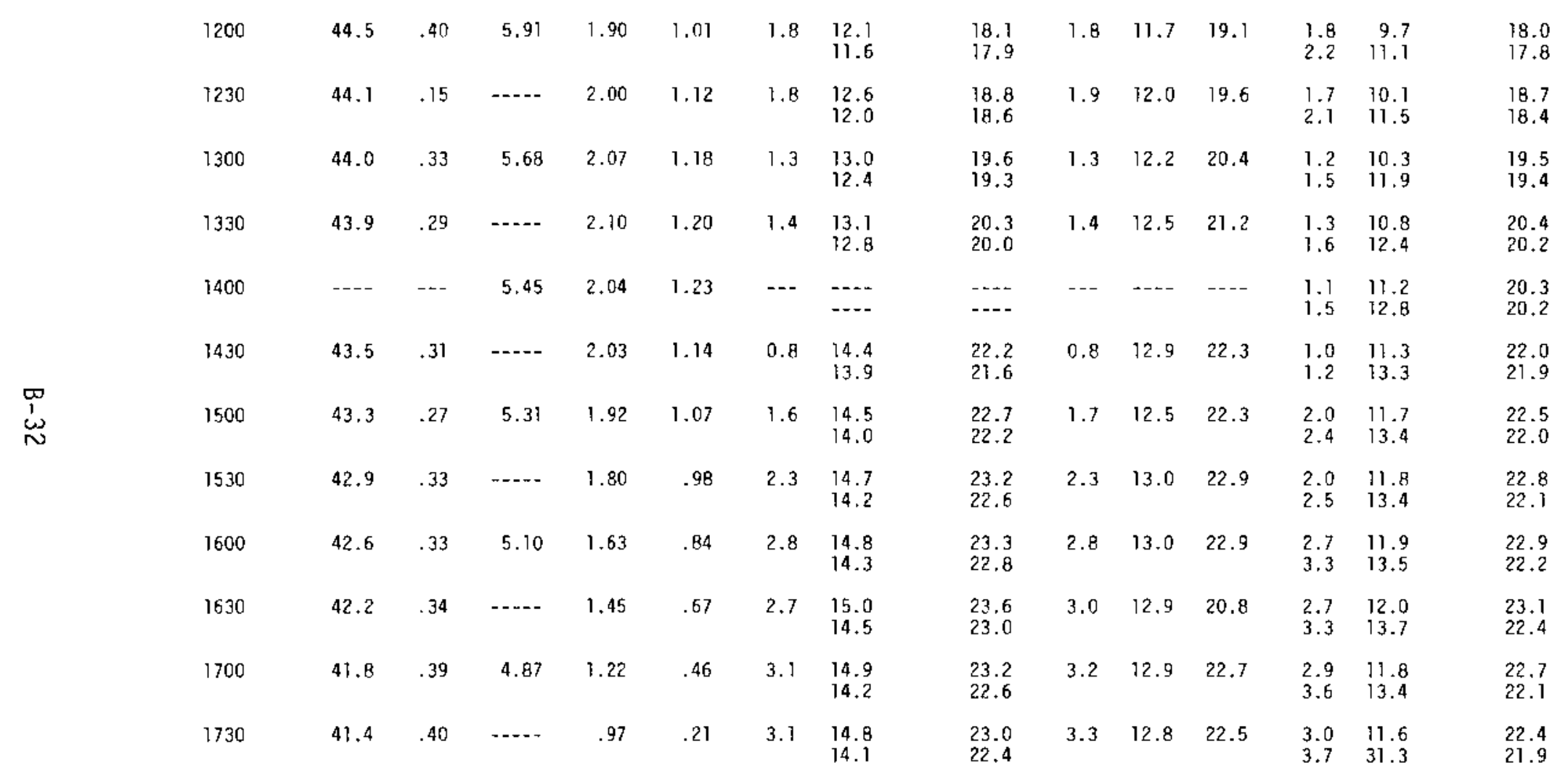


RAFT RIVER 2 (1978) - HOT IV (contd)

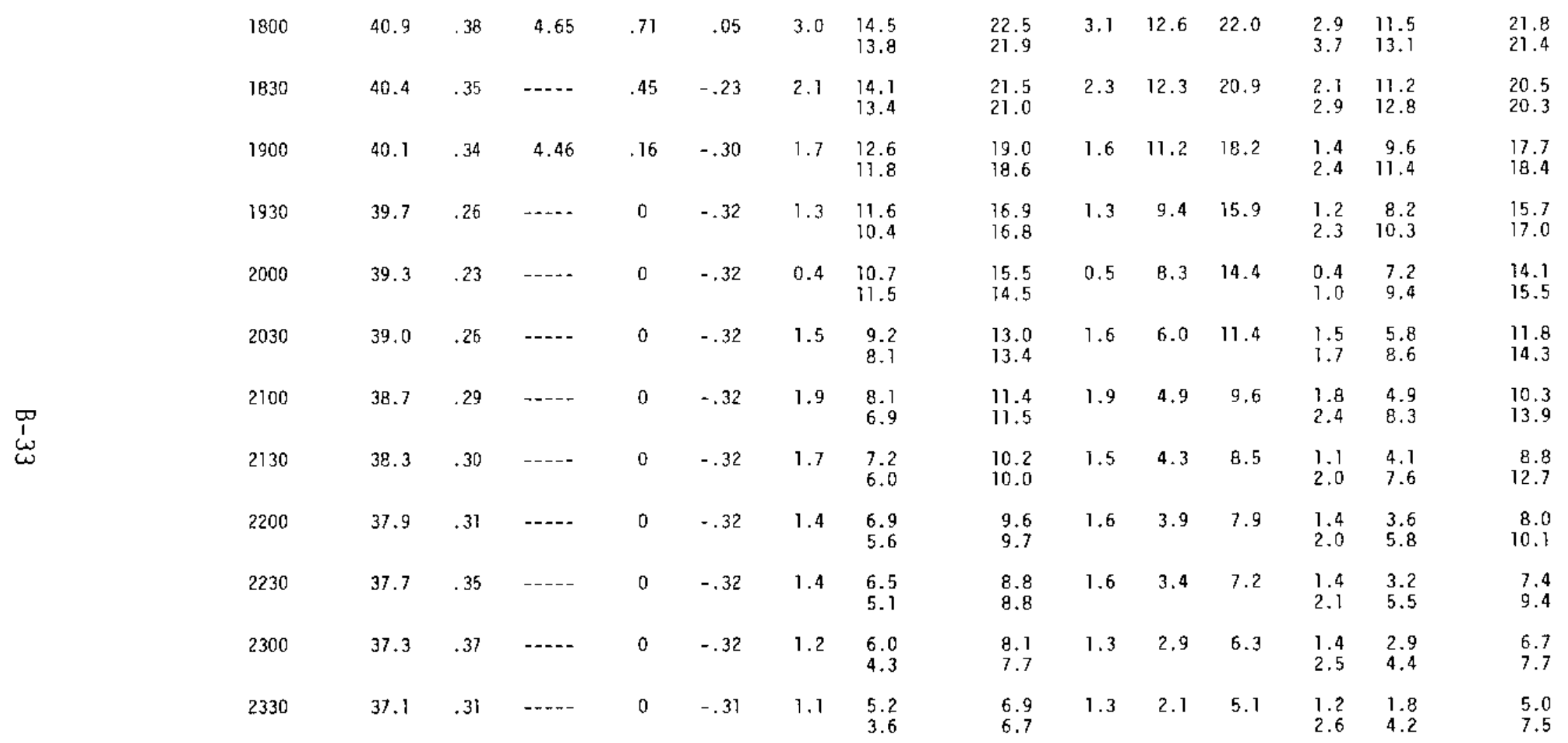


RAFT RIVER 2 (1978) - HOT IV (contd)

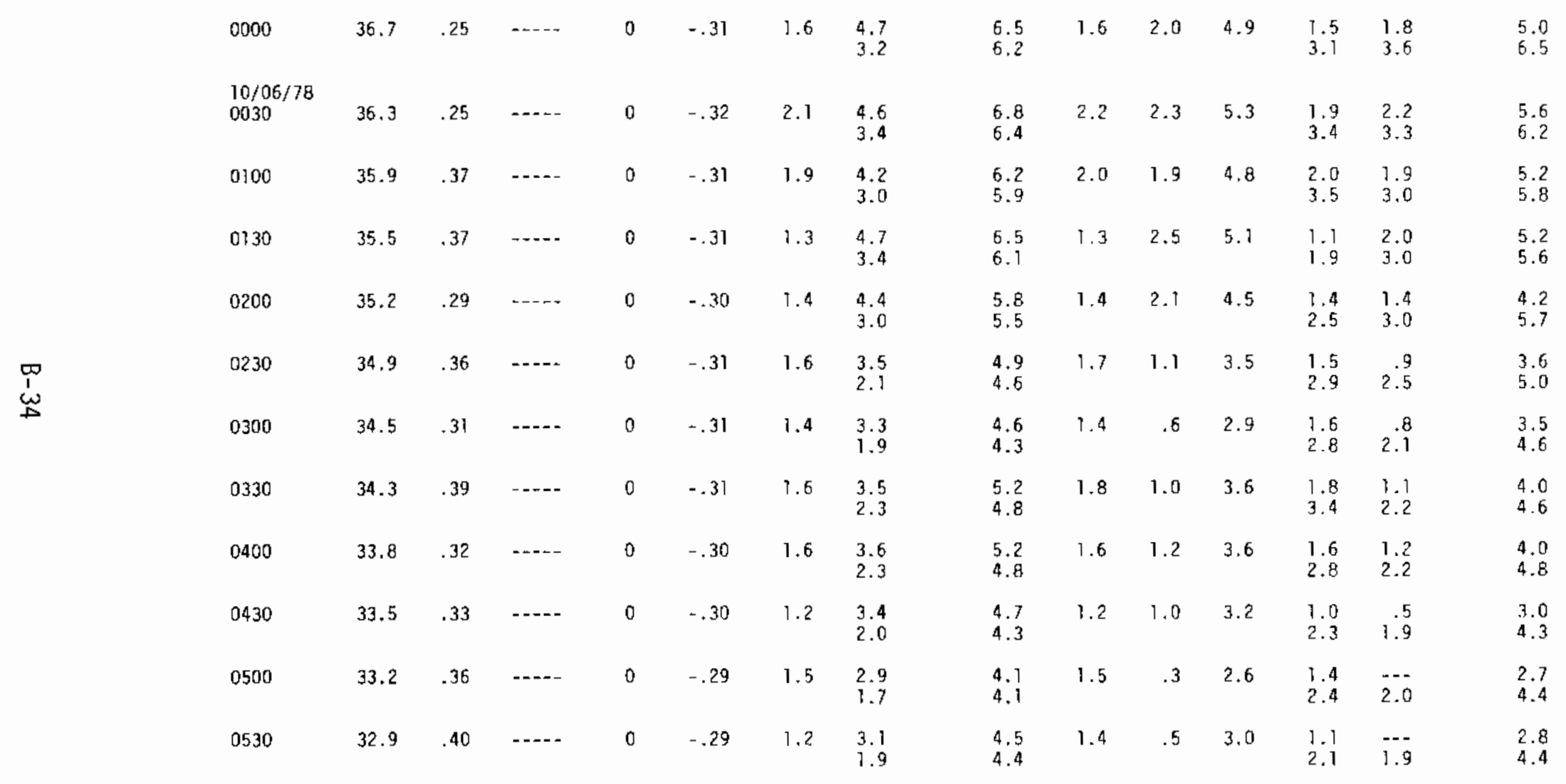


RAFT RIVER 2 (1978) - HOT IV (contd)

\begin{tabular}{|c|c|c|c|c|c|c|c|c|c|c|c|c|c|c|c|}
\hline & 0600 & 32.6 & .38 & ---- & 0 & -.29 & 0.8 & $\begin{array}{l}2.5 \\
1.2\end{array}$ & $\begin{array}{l}3.4 \\
3.1\end{array}$ & 0.8 & $\cdots$ & 1.8 & $\begin{array}{l}0.7 \\
1.5\end{array}$ & --- & $\begin{array}{l}1.5 \\
3.0\end{array}$ \\
\hline & 0630 & 32.3 & .40 & ---- & 0 & -.29 & 1.2 & $\begin{array}{r}1.9 \\
.6\end{array}$ & $\begin{array}{l}2.7 \\
2.6\end{array}$ & 1.2 & -- & 1.3 & $\begin{array}{l}1.2 \\
2.1\end{array}$ & .9 & $\begin{array}{l}1.2 \\
2.9\end{array}$ \\
\hline & 0700 & 32.0 & .38 & $\cdots$ & 0 & -.29 & 1.9 & $\begin{array}{r}1.8 \\
.7\end{array}$ & $\begin{array}{l}2.9 \\
2.9\end{array}$ & 1.9 & --- & 1.7 & $\begin{array}{l}1.8 \\
3.3\end{array}$ & 1.2 & $\begin{array}{l}1.8 \\
3.3\end{array}$ \\
\hline & 0730 & 31.7 & .41 & $\cdots$ & 0 & -.28 & 1.2 & $\begin{array}{r}1.6 \\
.4\end{array}$ & $\begin{array}{l}2.4 \\
2.5\end{array}$ & 1.4 & --- & 1.0 & $\begin{array}{l}1.5 \\
2.4\end{array}$ & $\because .0$ & $\begin{array}{l}1.2 \\
3.1\end{array}$ \\
\hline & 0800 & 31.5 & .38 & 2.33 & .06 & -.26 & 1.4 & $\begin{array}{r}1.6 \\
.4\end{array}$ & $\begin{array}{l}2.5 \\
2.4\end{array}$ & 1.4 & --- & .9 & $\begin{array}{l}1.5 \\
2.4\end{array}$ &.-8 & $\begin{array}{l}1.3 \\
2.9\end{array}$ \\
\hline & 0830 & $\cdots$ & --- & $\cdots$ & .28 & -.21 & 1.4 & $\begin{array}{l}3.2 \\
2.2\end{array}$ & $\begin{array}{l}5.0 \\
4.5\end{array}$ & 1.6 & 1.8 & 4.7 & $\begin{array}{l}1.4 \\
2.1\end{array}$ & $-\cdots$ & -- \\
\hline & 0900 & 31.2 & .29 & 2.18 & .55 & .04 & 2.0 & $\begin{array}{l}4.8 \\
4.2\end{array}$ & $\begin{array}{l}7.4 \\
7.2\end{array}$ & 1.8 & 4.1 & 8.0 & $\begin{array}{l}1.5 \\
2.0\end{array}$ & $\begin{array}{l}3.0 \\
3.6\end{array}$ & $\begin{array}{l}6.9 \\
6.7\end{array}$ \\
\hline & 0930 & 31.0 & .30 & -..-- & .83 & .31 & 1.7 & $\begin{array}{l}6.6 \\
6.4\end{array}$ & $\begin{array}{l}10.3 \\
10.3\end{array}$ & 1.6 & 6.1 & 11.2 & $\begin{array}{l}1.5 \\
1.8\end{array}$ & $\begin{array}{l}5.0 \\
5.9\end{array}$ & $\begin{array}{r}10.3 \\
9.9\end{array}$ \\
\hline & 1000 & 31.0 & .29 & 2.00 & 1.10 & .53 & 1.5 & $\begin{array}{l}8.4 \\
8.5\end{array}$ & $\begin{array}{l}13.2 \\
13.5\end{array}$ & 1.5 & 8.0 & 14.1 & $\begin{array}{l}1.3 \\
1.7\end{array}$ & $\begin{array}{l}6.8 \\
7.9\end{array}$ & $\begin{array}{l}13.3 \\
13.1\end{array}$ \\
\hline & 1030 & 30.9 & .30 & ----. & 1.34 & .67 & 0.9 & $\begin{array}{l}10.1 \\
10.5\end{array}$ & $\begin{array}{l}16.2 \\
16.7\end{array}$ & 0.9 & 10.7 & 17.7 & $\begin{array}{l}0.7 \\
0.8\end{array}$ & $\begin{array}{r}8.5 \\
10.0\end{array}$ & $\begin{array}{l}16.7 \\
16.6\end{array}$ \\
\hline & 1100 & 31.0 & .37 & 1.88 & 1.56 & .86 & 0.5 & $\begin{array}{l}11.1 \\
11.5\end{array}$ & $\begin{array}{l}17.6 \\
18.0\end{array}$ & 0.4 & 11.7 & 19.9 & $\begin{array}{l}0.5 \\
0.4\end{array}$ & $\begin{array}{r}9.5 \\
10.9\end{array}$ & $\begin{array}{l}18.1 \\
17.9\end{array}$ \\
\hline & 1130 & 31.0 & .39 & -..... & 1.74 & 1.04 & 0.9 & $\begin{array}{l}12.0 \\
12.2\end{array}$ & $\begin{array}{l}18.6 \\
18.8\end{array}$ & 1.0 & 12.3 & 20.5 & $\begin{array}{l}0.9 \\
1.1\end{array}$ & $\begin{array}{l}10.5 \\
12.0\end{array}$ & $\begin{array}{r}19.2 \\
19.2\end{array}$ \\
\hline
\end{tabular}


RAFT RIVER 2 (1978) - HOT IV (contd)

\begin{tabular}{|c|c|c|c|c|c|c|c|c|c|c|c|c|c|c|}
\hline 1200 & 31.1 & .39 & 1.75 & 1.88 & 1.17 & 1.5 & $\begin{array}{l}12.6 \\
12.8\end{array}$ & $\begin{array}{l}19.6 \\
19.8\end{array}$ & 1.5 & 12.5 & 20.9 & $\begin{array}{l}1.6 \\
2.0\end{array}$ & $\begin{array}{l}11.2 \\
12.7\end{array}$ & $\begin{array}{l}20.3 \\
20.2\end{array}$ \\
\hline 1230 & 31.2 & .44 & -..- & 2.00 & 1.78 & 1.8 & $\begin{array}{l}13.1 \\
13.2\end{array}$ & $\begin{array}{l}20.9 \\
20.8\end{array}$ & 1.9 & 12.9 & 22.2 & $\begin{array}{l}1.9 \\
2.2\end{array}$ & $\begin{array}{l}11.5 \\
13.2\end{array}$ & $\begin{array}{l}21.4 \\
21.3\end{array}$ \\
\hline 1300 & 31.2 & .48 & 1.60 & 2.07 & 1.33 & 1.3 & $\begin{array}{l}13.8 \\
13.9\end{array}$ & $\begin{array}{l}21.8 \\
21.7\end{array}$ & 1.4 & 13.4 & 23.1 & $\begin{array}{l}1.3 \\
1.7\end{array}$ & $\begin{array}{l}11.9 \\
13.7\end{array}$ & $\begin{array}{l}22.4 \\
22.3\end{array}$ \\
\hline 1330 & 31.3 & .47 & ----- & 2.10 & 1.35 & 1.6 & $\begin{array}{l}14.2 \\
14.4\end{array}$ & $\begin{array}{l}22.7 \\
22.6\end{array}$ & 1.7 & 13.9 & 24.0 & $\begin{array}{l}1.7 \\
2.1\end{array}$ & $\begin{array}{l}12.4 \\
14.2\end{array}$ & $\begin{array}{l}23.4 \\
23.1\end{array}$ \\
\hline 1400 & 31.4 & .50 & $\cdots$ & 2.08 & 1.33 & 1.5 & $\begin{array}{l}14.6 \\
14.7\end{array}$ & $\begin{array}{l}23.4 \\
23.1\end{array}$ & 1.7 & 13.8 & 24.1 & $\begin{array}{l}1.5 \\
1.8\end{array}$ & $\begin{array}{l}12.6 \\
14.5\end{array}$ & $\begin{array}{l}23.9 \\
23.7\end{array}$ \\
\hline 1430 & $\ldots$ & -- & ---- & 2.01 & 1.30 & 1.3 & $\begin{array}{l}14.7 \\
14.8\end{array}$ & $\begin{array}{l}23.7 \\
23.5\end{array}$ & 1.4 & 13.5 & 24.1 & $\begin{array}{l}1.5 \\
1.7\end{array}$ & $\begin{array}{l}12.3 \\
14.4\end{array}$ & $\begin{array}{l}24.0 \\
23.8\end{array}$ \\
\hline
\end{tabular}

$\infty$
$\omega$
$\sigma$ 
EAST MESA 1 (1979) - COOL I

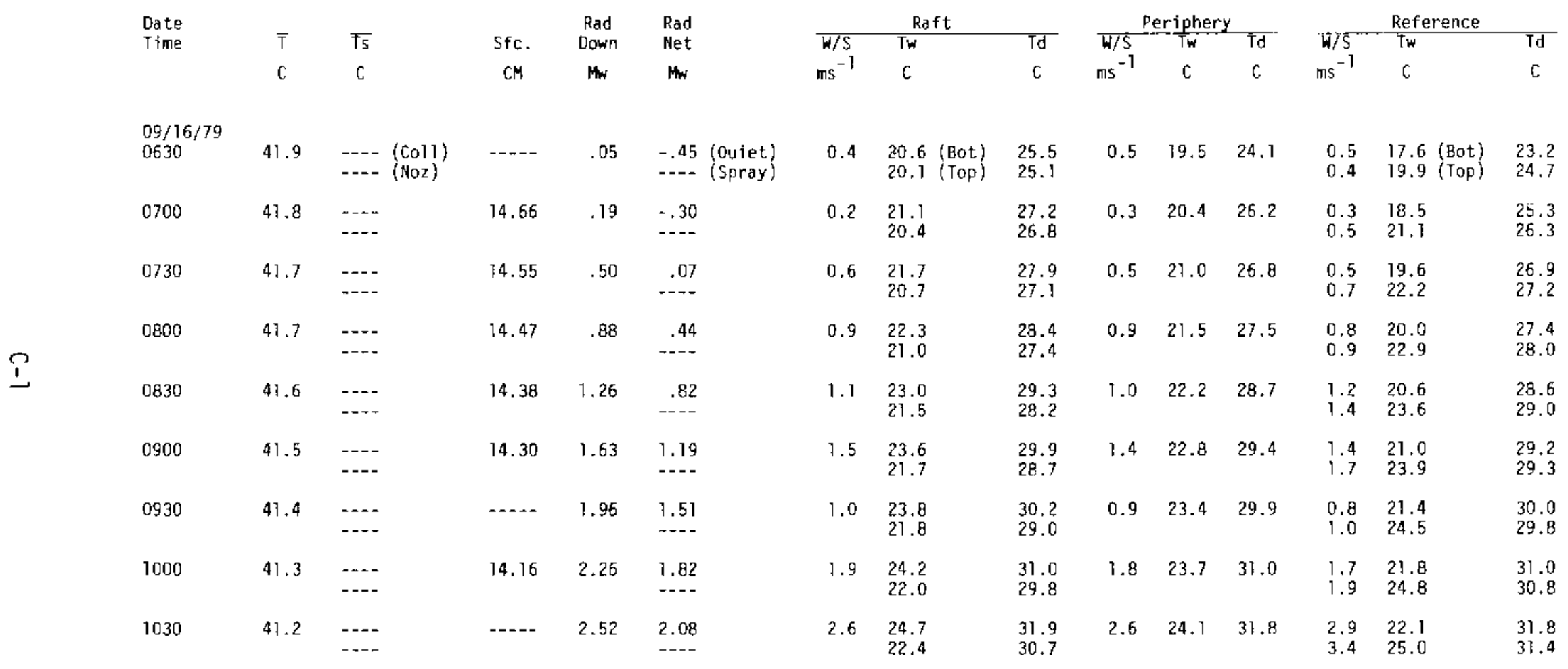


EAST MESA 1 (1979) - COOL I (contd)

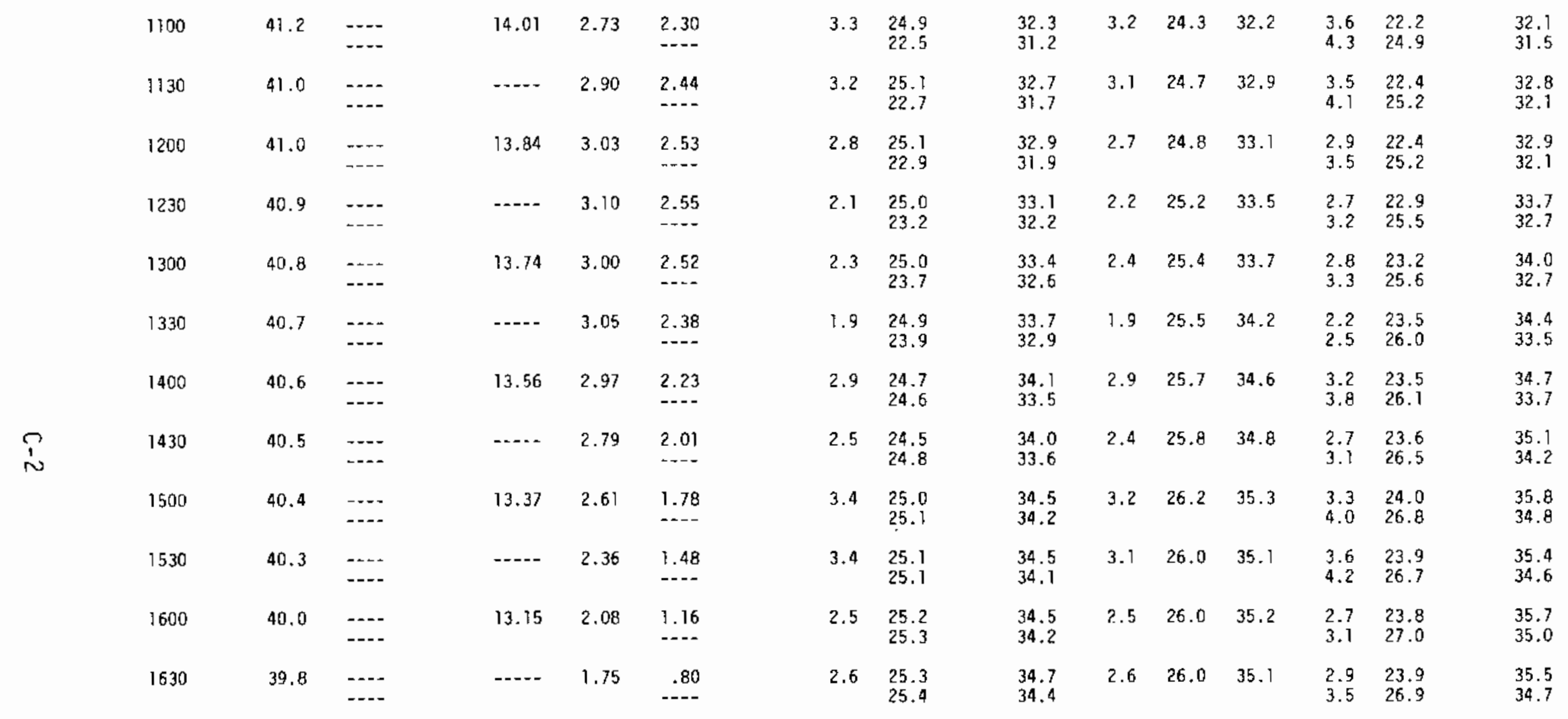


EAST MESA 1 (1979) - COOL I (contd)

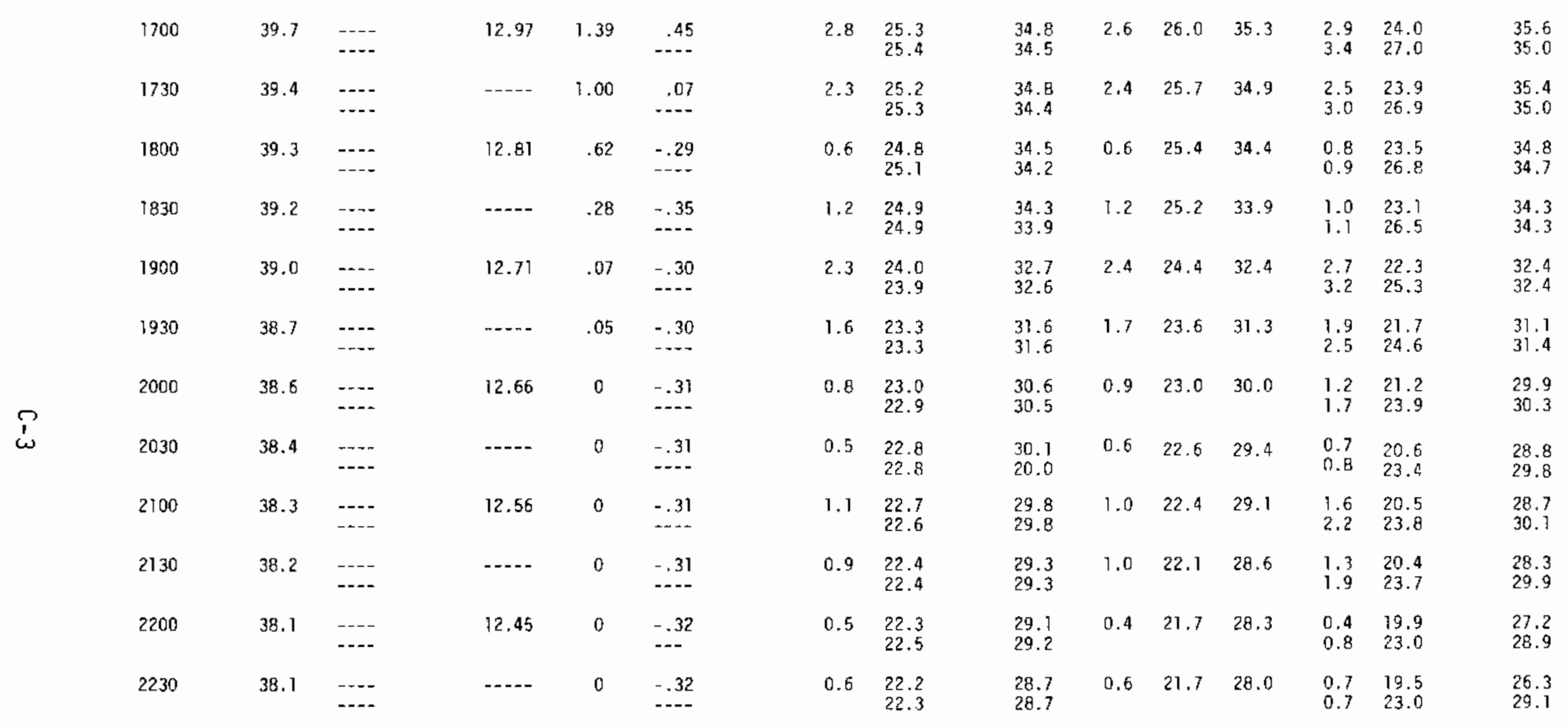


EAST MESA 1 (1979) - COOL I (contd)

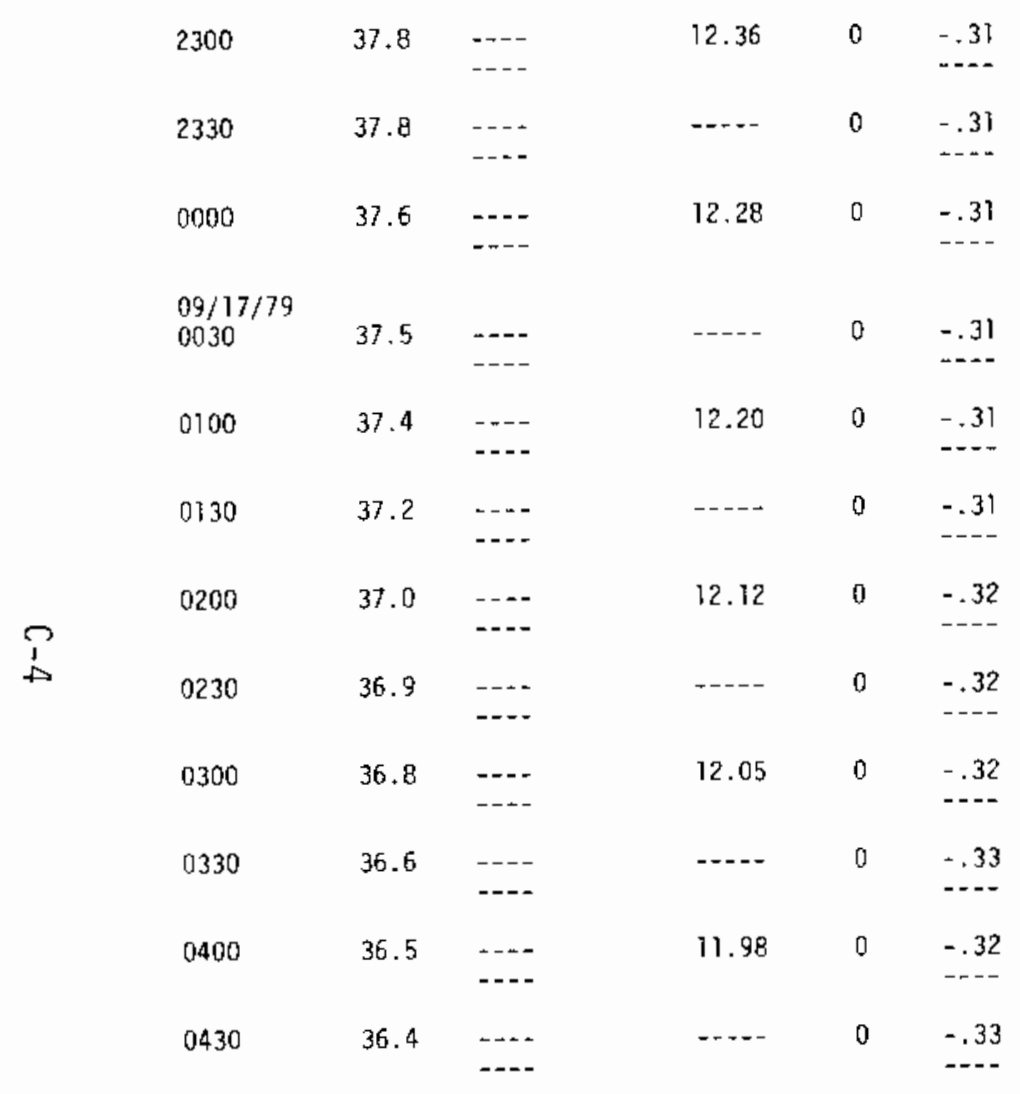

$\begin{array}{lllllllll}0.8 & 21.8 & 28.1 & 0.7 & 21.4 & 27.4 & 0.9 & 19.4 & 26.0 \\ & 21.8 & 28.1 & & & & 0.9 & 23.1 & 28.9 \\ 0.8 & 21.3 & 27.1 & 0.8 & 21.0 & 26.6 & 1.3 & 19.3 & 25.9 \\ & 21.3 & 27.1 & & & & 1.4 & 23.1 & 28.9 \\ 0.7 & 21.2 & 27.1 & 0.7 & 20.9 & 26.5 & 0.9 & 19.2 & 25.6 \\ & 21.2 & 27.0 & & & & 1.2 & 22.9 & 28.6 \\ & & & & & & & & \\ 0.7 & 21.1 & 26.8 & 0.6 & 20.6 & 26.0 & 0.7 & 18.8 & 24.9 \\ & 21.1 & 26.7 & & & & 1.0 & 22.4 & 28.0 \\ 0.9 & 20.5 & 25.8 & 0.9 & 20.2 & 25.2 & 1.0 & 18.6 & 24.5 \\ & 20.5 & 25.7 & & & & 1.6 & 22.1 & 27.3 \\ 1.4 & 20.4 & 25.9 & 1.5 & 20.3 & 25.3 & 1.7 & 18.7 & 24.6 \\ & 20.4 & 25.7 & & & & 2.7 & 21.4 & 26.2 \\ 1.0 & 20.3 & 25.7 & 1.0 & 20.0 & 25.1 & 1.4 & 18.5 & 24.4 \\ & 20.3 & 25.6 & & & & 2.2 & 21.2 & 26.2 \\ 0.6 & 20.1 & 25.4 & 0.5 & 19.6 & 24.5 & 0.8 & 18.1 & 23.7 \\ & 20.3 & 25.4 & & & & 1.4 & 20.9 & 25.8 \\ 0.3 & 20.4 & 24.8 & 0.3 & 19.2 & 23.4 & 0.2 & 17.6 & 22.3 \\ & 20.5 & 24.7 & & & & 0.6 & 20.4 & 25.1 \\ 0.6 & 19.7 & 24.8 & 0.7 & 19.2 & 23.9 & 0.8 & 17.5 & 22.5 \\ & 19.7 & 24.6 & & & & 1.4 & 20.2 & 24.6 \\ 0.5 & 19.5 & 25.3 & 0.5 & 18.6 & 22.2 & 0.5 & 17.4 & 21.4 \\ & 19.5 & 23.3 & & & & 0.6 & 19.5 & 23.7 \\ 0.2 & 19.4 & 23.8 & 0.2 & 18.8 & 22.9 & 0.3 & 17.2 & 21.4 \\ & 19.6 & 23.8 & & & & 0.8 & 19.6 & 23.7\end{array}$


EAST MESA 1 (1979) - COOL I (contd)

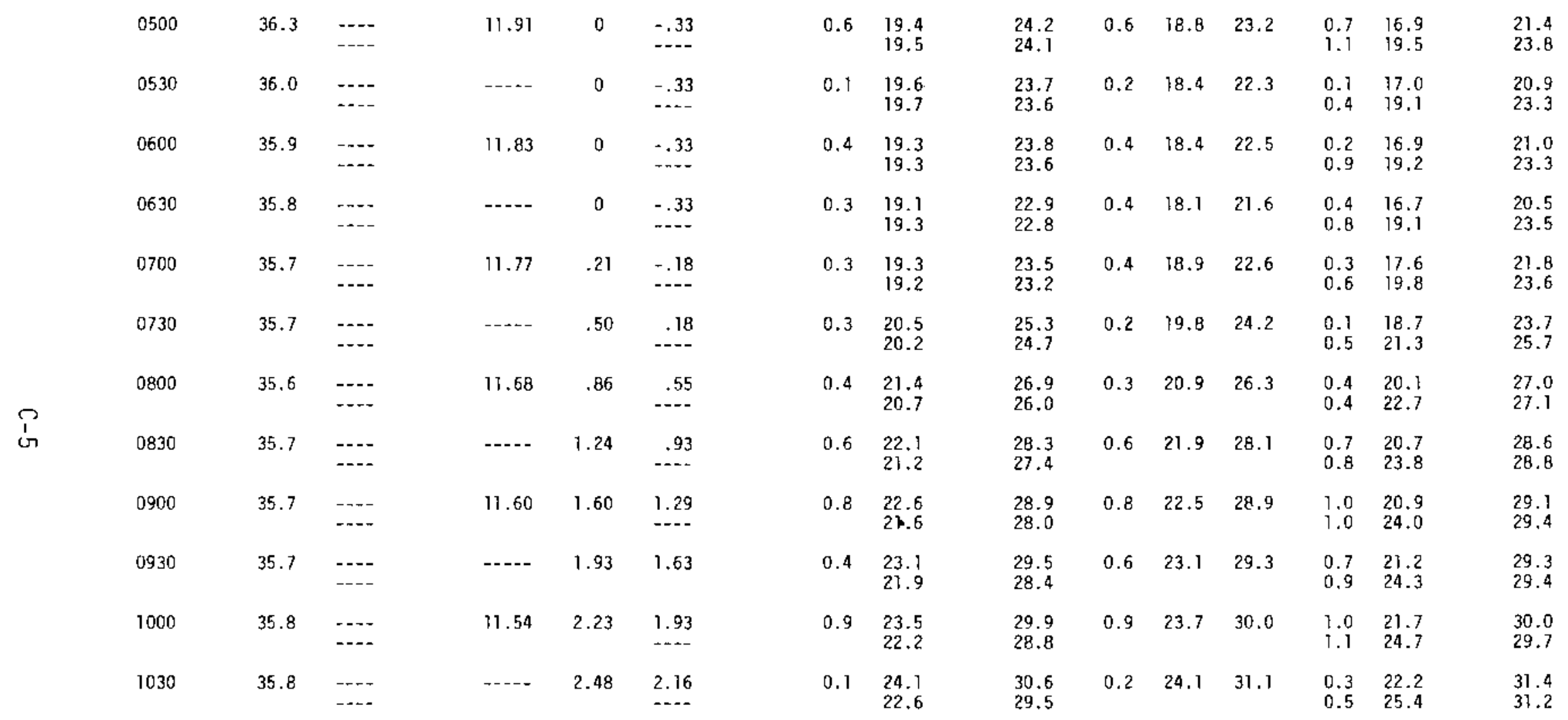


EAST MESA 7 (1979) - COOL I (contd)

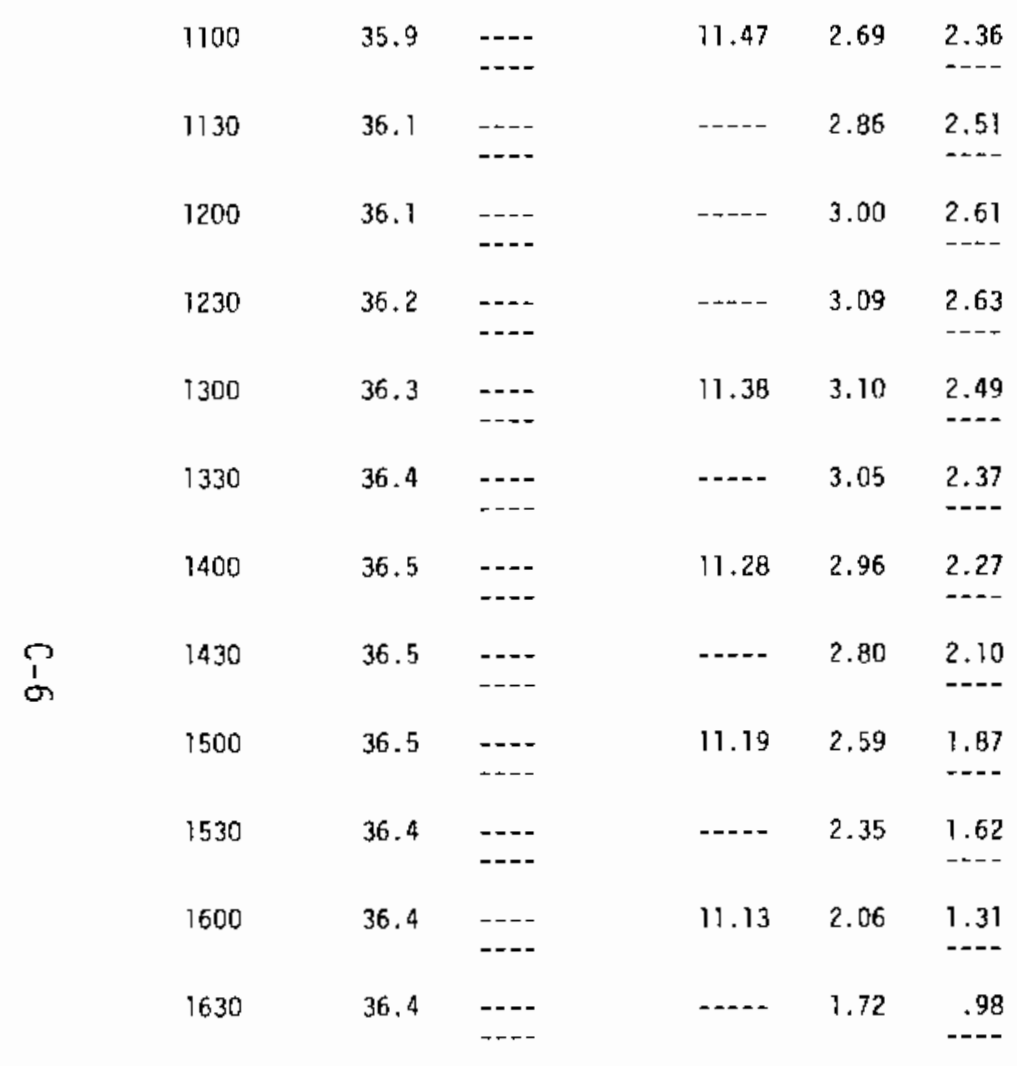

$\begin{array}{lllllllll}0.4 & 24.2 & 31.2 & 0.4 & 24.5 & 31.8 & 0.3 & 22.6 & 32.4 \\ & 22.6 & 30.1 & & & & 0.3 & 25.7 & 32.1 \\ 0.7 & 24.4 & 31.8 & 0.8 & 24.9 & 32.4 & 0.2 & 22.7 & 33.1 \\ & 22.9 & 30.7 & & & & 0.3 & 26.0 & 32.5 \\ 0.8 & 24.0 & 32.4 & 0.8 & 25.2 & 33.4 & 1.3 & 22.7 & 33.4 \\ & 23.4 & 31.5 & & & & 1.5 & 25.9 & 32.9 \\ 1.0 & 24.8 & 32.9 & 1.1 & 25.4 & 33.3 & 1.1 & 23.3 & 34.2 \\ & 23.9 & 32.0 & & & & 1.4 & 26.1 & 33.2 \\ 1.0 & 25.0 & 33.4 & 1.0 & 25.7 & 34.3 & 1.1 & 23.8 & 34.8 \\ & 24.3 & 32.6 & & & & 1.4 & 26.3 & 33.8 \\ 0.4 & 24.8 & 33.5 & 0.5 & 25.9 & 34.5 & 0.7 & 24.0 & 35.2 \\ & 24.4 & 32.7 & & & & 0.8 & 26.7 & 34.4 \\ 2.1 & 24.5 & 33.4 & 2.2 & 26.0 & 34.3 & 2.3 & 24.0 & 35.1 \\ & 24.5 & 32.8 & & & & 2.5 & 26.7 & 34.2 \\ 2.4 & 24.4 & 33.2 & 2.4 & 26.0 & 34.2 & 2.4 & 24.0 & 35.2 \\ & 24.8 & 33.9 & & & & 2.8 & 26.8 & 34.2 \\ 2.0 & 24.7 & 33.4 & 2.2 & 26.3 & 34.5 & 2.3 & 24.3 & 35.4 \\ & 25.0 & 33.2 & & & & 2.6 & 27.1 & 34.6 \\ 2.4 & 25.7 & 33.7 & 2.4 & 26.3 & 34.5 & 2.2 & 24.4 & 35.5 \\ & 25.3 & 33.5 & & & & 2.5 & 27.3 & 34.7 \\ 1.5 & 25.0 & 33.9 & 2.5 & 26.2 & 34.8 & 1.4 & 24.1 & 35.4 \\ & 25.5 & 33.7 & & & & 1.7 & 27.3 & 34.7 \\ 1.9 & 25.4 & 34.0 & 2.1 & 26.3 & 34.5 & 2.1 & 24.4 & 35.6 \\ & 25.6 & 33.7 & & & & 2.3 & 27.4 & 34.9\end{array}$


EAST MESA I (1979) - COOL I (contd)

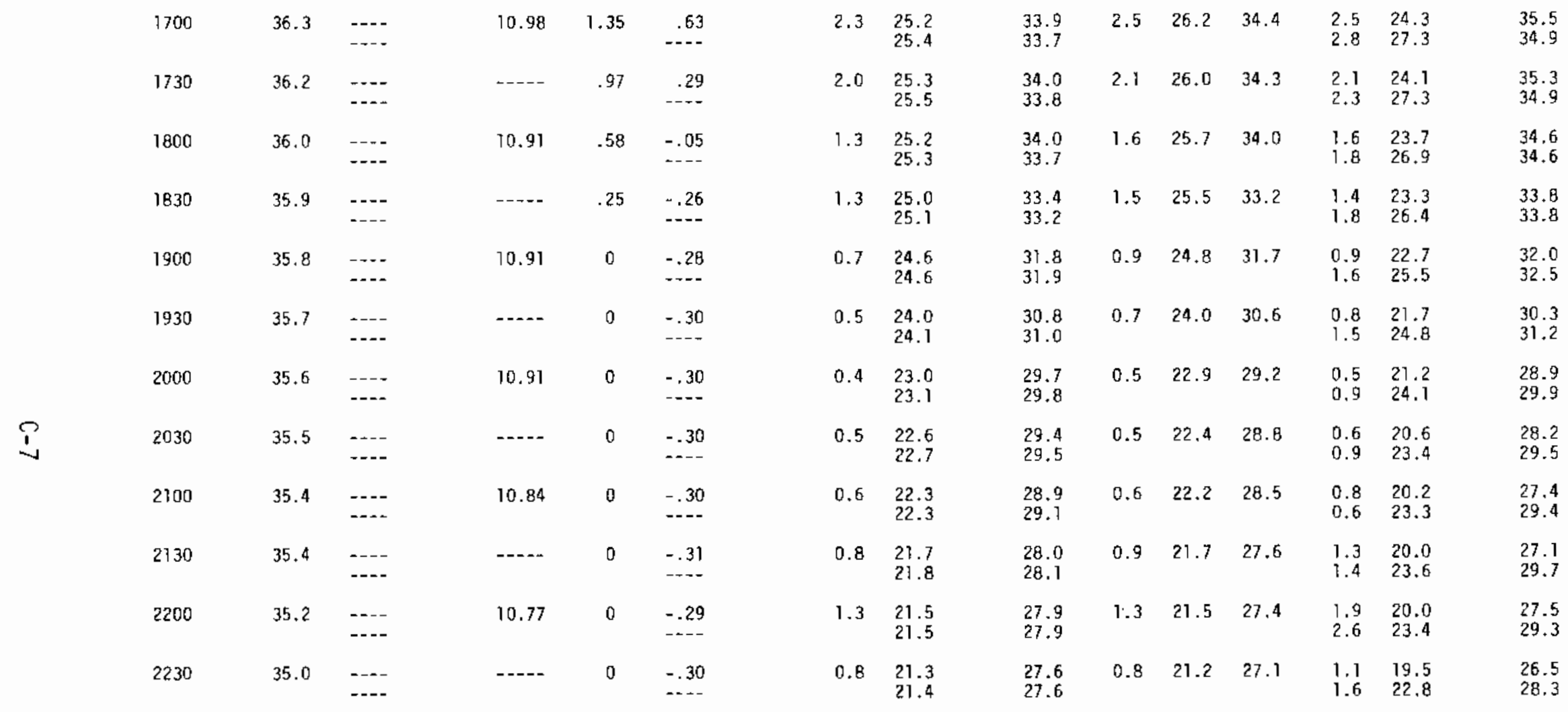


EAST MESA 1 (1979) - COOL I (contd)

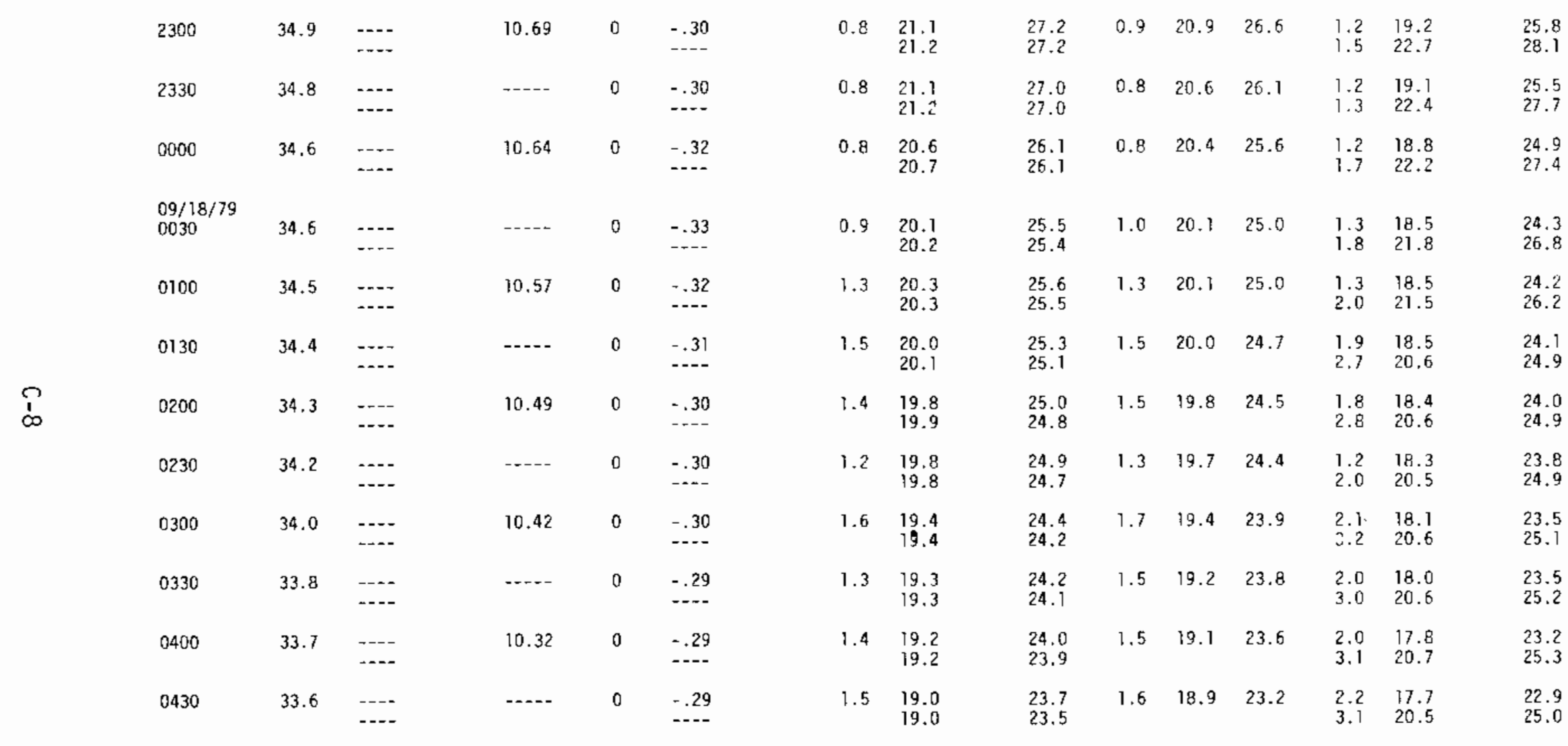


EAST MESA 1 (1979) - COOL I (contd)

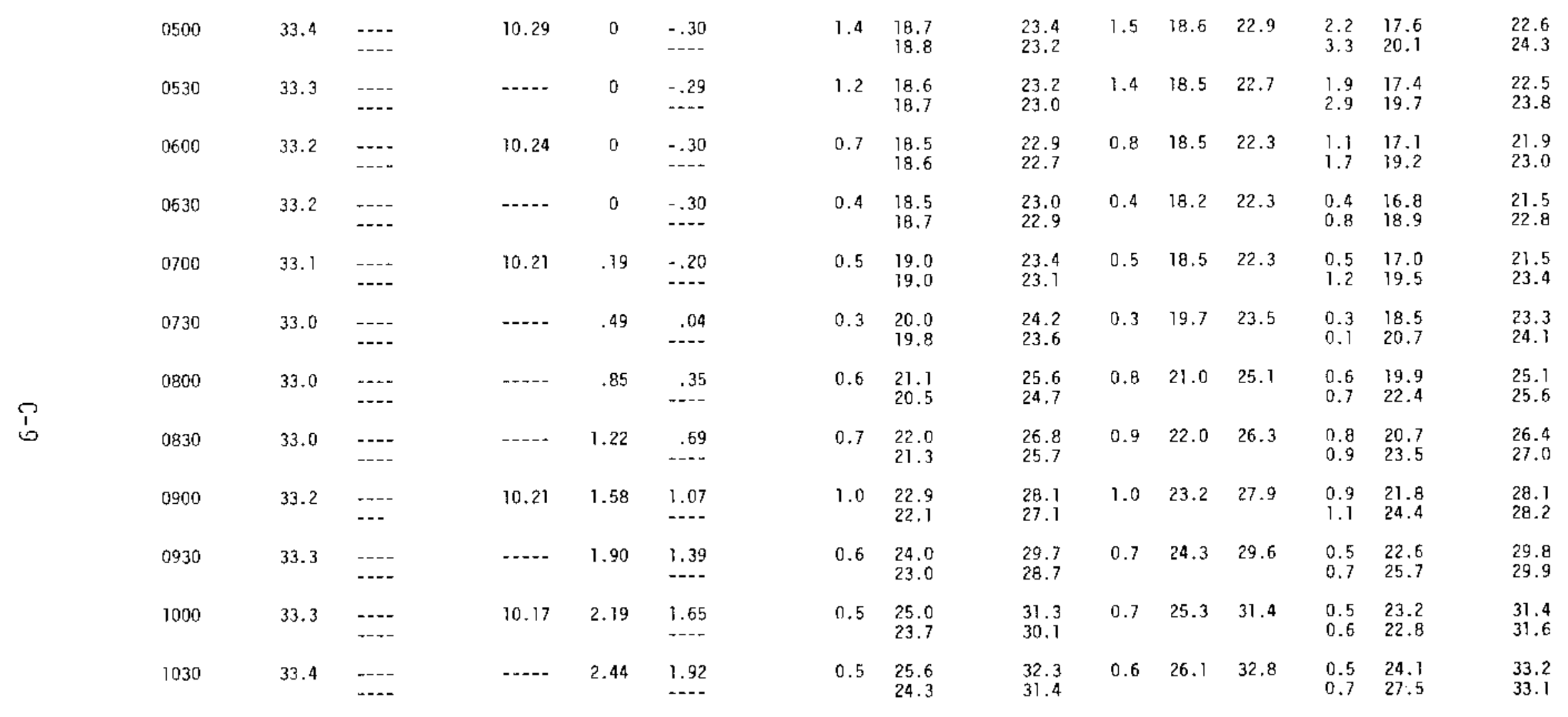




\section{EAST MESA 1 (1979) - COOL I (contd)}

\begin{tabular}{|c|c|c|c|c|c|c|}
\hline & 1100 & 33.6 & -.-- & 10.12 & 2.67 & $\begin{array}{l}2.15 \\
-\end{array}$ \\
\hline & 1130 & 33.6 & --- & $\cdots$ & 2.86 & 2.33 \\
\hline & 1200 & 33.7 & $-\cdots$ & 10.06 & 2.97 & $\begin{array}{l}2.40 \\
-\end{array}$ \\
\hline & 1230 & 33.9 & --. & $\cdots$ & 3.03 & $\begin{array}{l}2.45 \\
-\end{array}$ \\
\hline & 1300 & 34.0 & $-\cdots$ & 9.96 & 3.05 & 2.43 \\
\hline & 1330 & 34.1 & 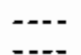 & --- & 3.03 & 2.33 \\
\hline & 1400 & 34.2 & $--\cdot$ & 9.88 & 2.92 & $\begin{array}{l}2.21 \\
-\end{array}$ \\
\hline$?$ & 1430 & 34.3 & $--\cdot$ & $-\cdots$ & 2.76 & 2.06 \\
\hline & 1500 & 34.4 & - & 9.81 & 2.57 & $\begin{array}{l}1.85 \\
-\ldots\end{array}$ \\
\hline & 1530 & 34.4 & $\cdots$ & $\cdots$ & 2.32 & $\begin{array}{l}1.57 \\
-\ldots--\end{array}$ \\
\hline & 1600 & 34.4 & $\cdots$ & 9.73 & 2.07 & $\begin{array}{l}1.29 \\
-\end{array}$ \\
\hline & 1630 & 34.4 & 敒 & $\cdots$ & $\cdots$ & $\cdots$ \\
\hline
\end{tabular}

$\begin{array}{lllllllll}0.9 & 26.1 & 34.1 & 0.9 & 26.7 & 34.9 & 1.0 & 24.5 & 35.3 \\ & 24.8 & 33.2 & & & & 1.0 & 28.0 & 34.9 \\ 1.6 & 26.4 & 34.8 & 1.6 & 26.7 & 35.5 & 1.6 & 24.4 & 36.1 \\ & 25.1 & 34.1 & & & & 1.7 & 27.8 & 35.5 \\ 1.5 & 26.5 & 35.0 & 1.4 & 27.1 & 36.2 & 1.7 & 24.4 & 36.4 \\ & 25.3 & 34.3 & & & & 2.0 & 27.9 & 35.9 \\ 1.6 & 26.5 & 35.4 & 1.7 & 27.3 & 36.5 & 2.0 & 25.1 & 37.4 \\ & 25.6 & 34.8 & & & & 2.1 & 28.1 & 36.4 \\ 1.4 & 26.5 & 35.8 & 1.5 & 27.4 & 36.9 & 1.6 & 25.5 & 38.0 \\ & 25.8 & 35.2 & & & & 1.7 & 28.4 & 37.0 \\ 1.3 & 26.4 & 36.1 & 1.4 & 27.7 & 37.4 & 1.5 & 25.5 & 37.9 \\ & 26.1 & 35.7 & & & & 1.7 & 28.4 & 37.0 \\ 0.8 & 26.2 & 36.2 & 0.8 & 27.9 & 37.6 & 1.1 & 25.6 & 38.2 \\ & 26.2 & 35.8 & & & & 1.2 & 28.8 & 37.6 \\ 1.1 & 25.9 & 36.1 & 1.0 & 28.0 & 37.7 & 1.3 & 25.7 & 38.4 \\ & 26.5 & 36.0 & & & & 1.4 & 29.1 & 38.0 \\ 0.6 & 26.0 & 36.2 & 0.6 & 28.0 & 37.7 & 0.9 & 25.7 & 38.3 \\ & 26.6 & 36.2 & & & & 1.1 & 29.1 & 37.7 \\ 1.3 & 26.3 & 36.5 & 1.3 & 27.9 & 37.8 & 1.1 & 25.8 & 38.7 \\ & 26.8 & 36.5 & & & & 1.2 & 29.2 & 38.1 \\ 0.5 & 26.3 & 36.5 & 0.5 & 28.0 & 37.8 & 0.7 & 25.7 & 39.0 \\ & 26.9 & 36.5 & & & & 0.8 & 29.5 & 38.4 \\ 1.5 & 26.4 & 36.9 & 1.5 & 28.0 & 38.0 & 2.1 & 25.7 & 39.0 \\ & 27.0 & 36.9 & & & & 2.4 & 29.3 & 38.5\end{array}$


EAST MESA 1 (1979) - COOL I (contd)

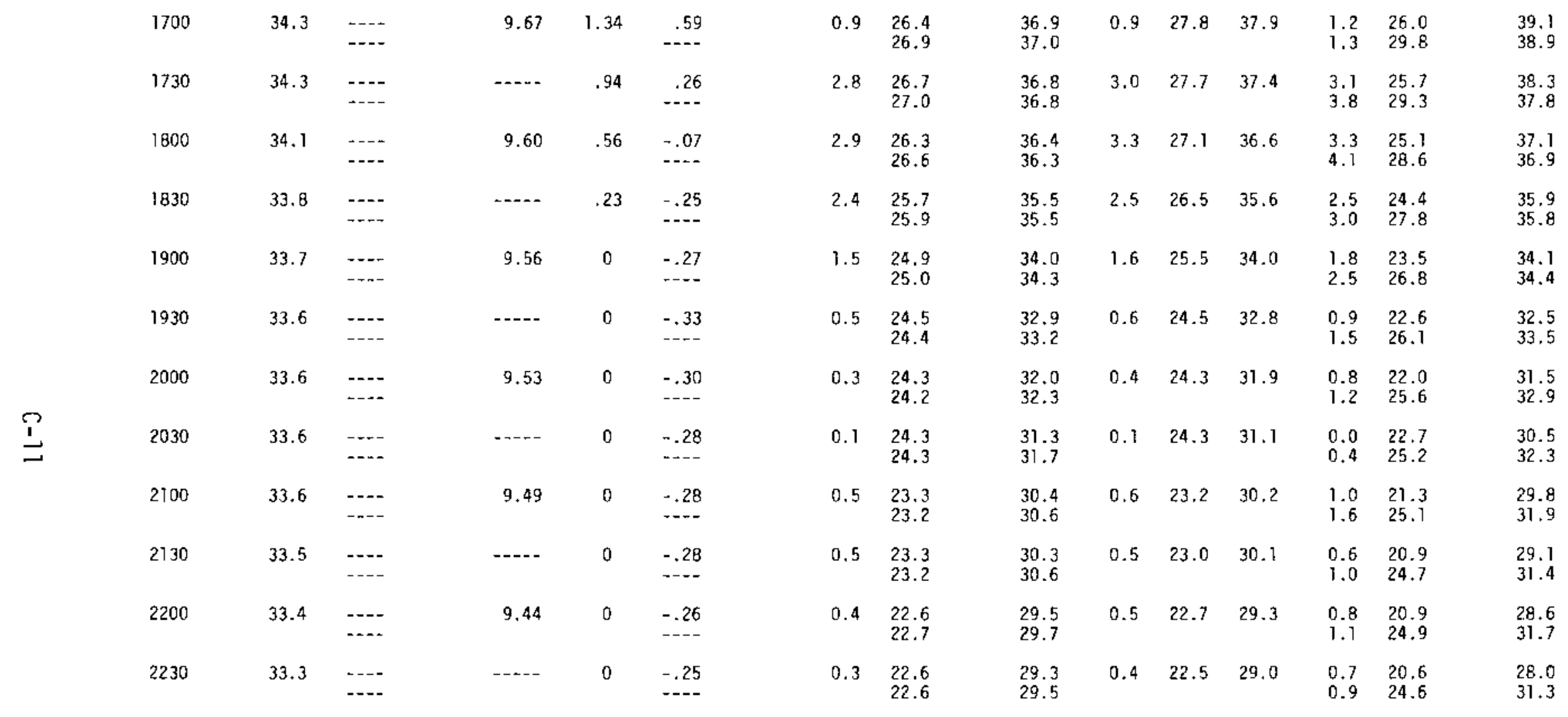


EAST MESA 1 (1979) - COOL I (contd)

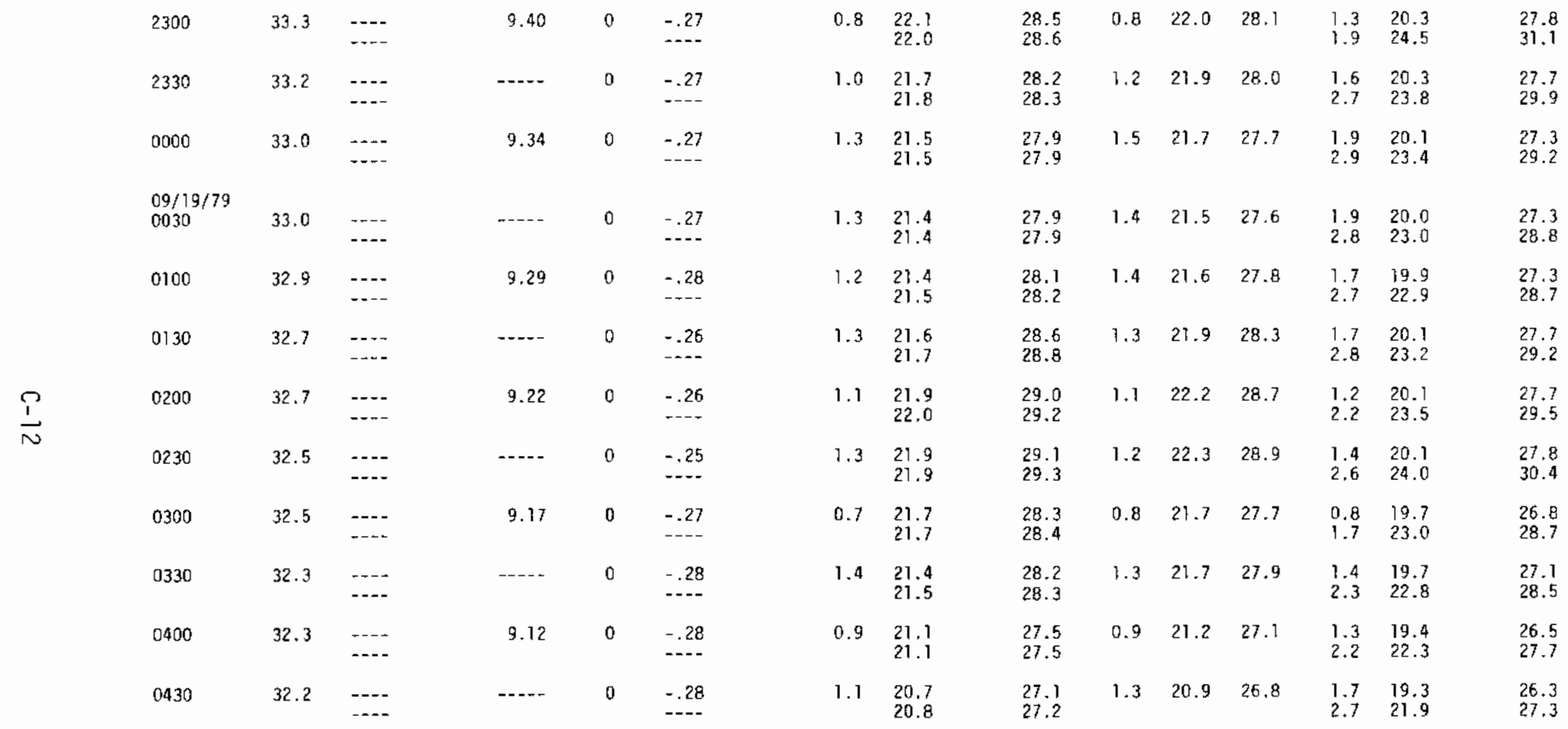


EAST MESA 1 (1979) - COOL I (contd)

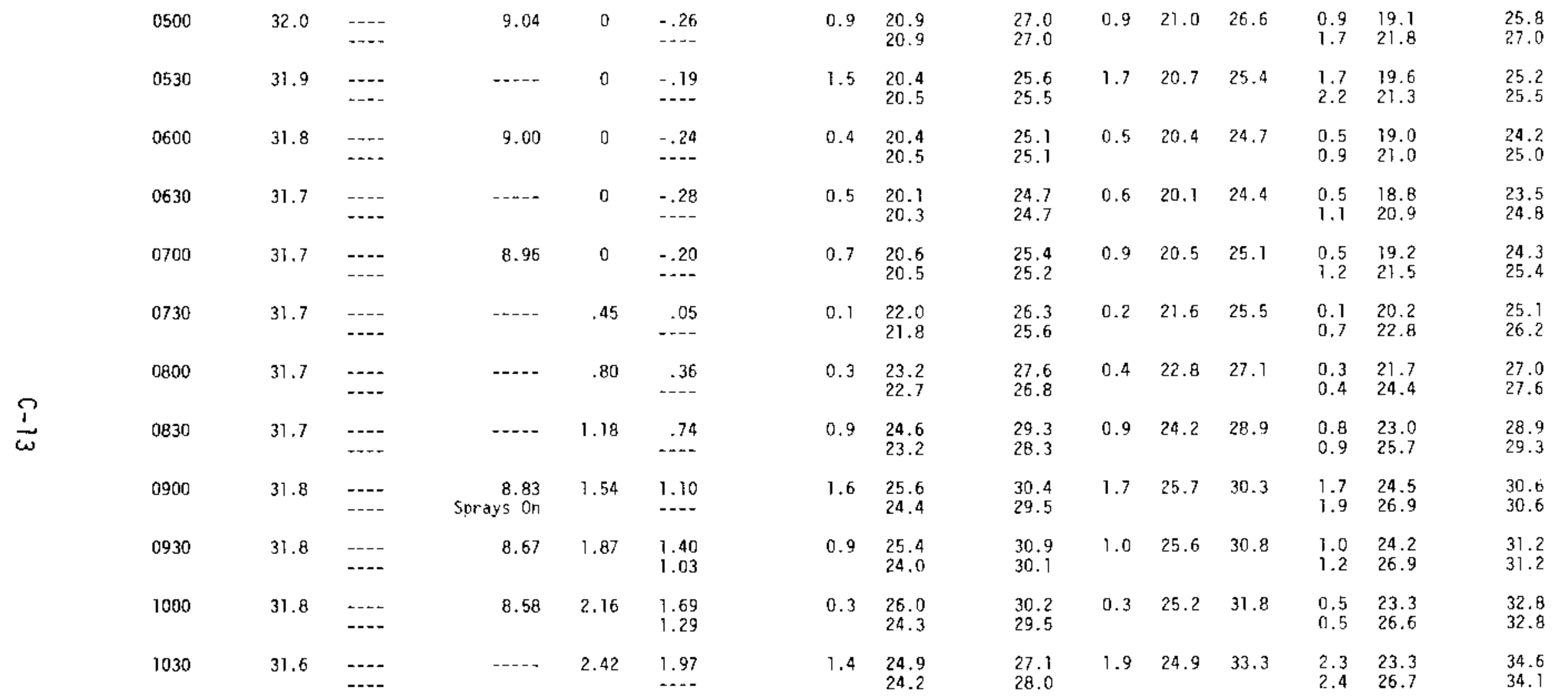


EAST MESA 1 (1979) - COOL I (contd)

\begin{tabular}{|c|c|c|c|c|c|c|c|c|c|c|c|c|c|c|}
\hline 1100 & 31.4 & $\begin{array}{l}29.3 \\
31.4\end{array}$ & 8.24 & 2.64 & $\begin{array}{l}2.16 \\
1.71\end{array}$ & 1.5 & $\begin{array}{l}24.3 \\
24.0\end{array}$ & $\begin{array}{l}26.8 \\
28.0\end{array}$ & 1.9 & 25.2 & 33.7 & $\begin{array}{l}2.2 \\
2.5\end{array}$ & $\begin{array}{l}23.6 \\
26.9\end{array}$ & $\begin{array}{l}35.2 \\
34.6\end{array}$ \\
\hline 1130 & 31.1 & $\begin{array}{l}26.8 \\
31.1\end{array}$ & ----- & 2.81 & $\begin{array}{l}2.33 \\
2.04\end{array}$ & 1.5 & $\begin{array}{l}24.9 \\
24.8\end{array}$ & $\begin{array}{l}27.5 \\
28.6\end{array}$ & 2.0 & 27.0 & 34.8 & $\begin{array}{l}2.2 \\
2.5\end{array}$ & $\begin{array}{l}24.2 \\
27.6\end{array}$ & $\begin{array}{l}36.1 \\
35.5\end{array}$ \\
\hline 1200 & 30.8 & $\begin{array}{l}28.4 \\
30.8\end{array}$ & 7.98 & 2.93 & $\begin{array}{l}2.42 \\
2.19\end{array}$ & 0.9 & $\begin{array}{l}26.1 \\
25.4\end{array}$ & $\begin{array}{l}29.0 \\
30.1\end{array}$ & 1.1 & 26.5 & 35.0 & $\begin{array}{l}1.8 \\
2.1\end{array}$ & $\begin{array}{l}24.3 \\
27.9\end{array}$ & $\begin{array}{l}36.5 \\
36.1\end{array}$ \\
\hline 1230 & 30.8 & $\begin{array}{l}29.0 \\
30.8\end{array}$ & $\cdots$ & 3.02 & $\begin{array}{l}2.51 \\
2.30\end{array}$ & 1.0 & $\begin{array}{l}26.6 \\
25.9\end{array}$ & $\begin{array}{l}29.9 \\
31.2\end{array}$ & 1.2 & 26.9 & 35.8 & $\begin{array}{l}1.5 \\
1.7\end{array}$ & $\begin{array}{l}25.7 \\
28.2\end{array}$ & $\begin{array}{l}37.4 \\
36.6\end{array}$ \\
\hline 1300 & 30.8 & $\begin{array}{l}27.6 \\
30.6\end{array}$ & 7.72 & 3.04 & $\begin{array}{l}2.45 \\
2.35\end{array}$ & 1.1 & $\begin{array}{l}26.1 \\
25.9\end{array}$ & $\begin{array}{l}29.5 \\
30.9\end{array}$ & 1.3 & 27.1 & 36.2 & $\begin{array}{l}1.5 \\
1.7\end{array}$ & $\begin{array}{l}25.6 \\
28.6\end{array}$ & $\begin{array}{l}38.3 \\
37.4\end{array}$ \\
\hline 1330 & 30.6 & $\begin{array}{l}27.4 \\
30.6\end{array}$ & .... & 3.01 & $\begin{array}{l}2.38 \\
2.35\end{array}$ & 1.0 & $\begin{array}{l}26.6 \\
26.6\end{array}$ & $\begin{array}{l}30.1 \\
31.3\end{array}$ & 1.5 & 27.8 & 37.3 & $\begin{array}{l}1.7 \\
2.0\end{array}$ & $\begin{array}{l}26.4 \\
29.4\end{array}$ & $\begin{array}{l}39.5 \\
38.4\end{array}$ \\
\hline 1400 & 30.5 & $\begin{array}{l}28.0 \\
30.5\end{array}$ & 7.40 & 2.89 & $\begin{array}{l}2.24 \\
2.25\end{array}$ & 0.9 & $\begin{array}{l}27.5 \\
27.9\end{array}$ & $\begin{array}{l}37.6 \\
33.4\end{array}$ & 0.8 & 28.3 & 38.2 & $\begin{array}{l}1.0 \\
1.1\end{array}$ & $\begin{array}{l}27.4 \\
30.8\end{array}$ & $\begin{array}{l}40.7 \\
40.1\end{array}$ \\
\hline 1430 & 30.6 & $\cdots$ & ----- & 2.75 & $\begin{array}{l}2.11 \\
2.29\end{array}$ & 1.7 & $\begin{array}{l}25.4 \\
26.4\end{array}$ & $\begin{array}{l}34.5 \\
35.9\end{array}$ & 1.6 & 28.2 & 38.8 & $\begin{array}{l}1.8 \\
2.2\end{array}$ & $\begin{array}{l}26.5 \\
29.9\end{array}$ & $\begin{array}{l}39.4 \\
38.7\end{array}$ \\
\hline 1500 & 30.8 & Sprays off & 7.67 & 2.55 & $\begin{array}{l}1.91 \\
2.15\end{array}$ & 1.6 & $\begin{array}{l}26.4 \\
26.3\end{array}$ & $\begin{array}{l}36.9 \\
37.3\end{array}$ & 1.6 & 28.0 & 38.8 & $\begin{array}{l}2.3 \\
2.6\end{array}$ & $\begin{array}{l}26.5 \\
29.8\end{array}$ & $\begin{array}{l}39.6 \\
39.0\end{array}$ \\
\hline 1530 & 30.9 & Sprays on & ----- & 2.28 & $\begin{array}{l}1.59 \\
1.76\end{array}$ & 0.1 & $\begin{array}{l}26.9 \\
26.9\end{array}$ & $\begin{array}{l}33.5 \\
34.5\end{array}$ & 0.3 & 28.1 & 37.6 & $\begin{array}{l}0.6 \\
0.7\end{array}$ & $\begin{array}{l}26.5 \\
30.1\end{array}$ & $\begin{array}{l}39.7 \\
39.2\end{array}$ \\
\hline 1600 & 30.7 & $\begin{array}{l}27.9 \\
30.3\end{array}$ & 7.07 & 2.00 & $\begin{array}{l}1.29 \\
1.44\end{array}$ & 1.0 & $\begin{array}{l}26.8 \\
26.8\end{array}$ & $\begin{array}{l}34.9 \\
35.9\end{array}$ & 1.2 & 27.9 & 37.0 & $\begin{array}{l}1.4 \\
1.6\end{array}$ & $\begin{array}{l}26.0 \\
29.9\end{array}$ & $\begin{array}{l}39.1 \\
38.6\end{array}$ \\
\hline 1630 & 30.4 & $\begin{array}{l}27.7 \\
30.4\end{array}$ & -..- & 1.65 & $\begin{array}{r}.96 \\
.13\end{array}$ & 2.8 & $\begin{array}{l}27.1 \\
26.7\end{array}$ & $\begin{array}{l}36.9 \\
37.0\end{array}$ & 2.9 & 26.8 & 36.4 & $\begin{array}{l}2.9 \\
3.3\end{array}$ & $\begin{array}{l}26.2 \\
29.9\end{array}$ & $\begin{array}{l}38.9 \\
38.3\end{array}$ \\
\hline
\end{tabular}


EAST MESA ? (1979) - COOL I (contd)

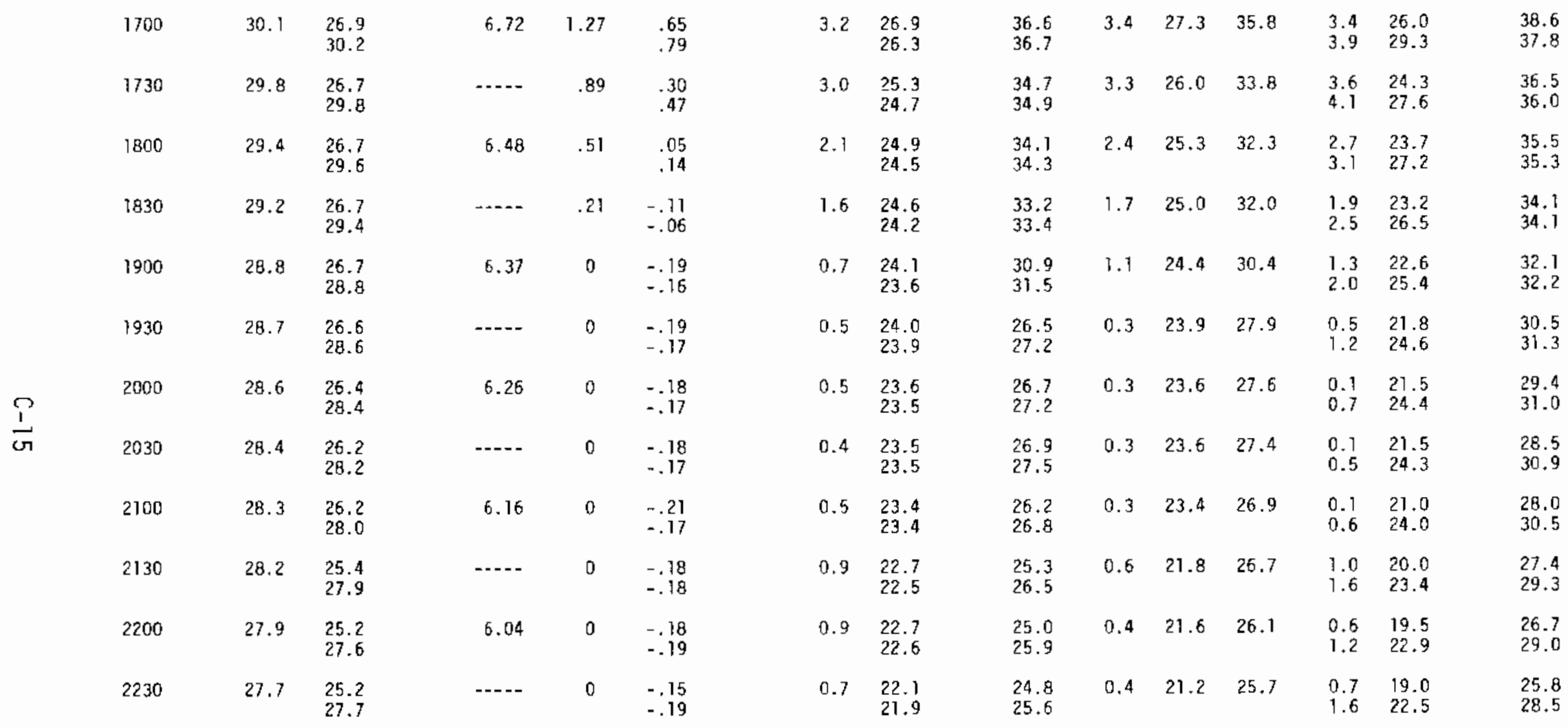




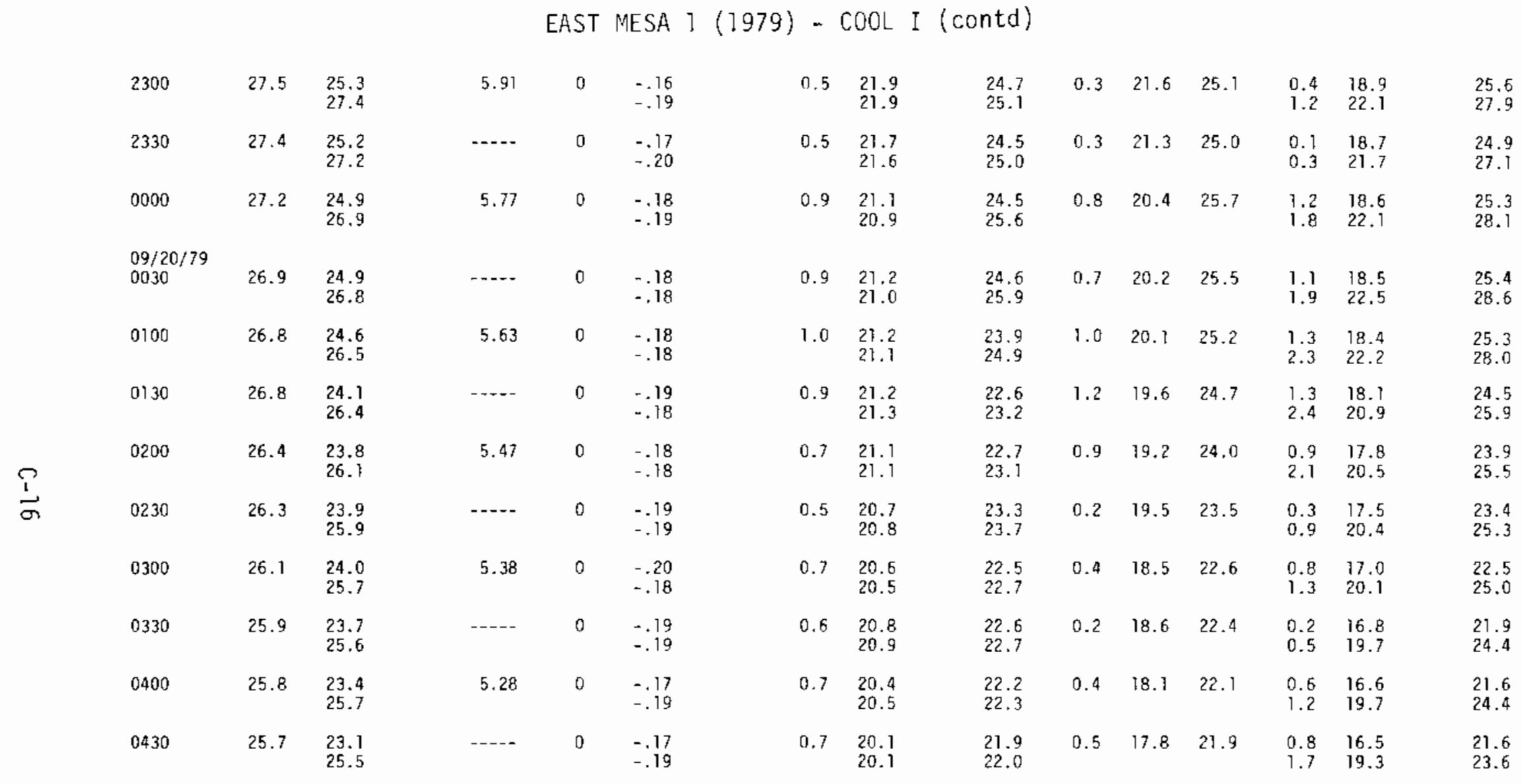


EAST MESA 1 (1979) - COOL I (contd)

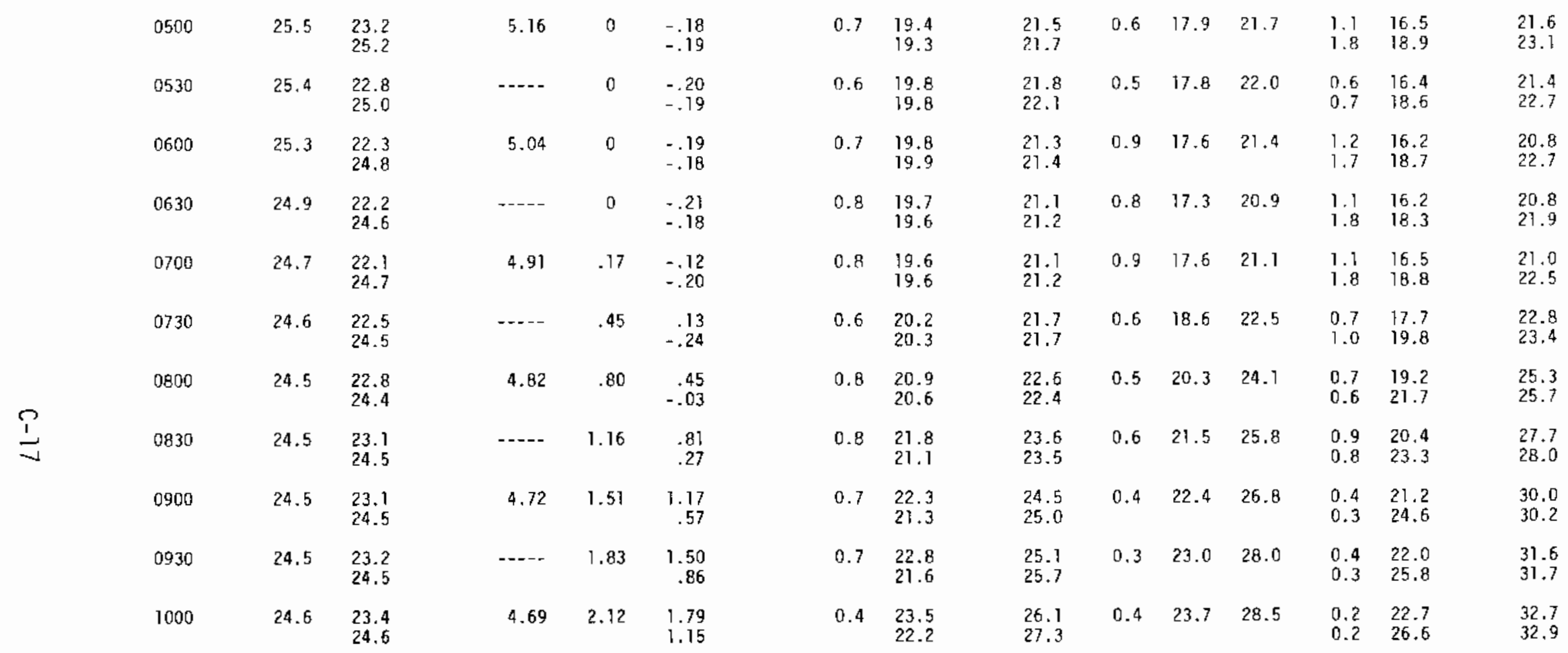


EASI EAST MESA 1 (1979) - WARM I

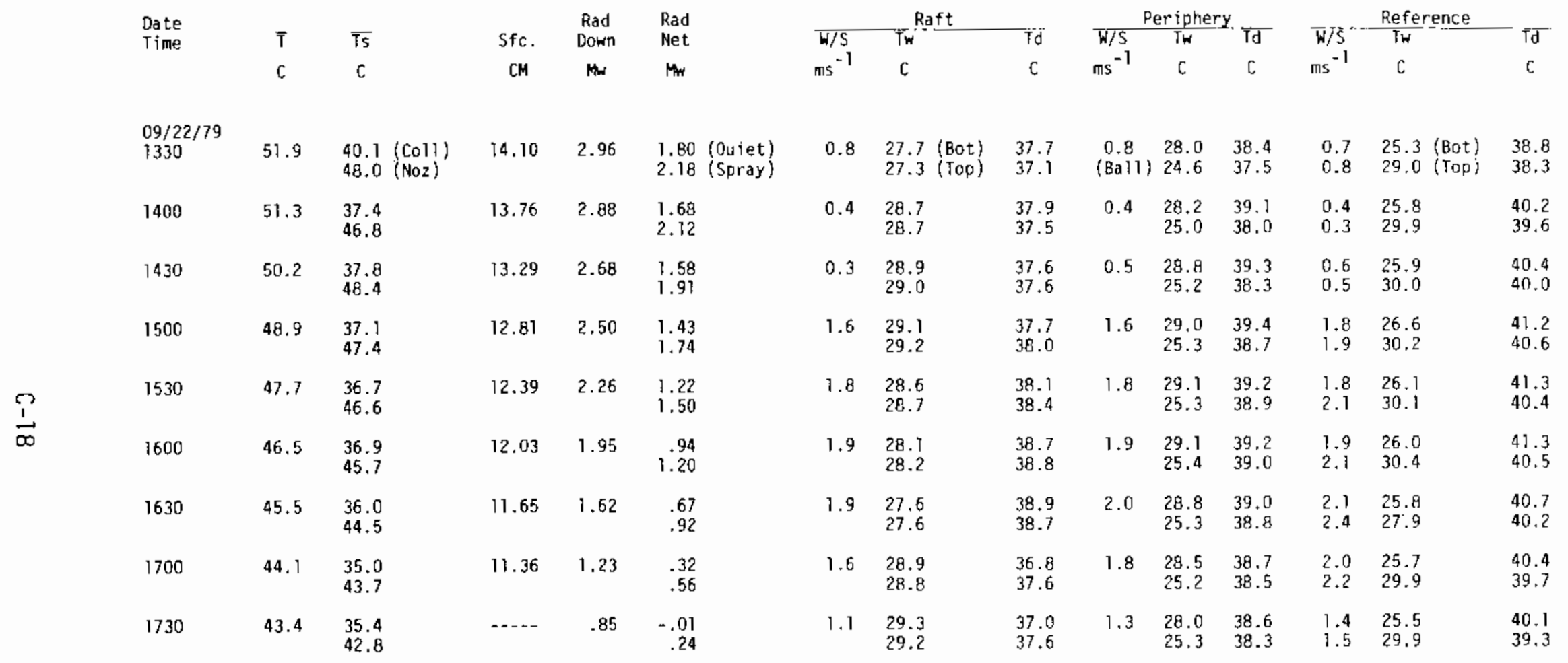


EAST MESA ? (1979) - WARM I (contd)

\begin{tabular}{|c|c|c|c|c|c|}
\hline 1800 & 42.5 & $\begin{array}{l}34.8 \\
41.9\end{array}$ & 10.90 & .48 & $\begin{array}{l}-.23 \\
-.03\end{array}$ \\
\hline 1830 & 41.5 & $\begin{array}{l}33.5 \\
41.2\end{array}$ & $\cdots--$ & .17 & $\begin{array}{l}-.32 \\
-.22\end{array}$ \\
\hline 1900 & 40.9 & $\begin{array}{l}33.7 \\
40.4\end{array}$ & 10.41 & 0 & $\begin{array}{l}-.37 \\
-.30\end{array}$ \\
\hline 1930 & 40.3 & $\begin{array}{l}33.2 \\
39.8\end{array}$ & $-\cdots$ & 0 & $\begin{array}{l}-.37 \\
-.29\end{array}$ \\
\hline 2000 & 39.6 & $\begin{array}{l}32.6 \\
39.1\end{array}$ & 10.17 & 0 & $\begin{array}{l}-.36 \\
-.29\end{array}$ \\
\hline 2030 & 38.8 & $\begin{array}{l}32.1 \\
38.5\end{array}$ & $-\ldots$. & 0 & $\begin{array}{l}-.35 \\
-.28\end{array}$ \\
\hline 2100 & 38.3 & $\begin{array}{l}31.6 \\
37.8\end{array}$ & 9.81 & 0 & $\begin{array}{l}-.34 \\
-.28\end{array}$ \\
\hline 2130 & 37.7 & $\begin{array}{l}31.2 \\
37.4\end{array}$ & $-\cdots$ & 0 & $\begin{array}{l}-.34 \\
-.29\end{array}$ \\
\hline 2200 & 37.1 & $\begin{array}{l}31.4 \\
36.8\end{array}$ & 9.53 & 0 & $\begin{array}{r}-.33 \\
-.27\end{array}$ \\
\hline 2230 & 36.7 & $\begin{array}{l}31.2 \\
36.3\end{array}$ & $\cdots-$ & 0 & $\begin{array}{l}-.33 \\
-.26\end{array}$ \\
\hline 2300 & 36.2 & $\begin{array}{l}30.2 \\
35.8\end{array}$ & 9.23 & 0 & $\begin{array}{l}-.32 \\
-.26\end{array}$ \\
\hline 2330 & 35.7 & $\begin{array}{l}31.0 \\
35.2\end{array}$ & - & 0 & $\begin{array}{l}-.31 \\
.226\end{array}$ \\
\hline
\end{tabular}

$\begin{array}{lllllllll}1.8 & 27.9 & 36.6 & 1.7 & 27.9 & 38.8 & 1.9 & 24.9 & 38.8 \\ & 27.9 & 37.2 & & 24.9 & 37.9 & 2.3 & 29.1 & 38.7 \\ 1.9 & 27.9 & 34.7 & 2.0 & 27.2 & 36.6 & 2.3 & 24.1 & 37.5 \\ & 27.4 & 36.1 & & 24.5 & 37.3 & 2.8 & 28.2 & 37.6 \\ 0.7 & 29.3 & 34.8 & 0.9 & 25.8 & 35.1 & 1.2 & 22.8 & 35.0 \\ & 29.0 & 34.9 & & 24.9 & 36.3 & 1.8 & 27.0 & 36.0 \\ 0.6 & 28.7 & 33.9 & 0.8 & 25.1 & 33.9 & 1.2 & 22.1 & 33.6 \\ & 28.5 & 33.9 & & 24.2 & 35.0 & 2.0 & 26.5 & 35.0 \\ 0.8 & 28.9 & 33.0 & 0.9 & 24.7 & 32.7 & 1.4 & 21.6 & 32.3 \\ & 28.8 & 33.0 & & 23.7 & 35.0 & 2.1 & 25.9 & 34.0 \\ 0.8 & 27.0 & 32.0 & 1.1 & 24.4 & 32.0 & 1.4 & 21.8 & 31.9 \\ & 26.4 & 32.1 & & 23.5 & 33.7 & 2.3 & 25.5 & 33.0 \\ 1.0 & 27.3 & 31.4 & 1.1 & 24.3 & 31.5 & 1.5 & 21.8 & 31.4 \\ & 26.3 & 31.6 & & 23.3 & 32.8 & 2.3 & 25.2 & 32.2 \\ 1.2 & 26.2 & 30.6 & 1.4 & 24.3 & 31.0 & 1.7 & 22.0 & 30.9 \\ & 25.2 & 30.9 & & 23.5 & 32.1 & 2.5 & 25.1 & 31.6 \\ 1.0 & 26.6 & 30.6 & 1.2 & 24.6 & 30.6 & 1.4 & 21.6 & 30.4 \\ & 26.0 & 30.8 & & 24.1 & 31.7 & 2.2 & 25.4 & 31.1 \\ 0.5 & 26.7 & 31.0 & 0.5 & 23.9 & 29.8 & 0.7 & 22.1 & 29.1 \\ & 26.7 & 30.9 & & 24.0 & 31.2 & 1.4 & 24.9 & 30.3 \\ 0.6 & 27.9 & 30.6 & 0.5 & 24.0 & 29.3 & 0.9 & 22.1 & 28.8 \\ & 27.8 & 30.6 & & 24.0 & 31.1 & 1.5 & 25.3 & 30.6 \\ 0.4 & 24.5 & 29.5 & 0.5 & 23.6 & 28.7 & 0.6 & 21.7 & 27.8 \\ & 24.8 & 29.6 & & 23.1 & 30.1 & 1.2 & 24.5 & 29.7\end{array}$


EAST MESA I (1979) - WARM I (contd)

\begin{tabular}{|c|c|c|c|c|c|c|c|c|c|c|c|c|c|c|}
\hline 0000 & 35.4 & $\begin{array}{l}30.0 \\
34.8\end{array}$ & 8.97 & 0 & $\begin{array}{l}-.29 \\
-.26\end{array}$ & 0.4 & $\begin{array}{l}25.4 \\
25.5\end{array}$ & $\begin{array}{l}29.3 \\
29.3\end{array}$ & 0.3 & $\begin{array}{l}23.1 \\
23.1\end{array}$ & $\begin{array}{l}28.0 \\
30.3\end{array}$ & $\begin{array}{l}0.4 \\
0.3\end{array}$ & $\begin{array}{l}21.1 \\
24.2\end{array}$ & $\begin{array}{l}27.0 \\
29.2\end{array}$ \\
\hline $\begin{array}{l}09 / 23 / 79 \\
0030\end{array}$ & 34.7 & $\begin{array}{l}29.4 \\
34.0\end{array}$ & -... & 0 & $\begin{array}{l}-.30 \\
-.25\end{array}$ & 1.0 & $\begin{array}{l}26.2 \\
25.6\end{array}$ & $\begin{array}{l}28.7 \\
28.8\end{array}$ & 1.1 & $\begin{array}{l}23.1 \\
22.5\end{array}$ & $\begin{array}{l}28.7 \\
29.3\end{array}$ & $\begin{array}{l}1.3 \\
2.0\end{array}$ & $\begin{array}{l}21.4 \\
23.9\end{array}$ & $\begin{array}{l}28.1 \\
29.1\end{array}$ \\
\hline 0100 & 34.2 & $\begin{array}{l}29.6 \\
33.8\end{array}$ & 8.73 & 0 & $\begin{array}{l}-.30 \\
-.24\end{array}$ & 0.5 & $\begin{array}{l}25.3 \\
25.2\end{array}$ & $\begin{array}{l}28.9 \\
28.9\end{array}$ & 0.3 & $\begin{array}{l}22.3 \\
22.3\end{array}$ & $\begin{array}{l}27.8 \\
28.6\end{array}$ & $\begin{array}{l}0.3 \\
0.7\end{array}$ & $\begin{array}{l}20.8 \\
23.3\end{array}$ & $\begin{array}{l}26.9 \\
28.3\end{array}$ \\
\hline 0130 & 33.9 & $\begin{array}{l}28.0 \\
33.3\end{array}$ & -..- & 0 & $\begin{array}{l}-.30 \\
-.22\end{array}$ & 0.7 & $\begin{array}{l}25.6 \\
25.6\end{array}$ & $\begin{array}{l}27.8 \\
27.7\end{array}$ & 0.9 & $\begin{array}{l}21.5 \\
21.9\end{array}$ & $\begin{array}{l}26.0 \\
27.9\end{array}$ & $\begin{array}{l}1.2 \\
1.7\end{array}$ & $\begin{array}{l}20.1 \\
22.7\end{array}$ & $\begin{array}{l}25.5 \\
27.3\end{array}$ \\
\hline 0200 & 33.3 & $\begin{array}{l}27.0 \\
32.9\end{array}$ & 8.45 & 0 & $\begin{array}{l}-.29 \\
-.22\end{array}$ & 1.1 & $\begin{array}{l}26.0 \\
25.8\end{array}$ & $\begin{array}{l}27.4 \\
27.3\end{array}$ & 1.4 & $\begin{array}{l}21.9 \\
21.9\end{array}$ & $\begin{array}{l}26.0 \\
27.9\end{array}$ & $\begin{array}{l}1.8 \\
2.8\end{array}$ & $\begin{array}{l}20.4 \\
22.7\end{array}$ & $\begin{array}{l}26.0 \\
27.0\end{array}$ \\
\hline 0230 & 32.9 & $\begin{array}{l}28.6 \\
32.6\end{array}$ & $-\ldots$ & 0 & $\begin{array}{l}-.29 \\
-.24\end{array}$ & 0.5 & $\begin{array}{l}23.6 \\
24.2\end{array}$ & $\begin{array}{l}26.7 \\
26.8\end{array}$ & 0.4 & $\begin{array}{l}20.6 \\
21.4\end{array}$ & $\begin{array}{l}25.0 \\
26.5\end{array}$ & $\begin{array}{l}0.3 \\
1.1\end{array}$ & $\begin{array}{l}19.7 \\
21.8\end{array}$ & $\begin{array}{l}24.8 \\
25.6\end{array}$ \\
\hline 0300 & 32.5 & $\begin{array}{l}28.2 \\
32.1\end{array}$ & 8.30 & 0 & $\begin{array}{l}-.28 \\
-.22\end{array}$ & 0.4 & $\begin{array}{l}22.8 \\
23.1\end{array}$ & $\begin{array}{l}26.4 \\
26.4\end{array}$ & 0.3 & $\begin{array}{l}20.6 \\
21.5\end{array}$ & $\begin{array}{l}24.8 \\
26.5\end{array}$ & $\begin{array}{l}0.2 \\
0.8\end{array}$ & $\begin{array}{l}19.1 \\
21.8\end{array}$ & $\begin{array}{l}23.7 \\
25.6\end{array}$ \\
\hline 0330 & 32.2 & $\begin{array}{l}27.8 \\
31.8\end{array}$ & ..... & 0 & $\begin{array}{l}-.28 \\
-.22\end{array}$ & 0.4 & $\begin{array}{l}23.3 \\
23.4\end{array}$ & $\begin{array}{l}26.5 \\
26.6\end{array}$ & 0.3 & $\begin{array}{l}20.5 \\
21.6\end{array}$ & $\begin{array}{l}24.6 \\
26.8\end{array}$ & $\begin{array}{l}0.4 \\
0.7\end{array}$ & $\begin{array}{l}18.9 \\
21.7\end{array}$ & $\begin{array}{l}23.3 \\
25.6\end{array}$ \\
\hline 0400 & 31.9 & $\begin{array}{l}27.0 \\
31.3\end{array}$ & 7.94 & 0 & $\begin{array}{l}-.27 \\
-.22\end{array}$ & 0.7 & $\begin{array}{l}24.4 \\
24.3\end{array}$ & $\begin{array}{l}26.4 \\
26.3\end{array}$ & 0.7 & $\begin{array}{l}20.8 \\
21.5\end{array}$ & $\begin{array}{l}24.5 \\
26.8\end{array}$ & $\begin{array}{l}1.0 \\
1.8\end{array}$ & $\begin{array}{l}19.1 \\
22.0\end{array}$ & $\begin{array}{l}23.5 \\
25.9\end{array}$ \\
\hline 0430 & 31.5 & $\begin{array}{l}27.3 \\
31.0\end{array}$ & ....- & 0 & $\begin{array}{l}-.28 \\
-.22\end{array}$ & 0.5 & $\begin{array}{l}22.7 \\
23.0\end{array}$ & $\begin{array}{l}25.5 \\
25.5\end{array}$ & 0.4 & $\begin{array}{l}20.0 \\
21.3\end{array}$ & $\begin{array}{l}23.7 \\
25.7\end{array}$ & $\begin{array}{l}0.3 \\
0.9\end{array}$ & $\begin{array}{l}18.7 \\
21.2\end{array}$ & $\begin{array}{l}22.9 \\
24.6\end{array}$ \\
\hline 0500 & 31.0 & $\begin{array}{l}27.2 \\
30.7\end{array}$ & -..-- & 0 & $\begin{array}{l}-.28 \\
-.20\end{array}$ & 0.6 & $\begin{array}{l}20.4 \\
20.9\end{array}$ & $\begin{array}{l}23.4 \\
23.5\end{array}$ & 0.6 & $\begin{array}{l}19.4 \\
20.6\end{array}$ & $\begin{array}{l}22.5 \\
24.1\end{array}$ & $\begin{array}{l}0.8 \\
1.3\end{array}$ & $\begin{array}{l}18.0 \\
20.6\end{array}$ & $\begin{array}{l}21.6 \\
23.5\end{array}$ \\
\hline 0530 & 30.8 & $\begin{array}{l}26.8 \\
30.3\end{array}$ & ..... & 0 & $\begin{array}{l}-.28 \\
-.19\end{array}$ & 0.4 & $\begin{array}{l}22.3 \\
22.4\end{array}$ & $\begin{array}{l}24.6 \\
24.6\end{array}$ & 0.5 & $\begin{array}{l}19.8 \\
20.9\end{array}$ & $\begin{array}{l}22.9 \\
23.9\end{array}$ & $\begin{array}{l}0.4 \\
0.4\end{array}$ & $\begin{array}{l}18.4 \\
20.6\end{array}$ & $\begin{array}{l}21.7 \\
23.3\end{array}$ \\
\hline
\end{tabular}


EAST MESA 1 (1979) - WARM I (contd)

\begin{tabular}{|c|c|c|c|c|c|}
\hline 0600 & 30.3 & $\begin{array}{l}26.0 \\
29.8\end{array}$ & 7.70 & 0 & $\begin{array}{l}-.27 \\
-.20\end{array}$ \\
\hline 0630 & 29.9 & $\begin{array}{l}26.0 \\
29.6\end{array}$ & $\cdots$ & 0 & $\begin{array}{l}-.26 \\
-.19\end{array}$ \\
\hline 0700 & 29.6 & $\begin{array}{l}25.9 \\
29.3\end{array}$ & 7.51 & .15 & $\begin{array}{l}-.18 \\
-.20\end{array}$ \\
\hline 0730 & 29.4 & $\begin{array}{l}25.7 \\
29.2\end{array}$ & $\cdots$ & .42 & $\begin{array}{r}.08 \\
-.24\end{array}$ \\
\hline 0800 & 29.2 & $\begin{array}{l}26.2 \\
29.2\end{array}$ & 7.33 & .76 & $\begin{array}{r}.40 \\
-.04\end{array}$ \\
\hline 0830 & 29.2 & $\begin{array}{l}26.7 \\
28.9\end{array}$ & $\cdots--$ & 1.13 & $\begin{array}{l}.78 \\
.26\end{array}$ \\
\hline 0900 & 29.2 & $\begin{array}{l}27.0 \\
29.2\end{array}$ & 7.18 & 1.48 & $\begin{array}{r}1.15 \\
.49\end{array}$ \\
\hline 0930 & 29.1 & $\begin{array}{l}27.0 \\
28.8\end{array}$ & $\ldots$ & 1. 81 & $\begin{array}{r}1.47 \\
.77\end{array}$ \\
\hline 1000 & 29.1 & $\begin{array}{l}27.0 \\
28.8\end{array}$ & 7.06 & 2.10 & $\begin{array}{l}1.75 \\
1.08\end{array}$ \\
\hline 1030 & 29.1 & $\begin{array}{l}27.1 \\
28.8\end{array}$ & ---- & 2.35 & $\begin{array}{l}1.96 \\
1.36\end{array}$ \\
\hline 1700 & 29.2 & $\begin{array}{l}27.3 \\
28.8\end{array}$ & 6.94 & 2.57 & $\begin{array}{l}2.10 \\
1.53\end{array}$ \\
\hline 1130 & 29.2 & $\begin{array}{l}27.3 \\
28.8\end{array}$ & $\ldots$ & 2.74 & $\begin{array}{l}2.19 \\
1.78\end{array}$ \\
\hline
\end{tabular}

$\begin{array}{lllllllll}0.8 & 24.8 & 25.7 & 1.0 & 20.1 & 22.9 & 1.3 & 18.6 & 21.9 \\ & 24.6 & 25.4 & & 21.3 & 24.7 & 2.0 & 21.3 & 24.1 \\ 0.7 & 23.6 & 24.9 & 0.6 & 20.1 & 22.8 & 0.9 & 18.6 & 21.8 \\ & 23.9 & 24.9 & & 21.4 & 25.1 & 1.9 & 21.3 & 24.1 \\ 0.6 & 21.8 & 23.0 & 0.5 & 19.6 & 22.1 & 0.6 & 18.5 & 21.5 \\ & 22.3 & 23.8 & & 20.7 & 24.1 & 1.2 & 20.4 & 22.8 \\ 0.8 & 23.7 & 24.7 & 0.8 & 20.6 & 23.6 & 1.0 & 19.8 & 23.6 \\ & 23.2 & 24.6 & & 20.7 & 24.6 & 1.5 & 21.6 & 24.4 \\ 0.7 & 24.0 & 25.9 & 0.8 & 22.2 & 25.9 & 0.8 & 21.4 & 26.4 \\ & 23.9 & 25.7 & & 21.3 & 25.5 & 0.9 & 23.5 & 26.6 \\ 0.7 & 23.9 & 27.4 & 1.0 & 23.8 & 28.4 & 1.0 & 22.7 & 28.9 \\ & 23.5 & 27.3 & & 23.4 & 27.6 & 1.0 & 25.5 & 29.3 \\ 0.3 & 24.5 & 29.0 & 0.6 & 24.9 & 29.4 & 0.5 & 23.1 & 30.2 \\ & 23.8 & 28.5 & & 25.0 & 32.4 & 0.5 & 26.2 & 30.5 \\ 0.4 & 25.7 & 29.9 & 0.7 & 25.8 & 30.5 & 0.6 & 23.6 & 31.1 \\ & 24.6 & 29.6 & & 26.8 & 35.2 & 0.8 & 26.7 & 31.2 \\ 0.6 & 25.8 & 31.1 & 0.9 & 26.3 & 31.5 & 0.9 & 24.4 & 32.3 \\ & 24.8 & 30.7 & & 27.2 & 37.3 & 1.0 & 27.4 & 32.2 \\ 0.4 & 26.7 & 31.2 & 0.7 & 27.1 & 32.2 & 0.6 & 25.2 & 33.6 \\ & 25.7 & 31.0 & & 26.3 & 34.5 & 0.8 & 28.2 & 33.3 \\ 0.5 & 27.0 & 32.1 & 0.8 & 27.7 & 33.3 & 0.8 & 25.6 & 34.5 \\ & 26.0 & 31.9 & & 25.8 & 34.3 & 1.0 & 28.6 & 34.2 \\ 0.8 & 27.5 & 33.1 & 1.0 & 27.8 & 34.2 & 1.2 & 26.0 & 35.8 \\ & 26.5 & 33.2 & & 26.4 & 35.3 & 1.4 & 29.0 & 35.2\end{array}$


EAST MESA 1 (1979) - WARIM I (contd)

\begin{tabular}{|c|c|c|c|c|c|}
\hline 1200 & 29.2 & $\begin{array}{l}27.4 \\
28.8\end{array}$ & 6.81 & 2.88 & $\begin{array}{l}2.21 \\
2.01\end{array}$ \\
\hline 1230 & $\cdots$ & $\cdots-$ & ---- & ---- & $\cdots$ \\
\hline 1300 & $\cdots$ & $\cdots$ & 6.59 & --. & $\ldots$ \\
\hline 1330 & 29.2 & $\begin{array}{l}26.6 \\
28.7\end{array}$ & ---- & 2.93 & $\begin{array}{l}2.05 \\
2.21\end{array}$ \\
\hline 1400 & 29.4 & $\begin{array}{l}26.6 \\
28.7\end{array}$ & 6.36 & 2.83 & $\begin{array}{l}1.92 \\
2.15\end{array}$ \\
\hline 1430 & 29.2 & $\begin{array}{l}26.4 \\
28.5\end{array}$ & $\cdots$ & 2.68 & $\begin{array}{l}1.83 \\
2.05\end{array}$ \\
\hline 1500 & 29.0 & $\begin{array}{l}26.5 \\
28.8\end{array}$ & 6.05 & 2.49 & $\begin{array}{l}1.66 \\
1.89\end{array}$ \\
\hline 1530 & 28.9 & $\begin{array}{l}26.4 \\
28.7\end{array}$ & ---- & 2.21 & $\begin{array}{l}1.40 \\
1.63\end{array}$ \\
\hline 1600 & 28.7 & $\begin{array}{l}26.3 \\
28.6\end{array}$ & 5.73 & 1.95 & $\begin{array}{l}1.16 \\
1.38\end{array}$ \\
\hline 1630 & 28.5 & $\begin{array}{l}26.1 \\
28.5\end{array}$ & .....- & 1.59 & $\begin{array}{r}.84 \\
1.05\end{array}$ \\
\hline 1700 & 28.2 & $\begin{array}{l}26.3 \\
28.3\end{array}$ & 5.49 & 1.22 & $\begin{array}{l}.51 \\
.73\end{array}$ \\
\hline 1730 & 28.1 & $\begin{array}{l}26.0 \\
28.1\end{array}$ & ---- & .84 & $\begin{array}{l}.22 \\
.41\end{array}$ \\
\hline
\end{tabular}

\begin{tabular}{|c|c|c|c|c|c|c|c|c|}
\hline 0.8 & $\begin{array}{l}27.7 \\
27.0\end{array}$ & $\begin{array}{l}33.8 \\
34.0\end{array}$ & 1.0 & $\begin{array}{l}28.2 \\
26.7\end{array}$ & $\begin{array}{l}35.0 \\
36.1\end{array}$ & $\begin{array}{l}1.2 \\
1.4\end{array}$ & $\begin{array}{l}26.0 \\
29.2\end{array}$ & $\begin{array}{l}36.4 \\
35.9\end{array}$ \\
\hline- & 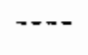 & ---- & -- & --- & -- & --- & --- & --- \\
\hline & -- & $\cdots$ & --- & --- & $\ldots$ & $\cdots$ & $-\cdot-$ & $\cdots$ \\
\hline .8 & $\begin{array}{l}26.6 \\
26.8\end{array}$ & $\begin{array}{r}31.0 \\
33.4\end{array}$ & 0.5 & $\begin{array}{l}28.2 \\
26.5\end{array}$ & $\begin{array}{l}37.0 \\
38.3\end{array}$ & $\begin{array}{l}0.6 \\
0.8\end{array}$ & $\begin{array}{r}26.2 \\
29.8\end{array}$ & $\begin{array}{l}39.5 \\
39.0\end{array}$ \\
\hline .4 & $\begin{array}{l}26.3 \\
26.7\end{array}$ & $\begin{array}{l}32.0 \\
34.0\end{array}$ & 0.3 & $\begin{array}{l}28.3 \\
26.5\end{array}$ & $\begin{array}{l}36.8 \\
38.7\end{array}$ & $\begin{array}{l}0.2 \\
0.3\end{array}$ & $\begin{array}{l}26.4 \\
30.2\end{array}$ & $\begin{array}{l}40.2 \\
39.6\end{array}$ \\
\hline 0.8 & $\begin{array}{l}26.0 \\
27.1\end{array}$ & $\begin{array}{l}30.7 \\
33.1\end{array}$ & 1.0 & $\begin{array}{l}28.3 \\
26.7\end{array}$ & $\begin{array}{l}37.4 \\
39.2\end{array}$ & $\begin{array}{l}1.4 \\
1.5\end{array}$ & $\begin{array}{l}26.7 \\
30.5\end{array}$ & $\begin{array}{l}40.8 \\
40.2\end{array}$ \\
\hline 1.2 & $\begin{array}{l}25.1 \\
26.4\end{array}$ & $\begin{array}{l}30.3 \\
33.0\end{array}$ & 1.4 & $\begin{array}{l}28.5 \\
26.7\end{array}$ & $\begin{array}{l}38.7 \\
39.4\end{array}$ & $\begin{array}{l}1.7 \\
1.8\end{array}$ & $\begin{array}{l}26.7 \\
30.4\end{array}$ & $\begin{array}{l}41.3 \\
40.8\end{array}$ \\
\hline 1.2 & $\begin{array}{l}25.5 \\
26.9\end{array}$ & $\begin{array}{l}29.9 \\
32.8\end{array}$ & 1.4 & $\begin{array}{l}28.5 \\
26.9\end{array}$ & $\begin{array}{l}37.9 \\
40.1\end{array}$ & $\begin{array}{l}1.4 \\
1.5\end{array}$ & $\begin{array}{l}26.6 \\
31.0\end{array}$ & $\begin{array}{l}41.4 \\
40.8\end{array}$ \\
\hline 1.3 & $\begin{array}{l}24.8 \\
26.3\end{array}$ & $\begin{array}{l}29.3 \\
32.2\end{array}$ & 1.5 & $\begin{array}{l}28.2 \\
26.6\end{array}$ & $\begin{array}{l}37.5 \\
39.4\end{array}$ & $\begin{array}{l}1.9 \\
2.0\end{array}$ & $\begin{array}{l}26.2 \\
30.3\end{array}$ & $\begin{array}{l}41.7 \\
41.1\end{array}$ \\
\hline 2.3 & $\begin{array}{l}25.3 \\
26.6\end{array}$ & $\begin{array}{l}32.8 \\
35.4\end{array}$ & 2.4 & $\begin{array}{l}27.8 \\
26.6\end{array}$ & $\begin{array}{l}37.4 \\
39.4\end{array}$ & $\begin{array}{l}2.7 \\
3.1\end{array}$ & $\begin{array}{l}26.0 \\
30.4\end{array}$ & $\begin{array}{l}41.4 \\
40.7\end{array}$ \\
\hline 1.9 & $\begin{array}{l}26.1 \\
26.8\end{array}$ & $\begin{array}{l}34.5 \\
36.6\end{array}$ & 2.0 & $\begin{array}{l}27.8 \\
26.7\end{array}$ & $\begin{array}{l}37.2 \\
39.3\end{array}$ & $\begin{array}{l}2.3 \\
2.6\end{array}$ & $\begin{array}{l}26.1 \\
30.3\end{array}$ & $\begin{array}{l}41.1 \\
40.3\end{array}$ \\
\hline 1 & $\begin{array}{l}26.3 \\
26.8\end{array}$ & $\begin{array}{l}33.5 \\
35.9\end{array}$ & 1.6 & $\begin{array}{l}27.4 \\
26.4\end{array}$ & $\begin{array}{l}36.7 \\
38.9\end{array}$ & $\begin{array}{l}1.8 \\
2.1\end{array}$ & $\begin{array}{l}25.7 \\
29.8\end{array}$ & $\begin{array}{l}39.6 \\
39.4\end{array}$ \\
\hline
\end{tabular}


EAST MESA 1 (1979) - WARM I (contd)

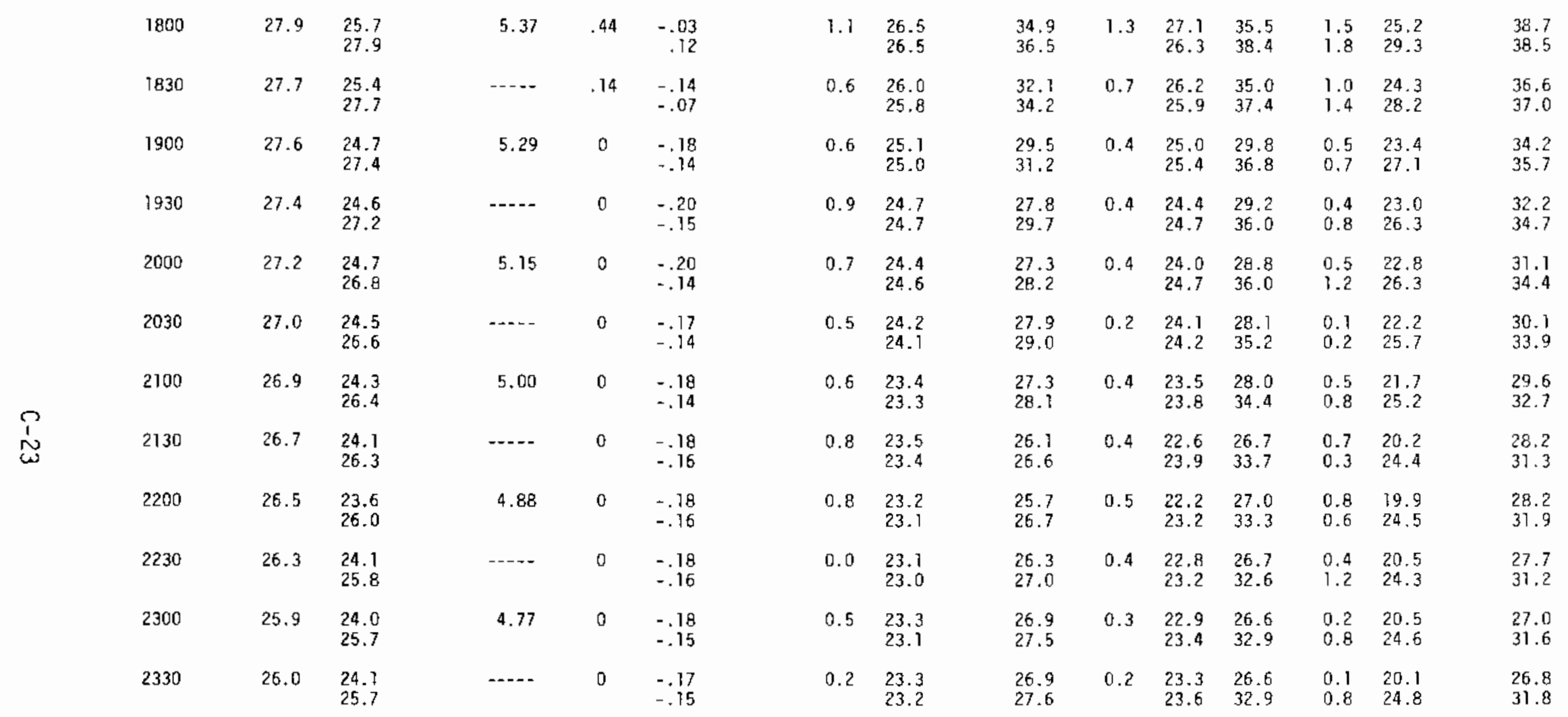


EAST MESA 1 (1979) - WARM I (contd)

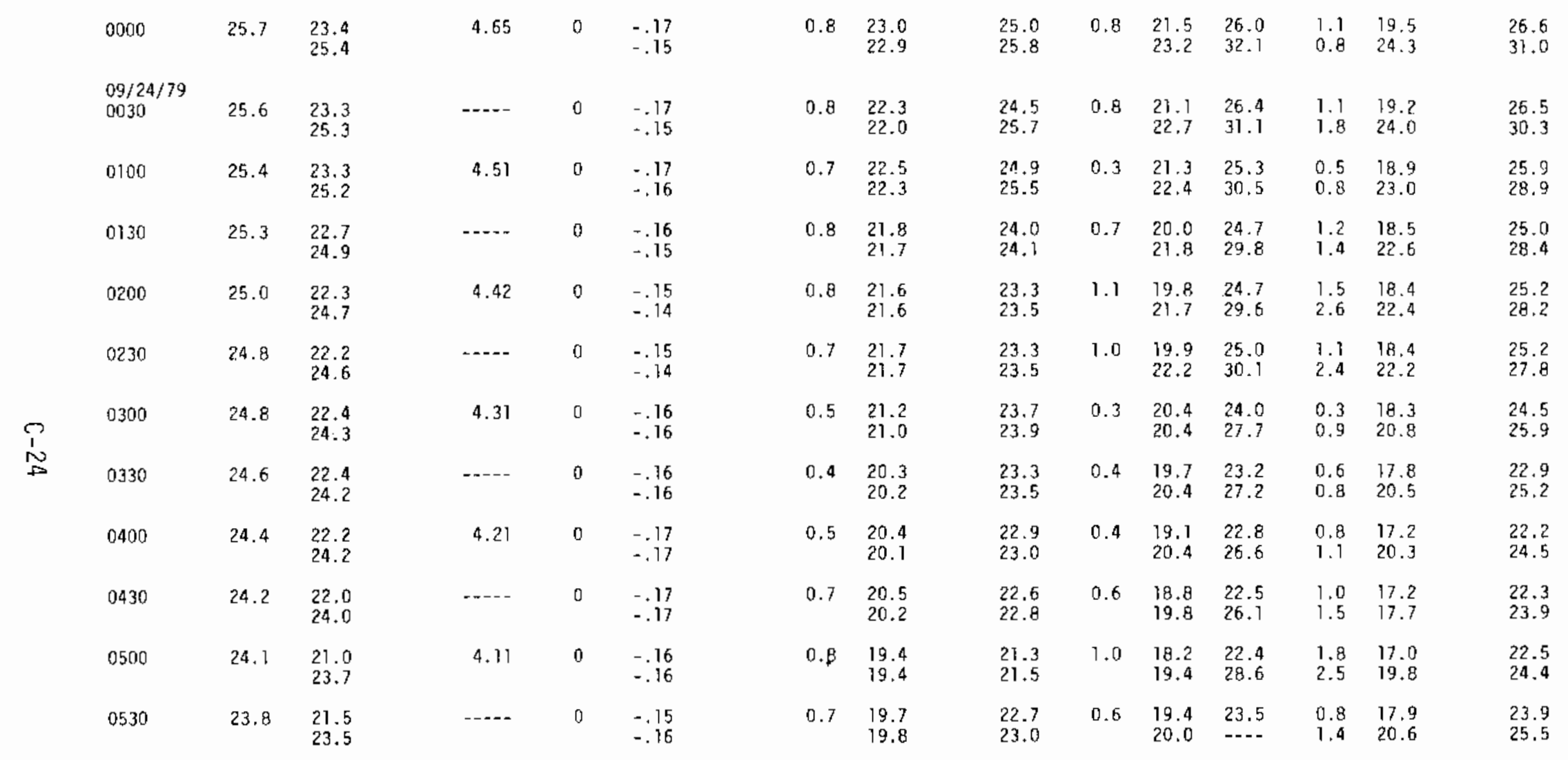


EAST MIESA 1 (1979) - WARM I (contd)

\begin{tabular}{|c|c|c|c|c|c|c|c|c|c|c|c|c|c|c|}
\hline 0600 & 23.7 & $\begin{array}{l}21.8 \\
23.4\end{array}$ & 4.01 & 0 & $\begin{array}{l}-.15 \\
-.17\end{array}$ & 0.6 & $\begin{array}{l}20.8 \\
20.6\end{array}$ & $\begin{array}{l}22.7 \\
23.0\end{array}$ & 0.3 & $\begin{array}{l}19.8 \\
20.5\end{array}$ & $\begin{array}{l}22.9 \\
-\end{array}$ & $\begin{array}{l}0.4 \\
0.8\end{array}$ & $\begin{array}{l}17.7 \\
20.4\end{array}$ & $\begin{array}{l}22.7 \\
24.9\end{array}$ \\
\hline 0630 & 23.5 & $\begin{array}{l}21.5 \\
23.3\end{array}$ & $-\cdots$ & $\cdots$ & $\begin{array}{l}-.16 \\
-.16\end{array}$ & 0.4 & $\begin{array}{l}20.2 \\
20.1\end{array}$ & $\begin{array}{l}22.3 \\
22.6\end{array}$ & 0.4 & $\begin{array}{l}19.0 \\
20.2\end{array}$ & $\begin{array}{l}22.5 \\
25.5\end{array}$ & $\begin{array}{l}0.8 \\
1.6\end{array}$ & $\begin{array}{l}17.2 \\
20.9\end{array}$ & $\begin{array}{l}22.1 \\
25.9\end{array}$ \\
\hline 0700 & 23.4 & $\begin{array}{l}21.4 \\
23.2\end{array}$ & 3.89 & .13 & $\begin{array}{l}-.08 \\
-.15\end{array}$ & 0.7 & $\begin{array}{l}20.4 \\
20.4\end{array}$ & $\begin{array}{l}22.1 \\
22.2\end{array}$ & 0.4 & $\begin{array}{l}18.9 \\
21.3\end{array}$ & $\begin{array}{l}22.4 \\
30.3\end{array}$ & $\begin{array}{l}0.7 \\
1.2\end{array}$ & $\begin{array}{l}17.2 \\
21.0\end{array}$ & $\begin{array}{l}22.0 \\
25.9\end{array}$ \\
\hline 0730 & 23.4 & $\begin{array}{l}21.4 \\
23.2\end{array}$ & ----- & .51 & $\begin{array}{r}.29 \\
-.12\end{array}$ & 0.9 & $\begin{array}{l}21.0 \\
21.1\end{array}$ & $\begin{array}{l}22.6 \\
23.1\end{array}$ & 0.6 & $\begin{array}{l}20.5 \\
22.1\end{array}$ & $\begin{array}{l}24.4 \\
32.2\end{array}$ & $\begin{array}{l}1.0 \\
1.2\end{array}$ & $\begin{array}{l}19.2 \\
22.7\end{array}$ & $\begin{array}{l}25.1 \\
27.7\end{array}$ \\
\hline 0800 & 23.4 & $\begin{array}{l}22.7 \\
23.2\end{array}$ & 3.79 & .94 & $\begin{array}{l}.69 \\
.17\end{array}$ & 0.6 & $\begin{array}{l}22.1 \\
22.2\end{array}$ & $\begin{array}{l}24.3 \\
25.4\end{array}$ & 0.4 & $\begin{array}{l}22.7 \\
22.5\end{array}$ & $\begin{array}{l}27.3 \\
31.2\end{array}$ & $\begin{array}{l}0.4 \\
0.6\end{array}$ & $\begin{array}{l}21.5 \\
24.4\end{array}$ & $\begin{array}{l}28.6 \\
29.3\end{array}$ \\
\hline 0830 & 23.4 & $\begin{array}{l}22.7 \\
23.3\end{array}$ & $\cdots$ & 1.48 & $\begin{array}{r}1.22 \\
.62\end{array}$ & 0.7 & $\begin{array}{l}23.4 \\
23.6\end{array}$ & $\begin{array}{l}25.2 \\
26.5\end{array}$ & 0.5 & $\begin{array}{l}24.6 \\
24.1\end{array}$ & $\begin{array}{l}29.2 \\
32.5\end{array}$ & $\begin{array}{l}0.5 \\
0.6\end{array}$ & $\begin{array}{l}23.6 \\
26.8\end{array}$ & $\begin{array}{l}31.5 \\
31.9\end{array}$ \\
\hline
\end{tabular}


EAST MESA 1 (1979) - WARM II

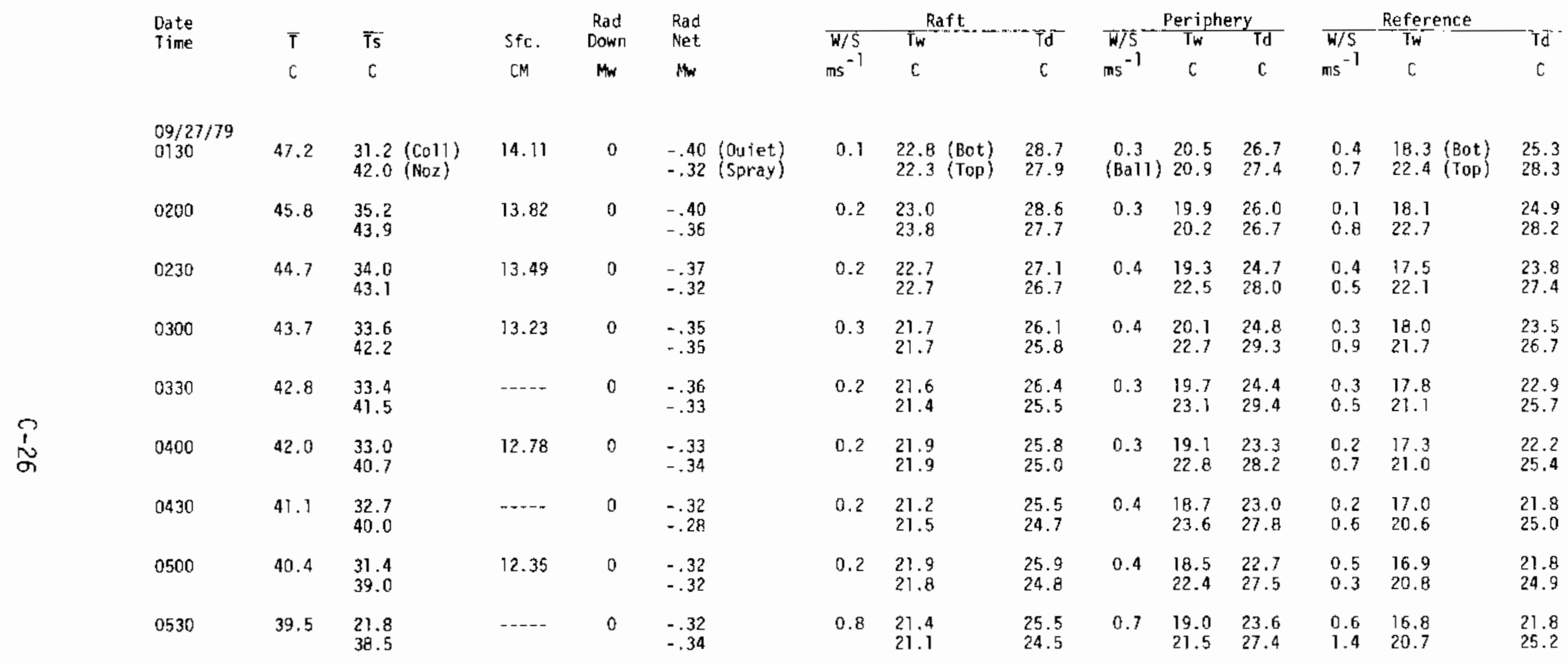


EAST MESA I (1979) - WARM II (contd)

\begin{tabular}{|c|c|c|c|c|c|c|c|c|c|c|c|c|c|c|}
\hline 0600 & 38.8 & $\begin{array}{l}30.4 \\
37.7\end{array}$ & 11.99 & 0 & $\begin{array}{l}-.31 \\
-.35\end{array}$ & 0.7 & $\begin{array}{r}19.3 \\
19.8\end{array}$ & $\begin{array}{l}22.9 \\
22.9\end{array}$ & 0.5 & $\begin{array}{r}17.9 \\
22.2\end{array}$ & $\begin{array}{l}21.3 \\
26.4\end{array}$ & $\begin{array}{l}0.5 \\
0.1\end{array}$ & $\begin{array}{l}16.2 \\
19.5\end{array}$ & $\begin{array}{l}20.5 \\
23.6\end{array}$ \\
\hline 0630 & 38.3 & $\begin{array}{l}29.4 \\
37.3\end{array}$ & $\ldots$ & 0 & $\begin{array}{l}-.29 \\
-.34\end{array}$ & 0.6 & $\begin{array}{l}21.1 \\
20.5\end{array}$ & $\begin{array}{l}20.4 \\
22.9\end{array}$ & 0.5 & $\begin{array}{l}17.4 \\
20.6\end{array}$ & $\begin{array}{l}20.9 \\
25.6\end{array}$ & $\begin{array}{l}0.8 \\
0.7\end{array}$ & $\begin{array}{l}15.8 \\
19.1\end{array}$ & $\begin{array}{l}20.1 \\
23.1\end{array}$ \\
\hline 0700 & 37.5 & $\begin{array}{l}28.9 \\
36.8\end{array}$ & 11.61 & .14 & $\begin{array}{l}-.22 \\
-.36\end{array}$ & 0.7 & $\begin{array}{l}21.6 \\
22.5\end{array}$ & $\begin{array}{l}24.2 \\
24.7\end{array}$ & 0.6 & $\begin{array}{l}17.7 \\
20.0\end{array}$ & $\begin{array}{l}21.3 \\
25.5\end{array}$ & $\begin{array}{l}0.7 \\
1.2\end{array}$ & $\begin{array}{l}16.4 \\
19.2\end{array}$ & $\begin{array}{l}21.0 \\
22.9\end{array}$ \\
\hline 0730 & 36.8 & $\begin{array}{l}29.5 \\
35.9\end{array}$ & -... & .32 & $\begin{array}{l}-.04 \\
-.27\end{array}$ & 0.5 & $\begin{array}{l}19.6 \\
20.4\end{array}$ & $\begin{array}{l}23.4 \\
23.3\end{array}$ & 0.3 & $\begin{array}{l}18.4 \\
21.3\end{array}$ & $\begin{array}{r}22.4 \\
2.5 .5\end{array}$ & $\begin{array}{l}0.2 \\
0.5\end{array}$ & $\begin{array}{l}17.1 \\
19.4\end{array}$ & $\begin{array}{l}21.8 \\
23.0\end{array}$ \\
\hline 0800 & 36.3 & $\begin{array}{l}29.6 \\
35.7\end{array}$ & 11.28 & .70 & $\begin{array}{r}.37 \\
-.09\end{array}$ & 0.4 & $\begin{array}{l}21.0 \\
22.0\end{array}$ & $\begin{array}{l}24.8 \\
26.2\end{array}$ & 0.3 & $\begin{array}{l}20.2 \\
20.6\end{array}$ & $\begin{array}{l}25.2 \\
26.1\end{array}$ & $\begin{array}{l}0.2 \\
0.3\end{array}$ & $\begin{array}{l}18.9 \\
21.4\end{array}$ & $\begin{array}{l}24.5 \\
24.9\end{array}$ \\
\hline 0830 & 35.9 & $\begin{array}{l}30.1 \\
35.0\end{array}$ & ..... & .87 & $\begin{array}{l}.61 \\
.18\end{array}$ & 0.5 & $\begin{array}{l}22.4 \\
24.0\end{array}$ & $\begin{array}{l}26.3 \\
29.2\end{array}$ & 0.7 & $\begin{array}{l}22.6 \\
21.7\end{array}$ & $\begin{array}{l}27.0 \\
27.0\end{array}$ & $\begin{array}{l}0.6 \\
0.7\end{array}$ & $\begin{array}{l}20.6 \\
22.9\end{array}$ & $\begin{array}{l}26.1 \\
26.5\end{array}$ \\
\hline 0900 & 35.4 & $\begin{array}{l}29.6 \\
34.8\end{array}$ & 10.96 & 1.45 & $\begin{array}{r}1.20 \\
.51\end{array}$ & 1.2 & $\begin{array}{l}24.2 \\
24.6\end{array}$ & $\begin{array}{l}30.8 \\
31.5\end{array}$ & 1.3 & $\begin{array}{l}24.2 \\
23.1\end{array}$ & $\begin{array}{l}29.4 \\
29.4\end{array}$ & $\begin{array}{l}1.2 \\
1.5\end{array}$ & $\begin{array}{l}22.3 \\
24.8\end{array}$ & $\begin{array}{l}28.9 \\
28.8\end{array}$ \\
\hline 0930 & 34.8 & $\begin{array}{l}28.4 \\
35 / 5\end{array}$ & $-\cdots$ & 1.88 & $\begin{array}{r}1.65 \\
.81\end{array}$ & 2.9 & $\begin{array}{l}25.4 \\
25.0\end{array}$ & $\begin{array}{l}30.9 \\
32.5\end{array}$ & 2.9 & $\begin{array}{l}25.3 \\
24.1\end{array}$ & $\begin{array}{l}31.2 \\
31.3\end{array}$ & $\begin{array}{l}3.0 \\
3.5\end{array}$ & $\begin{array}{l}23.3 \\
25.8\end{array}$ & $\begin{array}{l}31.1 \\
30.6\end{array}$ \\
\hline 1000 & 34.3 & $\begin{array}{l}27.7 \\
34.0\end{array}$ & 10.60 & 1.97 & $\begin{array}{r}1.75 \\
.97\end{array}$ & 3.3 & $\begin{array}{l}25.8 \\
25.1\end{array}$ & $\begin{array}{l}31.8 \\
33.0\end{array}$ & 3.2 & $\begin{array}{l}25.6 \\
24.4\end{array}$ & $\begin{array}{l}31.8 \\
32.1\end{array}$ & $\begin{array}{l}3.4 \\
3.9\end{array}$ & $\begin{array}{l}23.7 \\
26.2\end{array}$ & $\begin{array}{l}32.3 \\
31.5\end{array}$ \\
\hline 1030 & 34.0 & $\begin{array}{l}28.2 \\
33.6\end{array}$ & $\cdots$ & 2.38 & $\begin{array}{l}2.18 \\
1.38\end{array}$ & 2.9 & $\begin{array}{l}26.7 \\
25.9\end{array}$ & $\begin{array}{l}32.8 \\
34.3\end{array}$ & 2.9 & $\begin{array}{l}26.5 \\
25.0\end{array}$ & $\begin{array}{l}33.3 \\
33.1\end{array}$ & $\begin{array}{l}3.0 \\
3.4\end{array}$ & $\begin{array}{l}24.6 \\
27.1\end{array}$ & $\begin{array}{l}33.5 \\
32.6\end{array}$ \\
\hline 1100 & 33.6 & $\begin{array}{l}27.8 \\
33.3\end{array}$ & 10.25 & 2.51 & $\begin{array}{l}2.28 \\
1.58\end{array}$ & 3.4 & $\begin{array}{l}26.7 \\
25.7\end{array}$ & $\begin{array}{l}33.2 \\
34.5\end{array}$ & 3.4 & $\begin{array}{l}26.4 \\
24.7\end{array}$ & $\begin{array}{l}33.5 \\
33.3\end{array}$ & $\begin{array}{l}3.7 \\
4.2\end{array}$ & $\begin{array}{l}24.5 \\
26.9\end{array}$ & $\begin{array}{l}34.0 \\
32.9\end{array}$ \\
\hline 1730 & 33.2 & $\begin{array}{l}27.7 \\
33.0\end{array}$ & ..... & 2.63 & $\begin{array}{r}2.33 \\
1.74\end{array}$ & 3.2 & $\begin{array}{l}26.6 \\
25.6\end{array}$ & $\begin{array}{l}33.5 \\
34.5\end{array}$ & 3.2 & $\begin{array}{l}26.5 \\
24.6\end{array}$ & $\begin{array}{r}33.9 \\
33.5\end{array}$ & $\begin{array}{l}3.4 \\
3.8\end{array}$ & $\begin{array}{l}24.3 \\
26.9\end{array}$ & $\begin{array}{l}34.4 \\
33.3\end{array}$ \\
\hline
\end{tabular}


EAST MESA ] (1979) - WARM II (contd)

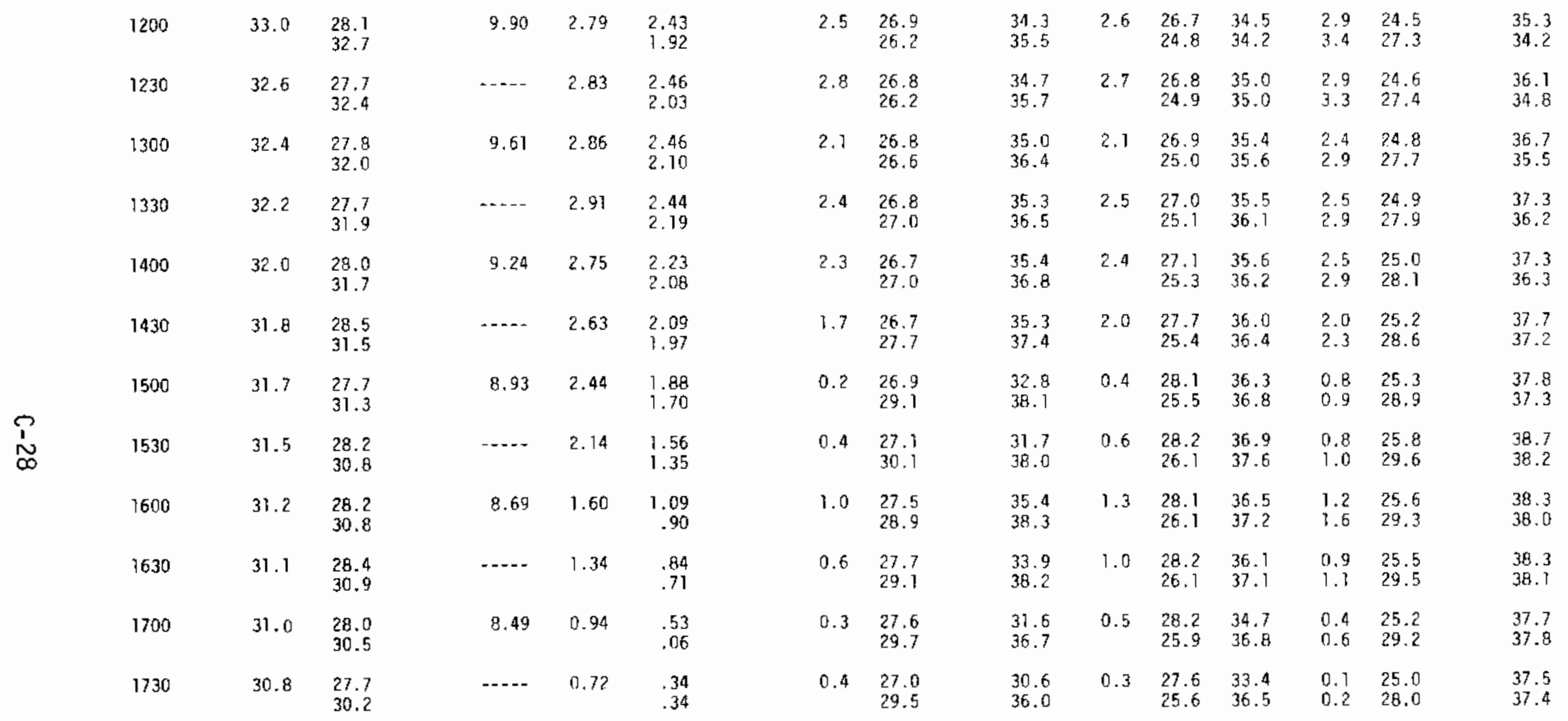


EAST MESA 1 (1979) - WARM II (contd)

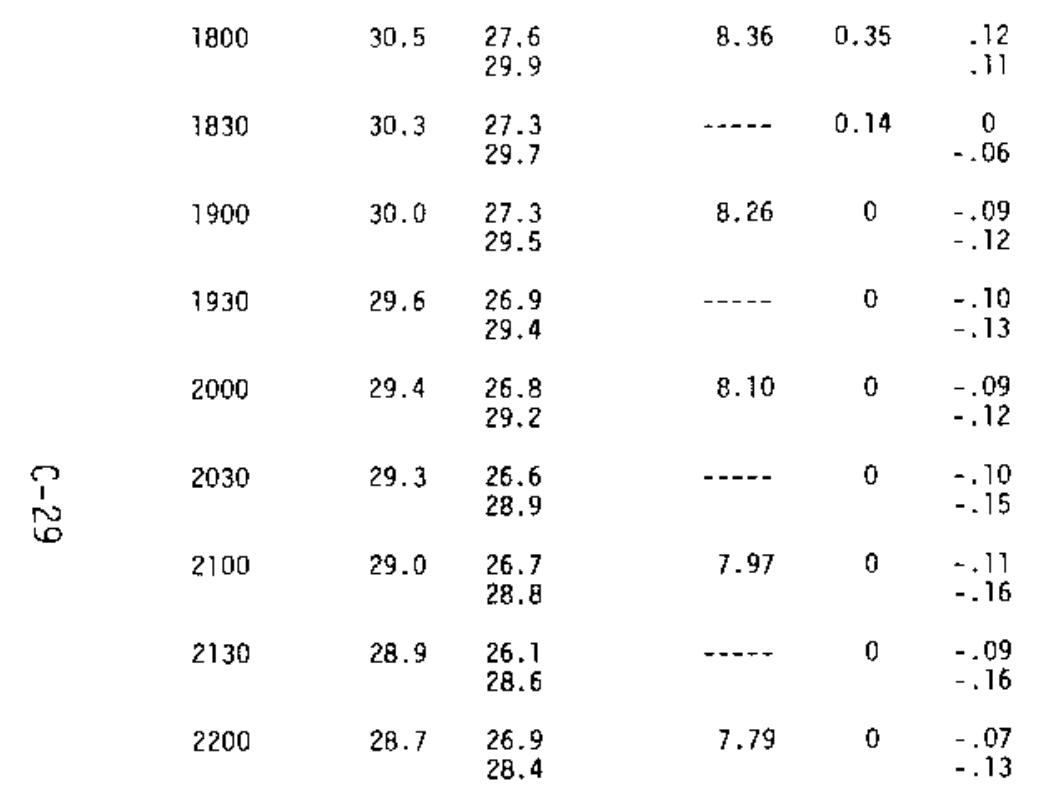

$\begin{array}{lllllllll}0.3 & 27.4 & 31.2 & 0.6 & 27.5 & 34.2 & 0.8 & 24.8 & 37.0 \\ & 28.0 & 34.1 & & 25.8 & 36.6 & 1.0 & 28.4 & 36.9 \\ 0.1 & 27.0 & 31.6 & 0.4 & 26.7 & 32.5 & 0.7 & 24.5 & 36.0 \\ & 26.9 & 31.8 & & 25.6 & 36.2 & 0.9 & 27.9 & 36.2 \\ 0.4 & 26.4 & 31.6 & 0.5 & 26.3 & 32.2 & 0.5 & 24.7 & 33.8 \\ & 25.7 & 31.2 & & 25.5 & 35.9 & 1.2 & 27.3 & 35.3 \\ 0.3 & 26.5 & 30.6 & 0.4 & 26.1 & 30.4 & 0.1 & 24.2 & 32.8 \\ & 25.3 & 30.1 & & 25.1 & 35.7 & 0.6 & 26.9 & 35.1 \\ 0.5 & 26.6 & 29.1 & 0.3 & 26.1 & 29.3 & 0.1 & 23.5 & 31.5 \\ & 25.9 & 28.5 & & 24.9 & 35.6 & 0.9 & 26.6 & 34.6 \\ 0.5 & 25.5 & 28.3 & 0.6 & 24.9 & 29.4 & 0.8 & 22.2 & 30.9 \\ & 24.8 & 27.6 & & 23.8 & 32.3 & 1.3 & 26.0 & 33.3 \\ 0.3 & 25.8 & 28.1 & 0.2 & 25.1 & 28.6 & 0.3 & 22.2 & 30.4 \\ & 24.8 & 27.2 & & --.- & -\ldots .- & 0.8 & 25.3 & 32.0 \\ 0.7 & 24.1 & 28.8 & 0.4 & 23.9 & 28.4 & 1.0 & 21.0 & 29.7 \\ & 23.8 & 27.3 & & -.-- & --.- & 1.2 & 24.8 & 31.8 \\ 0.1 & 24.2 & 28.2 & 0.4 & 23.9 & 28.1 & 0.5 & 21.2 & 29.4 \\ & 23.8 & 27.2 & & -\ldots .- & -. .- & 1.1 & 24.4 & 31.0\end{array}$


EAST MESA 1 (1979) - WARM III

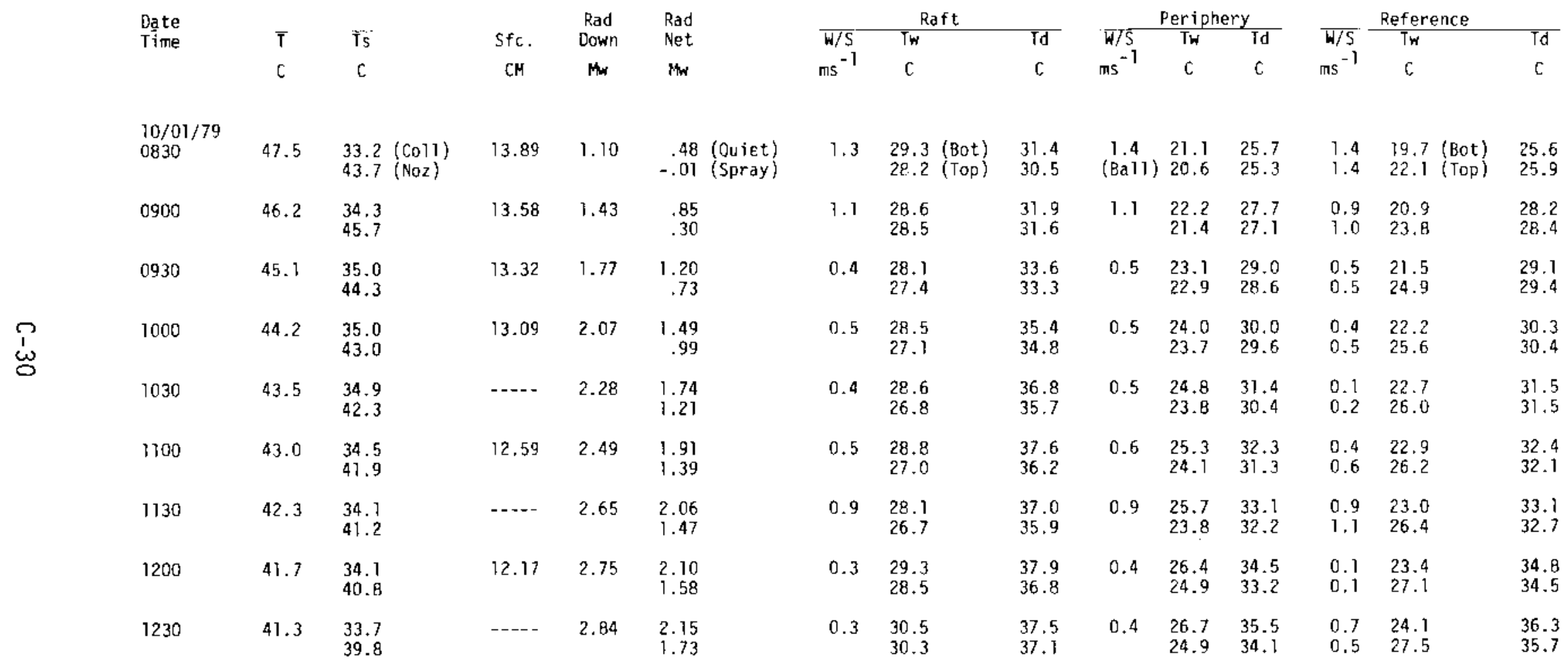




\section{EAST MESA 1 (1979) - WARM III (contd)}

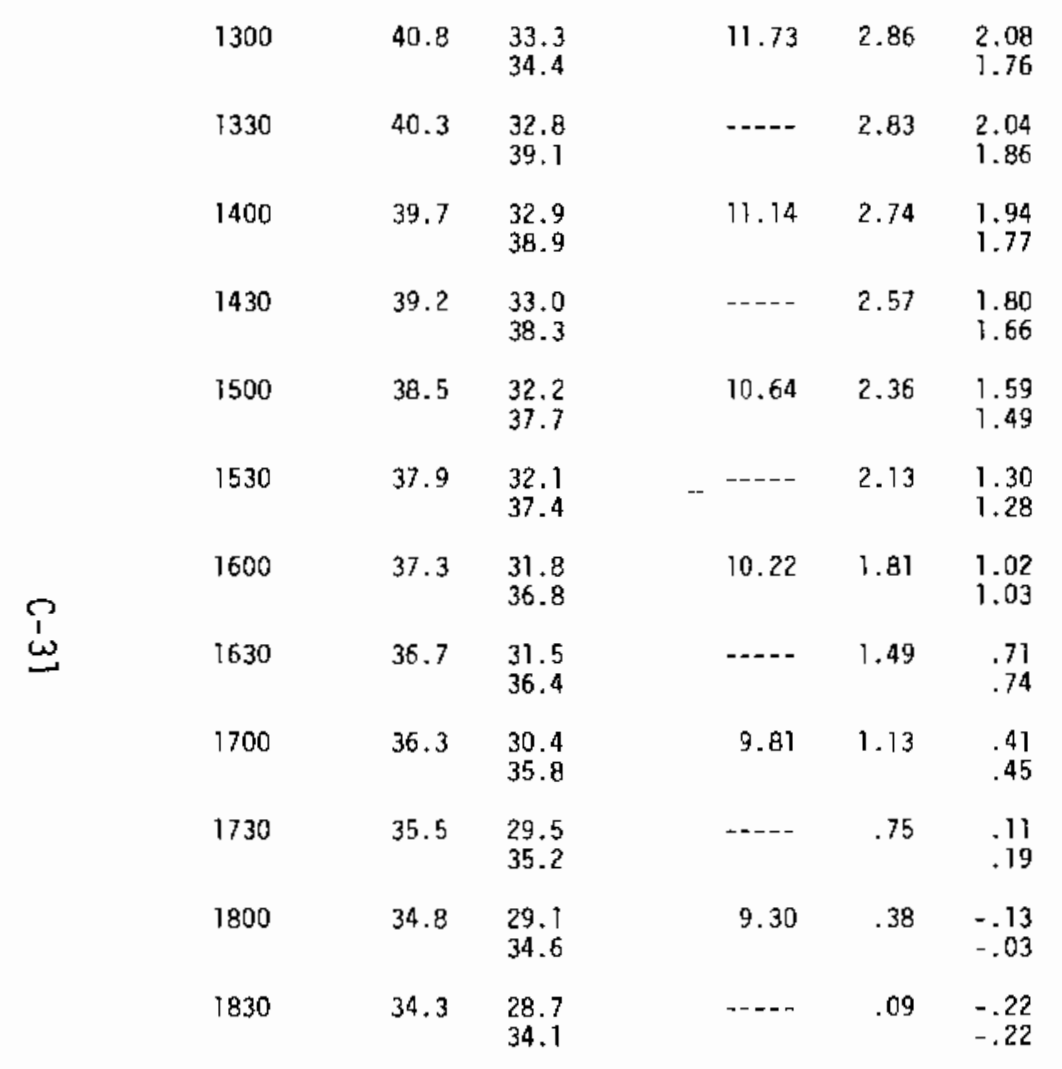

$\begin{array}{lllllllll}0.4 & 28.2 & 37.3 & 0.6 & 27.0 & 35.9 & 0.3 & 24.4 & 37.0 \\ & 28.6 & 37.3 & & 24.4 & 35.0 & 0.4 & 27.7 & 36.4 \\ 0.7 & 28.7 & 34.9 & 0.8 & 27.1 & 36.7 & 1.0 & 24.5 & 37.9 \\ & 29.4 & 36.7 & & 24.3 & 35.6 & 0.9 & 27.8 & 37.0 \\ 0.9 & 27.9 & 36.1 & 1.1 & 26.2 & 37.0 & 1.2 & 24.6 & 38.1 \\ & 28.7 & 37.6 & & 24.7 & 36.1 & 1.3 & 28.2 & 37.6 \\ 0.5 & 28.6 & 35.9 & 0.4 & 27.5 & 37.1 & 0.9 & 24.6 & 38.0 \\ & 29.6 & 38.2 & & 24.7 & 36.3 & 0.7 & 28.5 & 37.9 \\ 1.7 & 27.6 & 36.4 & 1.8 & 28.0 & 37.4 & 1.8 & 25.0 & 38.7 \\ & 28.0 & 38.0 & & 25.1 & 36.7 & 2.1 & 29.0 & 38.4 \\ 0.9 & 28.0 & 35.5 & 1.0 & 27.8 & 37.0 & 1.1 & 24.8 & 38.4 \\ & 28.8 & 37.8 & & 25.0 & 36.7 & 1.2 & 28.8 & 38.0 \\ 1.9 & 28.1 & 36.5 & 2.0 & 28.0 & 37.0 & 1.9 & 25.0 & 38.8 \\ & 27.9 & 38.1 & & 25.0 & 36.7 & 2.2 & 29.2 & 38.4 \\ 1.2 & 29.0 & 34.4 & 1.6 & 27.7 & 36.8 & 1.6 & 24.7 & 38.5 \\ & 29.6 & 37.2 & & 25.3 & 36.9 & 1.7 & 29.0 & 38.4 \\ 1.3 & 29.5 & 33.5 & 1.8 & 27.4 & 36.6 & 2.2 & 24.7 & 38.3 \\ & 30.2 & 36.2 & & 25.1 & 37.0 & 2.2 & 28.7 & 38.1 \\ 1.9 & 25.7 & 29.8 & 2.6 & 26.8 & 36.2 & 2.9 & 24.3 & 37.5 \\ & 27.7 & 32.7 & & 25.5 & 37.1 & 3.3 & 28.0 & 37.2 \\ 1.7 & 25.5 & 29.3 & 2.5 & 26.3 & 35.6 & 2.9 & 23.8 & 36.8 \\ & 27.4 & 31.8 & & 24.8 & 36.3 & 3.2 & 27.6 & 36.6 \\ 1.1 & 27.5 & 29.1 & 1.5 & 25.3 & 33.7 & 1.9 & 22.7 & 35.1 \\ & 27.4 & 30.6 & & 24.0 & 35.1 & 2.2 & 26.6 & 35.2\end{array}$




\section{EAST MESA 1 (1979) - WARM III (contd)}

\begin{tabular}{|c|c|c|c|c|c|}
\hline 1900 & 33.6 & $\begin{array}{l}29.4 \\
33.6\end{array}$ & 9.15 & 0 & $\begin{array}{l}-.25 \\
-.25\end{array}$ \\
\hline 1930 & 33.4 & $\begin{array}{l}29.1 \\
32.8\end{array}$ & $-\cdots--$ & 0 & $\begin{array}{l}-.25 \\
-.24\end{array}$ \\
\hline 2000 & 33.0 & $\begin{array}{l}27.7 \\
32.0\end{array}$ & 8.88 & 0 & $\begin{array}{l}-.25 \\
-.26\end{array}$ \\
\hline 2030 & 32.6 & $\begin{array}{l}28.4 \\
31.9\end{array}$ & $-\cdots$ & 0 & $\begin{array}{l}-.25 \\
-.30\end{array}$ \\
\hline 2100 & 32.1 & $\begin{array}{l}28.0 \\
31.7\end{array}$ & 8.67 & 0 & $\begin{array}{l}-.25 \\
-.30\end{array}$ \\
\hline 2130 & 31.8 & $\begin{array}{l}27.5 \\
31.4\end{array}$ & $\cdots--$ & 0 & $\begin{array}{l}-.25 \\
-.30\end{array}$ \\
\hline 2200 & 31.5 & $\begin{array}{l}27.2 \\
31.2\end{array}$ & 8.50 & 0 & $\begin{array}{l}-.25 \\
-.29\end{array}$ \\
\hline 2230 & 31.2 & $\begin{array}{l}27.1 \\
30.6\end{array}$ & ---- & 0 & $\begin{array}{l}-.24 \\
-.30\end{array}$ \\
\hline 2300 & 31.0 & $\begin{array}{l}26.9 \\
30.4\end{array}$ & 8.30 & 0 & $\begin{array}{l}-.24 \\
-.29\end{array}$ \\
\hline 2330 & 30.7 & $\begin{array}{l}26.6 \\
30.2\end{array}$ & $-\cdots$ & 0 & $\begin{array}{l}-.22 \\
-.30\end{array}$ \\
\hline 0000 & 30.3 & $\begin{array}{l}26.4 \\
29.8\end{array}$ & 8.13 & 0 & $\begin{array}{l}-.22 \\
-.30\end{array}$ \\
\hline $\begin{array}{l}10 / 02 / 79 \\
0030\end{array}$ & 29.8 & $\begin{array}{l}26.3 \\
29.6\end{array}$ & $\cdots$ & 0 & $\begin{array}{l}-.24 \\
-.32\end{array}$ \\
\hline
\end{tabular}

$\begin{array}{lllllllll}0.7 & 25.6 & 28.7 & 0.6 & 24.8 & 32.0 & 1.3 & 21.4 & 32.8 \\ & 25.6 & 23.7 & & 23.6 & 34.5 & 1.8 & 25.9 & 34.3 \\ 0.2 & 24.7 & 28.4 & 0.4 & 24.4 & 31.0 & 0.3 & 21.3 & 30.8 \\ & 24.7 & 29.1 & & 23.2 & 33.3 & 0.4 & 24.8 & 32.7 \\ 1.3 & 22.2 & 28.7 & 1.5 & 23.3 & 30.2 & 1.7 & 21.4 & 30.3 \\ & 21.6 & 28.7 & & 22.7 & 31.3 & 2.4 & 24.3 & 31.0 \\ 1.0 & 24.5 & 28.1 & 1.2 & 23.2 & 30.1 & 1.2 & 21.5 & 29.9 \\ & 23.2 & 28.3 & & 23.2 & 31.2 & 2.1 & 24.6 & 31.0 \\ 0.6 & 25.1 & 27.6 & 0.5 & 22.6 & 28.7 & 1.0 & 20.2 & 28.4 \\ & 24.2 & 27.5 & & 22.8 & 30.3 & 0.9 & 23.9 & 30.1 \\ 0.6 & 25.8 & 27.4 & 0.4 & 21.7 & 28.0 & 0.7 & 19.4 & 27.4 \\ & 25.1 & 27.0 & & 22.8 & 30.8 & 1.3 & 23.9 & 30.3 \\ 0.5 & 25.0 & 26.7 & 0.2 & 21.0 & 27.3 & 0.5 & 18.8 & 26.1 \\ & 24.9 & 26.5 & & 22.6 & 30.5 & 1.1 & 23.4 & 29.8 \\ 0.4 & 22.1 & 25.2 & 0.7 & 21.5 & 26.0 & 0.8 & 19.0 & 25.2 \\ & 22.9 & 25.0 & & 21.7 & 28.2 & 1.3 & 22.2 & 27.6 \\ 0.3 & 21.3 & 24.5 & 0.5 & 21.2 & 26.1 & 0.5 & 19.5 & 25.5 \\ & 21.3 & 24.4 & & 21.6 & 26.8 & 1.2 & 21.9 & 26.6 \\ 0.3 & 22.9 & 25.3 & 0.2 & 20.7 & 25.5 & 0.3 & 19.2 & 25.0 \\ & 22.3 & 25.0 & & 21.9 & 27.0 & 0.3 & 21.8 & 26.5 \\ 0.8 & 24.3 & 25.5 & 0.6 & 20.2 & 25.0 & 0.9 & 18.1 & 23.9 \\ & 23.5 & 25.2 & & 21.8 & 28.1 & 0.7 & 22.4 & 27.7 \\ 0.8 & 23.8 & 24.8 & 0.7 & 19.9 & 24.8 & 1.0 & 17.8 & 23.6 \\ & 23.2 & 24.8 & & 21.3 & 27.7 & 1.0 & 22.1 & 27.5\end{array}$


EAST MESA 1 (1979) - WARI III (contd)

\begin{tabular}{|c|c|c|c|c|c|c|c|c|c|c|c|c|c|c|}
\hline 0100 & 29.6 & $\begin{array}{l}26.0 \\
29.2\end{array}$ & 7.96 & 0 & $\begin{array}{l}-.24 \\
-.30\end{array}$ & 0.4 & $\begin{array}{l}22.8 \\
22.3\end{array}$ & $\begin{array}{l}24.0 \\
24.0\end{array}$ & 0.4 & $\begin{array}{l}19.4 \\
21.4\end{array}$ & $\begin{array}{l}24.4 \\
27.4\end{array}$ & $\begin{array}{l}0.4 \\
0.9\end{array}$ & $\begin{array}{l}17.5 \\
21.7\end{array}$ & $\begin{array}{l}23.2 \\
26.6\end{array}$ \\
\hline 0130 & 29.3 & $\begin{array}{l}26.0 \\
28.7\end{array}$ & $\cdots$ & 0 & $\begin{array}{l}-.23 \\
-.30\end{array}$ & 0.9 & $\begin{array}{l}20.8 \\
20.3\end{array}$ & $\begin{array}{l}23.9 \\
23.8\end{array}$ & 1.1 & $\begin{array}{l}20.5 \\
20.5\end{array}$ & $\begin{array}{l}26.0 \\
27.4\end{array}$ & $\begin{array}{l}0.9 \\
1.8\end{array}$ & $\begin{array}{l}17.8 \\
21.4\end{array}$ & $\begin{array}{l}23.8 \\
26.9\end{array}$ \\
\hline 0200 & 29.0 & $\begin{array}{l}25.2 \\
28.6\end{array}$ & 7.76 & 0 & $\begin{array}{l}-.23 \\
-.30\end{array}$ & 1.0 & $\begin{array}{l}19.4 \\
18.9\end{array}$ & $\begin{array}{l}23.8 \\
23.7\end{array}$ & 1.2 & $\begin{array}{l}19.8 \\
19.8\end{array}$ & $\begin{array}{l}24.7 \\
25.7\end{array}$ & $\begin{array}{l}1.4 \\
2.2\end{array}$ & $\begin{array}{l}18.4 \\
20.7\end{array}$ & $\begin{array}{l}24.5 \\
25.6\end{array}$ \\
\hline 0230 & 28.7 & $\begin{array}{l}24.8 \\
28.4\end{array}$ & $\cdots$ & 0 & $\begin{array}{l}-.23 \\
-.30\end{array}$ & 0.4 & $\begin{array}{l}19.3 \\
19.4\end{array}$ & $\begin{array}{l}22.5 \\
22.4\end{array}$ & 0.5 & $\begin{array}{l}18.7 \\
19.6\end{array}$ & $\begin{array}{l}23.0 \\
23.6\end{array}$ & $\begin{array}{l}0.7 \\
0.8\end{array}$ & $\begin{array}{l}17.1 \\
19.5\end{array}$ & $\begin{array}{l}22.0 \\
23.8\end{array}$ \\
\hline 0300 & 28.4 & $\begin{array}{l}25.0 \\
28.0\end{array}$ & 7.61 & 0 & $\begin{array}{l}-.23 \\
-.29\end{array}$ & 0.1 & $\begin{array}{l}19.5 \\
19.5\end{array}$ & $\begin{array}{l}22.2 \\
22.2\end{array}$ & 0.2 & $\begin{array}{l}18.5 \\
20.0\end{array}$ & $\begin{array}{l}23.0 \\
24.0\end{array}$ & $\begin{array}{l}0.1 \\
0.6\end{array}$ & $\begin{array}{l}16.8 \\
19.7\end{array}$ & $\begin{array}{r}21.5 \\
23.9\end{array}$ \\
\hline 0330 & 28.2 & $\begin{array}{l}24.7 \\
27.7\end{array}$ & $-\cdots-$ & 0 & $\begin{array}{l}-.22 \\
-.28\end{array}$ & 0.1 & $\begin{array}{l}19.7 \\
19.7\end{array}$ & $\begin{array}{l}22.0 \\
21.9\end{array}$ & 0.3 & $\begin{array}{l}18.1 \\
19.9\end{array}$ & $\begin{array}{l}22.0 \\
23.6\end{array}$ & $\begin{array}{l}0.3 \\
0.7\end{array}$ & $\begin{array}{l}16.3 \\
19.6\end{array}$ & $\begin{array}{l}20.7 \\
23.5\end{array}$ \\
\hline 0400 & 27.9 & $\begin{array}{l}24.3 \\
27.5\end{array}$ & 7.47 & 0 & $\begin{array}{l}-.20 \\
-.26\end{array}$ & 0.6 & $\begin{array}{l}19.1 \\
19.0\end{array}$ & $\begin{array}{l}21.6 \\
21.4\end{array}$ & 0.8 & $\begin{array}{l}19.2 \\
19.5\end{array}$ & $\begin{array}{l}22.5 \\
24.6\end{array}$ & $\begin{array}{l}0.8 \\
1.7\end{array}$ & $\begin{array}{l}16.8 \\
19.7\end{array}$ & $\begin{array}{l}20.8 \\
23.7\end{array}$ \\
\hline 0430 & 27.6 & $\begin{array}{l}24.4 \\
27.3\end{array}$ & ...- & 0 & $\begin{array}{l}-.20 \\
-.26\end{array}$ & 0.6 & $\begin{array}{l}21.3 \\
20.6\end{array}$ & $\begin{array}{l}22.9 \\
22.6\end{array}$ & 0.6 & $\begin{array}{l}18.9 \\
20.1\end{array}$ & $\begin{array}{l}22.8 \\
24.4\end{array}$ & $\begin{array}{l}0.8 \\
0.8\end{array}$ & $\begin{array}{l}17.3 \\
20.1\end{array}$ & $\begin{array}{l}21.8 \\
23.9\end{array}$ \\
\hline 0500 & 27.2 & $\begin{array}{l}23.8 \\
27.0\end{array}$ & 7.34 & 0 & $\begin{array}{l}-.21 \\
-.27\end{array}$ & 0.8 & $\begin{array}{l}21.8 \\
21.1\end{array}$ & $\begin{array}{l}22.6 \\
22.2\end{array}$ & 0.7 & $\begin{array}{l}17.7 \\
19.2\end{array}$ & $\begin{array}{l}21.5 \\
23.6\end{array}$ & $\begin{array}{l}1.1 \\
1.8\end{array}$ & $\begin{array}{l}16.5 \\
18.9\end{array}$ & $\begin{array}{l}21.2 \\
22.7\end{array}$ \\
\hline 0530 & 26.9 & $\begin{array}{l}23.6 \\
26.8\end{array}$ & $\ldots$ & 0 & $\begin{array}{l}-.21 \\
-.27\end{array}$ & 0.7 & $\begin{array}{l}21.0 \\
20.5\end{array}$ & $\begin{array}{l}21.9 \\
21.5\end{array}$ & 0.6 & $\begin{array}{l}17.1 \\
17.9\end{array}$ & $\begin{array}{l}21.1 \\
22.0\end{array}$ & $\begin{array}{l}0.9 \\
1.6\end{array}$ & $\begin{array}{l}15.9 \\
18.0\end{array}$ & $\begin{array}{l}20.9 \\
21.7\end{array}$ \\
\hline 0600 & 26.7 & $\begin{array}{l}23.4 \\
26.5\end{array}$ & 7.19 & 0 & $\begin{array}{l}-.20 \\
-.28\end{array}$ & 0.4 & $\begin{array}{l}19.9 \\
20.0\end{array}$ & $\begin{array}{l}21.2 \\
21.1\end{array}$ & 0.2 & $\begin{array}{l}16.9 \\
18.3\end{array}$ & $\begin{array}{l}21.1 \\
22.1\end{array}$ & $\begin{array}{l}0.2 \\
0.5\end{array}$ & $\begin{array}{l}15.5 \\
17.7\end{array}$ & $\begin{array}{l}20.1 \\
21.5\end{array}$ \\
\hline 0630 & 26.4 & $\begin{array}{l}23.4 \\
26.0\end{array}$ & -.... & 0 & $\begin{array}{l}-.21 \\
-.27\end{array}$ & 0.1 & $\begin{array}{l}18.8 \\
18.7\end{array}$ & $\begin{array}{l}20.6 \\
20.3\end{array}$ & 0.1 & $\begin{array}{l}17.2 \\
18.9\end{array}$ & $\begin{array}{l}20.7 \\
22.4\end{array}$ & $\begin{array}{l}0.2 \\
0.3\end{array}$ & $\begin{array}{l}15.4 \\
18.0\end{array}$ & $\begin{array}{l}19.3 \\
21.7\end{array}$ \\
\hline
\end{tabular}


EAST MESA 1 (1979) - WARM III (contd)

\begin{tabular}{|c|c|c|c|c|c|c|c|c|c|c|c|c|c|c|}
\hline 0700 & 26.2 & $\begin{array}{l}23.1 \\
25.5\end{array}$ & 7.03 & .03 & $\begin{array}{l}-.18 \\
-.25\end{array}$ & 0.2 & $\begin{array}{l}17.7 \\
17.4\end{array}$ & $\begin{array}{l}19.8 \\
19.7\end{array}$ & 0.3 & $\begin{array}{l}17.5 \\
19.0\end{array}$ & $\begin{array}{l}20.6 \\
23.2\end{array}$ & $\begin{array}{l}0.4 \\
0.8\end{array}$ & $\begin{array}{l}15.8 \\
18.0\end{array}$ & $\begin{array}{l}19.4 \\
21.3\end{array}$ \\
\hline 0730 & 26.0 & $\begin{array}{l}23.0 \\
25.5\end{array}$ & $\cdots--$ & .27 & $\begin{array}{l}-.01 \\
-.26\end{array}$ & 0.2 & $\begin{array}{l}18.9 \\
18.8\end{array}$ & $\begin{array}{l}21.0 \\
21.0\end{array}$ & 0.2 & $\begin{array}{l}17.8 \\
18.7\end{array}$ & $\begin{array}{l}21.2 \\
22.7\end{array}$ & $\begin{array}{l}0.3 \\
0.4\end{array}$ & $\begin{array}{l}16.3 \\
18.6\end{array}$ & $\begin{array}{l}20.5 \\
22.0\end{array}$ \\
\hline 0800 & 25.8 & $\begin{array}{l}23.0 \\
25.6\end{array}$ & 6.92 & .56 & $\begin{array}{r}.24 \\
-.16\end{array}$ & 0.6 & $\begin{array}{l}21.4 \\
21.0\end{array}$ & $\begin{array}{l}23.3 \\
23.2\end{array}$ & 0.5 & $\begin{array}{l}18.5 \\
18.6\end{array}$ & $\begin{array}{l}22.2 \\
22.6\end{array}$ & $\begin{array}{l}0.6 \\
0.6\end{array}$ & $\begin{array}{l}17.4 \\
19.6\end{array}$ & $\begin{array}{l}22.2 \\
22.9\end{array}$ \\
\hline 0830 & 25.7 & $\begin{array}{l}23.5 \\
25.8\end{array}$ & $\cdots$ & 1.06 & $\begin{array}{l}.70 \\
.12\end{array}$ & 0.5 & $\begin{array}{l}23.6 \\
23.0\end{array}$ & $\begin{array}{l}26.8 \\
26.5\end{array}$ & 0.3 & $\begin{array}{l}20.6 \\
19.7\end{array}$ & $\begin{array}{l}24.9 \\
24.3\end{array}$ & $\begin{array}{l}0.3 \\
0.2\end{array}$ & $\begin{array}{l}19.3 \\
22.0\end{array}$ & $\begin{array}{l}25.4 \\
25.7\end{array}$ \\
\hline
\end{tabular}


APPENDIX D

EAST MESA 2 (1981) - EXPERIMENTS $1-6$ 


\section{EAST MESA 2 (1981) - EXPERIMENT 1}

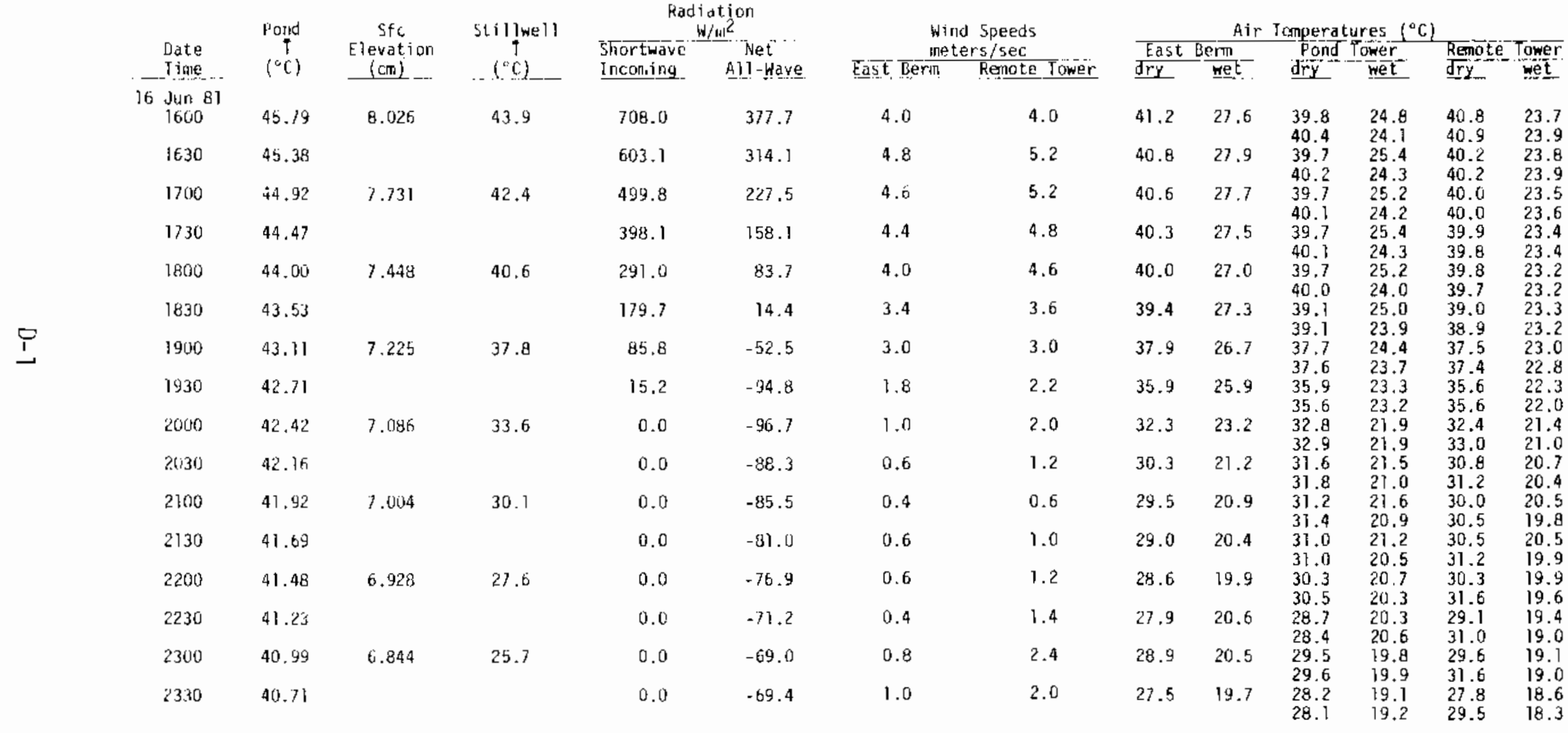




\section{EAST MESA 2 (1981) - EXPERIMENT 1 (contd)}

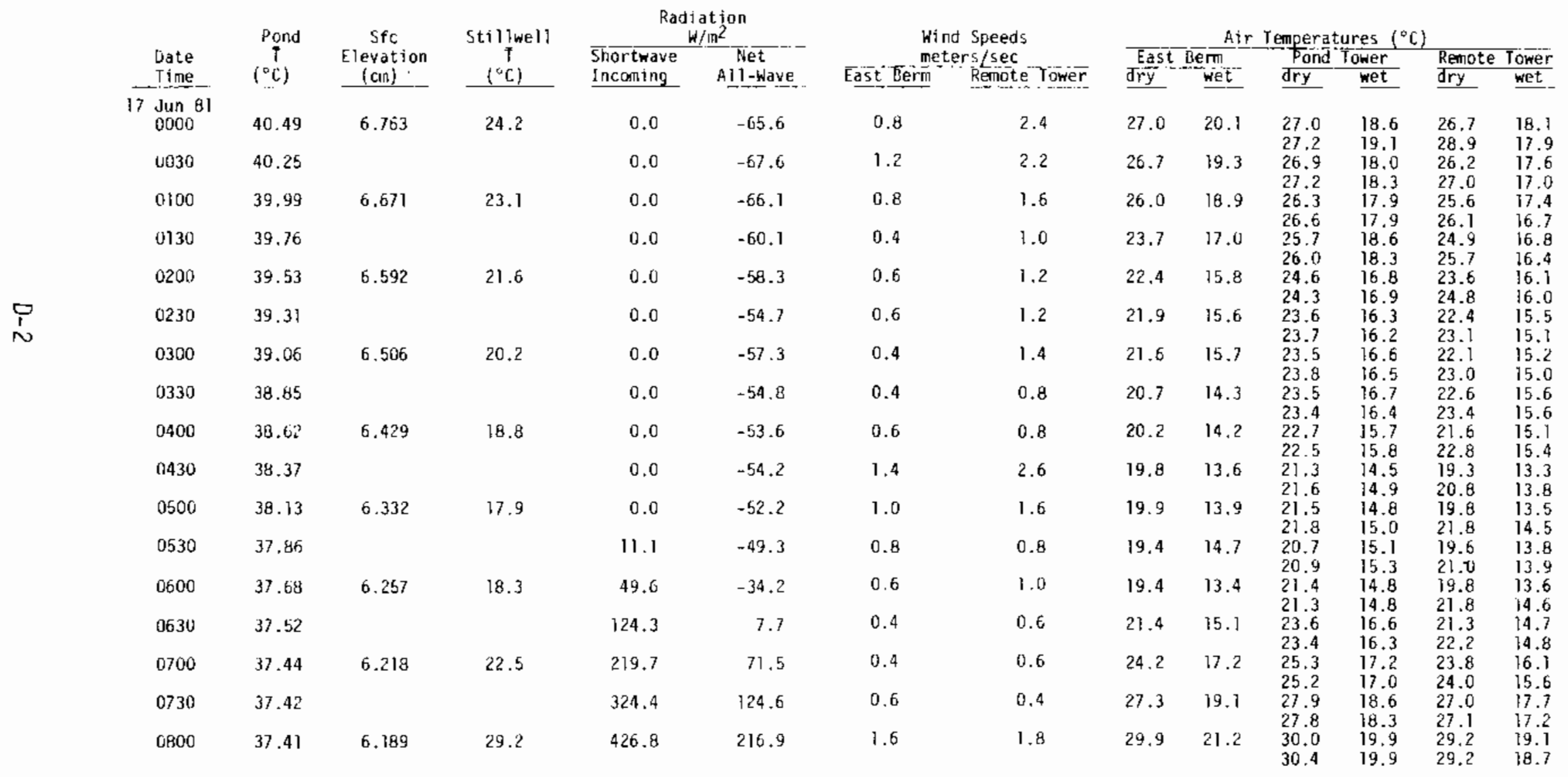




\section{EAST MESA 2 (1981) - EXPERIMENT 1 (contd)}

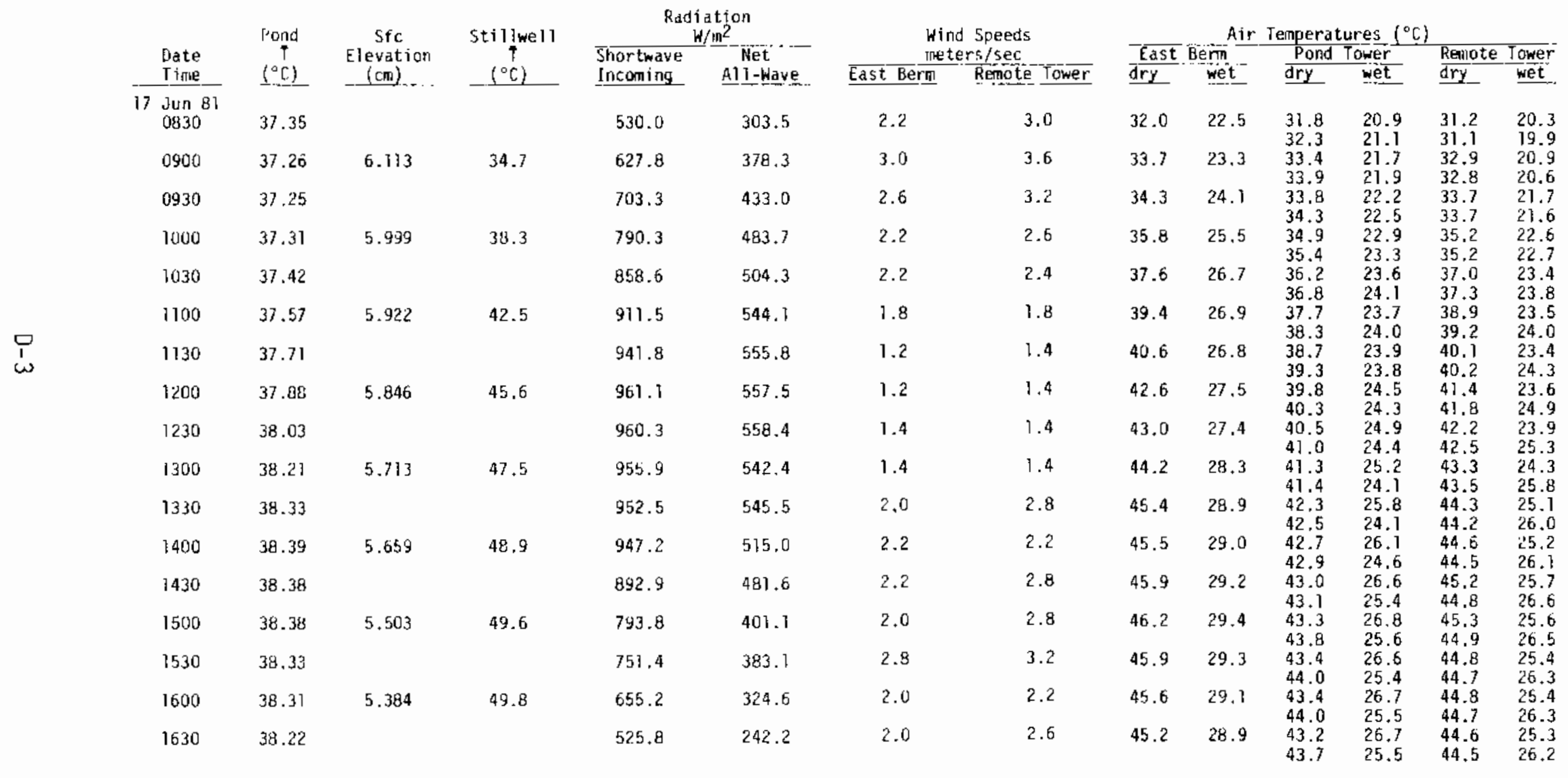


EAST MESA 2 (1981) - EXPERIMENT 1 (contd)

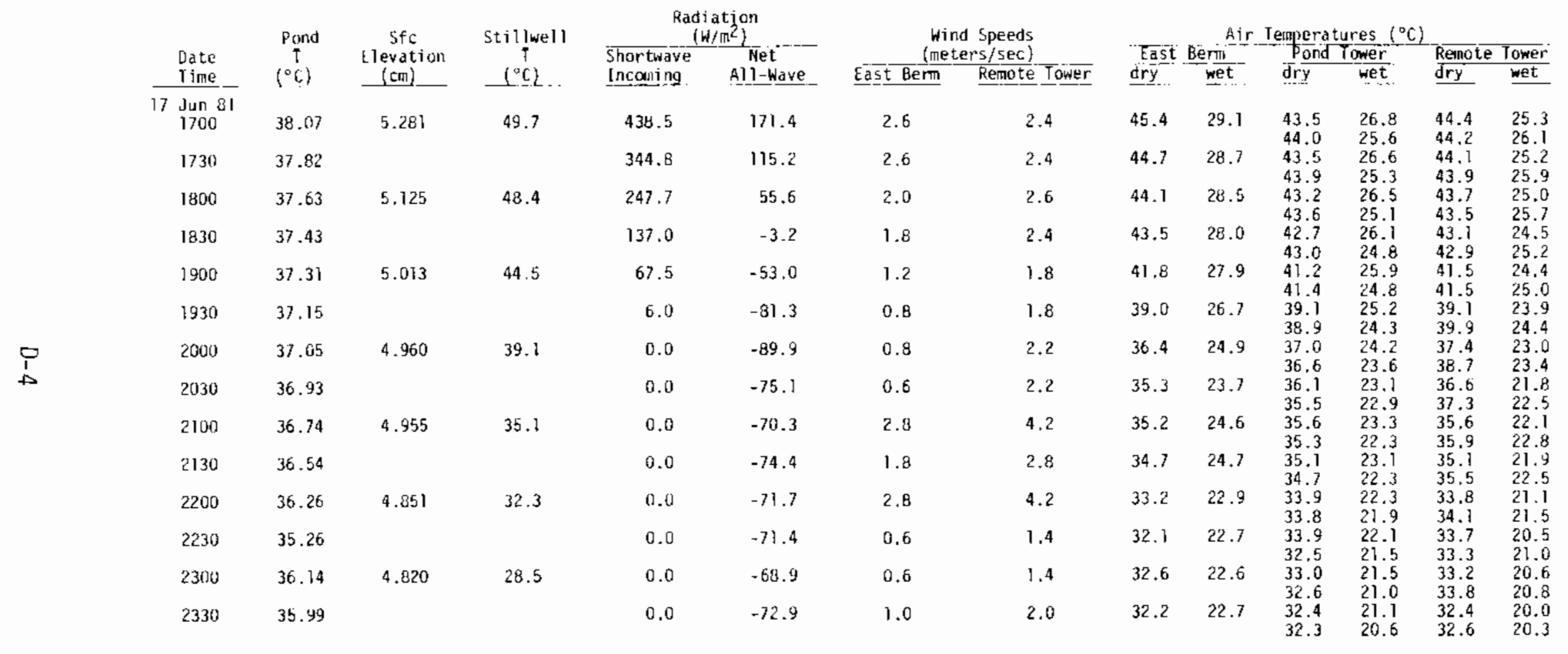




\section{EAST MESA 2 (1981) - EXPERIMENT 1 (contd)}

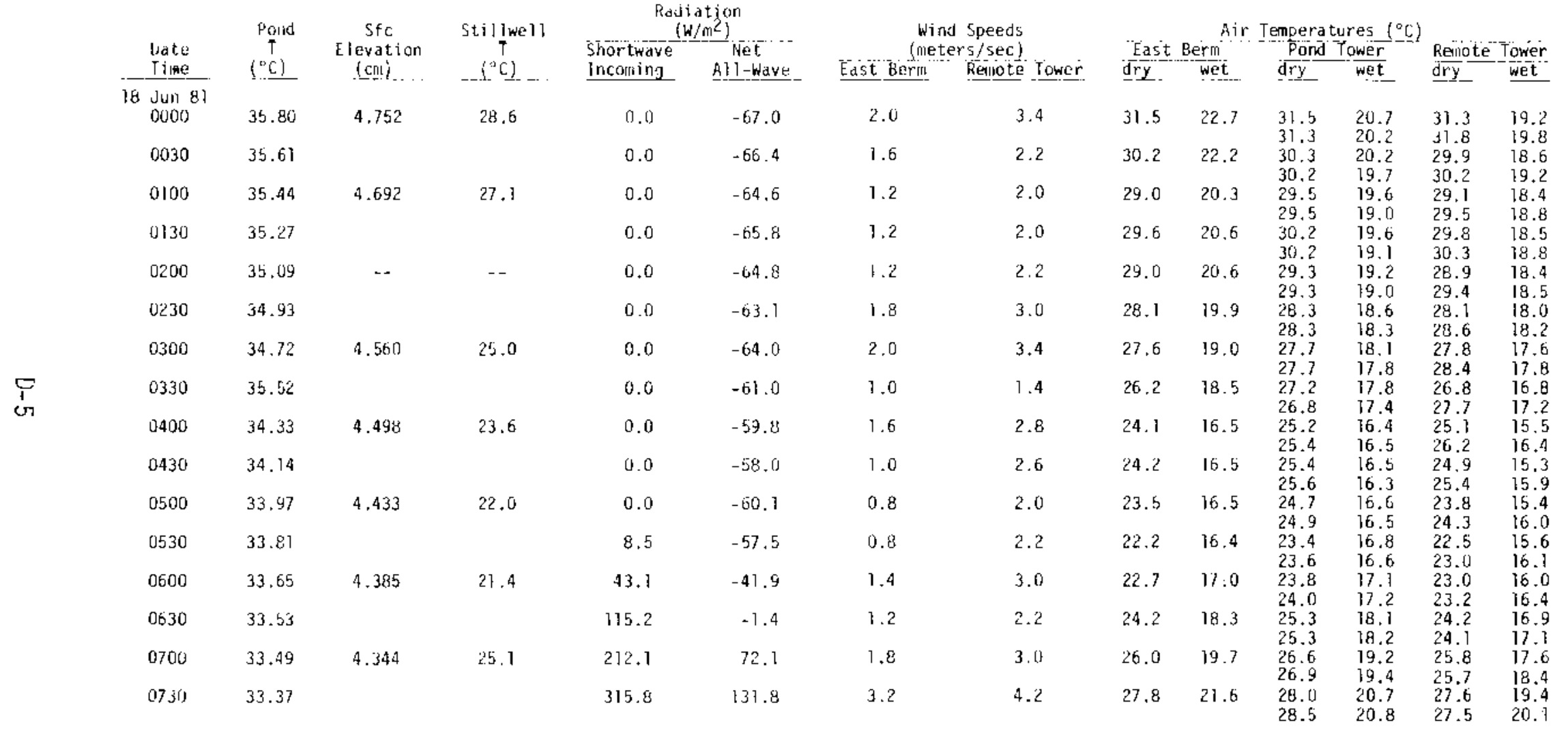


EAST MESA 2 (1981) - EXPERIMENT 1 (contd)

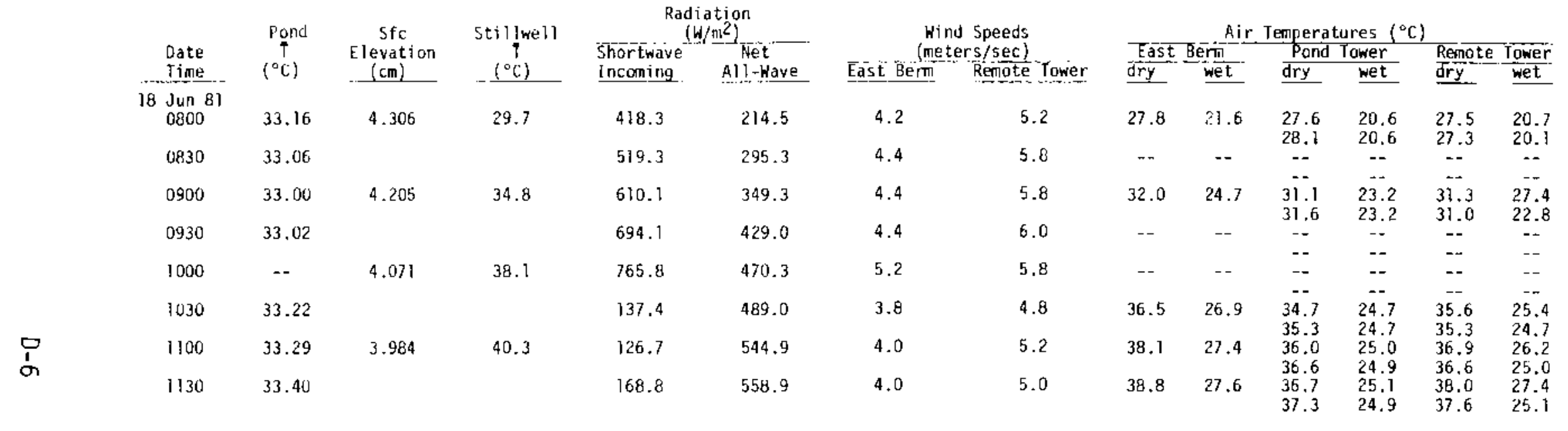


EAST MESA 2 (1981) - EXPERIMENT 2

\begin{tabular}{|c|c|c|c|c|c|c|c|c|c|c|c|c|c|c|}
\hline & & & Stc & Stillwe11 & & ation & & Speeds & & Air & emper & ures 1 & & \\
\hline & Date & 7 & Elevation & 1 & Shortwave & Net & & $\mathrm{rs} / \mathrm{sec})$ & East & Ber|ly & Fond & Tower & Remote & Tower \\
\hline & Time & $106)$ & (cm) & $\left({ }^{\circ} \mathrm{C}\right)$ & Incurring & All-Wave & East Berm & Reriote Tower & dry & wet & $d r y$ & wet & dry & wet \\
\hline & 20 Jun 81 & & & & & & & & & & & & & \\
\hline & 1500 & -- & 3.019 & 47.3 & 812.8 & 451.1 & 2.8 & 3.0 & -- & $\cdots$ & -- & -- & + & - \\
\hline & 1530 & 45.92 & & & 729.7 & 406.6 & 2.4 & 2.8 & 42.7 & 28.9 & 43.3 & 31.7 & -- & -- \\
\hline & 1600 & 46.38 & 7.828 & 48.4 & 669.4 & 390.8 & 1.4 & 2.2 & 44.9 & 29.9 & $\begin{array}{l}43.4 \\
46.1\end{array}$ & 34.0 & -- & $\begin{array}{l}-- \\
--\end{array}$ \\
\hline & & & & & & & & & & & 46.0 & 33.5 & -- & -- \\
\hline & 1630 & 46.13 & & & 550.0 & 245.7 & 1.6 & 1.6 & 44.3 & 29.8 & 46.0 & -- & 44.2 & 28.4 \\
\hline & 1700 & 45.74 & 7.689 & 48.9 & 454.7 & 133.8 & 2.4 & 2.8 & 44.8 & 30.0 & 46.0 & - & 44.3 & 28.5 \\
\hline & 1730 & 45.39 & & & 350.4 & 131.6 & 2.2 & 2.6 & 44.5 & 30,0 & $\begin{array}{l}40.9 \\
45.8\end{array}$ & $\begin{array}{c}33.0 \\
-.\end{array}$ & $\begin{array}{l}44.1 \\
44.2\end{array}$ & $\begin{array}{l}27.4 \\
28.4\end{array}$ \\
\hline & & & & & & & & & & & 45.8 & 33.0 & 44.0 & 27.3 \\
\hline & 1800 & 44.96 & 7.495 & 48.2 & 252.3 & 89.2 & 2.6 & 3.6 & 44.3 & 29.5 & $\begin{array}{l}45.2 \\
45.2\end{array}$ & 32 & $\begin{array}{l}43.8 \\
43.5\end{array}$ & 28.2 \\
\hline & 1830 & 44.96 & & & 151.3 & 31.8 & 3.2 & 4.4 & 43.6 & 29.2 & 44.4 & $-\ldots$ & 43.2 & 28.0 \\
\hline & 1900 & 43.90 & 7.243 & 44.8 & 72.1 & -30.0 & 4.0 & 5.6 & 42.2 & 29.0 & $\begin{array}{l}44.4 \\
42.8\end{array}$ & $\begin{array}{l}31.8 \\
\ldots\end{array}$ & $\begin{array}{l}42.9 \\
41.9\end{array}$ & $\begin{array}{l}26.7 \\
28.0\end{array}$ \\
\hline & & & & & & & & & & & 42.8 & 31.1 & 41.7 & 26.7 \\
\hline & 1930 & 43.39 & & & 13.8 & -63.9 & 3.4 & 4.6 & 40.0 & 28.3 & 40.5 & -- & 39.8 & 27.5 \\
\hline & 2000 & 42,94 & 6.987 & 39.9 & 0.0 & -85.7 & 2.4 & 3.2 & 38.0 & 27.3 & $\begin{array}{l}40.4 \\
38.4\end{array}$ & $\begin{array}{l}29.7 \\
--\end{array}$ & $\begin{array}{l}39.7 \\
37.9\end{array}$ & $\begin{array}{l}26.1 \\
26.3\end{array}$ \\
\hline & & & & & & & & & & & 38.2 & 28.0 & 37.9 & 24.9 \\
\hline & 2030 & 42.66 & & & 0.0 & -63.7 & 1.6 & 2.4 & 35.7 & 26.7 & 35.6 & $\approx 0$ & 35.5 & 25.7 \\
\hline & 2100 & 42,37 & 6.887 & 35.9 & 0.0 & -67.3 & 1.4 & 2.2 & 34.3 & 26.5 & 34.0 & 2 & 34.3 & 25.2 \\
\hline & & & & & & & & & & & 33.8 & 26.1 & 34.6 & 24.0 \\
\hline & 2130 & 42,11 & & & 0.0 & -68.6 & 1.6 & $? .2$ & 34.7 & 26.2 & 33.8 & 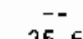 & 34.4 & 24.9 \\
\hline & 2200 & 41.84 & 6.814 & 33.2 & 0.0 & -71.4 & 1.4 & $2 . ?$ & 34.2 & 25.2 & 33.9 & - & 34.0 & 24.2 \\
\hline & & & & & & & & & & & 33.9 & 25.5 & 34.2 & 22.8 \\
\hline & 2230 & 41.59 & & & 0.0 & -71.7 & 1.4 & 2.6 & 32.5 & 24.2 & 32.8 & -- & 32.3 & 23.6 \\
\hline & 2300 & 41.35 & 6.728 & 31.1 & 0.0 & -56.3 & 1.0 & 2.0 & 31.9 & 24.2 & 31.7 & $\begin{array}{c}24.6 \\
--\end{array}$ & $\begin{array}{l}32.7 \\
31.7\end{array}$ & $\begin{array}{l}22.2 \\
23.1\end{array}$ \\
\hline & $\because$ & 4) 39 & & & 0 & 55.0 & 12 & 20 & 314 & 239 & 31.5 & 24.2 & 32.0 & 21.7 \\
\hline & 2330 & 41.49 & & & 0.0 & -35.9 & 1.5 & 2.0 & $3 ! .4$ & 23,9 & 30.8 & 23.6 & 31.3 & 21.3 \\
\hline
\end{tabular}


EAST MESA 2 (1981) - EXPERIMENT 2 (contd)

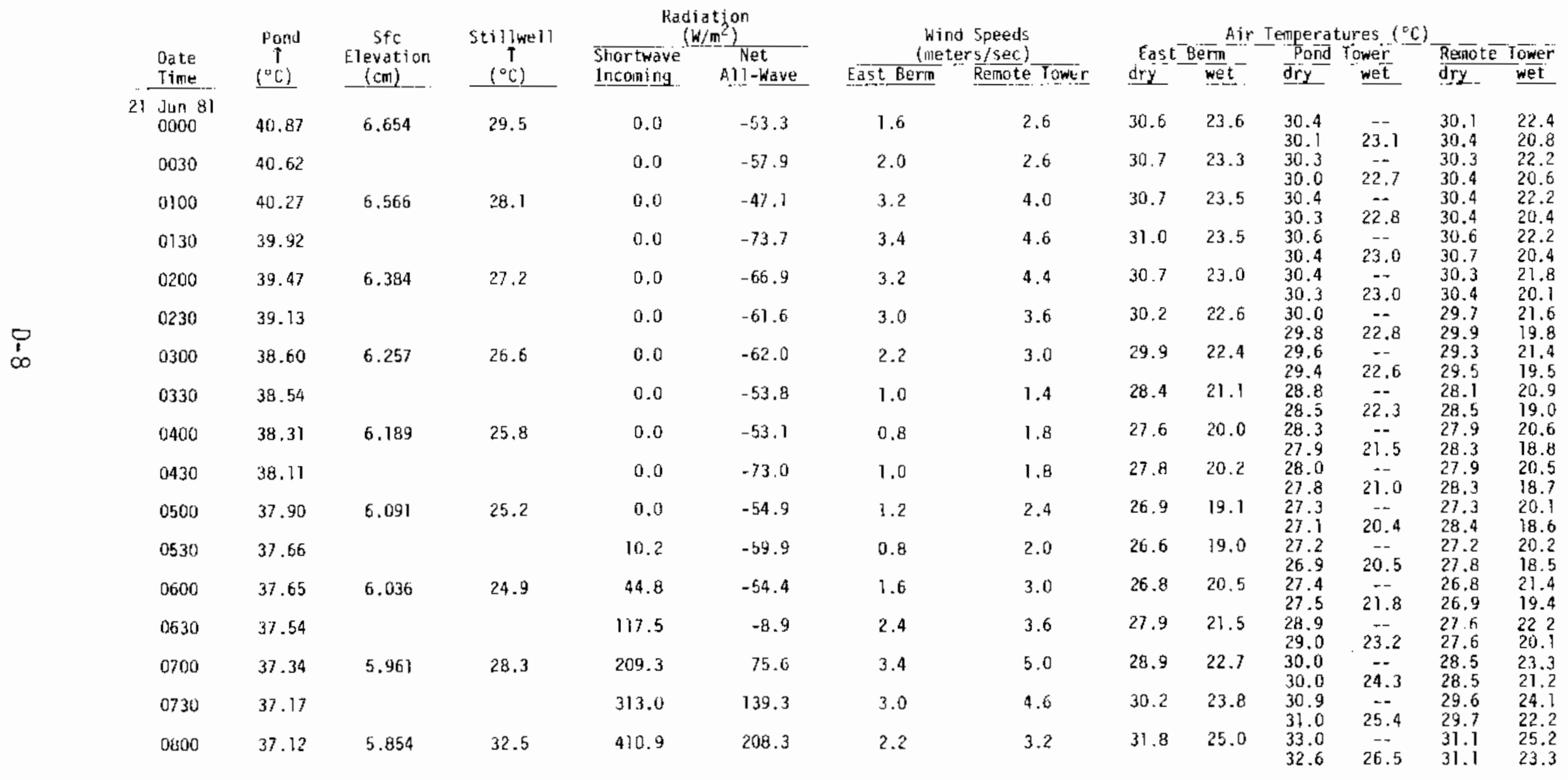


EAST MESA 2 (1981) - EXPERIMENT 2 (contd)

\begin{tabular}{|c|c|c|c|c|c|c|c|c|c|c|c|c|c|c|}
\hline & & & Sfo & Stillwell & & $\begin{array}{l}\text { tion } \\
\left.\mathrm{m}^{2}\right)\end{array}$ & & Speeds & & Air & empera & ires $1^{\circ}$ & & \\
\hline & Date & $\begin{array}{c}T \\
\end{array}$ & Elevation & & Shortwave & Met & lime & $\mathrm{rs} / \mathrm{sec}\}$ & tast & Berm & Pond & ower & Remote & Tower \\
\hline & & & & & & & East Bertm & & & & dry. & wet & & wet \\
\hline & $21 \operatorname{Jun}_{0830} 81$ & 37.11 & & & 511.4 & 326.9 & 2.6 & 3.4 & 33.3 & 26.2 & 34.2 & -- & 32.5 & 26.2 \\
\hline & 0900 & 37.12 & 5.772 & 36.9 & 602.1 & 378.6 & 2.8 & 3.6 & 34.8 & 27.1 & 35.7 & -8 & 33.9 & $\begin{array}{l}24.5 \\
26.8\end{array}$ \\
\hline & 0930 & 37.16 & & & 680.6 & 408.8 & 2.6 & 3.4 & 36.4 & 27.5 & $\begin{array}{l}53.1 \\
36.6 \\
36.4\end{array}$ & $\begin{array}{l}9.0 \\
29.6\end{array}$ & $\begin{array}{l}34.0 \\
35.5 \\
35.4\end{array}$ & $\begin{array}{l}27.1 \\
25.6\end{array}$ \\
\hline & 1000 & 37.41 & 5.701 & 40.6 & 759.2 & 480.7 & 2.6 & 3.2 & 38.1 & 28.0 & 36.7 & -- & 37.2 & 24.9 \\
\hline & 1030 & 37.45 & & & 825.7 & 474.8 & 2,4 & 2.8 & 38.9 & 28.2 & 37.1 & 30.3 & 38.0 & $\begin{array}{l}23.9 \\
25.3\end{array}$ \\
\hline & 1100 & 37.61 & $5.60^{2}$ & 43.2 & 873.8 & 511.2 & 2.4 & 3.4 & 40.1 & 28.6 & $\begin{array}{l}37.4 \\
38.1\end{array}$ & $\begin{array}{l}31.1 \\
-.\end{array}$ & $\begin{array}{l}37.8 \\
38.9\end{array}$ & $\begin{array}{l}26.0 \\
24.7\end{array}$ \\
\hline & & & & & & & & & & & 38.2 & 31.7 & 38.8 & 26.2 \\
\hline & 1130 & 37.70 & & & 920.2 & 552.8 & 2.4 & 3.4 & 40.5 & 28.8 & 38.4 & $\vec{a} a$ & 39.4 & 24.8 \\
\hline & 1200 & 37.85 & 5.477 & 44.6 & 940.9 & 553.4 & 2.0 & 2.8 & 41.3 & 29.0 & 39.1 & -- & 39.9 & 25.0 \\
\hline & 1230 & 37.99 & & & 934.3 & 571.6 & 2.4 & 2.8 & 42.0 & 29.1 & $\begin{array}{l}39.1 \\
39.7\end{array}$ & $\begin{array}{l}32.2 \\
--\end{array}$ & $\begin{array}{l}40.2 \\
40.9\end{array}$ & $\begin{array}{l}20.7 \\
25.8\end{array}$ \\
\hline & 1300 & 38.15 & 5.386 & 45.5 & 919.7 & 548.5 & 2.6 & 3.2 & 42.2 & 29.5 & $\begin{array}{l}39.6 \\
40.4\end{array}$ & $\begin{array}{c}32.2 \\
--\end{array}$ & $\begin{array}{l}41.1 \\
41.5\end{array}$ & $\begin{array}{r}27.0 \\
26.4\end{array}$ \\
\hline & 1330 & 38.11 & & & 0433 & 5604 & 2.4 & 38 & 430 & 300 & 40.4 & $33 . !$ & 41.5 & 27.3 \\
\hline & & & & & & & & & & & 41.4 & 33.9 & 42.0 & 27.5 \\
\hline & 1400 & 38.06 & 5.223 & 46.4 & 924.2 & 533.6 & 2.6 & 3.0 & 43.5 & 30.2 & 41.7 & 31.1 & 42.6 & 27.7 \\
\hline & 1430 & 38,15 & & & 881.0 & 480.3 & 2.0 & 2.4 & 43.2 & 30.1 & 41.7 & $\begin{array}{l}34.0 \\
31.4\end{array}$ & $\begin{array}{l}42.4 \\
42.9\end{array}$ & 27.9 \\
\hline & 1500 & 38.20 & 5.110 & 47.9 & 791.6 & 377.3 & 1.8 & 2.2 & 43.8 & 30.3 & $\begin{array}{l}42.4 \\
42.2\end{array}$ & $\begin{array}{l}35.0 \\
32.1\end{array}$ & $\begin{array}{l}42.7 \\
43.4\end{array}$ & $\begin{array}{l}27.8 \\
28.1\end{array}$ \\
\hline & & & & & & & & & & & 42.5 & 35.6 & 43.2 & 28.1 \\
\hline & 1530 & 38.24 & & & 750.45 & 365.6 & 2.4 & 2.6 & 43.6 & 30.2 & 42.5 & 32.3 & 43.5 & 28.2 \\
\hline & 1600 & 38.25 & 5.025 & 49.0 & 667.8 & 312,2 & 3.0 & 3.8 & 44.4 & 30.9 & 43.8 & 30.8 & $\begin{array}{l}43.4 \\
43.6\end{array}$ & 28.9 \\
\hline & 1530 & 38.14 & & & $58 \div 4$ & 294.2 & 3.6 & 4.6 & 44.1 & 30.9 & $\begin{array}{l}43.3 \\
42.9\end{array}$ & -- & $\begin{array}{l}43.4 \\
43.5\end{array}$ & 28.6 \\
\hline & & & & & & & & & & & 43.4 & $=$ & 43.2 & 28.6 \\
\hline
\end{tabular}


EAST MESA 2 (1981) - EXPERIMENT 2 (conto)

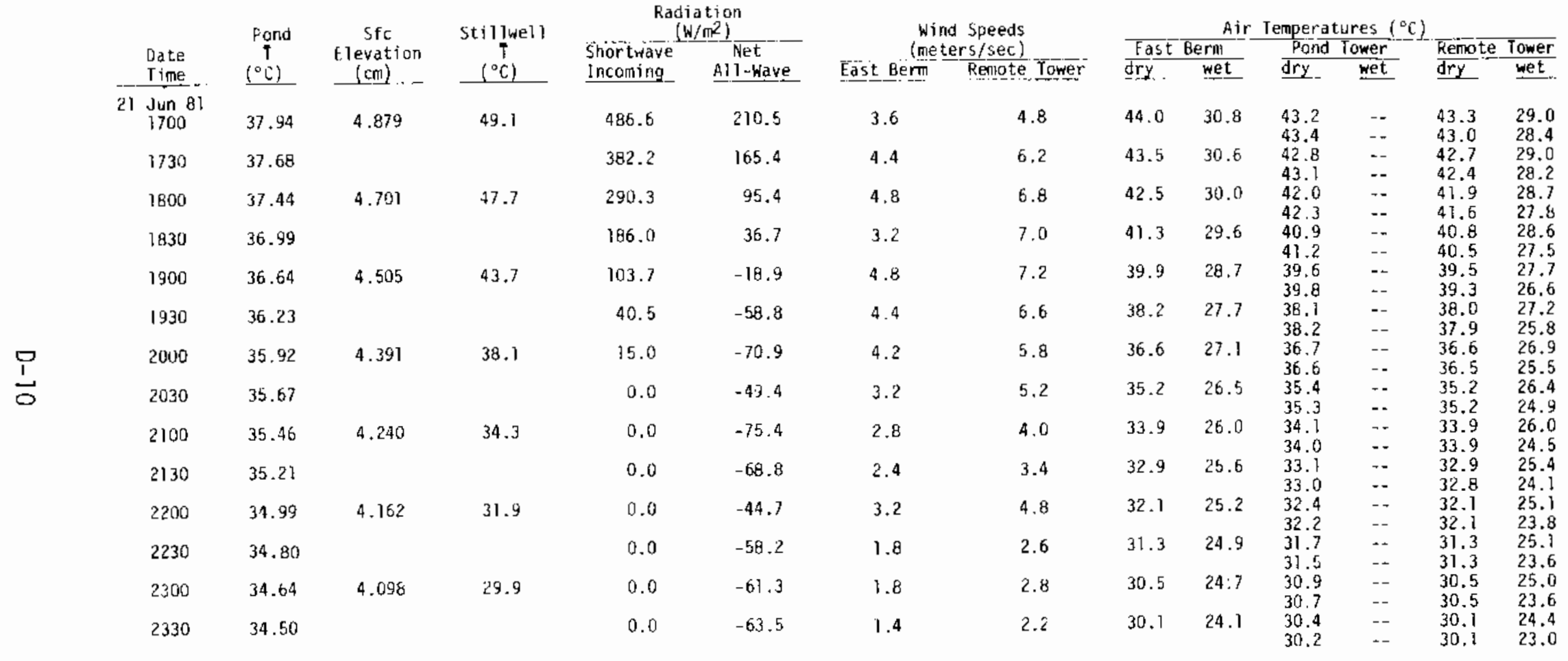


EAST MESA 2 (1981) - EXPERIMENT 2 (contd)

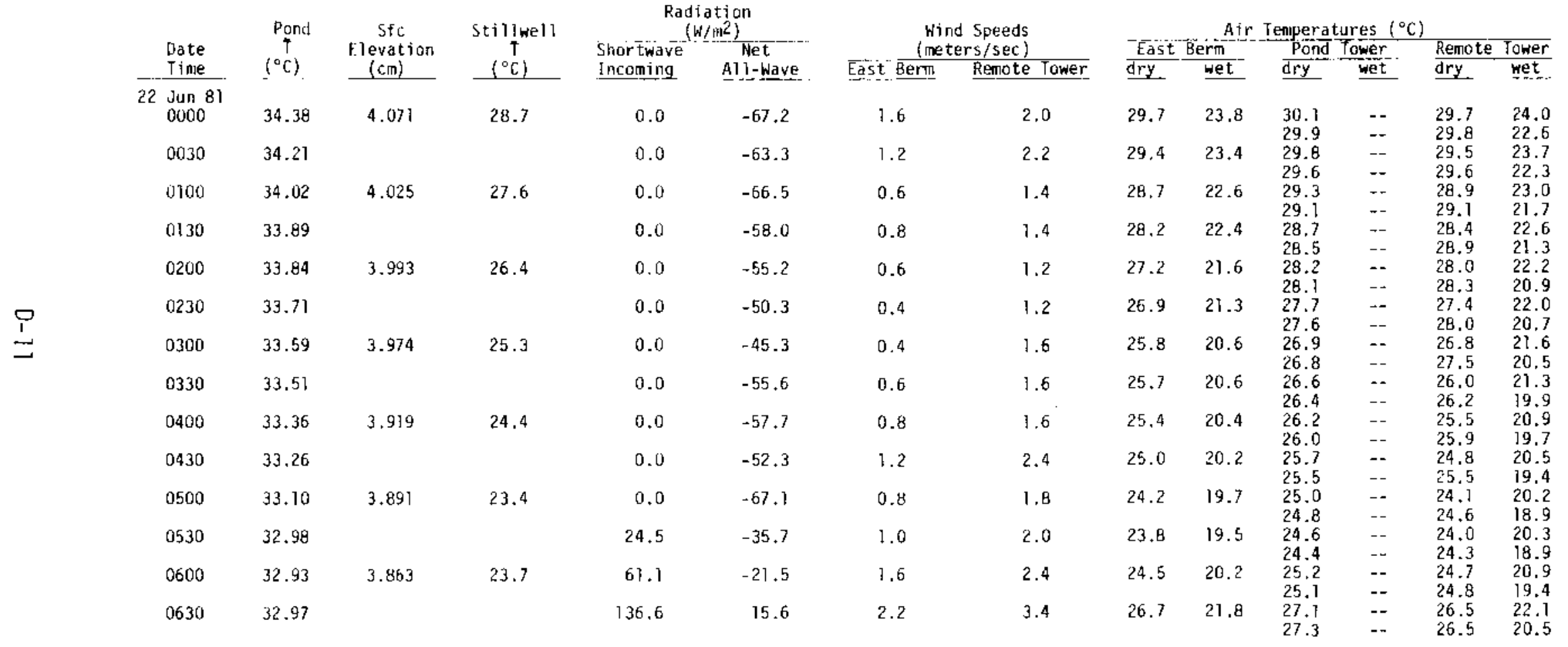




\section{EAST MESA 2 (1981) - EXPERIMENT 2 (contd)}

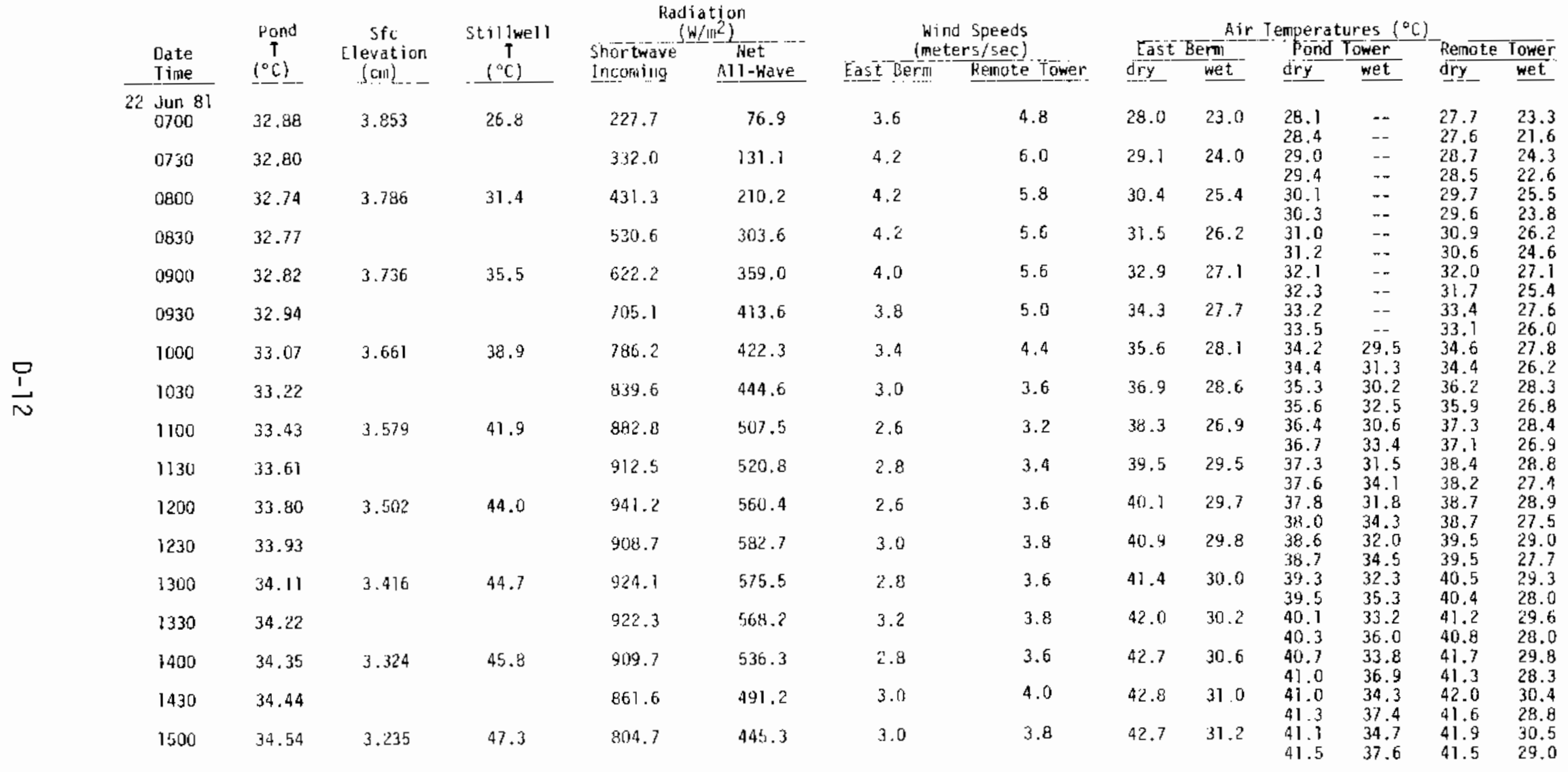




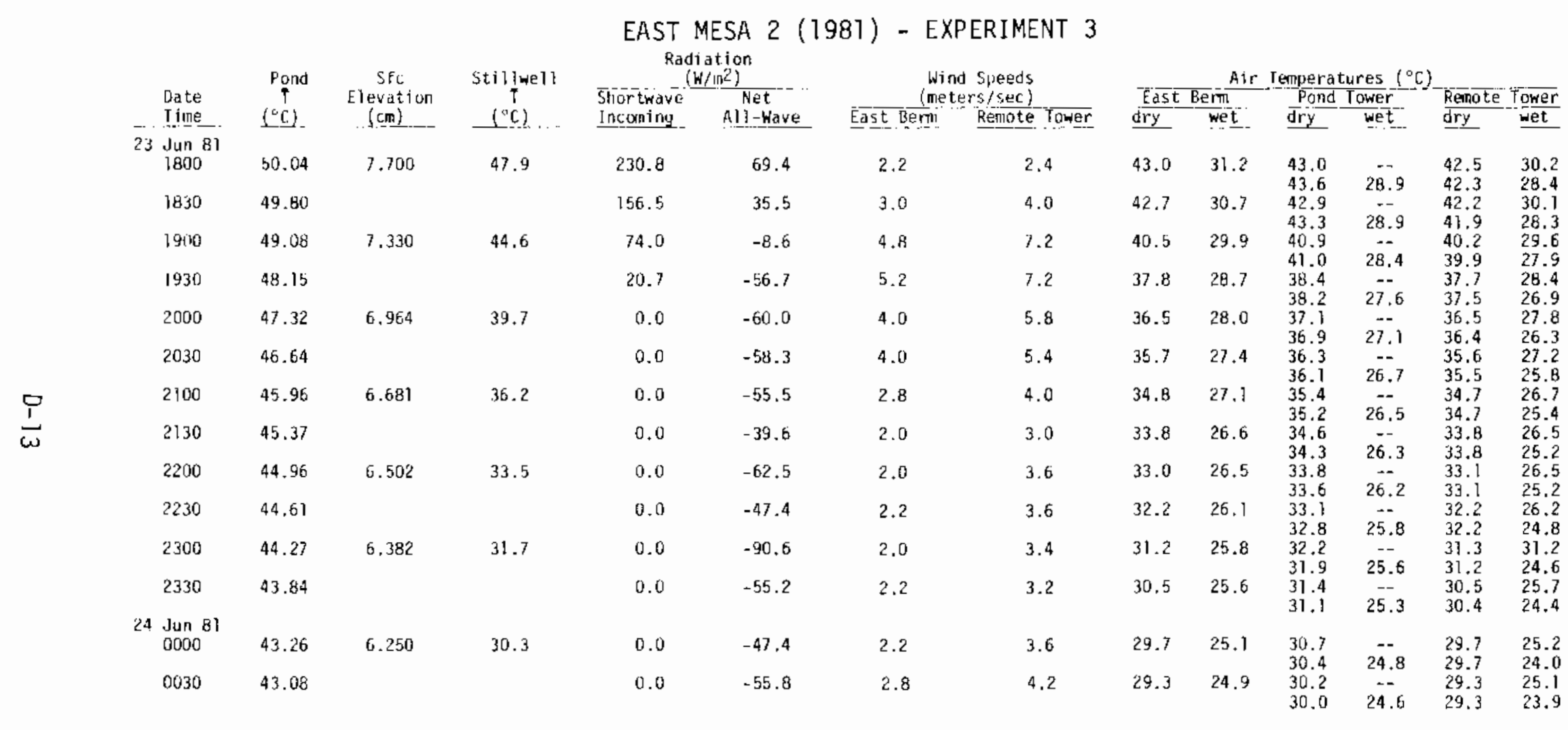


EAST MESA 2 (1981) - EXPERIMENT 3 (contd)

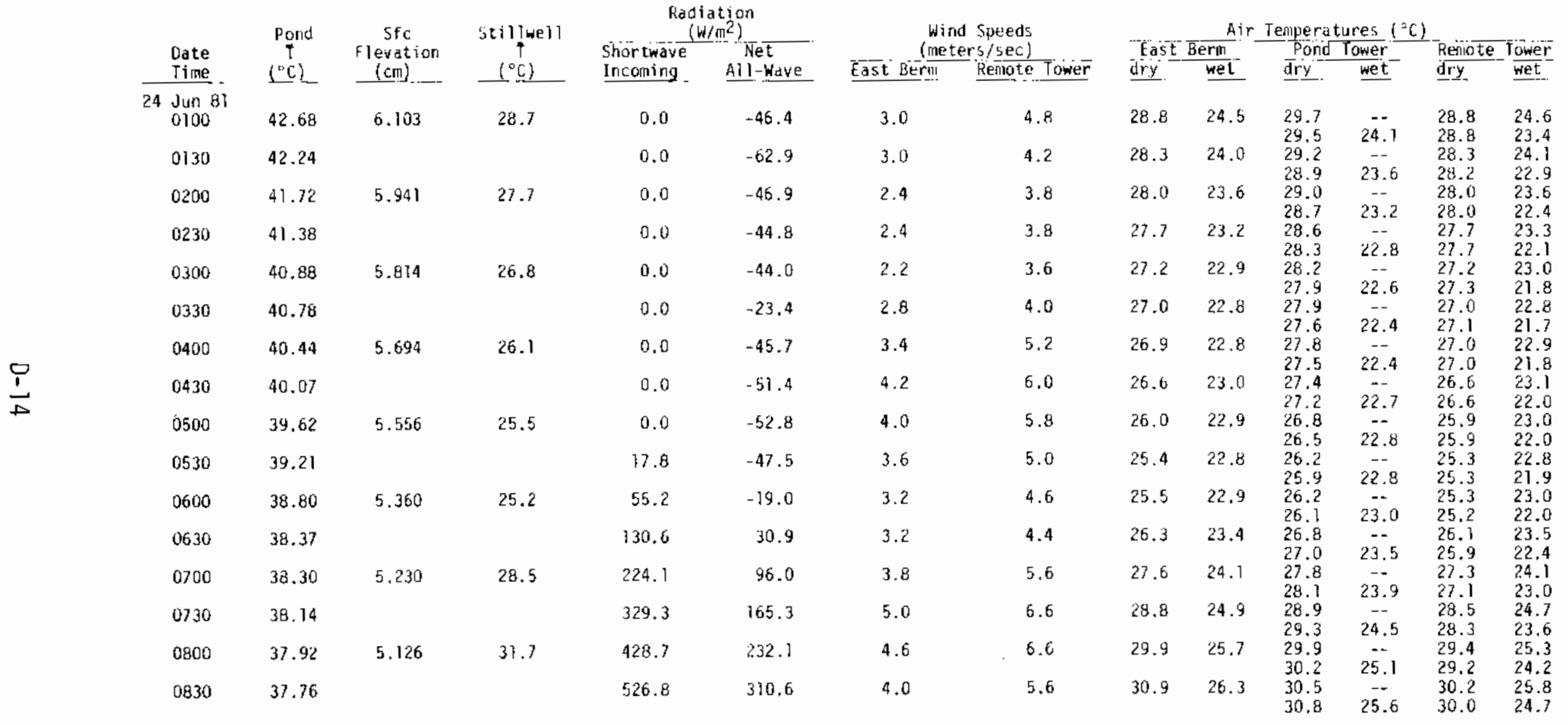


EAST MESA 2 (1981) - EXPERIMENT 3 (contd)

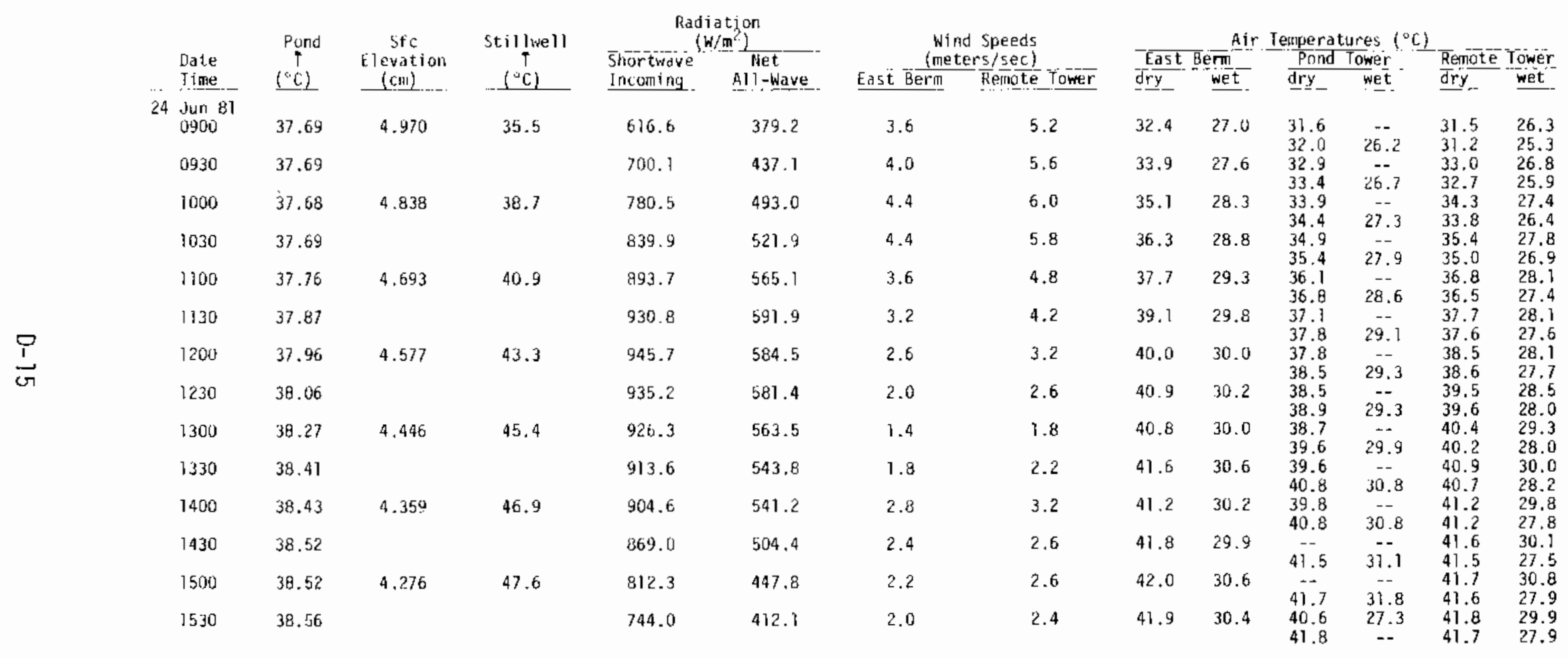




\section{EAST MESA 2 (1981) - EXPERIMENT 3 (contd)}

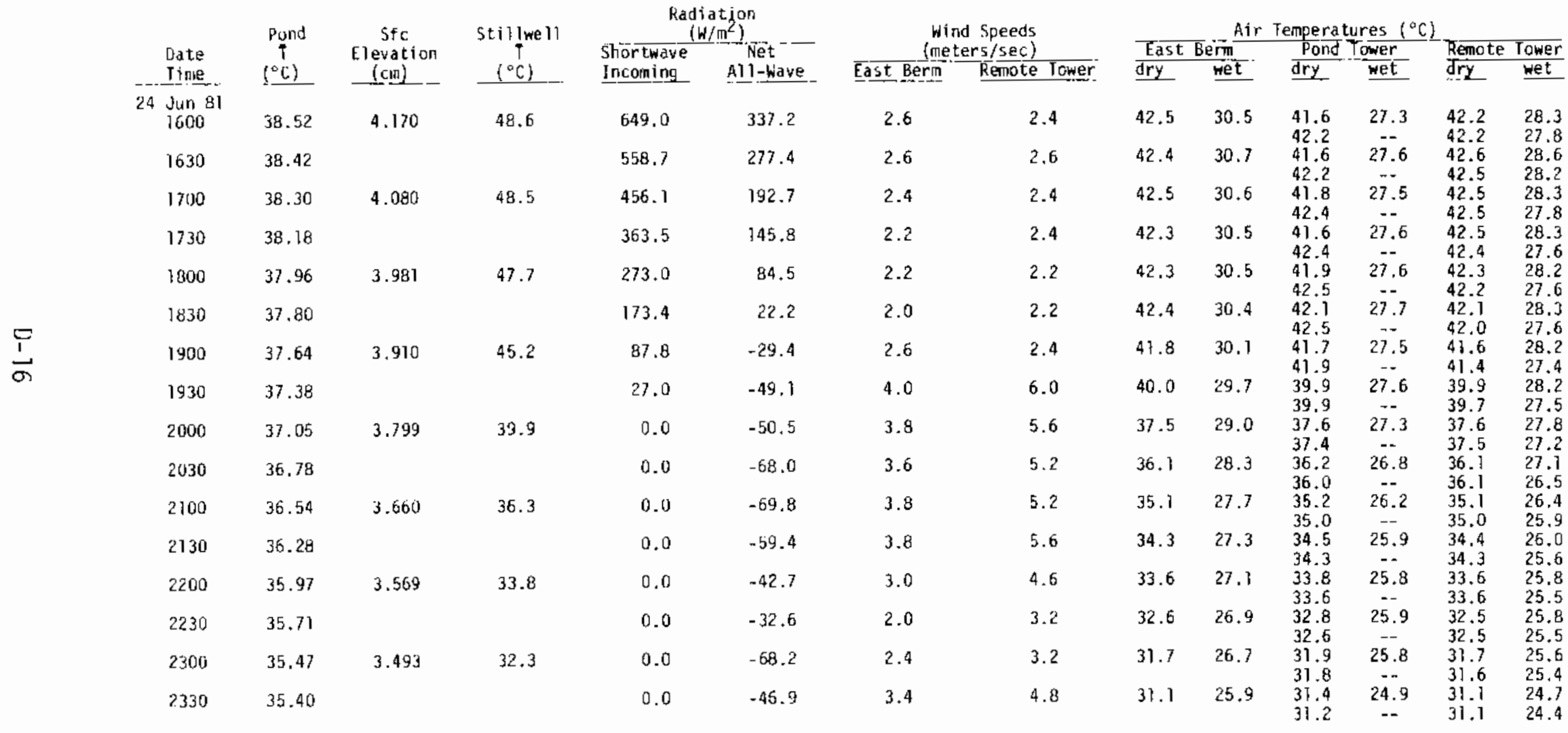


EAST MESA 2 (1981) - EXPERIMENT 3 (contd)

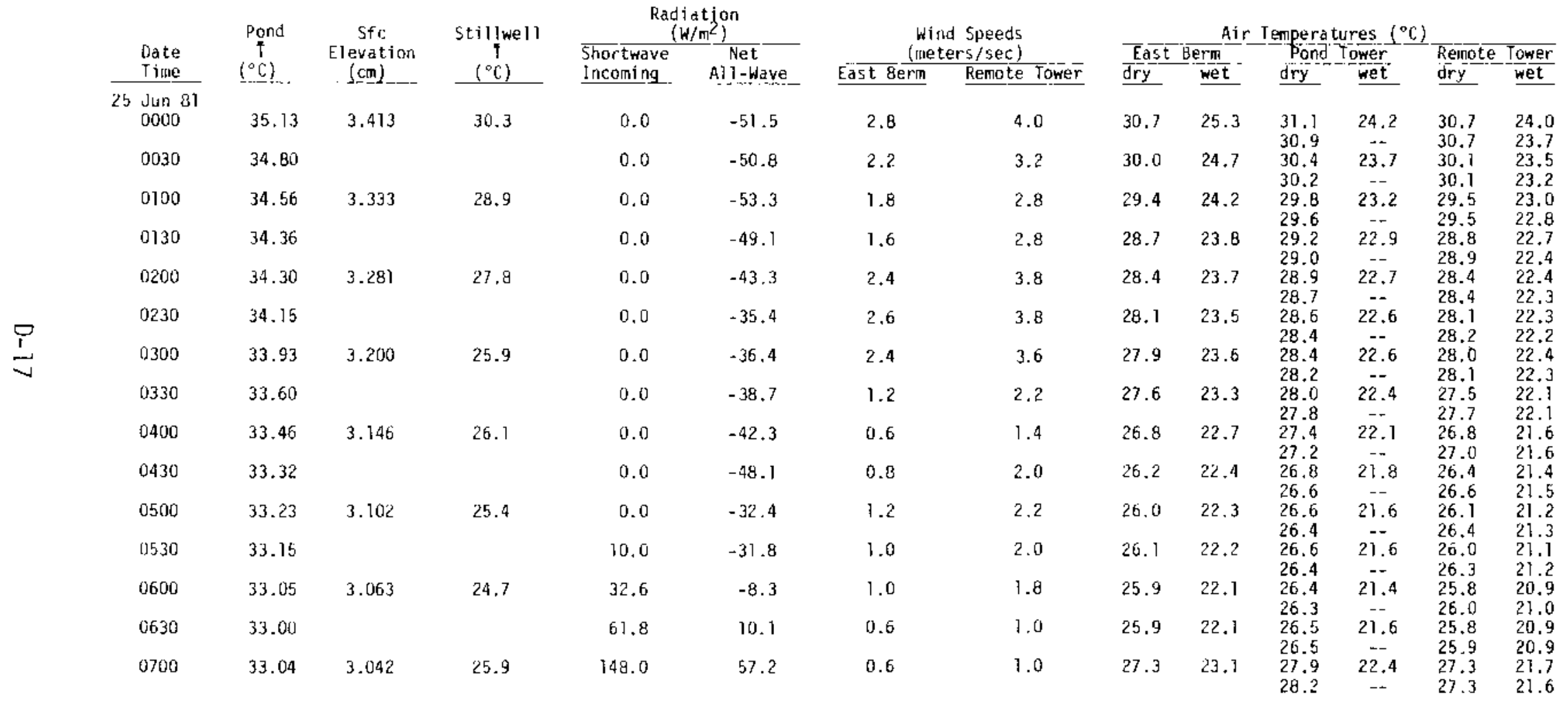


EAST MESA 2 (1981) - EXPERIMENT 3 (contd)

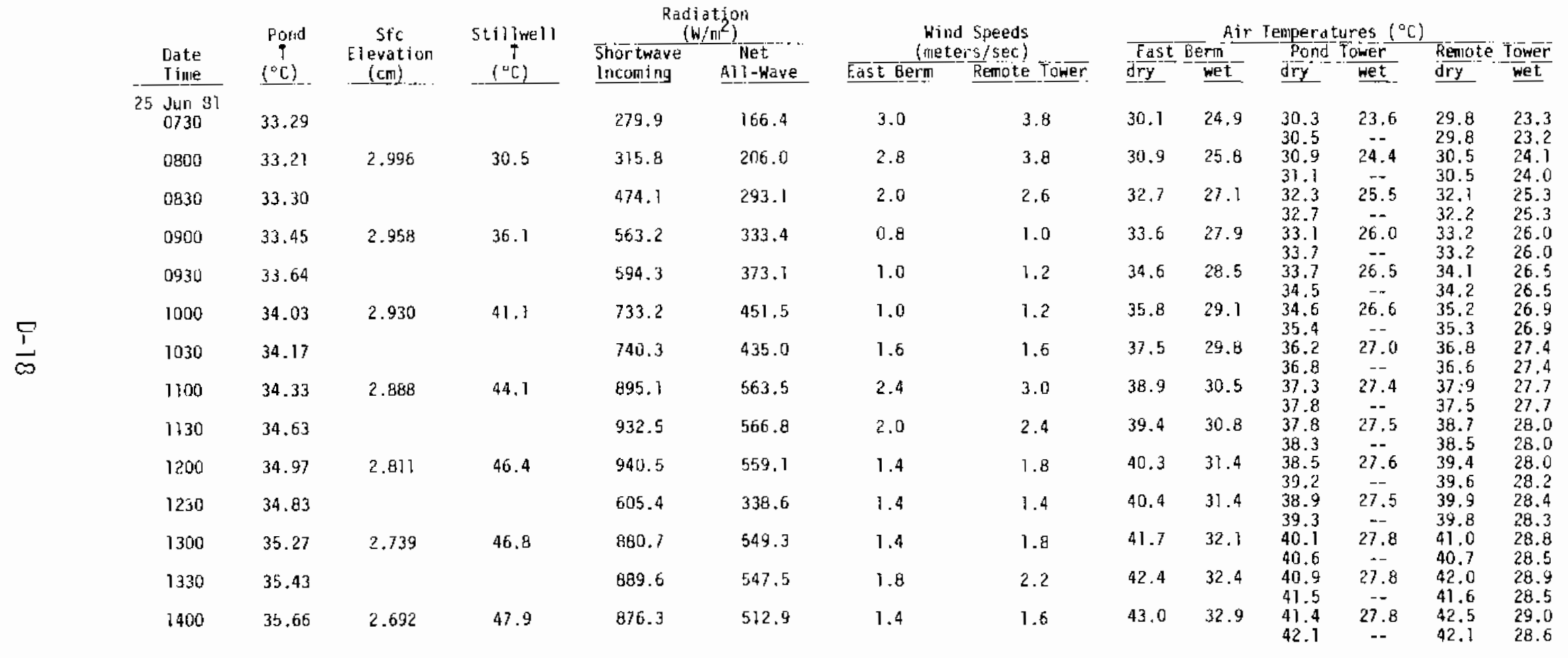


EAST MESA 2 (1981) - EXPERIMENT 3 (contd)

\begin{tabular}{|c|c|c|c|c|c|c|c|c|c|c|c|c|c|c|}
\hline \multirow{3}{*}{\multicolumn{2}{|c|}{$\begin{array}{l}\text { Date } \\
\text { Time }\end{array}$}} & \multirow{3}{*}{$\begin{array}{c}\text { Pond } \\
7 \\
\left({ }^{\circ} \mathrm{C}\right)\end{array}$} & \multirow{3}{*}{$\begin{array}{c}\text { sfc } \\
\text { Elevation } \\
\text { (cmil) }\end{array}$} & \multirow{3}{*}{ stillwell } & \multicolumn{2}{|c|}{$\begin{array}{c}\text { Radiation } \\
\left(W / \mathrm{n}^{2}\right)\end{array}$} & \multicolumn{2}{|c|}{ Wind Speeds } & \multicolumn{6}{|c|}{ Air Temperatures $\left({ }^{\circ} \mathrm{C}\right)$} \\
\hline & & & & & shortwave & Net & & $\mathrm{rs} / \mathrm{sec}$ ) & East & Berm & Pond & tower. & kemute & Tower \\
\hline & & & & & Incoming. & Alt-Wave & East Berni & Remote Tower & $d r y$ & wet & $d r y$ & wet & dry & wet \\
\hline 25 & Jun 81 & 35.30 & & & & & & & & & & & & \\
\hline & & 35.80 & & & 340.2 & 468.8 & 1.6 & 2.0 & 43.5 & 33.1 & $\begin{array}{l}41.9 \\
42.7\end{array}$ & $\begin{array}{c}27.8 \\
\ldots .\end{array}$ & $\begin{array}{l}42.9 \\
42.7\end{array}$ & $\begin{array}{l}28.9 \\
28.4\end{array}$ \\
\hline & 1500 & 35.85 & 2.618 & 49.5 & 783.2 & 403.8 & 1.8 & 1.8 & 43.7 & 33.0 & 42.6 & 27.8 & 43.6 & 29.0 \\
\hline & 1530 & 35.79 & & & 700.5 & 334.5 & 2.2 & 2.4 & 44.7 & 33.4 & $\begin{array}{l}43.5 \\
44.2\end{array}$ & 28.0 & $\begin{array}{l}44.3 \\
44.0\end{array}$ & 30.9 \\
\hline & 1600 & 35.81 & 2.538 & 50.3 & 614.2 & 277.4 & 1.8 & 2.2 & 44.4 & 33.5 & 43.4 & 28.2 & 43.9 & 31.0 \\
\hline & 1630 & 37.73 & & & 544.8 & 269.8 & 3.0 & 4.0 & -- & $\cdots$ & $\begin{array}{l}43.9 \\
--\end{array}$ & $\begin{array}{l}28.5 \\
23.2\end{array}$ & $\begin{array}{l}43.1 \\
44.1 \\
43.8\end{array}$ & $\begin{array}{l}28.0 \\
31.5 \\
28.7\end{array}$ \\
\hline
\end{tabular}




\section{EAST MESA 2 (1981) - EXPERIMENT 4}

\begin{tabular}{|c|c|c|c|c|c|c|c|c|c|c|c|c|c|c|}
\hline & & Pond & & Scillyell & & $\begin{array}{l}\text { (ion } \\
\text { n?) }\end{array}$ & & Speeds & & Air & empera & res $!^{\circ}$ & & \\
\hline & Date & $i$ & Elevation & $\uparrow$ & Shortwave & Net & & $\mathrm{rs} / \mathrm{sec}$ & Eas $\bar{t}$ & erin & Pond & over- & Rento & Tnwer \\
\hline & Tinıe & & & & Inconning & All-wave & East Bern & Remote Tower & dry & wet_ & dry & wet & $d r y_{-}$ & wet \\
\hline & $\begin{array}{l}27 \text { Jun B1 } \\
0900\end{array}$ & 50.89 & 7.579 & $3 \% .7$ & 500.6 & 291.5 & 3.2 & 4.6 & 34.8 & 24.7 & 34.6 & 26.9 & 33.7 & 25.8 \\
\hline & 0930 & 50.39 & & & 590.0 & 350.1 & 2.4 & 3.0 & 35.2 & 24.9 & 35.0 & 27.1 & 34.2 & $\begin{array}{l}26.1 \\
26.0\end{array}$ \\
\hline & 1000 & 50.18 & 7.316 & 38.8 & 675.5 & 411.5 & 1.8 & 2.0 & 36.2 & 25.5 & $\begin{array}{l}35.5 \\
36.2\end{array}$ & 27.2 & 35.1 & $\begin{array}{l}26.4 \\
26.4\end{array}$ \\
\hline & 1030 & 50.02 & & & 840.8 & 523.2 & 2.4 & 3.2 & 37.6 & 25.3 & $\begin{array}{l}36.8 \\
37.3\end{array}$ & $\begin{array}{l}27.4 \\
26.3\end{array}$ & $\begin{array}{l}36.6 \\
36.2\end{array}$ & $\begin{array}{l}26.8 \\
26.7\end{array}$ \\
\hline & 1100 & 49.40 & 7.088 & 41.4 & -- & -- & 2.6 & 3.8 & 37.6 & 25.4 & $\begin{array}{l}37.3 \\
37.7\end{array}$ & $\begin{array}{l}27.8 \\
26.5\end{array}$ & $\begin{array}{l}37.0 \\
36.6\end{array}$ & $\begin{array}{l}27.1 \\
27.0\end{array}$ \\
\hline P & 1130 & 49.31 & & & 835.6 & 533.8 & 2.8 & 3.8 & 38.7 & 25.9 & $\begin{array}{l}38.1 \\
38.6\end{array}$ & $\begin{array}{l}28.2 \\
26.9\end{array}$ & $\begin{array}{l}38.0 \\
37.0\end{array}$ & $\begin{array}{l}27.6 \\
27.6\end{array}$ \\
\hline 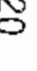 & 1200 & 48.88 & 6.820 & 42.0 & 698.4 & 475.8 & 2.8 & 3.4 & 39.5 & 25.8 & $\begin{array}{l}38.7 \\
39.0\end{array}$ & $\begin{array}{l}28.2 \\
26.8\end{array}$ & $\begin{array}{l}38.6 \\
38.3\end{array}$ & $\begin{array}{l}28.4 \\
27.6\end{array}$ \\
\hline & 1230 & -- & & & -- & - & -- & $\omega$ & -- & -- & -- & $\cdots$ & -- & -- \\
\hline & 1300 & 47.96 & 6.580 & 40.1 & -- & $-\cdot$ & 1.8 & 2.6 & 37.6. & 25.1 & $\begin{array}{l}37.6 \\
37.6\end{array}$ & $\begin{array}{l}27.6 \\
25.9\end{array}$ & $\begin{array}{l}37.4 \\
37.4\end{array}$ & $\begin{array}{l}27.3 \\
26.8\end{array}$ \\
\hline & 1330 & 48.10 & & & 672.8 & $443.0\}$ & 2.0 & 3.2 & 39.9 & 25.9 & $\begin{array}{l}39.6 \\
40.1\end{array}$ & $\begin{array}{l}28.7 \\
27.3\end{array}$ & $\begin{array}{l}39.4 \\
39.2\end{array}$ & $\begin{array}{l}28.2 \\
27.9\end{array}$ \\
\hline & 1400 & 48.03 & 6.430 & 41.8 & 741.7 & 498.2 & 3.4 & 4.4 & 41.0 & 26.2 & $\begin{array}{l}40.2 \\
40.6\end{array}$ & $\begin{array}{l}28.8 \\
27.4\end{array}$ & $\begin{array}{l}40.0 \\
39.5\end{array}$ & $\begin{array}{l}29.0 \\
28.1\end{array}$ \\
\hline & 1430 & 47.67 & & & 662.6 & 404.1 & 2.2 & 3.2 & 40.7 & 26.1 & $\begin{array}{l}40.1 \\
40.6\end{array}$ & $\begin{array}{l}28.6 \\
27.4\end{array}$ & $\begin{array}{l}40.2 \\
39.7\end{array}$ & $\begin{array}{l}28.8 \\
28.1\end{array}$ \\
\hline & 1500 & 47.31 & 6.227 & 43.1 & 538.6 & 314.0 & 2.6 & 3.6 & 41.3 & 26.1 & 40.8 & 28.8 & 40.7 & $\begin{array}{l}28.9 \\
28.1\end{array}$ \\
\hline & 1530 & 47.05 & & & 486.3 & 318.1 & 2.6 & 4.0 & 41.5 & 26.1 & $\begin{array}{l}41.0 \\
41.4\end{array}$ & $\begin{array}{l}28.9 \\
27.4\end{array}$ & $\begin{array}{l}41.2 \\
40.8\end{array}$ & $\begin{array}{l}29.1 \\
28.4\end{array}$ \\
\hline & 1600 & 46.65 & 9. & 43.5 & 432.2 & 204.7 & 2.8 & 3.6 & 41.4 & 26.0 & $\begin{array}{l}41.2 \\
41.4\end{array}$ & $\begin{array}{l}28.8 \\
27.2\end{array}$ & $\begin{array}{l}40.8 \\
40.5\end{array}$ & $\begin{array}{l}28.7 \\
23.0\end{array}$ \\
\hline
\end{tabular}




\section{EAST MESA 2 (198?) - EXPERIMENT 4 (contd)}

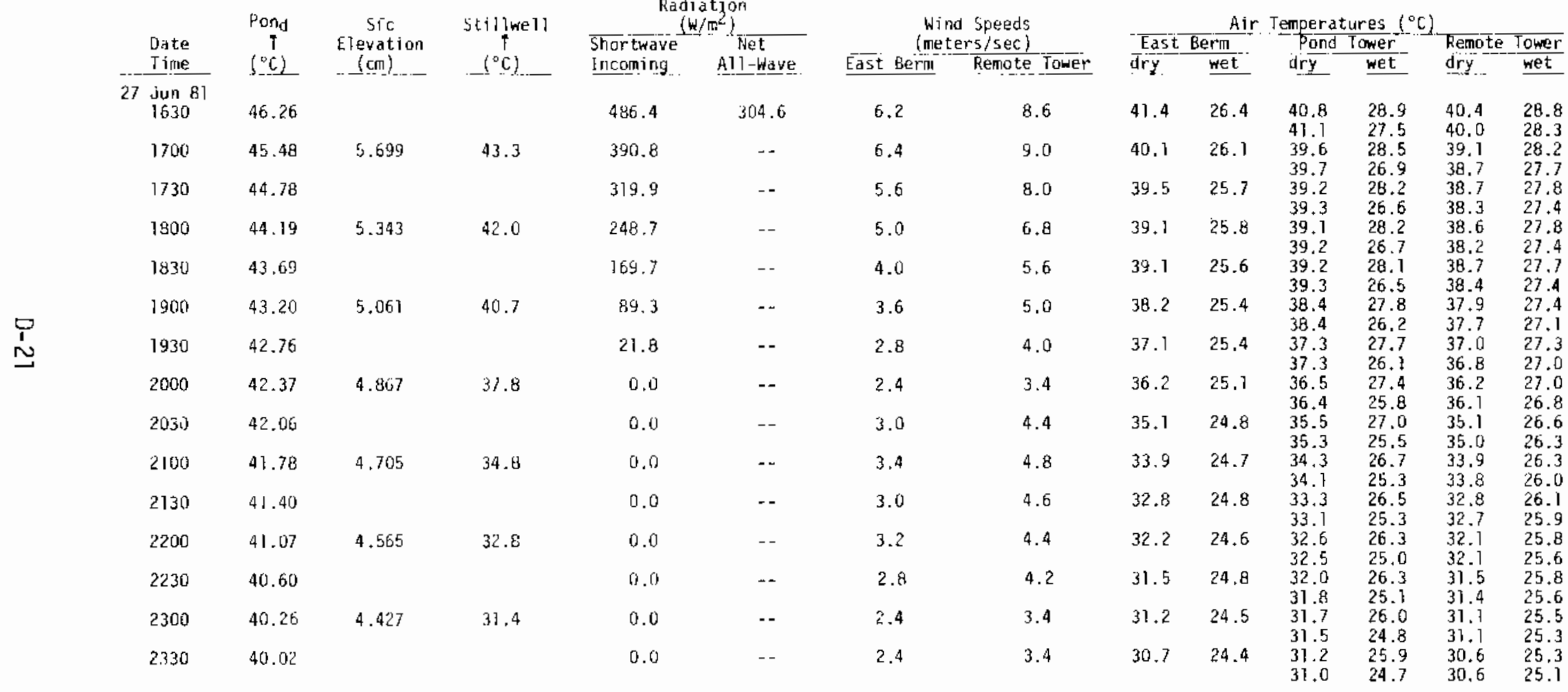


EAST MESA 2 (1981) - EXPERIMENT 4 (contd)

\begin{tabular}{|c|c|c|c|c|c|c|c|c|c|c|c|c|c|c|}
\hline & & & $\mathrm{SFc}$ & Stillwell & & $\begin{array}{l}\operatorname{tion} \\
\left.\mathrm{m}^{2}\right)\end{array}$ & & Speeds & & Air & emper & res ( & & \\
\hline & Date & 1 & Elevation & $\stackrel{1}{\circ}$ & Shortwave & Net & $\frac{\text { lme }}{\text { cast Berm }}$ & $\mathrm{rs} / \mathrm{sec})$ & East & Berm & Fon & ower & Remote & Tower \\
\hline & $11 \mathrm{me}$ & & & & Inconing & All-wave & East Berm & Remote lower & dry. & wet & dry & wet & & \\
\hline & 28 Jun 81 & 39.54 & 4.325 & 30.3 & 0.0 & -- & 2.4 & 3.6 & 30.0 & 24.7 & 30.4 & 26.0 & 29.9 & 25.5 \\
\hline & 0030 & 39.66 & & & 0.0 & -- & 3.0 & 4.4 & 29.5 & 24.6 & 30.0 & 25.9 & 29.4 & 25.4 \\
\hline & 0100 & 39.24 & 4.223 & 28.9 & 0.0 & -48.3 & 3.2 & 4.4 & 29.6 & 23.9 & $\begin{array}{l}29.8 \\
30.1\end{array}$ & $\begin{array}{l}24.8 \\
25.3\end{array}$ & $\begin{array}{l}29.4 \\
29.6\end{array}$ & $\begin{array}{l}25.7 \\
24.7\end{array}$ \\
\hline & 0130 & 38.92 & & & 0.0 & -44.3 & 28 & 42 & 29.6 & 23.4 & $\begin{array}{l}29.9 \\
30.0\end{array}$ & $\begin{array}{l}24.1 \\
24.8\end{array}$ & $\begin{array}{l}29.6 \\
29.5\end{array}$ & $\begin{array}{l}24.5 \\
24.3\end{array}$ \\
\hline & & & & & & & & & & & 29.9 & 23.6 & 29.5 & 24.1 \\
\hline & 0200 & 38.59 & 4.087 & 28.1 & 0.0 & -48.9 & 2.6 & 4.0 & 29.1 & 23.4 & $\begin{array}{l}29.6 \\
29.4\end{array}$ & $\begin{array}{l}24.8 \\
23.6\end{array}$ & $\begin{array}{l}29.1 \\
29.1\end{array}$ & $\begin{array}{l}24.2 \\
24.1\end{array}$ \\
\hline & 0230 & 38.43 & & & 0.0 & -45.8 & 2.8 & 4.2 & 28.7 & 23.6 & $\begin{array}{l}29.3 \\
29.1\end{array}$ & $\begin{array}{r}24.9 \\
23.8\end{array}$ & $\begin{array}{l}28.7 \\
28.7\end{array}$ & $\begin{array}{l}24.3 \\
24.1\end{array}$ \\
\hline 2 & 0300 & 38.22 & 3.972 & 27.4 & 0.0 & -42.2 & 2.8 & 4.4 & 28.3 & 23.4 & $\begin{array}{l}28.9 \\
28.7\end{array}$ & $\begin{array}{l}24.6 \\
23.5\end{array}$ & $\begin{array}{l}28.3 \\
28.3\end{array}$ & $\begin{array}{l}24.0 \\
23.9\end{array}$ \\
\hline & 0330 & 37.92 & & & 0.0 & -46.0 & 2.8 & 4.0 & 27.9 & 23.2 & $\begin{array}{l}28.5 \\
28.3\end{array}$ & $\begin{array}{l}24.5 \\
23.4\end{array}$ & $\begin{array}{l}27.9 \\
27.9\end{array}$ & $\begin{array}{l}23.9 \\
23.7\end{array}$ \\
\hline & 0400 & 37.56 & 3.830 & 26.8 & 0.0 & -53.8 & 2.4 & 3.6 & 27.5 & 23.1 & 28.1 & 24.3 & 27.5 & 23.7 \\
\hline & 0430 & 37.32 & & & 0.0 & -55.0 & 2,2 & 3.4 & 27.2 & 22.8 & 27.8 & $\begin{array}{l}23.2 \\
24.1\end{array}$ & $\begin{array}{l}27.5 \\
27.1\end{array}$ & $\begin{array}{l}23.5 \\
23.4\end{array}$ \\
\hline & & & & & & & & & & & 27.6 & 23.0 & 27.2 & 23.2 \\
\hline & 0500 & 37.03 & 3.777 & 26.1 & 0.0 & -51.6 & 1.6 & 2.6 & 26.7 & 22.3 & $\begin{array}{l}27.3 \\
27.1\end{array}$ & $\begin{array}{l}23.6 \\
22.5\end{array}$ & $\begin{array}{l}26.7 \\
26.7\end{array}$ & $\begin{array}{l}22.9 \\
22.7\end{array}$ \\
\hline & 0530 & 36.88 & & & $\cdots$ & -35.9 & 1.6 & 2.6 & 26.3 & 22.0 & 27.0 & 23.3 & 26.4 & 22.6 \\
\hline & 0600 & $36.7 ?$ & 3.703 & 25.4 & $\cdots$ & -24.5 & 1.8 & 2.8 & 26.2 & 22.0 & 26.8 & 23.2 & 26.2 & $\begin{array}{l}22.5 \\
22.6\end{array}$ \\
\hline & 0630 & 36.72 & & & -- & -17.3 & 2,0 & 3.0 & 27.2 & 22.7 & $\begin{array}{l}26.7 \\
27.7\end{array}$ & $\begin{array}{l}22.3 \\
24.0\end{array}$ & 26.3 & 22.4 \\
\hline & & 30.16 & & & - & -17.2 & $<, 1$ & 3.0 & & & 27.8 & 23.0 & 26.9 & 23.0 \\
\hline & 0700 & 36.81 & 3.645 & 28.1 & -- & 58.5 & 3.0 & 4.2 & 28.5 & 23.6 & $\begin{array}{l}28.7 \\
28.8\end{array}$ & $\begin{array}{r}24.8 \\
23.9\end{array}$ & $\begin{array}{l}28.0 \\
27.9\end{array}$ & $\begin{array}{l}24.1 \\
23.9\end{array}$ \\
\hline
\end{tabular}


EAST MESA 2 (1981) - EXPERIMENT 4 (contd)

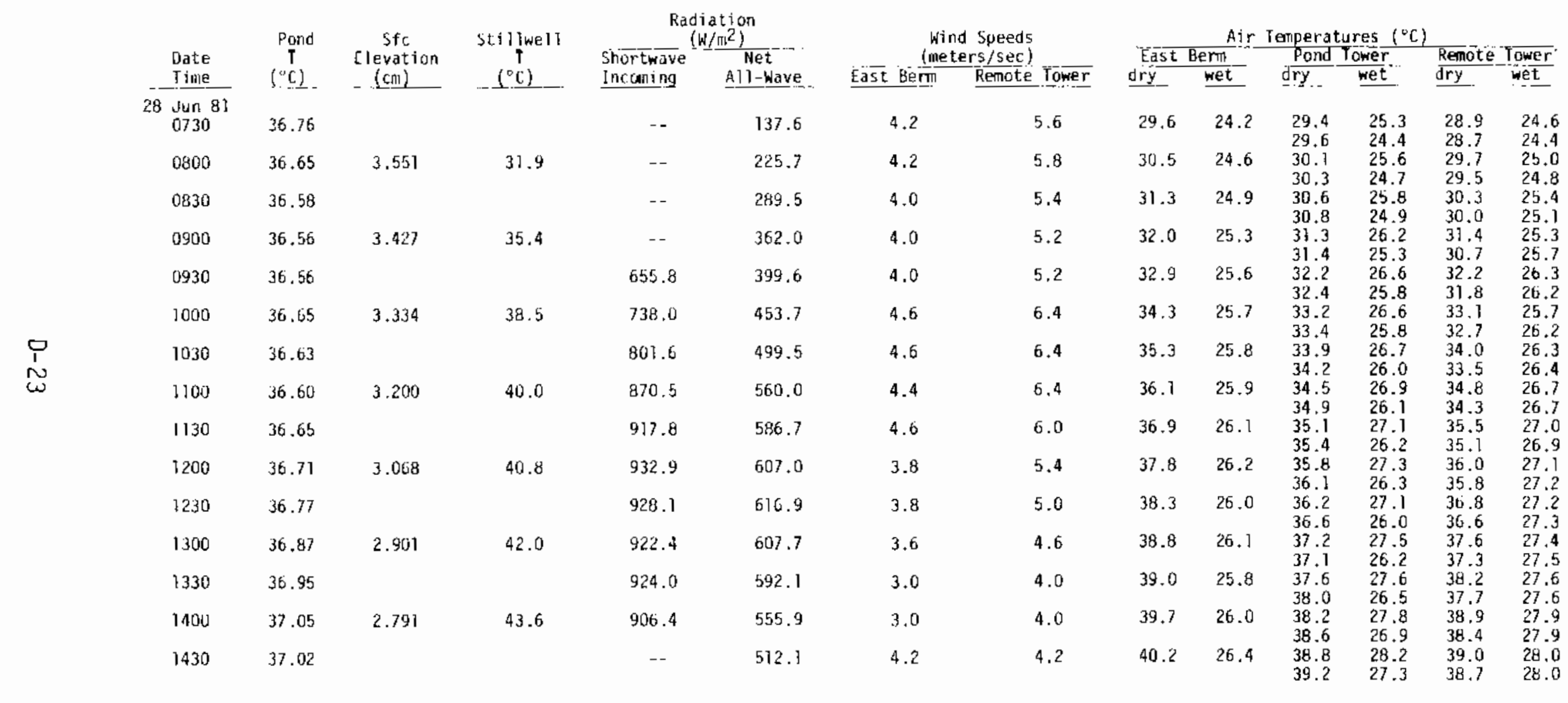


EAST MESA 2 (1981) - EXPERIMENT 4 (contd)

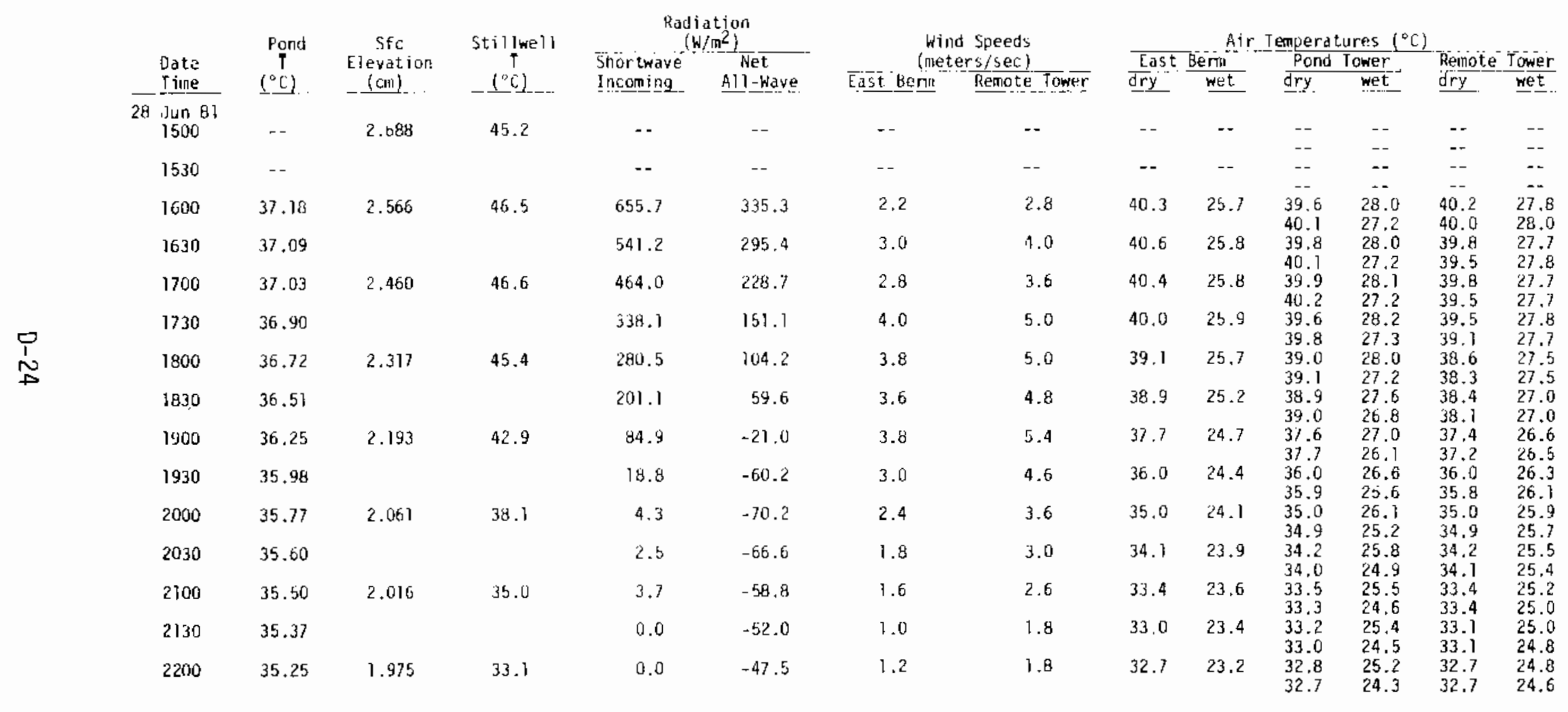


EAST MESA 2 (1981) - EXPERIMENT 4 (contd)

\begin{tabular}{|c|c|c|c|c|c|c|c|c|c|c|c|c|c|c|}
\hline & & & $5 f c$ & Stillwell & Rad & $\begin{array}{l}\text { tion } \\
\left.x^{2}\right)\end{array}$ & & Speeds & & Air & empera & ures! & & \\
\hline & Wate & $\overbrace{}^{\top}$ & Elevacion & $\uparrow^{\top}$ & Shor twave & Net & $\underline{f a t c}$ & $(\mathrm{rs} / \mathrm{sec})$ & East & Berin! & Pord & Tower & Renote & Tower \\
\hline & 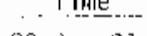 & & & & & & East Berm & Remote Tower & & wet & & wet. & ${ }^{d r y} \underline{y}_{-}$ & wet \\
\hline & $\begin{array}{c}28 \text { Jun } 81 \\
2230\end{array}$ & 35.18 & & & 0.0 & -50.5 & 1.4 & 2.4 & 32.3 & 23.1 & 32.5 & 249 & 32.3 & 24.6 \\
\hline & & & 1000 & & & & & & s... & . & 32.3 & 24.7 & 32.4 & 24.4 \\
\hline & 2300 & 35.05 & 1.944 & 31.5 & 0.0 & -51.7 & 1.2 & 2.2 & 31.9 & 23.0 & 32.1 & 24.8 & 31.3 & 24.5 \\
\hline & 2330 & 35.05 & & & 0.0 & -53.0 & 1.2 & 2.2 & 31.2 & 22.9 & 31.5 & 24.6 & 31.3 & 24.3 \\
\hline & 29 Jun 81 & & & & & & & & & & 31.4 & 23.9 & 31.4 & 24.2 \\
\hline & 0000 & 34.90 & 1.908 & 30.7 & 0.0 & -53.7 & 2.0 & 3.2 & 30.5 & 22.7 & $\begin{array}{l}30.8 \\
30.7\end{array}$ & $\begin{array}{l}24.3 \\
23.6\end{array}$ & $\begin{array}{l}30.6 \\
30.6\end{array}$ & $\begin{array}{l}24.0 \\
23.9\end{array}$ \\
\hline & 0030 & 34.99 & & & 0.0 & -54.4 & 2.4 & 3.8 & 29.9 & 23.2 & 30.2 & 24.5 & 29.9 & 24.2 \\
\hline & 0100 & 34.95 & 1.845 & 28.7 & 0.0 & -52.4 & 3.2 & 4.8 & 29.4 & 22.8 & $\begin{array}{l}30.0 \\
29.7\end{array}$ & $\begin{array}{l}23.9 \\
24.7\end{array}$ & $\begin{array}{l}29.9 \\
29.4\end{array}$ & $\begin{array}{l}24.0 \\
23.7\end{array}$ \\
\hline & 0130 & 34.80 & & & 0.0 & -49.2 & 3.2 & 4.6 & 29.0 & 22.5 & $\begin{array}{l}29.6 \\
29.4\end{array}$ & $\begin{array}{l}23.5 \\
23.8\end{array}$ & $\begin{array}{l}29.4 \\
29.1\end{array}$ & $\begin{array}{l}23.5 \\
23.4\end{array}$ \\
\hline & & & & & & & & & & & 29.2 & 23.2 & 29.1 & 23.3 \\
\hline & QRUN & $\cdots$ & 1.884 & 27.7 & 0.0 & -53.2 & 3.0 & 4.2 & 28.5 & 22,9 & $\begin{array}{l}28.9 \\
28.7\end{array}$ & $\begin{array}{l}24.0 \\
23.4\end{array}$ & $\begin{array}{l}28.5 \\
28.5\end{array}$ & $\begin{array}{l}23.6 \\
23.4\end{array}$ \\
\hline & 0230 & $m$ & & & 0.0 & -52.5 & 3.0 & 4.2 & 27.8 & 22.7 & 28.2 & 23.7 & 27.8 & 23.3 \\
\hline & 0300 & -- & 1.685 & 26.8 & 0.0 & -52.5 & 2.2 & 3.6 & 27.7 & 21.4 & $\begin{array}{l}28.0 \\
28.1\end{array}$ & $\begin{array}{l}23.2 \\
22.8\end{array}$ & $\begin{array}{l}27.7 \\
27.8\end{array}$ & $\begin{array}{l}23.1 \\
22.3\end{array}$ \\
\hline & & & & & & & & & & & 28.0 & 22.2 & 27.8 & 22.1 \\
\hline & 0330 & $\cdots$ & & & 0.0 & $-57+5$ & 2.0 & 3.0 & 27.3 & 20.7 & 27.7 & 22.2 & 27.3 & 21.7 \\
\hline & 0400 & - & 1.629 & 25.9 & 0.0 & -50.1 & 1.4 & 2.4 & 26.6 & 20.8 & $\begin{array}{l}27.5 \\
27.7\end{array}$ & $\begin{array}{l}21.6 \\
22.1\end{array}$ & $\begin{array}{l}27.3 \\
26.6\end{array}$ & $\begin{array}{l}21.5 \\
21.6\end{array}$ \\
\hline & & & & & & & & & & & 26.9 & 21.5 & 26.7 & 21.5 \\
\hline & 0430 & $\cdots$ & & & 0.0 & -48.9 & 1.4 & 2.6 & 26.1 & 20.7 & 26.4 & 21.9 & 26.0 & 21.5 \\
\hline & 0500 & -- & 1.593 & 24.8 & 0.0 & -50.2 & 2.0 & 3.2 & 25.8 & 21.5 & 26.1 & 22.4 & $\begin{array}{l}26.1 \\
25.6\end{array}$ & $\begin{array}{l}21.4 \\
21.9\end{array}$ \\
\hline & 0530 & -- & & & 0.0 & -45.5 & 2.2 & 3.6 & 25.9 & 27.6 & $\begin{array}{l}25.9 \\
26.4\end{array}$ & $\begin{array}{l}21.8 \\
22.6\end{array}$ & $\begin{array}{l}25.6 \\
26.0\end{array}$ & 21.8 \\
\hline & & & & & & & & & & & 26.2 & 22.0 & 26.1 & 22.0 \\
\hline
\end{tabular}


EAST MESA 2 (1981) - EXPERIMENT 4 (contd)

\begin{tabular}{|c|c|c|c|c|c|c|c|c|c|c|c|c|c|c|}
\hline & & Pond & $S f c$ & Stillwe1 & & $\begin{array}{l}\text { tion } \\
\left.m^{2}\right)\end{array}$ & & Speads & & & engera & res 1 & & \\
\hline & Date & $T$ & Elevation & & Shor twave & Net & & s/sect & Eas & חה & Pond & ower & Remote & Tower \\
\hline & Time & & & & Incolining. & A] l-wave & East Berm! & Renote Tower & dry & wet & dry & wet & dry & wet \\
\hline & $\begin{array}{c}29 \text { Jun } 81 \\
0600\end{array}$ & -- & 1.518 & 24.7 & 25.1 & -35.8 & 1.6 & 2.8 & 26.1 & 21.4 & 26.5 & 22.4 & 26.0 & 21.9 \\
\hline & 0630 & -- & & & 93.6 & 8.7 & 1.2 & 2.0 & 26.7 & 21.3 & $\begin{array}{l}26.4 \\
27.1\end{array}$ & 21.5 & $\begin{array}{l}26.0 \\
26.5\end{array}$ & $\begin{array}{l}21.8 \\
21.9\end{array}$ \\
\hline & 0700 & 32.84 & 1.502 & 27.6 & 194.0 & 68.9 & 1.8 & 2.4 & 28.1 & 21.7 & $\begin{array}{l}28.3 \\
28.7\end{array}$ & $\begin{array}{l}22.8 \\
22.9 \\
22.7\end{array}$ & $\begin{array}{l}27.4 \\
27.9\end{array}$ & $\begin{array}{l}21.1 \\
22.5 \\
22.3\end{array}$ \\
\hline & 0730 & 32.16 & & & 340.6 & 170.7 & 2.0 & 2.8 & 30.4 & 22.6 & 30.2 & 23.9 & 29.7 & 23.4 \\
\hline & 0800 & 32.29 & 1.477 & 33.6 & 465.8 & 258.7 & 2.2 & 2.8 & 31.4 & 23.5 & $\begin{array}{l}30.5 \\
30.9 \\
31.2\end{array}$ & $\begin{array}{l}23.7 \\
24.7 \\
24.5\end{array}$ & $\begin{array}{l}29.8 \\
30.6 \\
30.6\end{array}$ & $\begin{array}{l}23.2 \\
24.3 \\
24.2\end{array}$ \\
\hline$\checkmark$ & 0830 & 32.34 & & & 455.9 & 254.8 & 2.0 & 2.6 & 32.2 & 24.3 & $\begin{array}{l}31.7 \\
32.0\end{array}$ & $\begin{array}{l}25.5 \\
25.3\end{array}$ & $\begin{array}{l}31.5 \\
31.4\end{array}$ & $\begin{array}{l}25.1 \\
24.9\end{array}$ \\
\hline 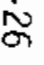 & 0900 & 32.41 & 1.444 & 37.0 & 493.5 & 246.8 & 2.0 & 2.6 & 32.8 & 24.3 & $\begin{array}{l}32.2 \\
32.4\end{array}$ & $\begin{array}{l}25.5 \\
25.3\end{array}$ & $\begin{array}{l}32.0 \\
32.0\end{array}$ & $\begin{array}{l}25.2 \\
25.1\end{array}$ \\
\hline
\end{tabular}




\section{EAST MESA 2 (1981) - EXPERIMENT 5}

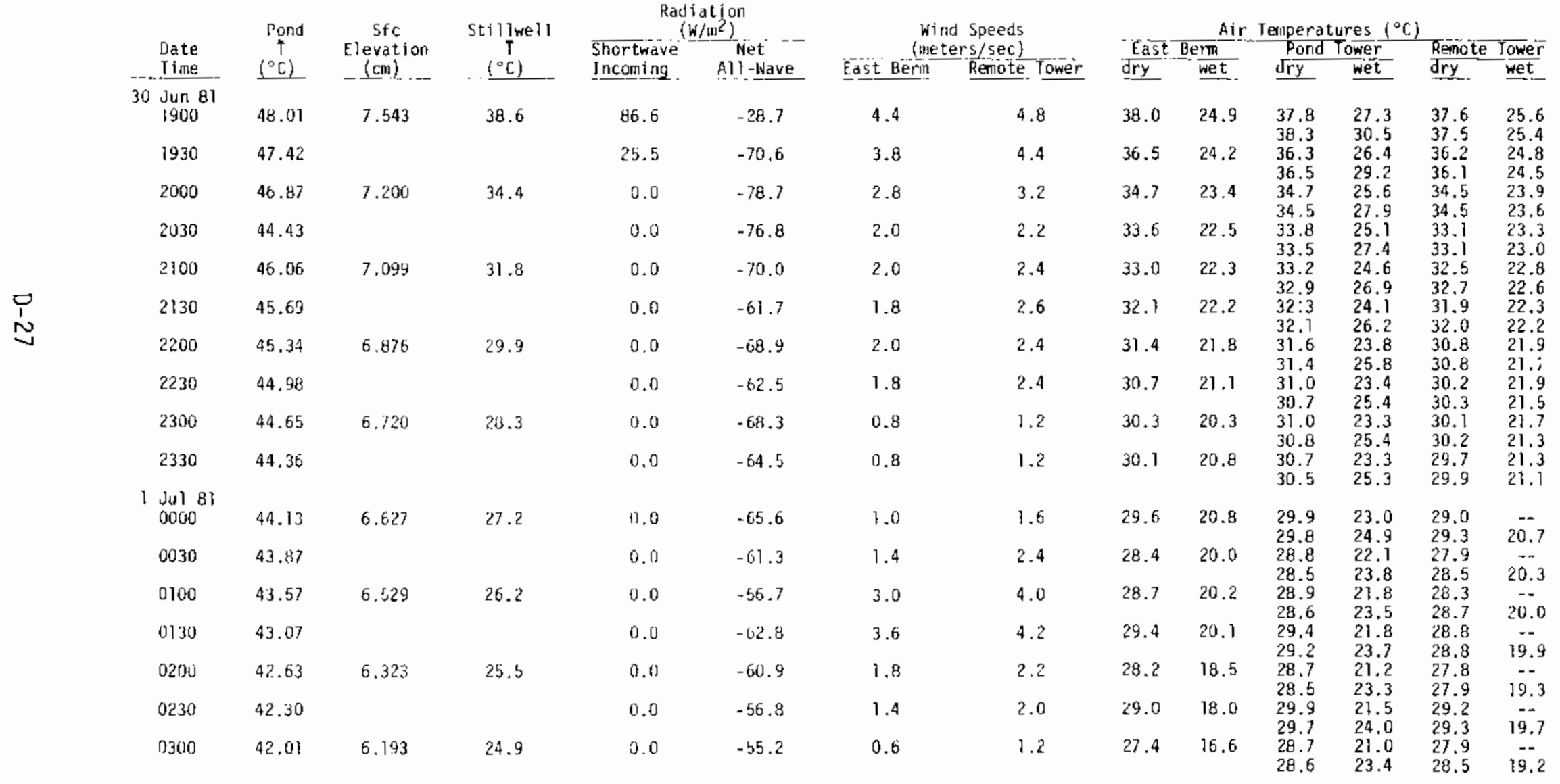




\section{EAST MESA 2 (1981) - EXPERIMENT 5 (contd)}

\begin{tabular}{|c|c|c|c|c|c|c|c|c|c|c|c|c|c|c|}
\hline & & & $S f c$ & Stillwell & $\mathrm{Rad}$ & $\begin{array}{l}\text { tion } \\
\left.\mathrm{m}^{2}\right)\end{array}$ & & Speeds & & Air & empera & res! & & \\
\hline & Date & i & Elevation & i & shor twave & Net & & $r s / \mathrm{sec})$ & East & sern & Pond & ower & Remote & Tower \\
\hline & Time & & & & Incoming & All-wave & East Berm & Renote Tower & dry & wet & dro $\underline{y}_{-}$ & wet & dry & wet \\
\hline & $\begin{array}{l}140181 \\
0330\end{array}$ & 41.77 & & & 0.0 & -52.4 & 0.4 & 0.6 & 26.0 & 17.0 & 27.5 & 20.9 & 26.4 & -- \\
\hline & 0400 & 41.56 & 6.084 & 24.0 & 0.0 & -48.4 & 0.6 & 1.4 & 25.0 & 16.0 & $\begin{array}{l}27.5 \\
26.6\end{array}$ & $\begin{array}{l}22.9 \\
20.4\end{array}$ & $\begin{array}{l}27.4 \\
26.0\end{array}$ & $\begin{array}{c}18.7 \\
-\ldots\end{array}$ \\
\hline & 0430 & 41.37 & & & 0.0 & -51.6 & 0.6 & 1.8 & 24.4 & 17.2 & $\begin{array}{l}26.5 \\
25.9\end{array}$ & $\begin{array}{l}22.2 \\
20.6\end{array}$ & $\begin{array}{l}26.9 \\
24.8\end{array}$ & $\begin{array}{l}19.0 \\
--\end{array}$ \\
\hline & & & & & & & & & & & 25.8 & 22.0 & 26.4 & 18.7 \\
\hline & 0500 & 41.11 & 5.998 & 23.1 & 0.0 & -47.5 & 0.4 & 1.4 & 24.6 & 16.8 & 26.3 & 20.7 & 24.9 & $\ddot{189}$ \\
\hline & 0530 & 40.85 & & & 13.5 & -41.7 & 2.0 & 3.6 & 24.9 & 17.8 & 26.0 & 20.6 & 25.2 & -- \\
\hline & 0600 & 40.60 & 5.918 & 23.2 & 51.2 & -36.5 & 2.2 & 3.2 & 25.2 & 19.5 & 26.1 & 27.6 & 25.1 & -2 \\
\hline & 0630 & 40.39 & & & 126.6 & 18.9 & 2.0 & 3.2 & 26.3 & 20.8 & 27.1 & 22.8 & $\begin{array}{l}24.9 \\
25.9\end{array}$ & 20.2 \\
\hline & & & & & & & 20 & & & & $27 \cdot 2$ & 24.2 & 25.9 & 21.4 \\
\hline & 0700 & 40.19 & 5.811 & 26.6 & 220.0 & 76.3 & 3.0 & 4.2 & 28.3 & 23.4 & $\begin{array}{l}28.7 \\
28.8\end{array}$ & $\begin{array}{l}25.0 \\
26.2\end{array}$ & $\begin{array}{l}27.7 \\
27.7\end{array}$ & $2 \overline{3} .7$ \\
\hline & 0730 & 39.98 & & & 325.6 & 155.2 & 4.4 & 6.2 & 2.9 .7 & 24.4 & 29.7 & 25.8 & 28.9 & - \\
\hline & 0800 & 39.78 & 5.710 & 31.8 & 425.0 & 230.0 & 4.2 & 5.8 & 31.1 & 24.9 & $\begin{array}{l}29.8 \\
30.8\end{array}$ & $\begin{array}{l}27.1 \\
26.4\end{array}$ & $\begin{array}{l}28.8 \\
30.2\end{array}$ & $\begin{array}{c}24.6 \\
.-\end{array}$ \\
\hline & & & & & & & & & & & 30.9 & 27.8 & 30.0 & 25.3 \\
\hline & 0830 & 39.58 & & & 522.5 & 304.9 & 4.0 & 5.4 & 32.3 & 25.2 & 32.0 & 26.9 & 31.3 & $=$ \\
\hline & 0900 & 39.45 & 5.565 & 35.3 & 605.3 & 371.3 & 4.0 & 5.4 & 33.2 & 25.4 & 32.5 & $\begin{array}{l}28.0 \\
26.9\end{array}$ & 32,3 & 26.8 \\
\hline & & & & & & & & & & & 32.7 & 28.0 & 31.8 & 25.9 \\
\hline & 0930 & 39.31 & & & 682.8 & 428.6 & 4.2 & 5.6 & 34,3 & 25.3 & 33.4 & 27.0 & 33.2 & 27.1 \\
\hline & 1000 & 39.24 & 5.416 & 38.0 & 767.8 & 485.7 & 3.8 & 5.0 & 35.4 & 25.1 & 34.3 & 27.0 & 34.1 & 27.1 \\
\hline & & & & & & & & & & & 34.5 & 28.8 & 33.9 & 26.0 \\
\hline & 1030 & 39.25 & & & 827.9 & 500.7 & 2.6 & 3.6 & 36.3 & 24.6 & 35.0 & $\begin{array}{l}26.7 \\
29.4\end{array}$ & $\begin{array}{l}35.2 \\
35.0\end{array}$ & 27.1 \\
\hline & 1100 & 39.31 & 5.275 & 40.8 & 896.6 & 540.7 & 2.2 & 2.8 & 37.1 & 24.7 & 35.5 & 26.7 & 36.0 & 27.3 \\
\hline & 1130 & 39.38 & & & 937.7 & 556.5 & 2.0 & 2.8 & 38.1 & 25.0 & 36.4 & 27.2 & 37.0 & 27.7 \\
\hline & & & & & & & & & & & 36.8 & 30.5 & 37.0 & 26.6 \\
\hline
\end{tabular}




\section{EAST MESA 2 (1981) - EXPERIMENT 5 (contd)}

\begin{tabular}{|c|c|c|c|c|c|c|c|c|c|c|c|c|c|c|}
\hline & & Ponid & $\mathrm{SfC}$ & Stilgwell & & $\begin{array}{l}\text { tion } \\
\left.n^{2}\right\}\end{array}$ & & Speeds & & Air & femper & res ( & & \\
\hline & Date & 7 & Elevation & & Shor twave & Net & & $\mathrm{rs} / \mathrm{sec})$ & East & enil & Pone & ower & Remote & Tower \\
\hline & Iíme & $\left\{{ }^{\circ} \mathrm{C}\right\}$ & $-(\mathrm{Cn})$ & $\left({ }^{\circ} \mathrm{C}\right)$ & Incoming & All-Wave & East Berm & Remote Tower & dry & wet & $\overline{d r y}$ & wet & dry & wet \\
\hline & 134818 & & & & & & & & & & & & & \\
\hline & 1200 & 39.44 & 5.185 & 42.5 & 960.9 & 584.9 & 2.4 & 3.0 & 38.9 & 24.6 & $\begin{array}{l}37.0 \\
37.4\end{array}$ & $\begin{array}{l}26.9 \\
30.7\end{array}$ & $\begin{array}{l}37.2 \\
37.4\end{array}$ & $\begin{array}{l}27.4 \\
26.2\end{array}$ \\
\hline & 1230 & 39.43 & & & 954.1 & 589.7 & 3.0 & 3.6 & 39.6 & 24.0 & 37.4 & 26.6 & 38.2 & 27.5 \\
\hline & 1300 & 39.49 & 5.012 & 42.7 & 940.4 & 579.3 & 2.2 & 2.8 & 39.8 & 24.0 & 38.0 & 27.0 & 38.6 & 27.8 \\
\hline & 1330 & 39.55 & & & 934.3 & 552.6 & 2.2 & 3.0 & 39.9 & 24.0 & $\begin{array}{l}38.6 \\
38.6\end{array}$ & $\begin{array}{l}30.7 \\
27.5\end{array}$ & $\begin{array}{l}36.5 \\
39.4\end{array}$ & $\begin{array}{l}20.3 \\
28.4\end{array}$ \\
\hline & & 3954 & 4873 & 439 & 9123 & 5350 & & & & 281 & 39.1 & 31.7 & 39.0 & 26.6 \\
\hline & 1400 & 39.04 & $4.8 / 3$ & 43.0 & 413.2 & 535.0 & 2.4 & 2,8 & 40.0 & 24.1 & $\begin{array}{l}38.7 \\
39.1\end{array}$ & $\begin{array}{l}27.7 \\
32.1\end{array}$ & $\begin{array}{l}38.7 \\
38.4\end{array}$ & $\begin{array}{l}28.2 \\
26.6\end{array}$ \\
\hline & $143 \mathrm{G}$ & 39.60 & & & 860.9 & 486.0 & 2.6 & 2.8 & 40.0 & 24.5 & 38.7 & 27.8 & 39.5 & 28.6 \\
\hline & 1500 & 39.61 & 4.737 & 44.6 & 801.5 & 439.4 & 2.2 & 2.6 & 39.8 & 25.0 & 38.5 & 27.9 & 39.2 & 28.5 \\
\hline & 1530 & 39.63 & & & 730.2 & 382,6 & 1.8 & 1.8 & 39.9 & 24.9 & $\begin{array}{l}39.2 \\
38.9\end{array}$ & $\begin{array}{l}32.5 \\
28.0\end{array}$ & $\begin{array}{l}39.0 \\
39.5\end{array}$ & $\begin{array}{l}26.9 \\
28.7\end{array}$ \\
\hline & & & & & & & & & & & 39.5 & 32.8 & 39.3 & 27.2 \\
\hline & 1600 & 39.60 & 4.640 & 46.7 & 6.36 .1 & 339.6 & 2.2 & 2.6 & 39.6 & 25.0 & $\begin{array}{l}38.6 \\
39 . ?\end{array}$ & $\begin{array}{l}28.0 \\
32.8\end{array}$ & 39.1 & 28.6 \\
\hline & 1630 & 39.51 & & & 536.1 & 273.6 & 2.0 & 2.8 & 40.2 & 24.2 & 39.5 & 27.9 & 40.0 & 28.4 \\
\hline & 1700 & 39.38 & 4.530 & 46.5 & 458.3 & 206.2 & 3.0 & 3.4 & 40.1 & 23.9 & 39.5 & 27.5 & 39.8 & 27.8 \\
\hline & 1730 & 39.16 & & & 3699 & 1518 & 40 & 43 & 39.7 & 23.9 & 40.6 & $\begin{array}{l}32.6 \\
27.5\end{array}$ & 39.9 & 26.2 \\
\hline & 190 & (t) & & & 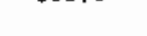 & (1) & 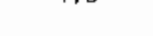 & 1.2 & & & 40.0 & 32.4 & 39.8 & 25.9 \\
\hline & 1800 & 38.95 & 4.338 & 43.7 & 276.0 & 89.0 & 4.4 & 4.6 & 39.0 & 24.0 & 38.9 & 27.5 & 39.2 & 27.7 \\
\hline & 1830 & 38.68 & & & 140.5 & 9.9 & 4.8 & 4.8 & 37.6 & 23.9 & $\begin{array}{l}39.6 \\
37.4\end{array}$ & $\begin{array}{l}3 Z, 1 \\
27.0\end{array}$ & 39.2 & $\begin{array}{l}20.1 \\
27.2\end{array}$ \\
\hline & & & & & & & & & & & 37.9 & -- & 37.6 & 25.7 \\
\hline & 1900 & 38.16 & 4.134 & 39.6 & 101.8 & -83.9 & 5.0 & 5.4 & 36.0 & 23.3 & 35.9 & 26.1 & 36.0 & 26.2 \\
\hline & 1930 & 37.83 & & & 34.5 & -69.6 & 5.0 & 5.4 & 34.7 & 22.0 & $\begin{array}{l}34.6 \\
34.7\end{array}$ & $\begin{array}{l}24.9 \\
28.2\end{array}$ & $\begin{array}{l}34.8 \\
34.7\end{array}$ & $\begin{array}{l}25.0 \\
23.4\end{array}$ \\
\hline
\end{tabular}


EAST MESA 2 (1981) - EXPERIMENT 5 (contd)

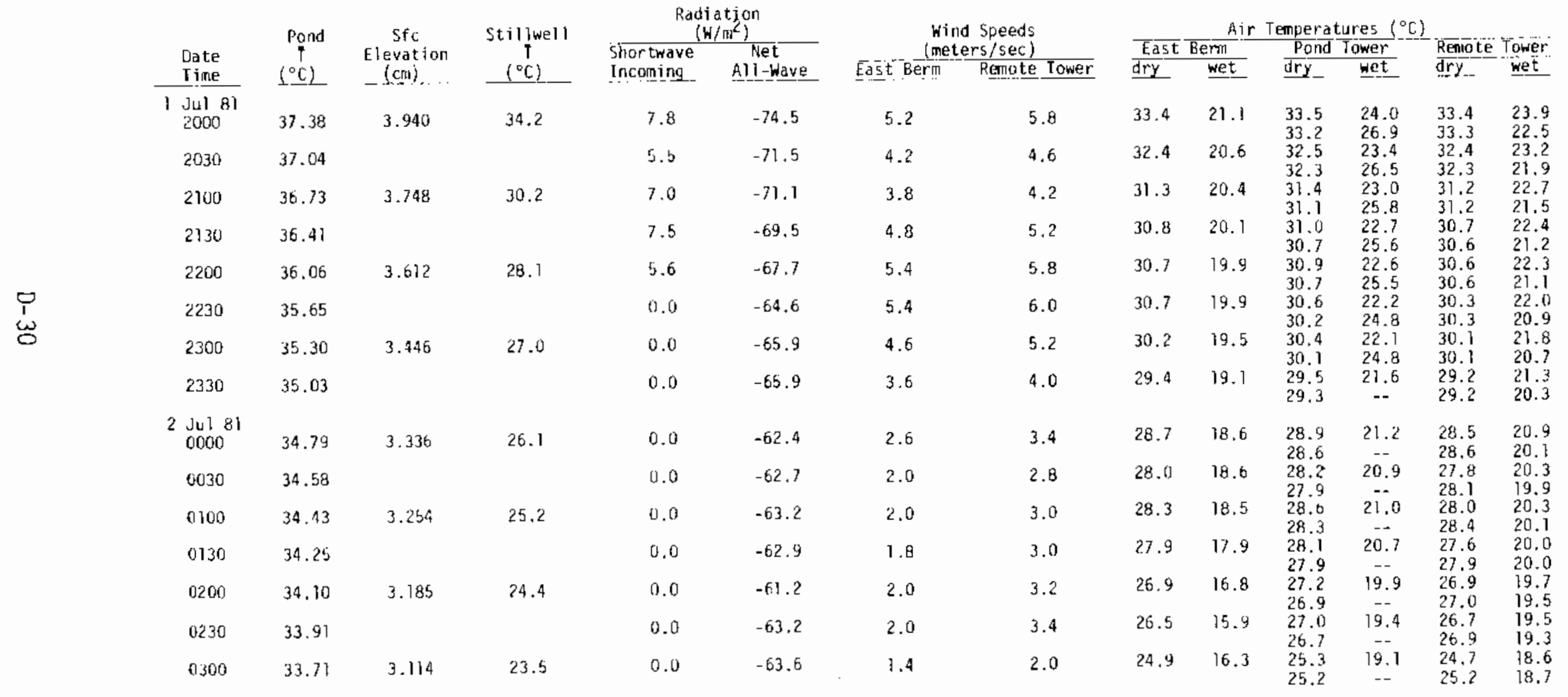




\section{EAST MESA 2 (1981) - EXPERIMENT 5 (contd)}

\begin{tabular}{|c|c|c|c|c|c|c|c|c|c|c|c|c|c|c|}
\hline & & & $S f c$ & Stillwwell & & tion & & Speeds & & & Emper & ires ( & & \\
\hline & Date & $1^{2}$ & Elevation & i & Shortwave & Wet & $(\pi)$ & $r s / \mathrm{sec})$ & East & Sent & Pan & Tower & Remote & Tower \\
\hline & & & & & Incosning & & East berm & Remote Tower & & & $d r y$ & & & wet \\
\hline & 2 Ju1 81 & 33.55 & & & 0.0 & -51.3 & 0.4 & 1.4 & 23.1 & 16.6 & 23.9 & 19.1 & 23.1 & 18.5 \\
\hline & 0400 & 33,41 & 3.011 & 22.5 & 0.0 & -59.3 & 0.4 & 1.2 & 22.7 & 16.2 & $\begin{array}{l}23.6 \\
23.9\end{array}$ & 19.7 & $\begin{array}{l}23.7 \\
23.1\end{array}$ & $\begin{array}{l}18.2 \\
18.4\end{array}$ \\
\hline & 0430 & 33.31 & & & 0.0 & -58.3 & 0.4 & 1.2 & 23.2 & 16.5 & $\begin{array}{l}23.6 \\
24.2\end{array}$ & $\ddot{19.3}$ & $\begin{array}{l}23.8 \\
23.1\end{array}$ & $\begin{array}{l}18.2 \\
18.3\end{array}$ \\
\hline & & & & & & & & & & & 24.0 & -- & 23.9 & 18.0 \\
\hline & 0500 & 33.19 & 2.986 & 21.2 & 0.0 & -56.5 & 0.6 & T.0 & 22.8 & 14.7 & 24.1 & 18.5 & 23.9 & 17.9 \\
\hline & 0530 & 33.05 & & & 0.0 & -50.2 & 0.6 & 3.4 & 21.5 & 14.0 & 22.5 & 17.7 & 22.2 & 17.2 \\
\hline & 0600 & 32.96 & 2.948 & 20.7 & 42.9 & -35.4 & 0.6 & 1.0 & 22.4 & 14.5 & $\begin{array}{l}22.3 \\
23.5\end{array}$ & 18.2 & $\begin{array}{l}23.3 \\
23.0\end{array}$ & $\begin{array}{l}17.8 \\
17.4\end{array}$ \\
\hline & & & & & & & & & & & 23.5 & - & 23.5 & 17.5 \\
\hline & 0630 & 32.89 & & & 175.1 & 13.2 & 0.8 & 1.2 & 23.9 & 15.4 & 24.8 & 18.9 & 24.1 & 18.2 \\
\hline & 0700 & 32.88 & 2.884 & 24.4 & 204.1 & 75.3 & 0.4 & 0.4 & 27.0 & 17.7 & 27.2 & 20.9 & $\begin{array}{l}24.8 \\
26.4\end{array}$ & $\begin{array}{l}18.8 \\
20.0\end{array}$ \\
\hline & 0730 & 32,92 & & & 308,7 & 132.4 & 0.6 & 06 & 29.7 & 19.7 & 27.7 & $22_{4}^{-}$ & 26.6 & 20.3 \\
\hline & 0700 & & & & 300.1 & 102.4 & 0.0 & 0.0 & $23+1$ & & 29.4 &.-- & 28.4 & 22.7 \\
\hline & 0800 & 33.01 & 2.887 & 31.0 & 408.5 & 199.5 & 0.8 & 0.8 & 30.5 & 21.3 & 30.0 & 23.7 & 29.6 & 23.3 \\
\hline & 0830 & 33.11 & & & 508.8 & 286.7 & 1.0 & 1.2 & 31.8 & 21.3 & 30.8 & 23.7 & 30.9 & $\begin{array}{l}23.7 \\
23.5\end{array}$ \\
\hline & 0900 & 33.30 & 2.832 & 36.3 & 596.1 & 360.3 & 1.2 & 1.4 & 32.6 & 21.2 & $\begin{array}{l}31.4 \\
31.5\end{array}$ & 23.7 & $\begin{array}{l}31.0 \\
31.8\end{array}$ & 23.8 \\
\hline & & & & & & & & & & & 32.1 & $\ddot{0}$ & 31.7 & $\ddot{0}$ \\
\hline & 0930 & 33.43 & & & 651.2 & 414.9 & 2.0 & 2.2 & 33.5 & 21.0 & 32.3 & 23.8 & 32.6 & 24.0 \\
\hline & 1000 & 33.52 & 2.802 & 38.2 & 704.7 & 493.5 & 2.2 & 2.2 & 34.2 & 21.1 & 33.1 & 24.1 & $\begin{array}{l}36.4 \\
33.4\end{array}$ & 24.5 \\
\hline & & & & & 8276 & 197 & 24 & 24 & 350 & 216 & 33.5 & -- & 33.1 & -2 \\
\hline & 1030 & 33.06 & & & 827.6 & $43 \% .0$ & 2.4 & 2.4 & 35.0 & 21.6 & $\begin{array}{l}33.6 \\
34.2\end{array}$ & 24.3 & $\begin{array}{l}34.2 \\
34.7\end{array}$ & $\begin{array}{c}24.7 \\
\ldots\end{array}$ \\
\hline
\end{tabular}




\section{EAST MESA 2 (1981) - EXPERIMENT 5 (contd)}

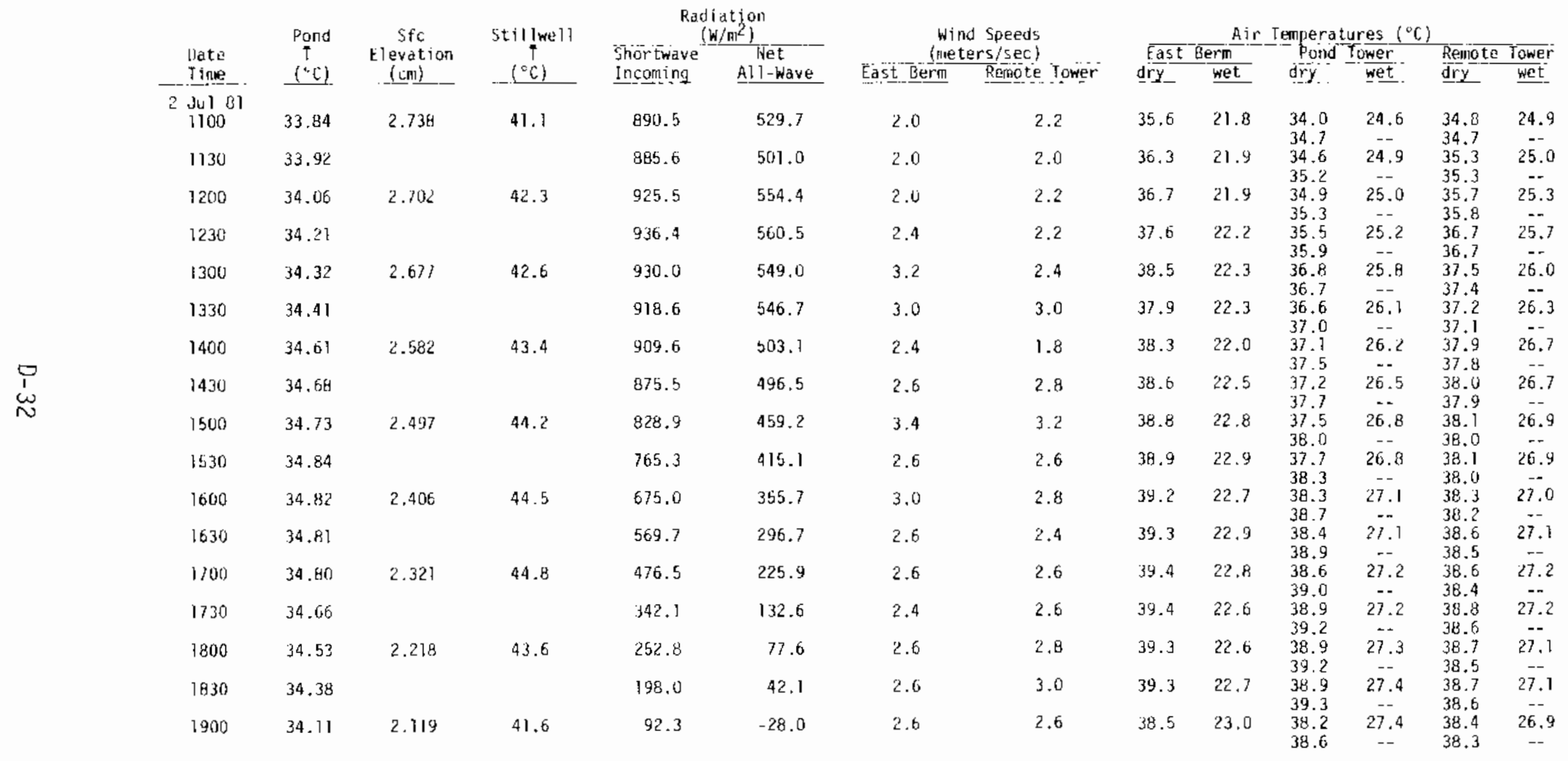


EAST MESA 2 (1981) - EXPERIMENT 6

\begin{tabular}{|c|c|c|c|c|c|c|c|c|c|c|c|c|c|c|}
\hline & & & & Stillwell & & tion & & Speeds & & Air & emper & ires (" & & \\
\hline & Wate & $\uparrow$ & Elevation & & Shor twave & Net & & $\mathrm{rs} / \mathrm{sec}$ & East & serm & Pons & ower & Remot & Tower \\
\hline & Tinne & $\left({ }^{\circ} \mathrm{C}\right)$ & $-(\mathrm{cm})$ & & Incoming & All-have & East Berni & Renlote Tower & $\frac{d \bar{y}}{y}$ & wet & dry & wet & $d r \underline{y}$ & wet \\
\hline & $\begin{array}{l}4 \mathrm{Ju1} 81 \\
0700\end{array}$ & 45.75 & 6.084 & 31.8 & 189.5 & 61.5 & 4.4 & 4.6 & 29.8 & 22.5 & 30.4 & 25.5 & 29.3 & 24.2 \\
\hline & 0730 & 45.23 & & & 291.3 & 117.2 & 4.8 & 3.2 & 30.9 & 24.0 & $\begin{array}{l}31.2 \\
31.2\end{array}$ & $\begin{array}{c}26.6 \\
\ldots-\end{array}$ & $\begin{array}{l}30.2 \\
30.1\end{array}$ & $\begin{array}{r}25.5 \\
--\end{array}$ \\
\hline & 0800 & 44.85 & 5.894 & 34.1 & 392.2 & 170.8 & 5.2 & 5.6 & 37.8 & 24.8 & 31.8 & 27.3 & 30.9 & 26.2 \\
\hline & 0830 & 44.48 & & & 440.3 & 240.9 & 4.6 & 5.0 & 32.8 & 25.2 & $\begin{array}{l}31.9 \\
32.9\end{array}$ & 27.9 & $\begin{array}{l}32.0 \\
32.0 \\
31.8\end{array}$ & 26.8 \\
\hline & 0900 & 44.22 & 5.701 & 36.2 & 544.3 & 335.4 & 4.6 & 4.6 & 33.9 & 25.7 & $\begin{array}{l}33.7 \\
33.8\end{array}$ & 28.2 & $\begin{array}{l}33.0 \\
32.8\end{array}$ & $\begin{array}{c}27.4 \\
--\end{array}$ \\
\hline & 0930 & 44.06 & & & 649.2 & 410.9 & 4.6 & 4.6 & 35.8 & 26.3 & $\begin{array}{l}35.4 \\
35.5\end{array}$ & $\begin{array}{c}29.0 \\
\ldots\end{array}$ & $\begin{array}{l}34.8 \\
34.6\end{array}$ & $\begin{array}{c}28.3 \\
--\end{array}$ \\
\hline$c$ & 1000 & 43.87 & 5.574 & 39.7 & 734.1 & 464.9 & 4.6 & 4.4 & 37.3 & 26.4 & $\begin{array}{l}36.4 \\
36.7\end{array}$ & $\begin{array}{c}29.2 \\
-.\end{array}$ & $\begin{array}{l}36.2 \\
35.9\end{array}$ & $\begin{array}{r}28.7 \\
--\end{array}$ \\
\hline & 1030 & 43.71 & & & 792.8 & 491.2 & 4.2 & 4.2 & 38.4 & 26.4 & $\begin{array}{l}37.3 \\
37.6\end{array}$ & 29.4 & $\begin{array}{l}37.3 \\
37.0\end{array}$ & $\begin{array}{r}29.0 \\
--\end{array}$ \\
\hline & 1100 & 43.63 & 5.335 & 42.0 & 863.3 & 530,0 & 3.4 & 3.2 & 39.2 & 26.0 & $\begin{array}{l}38.0 \\
38.4\end{array}$ & $\begin{array}{c}29.4 \\
-.\end{array}$ & $\begin{array}{l}38.2 \\
37.9\end{array}$ & $\begin{array}{r}29.0 \\
\ldots\end{array}$ \\
\hline & 1130 & 43.59 & & & 908.2 & 552.1 & 4.0 & 3.4 & 40.5 & 26.2 & $\begin{array}{l}38.9 \\
39.4\end{array}$ & $\begin{array}{c}29.7 \\
-\end{array}$ & $\begin{array}{l}39.2 \\
39.0\end{array}$ & $\begin{array}{c}29.3 \\
--\end{array}$ \\
\hline & 1200 & 43.48 & 5.179 & 43.9 & 922.9 & 566.4 & 4.0 & 3.6 & 41.5 & 26.2 & $\begin{array}{l}39.9 \\
40.2\end{array}$ & $\begin{array}{c}30.0 \\
--\end{array}$ & $\begin{array}{l}40.0 \\
40.0\end{array}$ & 29.5 \\
\hline & 1230 & 43.37 & & & 918.0 & 562.5 & 4.6 & $4 \cdot 2$ & 42.1 & 26.0 & $\begin{array}{l}40.2 \\
40.6\end{array}$ & 29.8 & $\begin{array}{l}40.7 \\
40.7\end{array}$ & 29.6 \\
\hline & 1300 & 43.31 & 5.008 & 44.9 & 908.7 & 343.6 & 3.6 & 2.8 & 42.5 & 25.9 & $\begin{array}{l}41.0 \\
41.0\end{array}$ & $\begin{array}{r}29.9 \\
--\end{array}$ & $\begin{array}{l}41.3 \\
41.2\end{array}$ & $\begin{array}{c}29.7 \\
---\end{array}$ \\
\hline & 1330 & 43.29 & & & 908.5 & 525.5 & 3.0 & 2.2 & 42.8 & 25.9 & $\begin{array}{l}41.4 \\
41.9\end{array}$ & $\begin{array}{c}30.4 \\
\ldots\end{array}$ & $\begin{array}{l}42.0 \\
41.7\end{array}$ & $\begin{array}{c}30.3 \\
--\end{array}$ \\
\hline & 1400 & 43.29 & 4.868 & 46.1 & 890.8 & 517.3 & 3.2 & 2.8 & 43.3 & 26.5 & $\begin{array}{l}42.1 \\
42.6\end{array}$ & $\begin{array}{c}31.1 \\
--\end{array}$ & $\begin{array}{l}42.6 \\
42.2\end{array}$ & 30.5 \\
\hline
\end{tabular}




\section{EAST MESA 2 (1981) - EXPERIMENT 6 (contd)}

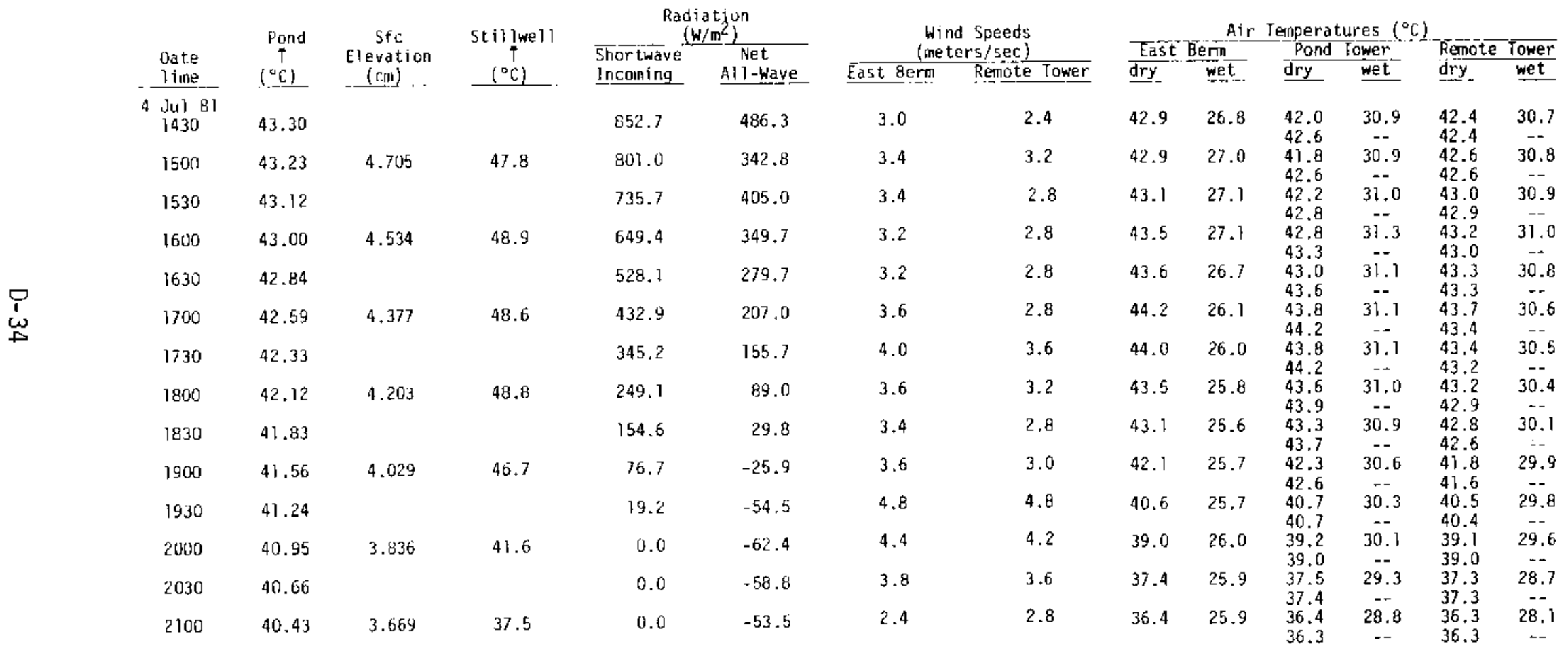




\section{EAST MESA 2 (1981) - EXPERIMENT 6 (contd)}

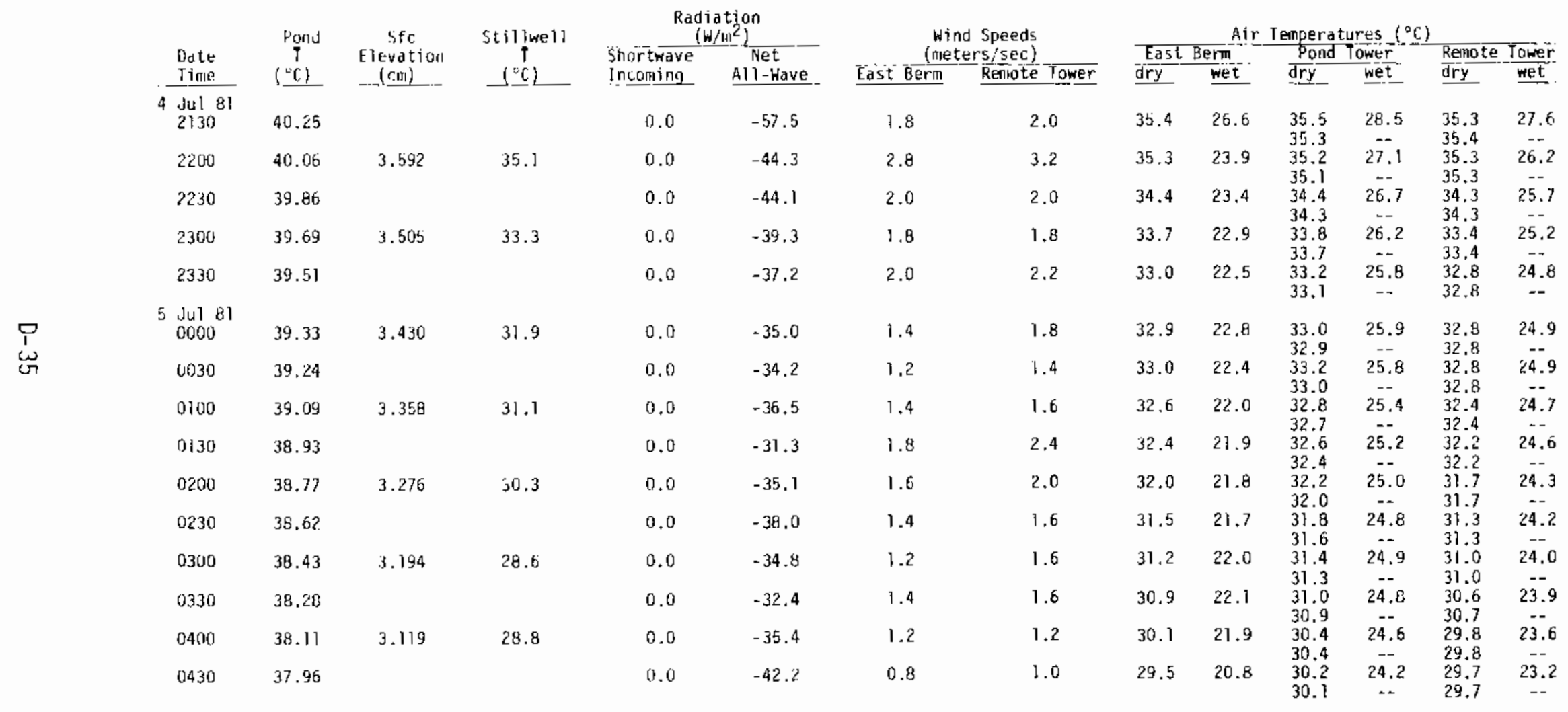


EAST MESA 2 (1981) - EXPERIMENT 6 (contd)

\begin{tabular}{|c|c|c|c|c|c|c|c|c|c|c|c|c|c|}
\hline \multirow{3}{*}{$\begin{array}{l}\text { Date } \\
\text { Tilue }\end{array}$} & \multirow{3}{*}{$\begin{array}{c}\text { Pond } \\
T \\
(* C)\end{array}$} & \multirow{3}{*}{$\begin{array}{l}5 f a \\
\text { flevation } \\
\text { (rin) }\end{array}$} & \multirow{3}{*}{$\begin{array}{c}\text { stilinell } \\
\text { (oc) } \\
\text { (oc) }\end{array}$} & \multicolumn{2}{|c|}{$\begin{array}{l}\text { Radiotion } \\
\left(\mathrm{W} / \mathrm{m}^{2}\right)\end{array}$} & \multirow{2}{*}{\multicolumn{2}{|c|}{$\begin{array}{l}\text { Wind Speeds } \\
\text { (rileters } / \text { sec) }\end{array}$}} & \multicolumn{6}{|c|}{ Air Teliperatures $\left({ }^{\circ} \mathrm{C}\right)$} \\
\hline & & & & Shortwave & Net & & & Eas & Sertn & Pon & ower & Remio & Tower \\
\hline & & & & Incoming . & All-wave & East Berill & kenote Tower & dry & wet & $d r y$ & wet & dry & wet \\
\hline 5 Jui 81 & & & & & & & & & & & & & \\
\hline 0500 & 37.84 & 3.066 & 28.4 & 0.0 & -44.4 & 0.6 & 0.6 & 29.0 & 20.3 & $\begin{array}{l}29.9 \\
29.8\end{array}$ & 24.1 & $\begin{array}{l}29.4 \\
29.5\end{array}$ & 23.0 \\
\hline 0530 & 37.66 & & & 5.1 & -33.7 & 1.0 & 1.0 & 28.5 & 19.9 & 29.4 & 23.6 & 29.0 & 22.6 \\
\hline 0600 & 37.58 & 2.990 & 27.3 & 43.4 & -19.2 & 0.8 & 1.0 & 28.7 & 20.0 & $\begin{array}{l}29.3 \\
29.4\end{array}$ & 23.5 & $\begin{array}{l}29.3 \\
28.7\end{array}$ & $\overline{22.4}$ \\
\hline 0630 & 37.52 & & & 115.7 & 26.0 & 1.4 & 1.6 & 30.0 & 20.7 & $\begin{array}{l}29.5 \\
30.4\end{array}$ & 24.0 & $\begin{array}{l}29.0 \\
29.6\end{array}$ & 23.0 \\
\hline 0700 & 37.49 & 2.985 & 30.0 & 178.7 & 65.0 & 1.8 & 2.0 & 31.3 & 21.6 & $\begin{array}{l}30.6 \\
31.6 \\
31.8\end{array}$ & $\begin{array}{c}-- \\
25.0 \\
--\end{array}$ & $\begin{array}{l}29.6 \\
31.0 \\
30.9\end{array}$ & 24.1 \\
\hline
\end{tabular}




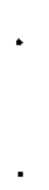




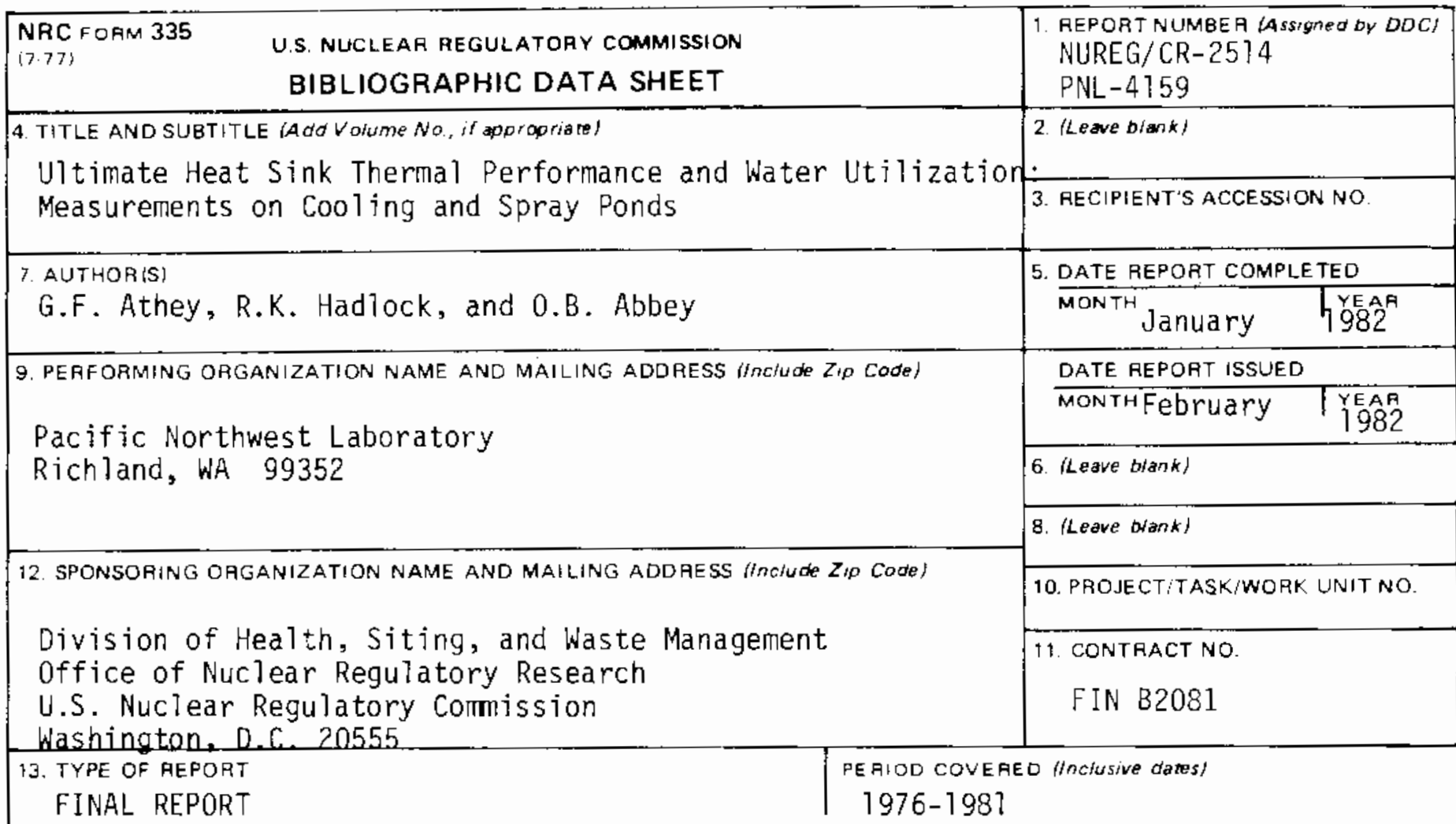

15. SUPPLEMENTARY NOTES

14. (Leave biank)

16. ABSTAACT (200 words or less)

A data acquisition research program, entitled "UTtimate Heat Sink Performance Field Experiments," has been completed. The primary objective was to obtain the requisite data to characterize thermal performance and water utitization for cooling ponds and spray ponds at elevated temperatures. Such data are useful for modeling purposes; such modeling efforts were beyond the scope of the present study.

Constructed water retention ponds, provided with absolute seals against seepage, have been chosen as facilities fot the data collection program; the first pond was located at Raft River, Idaho, and the second at East Mesa, California. The data illustrate and describe, for both cooling ponds and spray ponds, thermal performance and water utilization as the ponds cool from an initially elevated temperature, nominally $130^{\circ} \mathrm{F}$. The data reflect thermal performance and water utilization for meteorological and solar influences which are representative of worst-case combinations of conditions. The data are described and discussed in the text and presented in the form of data volumes as appendices.

17b. IDENTIFIERSIOPEN-ENDEO TERMS

18. AVAILABILITY STATEMENT

Unlimjted

\begin{tabular}{|c|c|}
\hline $\begin{array}{c}\text { 19. SE CUAITY CLASS (This report) } \\
\text { UnClass if ied }\end{array}$ & 21. NO. OF PAGES \\
\hline $\begin{array}{c}\text { 20. SECURITY CLASS /This page) } \\
\text { UnC laSS if ied }\end{array}$ & $\begin{array}{c}\text { 22. PRICE } \\
\$\end{array}$ \\
\hline
\end{tabular}


